\title{
A arquiltetura doméstica da classe média paulistana nos anos 1950: o "bem viver" moderno
}

Tese apresentada ao Programa de Pós-Graduação em Arquitetura e Urbanismo na Área de Teoria e História da Arquitetura e Urbanismo - Instituto de Arquitetura e Urbanismo - Universidade de São Paulo, como exigência para obtenção do título de Doutor em Arquitetura e Urbanismo.

Versão corrigida

Orientador: Prof. Dr. Carlos Roberto Monteiro de Andrade 


\section{AUTORIZO A REPRODUCCÃO TOTAL OU PARCIAL DESTE TRABALHO, POR QUALQUER MEIO CONVENCIONAL OU ELETRÔNICO, PARA FINS DE ESTUDO E PESQUISA, DESDE QUE CITADA A FONTE.}

Silva Janjulio; orientador Carlos Roberto Monteiro de Andrade. São Carlos, 2014.

Tese (Doutorado) - Programa de Pós-Graduação em Arquitetura e Urbanismo e Área de Concentração em Teoria e História da Arquitetura e do Urbanismo -Instituto de Arquitetura e Urbanismo da Universidade de São Paulo, 2014 .

1. Arquitetura moderna doméstica. 2. Arquitetura doméstica americana. 3. Casa e Jardim anos 1950. 4. Arquitetura classe média. 5. Arquitetura paulistana anos 1950. I. Título. 


\section{FOLHA DE JULGAMENTO}

Candidata: Arquiteto Maristela da Silva Janjulio

Título da tese: "A arquitetura doméstica da classe média paulistana nos anos 1950: o "bem viver" moderno".

Data da defesa: $23 / 03 / 2015$

\section{Comissão Julgadora:}

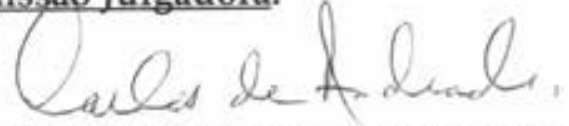

Prof. Dr. Carlos Roberto Monteiro de Andrade (Orientador)

(Instituto de Arquitetura e Urbanismo - IAU/USP)
Resultado:

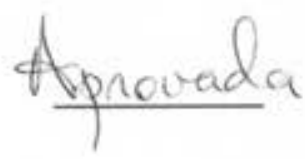

Prof. Dr. Francisco Sales Trajano Filho

(Instituto de Arquitetura e Urbanismo- IA (U/USP)
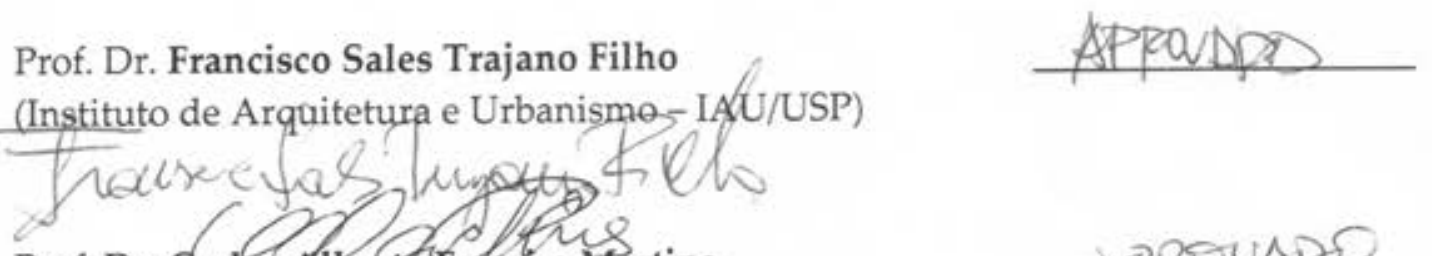

Prof. Dr. Carros Atbertoferreira Martins

(Instituto de Arquitetura e Urbanismo - IAU/USP)

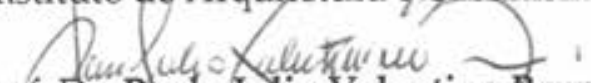

Prof. Dr. Paulo Jukjo Valentino Bruna

(Faculdade de Arquitetura e Urbanismo - FAU/USP)
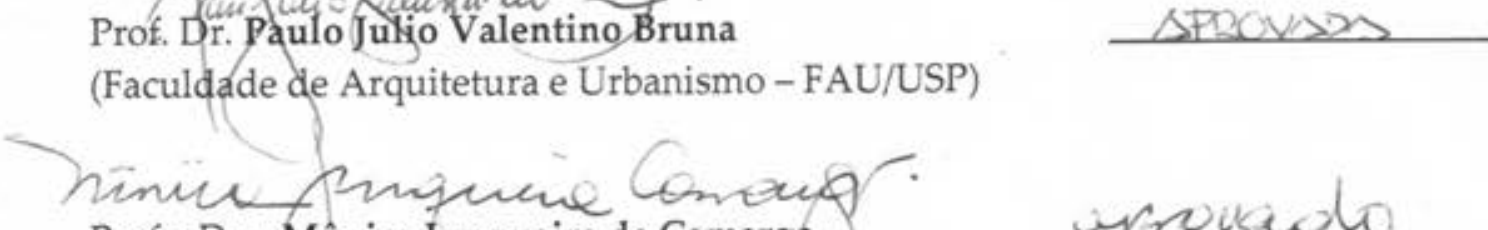

Profa. Dra. Mônica Junqueira de Camargo

((Faculdade de Arquitetura e Urbanismo - FAU/USP)

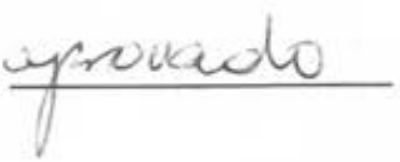

Coordenador e Presidente da Comissão de Pós-Graduação do Programa de PósGraduação em Arquitetura e Urbanismo: Prof. Dr. Márcio Minto Fabrício 

Às minhas queridas filhas, Laura e Débora. 



\section{Agradecimentos}

A meu orientador, Carlos Roberto Monteiro de Andrade, meus agradecimentos sinceros pela orientação e pela grande amizade que cultivamos ao longo desses anos.

Laura, Débora e Armando, agradeço pelo carinho, pela compreensão das dificuldades e por compartilharem as alegrias das conquistas.

Ruty e Antônio, queridos pais, muito obrigada por todo o apoio, em momentos difíceis ou não.

Amigos, Fabíola Cordovil, Lucas Cestaro, Thaís Cruz, agradeço pelo apoio, amizade, contribuições. Dividimos as alegrias, as preocupações, muitos momentos preciosos.

Aos professores Francisco Sales Trajano e José Tavares Correia de Lira, agradeço pela atenção e pelas contribuições na banca de qualificação.

Sales, muito obrigada, também, pela amizade, por me apresentar textos importantíssimos para a pesquisa e pelos livros todos.

Walquíria e Paulo, outra vez, como no mestrado, muito obrigada por me proporcionarem uma casa em São Carlos, e por todo o carinho.

Aos colegas do URBIS, obrigada pela amizade e pelas contribuições.

Aos funcionários do IAU-USP, obrigada pelas gentilezas todas.

Agradeço também às bibliotecárias e demais funcionários da Biblioteca Central da EESC-USP, especialmente a Lílian e Gisele.

À Diuliana, obrigada pelo carinho na impressão de minha tese.

À FAPESP, um agradecimento especial, pela concessão de uma bolsa de doutorado, fundamental para uma pesquisa mais tranquila. 

Mas para quê Tanto sofrimento, Se o meu pensamento É livre na noite?

(Tema e Voltas, Manuel Bandeira) 



\section{RESUMO}

\section{JANJULIO, Maristela da Silva. A arquitetura doméstica da classe média}

paulistana nos anos 1950: o "bem viver" moderno. 2014. 342 f. Tese (Doutorado) - Instituto de Arquitetura e Urbanismo da Universidade de São Paulo, São Carlos, 2014.

Na revista Casa e Jardim, nos anos 1950, constitui-se uma arquitetura voltada à classe média, a que chamamos "bem viver," que analisamos nesta tese. Em seu desenho, está presente a linguagem moderna, que é transmitida aos leitores de forma didática. Essa arquitetura aparece como cenário para um cotidiano confortável, com a ajuda da técnica e dos novos produtos, que estão disponíveis naqueles anos. Estes promovem uma grande renovação nos hábitos e costumes da classe média urbana brasileira, tendo os Estados Unidos e a vida americana como modelos. O contexto onde surge o "bem viver" é o da modernização brasileira, particularmente da metrópole paulistana, com transformações econômicas, sociais, políticas e culturais.

Palavras-chave: Arquitetura moderna doméstica. Arquitetura doméstica americana. Casa e Jardim anos 1950. Arquitetura classe média. Arquitetura paulistana anos 1950. 


\title{
ABSTRACT
}

\author{
JANJULIO, Maristela da Silva. The domestic architecture of the middle \\ class in São Paulo in the 1950s: the modern "good life." 2014. 342 f. Tese \\ (Doutorado) - Instituto de Arquitetura e Urbanismo da Universidade de \\ São Paulo, São Carlos, 2014.
}

In Casa e Jardim magazine in the 1950s, arises an architecture for the middle class, which we call "good living," whose analysis is our core issue. It uses the modern language, which is transmitted to readers in a didactic way. This architecture appears as the setting for a comfortable routine with the help of technique and new products, which are available in those years. These products promote a major renovation in the habits and customs of the Brazilian urban middle class, with the United States and American life as models. The context where it arises the "good life" is the Brazilian modernization, particularly the metropolis of São Paulo, with economic, social, political and cultural transformations.

Keywords: Domestic modern architecture. American domestic architecture. Casa e Jardim 1950s. Middle class Architecture. São Paulo Architecture 1950s. 


\section{Lista $^{1}$ de llustrações ${ }^{2}$}

\section{Capa}

Casa e Jardim, n.51, p.36

\section{Capítulo 1}

Fig.1.1 - Disponível em: <http://www.decoupage.net.br/2010/08/vida-e-estilo-dosanos-50.html>. Acesso em: 04 dez. 2014.

Fig.1.2 - Disponível em: <http://pro-memoria-de-campinassp.blogspot.com.br/2009/02/curiosidades-companhia-swift-do-brasil.html >. Acesso em: 31 out. 2014.

Fig.1.3 - Casa e Jardim, n.64, p.52.

Fig.1.4 - Casa e Jardim, n.62, contracapa.

Fig.1.5 - Casa e Jardim, n.18, p.22

Fig.1.6 - Casa e Jardim, n.18, p.23

Fig.1.7 - Casa e Jardim, n.52, p.11

Fig.1.8 - A Casa, set.- out. 1945, capa

Fig.1.9 - Casa e Jardim, n.1, capa

Fig.1.10 - Casa e Jardim, n.39, verso da contracapa

Fig.1.11 - Casa e Jardim, n.11, p.77

Fig.1.12 - Casa e Jardim, n.7, p.93

Fig.1.13 - Casa e Jardim, n.20, p.38

Fig.1.14 - Casa e Jardim, n.26, p.57

Fig.1.15 - Casa e Jardim, n.28, p.83

Fig.1.16 - Casa e Jardim, n.8, p.7

Fig.1.17 - Casa e Jardim, n.87, s.n.p.

Fig.1.18 - Casa e Jardim, n.13, p.9

Fig. 1.19 - Casa e Jardim, n. 11, s.n.p

Fig. 1.20 - Casa e Jardim, n.11,s.n.p

Fig.1.21 - Casa e Jardim, n.24,p.11

\footnotetext{
${ }^{1}$ Após o número da ilustração, está a fonte de onde foi retirada.

${ }^{2}$ AR refere-se a fotos do álbum 82 Distinctive Houses from Architectural Record. New York: F.W. Dodge Corp., c1952.
} 
Fig.1.22 - Casa e Jardim, n.9, s.n.p

Fig.1.23 - Casa e Jardim, n.84, s.n.p.

Fig.1.24 - Casa e Jardim, n.100, s.n.p.

\section{Capítulo 2}

Fig.2.1 - Disponível em: < http://entrenessa.com.br/moda-praia-anos-50-e-60/>. Acesso em: 04 dez. 2014.

Fig.2.2 - Casa e Jardim, n.45, p.52

Fig.2.3 - Casa e Jardim, n.45, p.54

Fig.2.4 - Casa e Jardim, n.45, p.55.

Fig.2.5 - Casa e Jardim, n.45, p.53

Fig.2.6 - Casa e Jardim, n.49, p.5

Fig.2.7 - Casa e Jardim, n.49, p.8

Fig.2.8 - Casa e Jardim.n.51, p.18

Fig.2.9 - Casa e Jardim. n.51, p.22

Fig.2.10 - Casa e Jardim, n.51, p.18

Fig.2.10 - Casa e Jardim, n.51, p.39

Fig.2.11 - Casa e Jardim, n.51, p.36

Fig.2.12 - Casa e jardim n.51, p.37

Fig. 2.13 - Casa e Jardim, n.10, p.36

Fig. 2.14 - Casa e Jardim, n.10, p.37

Fig. 2.15 - Casa e Jardim, n.52, p.8

Fig.2.16 - Casa e Jardim, n.10, p.7

Fig.2.17 - Casa e Jardim, n.10, p.8

Fig.2.18 - Casa e Jardim, n.55, p.50

Fig. 2.19 - BLAU, 1999

Fig.2.20 - TESSENOW, 1999.

Fig.2.21 - Casa e Jardim, n.27, p.18

Fig.2.22 - Casa e Jardim, n.41, p.10

Fig.2.23 - Casa e Jardim, n.41, p.9

Fig.2.24 - Casa e Jardim, n.31, p.37

Fig.2.25 - Casa e Jardim, n.5, p.26-7

Fig.2.26 - Casa e Jardim, n.48, p.18 
Fig.2.27 - Casa e Jardim, n.18, p.26

Fig.2.28 - Casa e Jardim, n.18, capa

Fig.2.29 - Casa e Jardim, n.27, p.16

Fig.2.30 - Casa e Jardim, n.27, p.12

Fig.2.31 - Casa e Jardim, n.27, p.12

Fig.2.32 - Casa e Jardim, n.29, p.21

Fig.2.33 - Casa e Jardim, n.29, p.23

Fig.2.34 - Casa e Jardim, n.29, p.31

Fig.2.35 - Casa e Jardim, n.2-Capa

Fig.2.36 - Casa e Jardim, n.13, p.37

Fig.2.37 - Casa e Jardim, n.6.pag.10

Fig.2.38 - Casa e Jardim, n.6, p.12

Fig.2.39 - Casa e Jardim, n.5, p.10

Fig.2.40 - Casa e Jardim, n.5, p.12

Fig.2.41 - Casa e Jardim, n.5, p.15

Fig.2.42 - Casa e Jardim, n.24, p.17

Fig.2.43 - Casa e Jardim, n.54, p.10

Fig.2.44 - Casa e Jardim, n.11, p.5

Fig.2.45 - Casa e Jardim, n.11, p.6

Fig.2.46 - Casa e Jardim, n.11, p.19

Fig.2.47 - Casa e Jardim, n.11, p.19

Fig.2.48 - Casa e Jardim, n.53, p.55

Fig.2.49 - Casa e Jardim, n.53, p.56

Fig.2.50 - Casa e Jardim, n.26, p.4

Fig.2.51 - Casa e Jardim, n.8, p.16

Fig.2.52 - Casa e Jardim, n.8, p.20

Fig.2.53 - Casa e Jardim, n.50, p.33

Fig.2.54 - Casa e Jardim, n.26, p.19

Fig.2.55 - Casa e Jardim, n.26, p.6

Fig.2.56 - Casa e Jardim, n.26, p.8

Fig.2.57 - Casa e Jardim, n.14, p.16

Fig.2.58 - Casa e Jardim, n.14, p.20

Fig.2.59 - Casa e Jardim, n.28, p.20

Fig.2.60 - Casa e Jardim, n.28, p.18 
Fig.2.61 - SEGAWA; DOURADO, 1997, p.111

Fig.2.62 - SEGAWA; DOURADO, 1997, p.125

Fig.2.63 - Casa e Jardim, n.49, p.13

Fig.2.64 - Casa e Jardim, n.26, p.16

Fig.2.65 - Casa e Jardim, n.26, p.19

Fig.2.66 - Casa e Jardim, n.26, p.18

Fig.2.67 - Casa e Jardim, n.23, p.16

Fig.2.68 - Casa e Jardim, n.23, p.18

Fig.2.69 - Casa e Jardim, n.39, p.35

Fig.2.70 - Casa e Jardim, n.43, p.18

Fig.2.71 - Casa e Jardim, n.43, p.19

Fig.2.72 - Casa e Jardim, n.39, p.29

Fig.2.73 - Casa e Jardim, n.37, p.38

Fig.2.74 - Casa e Jardim, n.37, p.40

Fig.2.75 - Casa e Jardim, n.30, p.36

Fig.2.76 - Casa e Jardim, n.42, p.18

Fig.2.77 - Casa e Jardim, n.13, capa

Fig.2.78 - Casa e Jardim, n.29, p.7

Fig.2.79 - Casa e Jardim, n.30, p.20

Fig.2.80 - Casa e Jardim, n.33, p.9

Fig.2.81 - Casa e Jardim, n.31, p.5

Fig.2.82 - Casa e Jardim, n.31, p.11

Fig.2.83 - Casa e Jardim, n.31, p.12

Fig.2.84 - Casa e Jardim, n.32, p.12

Fig.2.85 - Casa e Jardim, n.32, p.15

Fig.2.86 - Casa e Jardim, n.41, p.30

Fig.2.87 - Casa e Jardim, n.41, p.29

Fig.2.88 - Casa e Jardim, n.77, p.49

Fig.2.89 - Acrópole, n. 209, p.178

Fig.2.90 - Acrópole, n. 209, p.177

Fig.2.91 - Acrópole, n. 224, p.281

Fig.2.92 - Acrópole, n. 224, p.280

Fig.2.93 - Acrópole, n. 224, p.282 
Fig.2.94 - Casa e Jardim, n.30, p.16

Fig.2.95 - Casa e Jardim, n.27, p.17

Fig.2.96 - Casa e Jardim, n.13, p.20

Fig.2.97 - Casa e Jardim, n.13, p.22

Fig.2.98 - Casa e Jardim, n.9, p.64

Fig.2.99 - Casa e Jardim, n.1, p.27

\section{Capítulo 3}

Fig.3.1 - Disponível em: <http://www.incasamia.com.br/wp-

content/uploads/2012/12/cadeiras-eames.jpg>. Acesso em: 04 dez. 2014.

Fig.3.2 - Disponível em: < Breuer Wolfson Trailer House 1949 \& 60 http://art-nowand-then.blogspot.com.br/2013/10/marcel-breuer.html >. Acesso em: 30 out. 2014.

Fig.3.3 - Disponível em: < http://www.pinterest.com/pin/239816748878145926/>. Acesso em: 30 out. 2014.

Fig.3.4 - House \& Home, n.1, capa.

Fig.3.5 - House \& Home, n.1,p.108

Fig.3.6 - House \& Home, n.1,p.111

Fig.3.7 - House \& Home, n.1,p.108

Fig.3.8 - AR, p.288

Fig.3.9 - AR, p.284

Fig.3.10 - AR, p 65

Fig.3.11 - AR, p.63

Fig.3.12 -AR, p.66

Fig.3.13 - AR, p.268

Fig.3.14 - AR, p.69

Fig.3.15 -AR, p.81

Fig.3.16 - AR, p.118

Fig.3.17 - AR, p.118

Fig.3.18 - AR, p.119

Fig.3.19 - AR, p.195

Fig.3.20 - AR, p.107

Fig.3.21 - AR, p.21

Fig.3.22 - AR, p.78 
Fig.3.23 - AR, p.83

Fig.3.24 - AR p.124

Fig.3.25 - AR, p.193

Fig.3.26 - AR, p.80

Fig.3.27 - AR, p.197

Fig.3.28 - AR, p.310

Fig.3.29 - AR, p.89.

Fig.3.30 - AR, p.156

Fig.3.31 - AR, p.286

Fig.3.32 - Disponível em: <http://upstatehistoricproperty.com/exterior.htm>. Acesso em: 30 out. 2014.

Fig.3.33 - Disponível em: <http://streetsofsalem.com/tag/colonial-revival>. Acesso em: 30 out. 2014.

Fig.3.34 - AR, p.32

Fig.3.35 - AR, p.108

Fig.3.36 - AR, p.234

Fig.3.37 - AR, p.335

Fig.3.38 - AR, p.334

Fig.3.39 - AR, p.235

Fig.3.40 - AR, p.232

Fig.3.41 - AR, p.316

Fig.3.42 - AR, p.105

Fig.3.43 - AR, p.231

Fig.3.44 - AR, p.132

Fig.3.45 - AR, p.312

Fig.3.46 - KREISMAN e MASON, p. 162

Fig.3.47 - Disponível em: < http://www.apartmenttherapy.com/classic-americanstyle-frank-I-152338>. Acesso em: 21 out. 2014.

Fig.3.48 - Disponível em: < http://www.apartmenttherapy.com/classic-americanstyle-frank-I-152338>. Acesso em: 21 out. 2014.

Fig.3.49 - Disponível em: < http://architectonicto.blogspot.com.br/2013/09/formspace-and-order.html >. Acesso em: 21 out. 2014.

Fig.3.50 - AR, p.316

Fig.3.51 - COLOMINA, p.132

Fig.3.52 - JACKSON, 2007, p.44 
Fig.3.53 - JACKSON, 2007, p.43

Fig.3.54 - COLOMINA, p.76

Fig.3.55 - COLOMINA, 2007,p.66

Fig.3.56 - COLOMINA, p.67

Fig.3.57 - COLOMINA, p.68.

Fig.3.58 - FULLAONDO, p.190

Fig.3.59 - FULLAONDO, p.186

Fig.3.60 - COLOMINA, p.82

Fig.3.61 - MOCK,32

Fig.3.62 - House \& Home, maio 1954, p.123

Fig.3.63 - House \& Home, maio de 1954, p.134

Fig.3.64 - House \& Home, maio 1954, p.153

Fig.3.65 - House \& Home, maio 1954, p.165

Fig.3.66 - MOCK, 85

Fig.3.67 - House \& Home, maio 1954, p.147

Fig.3.68 - MOCK,65

Fig.3.69 - COLOMINA, p.305

Fig.3.70 - COLOMINA, 209

Fig.3.71 - House \& Home, maio 1954, capa.

Fig.3.72 - Disponível em: <ocalarchhistory.blogspot.com.br/2010/12/quincy-jonesand-pueblo-gardens-first_29.html >. Acesso em: 30 out. 2014.

Fig.3.73 - Disponível em: < http://socalarchhistory.blogspot.com.br/2010/12/quincyjones-and-pueblo-gardens-first_29.html >. Acesso em: 30 out. 2014.

Fig.3.74 - House \& Home, v.5, n.6, jun. 1954. capa,

Fig.3.75 - AR, p.44

Fig.3.76 - AR, p.44

Fig.3.77 - Disponível em:

$<$ http://historicsurvey.lexingtonma.gov/lexareas/area_u.htm >. Acesso em: 30 out. 2014.

Fig.3.78 - House \& Home, agosto 1952, n.p.88

Fig.3.79 - Disponível em:

<http://historicsurvey.lexingtonma.gov/lexareas/area_u.htm >. Acesso em: 30 out. 2014.

Fig.3.80 - Disponível em: <http://modernmass.blogspot.com.br/2010/10/ezra-stollershots.html >. Acesso em: 30 out. 2014. 
Fig.3.81 - Disponível em: <http://socalarchhistory.blogspot.com.br/2010/12/quincyjones-and-pueblo-gardens-first_29.html >. Acesso em: 30 out. 2014.

Fig.3.82 - MOCK, 23

Fig.3.83 - House \& Home, jun.1954, p.147.

\section{Capítulo 4}

Fig.4.1 - Disponível em: < http://www.lojaskd.com.br/blog/2011/04/26/decorandocom-cobogos/\#.VlbrbkudKT4>. Acesso em: 09 dez. 2014.

Fig.4.2 - Casa e Jardim, n.41, p.53

Fig.4.3 - Casa e Jardim, n.25, p.3.

Fig.4.4 - Casa e Jardim, n.12, p.22

Fig.4.5 - Casa e Jardim, n.12, p.24

Fig.4.6 - Casa e Jardim, n.14, p.26

Fig.4.7 - Casa e Jardim, n.31, p.21

Fig.4.8 - Casa e Jardim, n.14, p.28

Fig.4.9 - Casa e Jardim, n.32, p.5

Fig.4.10 - Casa e Jardim, n.20, p.11

Fig.4.11 - Casa e Jardim, n.34, p.5

Fig.4.12 - AR, p.339

Fig.4.13 - AR, p.336-7 


\section{Sumário}

Introdução, 25

\section{Capítulo 1 - Os anos 1950, 41}

1.1 O Brasil, no pós-guerra, 42

1.1.2 Transformações sociais: a formação de uma sociedade de consumo, 46

1.20 modelo de vida americano, 51

1.2.1 A hegemonia americana no pós-guerra, 55

1.3 Hábitos antigos / novos comportamentos, 60

1.3.1 Alguns hábitos de consumo, 66

1.3.2 A publicidade, 76

1.4 A Cultura metropolitana, 83

1.4.1 Referências da arquitetura americana no Brasil, 85

Capítulo 2 - A arquitetura do “bem viver," 91

2.1 "a casa do 'morar bem'," 92

2.2 Pequenas casas, 106

2.3 Totalidade, 127

2.4 Subjetividade, 137 
2.5 Uma arquitetura cheia de contrastes: cores, materiais, luzes, sólidos, vazios, 147

2.6 Adaptações: culturais, regionais, ao sítio e clima, 159

2.7 Por quê a linguagem moderna?, 178

\section{Capítulo 3 - O Good-Life Modernism, 193}

3.1 Uma crítica interna ao Movimento Moderno, 194

3.2 Uma seleção de casas modernas, 202

3.2.1 Totalidade e fluidez, 210

3.2.2 Spaciousness, o espaço psicológico, 221

3.2.3 Contrastes: texturas e cores, 228

3.2.4 Um manifesto, 231

3.3 O International Style e outras experiências modernas, 235

3.3.1 A linguagem do Movimento Moderno, 241

3.4 O Good-Life Modernism, 243

3.4.1 Sonhos de Guerra, 247

3.4.2 O papel do MOMA e das revistas na constituição do Good Life Modernism, 250

3.4.3 If you want to build a house, 260

3.4.4 Subúrbios, 271

3.4.4.1 Grandes e pequenos empreendimentos, 276

3.4.5 Novas técnicas e materiais, 286

\section{Capítulo 4 - O papel do arquiteto, 293}

4.1 A modernização da arquitetura em São Paulo e a dedicação exclusiva ao projeto, 294

4.1.1 O trabalho no escritório, 298 
4.1.2 O relacionamento com o cliente, 300

4.1.3 O processo de projeto, 306

4.1.4 Uma relação complexa, 309

4.1.5 Após a obra, 317

4.2 O arquiteto “menor” nos EUA, 320

4.3 A nova geração e o trabalho em equipe, 325

4.4 A função social do arquiteto, 328

Conclusão, 331

Referências, 343 


\section{Introdução}

Esta pesquisa de doutorado, ainda que com suas várias alterações de rota, configura-se como uma continuação do nosso mestrado. ${ }^{1}$ Permanecemos pesquisando uma arquitetura voltada para a classe média, investigando, de certa forma, as "franjas" da historiografia, objetos considerados de "segunda linha." Mostrada, principalmente, em revistas dirigidas ao público leigo e nas revistas de decoração e femininas, em uma espécie de tradução do erudito para o gosto do homem comum. Assim, além da arquitetura com "autoria," analisamos aqui aquela "anônima," que também já se encontrava presente em nossa dissertação.

O plano inicial de pesquisa do doutorado pretendia investigar, na cidade de São Paulo, no período 1930-1955, a presença da linguagem moderna na arquitetura doméstica e seus contrapontos e aproximações com a arquitetura tradicional.

A pesquisa histórica, para Ginzburg (2011), não é um percurso linear, mecânico. Uma afirmação que em nosso caso permite compreender os caminhos tomados pela pesquisa, com várias derivações e retornos. Chegando ao recorte temporal: São Paulo, nos anos 1950. Como lembra Eco (2004, p.10), quanto mais se restringe o campo de pesquisa, trabalha-se com mais segurança.

Trata-se de um momento em que, na cidade de São Paulo, a arquitetura moderna conquistara sua hegemonia e, por diversos fatores que analisaremos, acaba por chegar à classe média. Nossa principal fonte documental é a revista Casa e Jardim. ${ }^{2}$ Desde que se começou a pesquisar a revista, puderam ser observadas tentativas de se transmitir a linguagem moderna ao público de classe média, em uma espécie de "aula de arquitetura moderna," mesclando-a ao mundo doméstico, sempre procurando uma casa prática e confortável.

\footnotetext{
${ }^{1}$ JANJULIO, 2009.

${ }^{2}$ Essa fonte apresenta material muito rico e um discurso constituído, já tendo sido objeto de inúmeras pesquisas. Não é o texto de Casa e Jardim que constitui nosso objeto. Essa afirmação parece óbvia. Mas, quando se tem uma fonte primária tão importante, existe sempre o risco de estudá-la diretamente, e transformá-la em nosso objeto.
} 
A dimensão educativa está sempre presente e o tom didático repete-se. Essa questão mostra-se bastante instigante: aparentemente, o intuito é "ensinar" a linguagem moderna ${ }^{3}$ ao público, mas qual a intenção real?

Assim, pesquisou-se a revista, desde o seu início em 1953 e pelos dez anos seguintes. Mostrou-se mais produtiva a década de 1950, em que o discurso construído pela revista mostra-se mais "expressivo," mais coerente, em relação à transmissão da linguagem moderna, dispersando-se um tanto, depois. ${ }^{4}$

Após uma ampla investigação, nosso objeto foi surgindo aos poucos. Muitas vezes, sabe-se exatamente o que pesquisar, em que direção seguir. Mas, nesse caso, a riqueza de material, entre outros aspectos, não permitiu que se configurassem os limites de nosso objeto - a arquitetura do "bem viver" -, desde o início.

Analisar esse objeto é a questão central da tese.

Ao mesmo tempo, investigou-se a arquitetura doméstica nos Estados Unidos, ${ }^{5}$ no pós-guerra, considerando-se as referências americanas, inclusive em relação à arquitetura, no Brasil, à época. E, a partir dessa análise, pudemos perceber paralelos com o que se via em Casa e Jardim.

Procuramos sempre nos ater às diferenças de contexto e outros aspectos que divergem - as particularidades brasileiras, culturais, sociais, econômicas -, que se refletem no desenho e na utilização da casa, para que nosso objeto não se configurasse como mera extensão do que ocorreu nos Estados Unidos. Este é um dos objetivos da tese, o paralelo entre as arquiteturas americana e brasileira.

Foi necessário ir e voltar da micro à macro escala, dos pequenos detalhes arquitetônicos - nas imagens ou textos da revista - ao contexto daquele momento em nosso país e nos Estados Unidos. ${ }^{6}$

Foram analisados a modernização brasileira nos anos 1950, o modo de vida

\footnotetext{
${ }^{3}$ Ao dizermos "linguagem moderna," nos referimos à linguagem desenvolvida pelo Movimento Moderno, na arquitetura, nos anos 1920, na Europa. Quanto à "arquitetura moderna" corresponde à arquitetura do Movimento Moderno, que se desenvolve nos anos 1920, particularmente sua vertente alemã e a arquitetura de Le Corbusier, ambas apresentadas nos CIAMs e levando - ainda que não apenas elas - à constituição do "Estilo Internacional."

${ }^{4}$ Por volta do n.54 de Casa e Jardim, de julho de 1959, já não são publicadas tantas reportagens sobre arquitetura, mas o número de artigos sobre decoração de ambientes aumenta. $\mathrm{E}$, as fotos coloridas quase que se restringem aos anúncios.

${ }^{5}$ As revistas Architectural Forum e House \& Home são as principais fontes em relação à arquitetura doméstica americana.

${ }^{6}$ A metodologia aplicada aliou a pesquisa bibliográfica à das fontes documentais.
} 
americano visto como modelo, as referências da arquitetura americana na arquitetura paulistana, entre outros aspectos.

Pois, uma evidência histórica, como um texto de revista, deve ser interpretada e para isso é necessário conhecer-se o código segundo o qual esta foi construída e pode ser percebida. Esses códigos são como distorções produzidas por espelhos e devem ser analisados para uma correta reconstrução da história. Uma leitura apenas interna da evidência não é suficiente, pois é necessário conhecer-se as referências que a ligam à realidade, a partir da qual foi construída. (GINZBURG, 2011, p.348-9)

É preciso recuperar o relacionamento entre essas evidências e o contexto em que se desdobram. "O contexto, visto como espaço de possibilidades históricas, dá ao historiador o ensejo de integrar a evidência (...)."(GINZBURG, 2011, p.356)

O poder de consumo, os novos produtos, a vontade de renovar hábitos e costumes torna esse cenário particularmente relevante para a pesquisa. Como se relaciona essa "lição de arquitetura moderna" da revista Casa e Jardim com ele?

Depois disso é necessário focar novamente nosso objeto e seus pequenos detalhes.

Trabalhando sobre um material que já foi amplamente analisado, procuramos abrir uma nova perspectiva, tentar um novo olhar. Uma nova "moldura" interpretativa que extrapola a disciplina e estabelece um "campo ampliado da arquitetura." (COHEN, 2011)

Os arquitetos são componentes deste campo, que extrapola a disciplina arquitetônica, mas não os únicos. Pois é importante levar em consideração as relações entre a arquitetura como profissão e outros elementos da sociedade, caso contrário, sujeitos importantes são desconsiderados ou colocados em posições marginais.

Ali estão também as pessoas que produzem a arquitetura, o edifício, e na disciplina, principalmente pessoas que falam sobre arquitetura. " $A$ função central da disciplina da arquitetura é fornecer os instrumentos intelectuais por meio dos quais a 'arquitetura' é valorizada. O discurso sobre esses instrumentos constitui o capital simbólico primeiro da disciplina." (STEVENS, 2003, p.236)

Ampliando o campo, não se pretende mais limitar-se à chamada cultura intelectual e artística, à disciplina stricto sensu. Procura-se entender os fenômenos arquitetônicos 
inseridos na produção cultural e do espaço habitado, ao invés de se estudarem apenas grandes obras e autores. ${ }^{7}$

Trata-se de uma redefinição do objeto de pesquisa que apresenta um novo panorama, mais abrangente, da produção arquitetônica de determinada época. Pois, a arquitetura como objeto interdisciplinar participa das transformações sociais e culturais de sua época.

Que todas estas situações arquitetônicas não reúnam a limpidez das circunstâncias canônicas, (...) uma situação de mudança produzida não tanto a partir das afirmações programáticas, mas a partir das condições materiais de produção e uso da arquitetura. " (SOLÀ-MORALES, 1980, p. $105)^{8}$

Para Calabi (2003): “(...) a história da arquitetura como a história dos edifícios e das formas teve frequentemente dificuldades de sair das próprias categorias habituais (feitas de cânones e de atribuições) e negligenciou a cidade entendida como o conjunto de edifícios (e de contrastes)."

Assim, as referências teóricas principais para esta pesquisa são as leituras críticas da arquitetura moderna de Colquhoun (2002) e Tafuri e Dal Co (1979), ${ }^{9}$ cronológicas, mas que evitam a simplificação e o simples relato da arquitetura dos "grandes mestres" e mostram sobreposições de movimentos, contradições e, principalmente, a arquitetura inserida em seu contexto histórico e suas relações com a cidade. A arquitetura como um produto de sua época. Analisam-se as motivações complexas por trás do Movimento Moderno e suas realizações.

A arquitetura do "bem viver" participa também da construção da cidade. Localiza-se na "expansão" dos bairros pesquisados anteriormente, em nosso mestrado, os bairros-jardim abertos pela Companhia City, inicialmente o Jardim América e o Pacaembu. Ou são a segunda ou terceira geração de casas construídas nesses

\footnotetext{
${ }^{7}$ Outro sinal evidente da constituição desta nova "história cultural da arquitetura" é a utilização de fontes como a revista Casa e Jardim.

${ }^{8}$ Ainda que o autor refira-se ao Modernismo Catalão, podemos estender sua observação à nossa arquitetura do "bem viver."

${ }^{9}$ No caso de Manfredo Tafuri e Francesco Dal Co, as referências estendem-se à "Escola de Veneza," como um todo. Para Donatella Calabi, em sua atual fase de pesquisa, o Departamento de História de Veneza, substitui a "história dos eventos" por outra que põe em relevo as "mudanças geográficas, econômicas, sociais, culturais (das mentalidades), na longa duração".
} 
loteamentos. E, ainda, outros subúrbios de classe média que se constituem à época. ${ }^{10}$

O mercado consumidor de arquitetura ampliara-se, passando a abranger essa classe. ${ }^{11}$ A produção de habitações aumentara de forma expressiva, assim como o número de arquitetos. O campo da arquitetura muda de escala.

Modifica-se a divisão do trabalho profissional e a relação entre o escritório de projeto e o canteiro de obras.

Procuramos também perceber essas transformações na prática profissional, o que constitui outro objetivo de nossa tese. Qual o relacionamento entre arquiteto e cliente?

Nosso objeto está profundamente imbricado a esse processo de modernização brasileiro, que acontece nesse contexto de mudanças econômicas, sociais e políticas do pós guerra, mas principalmente dos anos 1950, e de referências do modo de vida americano. São Paulo liderava esse processo de modernização e pretendia atingir também a hegemonia no campo cultural.

O "bem viver" foi possível porque existia este cenário específico e com ele se relaciona, de forma dinâmica.

\section{Arquitetura do cotidiano}

$\mathrm{Na}$ arquitetura do pós guerra, em nível internacional, vê-se o envolvimento com as práticas espaciais cotidianas. A linguagem moderna expande seu público, atinge a classe média, diminuindo a distância entre a alta cultura e o domínio da vida diária.

Segundo Avermaete (2005, p.23), pesquisas recentes sobre a cultura arquitetônica da época sugerem que as principais contribuições desse período não se relacionam aos debates entre os "mestres modernos," mas, antes, às experiências reais de arquitetura. $^{12}$

Uma mediação entre a abordagem tecnocrática e a atitude utópica da vanguarda, entre os contextos locais e o internacional.

\footnotetext{
${ }^{10}$ Ainda que não seja um dos objetivos da tese, sempre que é mencionada a localização das residências analisadas, ela é informada, assim como o nome do proprietário.

${ }^{11}$ Processo que já fora visto, ao menos de forma incipiente, em nossa pesquisa de mestrado.

${ }^{12}$ Avermaete (2005) descreve o trabalho de Candilis-Josic-Woods, mas essa análise pode ser ampliada à arquitetura doméstica moderna no pós-guerra como um todo, como uma "cultura do habitar".
} 
Como mencionamos, é a visão da arquitetura não como uma disciplina autônoma, baseada em princípios ideais, mas como algo que toca diretamente a existência humana, onde são considerados parâmetros econômicos, geográficos e sociais. $O$ regionalismo que pode ser reconhecido na maneira como a organização da paisagem revela um modo particular de habitar.

$\mathrm{Na}$ realidade que investigamos, também acontecem práticas concretas de projeto e construção. Ela abarca, ainda, o habitar ainda que, nesse caso, sob a perspectiva do discurso construído em uma revista, imbricado à questão do consumo.

Devemos ressaltar que, possivelmente, o século $X X$ foi aquele em que os arquitetos dedicaram mais tempo e energia a essas questões. O tema da casa, o interior doméstico, que já se tornara objeto de estudo e de experimentações, mereceu uma atenção sem precedentes. ${ }^{13}$

Mas, a matriz de ambas as nossas pesquisas - de mestrado e de doutorado encontra-se, na verdade, no século XIX, na casa burguesa, que se constitui na Inglaterra Vitoriana, quando, por uma série de razões, a casa "fecha-se" em torno da família, como um ninho.

John Ruskin a definiu como o lugar da paz e do refúgio, tendo a mulher a tarefa de construí-la e defendê-la.

Assim, a "domesticidade é uma construção do século XIX. O termo refere-se a todo um conjunto de ideias que foram desenvolvidas em reação à divisão entre trabalho e casa. Tais ideias enfatizavam a crescente separação entre as esferas masculina e feminina, justificada pela presunção em relação às diferenças 'naturais' entre os gêneros." (HEYNE, 2005, p.105)

Define-se o papel de cada sexo, com uma esfera doméstica, suburbana e feminina, e outra, pública, urbana e masculina.

Regulam-se as ligações pessoais internamente ao núcleo familiar, para que o espaço doméstico seja moral, além de higiênico e racional. Dessa forma, a casa torna-se um instrumento para se eliminarem os males sociais. Uma solução para os "males urbanos." Cria-se um mundo artificial e particular através da arquitetura doméstica.

\footnotetext{
${ }^{13} \mathrm{~A}$ casa extrapola os limites da arquitetura, mais do que qualquer outro programa, constituindo um autêntico campo de forças - em que nem sempre o arquiteto está presente.
} 
O movimento Arts and Crafts desempenhou um papel central nessa configuração da cultura doméstica, no século XIX, na Grã-Bretanha: ${ }^{14}$ a arte, personificada na casa, torna-se um instrumento educativo e moralizador, deve exercer uma influência benéfica, elevando espiritualmente e moralmente seus moradores. O belo é o que é apropriado.

As análises de Simmel sobre o interior doméstico, no início do século $X X$, ressaltam a força dessa cultura. Esse ambiente doméstico, contraposto à agitação urbana, tem a cidade, não apenas como sua localização geográfica, mas como seu "negativo."

Para analisar a habitação, podemos tomar de empréstimo uma ideia de Ábalos (2000), que percorre algumas casas do século $X X,{ }^{15}$ relacionadas a diversos modos de se ver e pensar o mundo e, em última análise, de se viver e de se projetar. ${ }^{16}$

A família, à qual destina-se à casa, modifica-se ao longo do século, sob vários aspectos e nas expectativas em relação ao viver. Assim, devido a essas e outras razões, a casa também se altera, implicando em diferentes abordagens por parte do arquiteto.

São maneiras diversas de habitar.

Martin Heidegger nos interroga sobre o real sentido do habitar e do construir, em "Construir, habitar, pensar." ${ }^{\text {"17 }}$ Ele reflete sobre a concepção de mundo moderna e sua fé no progresso trazido pelo futuro, que legitima as ações do presente. A partir dessa observação, o filósofo reafirma a dimensão temporal do habitar, ao lado da espacial.

O que primeiro ressalta na cabana de Heidegger ${ }^{18}$ é a recusa à representação pública, ali deve haver tranquilidade e isolamento. Essa casa existencial é o reino do homem interior. A cultura objetual que se estende pela habitação é mínima, com

\footnotetext{
${ }^{14}$ Seus princípios foram investigados e reproduzidos em sua essencialidade, disseminando-se por vários países.

${ }^{15}$ Aqui não mencionaremos todas as casas mostradas pelo autor, mas apenas três que se dirigem de forma particular a esse trabalho.

${ }^{16} \mathrm{O}$ autor faz uma simplificação, para uma melhor compreensão, ressaltando uma série de arquétipos, por seus traços mais visíveis. Porém, a realidade é muito mais complexa e cheia de matizes. A vida que "corre" dentro dessas casas é muito mais rica e incoerente do que as tentativas de normatizá-la.

${ }^{17}$ A partir de conferência dada em 5 de agosto de 1951, no Segundo "Colóquio de Darmstadt," para arquitetos envolvidos na reconstrução alemã após a Segunda Guerra Mundial. Um aspecto fundamental era a necessidade de se construírem habitações para milhões de alemães. A conferência foi transcrita no livro Vorträge und Aufsätze (Conferências e artigos), publicado em 1954.

${ }^{18}$ A casa existencialista de Ábalos (2000).
} 
móveis de família cuidadosamente conservados, objetos que marcam a presença do tempo. Não existe espaço para privacidade, nem prazer individual.

A casa é feita com materiais naturais, reforçando a ligação com o lugar, a autenticidade do habitar.

Existe na concepção doméstica de Heidegger uma nostalgia do sujeito centrado e dominante que constrói a casa ao habitá-la, que herda a propriedade e seus bens e os administra com prudência para transmiti-los aos filhos - que se constitui a si mesmo como ponte. (ÁBALOS, 2000, p.50)

Implícita, aí, está a ideia da tradição, como essa ponte que liga gerações.

O habitar existencial se erige contra a cidade moderna e seus implementos técnicos que conduzem tanto ao abuso da natureza quanto ao esquecimento da tradição; a casa é uma defesa que preserva da banalidade do cosmopolitismo. A introdução do mundo no interior da casa, através do rádio, TV, jornais, supõe uma violência.

Mas, o próprio Heidegger reconhece a impossibilidade de se viver dessa forma já nos anos 1950. Ele tem a consciência de que está apenas de férias em sua cabana da Floresta Negra.

Ao questionar a concepção de mundo moderna, o filósofo examina a casa em que o paradigma positivista ${ }^{19}$ estende-se à esfera da vida privada. Nos anos 1920, o progresso científico e a ordem são colocados à disposição do homem, nos estudos dos arquitetos modernos, a respeito da racionalização do ambiente doméstico e da aplicação do taylorismo. ${ }^{20}$ Almeja-se uma sociedade perfeita, sem conflitos, organizada pela ciência, que deseja aperfeiçoar-se progressivamente.

A concepção positivista da grande regeneração do mundo era um ponto central na doutrina do Movimento Moderno.

Mas, essa casa positivista é uma casa sem memórias, ${ }^{21}$ onde móveis e objetos são novos, modernos e eficientes. É um tipo de habitação que está profundamente imbricado no modo de produção capitalista da cidade.

\footnotetext{
${ }^{19}$ Outro arquétipo destacado por Ábalos (2000).

${ }^{20}$ Essa casa foi retratada pelo cineasta Jacques Tati, em 1957, no filme Mon oncle. Ele contrapõe os Arpel, a "família modelo," que vive na casa moderna, mecanizada, nos subúrbios, ao Sr. Hulot, o tio que não consegue compreender aquele ambiente. Ele se mostra um sujeito que vive cada experiência de maneira intensa e de forma autônoma, com sentido em si mesma, enquanto cada ação dos Arpel é cuidadosamente pensada, de acordo com um plano traçado. Os princípios tayloristas são aplicados aos menores detalhes da vida.

${ }^{21} \mathrm{E}$ o espaço é medido em metros quadrados, o espaço abstrato de que trata Heidegger.
} 
Outra casa visitada por Ábalos (2000) é a que corresponde ao "bem viver," a pragmática.

Moderna, ela constitui-se de forma plena, inicialmente nos EUA, ao final da segunda guerra, quando a tecnologia utilizada para fins militares pode transferir-se para a utilização civil. É também a casa do Good-Life Modernism. ${ }^{22}$

Como mencionamos, um de nossos questionamentos são os paralelos entre o Good- Life Modernism e a nossa arquitetura do "bem viver."23

Existe, nesta casa, uma concepção subjetiva do mundo. Cada morador tem seu espaço particular, vive suas próprias experiências que constituem sua identidade e onde procura sua realização. ${ }^{24}$ Não se liga a um projeto coletivo, como a casa positivista do Movimento Moderno.

A arquitetura, aqui, talvez ainda mais do em que outros tipos de habitação, aparece como um pano de fundo para a vida diária, para o cotidiano dos pequenos fatos e ações. Como uma dimensão repetitiva, regular, múltipla, típica.

Nessa casa, a técnica é colocada, inicialmente, a serviço da construção simples e econômica do edifício ${ }^{25}$ e, depois, do conforto e do prazer que podem ser proporcionados a seus moradores.

As máquinas já não são heroicas, representação de uma civilização moderna, que as vê como seu maior símbolo. São reais e proveem conforto: calor, frio, ventilação, isolamento térmico, acústico ou segurança.

A esfera pública penetra na casa, principalmente através dos meios de comunicação de massa, interferindo na vida familiar. Estes trazem também a dimensão do consumo.

\footnotetext{
${ }^{22}$ No caso do Good-Life Modernism, escolhemos grafar o termo em maiúsculas, com hífen, como o autor que o cunhou, Jarzombek (1991). No caso da arquitetura do "bem viver," preferimos a mesma forma de "casa do 'morar bem', entre aspas, como está no artigo de Casa e Jardim. (HUBERTO, 1958, p.52). Acreditamos que essa forma de escrever carrega o mesmo significado de algo moderno, simples, descontraído.

${ }^{23}$ Além do fato da maior parte das residências mostradas em Casa e Jardim, no período analisado, constituírem residências unifamiliares, o Good-Life Modernism está diretamente associado a esse tipo de habitação. Assim, nosso objeto de pesquisa é, basicamente, entre outras características, uma moradia unifamiliar.

${ }^{24}$ Ao contrário da casa existencialista, onde não há espaço para individualidades.

${ }^{25}$ Ao menos na versão americana.
} 
Como se vê, são muitos aspectos a serem considerados, que extrapolam a disciplina arquitetônica. Todas essas questões, presentes em um mundo cada vez mais complexo, interagem entre si, em nosso objeto de estudo.

Assim, procurando analisar as variáveis aqui mencionadas, buscamos nos aproximar e conhecer nosso objeto, a arquitetura doméstica da classe média urbana nos anos 1950, na cidade de São Paulo: a casa do "bem viver."

Inicialmente, apresentamos nossa principal fonte documental, a revista Casa e Jardim.

\section{A revista Casa e Jardim}

Em circulação até os dias de hoje, a revista Casa e Jardim teve sua primeira edição em 1953, correspondente aos meses de março e abril, tendo sido, inicialmente, bimestral. Era propriedade da Editora Monumento, empresa sediada na cidade de São Paulo.

O primeiro número da revista, em formato de $20 \times 30 \mathrm{~cm}$, tinha 72 páginas, das quais pouco mais de $8 \%$ correspondiam a anúncios. ${ }^{26}$ Esse número aumenta gradativamente na medida em que aumenta a aceitação da revista pelo público. ${ }^{27}$

A evolução da tiragem comprova essa aceitação. Inicialmente, foram impressos 50.000 exemplares, passou-se depois a 70.000, no n.32 (jan.- fev. 1957), e a 85.000, no n.46 (set.- out. 1958). ${ }^{28}$ Pode-se dizer, assim, que a revista manteve-se estável no mercado editorial, fato demonstrado pela sua duração e pela grande quantidade de anunciantes que conseguiu atrair e manter.

Casa e Jardim era impressa em off-set pela Companhia Litographica Ypiranga, que também imprimia O Estado de S. Paulo e Seleções do Reader's Digest. Em maio de 1962, passou a ser publicada pela Editora Efece, do grupo carioca Fernando Chinaglia Ltda. Em 1995, passou a fazer parte do grupo da Editora Globo, onde permanece até hoje. (PINTO JÚNIOR, 2014, s.n.p.)

A revista Casa e Jardim não apresentava, no período pesquisado, características de publicação feminina unicamente. Ela se dirigia de forma preferencial à mulher

\footnotetext{
${ }^{26}$ As principais seções do primeiro número eram: arquitetura, decoração, arte, jardim, cozinha, segundo o sumário.

${ }^{27}$ O número de páginas também variava, entre 72 e pouco mais de 100.

${ }^{28}$ Mais de $80 \%$ dos números editados estariam esgotados à altura do número 50 , havendo assinantes em várias partes do mundo. (REICHENBACH, 1950, p.4)
} 
apenas nas seções dedicadas a receitas culinárias e trabalhos manuais, localizadas na parte final da revista.

Os artigos com os temas principais - arquitetura, decoração, arte e paisagismo voltam-se a toda a família, não apenas à mulher. Localizam-se nas páginas iniciais, às vezes com continuação nas páginas finais.

Rachel Sisson, uma das antigas colaboradoras da revista, em entrevista à Machado (2007, p.33), também discorda da classificação da revista como feminina, concordando com seu caráter familiar. "É uma revista do lar, da família, com artigos legíveis, acessíveis para o leitor de classe média."

Nas cartas de leitores também as mulheres não são as únicas. Nesta seção, é interessante observar-se, também, o alcance de Casa e Jardim, através da origem das cartas. Elas provêm de várias cidades do interior de São Paulo, Minas Gerais e Paraná, entre outros locais. ${ }^{29}$

\section{O corpo editorial da revista}

O corpo editorial da revista, no primeiro número, é assim constituído: Carlos Oscar Reichenbach, diretor-presidente, Fernando Chinaglia, diretor vice-presidente, Curt Werner Reichenbach, diretor comercial, Théo Gygas, superintendente, Arnaldo Pedroso d' Horta, redator chefe, Francisco Donato, redator gerente, e llona Colos e Maria Kloss, redatoras-secretárias.

No segundo exemplar publicado, Reichenbach permanece como diretor-presidente, mantendo-se, ainda, as redatoras-secretárias, Ilona Colos e Maria Kloss, e Francisco Donato como redator-gerente. No entanto, o editor passa a ser Théo Gygas.

Esse corpo editorial varia bastante ao longo do tempo, mas sempre mantêm-se os nomes do editor e do presidente, Gygas e Reichenbach, principais responsáveis pela criação da revista, em nosso período de estudo.

Em relação a Gygas, pudemos obter informações sobre ele através de em discurso proferido pelo deputado estadual Osvaldo Santos Ferreira, em 8 de dezembro de 1961, na Assembleia Legislativa de São Paulo. Seria uma homenagem ao editor, quando de sua aposentadoria de Casa e Jardim. ${ }^{30}$

\footnotetext{
${ }^{29}$ Casa e Jardim, n. 10, set.- out.1954.

${ }^{30}$ http://www.jusbrasil.com.br/diarios/4849000/pg-6-suplemento-poder-executivo-diario-oficial-do-
} 
Ainda segundo o deputado Ferreira, a revista teria sido idealizada, orientada, paginada e executada com o auxilio de apenas uma secretária, tendo permanecido sob a direção de Gygas, sem interrupção, até outubro de 1961, quando teria se aposentado. Não é possível verificar essa informação.

Gygas teria nascido na Alemanha, em 26 de abril de 1900, e realizado seus estudos superiores na Universidade de Berlim, no curso de jornalismo e na Academia de Artes, onde realizou curso de artes gráficas. Foi colaborador da empresa cinematográfica "UFA", de Berlim, bem como de revistas de Londres e Paris.

Em 1936 veio para o Brasil, passando a dirigir, no ano seguinte, os estúdios de desenho da Empresa Época, do Rio de Janeiro. ${ }^{31}$

Em 1944, assumiu a chefia dos estúdios fotográficos e de arte da Companhia Lithographica Ipiranga, em São Paulo. Naturalizou-se em 1951 e passou a comandar as revistas da empresa, inclusive, mais tarde, Casa e Jardim.

O sucesso de Casa e Jardim fez com que a direção da Editora Monumento lançasse uma nova revista, sob o titulo "Lady", ${ }^{32}$ e cuja criação, planejamento e execução teriam sido confiados a Theo Gyges, ainda segundo o deputado Ferreira. ${ }^{33}$

Em relação a Reichenbach, este nasceu em 1907 e era filho do mestre de artes gráficas Gustav Reichenbach, que veio para o Brasil no início do século, para montar a primeira litografia do país - sistema de impressão com pedras planas muito usado na época. A empresa cresceu e depois ficou conhecida como Companhia Lithographica Ipiranga, sendo responsável por grande número de publicações.

estado-de-sao-paulo-dosp-de-08-12-1961, acesso em 04/04/2015.

${ }^{31}$ Criando para o mercado de publicidade dessa firma os primeiros cartazes de 4 folhas: gigantografia. Seria uma espécie de outdoor ampliado ponto a ponto.

${ }^{32}$ Lady é anunciada em Casa e Jardim, em várias edições, como uma nova revista feminina. Foi publicada por três anos, entre 1956 e 1959. Escritoras como Dinah de Queiroz e Cecilia Meireles teriam escrito para a revista. (DOIS AMORES, 1956, p.87)

Segundo Silva (2010, p.98), Lady apresenta mulheres já com uma dupla jornada de trabalho: além das funções domésticas, exercem uma atividade profissional. Ainda, assim, os rígidos padrões morais, a que as mulheres eram submetidas, estão presentes nas páginas da revista.

Mesmo assim, trazer essas questões - até mesmo o divórcio - para uma revista feminina, ainda nos anos 1950, pode ser considerado revolucionário.

${ }^{33}$ Após aposentar-se, Theo Gygas, que tinha como hobby a criação de cães pastores alemães, escreveu um livro sobre o tema, intitulado "O cão em nossa casa." Obteve muito sucesso, com várias edições. Foi também colaborador do jornal "O Estado de São Paulo," escrevendo sobre esse tema. Além disso, o Instituto Histórico e Geográfico de São Paulo, concedeu-Ihe a venera da Imperatriz da Independência. 
Carlos Reichenbach assumiu a presidência da empresa em $1941 .{ }^{34}$ Ele não era um amador e estava consciente das transformações por que passava a imprensa no Brasil. Havia renovação da linguagem e introdução de novas técnicas e novos padrões de apresentação gráfica.

Como empresário do ramo editorial, Reichenbach circulava na elite paulista. Nomes importantes da Faculdade de Medicina, da Politécnica e da Escola Superior de Agricultura Luiz de Queiroz foram colaboradores e articulistas de diversas de suas revistas. Essas publicações - entre elas, Seleções do Reader's Digest, Médico Moderno, Dirigente Industrial, Dirigente Agrícola e Lady - comprometiam-se com a modernidade paulista, em sintonia com a política oficial do governo. (PINTO JÚNIOR, 2014, s.n.p.)

\section{Colaboradores da revista}

Parte dos artigos de Casa e Jardim não é assinada, ${ }^{35}$ mas pode-se ter uma ideia dos colaboradores, através da coluna "Colaboraram neste Número," sempre publicada junto ao sumário. Entre eles, são sempre mencionados os autores dos projetos de arquitetura mostrados em determinada edição.

Entre os autores, podemos citar, nos artigos relacionados ao nosso tema: Henrique Alexander, Aurélio Hedvig, Rachel E. Prochnik, Liba Frydman; Alexandre França, Olga Meraviglia; Vilma Crivelli, Huberto Campobelo, às vezes assina apenas como Huberto, Regina Zonta; Dorca; G. Luckmann, Yvonne Jean, Margô, Ivy Cox Villela, José Scapinelli.

Existem informações sobre Gerhart Luckmann, que seria desenhista, serventuário da Diretoria de Turismo e Propaganda, em $1939,{ }^{36}$ e sobre Ivy Cox Villela ${ }^{37}$ - Ivy Careen Cox Vilela -, provavelmente uma dona de casa, que tinha pelo menos um filho, e vivia em São Paulo, ao menos desde 1940. Morava na Rua Estados Unidos, em 1966 e era casada com o advogado Gabriel Botelha Villela.

\footnotetext{
${ }^{34}$ A morte de Carlos Reichenbach, ocorrida em 13 de junho de 1960, é anunciada no número 66, de julho.

${ }^{35}$ Porém, percebe-se, mais ou menos a partir do número 14, que aumenta o número de artigos com autor definido.

${ }^{36}$ http://www.jusbrasil.com.br/diarios/2168287/pg-3-secao-2-diario-oficial-da-uniao-dou-de-09-031939, acesso em 05/04/2015.

${ }^{37}$ http://www.jusbrasil.com.br/diarios/4897061/pg-24-poder-judiciario-diario-oficial-do-estado-desao-paulo-dosp-de-18-11-1966, acesso em 05/04/2015
} 
Essas informações esparsas nos permitem perceber como era variado esse grupo de colaboradores, provavelmente "recrutados" entre pessoas conhecidas dos editores.

De outro colaborador, em particular, conseguiu-se obter mais informações: Ray $\mathrm{H}$. Hookway. ${ }^{38}$ Ele é apresentado, logo na primeira edição da revista, como "perito em cores", mundialmente reconhecido, que enviava dos Estados Unidos artigos exclusivos para Casa e Jardim, que seriam "aventuras colorísticas." (APRESENTAMOS, 1953, p.5) Hookway trabalhava para a Sherwin Williams, que era uma importante anunciante da revista. ${ }^{39}$

Ele explica em vários artigos, de forma detalhada, as cores primárias, as complementares e como essas deveriam ser utilizadas de forma equilibrada, o que envolveria uma concepção sofisticada de cor, ritmo e equilíbrio. Explicam-se, ainda, as cores quentes, frias e intermediarias e seus efeitos na percepção visual de um ambiente.

Deveria haver "coragem de experimentar estas cores novas e materiais," sendo possível, assim, descobrir "novas e mais agradáveis experiências de vida." (HOOKWAY, 1953, p.15)

Conseguimos dados, também, sobre Rachel Esther Prochnik, hoje conhecida como Rachel Sisson, ${ }^{40}$ uma das colaboradoras mais frequentes da revista Casa e Jardim, onde trabalhou entre 1954 e 1959. O convite para o trabalho foi feito pelo editor, Théo Gygas, a quem fora apresentada por um amigo. Gygas, para quem enviava os artigos e as imagens, foi, praticamente, a única pessoa com quem manteve contato na revista.

Sisson utilizava alguns pseudônimos, como Silvia Reis ou Ester Wit, estratégia comum na época para que, segundo ela, um mesmo nome não fosse publicado como autor de muitos artigos numa mesma edição.

Era a principal correspondente no Rio de Janeiro, apesar de não ter formação em jornalismo. Começou a escrever artigos sobre casas, ainda no último período da

\footnotetext{
${ }^{38}$ Ele aparece como autor de artigos para as edições de números 1, 5 e 11.

${ }^{39}$ A Sherwin-Williams, de origem americana, chegou ao Brasil em 1938. A empresa investiu muito em publicidade para fortalecer sua marca nos EUA e em outros países. Existem anúncios da empresa nos números $2,3,4,5,6,7,9,10,11,12,13,18,20,23$ e 29 da revista, de página inteira com fotos coloridas, sempre na contracapa ou no verso da capa.

${ }^{40}$ Localizada e entrevistada por Machado (2007), no dia 13 de julho de 2006. Ela assinava os artigos como Rachel E. Prochnik, pois, à época, era casada com o arquiteto Wit-Olaf Prochnik, também colaborador frequente da revista.
} 
faculdade de arquitetura. E, sua condição de arquiteta transparece na forma como descreve e analisa os projetos.

Sisson revela, na entrevista, que possuía liberdade para escolher os assuntos abordados. Segundo ela, de forma "bem descontraída" (MACHADO, 2007, p.42), entrava em contato com os arquitetos - a maioria, colegas de turma -, visitava as casas e escrevia os artigos, que eram acompanhados de desenhos e fotografias. Mas, sempre de maneira acessível ao leitor de classe média.

Ela tentava mostrar ao leitor como obter mais conforto e segurança em sua casa e tratava, também, de outros temas presentes em seu cotidiano, de forma clara e prática.

O fotógrafo Flávio Damm ${ }^{41}$ também trabalhou em Casa e Jardim. Fazia fotos, mas não era contratado como fotógrafo e sim como secretário de redação. Na revista, seu nome aparece como assistente editorial, mas apenas a partir de agosto de 1960.

Foi convidado por Zygmunt Damm, diretor da revista, a ajudar na sua reformulação, em substituição a Hélio Fernandes. Comprometeu-se, então, a passar uma semana por mês em São Paulo onde se reuniria com Zygmunt Damm e Théo Gygas para criarem a revista, escolhendo as matérias e assuntos a serem abordados, consultando números anteriores para se evitarem repetições.

Flávio colaborou na introdução de algumas modificações, como no formato, para acompanhar outras publicações existentes, em uma tentativa de se racionalizarem os custos.

Théo Gygas se dizia, segundo Damm, "um europeu muito conservador que se mostrou bem inseguro com as modificações introduzidas." (MACHADO, 2007, p.68) Para Gygas, fundamental era que a revista tivesse bons anunciantes. Devido a certas diferenças de ponto de vista, Flavio conta que permaneceu na revista por pouco tempo, cerca de um ano e meio. Gygas também deixou a revista nessa época, em outubro de 1961.

Estas informações a respeito da revista, apesar de esparsas, servem para se tentar compreender como e por quem a revista era produzida, a fim de que possamos analisar melhor nosso objeto.

\footnotetext{
${ }^{41}$ Damm foi entrevistado por Machado (2007) no dia 26 de julho de 2006, seguindo a indicação de Rachel Sisson. Ele trabalhava, no final dos anos 1950, como fotógrafo para a revista $O$ Cruzeiro.
} 


\section{Capítulo 1 Os anos 1950}

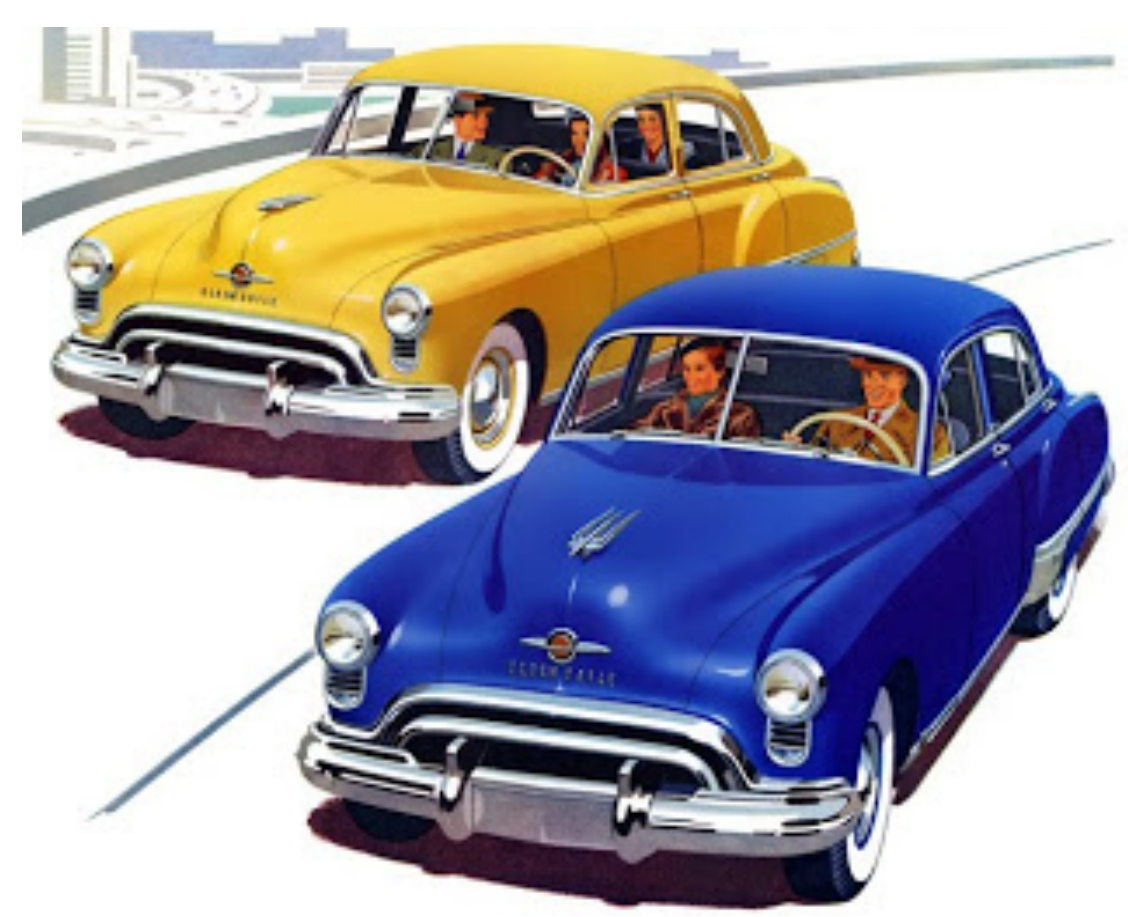

Fig. 1.1 - Movimento: característica fundamental dos 1950's.

Nesta primeira parte de nossa narrativa, procuramos conhecer esse campo que extrapola a disciplina arquitetônica, a que nos referimos.

Analisamos o contexto dos anos 1950, em nosso país - especialmente na cidade de São Paulo -, e sua modernização, com as transformações econômicas e sociais.

Além disso, procuramos compreender as referências ao modo de vida americano, desde a Segunda Guerra, ${ }^{1}$ particularmente em relação à cultura e, mais especificamente, à arquitetura.

\footnotetext{
${ }^{1}$ Ainda que já estivessem presentes, anteriormente, mesmo que não com a dimensão vista a partir dessa época.
} 


\subsection{O Brasil, no pós-guerra.}

Os anos 1950 foram uma época de grandes transformações políticas, econômicas e sociais, não apenas no Brasil. Houve grandes avanços científicos e tecnológicos e mudanças culturais e comportamentais.

Com o fim da Segunda Guerra Mundial, em 1945, o cenário internacional mostrava a divisão do mundo em dois blocos político-militares, correspondentes às duas superpotências emergentes: os Estados Unidos e a União Soviética.

Nesse cenário da Guerra Fria, os EUA usaram sua enorme força política e econômica para conter a expansão comunista e preservar espaço para o desenvolvimento capitalista.

Havia, no ar, muita tensão, devido a essa polarização, principalmente nos EUA, misturada à euforia daquela década agitada.

No Brasil, essa euforia e o otimismo estavam presentes no desejo de transformar a realidade - econômica, política, social, cultural - de um país subdesenvolvido, retirálo do atraso e constituir uma nação moderna. ${ }^{2}$ Disseminava-se esse pensamento nacionalista, de um país rumo ao progresso. Um dos símbolos maiores deste processo de modernização foi a construção de Brasília, nova capital do país inaugurada no início dos anos 1960.

No imaginário social, acreditava-se que a modernidade estava prestes a acontecer, principalmente ao adotar um padrão de vida diverso, muito próximo ao modelo consumista do capitalismo norte-americano.

Essas mudanças na configuração do modo de vida significavam uma passagem da sociedade rural, abafada pelo tradicionalismo, para o mundo da grande cidade, em busca de um futuro de progresso individual. Migraram para as cidades brasileiras, naquela década, 8 milhões de pessoas, cerca de $24 \%$ da população rural do Brasil em 1950. ${ }^{3}$

No período entre 1945 e 1964, com a aceleração dessas migrações internas e da urbanização, acontece a fase decisiva do processo de industrialização brasileiro,

\footnotetext{
${ }^{2}$ Vivemos, nessa década, os governos de Getúlio Vargas (1951-1954) e de Juscelino Kubitschek (19561961).

${ }^{3}$ MERRICK, Thomas W. "A população brasileira a partir de 1945." In: BACHA, Edmar; KLEIN, Herbert S. (Orgs.). A Transição incompleta - Brasil desde 1945. Rio de Janeiro: Paz e Terra, 1986 apud MELLO;NOVAIS, 2012, p.581.
} 
quando instalam-se os setores de tecnologia mais avançada, ${ }^{4}$ que necessitavam de consideráveis investimentos iniciais, só possíveis a grandes empresas multinacionais ou às estatais. (MELLO; NOVAIS, 2012, p.560-1) Implantá-las no Brasil era um dos principais objetivos de Kubitschek.

Foi necessária a presença mais efetiva do Estado na organização desse processo de industrialização, através de medidas que estabeleciam objetivos para as indústrias privadas e incentivos do Estado.

E também a melhoria das condições para que as empresas se estabelecessem, entre elas, do sistema de comunicações, de transportes, do fornecimento de energia, de água e da mão de obra. Tratava-se de uma necessidade urgente de modernização, através de um conjunto de mudanças quase compulsórias, devido ao projeto de Kubitschek e à conjuntura econômica mundial. Transformações necessárias nas esferas politica, social e econômica, para garantir os insumos de produção mencionados.

O principal instrumento para a execução dessa politica foi o Plano de Metas, elaborado por Kubitschek em 1956, que tinha como lema "50 anos em 5." Eram 30 metas, divididas por setores: energia, transporte, alimentação e indústria de base, elaboradas a partir de avaliações prévias.

Acelerar o processo industrial seria a reposta aos problemas estruturais e conjunturais do país, tanto para o governo Vargas quanto para o de Kubitschek. No caso do último, isso se daria através de uma "política comprometida com o capital estrangeiro." (MEYER, 1991, p.21)

A grande porta de entrada para esse capital e tecnologia foi São Paulo. ${ }^{5}$ Foram considerados nessa decisão o potencial apresentado pela metrópole e o parque industrial já existente. Este, até então voltado para a produção de bens de consumo, já sofrera transformações, a partir de 1950, com a instalação das indústrias de base, mencionadas, para fornecer bens de produção.

\footnotetext{
${ }^{4}$ Entre elas, a química, a nova indústria farmacêutica, a de máquinas e equipamentos mais sofisticados, a automobilística, a indústria naval, ou levar adiante indústrias estratégicas, como a siderúrgica, a do petróleo, entre outras.

${ }^{5} \mathrm{O}$ volume de capitais das empresas americanas, nas décadas de 1950 e 1960, é superior ao de empresas de qualquer outra procedência, sendo superior à soma dos capitais de todas as empresas europeias. Quanto aos empréstimos, em 1956, 60\% do dinheiro estrangeiro no Brasil eram de empréstimos americanos. Isso apenas para se refletir sobre como isso condicionou as relações BrasilEstados Unidos, sendo de especial importância nos aspectos relativos à metrópole paulistana.
} 
As novas indústrias instalam-se, principalmente, no $A B C$, marcando a segunda etapa da industrialização brasileira. ${ }^{6}$

Assim, uma nova fase econômica instala-se, no Brasil, a partir do governo Kubitschek (1956-1961) - o capitalismo monopolista. Caracterizou-se pela chegada maciça do capital estrangeiro ao país, pela instalação de empresas multinacionais, além de um processo de adaptação ${ }^{7}$ da burguesia à nova situação. ${ }^{8}$

Além disso, determinou ações marcantes no campo da urbanização e do urbanismo, tendo uma profunda repercussão na configuração da metrópole paulistana nos anos 1950. Com o poder politico e econômico nas mãos da burguesia industrial, reforçase a "cultura da cidade." (MEYER, 1991, p.258)

O fenômeno da metropolização é extremamente complexo, envolvendo elementos de natureza físico-espacial, econômico, social, cultural, entre outros. Já na década de 1950, a cidade de São Paulo apresenta elementos que a colocam na categoria de "metrópole moderna." Alguns desses atributos já se constituíam ao longo das décadas precedentes.

Mas, trata-se de um objeto permanentemente inacabado, "constantemente aberta à concepção," (Ibid., p.251) ${ }^{9}$ Essa abertura ao novo, ao movimento, não permitindo que se chegue a uma "forma fechada," traduz bem aquela década na cidade: "Fragmentada, simultânea, efêmera, imensurável, a metrópole desafiou e até mesmo tornou derrisórias as iniciativas do urbanismo, colocando-o na perigosa situação de tornar-se uma 'disciplina prescindível' como analisou Tafuri." (Ibid., p.281)

\footnotetext{
${ }^{6}$ A partir de 1956, através da política estabelecida pelo GEIA (Grupo Executivo da Indústria Automobilística), no contexto do Plano de Metas, a produção da indústria automobilística passa de cerca de 30.000 unidades ao ano em 1957, para 130.000 unidades em 1960. Sintomático disso, é o fato de que em 1950 circulavam na cidade 63.000 veículos a motor e em 1966 eram 415.000. (MEYER, 1991, p.279) É interessante notar que, inexistentes nos anos 1950, a partir dos anos 1960, surgem inúmeras propagandas de automóveis nas páginas de Casa e Jardim, com várias marcas e modelos.

${ }^{7}$ MOURA, Aristóteles Capitais Estrangeiros no Brasil. São Paulo: Editora Brasilense, 1960, p.8 e 210 apud MEYER, 1991, p.237.

${ }^{8}$ Ao longo da década de 1950 , o poder político passou definitivamente das mãos da aristocracia rural para as da burguesia industrial. Sua ascensão está intimamente ligada ao processo de industrialização do país, cujo arranque definitivo deu-se nos anos 1930. O final da década de 1920 é um período conturbado para o Brasil. Além da depressão que atingiu a economia mundial e causou uma crise no setor cafeeiro brasileiro, a Revolução de 1930 marca o fim da dominação da aliança formada pelas elites patrimonialistas e cafeeiras. Da nova aliança, que se tornará dominante, faz parte a burguesia industrial paulista.

${ }^{9}$ Os conceitos de metrópole apresentados por Meyer, 1991 partem dessa premissa.
} 
As narrativas sobre seu crescimento físico apresentam desde um tom triunfal até um reprovador, refletindo suas contradições e desigualdades. Pois, apesar dos benefícios trazidos pela modernização, não foram resolvidas as questões próprias de uma metrópole subdesenvolvida, com uma periferia desprovida de infraestrutura, equipamentos públicos e transporte adequado. ${ }^{10}$

As autoestradas - Via Anchieta, Via Anhanguera e Via Dutra - tiveram papel fundamental no estímulo ao desenvolvimento suburbano - com a constituição dessa periferia - e à industrialização. Acompanhando esses eixos, e também os ferroviários, houve expressiva ocupação por residências operárias, de que o sistema econômico-industrial necessitava. ${ }^{11}$

Periferia e centro são espaços complementares de que o capital industrial necessita. Assim, em contrapartida a essa expansão horizontal, acontece o crescimento vertical e o adensamento do centro da metrópole, constituindo-se, ali, novas funções. Mas, a compactação horizontal periférica é mais intensa do que a verticalização da área central.

Várias funções - trabalho, serviços e lazer - marcam a presença de grande número de pessoas na área central, sendo o comércio a mais característica. Com a ampliação do setor terciário, acontece um aumento expressivo da classe média e também de um novo conjunto de demandas: infraestrutura, transporte de massa, equipamentos sociais, circulação de veículos e estacionamento na área central.

Ali, ao lado do edifício de apartamentos, ${ }^{12}$ surge um novo programa funcional, bastante complexo: o "edifício-conjunto." Com ruas internas que seguem até as calçadas públicas, articulando cidade e edifício, e espaços para múltiplas atividades - comércio, restaurantes, escritórios, cinemas, garagens.

Um desses edifícios é o Conjunto Nacional, de David Libeskind, de 1955, emblemático da mudança de atividades tradicionalmente localizadas no centro,

\footnotetext{
${ }^{10}$ Era necessário integrar esses $270 \mathrm{~km}^{2}$ acrescentados no período 1930/1954, produzidos segundo um padrão periférico e especulativo, fornecendo-lhes os "atributos urbanos mínimos," bastante onerosos. E, também enfrentar os interesses do capital imobiliário que atuava nessa expansão periférica. (MEYER, 1991, p.246)

${ }^{11} \mathrm{O}$ "rebatimento espacial do crescimento populacional, entre as décadas de 1940 e 1960, foi maior nos 'arredores' do que na 'cidade'": $364 \%$ contra 171\%. Na média, o aumento da população foi da ordem de 207\%. LANGENBUCH, Jurgen Richard A estruturação da Grande São Paulo: Estudo de Geografia Urbana. São Paulo: Biblioteca Geográfica Brasileira, 1971, p.251 apud MEYER, 1991, p.15.

${ }^{12}$ O prédio de apartamentos é um dos marcos da verticalização central. Sua produção, nos anos 1950, utilizando a linguagem do Movimento Moderno, é emblemática. Destacam-se os edifícios COPAN, de Oscar Niemeyer (1951-2), Nações Unidas, de Abelardo de Souza (1953), Pauliceia e São Carlos do Pinhal, de Jacques Pilon e Giancarlo Gasperini (1956).
} 
como as bancárias, para a Avenida Paulista. É o início da substituição dos palacetes por edifícios modernos.

\subsubsection{Transformações sociais: a formação de uma sociedade de consumo}

Além da consolidação da estrutura produtiva brasileira, com a instalação da indústria pesada, e da organização de setores importantes como o financeiro, comercial e de comunicações, as décadas de 1950 e 1960 podem ser consideradas o momento fundamental na estruturação da nova classe média urbana, em São Paulo, e em outros grandes centros.

Entre as transformações sociais que ocorrem, as interferências da família passam a ser menores e nela já está presente o individualismo. A vida familiar não era mais "governada pelo passado, pela tradição, senão que pelo futuro, pela aspiração à ascensão individual, traduzida antes de tudo pela corrida ao consumo." (MELLO; NOVAIS, 2012, p.605)

Gostos, preferências, valores, comportamentos, ditos cosmopolitas, passam a pontuar a pauta de discussões destes moradores e a orientar a ação destes sujeitos sociais: o hábito de barbearem-se várias vezes na semana, de morarem em apartamentos em vez de casas, de realizarem leitura semanal de revistas, de gozarem de férias, de consumirem determinadas marcas, de se posicionarem a favor do biquíni e do divórcio e a nos revelar aspectos de integração a essa nova ordem mundial, moderna e capitalista em contraposição àquele mundo rural, arcaico, fundamentado na posse da terra e na agricultura de exportação. (MARTINI, 2011, p.35)

$\mathrm{Na}$ classe média, em especial, procuram-se utilizar todas as oportunidades de ascensão social abertas pela expansão da grande empresa privada ou estatal e pela ampliação da administração pública. ${ }^{13}$ "Através da educação dos filhos persegue-se tenaz e sistematicamente a subida de renda e a elevação na hierarquia do trabalho." (MELLO; NOVAIS, 2012, p.589)

Pois, as diretorias, gerências e chefias vão se especializando e exigindo novos profissionais com educação superior. Além da valorização do engenheiro, surgem as

\footnotetext{
${ }^{13}$ No setor produtivo estatal, constitui-se uma alta burocracia de diretores, gerentes, chefes, etc. E na administração pública, a figura do técnico vai ganhando importância. (MELLO; NOVAIS, 2012, p.595)
} 
figuras do administrador de empresas - especializado em produção, em marketing, em finanças, etc. - e do economista. ${ }^{14}$

O desenvolvimento, a industrialização acelerada e a urbanização rápida rompem a relativa homogeneidade da classe média. Surge uma camada de técnicos, ligados a grandes empresas, públicas ou privadas, na cúpula. Grande parte dos pequenos proprietários também sobe em direção à massa de pequenos e médios empresários, da indústria e dos serviços. (MELLO; NOVAIS, 2012, p.600) A distância social entre a classe média alta e a baixa aumenta. Essa era a classe B para o IBOPE, ${ }^{15}$ na época.

$\mathrm{Na}$ sociedade, como um todo, existe também uma heterogeneidade crescente, refletindo, entre outros aspectos, as transformações econômicas em curso no país.

$\mathrm{Na}$ base do mercado de trabalho, na classe $\mathrm{C},{ }^{16}$ estão os trabalhadores comuns, migrantes rurais e citadinos pobres. Depois, a camada de funcionários especializados, que amplia-se devido ao crescimento das grandes empresas. Seu nível de renda aproxima-o da classe média.

E, no topo da sociedade urbana, está um conjunto pequeno de capitalistas de maior porte, a classe $A{ }^{17}$

Para o instituto, existia uma relação direta entre a renda mensal de uma família e seus hábitos de consumo. $E$, as variações nesses hábitos apontavam os movimentos da sociedade.

\footnotetext{
${ }^{14}$ São criadas escolas de administração de empresas e de propaganda; e revistas especializadas que difundem os padrões americanos de gestão.

${ }^{15}$ As pesquisas de opinião pública do IBOPE - primeira empresa de opinião pública a se instalar no país e na América do Sul -, realizadas no Brasil a partir da década de 1940, constituem rica fonte documental para se estudar o comportamento e o cotidiano dos moradores dos grandes centros urbanos brasileiros.

${ }^{16}$ Para o IBOPE. Martini (2011, p.21) lembra que, ao se referir a classe social, o instituto, na verdade, alude a estrato social, categoria que define pessoas ou agrupamentos humanos, a partir de algumas características mensuráveis - no caso a renda -, conduta semelhante ou por atitudes ou opiniões comuns. Esses agregados não poderiam ser confundidos com classes sociais, já que reúnem grupos sociais sem participação direta no processo da produção (profissionais liberais, funcionários públicos) e parcelas de trabalhadores, da indústria, comércio e bancos, entre outros, que não se consideram "proletários", recusando tal identificação.

${ }^{17}$ O aumento da inflação, do custo de vida e, consequentemente, dos salários, nos anos 1950, obrigou o IBOPE a redefinir, por diversas vezes, sua classificação para as classes sociais. Mesmo o número de categorias variava. O entrevistador levava também em consideração, na definição da classe social do entrevistado, a profissão do chefe da família que, segundo o instituto, poderia influir mais nos hábitos de alimentação do que a própria capacidade econômica. Outro item considerado era a localização da casa do entrevistado.
} 
Constituía-se um novo modo de vida - moderno e urbano -, para parte da população brasileira, moradora dos grandes centros. Tudo isso foi se consolidando ao longo da década. Entre outros aspectos, o novo padrão de vida caracterizava-se pelo consumo de novos produtos, disponíveis após a guerra: o automóvel, a televisão, o aspirador de pó, a enceradeira, a geladeira e centenas de outros, frutos do capitalismo industrial.

O ideal de modernização era visto, por grande parte da população, como a elevação do padrão de vida, através do consumo, buscando significados e valores na posse de mercadorias.

Construiu-se a imagem desses utensílios e aparelhos domésticos como essenciais à vida moderna. Estava presente a ideia de que o status social do indivíduo era medido pelo consumo.

Elevação do padrão de vida significa fundamentalmente conforto doméstico, direito de possuir tudo aquilo que proporciona bemestar a uma família, isto é, aquele sem número de utilidades domésticas que a vida moderna, especialmente nas grandes cidades, tornou indispensáveis e transformou em símbolos do nível de vida. (FEIRA NACIONAL..., 1959, p.84)

Aos poucos, esses novos valores passam a orientar as relações sociais nos grandes centros, pois o consumo não era homogêneo no país. Riqueza e pobreza estavam concentradas em determinadas áreas.

Mas, a introdução desses novos produtos no cotidiano de homens e mulheres foi lenta e gradual, à medida em que se formava um mercado de consumo para eles.

Muitas novidades eletrodomésticas, como o ferro elétrico, o fogão a gás, panelas, de pressão, chuveiro elétrico, liquidificador, batedeira, geladeira, aspirador de pó, enceradeira, torradeira, máquina de lavar roupas, rádio, vitrola hi-fi, som estereofônico, TV.

Além disso, houve a introdução dos alimentos industrializados. Os enlatados, como o extrato de tomate, latas de ervilha, palmito, milho, leite condensado, leite em pó, creme de leite, entre outros. Linguiça, salsicha, presuntada e outros embutidos.

Cigarros com filtro, maior oferta de refrigerantes, sorvetes industrializados. Os hábitos de limpeza e higiene pessoal também se transformam, com a introdução de 
novos produtos. ${ }^{18}$

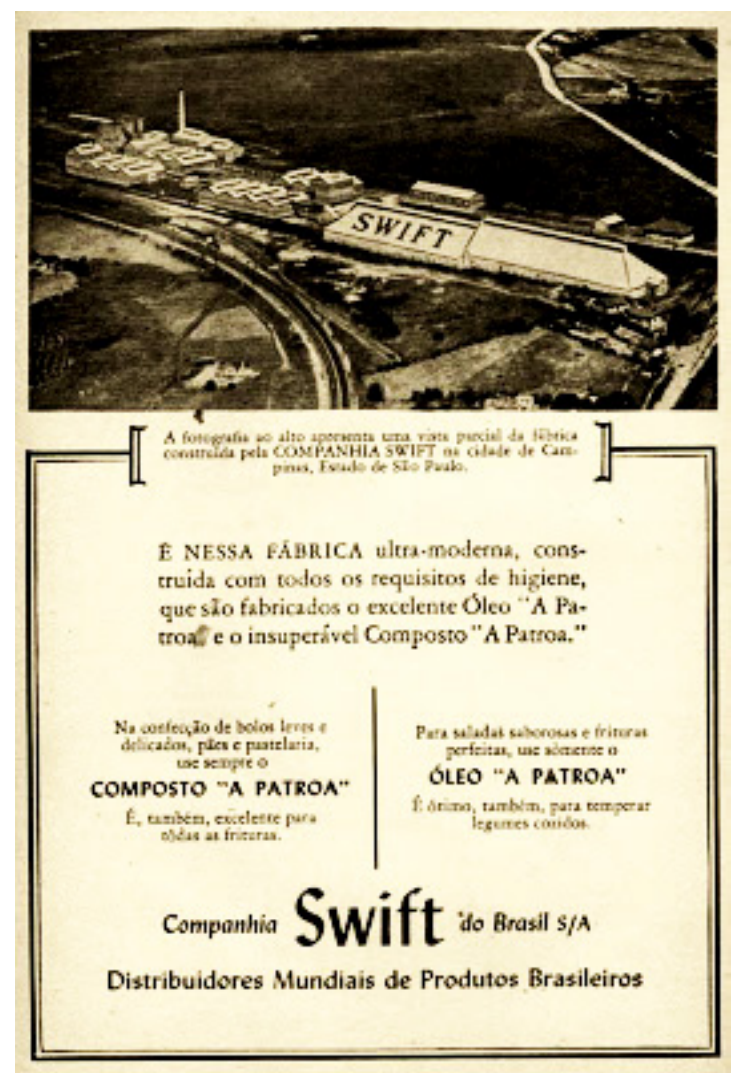

Fig. 1.2- Anúncio da revista Reader's Digest, dez.1942.

Consolidava-se a sociedade urbano-industrial, fortalecia-se o mercado consumidor e desenvolvia-se o setor terciário. Assim, nos anos 1940 e 1950, podemos falar na emergência da sociedade de consumo ${ }^{19}$ no Brasil. Caracterizando-se muito mais pela incipiência do que pela sua amplitude. E conectando-se ao mesmo processo em nível mundial. ${ }^{20}$

\footnotetext{
${ }^{18}$ O detergente, sabão em pó, bom bril, desodorante, shampoo, condicionador, absorventes femininos, cosméticos. E ocorre também a difusão nas camadas populares do uso da escova de dentes e do creme dental.

${ }^{19}$ A sociedade de consumo envolve, antes de tudo, o desejo de se adquirir o luxo, o supérfluo, sendo marcada pela constante insatisfação, onde uma necessidade satisfeita gera outras necessidades, num ciclo contínuo. (MARTINI, 2011, p.20)

${ }^{20}$ Emblemático desse processo, já em estágio avançado, é a realização da UD, Feira Nacional de Utilidades Domésticas, no início da década de 1960, patrocinada pela Federação das Indústrias do Estado de S. Paulo. Apresentando os produtos aos comerciantes e aos consumidores e tentando expandir o mercado interno brasileiro. A partir de CONFORTO..., 1959, aparecem vários artigos sobre o evento, que aconteceria em março de 1960, no Ibirapuera. Existem textos e propagandas da feira nos n.54, jul. 1959; n.55, ago.1959; n.56, set.1959; n.57, out.1959; n.58, nov.1959; n.62, mar. 1960. No n.64, maio 1960, comentários após sua realização.
} 


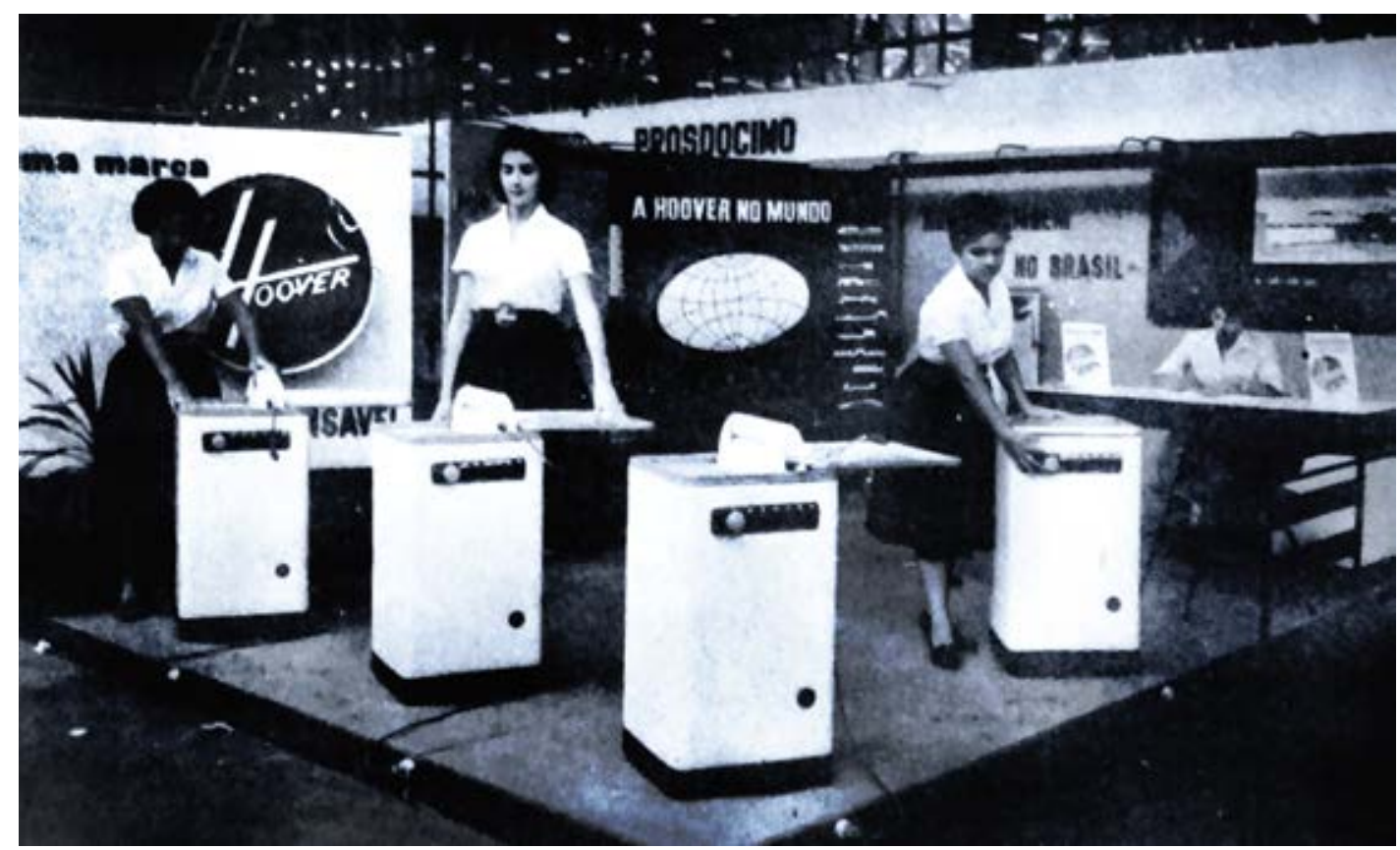

Fig. 1.3- Exposição de produtos na ud.

\section{feira nacional de utilidades domésticas}

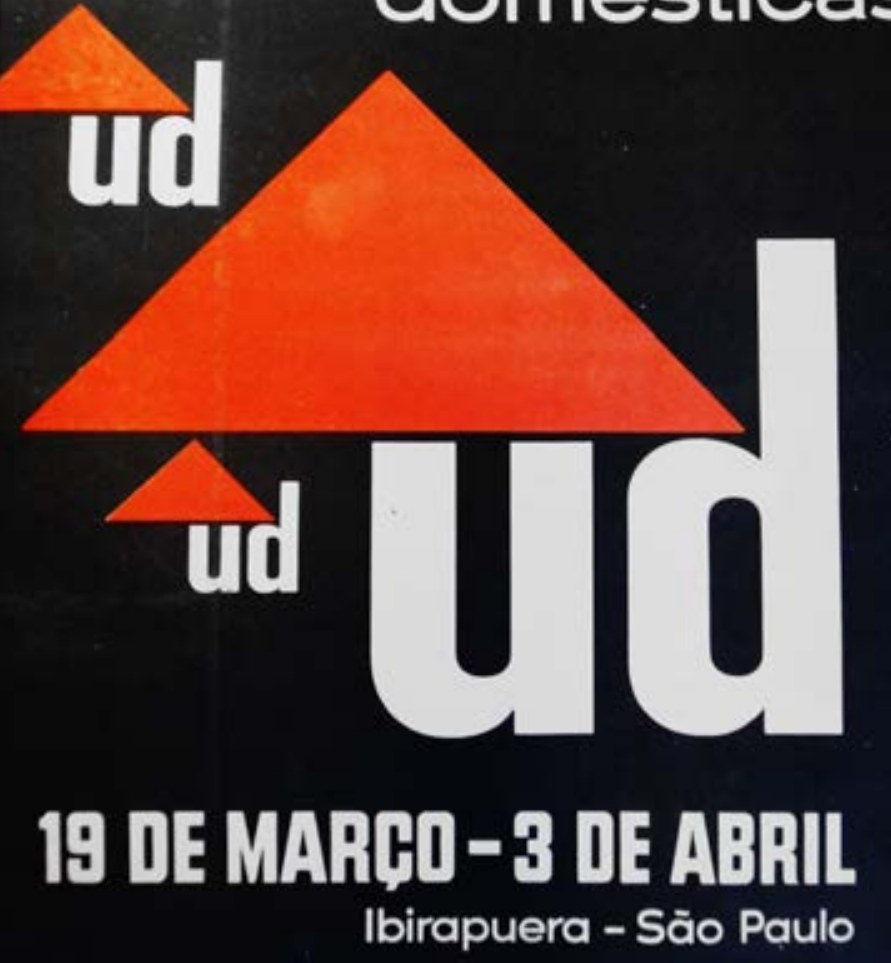

Fig. 1.4 - Cartaz da ud. 
A indústria moderna funciona hoje em função do bem-estar coletivo. A produção em massa determina, como condição de sobrevivência econômica, um consumo em escala cada vez maior, obrigando a uma modificação dos padrões clássicos da economia. (...) Hoje, produzindo em série, é preciso trabalhar para muitos, pois só o consumo em escala crescente garante o funcionamento das empresas industriais. (FEIRA NACIONAL DE..., 1959, p.81)

Para a formação do mercado para essa produção crescente, um fator fundamental foi a ampliação do crédito para as classes menos favorecidas. ${ }^{21}$

A difusão desse tipo de vida moderna deu-se, inicialmente, entre as camadas médias e altas, situadas nos grandes centros urbanos brasileiros e, posteriormente, pela força dos meios de comunicação - rádio e televisão- para as classes menos privilegiadas. A mídia mostrava, através de imagens e discursos, os novos produtos de uso cotidiano como sinais de progresso, de modernidade e da elevação do padrão de vida.

Elevação do padrão de vida - eis uma palavra de efeitos mágicos no mundo contemporâneo. Em todos os quadrantes da terra, povos civilizados, povos ainda em estágio semisselvagem clamam a melhoria das condições de existência, pelo direito de ganhar mais para gastar mais, ou seja, para viver melhor. Não se compreende mais o mundo sem que haja conforto e bem-estar para todos. (FEIRA NACIONAL..., 1959, p.84)

Assim, estimulados pela oferta de produtos, esses moradores dos grandes centros urbanos deixaram-se seduzir pelo estilo de vida americano, que promovia a esfera da vida privada e o consumo ininterrupto como ícones da modernidade. Um “(...) apelo à emoção e à mobilização do inconsciente, levando o indivíduo a acreditar que, por meio do consumo, ele se livraria de sua condição subalterna, uma vez que a ascensão social se media agora pelo consumo." (MARTINI, 2011, p.76)

\subsection{0 modelo de vida americano}

\footnotetext{
${ }^{21}$ A industrialização e a urbanização multiplicaram muito as oportunidades de investimento à disposição do empresariado nacional. O sistema bancário, por exemplo, conheceu uma grande expansão e passou, no final da década de 1950, a financiar ativamente o consumo, especialmente de bens duráveis de valor mais elevado - automóveis, TVs, geladeiras.
} 
O estilo de vida americano foi uma imagem cuidadosamente construída, que teve forte impacto sobre a sociedade brasileira. A presença cultural dos EUA envolveu modelos de comportamento, formas de conhecimento científico e técnico, presença nos veículos de comunicação de massa e expressões artísticas.

Essa presença remonta ao menos à época da Segunda Guerra Mundial, quando reforçou-se a "política de boa vizinhança" ${ }^{22}$ entre os Estados Unidos e os demais países americanos, que envolvia o apoio aos aliados no conflito. Essa política contava com medidas econômicas e políticas, além do intercâmbio entre as culturas americana e brasileira.

O governo Roosevelt criou, em agosto de 1940, um bureau para coordenar essas ações americanas envolvidas nas relações econômicas e culturais com a América Latina - o Office of the Coordinator of Inter-American Affairs. ${ }^{23}$ Chefiado por Nelson Rockefeller, ${ }^{24}$ era uma agência ligada à segurança nacional dos Estados Unidos, parte do esforço de preparação para a guerra, vista como inevitável. ${ }^{25}$

A região incorporou-se ao mercado norte-americano, contribuindo para a máquina de guerra, através, entre outras medidas, da compra de excedentes de produção e materiais estratégicos latino-americanos. ${ }^{26}$

Fazia parte dessa tática, ganhar a confiança dos lideres políticos e militares brasileiros, para a cooperação nos planos dos EUA, entre eles a criação de bases no território brasileiro, principalmente no Nordeste.

No entanto, os maiores esforços foram no campo da informação, em uma operação complexa de propaganda através dos meios de comunicação de massa. ${ }^{27} \mathrm{~A}$ cultura era considerada estratégica, como os demais produtos.

\footnotetext{
${ }^{22}$ Essa influência americana não era nova, talvez apenas tivesse uma escala muito maior, isso em nível mundial. Essa questão já estava colocada na "Política de Boa Vizinhança", pensada pelo presidente Herbert Hoover, eleito em 1928, que mencionou o "good neighbor," política e denominação adotadas por Roosevelt em 1933. Sobre esse assunto, ver: ATIQUE, Fernando Arquitetando a "Boa Vizinhança": a sociedade urbana do Brasil e a recepção do mundo norteamericano. Tese de Doutoramento. São Paulo: Faculdade de Arquitetura e Urbanismo, Universidade de São Paulo, 2007.

${ }^{23}$ Havia um Comitê de Coordenação no Brasil, no Rio de Janeiro, e uma agência do bureau em São Paulo.

${ }^{24}$ Rockefeller já tinha um plano com medidas políticas e econômicas para a América Latina, a fim de impedir a influência dos países do Eixo na região, controlando o antiamericanismo por via pacífica.

${ }^{25} \mathrm{Na}$ época, os EUA ainda não haviam entrado na guerra, o que ocorreria apenas no final de 1941.

${ }^{26}$ Grande parte dos materiais estratégicos necessários à guerra era encontrada na região. Um acordo de 1941 estabelecia o compromisso do Brasil vender apenas aos EUA toda a produção desses materiais.
} 
Wiener ${ }^{28}$ (s.d., p.13-14) mostrava-se otimista em relação à integração cultural entre Brasil e Estados Unidos: "Quanto a mim, é com grande satisfação que antevejo, na grande era arquitetural americana que desponta, a colaboração futura dos meus colegas daqui e dos Estados Unidos."

Em relação à arquitetura, uma ação americana que deve ser destacada é a exposição Brazil Builds, ocorrida em 1943, no MoMA, em Nova York, mostrando exemplares da arquitetura moderna brasileira. $O$ departamento de arquitetura do museu vinha discutindo a possibilidade de uma exposição sobre o tema desde 1939, mas, apenas em 1942, os preparativos iniciaram-se, logo após a Conferência do Rio, em janeiro de 1942, que trouxe a importância estratégica do Brasil ao front de discussões politicas.. (QUEZADO DECKKER, 2001, p.112)

Fomos, em parte em uma missão de boa vontade, e, em parte, para investigar a avançada arquitetura moderna, cujas fotografias vinham chegando a esse país há anos. ${ }^{29}$

Rockefeller também esteve no Brasil, em 1942, para inspecionar o programa e estimular suas atividades, como o trabalho com a imprensa. ${ }^{30} \mathrm{~A}$ estratégia incluía a publicação de brochuras, panfletos e revistas. A mais importante era Em Guarda, no estilo da Life Magazine, publicada em português, espanhol e inglês, veiculando uma imagem dos Estados Unidos como grande defensor da democracia nas Américas. ${ }^{31}$

\footnotetext{
${ }^{27}$ O total de recursos gastos pelo bureau em 6 anos de atividade foi de 140 milhões de dólares, aproximadamente. Além de empregar 1100 pessoas nos EUA e 200 no exterior, havia cidadãos americanos voluntários. (MOURA, 1986, p.23) Entre os funcionários, estavam muitas pessoas de confiança do coordenador, como executivos de grandes agências de publicidade americanas.

${ }^{28} \mathrm{O}$ arquiteto Paul Lester Wiener, que trabalhara com Lúcio Costa e Oscar Niemeyer, no Pavilhão Brasileiro, na Feira de Nova York, em 1939, e desde então atuara como professor visitante na Universidade Federal do Rio de Janeiro, foi a principal fonte de informações sobre a arquitetura brasileira, quando da organização da exposição Brazil Builds, realizada em 1943. (QUEZADO DECKKER, 2001, p.111-112)

${ }^{29}$ GOODWIN, Philip. Modern Architecture in Brazil. In: WILDER, Elizabeth (Ed.) Studies in Latin American Art: Ata da Conferência realizada no Museu de Arte Moderna, Nova York, 28 a 31 maio 1945. Washington, American Council of Learned Societies, 1949, p.89 apud QUEZADO DECKKER, 2001, p.111.

${ }^{30}$ A imprensa e a propaganda eram consideradas tão importantes que havia uma Divisão de Imprensa e Publicações no Office, integrada por profissionais oriundos dos grandes jornais e agências de noticias americanas. Entre as medidas adotadas, além das tradicionais formas de subsídio aos jornais e revistas, facilitavam-se as licenças de exportação de papel para os jornais favoráveis àquele país.

${ }^{31}$ Outra revista importante foi Seleções do Reader's Digest, cujo público alvo era o brasileiro da classe média urbana, na divulgação do American Way of Life. Com tiragem mundial de 5 milhões de exemplares (TOTA, 2000, p.59), foi lançada no Brasil na primeira metade de 1942, quando chegaram também a Coca-Cola e o sorvete Kibon.
} 
Outro campo fértil para o programa americano eram os filmes. Grande parte de seu material vinha pronto de Hollywood e os estúdios adequavam-no à audiência latinoamericana, para não ser transmitida uma imagem ruim dos Estados Unidos ou dos países da América Latina. ${ }^{32}$ Mas, também eram realizados documentários e cinejornais sobre os EUA e América Latina e filmes em português, distribuídos pelo bureau. ${ }^{33}$

Também eram patrocinadas turnês de artistas hollywoodianos à região e de artistas latino-americanos aos EUA, que passaram a trabalhar para os grandes estúdios. Os artistas americanos cooperavam com seu governo, colhendo informações para orientar suas ações.

É ao mesmo tempo estimulante e tranquilizador para as criaturas, nestes dias de pânico e desconfiança internacional, conhecermos definitivamente quem são os nossos verdadeiros amigos. Nós, nos Estados Unidos, sabemos que o Brasil é nosso amigo. (...) Penso que nós nos Estados Unidos, estamos plenamente convencidos de que não somos perfeitos. Não temos ilusões raciais nem de superioridade cultural. (FAIRBANKS JÚNIOR, 1941., s.n.p.)

Além dessas, outra forma de atuação era o rádio, que poderia alcançar um público amplo, de todas as camadas sociais. Eram transmitidos programas americanos a partir de emissoras locais ou dos EUA. ${ }^{34}$

Mas, apesar da presença da música americana no Brasil, esta foi uma das manifestações culturais que mais resistência manteve a esse processo. Várias canções dos anos 1930 e 1940 traziam mensagens criticando a americanização da música popular.

Havia ainda intercâmbio de técnicos entre o Brasil e os EUA. Aqueles que visitavam o país faziam levantamentos das potencialidades dos nossos recursos naturais e

\footnotetext{
${ }^{32}$ Não se deve esquecer a criação do personagem Zé Carioca, por Walt Disney, que fez grande sucesso no Brasil.

${ }^{33}$ Patrocinavam-se, também, sessões de cinema no Brasil, até mesmo onde não havia energia elétrica. Houve, ainda, a colaboração do DIP - o Departamento de Imprensa e Propaganda - do Brasil, que desejava consolidar a imagem de Vargas junto à opinião pública.

${ }^{34}$ Divulgavam-se informações para várias estações brasileiras e preparavam-se programas musicais, esportivos, representações teatrais e noticiários, entre eles o Repórter Esso, iniciado em 1941, um ícone do rádio brasileiro por muitos anos.
} 
mesmo da presença de imigrantes alemães e italianos, principalmente no sul do país. ${ }^{35}$

Como lembra Tota (2000, p.92), havia o esforço para se combater a expansão do Eixo, mas também lançaram-se as bases para a exploração econômica sistemática da América Latina, especialmente do Brasil, após a guerra.

Ainda durante o conflito, tentava-se desenvolver um mercado consumidor para os produtos americanos, estimulando-se centenas de empresas daquele país, entre elas a Ford, General Electric e General Motors, a colocar anúncios de seus produtos nos jornais e revistas da América Latina. Mesmo sem ter o que vender, pois as fábricas estavam produzindo materiais bélicos. Esses anúncios explicavam a escassez durante a guerra, com a necessidade de sacrifícios, para se garantir a abundância no pós-guerra.

A ideia dos Estados Unidos como modelo era fundamental nesse programa americano. Uma "conquista do coração" e não militar, como pretendiam outros órgãos do governo americano.

Mas, esse processo de aproximação foi de barganha constante, a fim de serem obtidos benefícios econômicos, políticos e militares. O governo Vargas alcançou, por exemplo, acordos com os Estados Unidos para a construção da siderúrgica de Volta Redonda, em 1941, fundamental para a arrancada da industrialização brasileira. ${ }^{36}$ Ainda assim, o programa do bureau não era totalmente aceito pelo governo do Brasil.

Esse esforço diminuía, na medida em que havia a percepção da vitória dos aliados na guerra.

\subsubsection{A hegemonia americana no pós-guerra}

No entanto, após a Segunda Guerra Mundial, os esforços americanos em relação à politica externa foram redobrados, em dois "fronts" - o político e o econômico.

\footnotetext{
${ }^{35}$ A implantação de escolas de inglês era outra estratégia. A União Cultural Brasil-Estados Unidos foi criada em 1938. Difundindo a língua e incluindo-a no currículo oficial, tentava-se afastar a forte presença do italiano e do alemão.

${ }^{36} \mathrm{O}$ concreto armado se desenvolveria e se popularizaria de forma plena no Brasil, apenas a partir da criação dessa siderúrgica.
} 
Os Estados Unidos, a fim de manter sua hegemonia econômica, política e cultural, precisavam conter a expansão comunista e preservar espaço para o desenvolvimento capitalista.

Assim, apesar dos programas existentes durante o conflito terem sido bastante reduzidos no imediato pós-guerra, manteve-se o esforço para apresentar uma boa imagem dos EUA ao resto do mundo. A política cultural e a política externa passam a ter um único objetivo. ${ }^{37}$ Várias medidas foram tomadas em uma crescente campanha para neutralizar os efeitos da propaganda anti-Estados Unidos. ${ }^{38}$

O presidente Eisenhower criou, em 1953, a United States Information Agency (USIA), com o objetivo de persuadir os vários países a seguirem a liderança dos EUA, opondo-se à expansão do comunismo.

Tentava-se vender a América e seu modo de vida, utilizando-se as técnicas de propaganda, para demostrar como a livre iniciativa e o American way of life eram melhores do que a contrapartida comunista. Apresentava-se o "espírito da América," uma imagem da vida e da cultura americanas. (HAINES, 1989, p.161) Seu poder de sedução era embalado por imagens coloridas, do cinema e das revistas.

Além da Europa e Ásia, as administrações de Harry Truman e de Dwight Eisenhower não negligenciaram a América Latina e, especialmente, o Brasil. Houve grande empenho para a preservação da região como mercado para a produção industrial e para os investimentos privados americanos, que incluíam a exploração das reservas de matérias primas, como petróleo e minerais estratégicos.

Era uma espécie de continuidade do que foi feito durante a guerra, quando preparou-se esse mercado para sua posterior exploração.

Mas, tentava-se, sempre, afastar a imagem de intromissão em assuntos internos brasileiros. Pois, desconfiava-se do interesse americano e percebia-se que as questões brasileiras sujeitavam-se aos interesses do capitalismo americano.

\footnotetext{
${ }^{37}$ O presidente Truman transfere os programas de informação e os culturais do Office of War Information (OWI) e do Office of the Coordinator of Inter-American Affairs (OCIAA) para o Departamento de Estado, o United States Information Service (USIS)

${ }^{38}$ Em 1948, o congresso americano aprovou a Smith-Mundt Act, definindo como o governo deveria lidar com a diplomacia, através de programas de informação e culturais. Estes seriam novos instrumentos de politica externa em tempos de paz. O Smith-Mundt Act institucionalizou a Voz da América e criou novos programas de intercâmbio. O objetivo era contrapor-se à propaganda soviética e vender a América ao mundo.
} 
No entanto, havia a percepção de que era necessário o apoio americano para reafirmar a posição do Brasil como nação mais importante da América do Sul - a maneira como o país se enxergava.

Também era necessário enfraquecer o nacionalismo econômico e o controle estatal, para se chegar a um clima favorável aos negócios americanos. ${ }^{39}$

A questão da exploração petrolífera é emblemática, nesse sentido. Desde 1938, toda a atividade petrolífera passara, por lei, a ser obrigatoriamente realizada por brasileiros e fora criado o Conselho Nacional do Petróleo (CNP). Porém, o governo Dutra era contrário à exploração estatal dos recursos petrolíferos, assim como grande parte da imprensa, defendendo a exploração por companhias estrangeiras. (SODRÉ, 1966, p.456)

Enormes recursos publicitários teriam contribuído para essa posição, ${ }^{40}$ mostrando o controle que as agências de publicidade estrangeiras ${ }^{41}$ exerciam sobre a imprensa brasileira, na defesa dos capitais estrangeiros. ${ }^{42}$

Washington intensificou, ainda, a dependência financeira do Brasil em relação aos EUA e influenciou as decisões governamentais na alocação de recursos.

A parceria no campo político, para manter o comunismo distante, não era tarefa tão difícil, pois o Brasil sempre fora o parceiro mais próximo dos EUA na América Latina. E, aproveitando a experiência acumulada durante o conflito, foi instituído um maciço programa cultural e de informação para o Brasil. ${ }^{43}$ Foram aproveitados canais

\footnotetext{
39 Técnicas de negócios e comércio americanas foram introduzidas no Brasil, além de novas tecnologias.

${ }^{40}$ É interessante relatar que a McCann Erickson, com sede em Nova York, esteve em grande evidência em novembro de 1957, quando ocorreu um inquérito parlamentar para apurar as atividades antinacionais dos trustes do petróleo no Brasil $\mathrm{Na}$ época, a agência distribuía anualmente 300 milhões de cruzeiros em publicidade de diversas empresas americanas instaladas no Brasil. Sua principal cliente era a Standard Oil Company, aqui chamada Esso Standard do Brasil, cuja publicidade era dirigida apenas aos órgãos de imprensa contrários ao monopólio estatal do petróleo. Novos rumos, Rio, 7 de setembro de 1962 apud Sodré, 1966, p. 468.

${ }^{41}$ A JW Thompson foi a primeira agência de publicidade internacional a chegar ao Brasil, ainda durante a crise econômica de 1929. Seria a pioneira, no país, na introdução da fotografia nos anúncios, na realização de pesquisas de mercado e em várias atividades na televisão.

${ }^{42}$ Esse confronto teve sua contrapartida no financiamento do jornal carioca $A$ Última Hora pelo governo Getúlio Vargas, recém eleito. Em resposta, foi montada uma grande campanha antinacionalista através das grandes agências de publicidade.

43 Já em 1950, os dois países haviam assinado um acordo cultural bilateral que permitia que cada pais estabelecesse institutos culturais, escritórios de informação, bibliotecas e film centers no território do outro. Os Estados Unidos aumentaram assim, suas atividades culturais no Brasil. (HAINES, 1989, p.164)
} 
tradicionais, como a própria embaixada, e estabeleceram-se - ou restabeleceram-se - conexões entre os meios de comunicação, universidades, institutos culturais e empresas. ${ }^{44}$ Promoveu-se o intercâmbio cultural de pessoas, livros, arte e música. Esse programa cresceu rapidamente, durante o início dos anos 1950 e, em 1954, tornara-se uma agência independente da embaixada, parte da United States Information Agency.

A utilização dos vários meios de comunicação de massa possibilitava a alteração de atitudes e opiniões de forma muito rápida. Assim, uma das estratégias envolvia a mídia - jornais, revistas, rádio, filmes, televisão -, assim como a agência de informação do governo, a Agência Nacional.

Abastecia-se a imprensa com material para influenciar seu conteúdo - mais de 500 jornais e revistas brasileiros -, concentrando-se nos principais. Eram escritos e distribuídos, sob pseudônimo, uma variedade de artigos anticomunistas.

O rádio e a televisão eram considerados especialmente importantes, devido à alta taxa de analfabetismo da população - mais de 60\%. (HAINES, 1989, p.171) A televisão, apesar de incipiente, ${ }^{45}$ crescia rapidamente. Eram produzidos scripts para programas, evitando-se qualquer identificação para que não fossem encarados como propaganda.

Em relação ao cinema, não eram necessárias muitas medidas, pois a produção daquele país era a mais popular no Brasil - mais de 70\% do total em 1952. (Ibid., p.173)

Além da "campanha" promovida diretamente pelos EUA, os veículos de comunicação também eram manipulados de outra forma, através da publicidade, como vimos. Apesar de, segundo a constituição de 1946, estrangeiros estarem proibidos de manter empresas jornalísticas, a propaganda comercial oriunda das grandes empresas estrangeiras as sustentava, acabando por controlá-las, de forma indireta. $^{46}$

\footnotetext{
${ }^{44}$ Os Estados Unidos pretendiam combater, além da influência comunista, a europeia, notadamente a francesa, ainda muito presente na cultura brasileira. Até mesmo o sistema de educação brasileiro que, como o europeu, enfatizava uma educação clássica para a elite nas ciências sociais, humanidades e nas leis, foi reformado, dando relevo à necessidade de treinamento profissional em campos como a engenharia, medicina, física e química. Uma educação mais pragmática.

${ }^{45}$ Segundo a embaixada americana, havia menos de 25 mil aparelhos de televisão no Rio de Janeiro e 20 mil em São Paulo, em 1952. (HAINES, 1989, p.171) Incentivaram-se os brasileiros a adotar as regulamentações e padrões utilizados nos EUA, para que pudessem ser importados aparelhos de televisão de marcas como RCA, GE, Zenith e Philco.

${ }^{46} \mathrm{E}$, havia casos de flagrante desrespeito à lei, como o da revista Seleções do Reader's Digest, de
} 
Além disso, a publicidade divulgava os produtos americanos e, por extensão, os valores daquela sociedade.

Fazia parte do "programa" americano, o convencimento sobre a "modernidade" de seus valores, de seus saberes, em contraste com os nossos, "atrasados."

A cultura americana e seus produtos, assim, tomaram a sociedade brasileira, garantindo um mercado consumidor para eles. E, as referências europeias na formação e inspiração dos artistas e da elite foram substituídas pela norteamericana.

Adotavam-se novos comportamentos, tendo como modelo o otimismo e a frivolidade, mostrados em filmes e programas de televisão. Geralmente, a classe média branca, radicada nos subúrbios, era retratada nesses veículos. ${ }^{47}$

Além do cinema e da televisão, esses padrões penetravam no Brasil através das revistas - principalmente, Time, Look e Life -, das viagens, da música e do esporte. Dos anúncios de bens de consumo - do blue jeans ao rock and roll, passando por automóveis e televisores. Incorporando palavras e termos originários do inglês.

Com a subida ao poder do General Eurico Gaspar Dutra (1946-50) estabelecera-se uma identidade ideológica inédita entre os governos americano e brasileiro. Ele institui uma política de livre importação, incentivado pela administração Truman, em 1946. E, incontáveis produtos americanos "invadem" o país: automóveis, sabonetes, cereais, produtos de beleza, inseticidas, tintas, eletrodomésticos.

Grande parte das reservas em dólar, acumuladas durante a guerra, foram gastas em um consumo desenfreado, o que levou Dutra a impor um sistema de controle sobre as importações de bens de consumo, incentivando a compra de equipamentos para a indústria. Porém, 47\% das importações ainda provinham dos Estados Unidos. (HAINES, 1989, p.133)

Haines (1989, p.xii) afirma que se tratou de um esforço contínuo e consistente para dirigir o desenvolvimento brasileiro a áreas que beneficiassem os EUA e

propriedade estrangeira, cuja política editorial era ditada nos EUA. Era a versão brasileira do Reader's Digest norte-americano.

47 Segundo Haines (1989, p.6), imagens preconceituosas, atitudes e estereótipos afetaram profundamente os esforços americanos para conduzir os negócios brasileiros. Americanos tinham a tendência a simplificar as referências e contextos culturais de outros países. A política americana foi formulada e projetada quase inteiramente baseada em imagens e mitos, sem atenção às diferenças de sensibilidade e culturas. Da mesma forma, os brasileiros tinham, em relação aos EUA, uma imagem distorcida, diversa da realidade. Almejava-se seu padrão de vida material, pois os americanos eram vistos como ricos e poderosos. 
eliminassem a influência comunista, promovendo métodos e práticas, enfim, a cultura americana, em um processo que já estava presente durante a guerra. E, apesar da relutância brasileira em aceitar totalmente 0 aconselhamento e a orientação americanas, essa política obteve enorme sucesso.

Assim, como seu modo de vida tornou-se referência.

\subsection{Hábitos antigos / novos comportamentos}

Essa modernidade, percebida inicialmente nos dois maiores centros urbanos brasileiros, Rio de Janeiro e São Paulo, onde estavam presentes valores da sociedade americana, contrastava com um Brasil ainda predominantemente rural. As profundas transformações por que passavam a sociedade brasileira conviviam com valores e hábitos conservadores, cultivados no cotidiano das famílias, alguns relacionados à moralidade e às mulheres.

Era difícil a aceitação de um novo papel para elas, que surgia ainda de forma embrionária.

As questões problemáticas, muitas vezes, Ihes eram atribuídas. Mas, essas "deformações" poderiam "ser sanadas." (PROBLEMAS...,1953, p.2) ${ }^{48}$ Discriminavam-se as mulheres que não desejavam ter filhos ou que continuavam a trabalhar depois de tê-los, principalmente em atividades exercidas por homens. E, também, aquelas que queriam comandar o lar ou ter seu próprio dinheiro e administrá-lo.

Ela era mostrada como um ser passivo, contrapondo-se ao homem, ativo, enérgico, cujo trabalho fora da casa era fonte de preocupações e aborrecimentos. Esse papel atribuído à mulher na revista transparece em vários momentos, como naquele em que uma mulher ensina uma receita que teria feito para agradar o marido "por desejar demonstrar-Ihe quão boa cozinheira e dona de casa ele havia tomado por esposa." (MENU, 1953, p.57) Ao fim da receita, ela comenta: "Garanto que, após ter provado esta sopa, teu marido te satisfará qualquer desejo, mesmo que tenha voltado aborrecido do serviço." (Ibid., p.57)

\footnotetext{
${ }^{48}$ Haveria um interesse crescente pela psicologia, nos Estados Unidos, com a publicação de vários livros sobre as "dificuldades que surgem na vida matrimonial, decorrentes da natureza psíquica da mulher." (PROBLEMAS..., 1953, p.2)
} 
Assim, o lar é visto, também, como o local para o repouso do corpo e da mente masculinos, onde ele deve ser cuidado e agradado. Havia ambientes criados para que ele pudesse desenvolver suas atividades ou relaxar. E outros espaços definidos para o "cultivo" de cada membro da família, no desenrolar da vida diária.

À essa visão tradicional do papel feminino, contrapõe-se uma valorização das crianças e dos jovens. O número de filhos diminuíra, devido ao controle da natalidade entre as camadas de maior renda e formação escolar, e era possível proporcionar-Ihes uma educação melhor. Eles constituíam, sempre mais, o centro da vida doméstica.

A ideia de independência dos jovens, que já está presente na sociedade, ainda que de forma incipiente, é apropriada para o consumo. "Se o lar é o centro da vida da criança, ele deve estar em condições de the proporcionar plena liberdade. A criança deve sentir-se inteiramente à vontade para brincar com amigos da mesma idade, sem ser molestada pelas restrições impostas pelos adultos." (CRIVELLI, 1959, p.10)

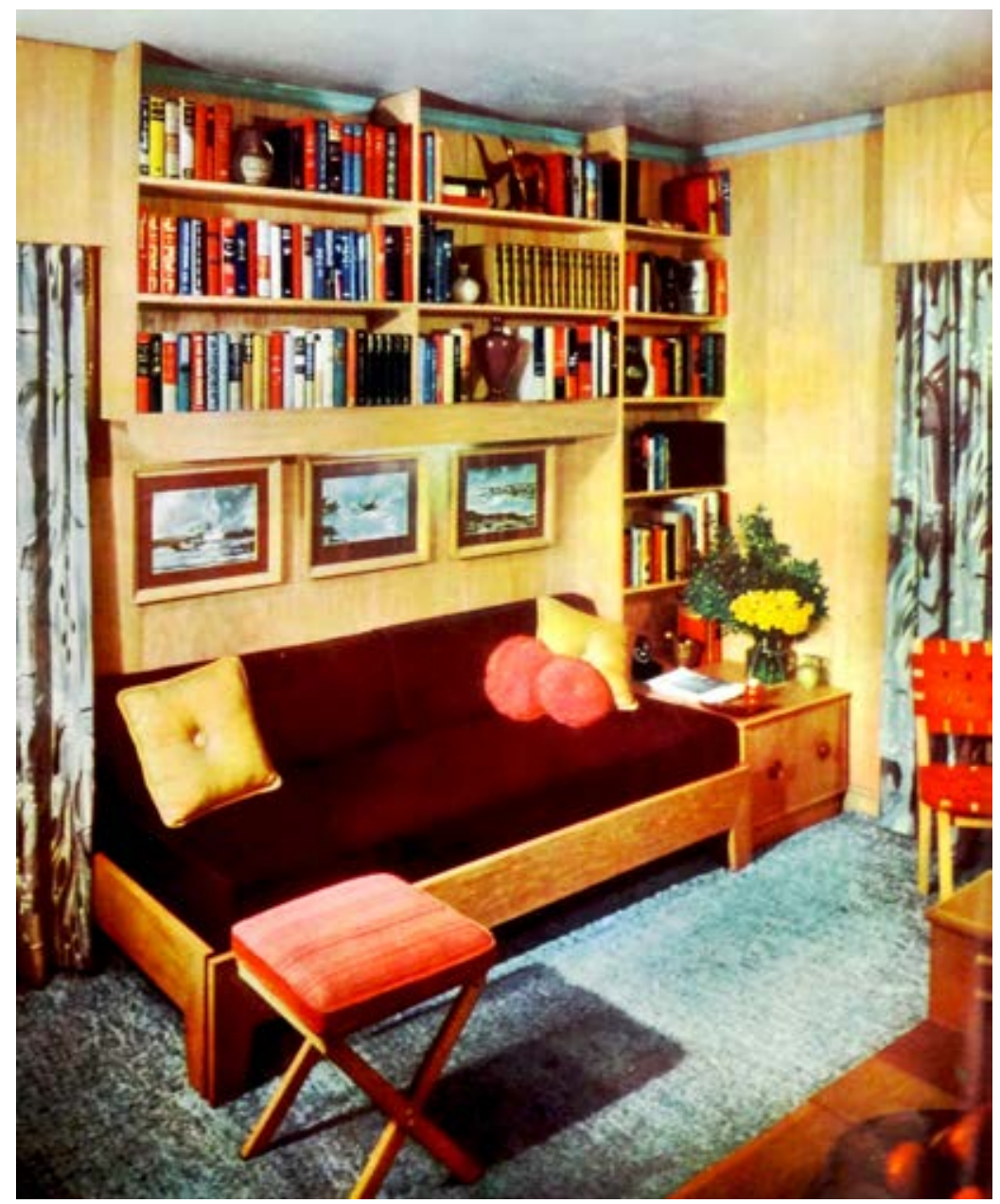

Fig. 1.5-Quarto de rapaz 


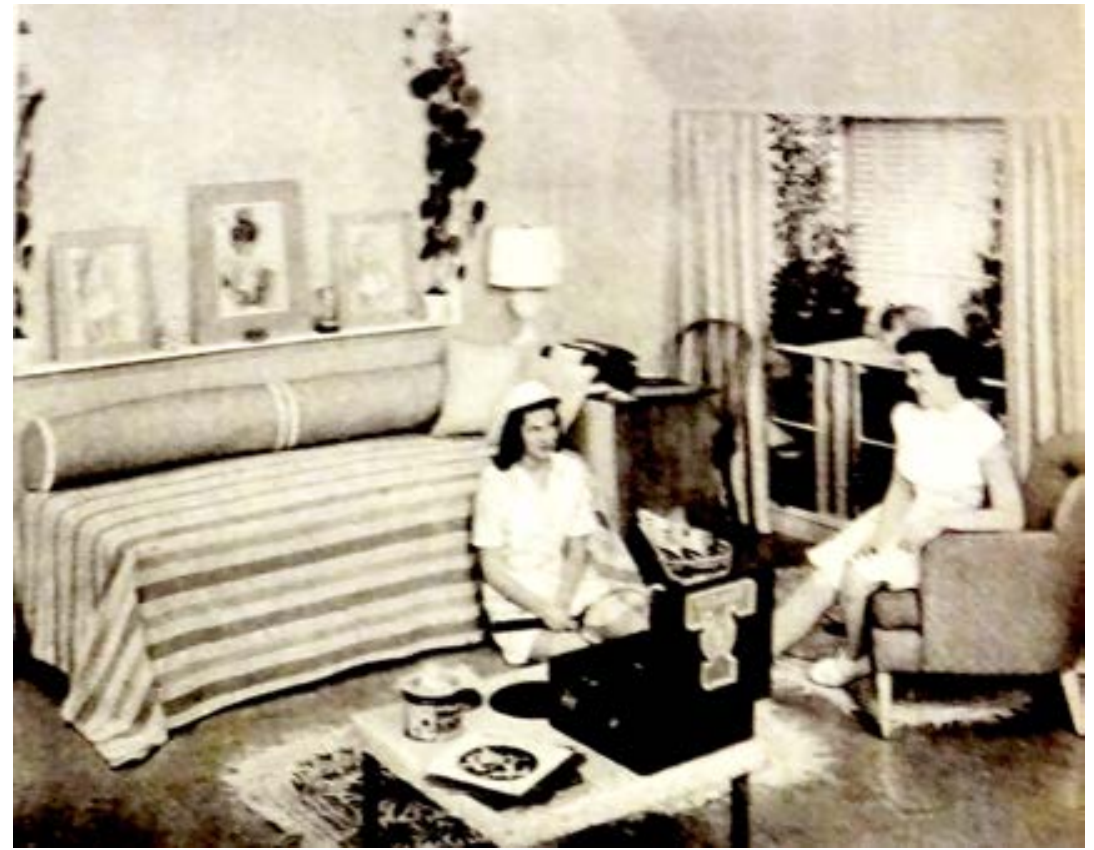

Fig. 1.6 - 0 quarto das moças.

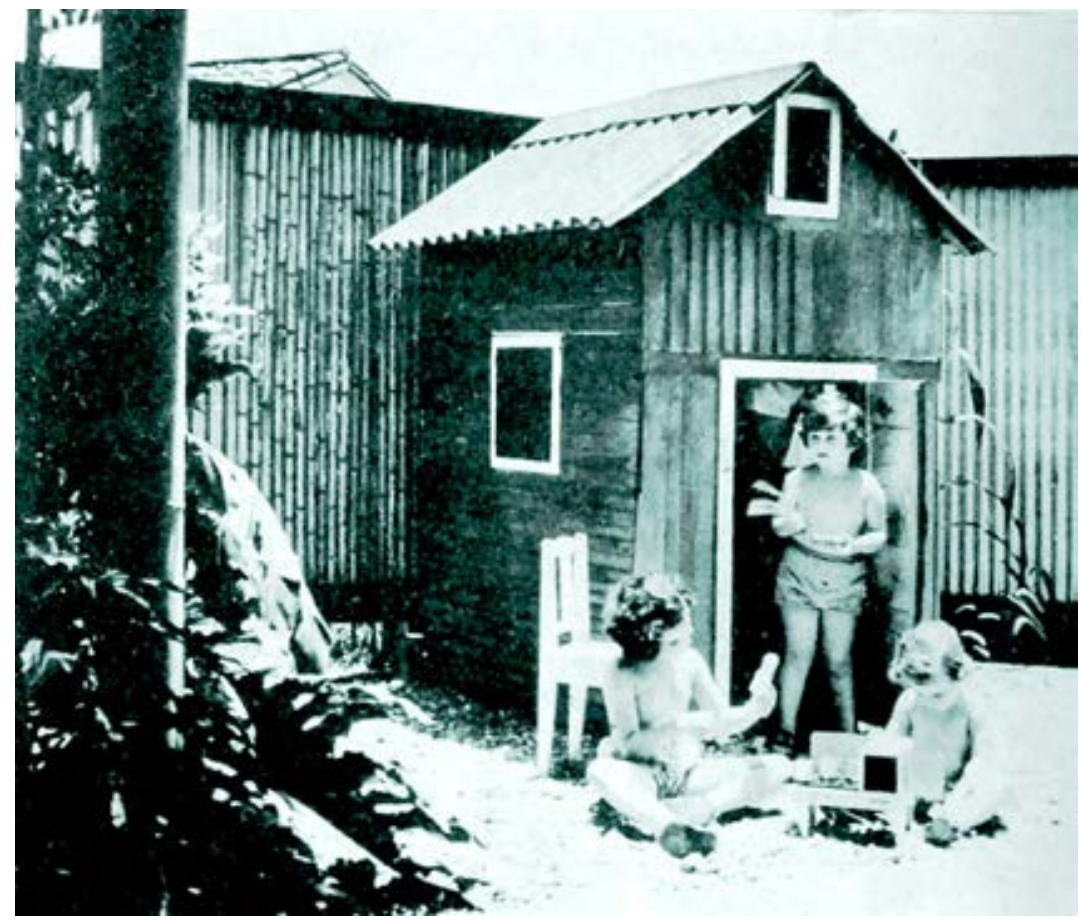

Fig. 1.7 - 0 espaço das crianças.

O objetivo era proporcionar privacidade, criando espaços variados, de acordo com a idade e o sexo. Eram vários ambientes, com móveis e objetos adequados: prateleiras, escrivaninhas, sofás, e elementos decorativos. Uma espécie de mundo particular: "Um quarto de criança é a sua fortaleza... e a decoração deve refletir seu 
gosto...deve ser adaptado às suas necessidades. (...) Até há bem pouco tempo, quartos de crianças eram verdadeiros enjeitadinhos da casa." (TEDDY, 1954, p.38.

Existe a percepção de que os jovens já contestam as escolhas dos pais, ao menos em relação ao que consumir: "O caráter, o temperamento e a individualidade do jovem revelam-se, então, pela primeira vez, em oposição à nossa própria personalidade e só com delicadeza, amor e compreensão, podemos guiá-lo através deste período mais difícil de sua vida." (CRIVELLI, 1955b, p.23 e 71)

Percebe-se uma preocupação com os pequenos acontecimentos diários. Esta é, provavelmente, uma das grandes diferenças em relação às revistas técnicas de arquitetura, em que a dimensão temporal parece ter sido "congelada."

O cotidiano é "invadido" pelos objetos e vivido por meio deles: produtos para a construção e decoração e para a "vida" na casa. Tenta-se estabelecer uma relação "emocional" dos moradores com a casa, como espaço físico, para transformá-la em um lar.

A vida cotidiana é componente da casa, com suas experiências, símbolos, objetos. Ali estão envolvidas a indústria da construção e da produção de bens de consumo móveis, objetos de decoração e utilitários, eletrodomésticos, alimentos, produtos de limpeza. Que estão presentes nas matérias, mas principalmente nas propagandas. O leitor é visto como um potencial consumidor.

Assim, a casa consolida-se como elemento da sociedade de consumo. Os produtos mostrados são "mediados" por ela, utilizados em determinado ambiente, seja um material de construção, um objeto decorativo ou um alimento.

É uma cultura da moradia relacionada ao consumo, presente nos Estados Unidos e na Europa, mas que se afirma aos poucos, no Brasil.

Ela relaciona-se a esse contexto, urbano, moderno, de crescimento das camadas médias e de seu poder de consumo.

É claro que uma revista como essa tem de conquistar, de preferência, a classe média. Os ricos têm seus decoradores, seus jardineiros, seus mestres-cucas que pouco aceitam sugestões: são artistas compenetrados de sua autossuficiência. Somos nós, as donas-de-casa, que lutam com poucos recursos, as que procuram avidamente revistas especializadas que nos ajudem a embelezar o nosso lar com os recursos e os móveis de que dispomos, já que os que aparecem, elegantes e macios, estão além de nossas possibilidade aquisitivas. Por isso, (...) peço-lhes sugestões 
acessíveis, compráveis e fabricáveis por nós mesmas, (...) modos de modernizar ambientes mais ou menos antigos. (...) (OBRIGADO!..., 1953, p.2)

O público alvo é a família nuclear de classe média: nem a família estendida, nem as pessoas que vivem sós, ao menos inicialmente. ${ }^{49}$ Se o homem não se casasse, teria uma "casa sem sorriso de mulher e alegria de crianças." (O LAR..., 1953, p.16) $)^{50}$

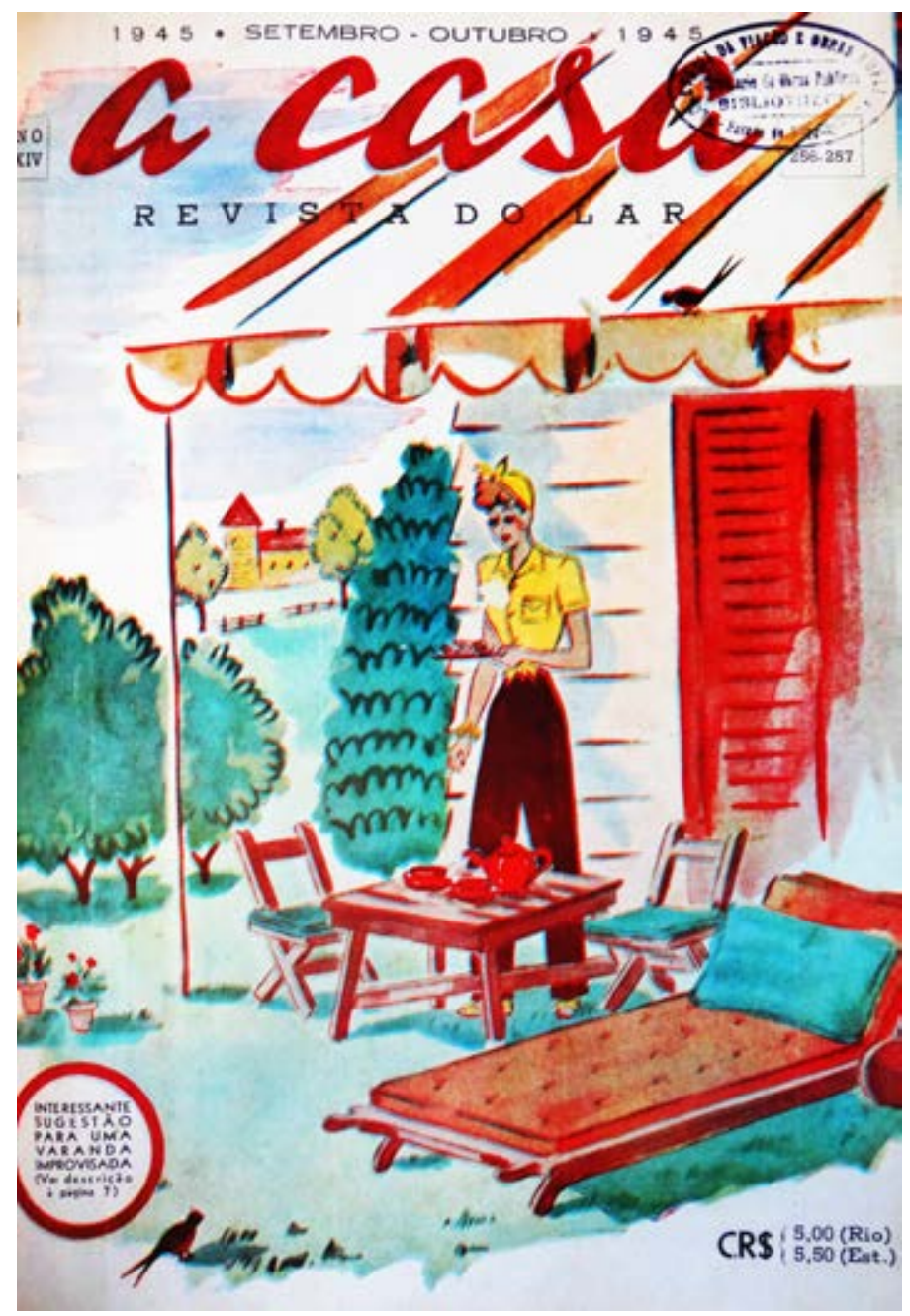

Fig.1.8 Revista A Casa, primeira destinada, também, ao público leigo de classe média.

Casa e Jardim foi pioneira entre as revistas dedicadas à casa, especificamente à essa camada da população. Nela, são "traduzidos" conteúdos, antes dirigidos a profissionais - arquitetos e engenheiros. Explica-se, por exemplo, a técnica do

\footnotetext{
${ }^{49}$ Esse aspecto acaba por se alterar e, aos poucos, a revista passa a mostrar ambientes para pessoas que vivem sós, em apartamentos maiores ou kitchenettes, inclusive mulheres.

${ }^{50}$ É mostrada a residência do arquiteto Henrique Alexandre (sic).
} 
concreto, de maneira simplificada. Discutem-se experiências relacionadas à construção ou reforma da casa, desde a compra do terreno. Existem "depoimentos de leitores," que procuram legitimar as narrativas construídas.

Houve outra revista voltada ao público leigo de classe média, A Casa, ${ }^{51}$ mas destinava-se também a profissionais - arquitetos, engenheiros, construtores.

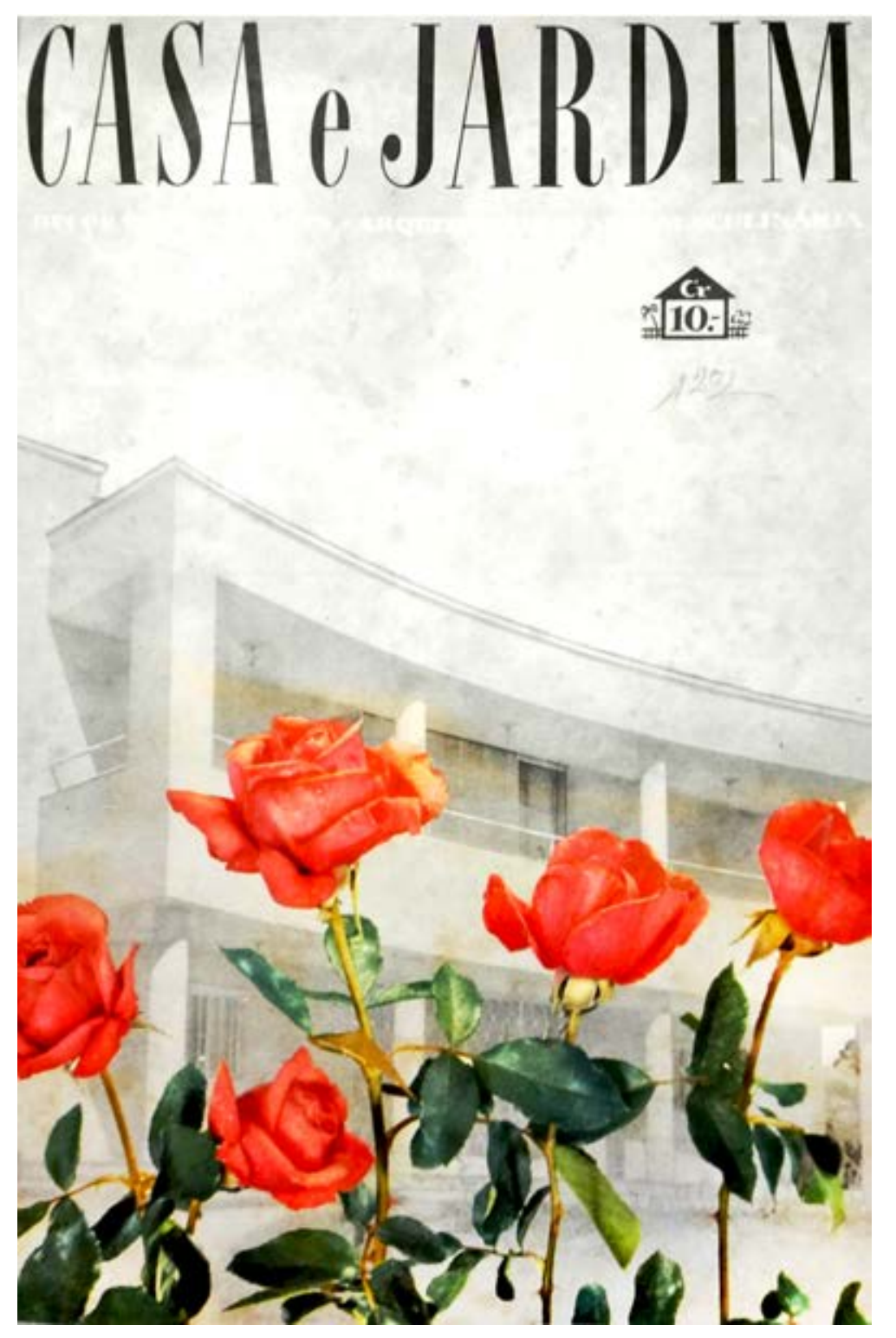

Fig.1.9 - Capa da primeira edição de Casa e Jardim, mar./abr.1953.

\footnotetext{
${ }^{51}$ As casas mostradas na revista eram de tamanho pequeno ou médio, com ou sem autoria. Foi fundada em 1923, no Rio de Janeiro, com periodicidade mensal. Foi publicada ao menos até 1945. Nesse ano, ela adotara o subtítulo Revista do Lar, e alterara seu conteúdo. Tentando atrair o público feminino, surgiram seções com contos, trabalhos manuais, cinema, conselhos sobre moda e decoração. (EVOLUÇÃO, 1945) A incerteza em relação aos rumos que a revista deveria tomar, provavelmente, acabou por encerrá-la. A respeito da revista, ver JANJULIO, 2009.
} 
Quando foi lançada, em 1953, Casa e Jardim já encontrou um mercado editorial mais definido, amplo, com certa diversidade de temas. $\mathrm{Na}$ época, expandia-se a imprensa periódica no Brasil, com o lançamento de novos títulos dirigidos a públicos específicos. ${ }^{52}$ Pode-se considerar o lançamento de Casa e Jardim inserido nesse processo.

Entre os vários tipos de periódicos, a revista é aquele que cria a relação mais íntima com seu público, uma identificação entre o leitor e o veículo. Nela pode-se encontrar coisas específicas: uma viagem, um objeto, uma roupa, uma casa. Ao contrário do jornal diário, pode ser lida, colecionada, emprestada, relida, consultada.

O poder dessas publicações, aí incluída Casa e Jardim, é o de criar desejos e satisfazê-los.

\subsubsection{Alguns hábitos de consumo}

Grande parte desses desejos relacionava-se aos novos produtos industrializados e às máquinas e equipamentos que trariam conforto ao ambiente doméstico. Apesar de, nos anos 1950, os hábitos de consumo desses produtos ainda não estarem arraigados, alguns deles, introduzidos em décadas anteriores, já faziam parte do cotidiano de paulistanos e cariocas. ${ }^{53}$

As grandes marcas já estavam instaladas no país e algumas já gozavam de certa hegemonia, anunciadas em jornais e revistas e em comerciais radiofônicos e televisivos.

As pesquisas do IBOPE $^{54}$ mostram, durante a década de 1950, um crescente número de cariocas e paulistanos interessados em adquirir eletrodomésticos e outras utilidades, sendo que, no final da década, o número de casas onde havia enceradeira, liquidificador, ${ }^{55}$ refrigerador, colchão de molas era maior do que

\footnotetext{
${ }^{52}$ Os primeiros anos de circulação de Casa e Jardim coincidiram com o período de estruturação da imprensa brasileira em grandes corporações, que, por vezes, reuniam jornais, revistas, emissoras de rádio e de televisão. Surgem, nessa época, grandes revistas, como Casa e Jardim (1953), Manequim (1959), Claudia (1961) e Quatro Rodas (1960). Publicações de variedades ou generalistas, sem um público determinado, acabam por ser encerradas.

${ }^{53}$ Os relatórios do IBOPE permitem-nos saber que as chamadas utilidades domésticas começaram a chegar aos lares cariocas e paulistas a partir dessa década, inicialmente naqueles classificados como classe A pelo instituto. Produtos como a máquina de lavar roupa e de costura elétrica, recém introduzidos no país, só eram acessíveis a parte das famílias que ocupavam o topo da pirâmide social.

${ }^{54}$ Divulgadas através dos boletins Serviço de Pesquisa entre Consumidores e Serviço X Nacional.

${ }^{55}$ Esse eletrodoméstico já estava bastante difundida nessa época. Presente em $76 \%$ dos lares cariocas considerados ricos, $45,8 \%$ dos lares considerados da classe média e $29,8 \%$ dos lares considerados
} 
aquelas onde não existiam. Tais aparelhos e utilidades de uso doméstico tiveram um crescimento sustentado naquela década. (MARTINI, 2011, p.132-3) ${ }^{56}$

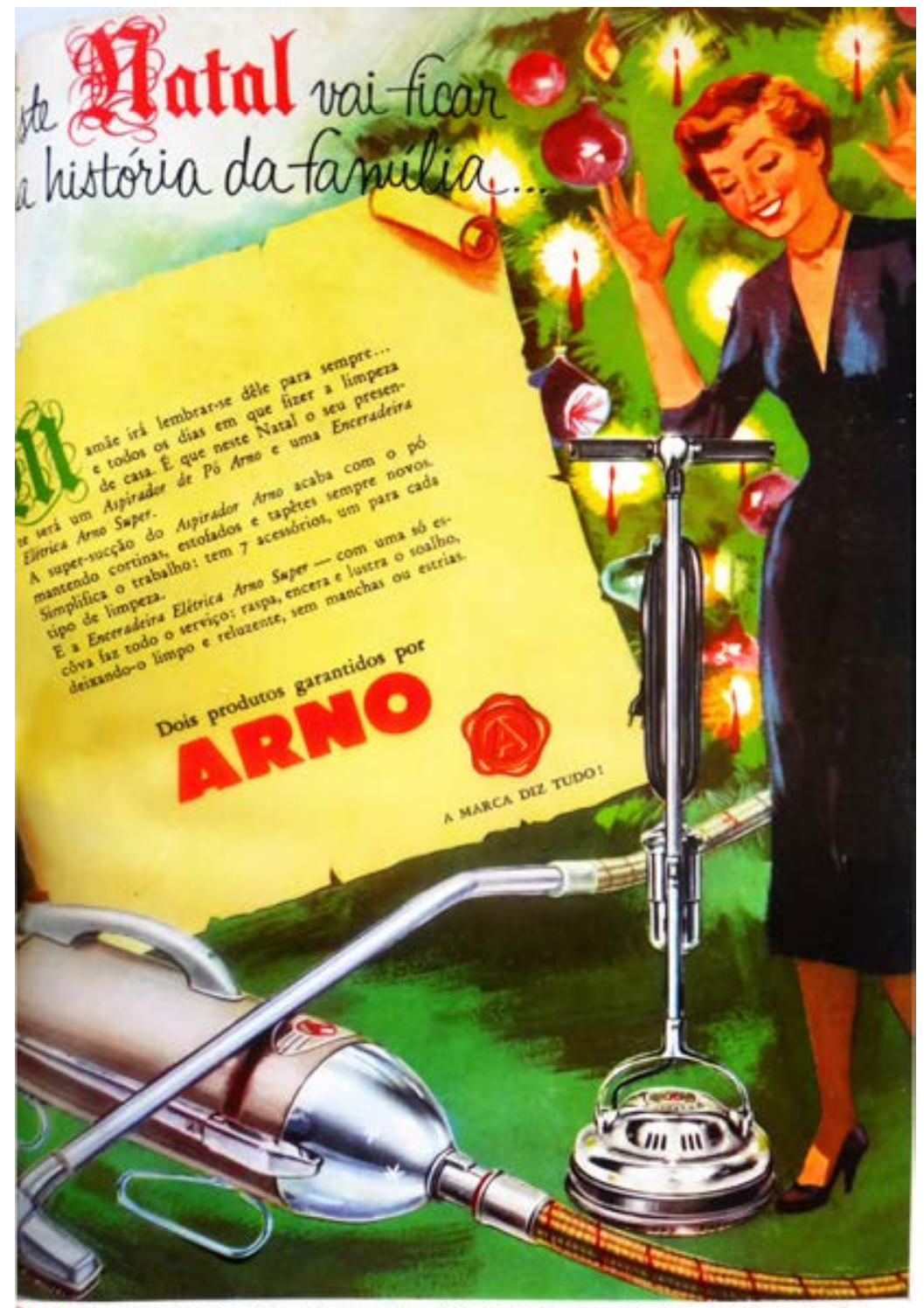

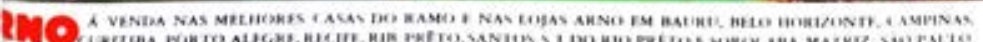

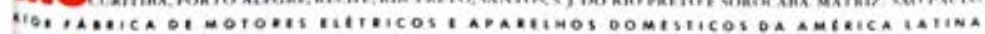

Fig.1.10 - Anúncio em Casa e Jardim.

As datas festivas já eram alvo de campanhas publicitárias especificas, particularmente dirigidas às mães. Os eletrodomésticos são mostrados como

pobres, no final da década de 1950. IBOPE. Pesquisas Especiais, 1957-1960 [Notação: IBOPE PE031/04] apud MARTINI, 2011, p.134.

${ }^{56}$ Pesquisa retrospectiva realizada entre os anos de 1957 e 1960 aponta que as enceradeiras elétricas estavam presentes em $69 \%$ dos lares cariocas. O índice chegava a 64\% em São Paulo. IBOPE. Pesquisas Especiais, 1957-1960 [Notação: IBOPE PE031/04] apud MARTINI, 2011, p.133. 
potenciais presentes de Natal, sempre nos meses próximos à data. (ESTE NATAL..., 1957, verso da contracapa): ${ }^{57 ~ " E s t e ~ N a t a l ~ v a i ~ f i c a r ~ n a ~ h i s t o ́ r i a ~ d a ~ f a m i ́ l i a . . . ~}$ Mamãe irá lembrar-se dele para sempre... e todos os dias em que fizer a limpeza de casa."

A associação à essa festa era constante. Em outra propaganda, uma criança faz uma oração e pede que a mãe ganhe presentes Walita no Natal. (...E QUE NESTE $\ldots, 1954$, p.77) $)^{58}$

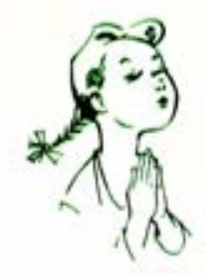

\section{...e que neste Tlatal mamäe ganhe un Walita}

Nenhum outro presente seró tōo itil paro olol

\section{Visite um revendedor Llalita}

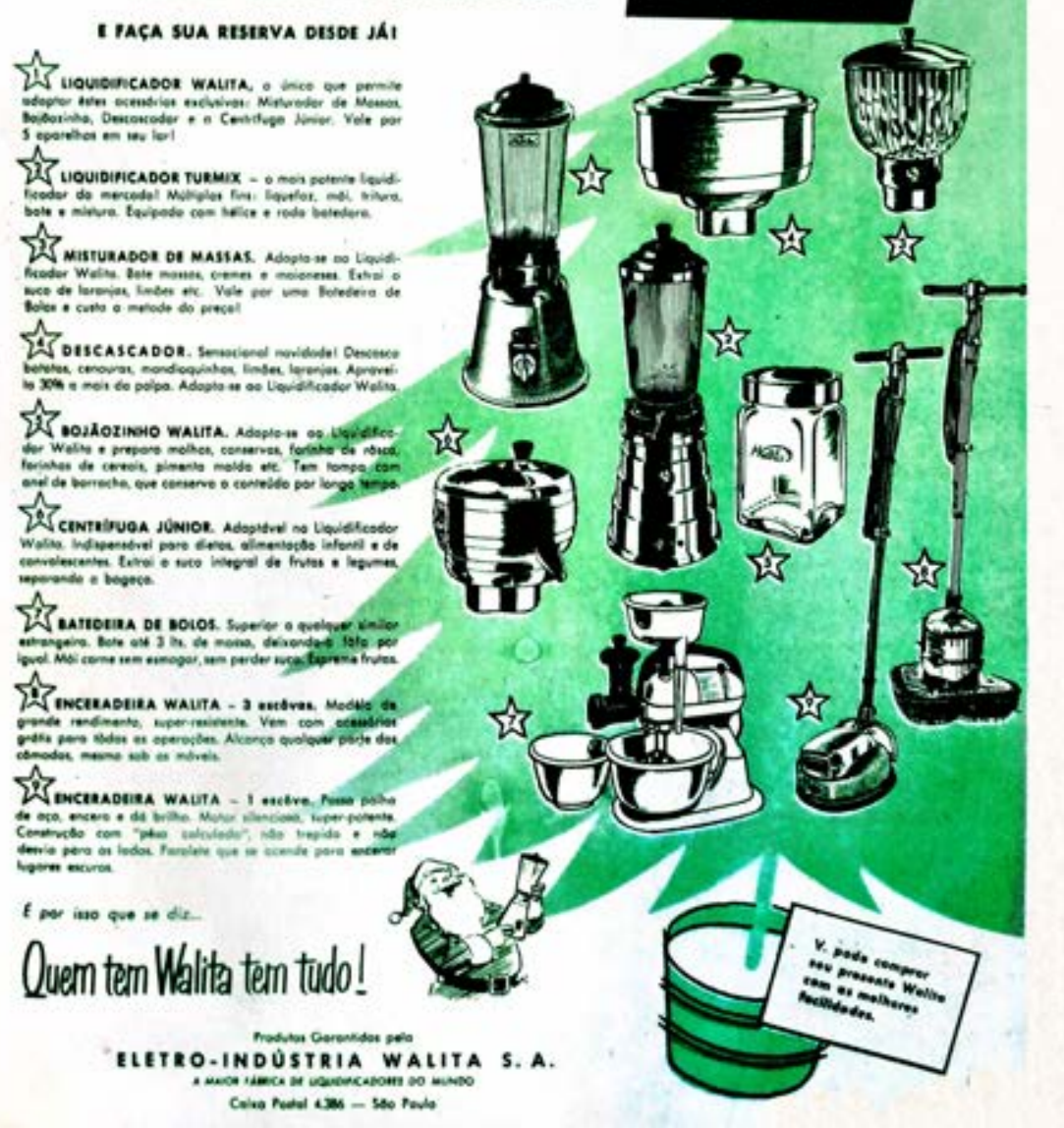

Fig.1.11 - Anúncio de produtos para o Natal.

\footnotetext{
${ }^{57}$ Anúncio de enceradeira e aspirador da marca Arno.

${ }^{58}$ Anúncio de liquidificador, batedeira e dois modelos de enceradeira.
} 
E, já havia certa sofisticação nos produtos: liquidificadores com acessórios, que poderiam ser adquiridos à parte, por exemplo, em uma espécie de "compra a prazo." (AGORA MAIS..., 1954, p.93)

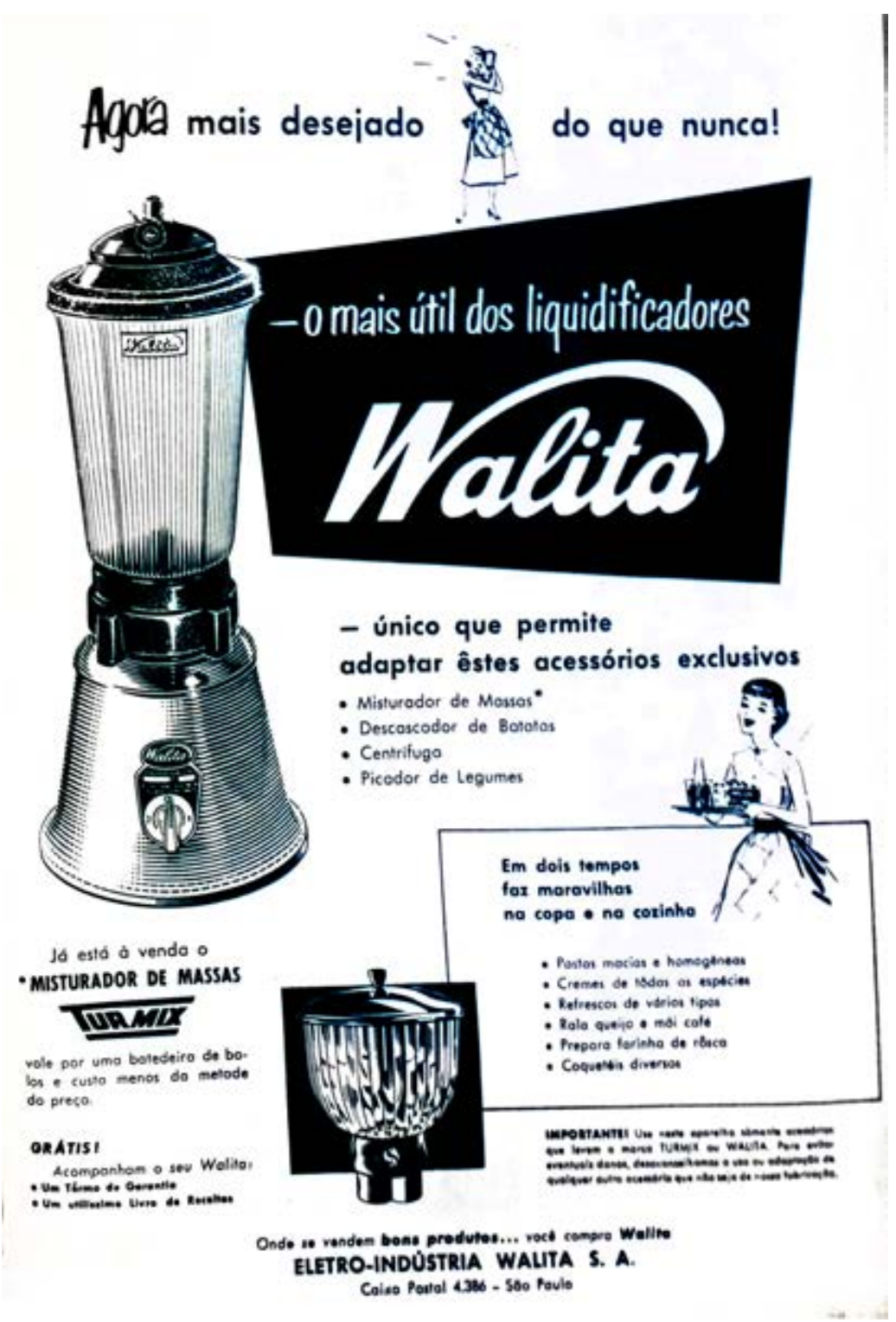

Fig.1.12-Anúncio de liquidificador com acessórios.

Quanto ao refrigerador elétrico, ${ }^{59}$ ele foi comprado em São Paulo, principalmente, nos últimos anos da década de 1950, mas em menor quantidade do que no Rio de

\footnotetext{
${ }^{59}$ Pesquisa realizada em 1952 traz a informação de que a utilidade doméstica mais cobiçada pela classe B e C era o refrigerador e pela Classe A, o receptor de televisão. O IBOPE instrui o cliente, no caso a Casa Ponto Frio, de que a propaganda para vender refrigerador deve atentar para o preço e as condições de pagamento visto serem os pobres e remediados os clientes preferenciais. IBOPE. Pesquisas Especiais, nov. 1952 [Notação: IBOPE PE011/08].
} 
Janeiro. No ano de 1959, por exemplo, 44\% dos entrevistados diziam não possuí-lo, contra $32 \%$ do Rio de Janeiro. ${ }^{60}$

Através do texto e da imagem dos anúncios, podemos perceber as transformações da sociedade, na direção da modernização. No anúncio ${ }^{61}$ que mostra uma dona-decasa, fazendo compras em um supermercado, com um carrinho cheio de produtos variados, a modernidade está implícita em, ao menos dois aspectos: na falta de tempo para se fazer compras diariamente, e no local onde são feitas, uma novidade para a época. "Economia multiplicada ... eis o que Ihe dá Frigidaire. Dispondo de grandes espaços controladamente refrigerados, V. pode fazer compras uma vez por semana, economizando tempo e dinheiro." (FRIGIDAIRE..., 1955, p.38)

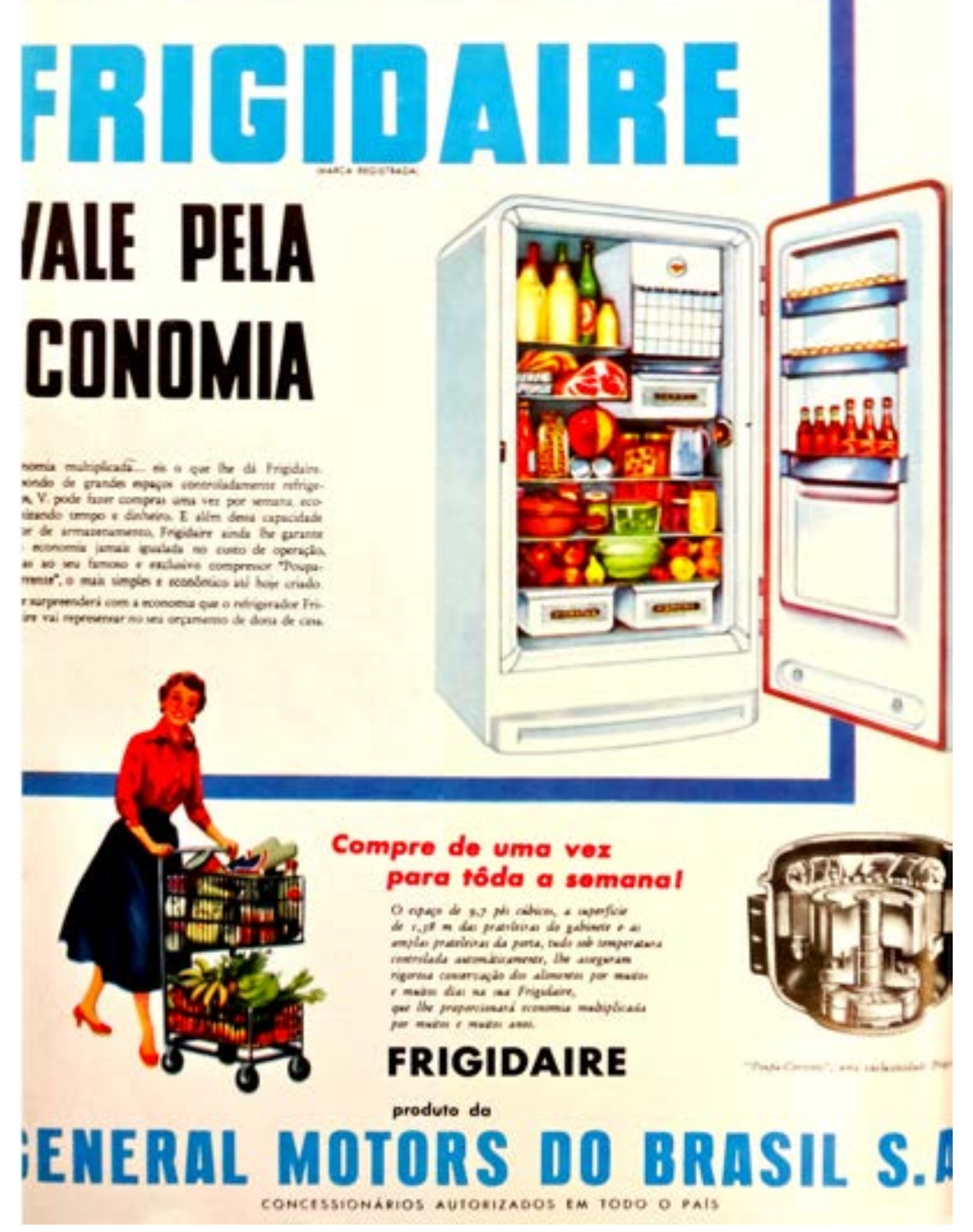

Fig.1.13 - Anúncio mostrando dona de casa em supermercado.

\footnotetext{
${ }^{60}$ Gráfico n.11. In: MARTINI, 2011, p.135.

${ }^{61}$ Anúncio da geladeira Frigidaire.
} 
Mello e Novais (2012, p.566) apontam que os avanços produtivos foram acompanhados de mudanças significativas no sistema de comercialização: o supermercado acaba derrotando, aos poucos, a venda, o armazém, o açougue, a quitanda e a carrocinha. Surgem, também, as grandes cadeias de lojas de eletrodomésticos e as revendedoras de automóveis.

A versatilidade crescente apresentada pelos produtos, dirigidos a faixas diferentes de consumidores, aponta, no caso dos refrigeradores, para famílias menores, pessoas que vivem sozinhas ou em apartamentos e o hábito de comer fora. $O$ produto é apresentado em dois modelos, ${ }^{62}$ o menor, "atendendo às conveniências de espaço nas modernas residências." (HÁ UM BRASTEMP, 1956, p.57)

\section{Há um Brastemp para cada conveniência}

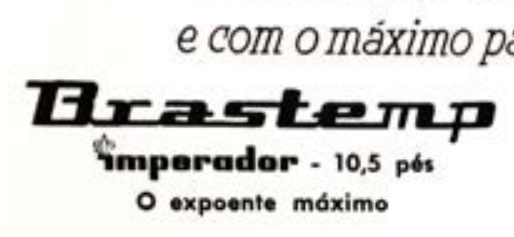

Suatuoso, nos minimos detalhes e dotado de amplo espaço interno, o refrizerador Bnustemp Imperador ateade às conveniéncias de um alto padrao de confórto. Permite conservar, folgadamente, uma quantidade muito maior
de alimeatos, com perfeita distribaiçao. E uan régio presente para o seu lar.

Congelador horixonfal Prateleiras corredicas Amplas gavetos para logumes Prateloiras na porta
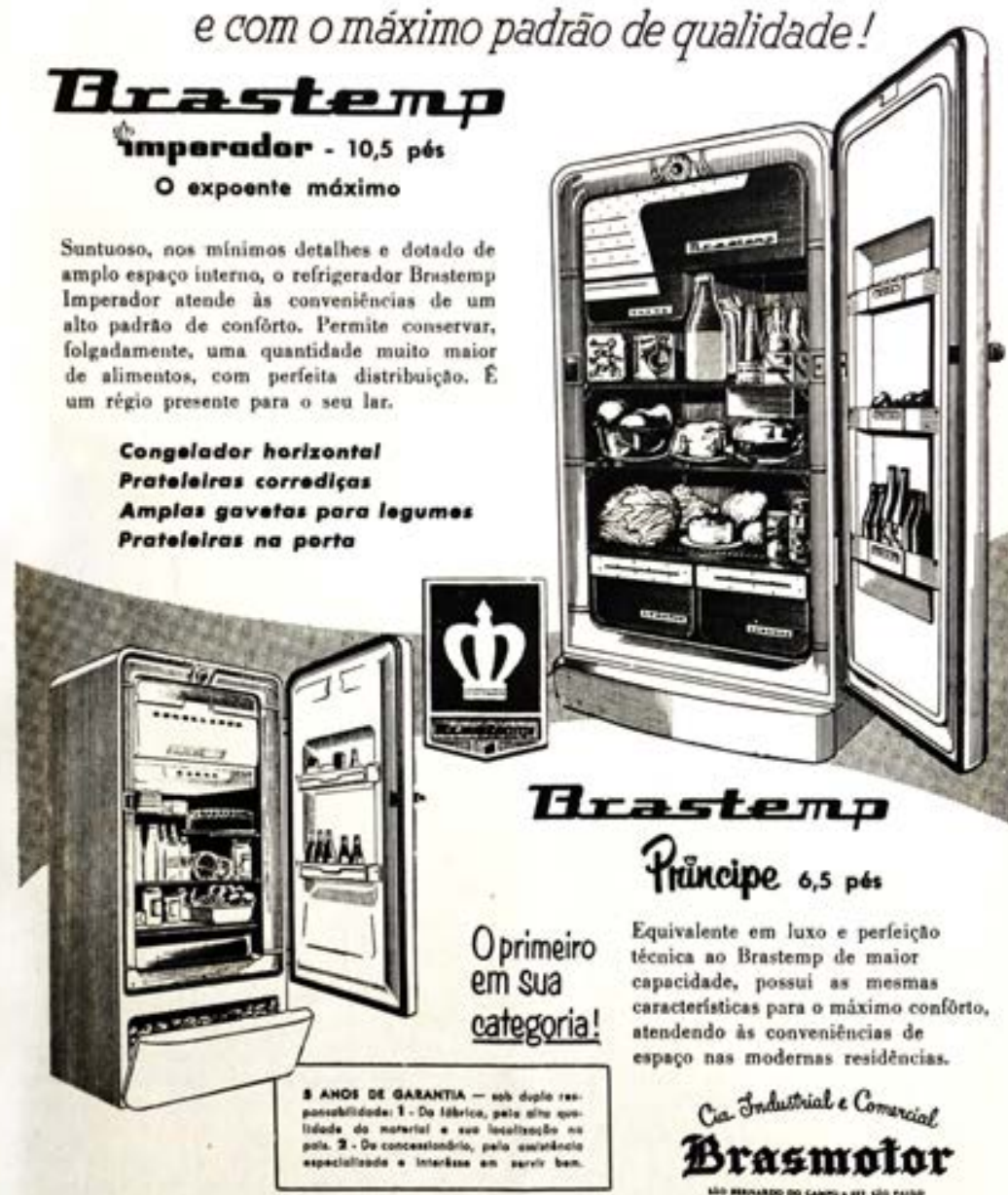

Exagtemp

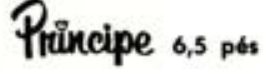

Equivalente em luxo e perfeiçấ téenica ao Brastemp de maior capocidade, possui as mesmas características para o máximo conforto, atendendo is conveniêteias de espaço nas modernas residèncias. Ces Induthial e Comeraial Brasmotor

- REFRIGERADOR MAIS PERFEITO ATÉ HOJE FABRICADO NO PAíS

Fig.1.14 - Refrigerador em dois modelos.

\footnotetext{
${ }^{62}$ Anúncio do refrigerador Brastemp.
} 
Mas, a família nuclear ainda era o principal alvo e personagem da publicidade. Muitas vezes, retratada em cenas familiares. "Em torno de cada Refrigerador G-E há uma historia humana... uma historia de família." (EM TORNO..., 1956, p.83)

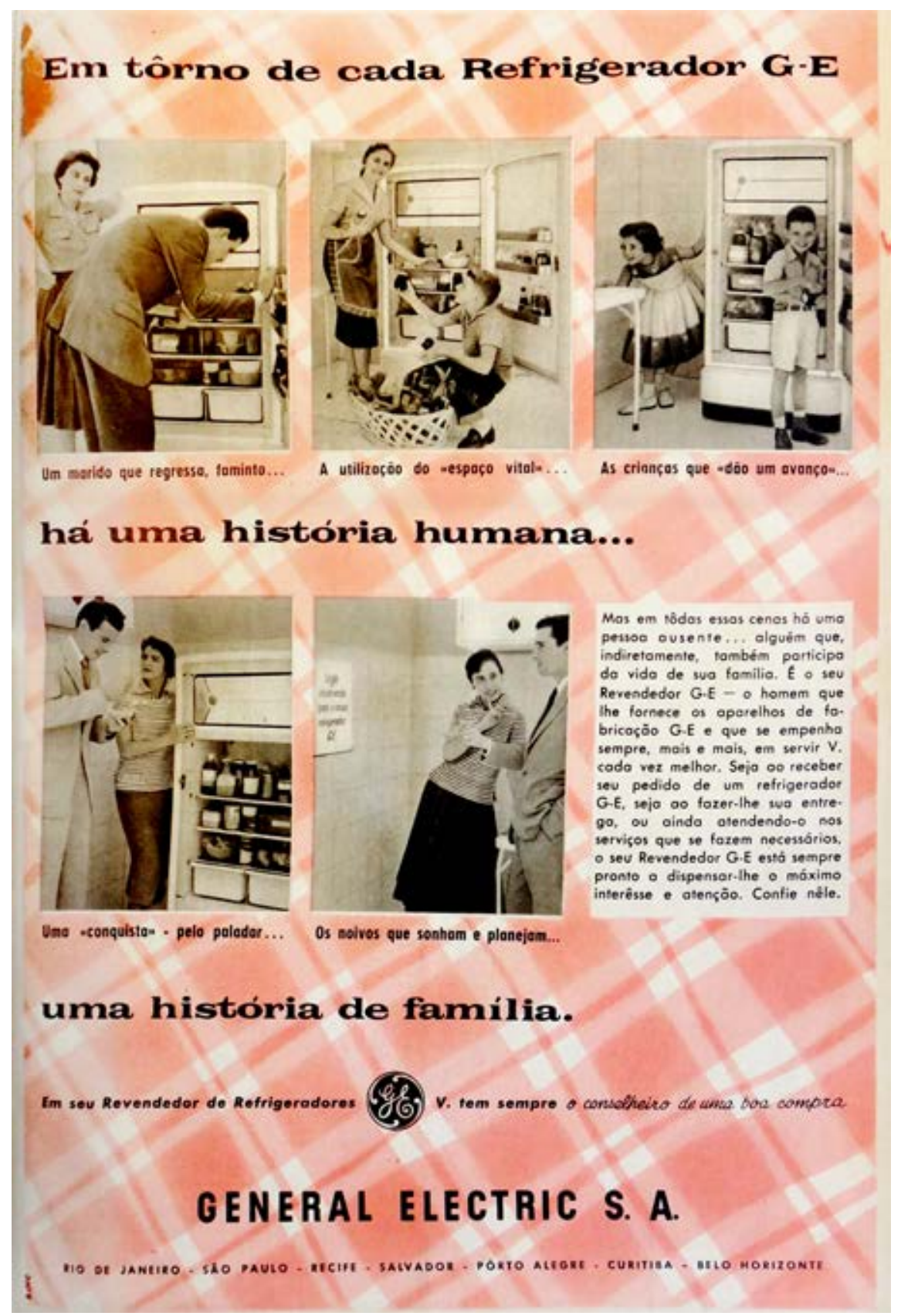

Fig.1.15 - Cenas familiares.

O IBOPE também indicava estratégias para os anúncios e para as vendas. Segundo o instituto, o colchão de molas, ${ }^{63}$ por exemplo, havia se tornado objeto de desejo.

${ }^{63}$ No início dos anos 1960, 64\% da população carioca já possuía colchão de molas. IBOPE. Pesquisas 
Sugeria-se uma propaganda mais assertiva: "falta um impulso inicial para a compra. Toda a propaganda que temos visto de colchões de molas ${ }^{64}$ exalta a maciez, o acabamento, as vantagens de determinado tipo de estrutura, o sono embalador, etc., mas nenhuma tem o poder de venda imediata: Vá já comprar um colchão de molas, em tal lugar ou telefone chamando um vendedor (...)." 65

São feitas associações com ambientes modernos e refinados, indicando o status social conferido a seu comprador. "Para ambientes modernos onde impera 0 conforto.(...) onde sente-se que tudo é regido pela lei do bom gosto e da comodidade, adivinha-se logo: o colchão é Probel." (PARA AMBIENTES..., 1954, p.7) ${ }^{66}$

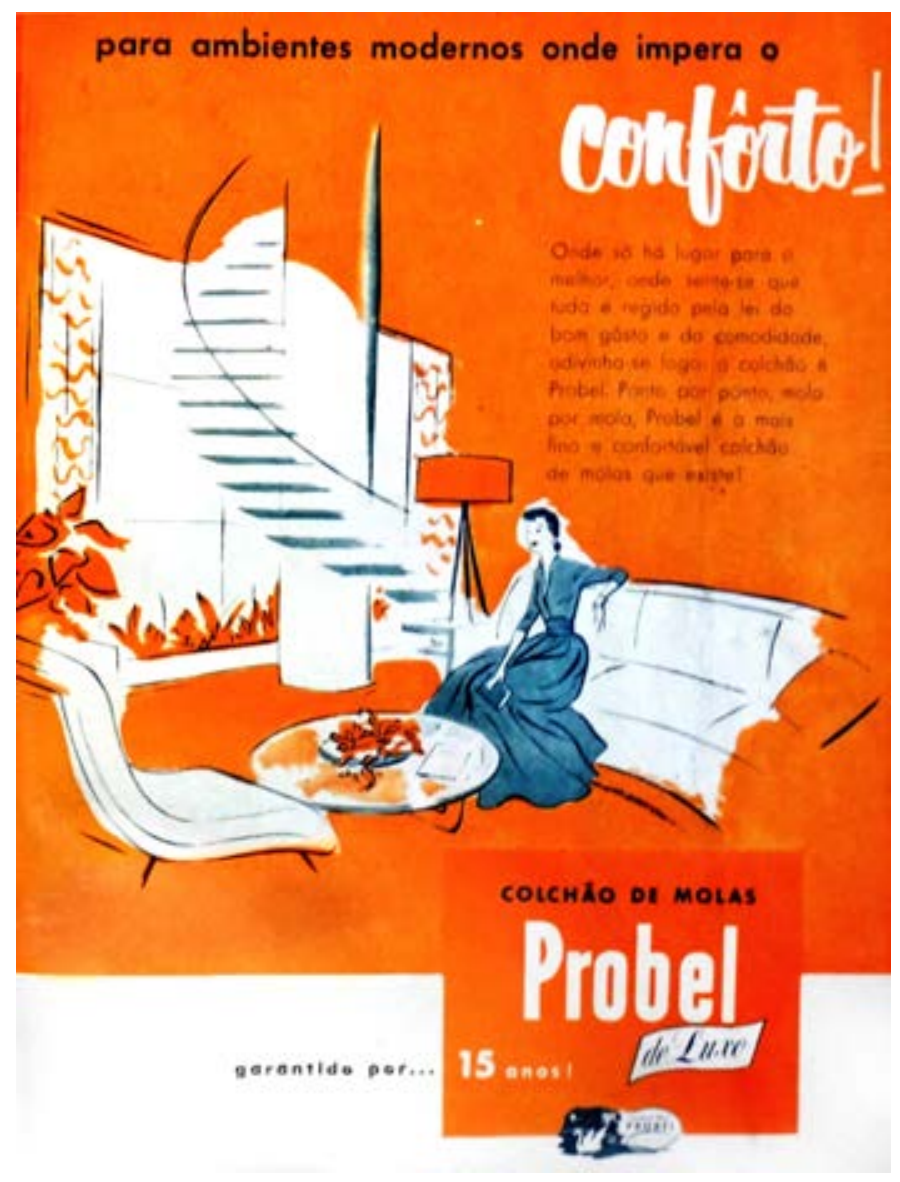

Fig.1.16 - Anúncio de colchões.

Especiais, nov. 1952 [Notação: IBOPE PE011/08], apud MARTINI, 2011, p.135. Em São Paulo o índice era maior: 74\%, IBOPE. Pesquisas Especiais, 1957-1960 [Notação: IBOPE PE031/04], apud MARTINI, 2011, p.136.

${ }^{64}$ Anunciavam-se, também, sofás-camas, associados a ambientes multifuncionais ou pequenos espaços, uma ideia essencialmente moderna.

${ }^{65}$ Cf. IBOPE. Pesquisas Especiais, jun. 1952 [Notação: IBOPE PE011/09] apud MARTINI, 2011, p.136.

${ }^{66}$ Até mesmo atrizes famosas, como Cleide laconis e Maria Della Costa, aparecem em algumas propagandas. 
E havia, na década de 1950, outras utilidades domésticas que a propaganda mostrava como essenciais à vida moderna, mas que não estavam presentes na maioria dos lares cariocas e paulistanos, até mesmo entre os mais ricos, como a batedeira elétrica e a máquina de lavar roupa. ${ }^{67}$

Esse último é um item que pode ser associado diretamente à presença ou não de empregados domésticos. ${ }^{68}$ As lavadoras surgem nas propagandas apenas nos anos 1960, talvez por uma dificuldade crescente em se encontrar mão-de-obra para as tarefas da casa.

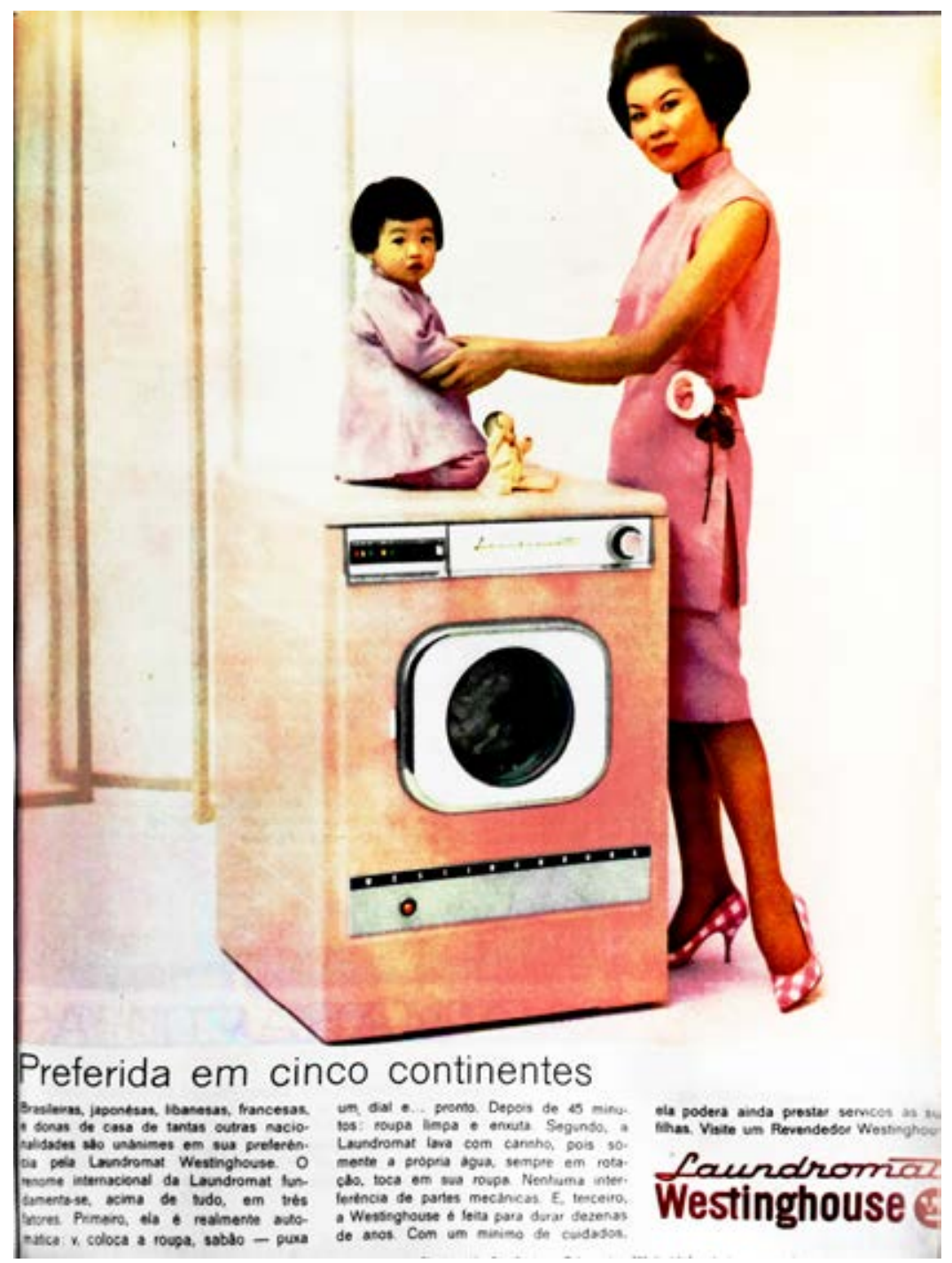

Fig.1.17 - Anúncio de lavadora.

\footnotetext{
${ }^{67}$ Pesquisa retrospectiva realizada entre os anos 1957-1960 aponta que as máquinas de lavar roupa estavam presentes em $14 \%$ dos lares cariocas. O índice chegava a $20 \%$ em São Paulo. IBOPE. Pesquisas Especiais, 1957-1960 [Notação: IBOPE PE031/04], apud MARTINI, 2011, p.137.

${ }^{68}$ Ou de pessoas que prestavam esse serviço em suas próprias casas.
} 
No entanto, o eletrodoméstico mais associado à essa década é o televisor. Principalmente, a partir de meados da década de 1950, um número menor de entrevistados, nos dois grandes centros urbanos, declarou não possuí-lo ou não utilizá-lo em suas residências. (MARTINI, 2011, p.139)

Um anúncio - com foguetes que partem do aparelho e chegam a outro planeta reforça a aura futurista em torno do aparelho: "Um novo mundo de experiência no campo do entretenimento aguarda-o com o televisor 'SUPER M' PHILIPS." (ATINGINDO..., 1955, p.9) ${ }^{69}$

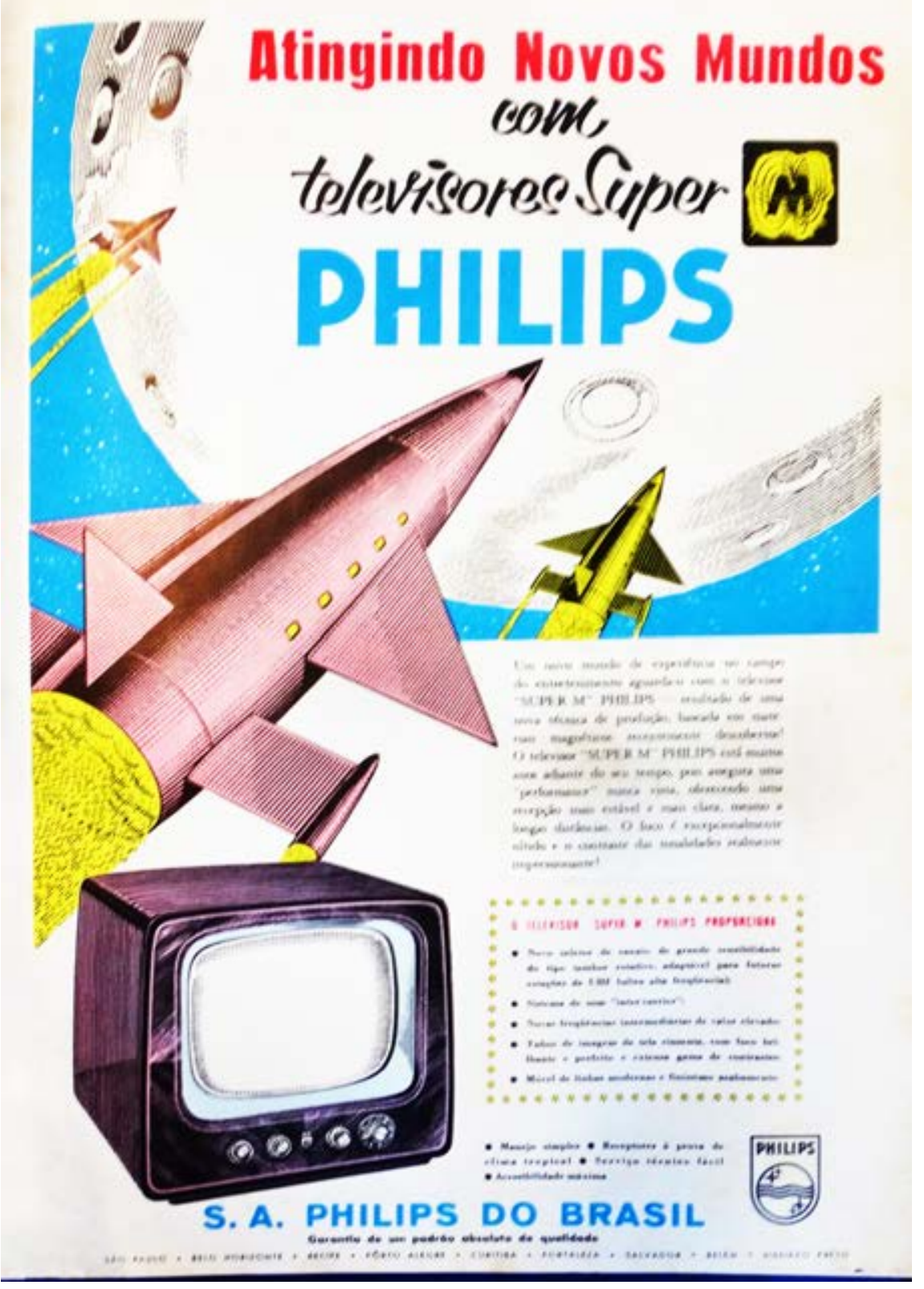

Fig.1.18 - Anúncio futurista.

${ }^{69}$ Existe, ao menos, um grande artigo sobre salas para tv em Casa e Jardim. (A CAÇULA..., 1954) 
E, apesar das restrições técnicas iniciais, em relação aos programas e às transmissões, e do alto custo dos aparelhos, a televisão, desde que surgiu no Brasil, tornou-se o sonho de consumo de grande parte das pessoas.

\subsubsection{A publicidade}

O domínio da publicidade ${ }^{70}$ sobre os veículos impressos também acontecia de maneira indireta, inclusive em relação ao papel para impressão.

Seu preço variava devido à alteração das taxas cambiais para a importação. Além disso, o Banco do Brasil regulava o número de cotas a serem negociadas no exterior pelos diversos veículos. ${ }^{71} \mathrm{Em}$ consequência, inúmeros jornais haviam fechado ou diminuído o número de páginas. ${ }^{72}$

Isso acabava por tornar revistas e jornais ainda mais dependentes dos recursos provenientes dos anúncios veiculados pelas agências.

A publicidade apresentava vários aspectos, era uma questão bastante complexa e estava intimamente ligada à consolidação da sociedade de consumo.

O crescimento econômico e industrial do país refletia-se no crescimento das agências e do mercado de publicidade e propaganda. São Paulo era o centro dessa produção, atendendo os setores em crescimento, principalmente o automobilístico, que promovia grandes campanhas.

Assim, a publicidade estava cada vez mais presente em jornais e revistas, na época. O destaque que passa a ocupar nas publicações é uma novidade. Um sinal da

\footnotetext{
${ }^{70}$ Propaganda vem de propagar e pode ser entendida como a divulgação de uma ideia, um conjunto de valores, com a intenção de informar e persuadir determinado público alvo, levando-o à sua adoção; um tipo de argumentação que tem a finalidade de convencer. (MARTINI, 2011, p.47)

${ }^{71}$ Havia alguns períodos de abastecimento satisfatório do papel para impressão, mas no geral não havia segurança nessa questão. A fabricação do papel no Brasil era monopolizada pelas Indústrias Klabin do Paraná de Celulose S.A., que elevavam o preço, acompanhando o do papel importado. Enquanto, em 1954, foram consumidas 126.300 toneladas métricas, em 1955, apenas 82.000 toneladas métricas estavam disponíveis. (SODRÉ, 1966, p.472) A escassez de papel duraria até a década de 1960, quando surgiram leis de incentivo à produção de papel nacional, incluindo a isenção de impostos e taxas para equipamentos e materiais relacionados à produção.

${ }^{72}$ Casa e Jardim também sofria com essas questões: greves no porto atrasando a importação, cotas insuficientes, custo proibitivo do papel nacional. A periodicidade da revista e a qualidade do papel e da impressão variavam, em decorrência disso: "Sendo regularizado o abastecimento do papel - a preocupação maior de toda a imprensa do Brasil - passaremos a editar a revista mensalmente." (GYGAS, 1955, p.3) Isso realmente aconteceu, a partir do n.15, jul.1955. Mas, houve edições bimestrais nos anos seguintes, não se sabe se devido à falta de papel, novamente. A partir de 1959, a revista passa, definitivamente, a ser publicada todos os meses.
} 
importância deste campo profissional é a criação, em 1951, da primeira escola de propaganda do país, a Escola Superior de Propaganda de São Paulo.

O rádio ainda era o principal veículo de propaganda e as radionovelas, programas de auditório, humorísticos e jornais recebiam patrocínio das grandes empresas. Nele, elaboravam-se crenças e opiniões. ${ }^{73}$

Através das propagandas e programas de rádio, o brasileiro aprendia novos hábitos, como a escovação dos dentes e o banho diário. Mas, a publicidade ia além, dizendo qual a marca do sabonete, escova e creme dental a serem utilizados. "O consumo, bem como novas práticas sociais, era incentivado ainda no texto ficcional radiofônico. Por meio das radionovelas, sugeriam-se ao radiouvinte alguns comportamentos, que estavam em sintonia com a nova realidade mundial: urbana, moderna e industrial." (MARTINI, 2011, p.179)

A televisão, que chegou ao Brasil na década de 1950, também foi muito importante nesse processo. As agências de publicidade, como a McCann Erikson e a J.W. Thompson, trouxeram o "know-how" para a publicidade nesse novo veículo, criando, redigindo e produzindo programas e comerciais ao vivo - de eletrodomésticos, produtos para as donas-de-casa, alimentos e automóveis, principalmente.

Algumas atrações de sucesso do rádio migraram para a TV, levando sua fórmulas: novelas, programas de auditório, o Repórter Esso. Era uma espécie de rádio com imagem. As telenovelas, que surgiram praticamente junto com a televisão no Brasil, no início eram patrocinadas por companhias multinacionais de sabão, como a Gessy Lever e a Colgate-Palmolive, tendo como referência as soap operas americanas.

E, a partir de meados da década de 1950, cada vez mais cariocas e paulistanos passaram a usar a TV como principal fonte de lazer e de informação.

No caso das revistas, os recursos provenientes da propaganda comercial também eram fundamentais para a sua sobrevivência. Em geral, mais de dois terços da renda bruta da empresa eram cobertos por eles. ${ }^{74} \mathrm{O}$ destaque que a publicidade

\footnotetext{
${ }^{73}$ Os pareceristas do IBOPE o indicavam aos clientes, para a divulgação de produtos variados. De acordo com pesquisa realizada em 1950, 95\% dos habitantes das cidades do Rio de Janeiro e de São Paulo, independentes da condição econômica, possuíam aparelho receptor de rádio. IBOPE. Boletim das Classes Dirigentes, ano 1, n. 2, 6-13 nov. 1950 [Notação: IBOPE BCD01/02] apud MARTINI, 2011, p.33.

${ }^{74}$ Os anúncios eram encaminhados ao departamento de publicidade das revistas com especificações, como as dimensões e as páginas onde seriam publicados, pois havia espaços fixos reservados. Na diagramação, inicialmente, assinalavam-se as páginas correspondentes à publicidade e só depois distribuíam-se as matérias da redação. Segundo o fotógrafo Flávio Damm, atuante na redação da revista Casa e Jardim, no início da década de 1960, os anúncios já vinham prontos das agências, com
} 
ocupa nas publicações da época é uma novidade.

Em Casa e Jardim, na contracapa ou nas páginas internas, os anúncios são as peças mais bem cuidadas. ${ }^{75}$ As propagandas, geralmente coloridas, contrapõem-se aos artigos, normalmente em preto e branco. ${ }^{76}$

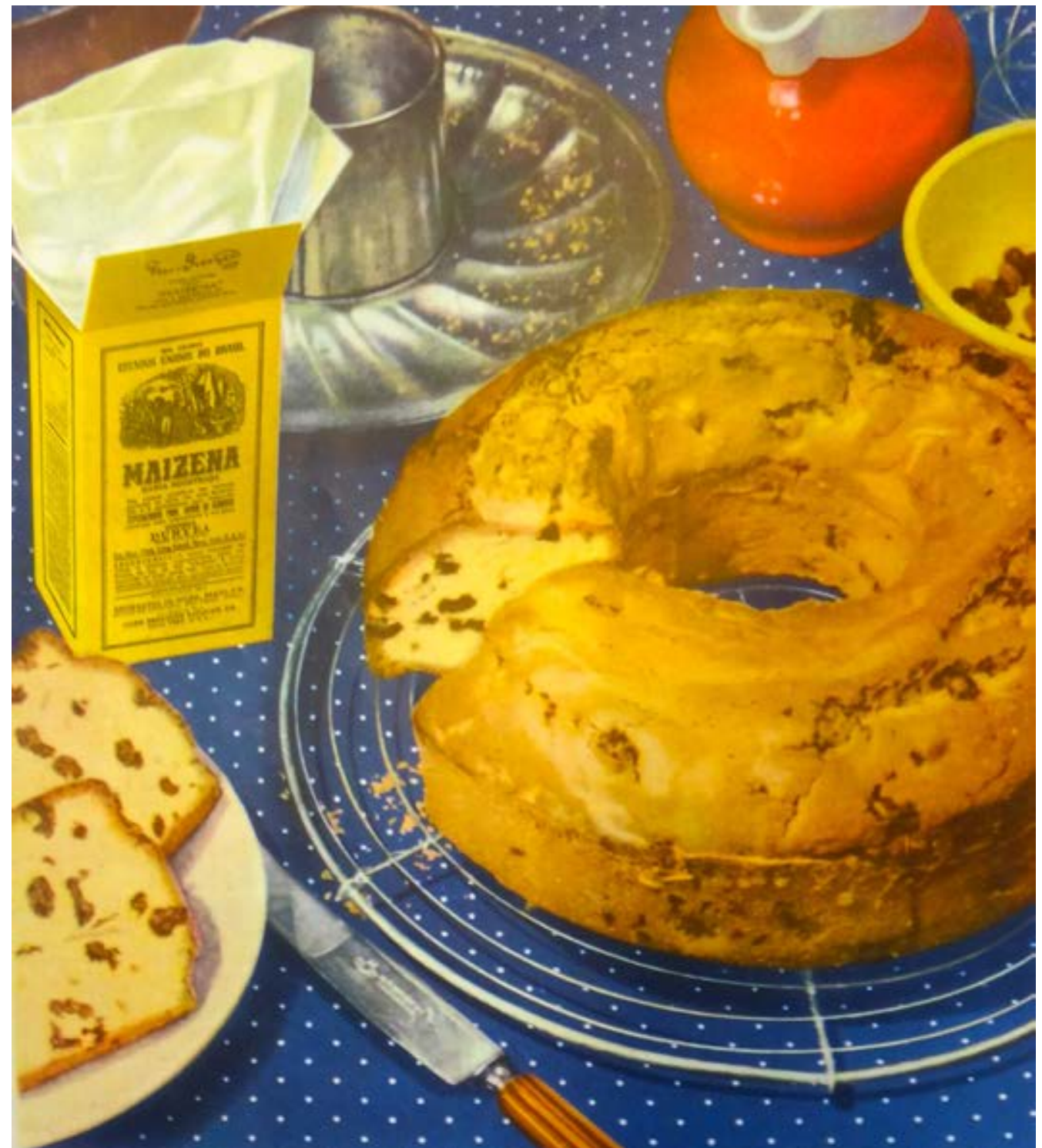

Fig. 1.19 - Anúncio de amido de milho

forte inspiração dos modelos americanos. (MACHADO, 2007, p.51)

${ }^{75}$ A partir do número 5, percebe-se um número crescente de propagandas.

${ }^{76}$ Nos primeiros números predominam anúncios de gêneros alimentícios, acessórios de cozinha, eletrodomésticos e alguns materiais de acabamento, como tintas, além de móveis. Ao longo do tempo, vão se enriquecendo graficamente e novos anunciantes são incorporados, como cigarros e automóveis. Notamos que novas empresas anunciantes começam a procurar a revista e diversifica-se a oferta de produtos à medida que ela ganha público. 
As reportagens, principalmente no início, mostravam-se um tanto improvisadas e descuidadas. A diagramação é falha, o número de colunas varia, reportagens prosseguem nas páginas finais. Nem sempre existe unidade entre texto e imagens, ao contrário dos anúncios. Nestes, percebe-se uma sintonia entre texto - conteúdo e forma - e as imagens.

Apresentam uma estrutura bem definida. Geralmente, uma imagem centrada tornase o ponto focal e estabelece-se um equilíbrio entre os vários elementos.

A mensagem é transmitida de forma elaborada, através de analogias e metáforas, investindo na imagem fotográfica.

São veiculadas marcas de produtos que se tornariam bem conhecidas e que existem até hoje: leite condensado Moça, amido de milho Maizena, fermento em pó Royal, açúcar UNIÃO.
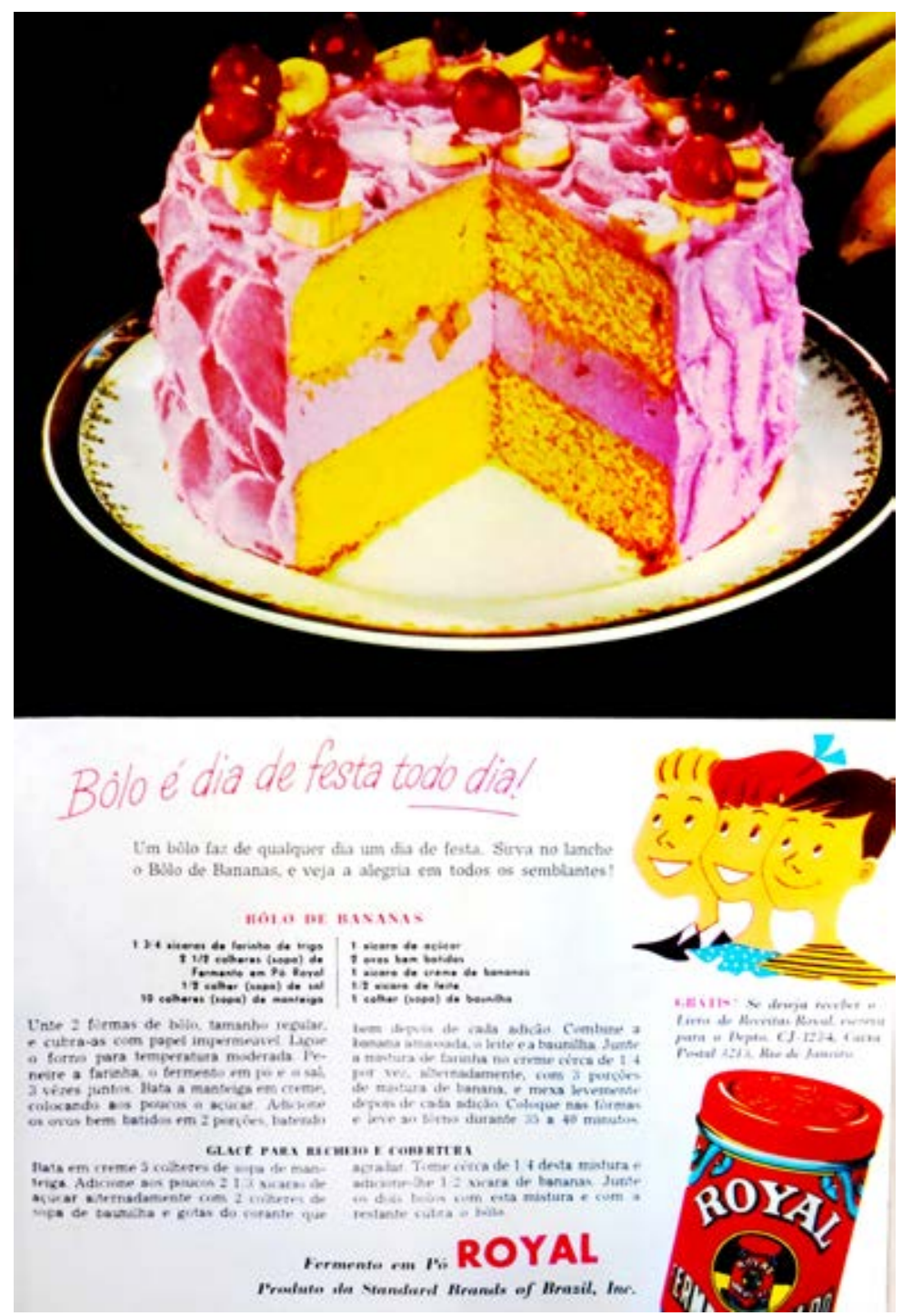

Fig.1.20 - Anúncio de fermento em pó. 
Os anúncios dos tapetes Chenile $^{77}$ são particularmente interessantes. Um deles mostra uma moça, sentada no tapete, ouvindo música em uma vitrola portátil: “...é tão macio! Chenile o tapete da moda." (UM ACORDE..., 1954, p.15) As roupas, a vitrola, o corte de cabelo, a maneira de se sentar, tudo é moderno e jovial.

As linhas diagonais do tapete, que enquadram a imagem da mulher, o foco da composição, dão ideia de movimento e profundidade, assim como as notas musicais e o título, com suas linhas curvas: "no reino das melodias - na realização do tapete - uma harmonia feliz para ver e ouvir." (Ibid., p.15) As letras, minúsculas, manifestam simplicidade.

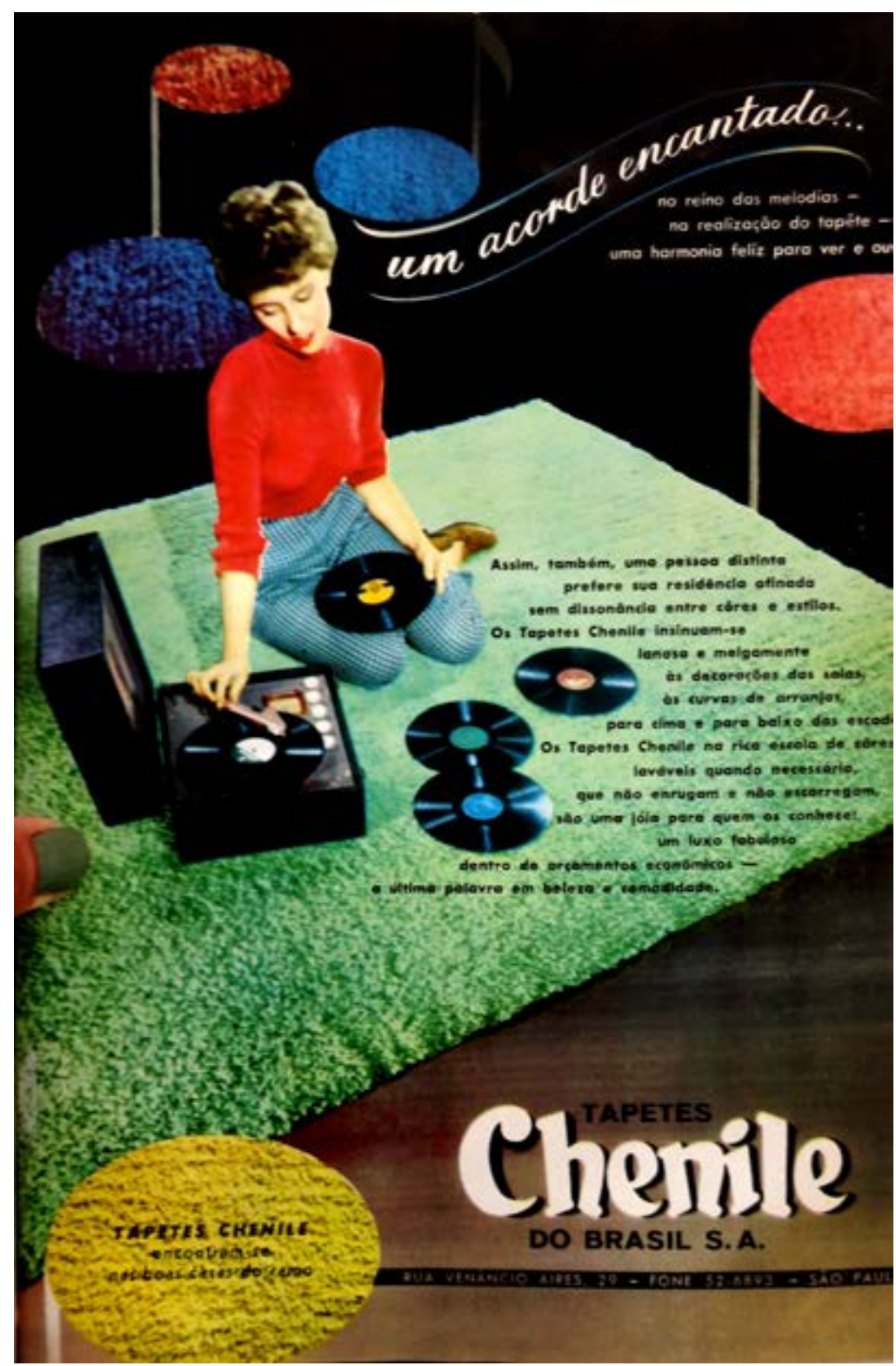

Fig.1.21 - Anúncio de tapete.

\footnotetext{
${ }^{77}$ Era um dos maiores anunciantes, presente em muitas das edições da revista.
} 
O tapete é moderno, suave, macio, refinado, para poucas pessoas. Confere status a quem o possui. Como, de certa forma, a revista procura constituir seu discurso sobre o "bem viver."

(...) uma pessoa distinta prefere sua residência afinada sem dissonância entre cores e estilos. Os tapetes Chenile insinuam-se lanosa e meigamente às decorações das salas, às curvas de arranjos, para cima e para baixo das escadas. (...) na rica escala de cores. (UM ACORDE..., 1954, p.15)

Outro anúncio mostra uma bailarina, vestida de branco, que flutua e contrasta com o tapete: "Sublime Perfeição. Na arte da dançarina. Na obra do tapete - o fruto de incansáveis esforços para conquistar o público." Harmonia nas cores, na dança. (SUBLIME..., 1954, s.n.p.)

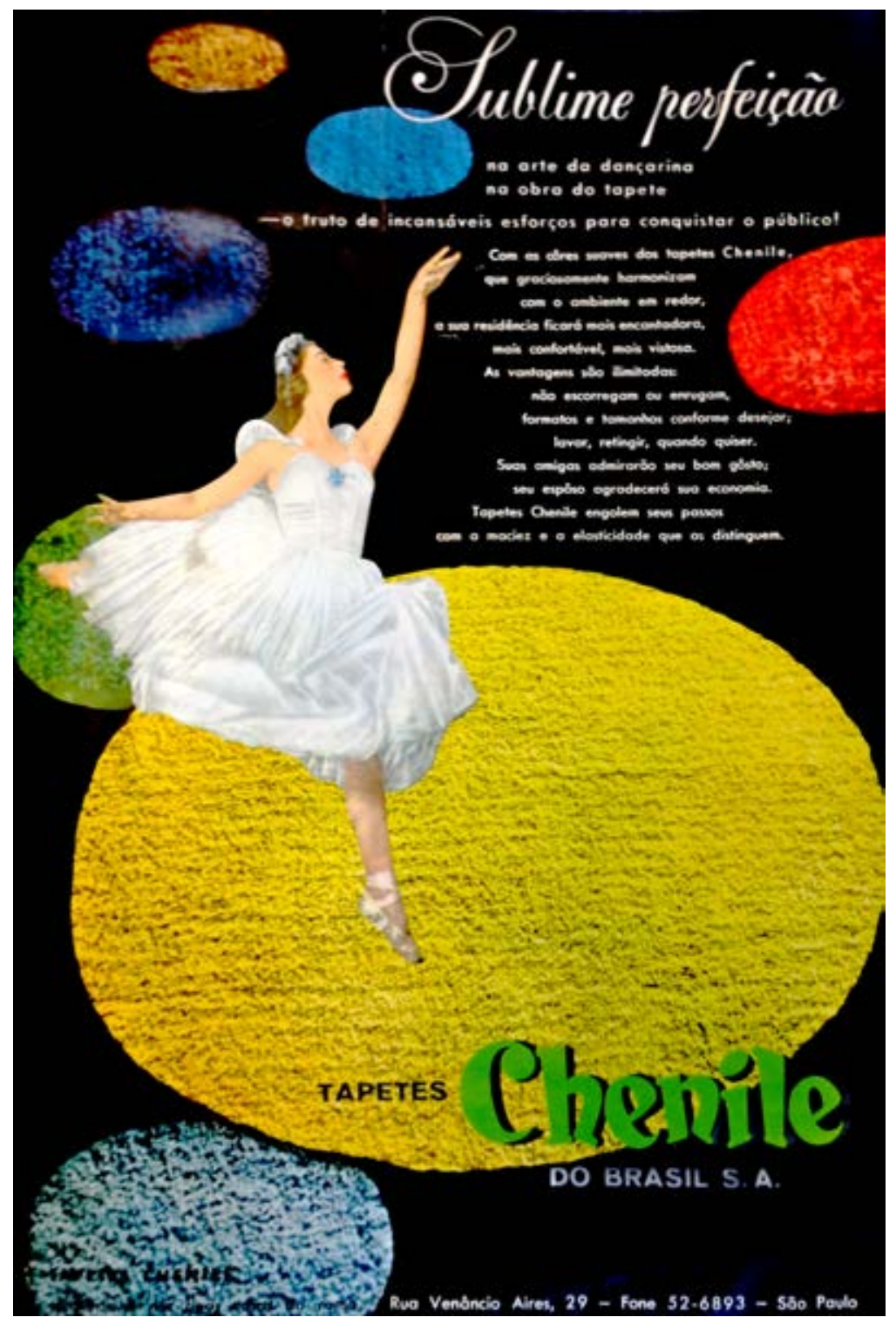

Fig.1.22 - Anúncio de tapete. 
Os tapetes Tabacow também têm anúncios elaborados e requintados, principalmente na década de 1960, com atrizes famosas, Inclusive Cacilda Becker. (TRANSFORME..., 1955, p.10-11) Em janeiro de 1962, começa uma nova série de anúncios em página dupla, com uma cor predominante.

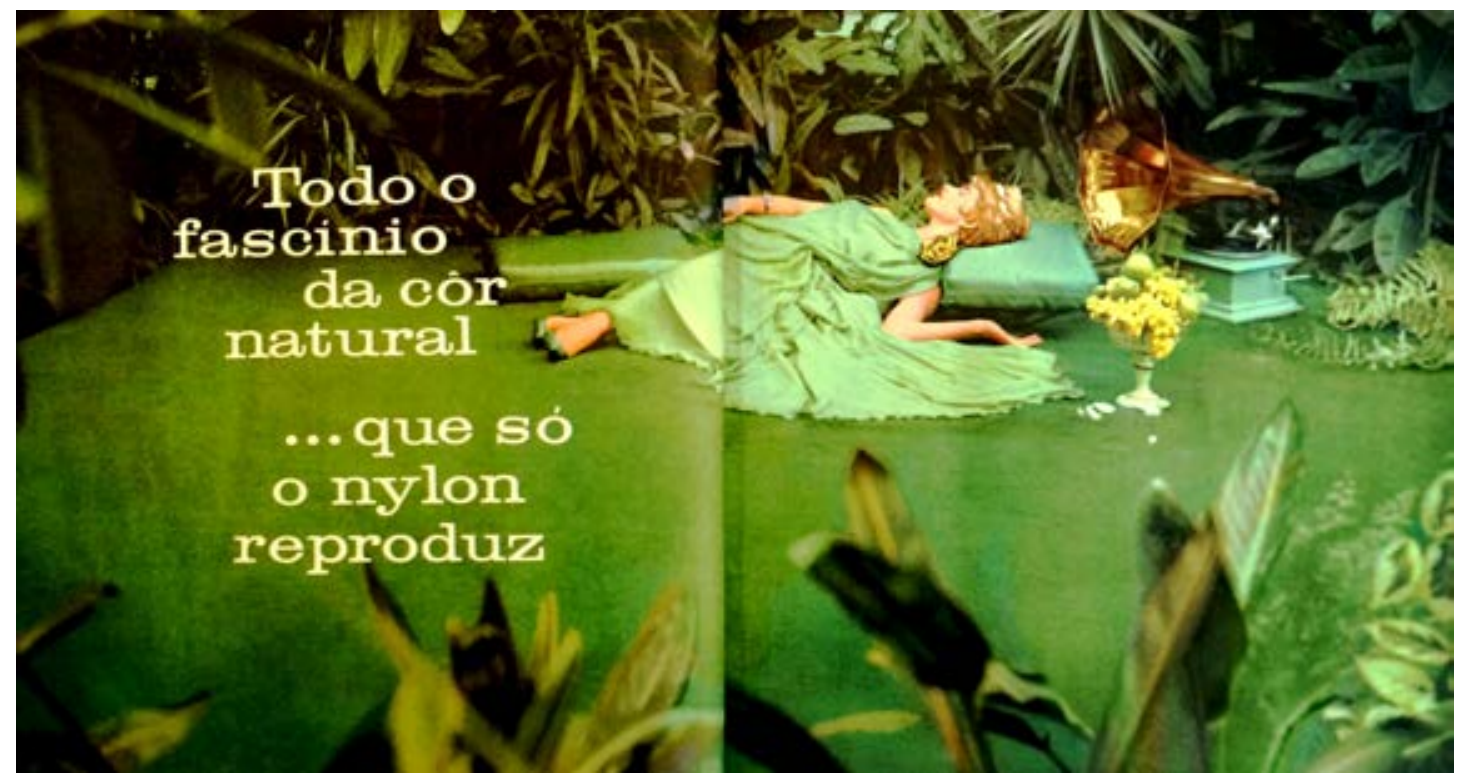

Fig.1.23 - Anúncio de tapete.

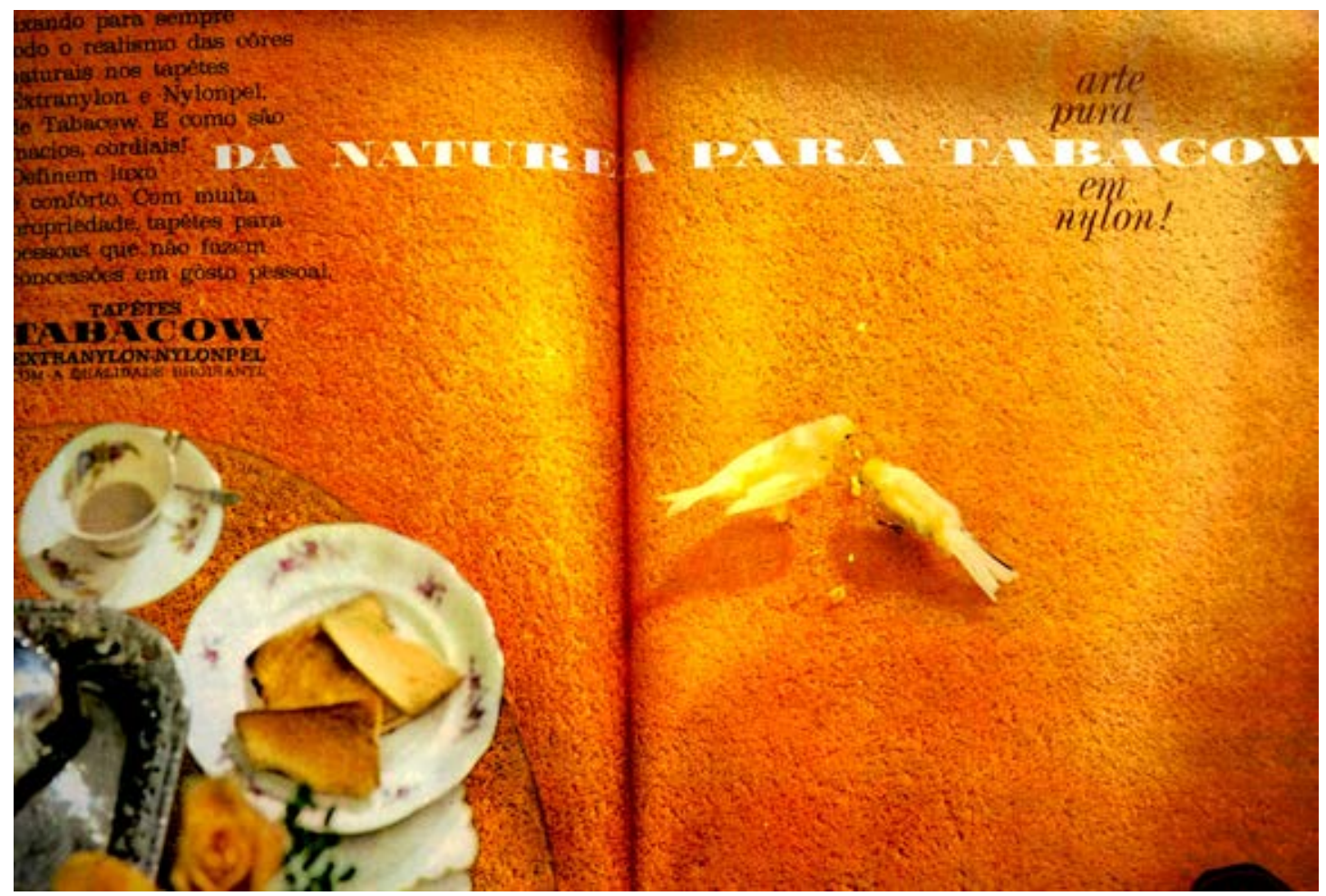

Fig.1.24 - Anúncio de tapete. 


\subsection{A Cultura metropolitana}

Segundo Meyer (1991, p.33), essa nova vida urbana expressa-se através de um conjunto de manifestações culturais com escala e complexidade possíveis apenas no interior da metrópole.

Em graus diferenciados, com suas especificidades, o cinema, o teatro, a música, a poesia e a arte, empenhados na construção de uma nova sociedade - cosmopolita, mas centrada na valorização do elemento nacional e popular -, abraçavam expressões artísticas e estéticas inovadoras que vinham sendo praticadas em outras partes do mundo.

O vigor do movimento cultural ecoava junto a setores das camadas médias urbanas em franca expansão, sobretudo os universitários, sintonizadas com o espírito nacionalista da época, que acreditava nas possibilidades de desenvolvimento do país. ${ }^{78}$

Essa classe média acaba por consolidar-se como consumidora de cultura, antes reservada à elite, dentro do processo de formação da sociedade de massa no Brasil. Os meios de comunicação expandem-se, tanto em relação ao lazer quanto à informação.

A televisão chega ao Brasil em 1950 e a TV Tupi de São Paulo é a primeira emissora, criada por Assis Chateaubriand, proprietário dos Diários Associados. ${ }^{79}$ Tudo isso aponta para um "embrião de indústria cultural e de massa, e por isso mesmo, cosmopolita e metropolitana”. (MEYER, 1991, p.35) ${ }^{80}$

Trata-se de uma vida urbana mais complexa e mais rica. ${ }^{81}$

\footnotetext{
${ }^{78} \mathrm{O}$ cinema e o teatro incluem-se nesse processo, tanto com produções de caráter popular quanto com outras mais sofisticadas. No caso do cinema, as populares chanchadas e comédias musicais, produzidas pela Atlântida. O teatro de revista, que também misturava humor e música, da mesma forma fazia muito sucesso. Além disso, havia experiências tanto de um cinema industrial, produzido pela Vera Cruz, quanto de um teatro menos popular, como o do Teatro Brasileiro de Comédia.

${ }^{79}$ No início, contou com a assessoria de técnicos americanos e de profissionais oriundos do rádio. A Tupi logo expandiu seu alcance, criando as Emissoras Associadas, com afiliadas em outras capitais. Em 1955, já havia estações em várias capitais. Desde 1952, já enfrentou a concorrência de outras emissoras.

${ }^{80}$ Meyer (1991, p.9-10) considera "marcos da cultura metropolitana" todos os fatos (desde que relevantes para a relação metrópole e urbanismo) que constituam um compromisso com uma nova forma de construir, comprar, morar, circular, divertir-se, usufruir e produzir objetos artísticos, comunicar-se e conviver de forma "cosmopolita".

${ }^{81}$ Quando comemora seu quarto centenário, em 1954, São Paulo possui 3 estações de televisão, 106 livrarias, 91 jornais, 3 universidades, 203 revistas. O cinema deve ser destacado, pois a cidade
} 
Essa nova vida implica em, além de novos comportamentos e atitudes, espaços diferenciados, como o Museu de Arte de São Paulo (MASP), fundado em 1947, e o Museu de Arte Moderna (MAM), criado em 1948. Estes e outros museus brasileiros foram criados tendo como modelo o MOMA - Museum of Modern Art -, de Nova York e recebendo a colaboração de Rockefeller.

A ideia de se fundar uma instituição que divulgasse a arte moderna, inspirada em instituições americanas, vinha sendo discutida por artistas, alguns remanescentes da Semana de 22, intelectuais e representantes da elite paulistana. Desde o final da década de 1940, a burguesia paulistana percebera que, além da modernização industrial e do crescimento econômico, era necessário um "aparato cultural" que tornasse São Paulo uma "metrópole ilustrada." (MEYER, 1991, p.35) Havia um vínculo entre essa burguesia e o novo cosmopolitismo.

Um acordo oficial foi firmado entre o MAM e o MOMA, em 19 de outubro de 1950, em Nova York: "Num mundo que se torna cada vez mais ciente da extensão na qual a prosperidade material do povo depende da cooperação na esfera econômica e política, é da maior importância que esses esforços sejam acompanhados por um intercâmbio no campo dos empreendimentos culturais." 82

A primeira bienal do MAM, em 1951, foi patrocinada por Francisco Matarazzo Sobrinho, o Ciccillo, com a colaboração do MOMA, inspirada pela Bienal de Veneza de 1948, na qual ele participara da organização da representação brasileira.

As bienais foram um marco de importância fundamental nas artes plásticas brasileiras. Com sua criação, São Paulo insere-se definitivamente no cenário internacional das artes plásticas e consolida-se um padrão cultural moderno para a cidade.

A elite paulistana sabia que era necessário conviver com o que se produzia a nível mundial - industrial e culturalmente. ${ }^{83}$

possuía, em 1950, 119 salas, frequentados por 35 milhões de espectadores ao ano. SIMOES, I.F. Salas de Cinema em São Paulo. São Paulo: Secretaria Municipal de Cultura, 1990 apud MEYER, 1991, p.36.

${ }^{82}$ Acordo entre o Museu de Arte Moderna de São Paulo e o Museum of Modern Art de Nova York. Rockefeller Archive Center. Citado em IRIGOYEN DE TOUCEDA, 2005, p.145. Uma relação se estabeleceu entre Ciccillo e Rockefeller, mediada pelo adido cultural dos Estados Unidos e conselheiro do MOMA, Carleton Sprague Smith. Rockefeller acabou doando obras para o MAM. As ligações entre o MOMA e o MAM, ou entre Rockefeller e Matarazzo, prosseguiram no âmbito da bienal.

${ }^{83}$ Em 1954, São Paulo tornara-se a maior metrópole brasileira, com 2.817 .600 habitantes. (MEYER, 1991, p.25) 
Outro aspecto a ser ressaltado é a presença de indivíduos de diversos países, com referências culturais variadas. Vindos a partir dos anos 1930, esses imigrantes eram urbanos, diversos daqueles do início do século $X X{ }^{84}$

Esse cosmopolitismo baseia-se em novos valores, em "pertencer ao mundo." A presença do capital estrangeiro, a modernização da vida cotidiana, a dimensão do consumo fazem parte desse processo.

Assim, nos chamados "anos dourados," que incorporaram o espírito otimista do governo Kubitschek, um conjunto de mudanças sociais e manifestações artísticas e culturais acontece, no bojo de um debate mais geral sobre a reconstrução nacional, em curso desde o início dos anos 50, até os primeiros anos da década seguinte.

O entusiasmo em construir algo novo fez surgir vários movimentos no campo artístico, que revigoraram o ambiente cultural, como a Bossa Nova e o Cinema Novo: novas formas de pensar a arte. Ou, em alguns casos, consolidou-se um movimento que já se iniciara em décadas passadas, como é o caso da arquitetura moderna.

\subsubsection{Referências da arquitetura americana no Brasil}

$\mathrm{Na}$ arquitetura brasileira, também existem inúmeras referências norte-americanas, principalmente na vertente paulista, nos anos 1950.

Um importante aspecto dessa questão é a polarização política, que não era nova, e que envolvia as duas grandes faculdades de arquitetura de São Paulo: a FAU e o Mackenzie.

$\mathrm{Na} F A U$, havia a questão do engajamento politico dos profissionais, ligados à esquerda, e uma inclinação de seus alunos, mais intelectualizados, à teorização da arquitetura. A influência de Vilanova Artigas era marcante, assim como as de Le Corbusier e Niemeyer.

Em contrapartida, o Mackenzie era visto como reduto dos "americanos próimperialistas." No entanto, as referências à arquitetura moderna americana revelam um pragmatismo desses profissionais, e não uma questão ideológica. ${ }^{85}$ Grande

\footnotetext{
${ }^{84} \mathrm{O}$ próprio editor de Casa e Jardim, Théo Gygas, insere-se nesse contexto.

${ }^{85}$ Houve um predomínio dos arquitetos formados ou ligados ao Mackenzie, ao menos no início da ocupação do Jardim América. Com as obras mais significativas e os cargos públicos nas mãos dos politécnicos, os mackenzistas souberam reconhecer e explorar este novo mercado que surgia - a arquitetura de classe média.
} 
parte desses mackenzistas ${ }^{86}$ inspirou-se na obra de Frank Lloyd Wright, Richard Neutra e Marcel Breuer, entre outros. A arquitetura americana era olhada com atenção, principalmente quanto à sua racionalização e à sua fluidez espacial, em busca de um novo desenho para a casa de classe média.

Entre esses arquitetos formados no Mackenzie, destacava-se Oswaldo Bratke. Em seu atelier da Rua Avanhandava, trabalharam vários arquitetos mais jovens, como Marino Barros, Rodolpho Ortenblad Filho, Arnaldo Furquim Paoliello, Villanova Artigas, Carlos Lemos, Alberto Botti.

Bratke também tinha a arquitetura americana como referência, particularmente sua funcionalidade, praticidade e a utilização de novas técnicas.

Essa arquitetura tornou-se conhecida no Brasil através de vários caminhos. Um dos mais importantes foram as revistas: grande número delas circulava entre estudantes e profissionais. Eram periódicos técnicos, ${ }^{87}$ mas também revistas voltadas ao publico leigo.

Além disso, as revistas brasileiras publicavam trabalhos dos arquitetos americanos ou reproduziam artigos. ${ }^{88}$

Alguns periódicos tiveram como modelo revistas americanas. A californiana Arts \& Architecture inspirou a Pilotis, criada por um grupo de alunos da Faculdade de Arquitetura da Universidade Mackenzie, formado por Carlos Millan, Salvador Candia, Jorge Wilheim, Roberto Carvalho Franco, Paola Tagliacozzo e Sidney Fonseca. Apesar do diretor da faculdade, Christiano Stockler das Neves, opor-se de forma radical à qualquer manifestação da arquitetura moderna,

Outra revista que deve ser mencionada é a Acrópole, fundada em 1938, que, na década de 1950, apresenta um predomínio dos projetos modernos em suas páginas. Irigoyen de Touceda (2005, p.90) lembra que, entre 1953 e 1955, o diretor da revista foi Rodolpho Ortenblad Filho, grande admirador da arquitetura moderna americana.

\footnotetext{
${ }^{86}$ Eles costumavam associar-se, não apenas com firmas estabelecidas, mas para projetos específicos. Uma análise mais aprofundada deve ser feita sobre a causa do esquecimento de muitos desses profissionais, formados no Mackenzie. Foram grandes figuras que marcaram a arquitetura moderna brasileira, projetaram e construíram muito, e ajudaram a modernizar a vida paulistana.

${ }^{87}$ Architectural Forum, Architectural Record, Pencil Points, Arts \& Architecture são algumas.

${ }^{88}$ Em 1937, a Revista de Engenharia Mackenzie publicou "Arquitetura Funcional”, um resumo de New building art in California, de Richard Neutra. Pilotis publicou, entre outros artigos, uma sinopse do livro de Richard Neutra, Arquitetura social em países de clima quente, projetos do mesmo arquiteto e comentários sobre a residência de Marcel Breuer no jardim do MOMA. Outro livro de Neutra, Neutra: residências, foi publicado no Brasil em 1951.
} 
As viagens dos arquitetos foram outra oportunidade para "trocas." ${ }^{89}$ Grande número de egressos do Mackenzie fez suas viagens de estudos para conhecer obras de vários arquitetos, entre eles Frank Lloyd Wright, Richard Neutra, Marcel Breuer e Walter Gropius. ${ }^{90}$

Oswaldo Bratke realizou sua primeira viagem à América em 1948, conhecendo obras de Neutra, que já havia encontrado em São Paulo. Esteve na redação de Arts \& Architecture, com fotos e projetos de sua casa e atelier na rua Avanhandava, que acabaram sendo publicados por John Entenza. ${ }^{91}$ Em Nova York, Bratke conheceu a casa de Breuer nos jardins do MOMA.

Em contrapartida, vários arquitetos estrangeiros nos visitaram nos anos 1940 e 1950. Richard Neutra e sua esposa Dione, patrocinados pelo Departamento de Estado americano, percorreram a América Latina por três meses, em 1945. No Brasil, o arquiteto esteve em São Paulo e no Rio de Janeiro, onde conheceu vários arquitetos. O MASP organizou, em 1951, a exposição "Residências de Neutra".

Neutra voltaria ao Brasil em 1959, para participar do Congresso Internacional de Críticos de Arte, onde arquitetos, urbanistas e críticos de arte discutiram Brasília, então em construção. Junto com Niemeyer, Neutra visitou o Rio de Janeiro, Petrópolis e São Paulo. Ali, fez uma conferência na USP, para plateia repleta de estudantes e arquitetos. O IAB/SP, instalado em 1943, recebeu-o no subsolo do Edifício Esther, sua primeira sede.

E, finalmente, as bienais. Estas foram um marco para a exposição dos trabalhos de profissionais estrangeiros, às vezes, também, com suas visitas à Exposição Internacional de Arquitetura, realizada desde a primeira bienal. ${ }^{92}$

\footnotetext{
${ }^{89}$ Entre os brasileiros que viajaram aos EUA para conhecer a arquitetura moderna americana, um dos primeiros foi João Batista Vilanova Artigas, que recebeu uma bolsa de estudos da Fundação Guggenheim, em 1947. Permaneceu 13 meses no país e conheceu a obra de Frank Lloyd Wright, Richard Neutra e George Frederick Keck.

${ }^{90}$ Miguel Forte e Jacob Ruchti viajaram entre março e agosto de 1947. Conseguiram contatos com Neutra, Philip Johnson, Paul Lester Wiener, William W. Wurster e Wright. Visitaram a sede da revista Architectural Record. Salvador Candia também esteve nos EUA em 1947, onde entrou em contato com Philip Johnson. Nos anos 1950, outros arquitetos, como Plinio Croce, César Luiz Pires de Mello, Arnaldo Furquim Paoliello e Roberto Aflalo, também estiveram na América, visitando várias obras. (IRIGOYEN DE TOUCEDA, 2005, p.122-5)

${ }^{91}$ Arts \& Architecture, Los Angeles, n.65, p.32-33, 1948.

92 De cuja organização, participaram Lourival Gomes Machado, Luiz Saia e Eduardo Kneese de Mello. Os dois últimos foram responsáveis pelo projeto da primeira sede da bienal, uma estrutura de madeira de cinco mil metros quadrados, temporária, erguida no local onde hoje se encontra o MASP.
} 
$\mathrm{Na}$ primeira, foram enviados projetos de mais de cento e cinquenta arquitetos de todo o mundo, superando as expectativas iniciais. O MOMA era o responsável pela seleção dos participantes dos Estados Unidos, cuja representação não foi tão significativa quanto desejava Rockefeller.

$\mathrm{Na}$ II Bienal, a participação americana seria mais expressiva. ${ }^{93}$ Grande parte das obras expostas havia feito parte da exposição Built in USA. Postwar architecture, apresentada no MOMA e em diversas cidades dos Estados Unidos.

Os prêmios distribuídos aos arquitetos causaram polêmica: dez estrangeiros - entre eles quatro americanos ${ }^{94}$ - foram selecionados, contra apenas três brasileiros. ${ }^{95}$

Essa bienal foi adiada até o final do ano de 1953, para abrir as comemorações do IV Centenário da Cidade de São Paulo, em janeiro de 1954. Aconteceu no Parque Ibirapuera, idealizado para as celebrações, em pavilhões criados por Oscar Niemeyer ${ }^{96}$ o primeiro conjunto arquitetônico moderno público construído na cidade de São Paulo.

Walter Gropius também esteve na II Bienal, na qual participou do júri, e sua presença teve grande repercussão. Ele permaneceu no Brasil entre 4 e 30 de Janeiro de 1954, participando também do IV Congresso Brasileiro de Arquitetos, em São Paulo. Fez conferências, deu entrevistas, visitando também o Rio de Janeiro e Petrópolis, onde conheceu alguns dos jardins de Burle Marx.

Já na IV Bienal, em 1957, ${ }^{97}$ entre as trinta e seis casas apresentadas na categoria moradia individual, nove eram dos EUA ${ }^{98}$ e quatorze do Brasil. Croce e Aflalo, Bratke, Forte e Ciampaglia, Ortenblad Filho, arquitetos com referências da arquitetura moderna americana em seus projetos, estavam entre os escolhidos.

\footnotetext{
${ }^{93}$ Entre cento e setenta obras, sessenta e duas eram daquele pais, e entre os cento e trinta arquitetos participantes, quarenta e cinco também provinham de lá. (IRIGOYEN DE TOUCEDA, 2005, p.152)

${ }^{94}$ Os americanos eram Craig Ellwood - ligado ao Case Study Houses -, Donald Barthelme, Paul Rudolph e Philip Johnson, além de Walter Gropius que, apesar de não ser americano, ali vivia. Além disso, foi outorgada pelo júri uma menção especial para a representação americana, pela qualidade de sua seleção.

${ }^{95}$ A revista Habitat descreveu a arquitetura doméstica americana como a mais destacada da bienal. Para onde vai a arquitetura. Habitat, São Paulo, n.14, p.25, fev.1954.

${ }^{96}$ Ele liderou uma equipe de arquitetos paulistas, formada por Zenon Lotufo, Hélio Uchoa Cavalcanti e Eduardo Kneese de Mello, que também contou com a colaboração dos arquitetos Gauss Estelita e Carlos Lemos.

${ }^{97} \mathrm{Na}$ III Bienal, em 1955, não fora realizada a Exposição Internacional de Arquitetura.

${ }^{98}$ Pierre Koenig participou dessa bienal e também da VI, em 1961, quando foi premiado. (BRASIL, 2007, p.56)
} 
Marcel Breuer - que já estivera aqui por três dias no Rio de Janeiro em 1947, a caminho da Argentina -, Kenzo Tange e Philip Johnson estiveram no júri da IV Bienal, em 1957, além dos representantes brasileiros. Porém, a estada de Breuer em São Paulo não teve maiores repercussões, como a de Gropius.

Mies van der Rohe era um dos convidados para participar do júri da IV Bienal, mas seu nome não aparece na ata publicada na revista Acrópole. ${ }^{99}$ Sua viagem, muito provavelmente, teve como foco o projeto do Consulado Americano em São Paulo, que acabou por não ser construído. Porém, na $V$ Bienal, Mies seria alvo de muitas atenções, devido à sala em sua homenagem.

Houve ataques às bienais, de diferentes orientações politicas ou correntes arquitetônicas. Reprovações de cunho estético, da autoria de Christiano Stockler das Neves, e críticas vindas da esquerda, principalmente de Vilanova Artigas, militante do Partido Comunista, que via o imperialismo americano representado pela figura de Nelson Rockefeller e, por extensão, pelo MAM. ${ }^{100}$ Esses ataques eram rebatidos pelo crítico de arte Mario Pedrosa, que integrou o júri da segunda e terceira bienais. Ele defendia a abstração na arte e na arquitetura, que Artigas dizia ser "uma expressão da decadência burguesa," 101 seguindo a orientação soviética de uma arte realista.

\footnotetext{
${ }^{99}$ Acrópole, São Paulo, n.227, 1957.

${ }^{100}$ Em 1951, o Partido Comunista colocou-se contra a bienal, impedindo que os artistas ligados ao partido participassem das exposições. Villanova Artigas, militante, no texto $A$ Bienal é contra os artistas brasileiros, de setembro de 1951, publicado na revista "Fundamentos", afirma que o evento era noticiado nos jornais "burgueses," pelo fato de ser favorável ao "imperialismo americano" e contra a "libertação da nossa pátria desse polvo que nos suga." Para ele, a bienal era apolítica, pois levava os artistas a se envolverem com pesquisas formais. (ACAYABA, 1994, p.22)

${ }^{101}$ AMARANTE, Leonor As Bienais de São Paulo/1951 a 1987. São Paulo: Projeto, 1989, p.16 apud IRIGOYEN DE TOUCEDA, 2005, p.180
} 


\section{Capítulo 2}

\section{A arquitetura do "bem viver"}

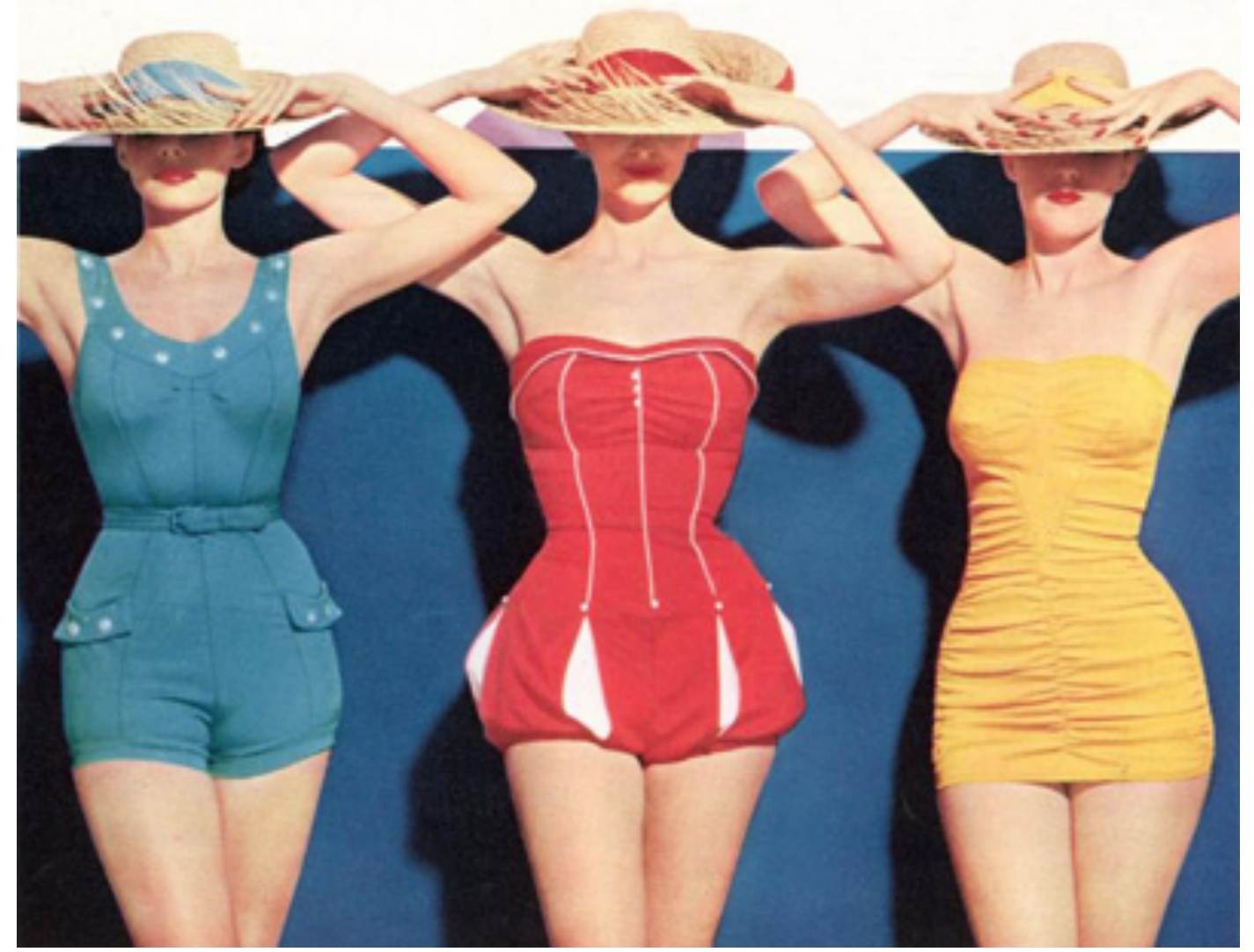

Fig.2.1 - Viver bem nos anos 1950.

Como vimos, os anos 1950 no Brasil, particularmente em São Paulo, foram uma época de muitas transformações. Estabeleceu-se de forma definitiva um contexto, que já se delineava em décadas passadas, o qual tornou possível o surgimento de publicações como a revista Casa e Jardim, voltada especificamente ao público leigo de classe média, que veicula certa arquitetura, imbricada à questão do consumo.

Assim, neste capítulo, analisaremos essa arquitetura, que denominamos arquitetura do "bem viver." 


\section{1 "a casa do 'morar bem"”}

Pesquisando em Casa e Jardim, um título de reportagem chama a atenção: "a casa do 'morar bem'." 1 O que seria o "morar bem" sob a ótica da revista?

A casa mostrada é pequena, construída com tijolinhos à vista e cobertura inclinada para um dos lados. De evidente simplicidade, "projetada (...) para proporcionar conforto e facilidade de vivência." (HUBERTO, 1958, p.53) Morar bem, então, associa-se a viver de forma fácil, simples e confortável, em uma pequena habitação.

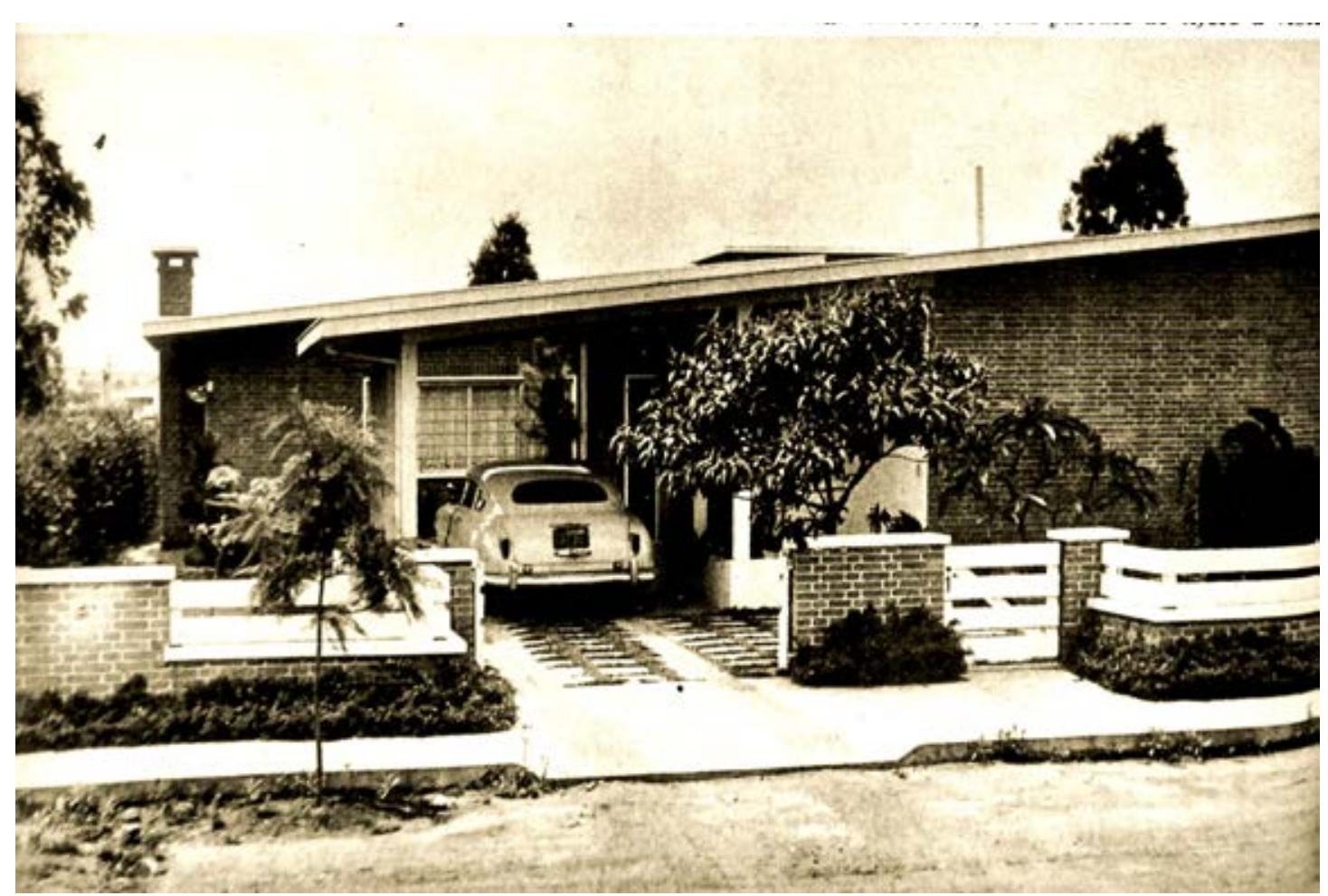

Fig.2.2 - A casa do "morar bem."

O living ${ }^{2}$ da casa não apresenta muitos paralelos com nossa antiga sala de visitas. ${ }^{3}$ Esse termo, inclusive, é raramente utilizado, substituído por living, estar, sala de

\footnotetext{
${ }^{1}$ Projeto da Construtora Ferraz Ltda., construção de Bresslau \& Bastian, na Rua Emboabas, 306, ainda existente.

${ }^{2}$ A palavra da língua inglesa significa vida, modo de vida (substantivos) ou vivo, ativo, estimulante, natural (adjetivos) e acabamos por associar o ambiente a um local onde se desenvolvem atividades informais e vibrantes.

${ }^{3}$ Nas décadas de 1910 e 1920, "Os segmentos médios foram, em São Paulo, o público-alvo predileto dos conselhos e campanhas publicitárias que previam o enfraquecimento da sala de visitas como zona de representação social e o seu fortalecimento como área de convívio familiar, íntimo e confortável, segundo o modelo inglês do living room." (CARVALHO, 2008, p. 165-6)
} 
estar, ${ }^{4}$ referindo-se a um ambiente onde são desenvolvidas várias atividades. Ler um livro - o que faz a garotinha -, ouvir música - com o sistema $\mathrm{Hi}-\mathrm{Fi}$ - ou admirar a obra de arte - um quadro do pintor José Antônio da Silva. Nesse ambiente, existem móveis leves, modernos, simples, com uma disposição diversa, tapetes confortáveis, cores variadas.

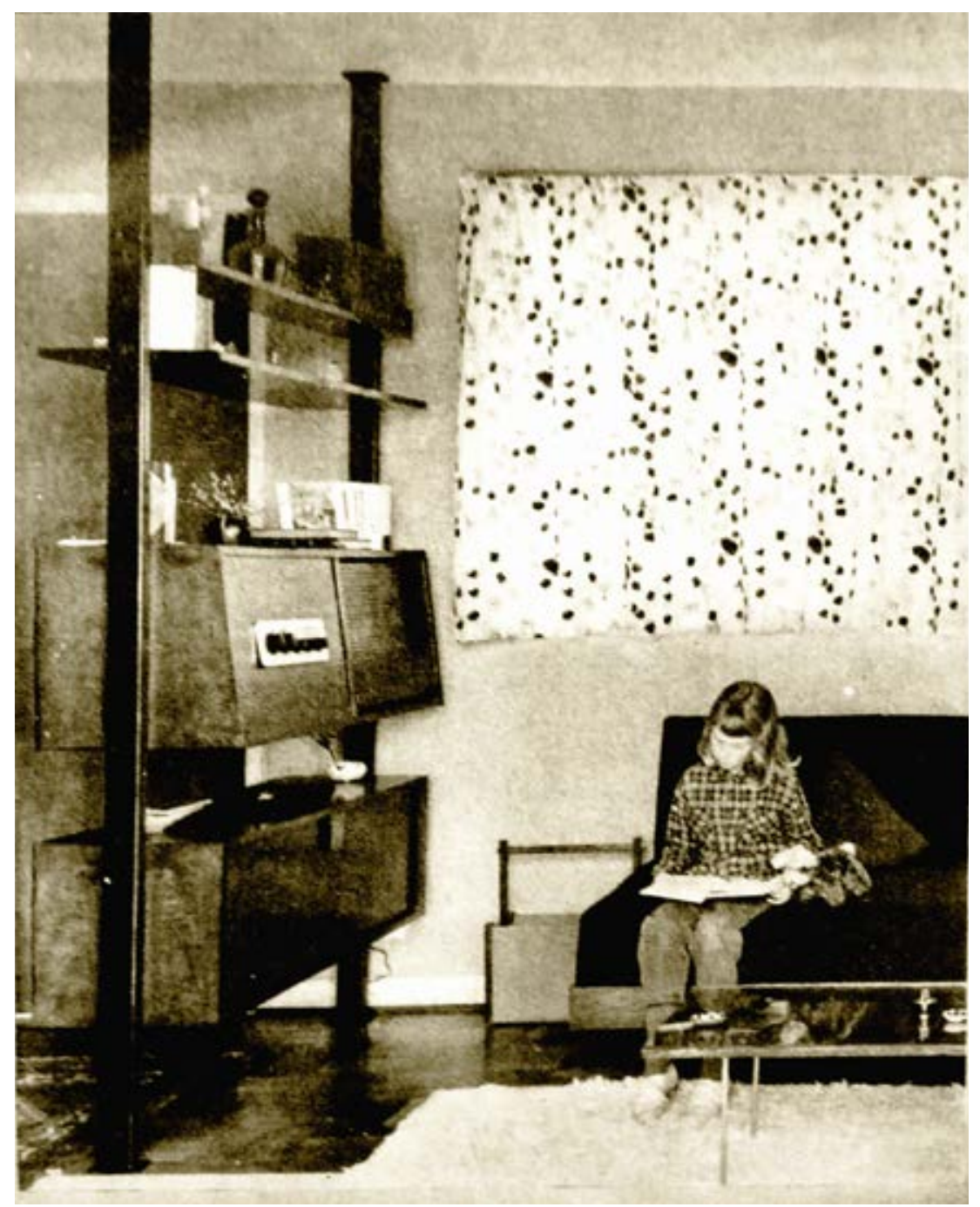

Fig.2.3 - Living da casa do "morar bem."

\footnotetext{
${ }^{4}$ Ainda nos anos 1920, na cidade de São Paulo, nos subúrbios de classe média, como o Jardim América em seu início, percebe-se uma grande presença de bangalôs e pequenos sobrados, com vários espaços de convivência familiar, cultivando um novo tipo de domesticidade. Uma vida mais simples e mais informal. As casas abriam-se para os jardins, que apresentavam equipamentos para favorecer a permanência, como pérgolas e mobiliário. A sala de estar geralmente ligava-se ao jantar através de um arco, ou formavam ambas um "L". Não se tratava apenas de uma mudança no desenho da casa, mas de comportamento; a antiga sala de visitas perde seu sentido nessas casas menores, às vezes sendo chamada sala de estar ou mesmo hall (geralmente quando havia lareira). Ver JANJULIO, 2009, capítulo 5 .
} 
O fato da menina se utilizar da sala reforça a percepção de que esse não é um ambiente formal e a "lareira convidativa" (HUBERTO, 1958, p.54) transmite a imagem de conforto.

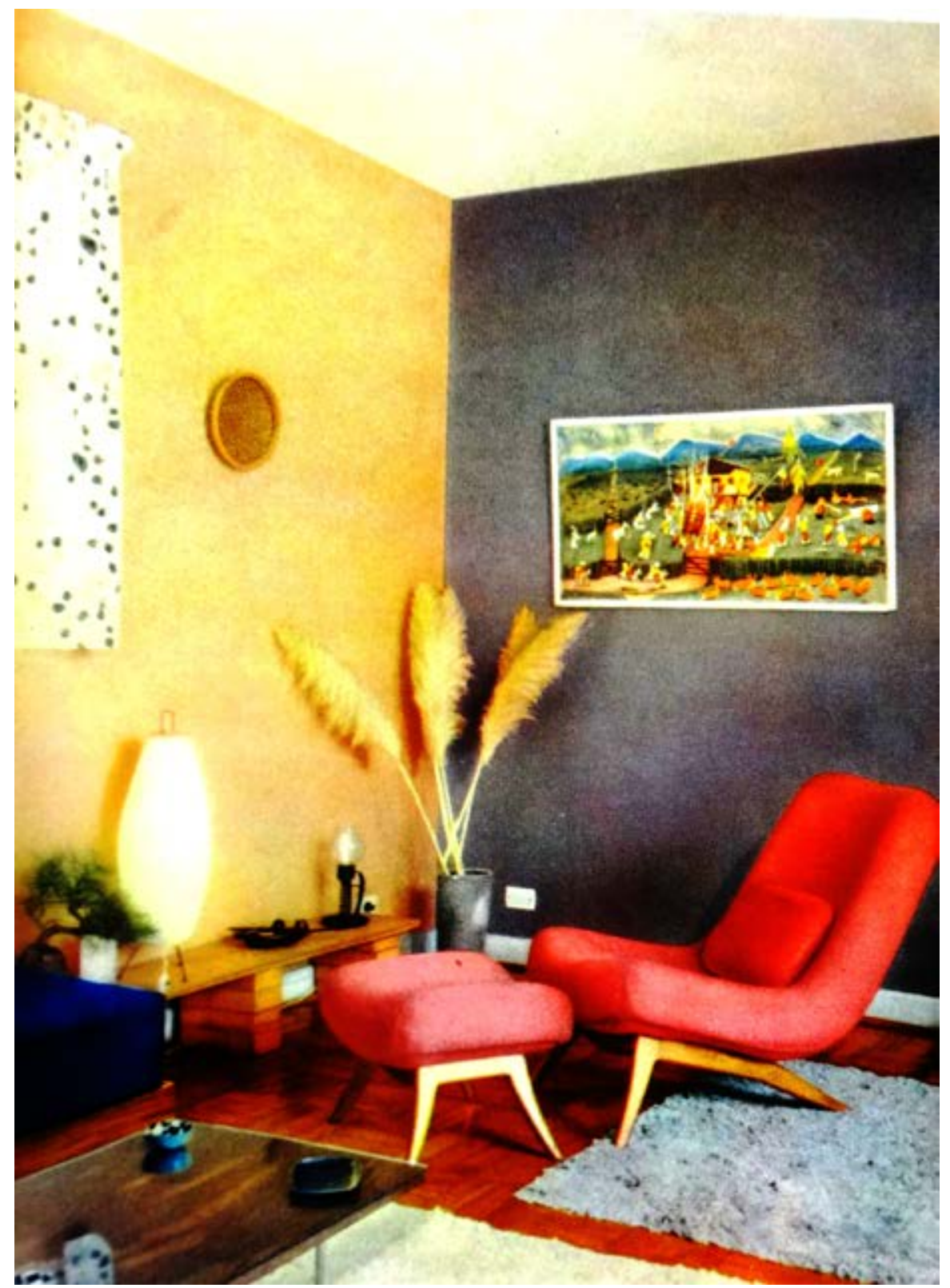

Fig.2.4 - Canto do living.

A casa, além disso, constitui-se em um refúgio: "Como é bom chegar em casa, deixando o carro na garagem de fácil acesso, e as possíveis preocupações no escritório." (Ibid., p.52) A distância das preocupações é também física, pois a residência localiza-se em "um acampado livre (...) onde as casas ainda escasseiam (...). Uma casa que poderíamos quase chamar de campestre." (Ibid., p.53). Trata-se 
de uma rua não pavimentada, em um bairro que era, então, um subúrbio, o Brooklyn Paulista.

Apesar do sossego e do pequeno muro frontal, não existem grandes aberturas voltadas para a rua. Os dormitórios abrem-se para uma espécie de pátio, onde os moradores são fotografados, em roupas informais, brincando com os cachorros. Uma cena montada, onde existem cadeiras confortáveis e uma pequena mesa com bebidas.

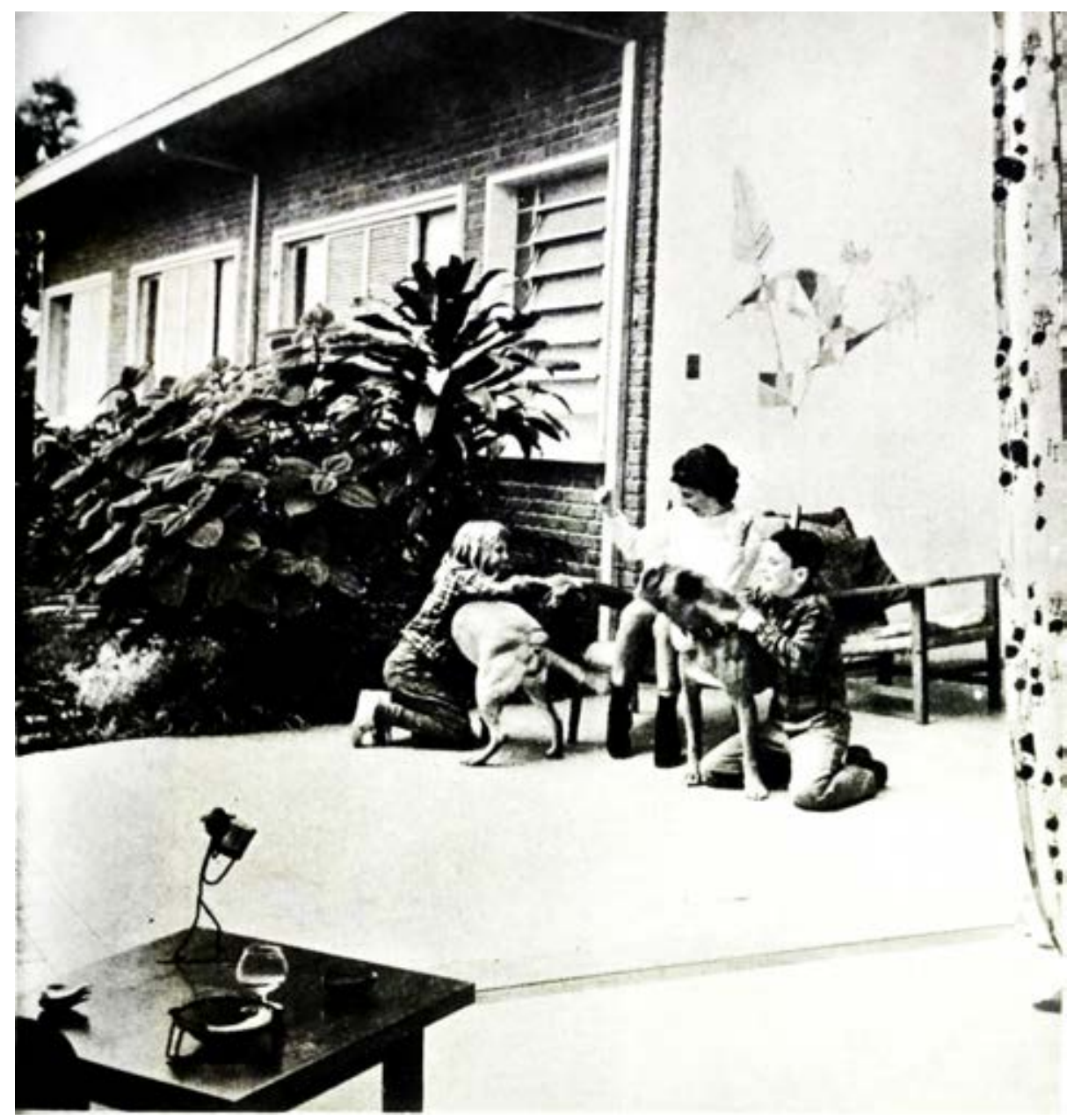

Fig.2.5 - Cena familiar.

A cena lembra um anúncio publicitário; tais momentos parecem naturais e as experiências ali vividas, simples, porém singulares e plenas.

Mas, o importante nesse caso não é a maneira como essa família realmente vive, mas como a revista transmite essas expectativas em relação ao viver nessa casa de subúrbio, localizada em uma metrópole como São Paulo. 
Como no trecho seguinte: o "(...) viver, neste caso, não significa apenas a moradia, mas o lugar onde descansamos, comemos e brincamos. Hoje em dia vivemos com menos cerimônia, mas talvez com bem mais humanidade." (O HOMEM..., 1959, p.4) Muitas das características da casa que abriga esse modo de se viver já vinham sendo apontadas em Casa e Jardim, desde as primeiras edições: em relação ao conforto, à simplicidade, às dimensões, ao tipo de vida que ali se desenvolve. Mas, como se ela finalmente houvesse se constituído, com todos os seus contornos, ganha um nome: "a casa do 'morar bem'." 5 Nós a nomeamos casa ou arquitetura do "bem viver."

Na revista, são feitas observações a respeito dos projetos, comentários e conselhos variados sobre os temas apontados, de forma recorrente.

Faz-se uma espécie de "passo a passo" de como se planejar - desde a escolha do terreno e do arquiteto -, projetar, construir, equipar, decorar e habitar uma residência.

Desse contexto, faz parte a dimensão do consumo, presente nos anúncios, que mostramos no capítulo 1. Existe sempre algo a ser melhorado na casa, algo a ser comprado: "Essa é também a razão pela qual não queremos que o nosso lar seja uma coisa completamente terminada, definitiva. (...). Mas queríamos sempre ficar com as possibilidades de alterações e preservar a liberdade de formar e transformar esse ninho que é nosso." (Ibid., p.4)

Às vezes, o discurso é atribuído aos proprietários. Os futuros moradores narram a "aventura" da construção de seu lar. Inicialmente, a procura pelo terreno ideal: "Estudamos o lote e planejamos o arranjo dos quartos em relação aos ventos prevalentes e o ciclo do sol. (...) Uma sala de projeção (...) (para) a exibição de filmes. Uma área coberta onde as crianças pudessem brincar, mas (...) que acomodasse várias idades (...) quando um grupo muito grande 'transbordasse' da sala de visitas. Equipamentos domésticos e mais uma infindável lista, comum a todos que constroem seu próprio lar." (LOUREIRO; LOUREIRO, 1959, p.6) Tudo arranjado para um tipo de vida informal, confortável, ativa e moderna.

Depois, encontraram um arquiteto, que apresentou casas flexíveis e bonitas: "cada uma parecia pertencer ao terreno onde se achava, como se tivesse brotado do solo, (pois queríamos) (...) um ninho de águia no topo de nossa montanha, estudado para satisfazer nosso gosto pessoal." (Ibid., p.6)

\footnotetext{
${ }^{5} \mathrm{Na}$ edição 45, de agosto de 1958
} 
Segundo Casa e Jardim (LOUREIRO; LOUREIRO, 1959, p.6), o resultado seria uma sensação de estabilidade e sossego e um desenho simples, sólido e bonito. Mas, podemos notar que ele é também sofisticado, com venezianas em madeira ajustáveis e um terraço em balanço, também em madeira e aço.

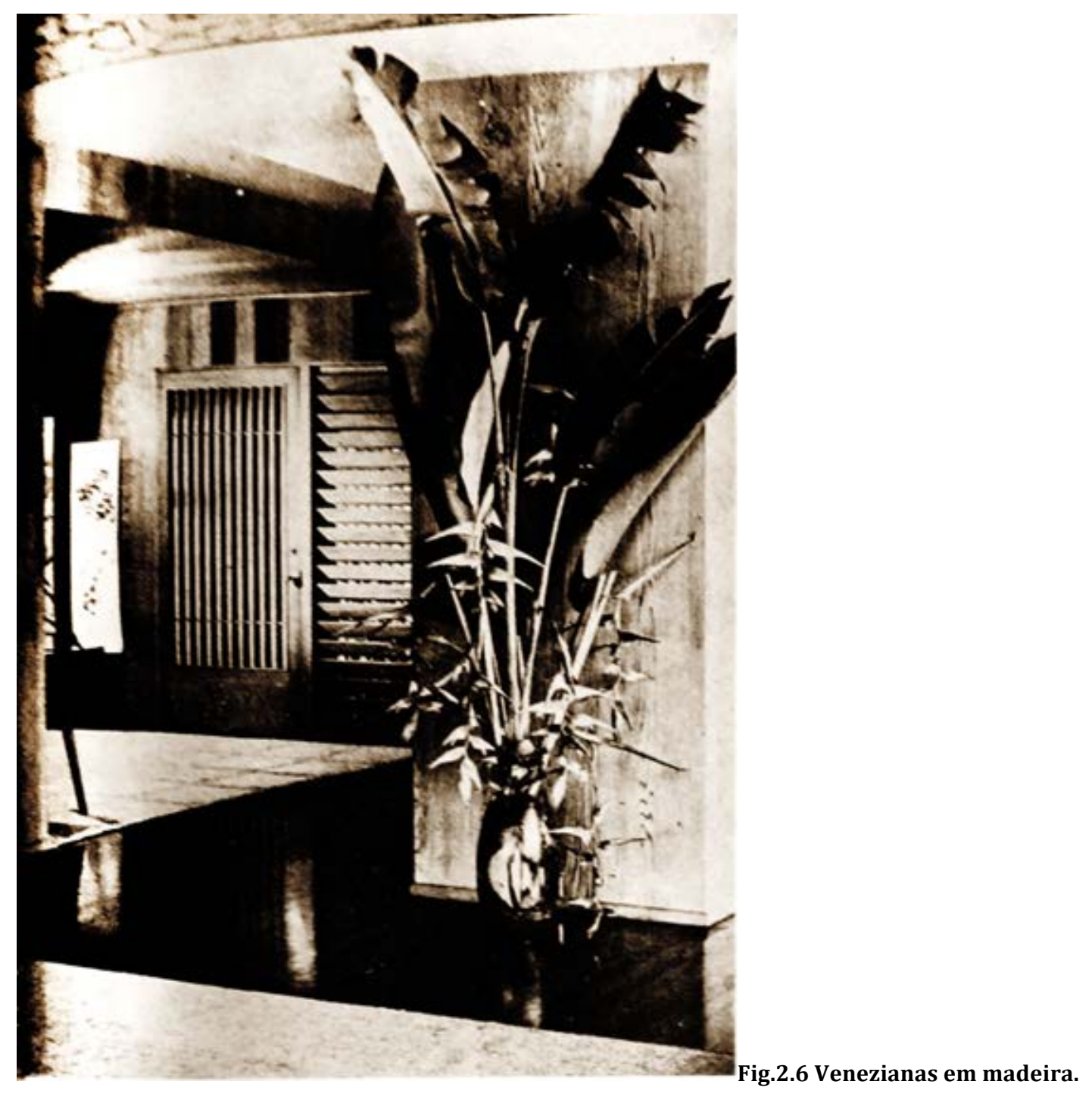

Essa casa apresentada na revista deveria ser moderna "por dentro, com todas as comodidades, porém, fora tem de ser uma casa de campo para combinar com a paisagem." (UMA CASA..., n.8, p.21) O diálogo reproduzido se dá entre marido e mulher e envolve a construção de sua casa. Esta vai se definindo aos poucos: deveria adaptar-se ao terreno, com garagem abaixo do corpo principal da casa; ter tamanho adequado ao morador, mas com ambientes amplos; apresentar integração com os jardins, utilizados como área de lazer; possuir equipamentos modernos que facilitariam o conforto. 


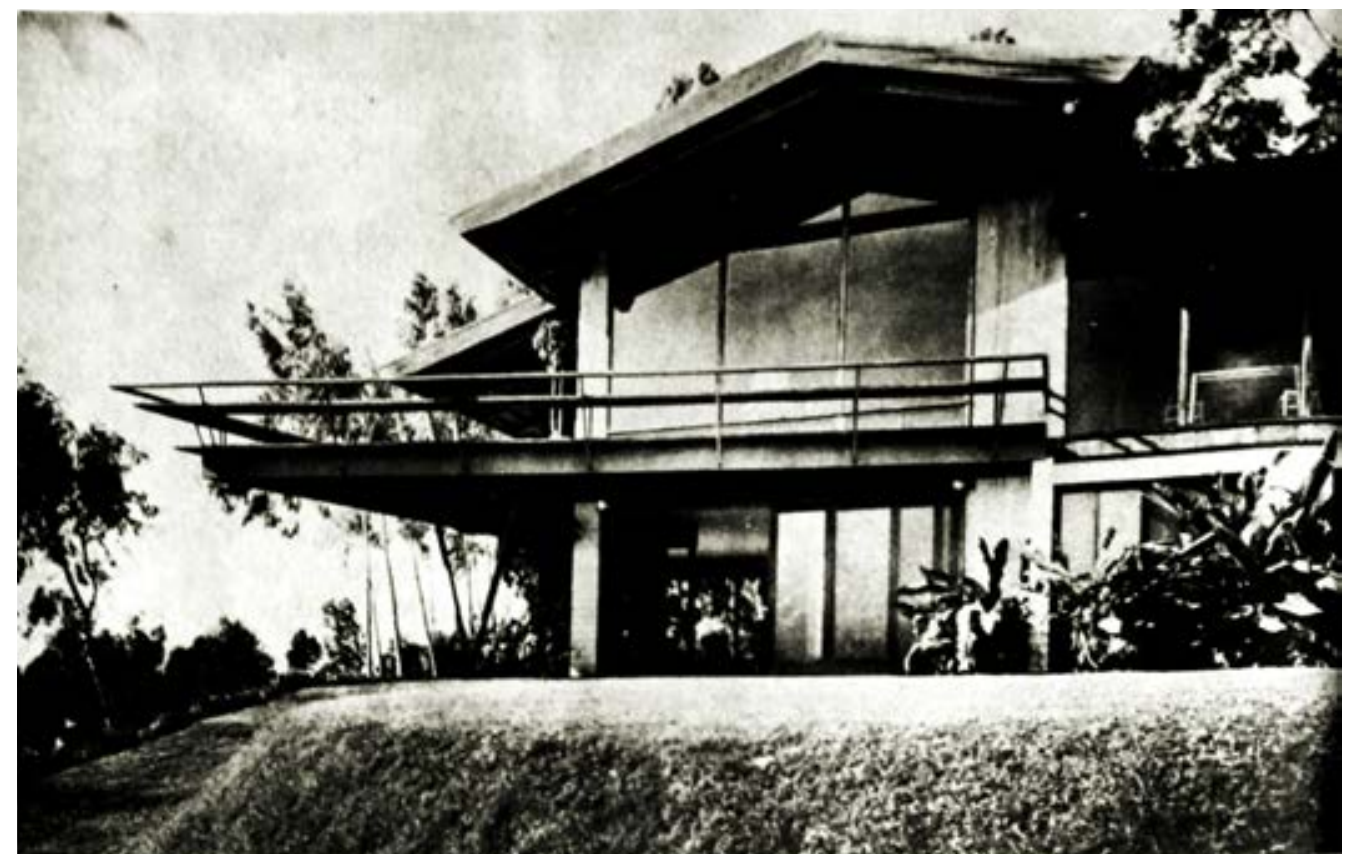

Fig.2.7 - Terraço em madeira e aço.

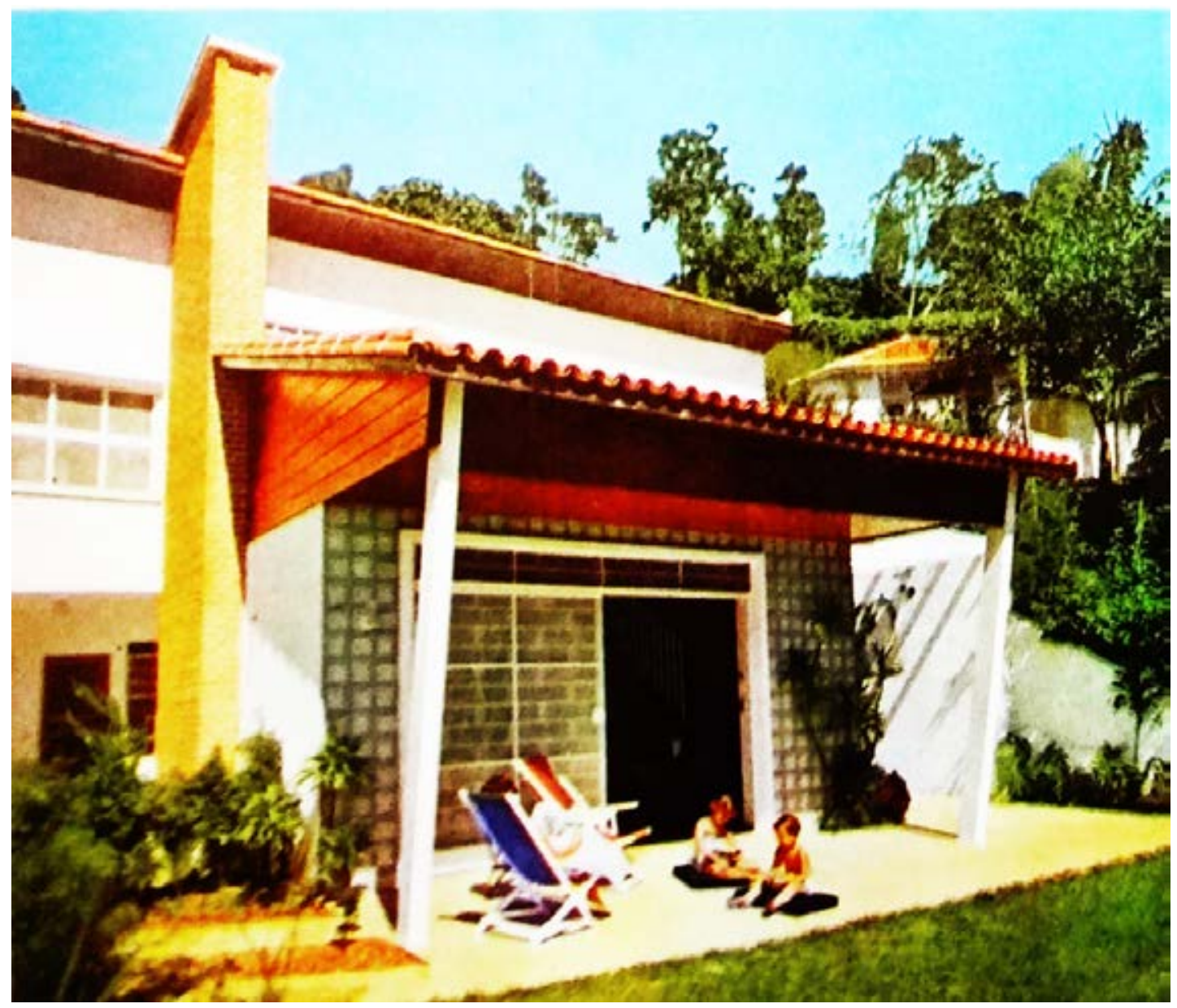

Fig.2.8 - Casa na represa de Santo Amaro. 
Às vezes, essa habitação era apenas um refúgio para os finais de semana, ${ }^{6}$ com verba limitada que, aliada à falta de funcionários domésticos, determinava a simplicidade e o tamanho da casa. $\mathrm{Na}$ figura 2.8, a família é mostrada confortavelmente instalada no terraço, que forma um conjunto com o living e o jardim. São utilizadas muitas cores e materiais contrastantes, como tijolos de vidro e madeira, até de forma um tanto exagerada. Mas, a impressão geral é de uma casa acolhedora.

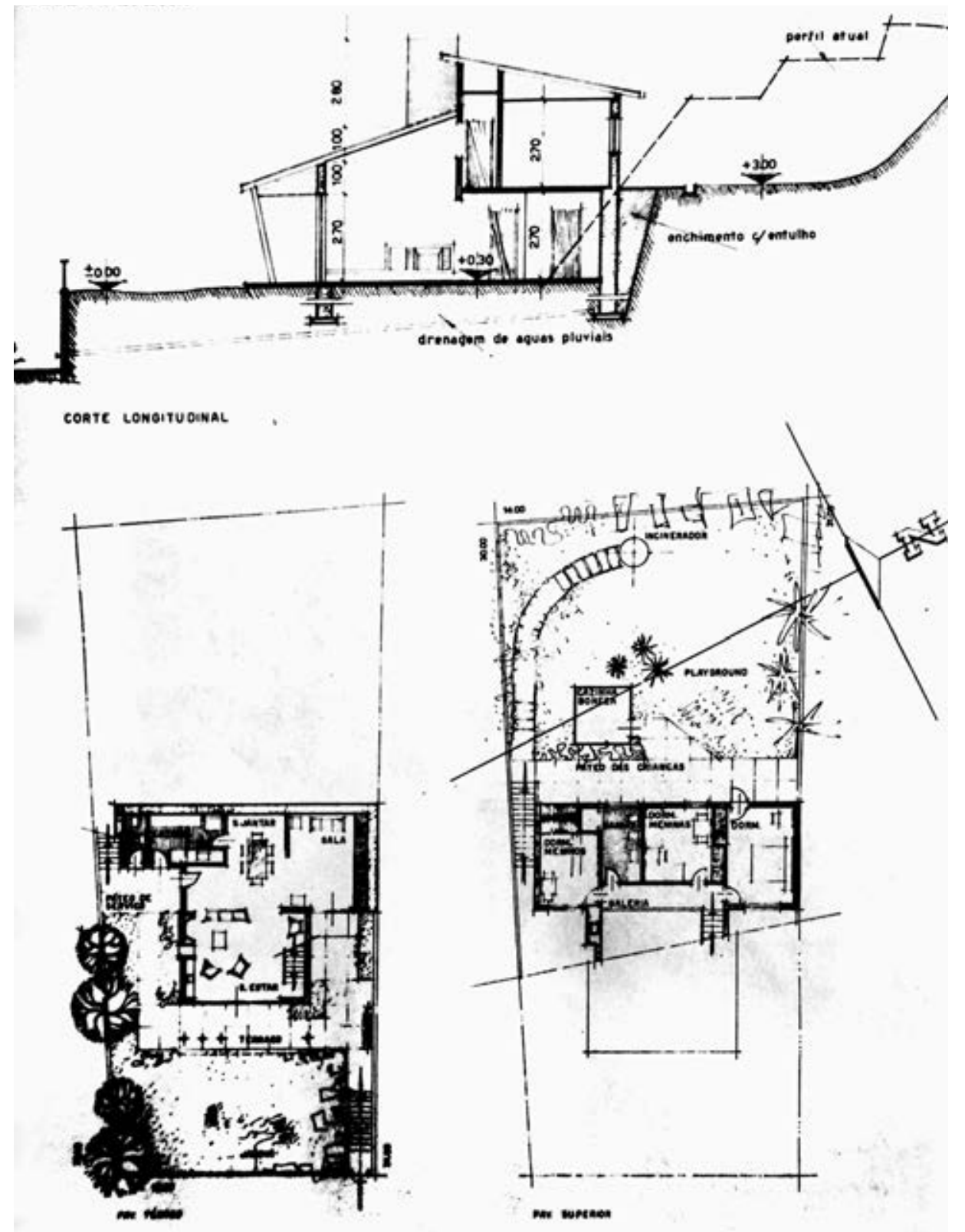

Fig.2.9 - Plantas e corte da mesma casa.

\footnotetext{
${ }^{6}$ Descanso..., 1959, arquiteto Gregório Zolko, firma construtora Alexandre Birmoser \& Cia. Ltda., decoração Formatex.
} 


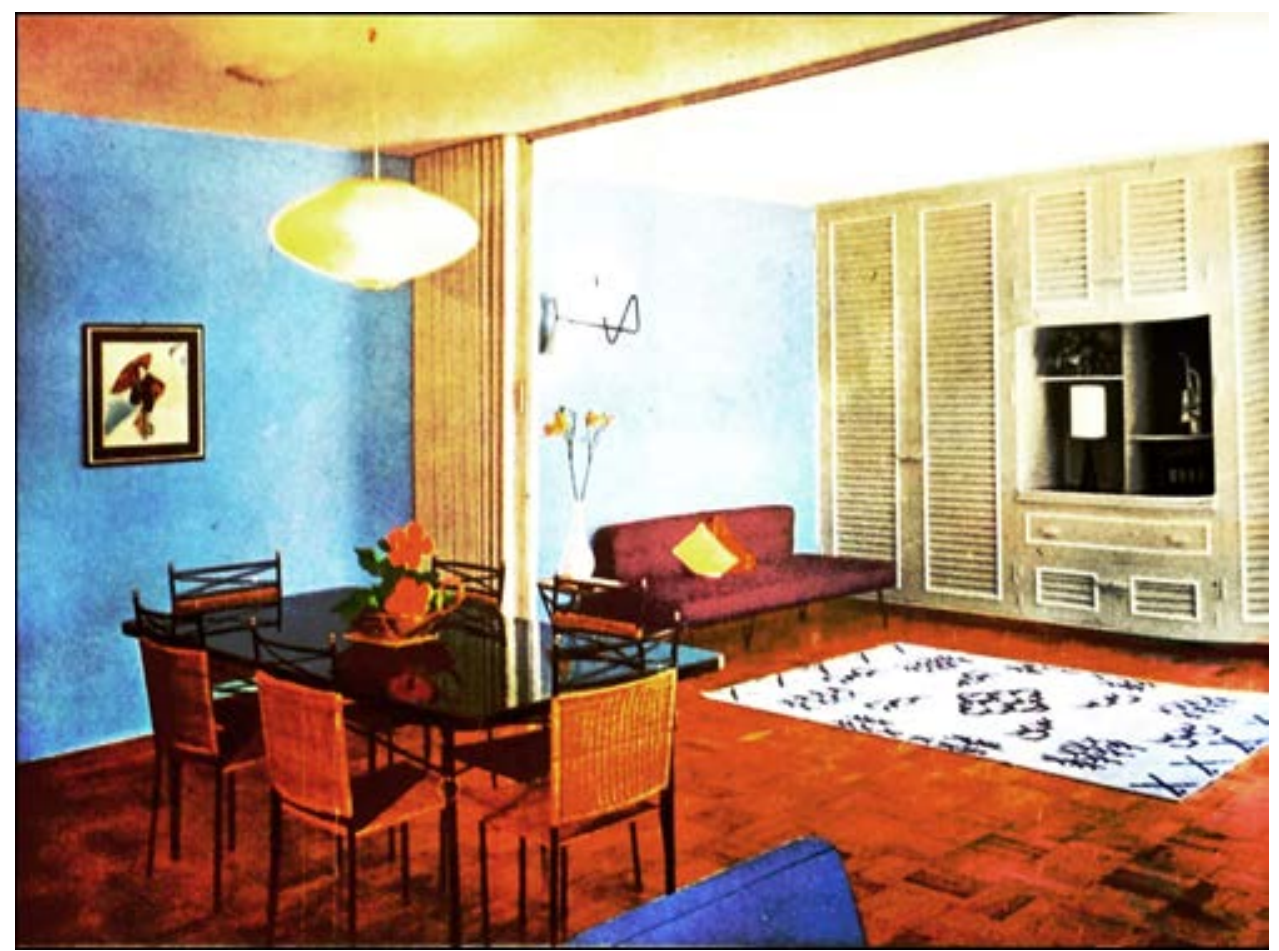

Fig.2.9 - Ambiente social da mesma casa.

Outro aspecto dessa moradia mostrada é a versatilidade. No ambiente social, por exemplo, pode ser criado um quarto de hóspedes, fechando-se parte dele. Essa característica é reforçada pelo uso de móveis retráteis e um sofá-cama.

Apesar das casas já mostradas serem modestas, esse tipo de vida confortável e estimulante também poderia se dar em casas maiores e mais luxuosas. "A Vivenda da Harmonia" 7 apresenta grande parte dos itens desejáveis nos anos 1950. Como objetos e equipamentos modernos e móveis feitos sob medida: ar condicionado, iluminação discreta, instalação Hi-FI, "que inunda de música a casa toda, por meio de bem camuflados alto-falantes." (HUBERTO, 1959b, p.41)

Além do conforto moderno, nesse caso havia obras de arte: um tapete chinês do século XVIII e outros elementos antigos, de várias procedências.

A casa localiza-se em um terreno extenso, com terraço, um grande jardim, piscina, horta, orquidário, estufa, canil: "Na piscina a vida é animada, e, olhando o panorama ensolarado, concluímos que o dono desta casa bem pode abrir mão das delícias da enseada das praias de Pernambuco e de Guaíba. Aqui está a vida salutar ao ar livre, ao alcance da mão, e ao alcance da vista também." (Ibid., p.41)

\footnotetext{
${ }^{7}$ Projeto de Henrique Alexander, na Chácara Flora.
} 


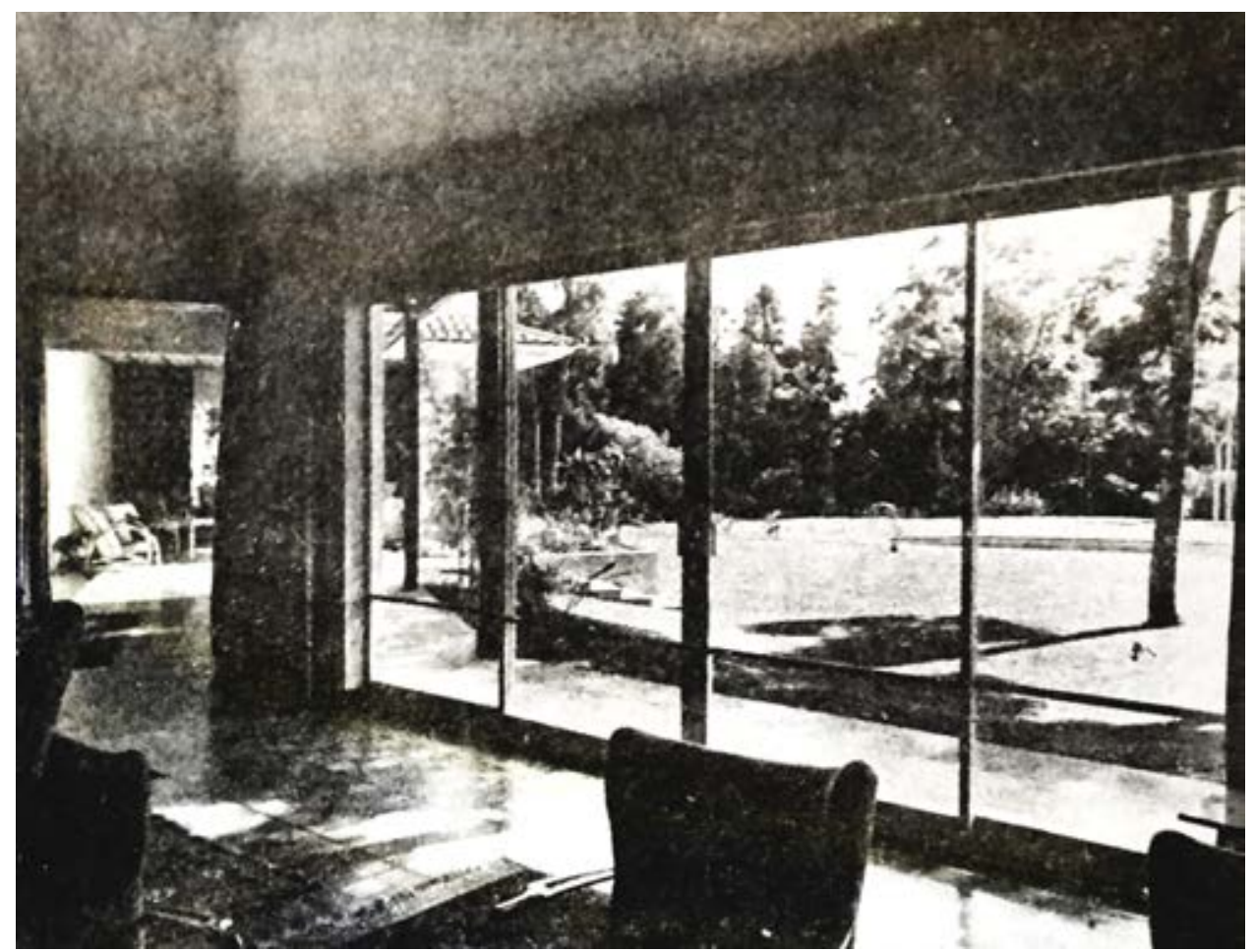

Fig.2.10 - "A Vivenda da Harmonia"

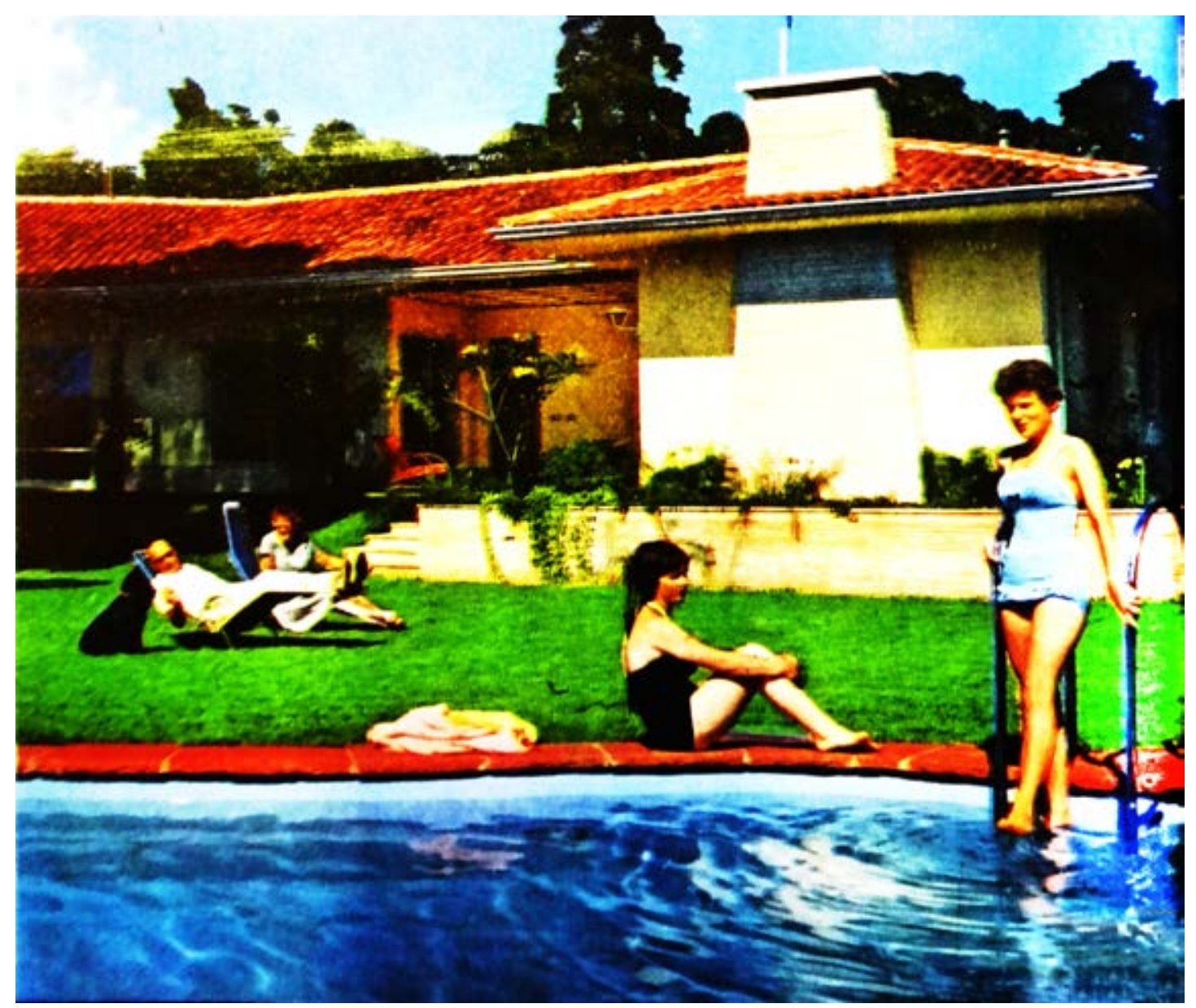

Fig.2.11 - A piscina da casa. 


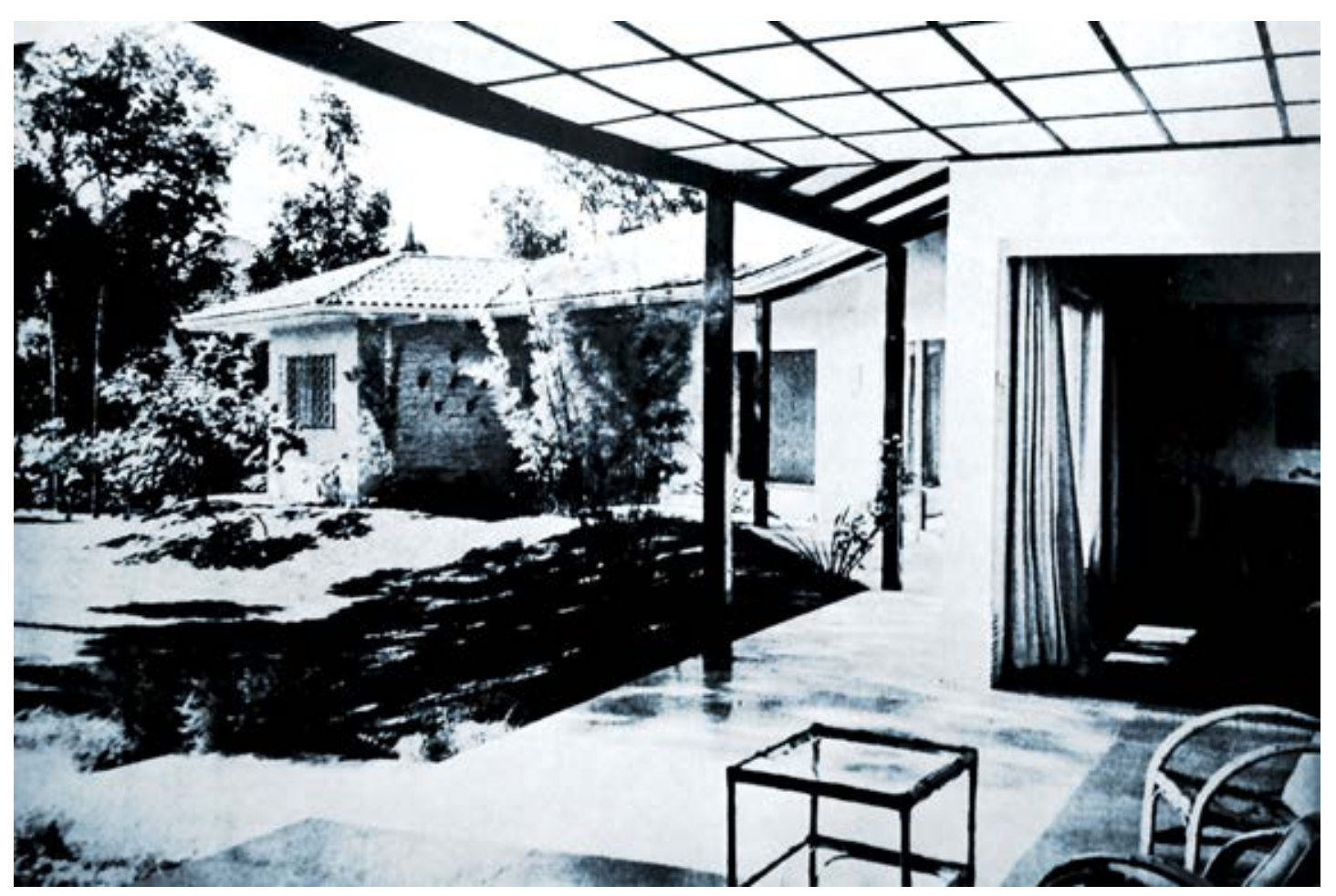

Fig.2.12 - Terraço da mesma casa.

A casa é vista, novamente, como o refúgio do mundo do trabalho, onde se passa a maior parte do tempo livre, evitando as dificuldades e desconfortos das viagens.

Mas, como lembra Ábalos (2000, p.199-200), natureza e cidade estão implícitos no doméstico, o definem através de contrastes.

Mas, se natureza e cidade contrastam com o mundo doméstico, mesmo poupandose de dificuldades e desconfortos, o homem precisa de todas essas experiências. Ao privar-se de uma delas, seu conhecimento do mundo se empobrece.

Outras questões levantadas em Casa e Jardim eram a simplicidade e o decoro, vistos sempre de forma positiva. A ostentação não se adequava a esse tipo de vida voltado para a família, em que visitantes eram recebidos com informalidade. $\mathrm{Na}$ casa projetada pelo arquiteto Roger Henry Weiler, ${ }^{8}$ por exemplo, pode-se vislumbrar "o caráter do proprietário: pessoa reservada que prefere um círculo íntimo de amigos a uma vida barulhenta." (CASA..., n.10, p.36)

O projeto utiliza-se da linguagem do Movimento Moderno: teto plano, geometria definida, linhas claras e, ligando dormitórios e área social, uma rampa, que "combina a sua utilidade com um modernismo modesto, evitando a elevação abrupta

\footnotetext{
${ }^{8}$ Proprietário H. Landsberg.
} 
de uma escada, que não harmonizaria com o ambiente singelo e individual." (CASA..., n.10, p.37)

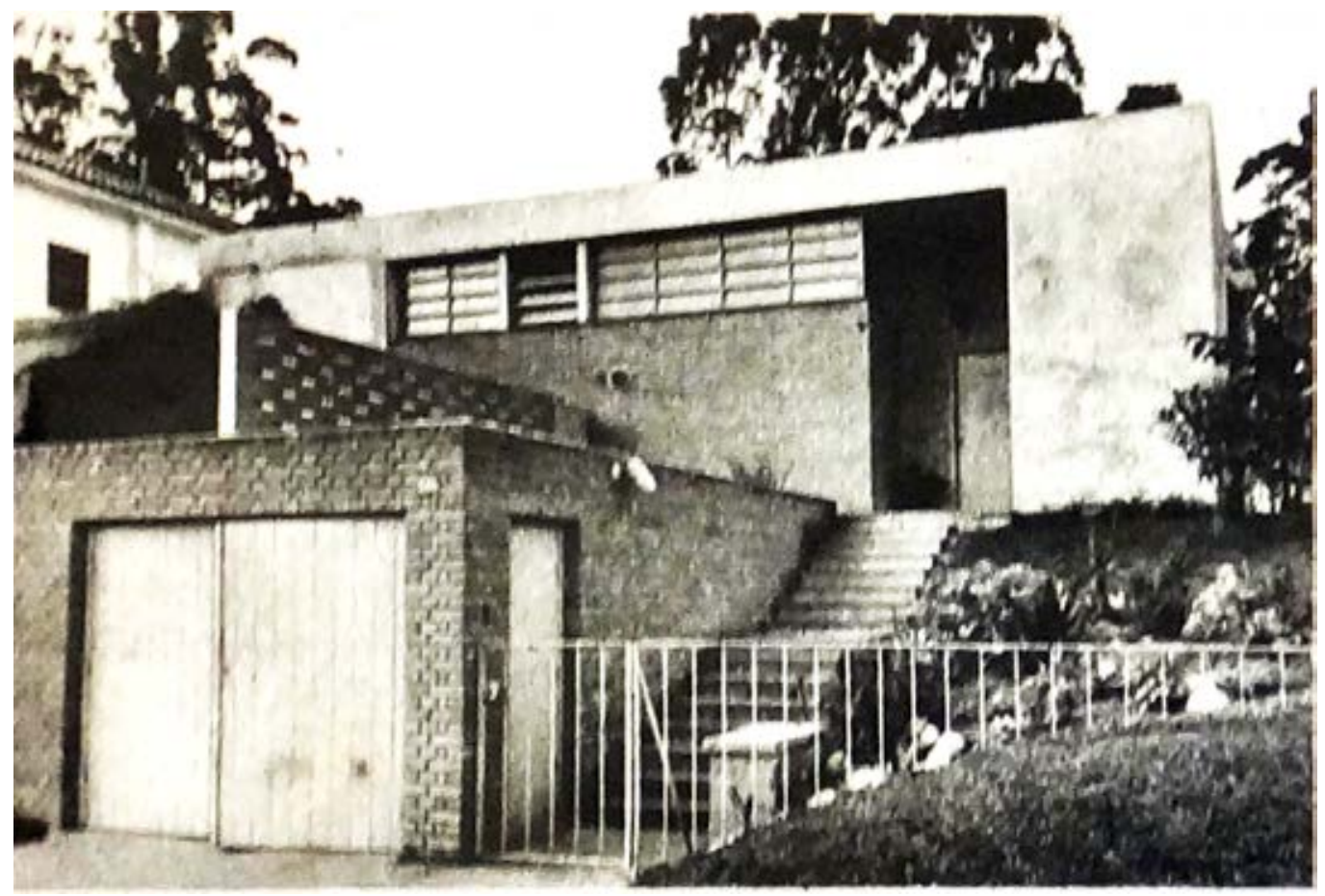

Fig. 2.13 - Casa projetada pelo arquiteto Roger Henry Weiler.

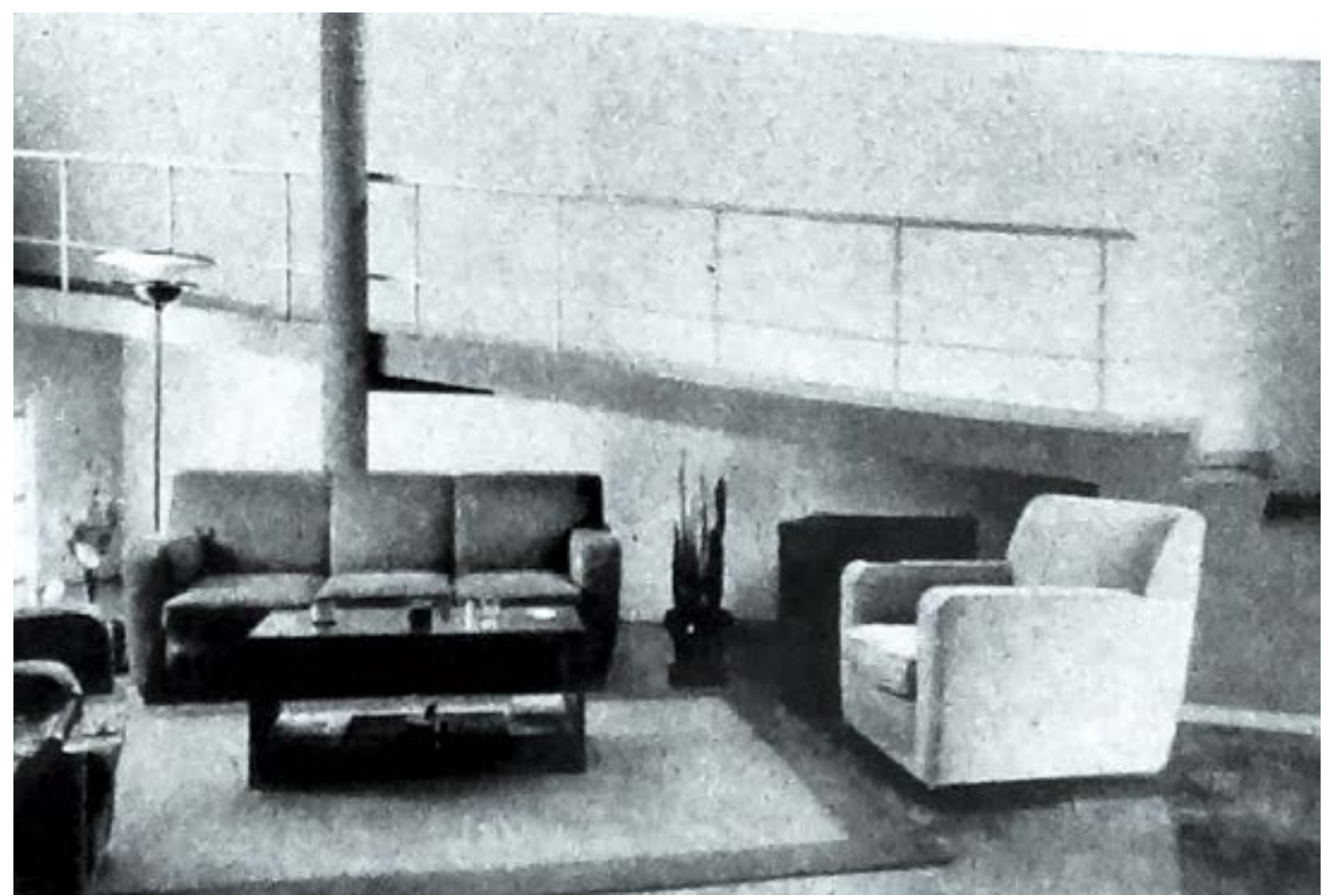

Fig. 2.14 - Ambiente social com rampa, na mesma casa. 
Os cômodos principais voltam-se para os fundos, recebendo a melhor insolação e proteção contra os ventos. O quintal de serviço localiza-se na frente, facilitando a utilização dos fundos para o lazer, onde existe um terraço, integrado ao jardim e aos ambientes sociais, em que podem-se desenvolver várias atividades. A sala de estar, com grandes esquadrias de ferro, foi projetada com tratamento acústico para a audição de música, nas horas livres dos donos da casa.

Ainda segundo a revista, o "lar (é visto) como um local onde morar - um ambiente dentro do qual se vive e não apenas se admira de fora." (COM..., 1959, p.3) Existe, como dissemos, a convicção de que ali deve haver modéstia, recolhimento e simplicidade.

Para Ábalos (2000, p.178), esta casa não é o local para experiências heroicas ou singulares, mas está ligada ao presente, com um olhar positivo ao cotidiano, ao "instante banal como uma experiência estética; de um espaço entendido como interação entre os meios natural e artificial; da técnica como suporte do conforto; do prazer individual como uma meta legítima e desejável."

O cotidiano com seus pequenos acontecimento repetitivos, típicos, ligados às vidas de seus moradores.

Em Casa e Jardim, o prazer também está intimamente ligado a momentos precisos, em que cada membro da família desenvolve uma atividade que lhe traz encanto, seja um mergulho na piscina, uma refeição no pátio, a vista admirada a partir da varanda. "Somente quando se pode viver como se quer, a vida vale a pena ser vivida." (COM...,. 1959, p.3)

O espaço físico, onde se pode viver essas experiências prazerosas e cotidianas vai, aos poucos, se constituindo, ${ }^{9}$ ao longo das várias edições da revista.

Eis aqui um novo tipo de sala para um novo tipo de vida familiar. Esta é uma sala sem nome. Ela tem tantos usos, que desafiamos alguém a classificá-la em uma só palavra. Por ser uma sala como nossos pais não conheceram igual, é uma magnífica ilustração de como nossos lares estão mudando para se adaptar às nossas necessidades mutáveis como indivíduos e famílias. É o coração da casa e a sala mais usada para reunir grupos de amigos como para leitura e para descanso, ouvir música, e se apresentar a oportunidade para dançar ou assistir televisão. Pode ser inteiramente aberta no verão ou fechada no inverno." (Ibid., p.9)

\footnotetext{
${ }^{9}$ Arquitetos Gastão S. Marcondes e Henrique Alexander.
} 
Trata-se de um ambiente informal, flexível, versátil, ideal para a vida moderna, para o "bem viver."

Nesta casa, apesenta parede em tijolinhos, portas de vidro que se abrem para o jardim e parte do pé direito é duplo. Existem ali móveis confortáveis, livros, alguns quadros na parede, em um ambiente descontraído. Não parece arrumado, como se não fossem esperadas visitas.

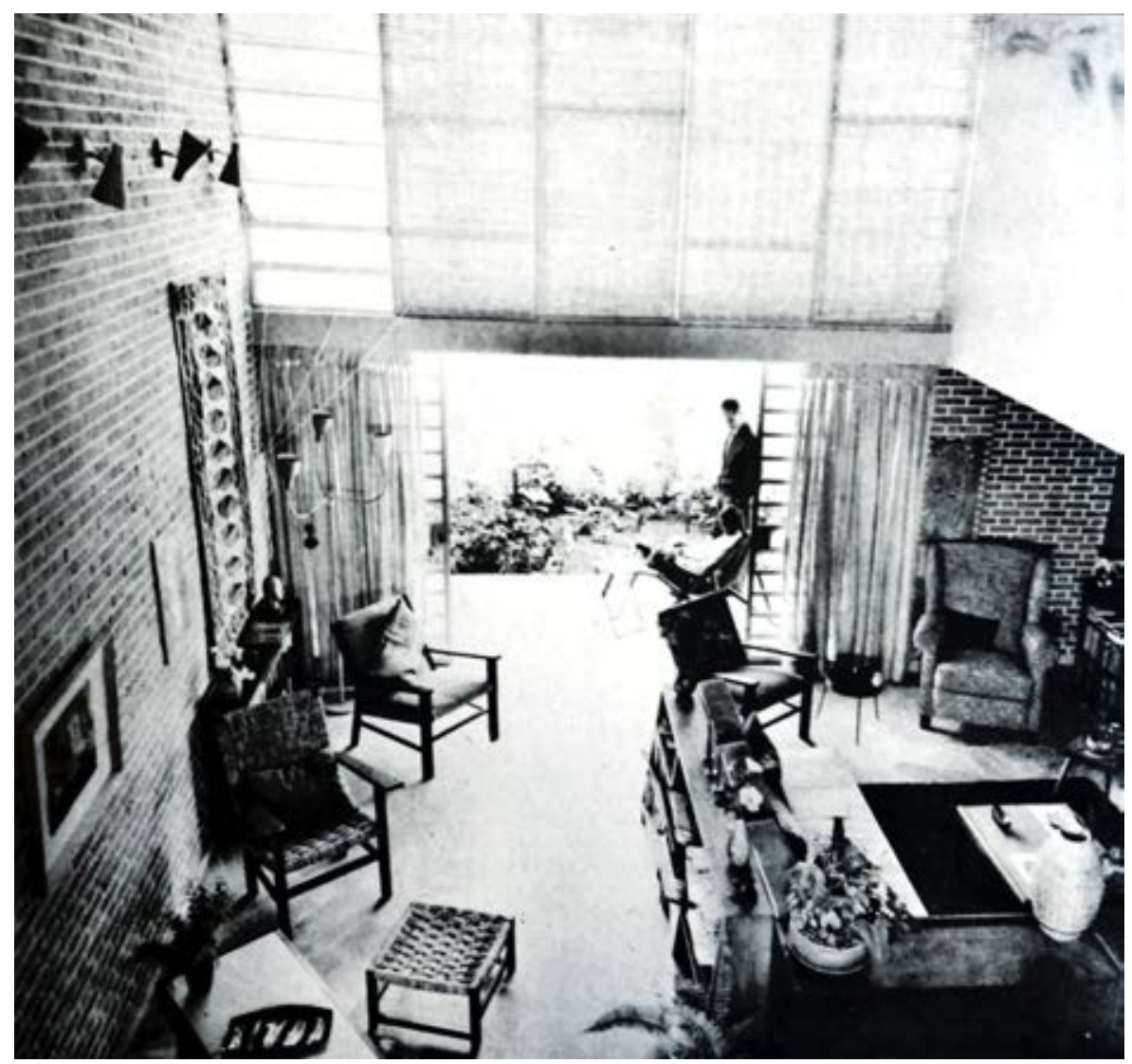

Fig. 2.15 - "Sala sem nome."

Estas transformações nos lares para acomodar o novo tipo de vida seriam uma espécie de resposta às "mudanças para pior no mundo público (que) provocam mudanças para melhorar o nosso mundo particular." (COMO..., 1959, p.9) Segundo Casa e Jardim, as dificuldades para se fazer um passeio nos finais de semana poderiam ser solucionadas através de um melhor aproveitamento da casa e do jardim. A vida ao ar livre quase se restringe aos espaços criados na casa para esse fim.

Observa-se, na revista, que tais questões repetem-se: o cultivo de uma vida ativa, confortável e prazerosa, refugiada no lar, em ambientes planejados e equipados 
com o que existia de mais moderno à época, no Brasil. Mas, abrindo mão da cidade e do contato com o mundo real.

\subsection{Pequenas casas}

Entre outros aspectos observados na arquitetura do "bem viver," a dimensão das casas é um dos mais importantes: grande parte delas é pequena, como aquela mostrada no início do capítulo, a casa do "morar bem."

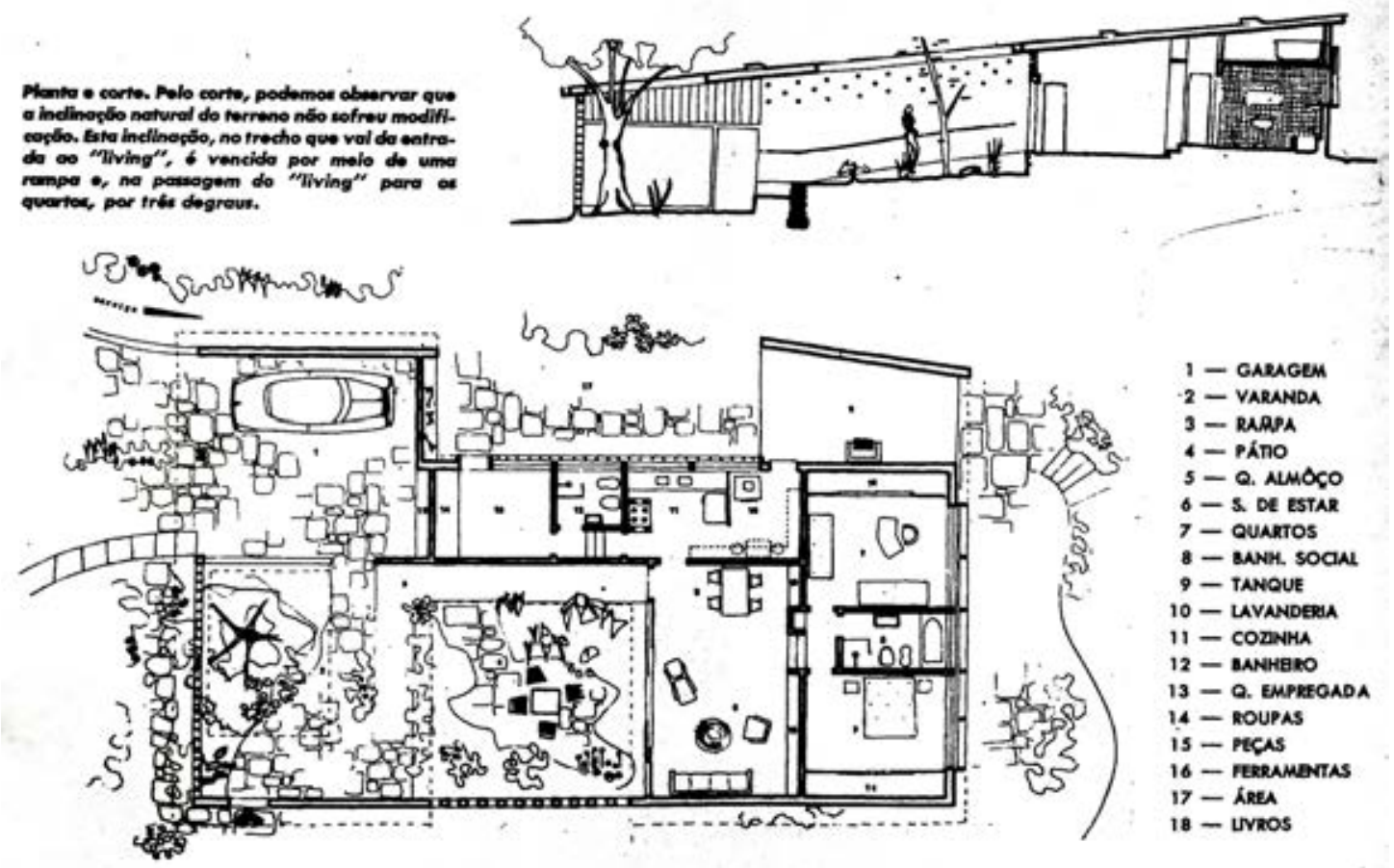

Fig.2.16 - Pequena casa projetada pelo arquiteto Mauro Müller.

Muitas vezes, apresentam apenas dois dormitórios, pois uma das recomendações é que deveria ser uma casa na medida da família, sem excessos: "Para uma arquitetura residencial de porte diminuto, as soluções complicadas não são em geral as melhores." (PROCHNIK, 1954a, p.8) ${ }^{10}$

\footnotetext{
${ }^{10}$ Residência projetada por Mauro Müller, um “jovem arquiteto."
} 


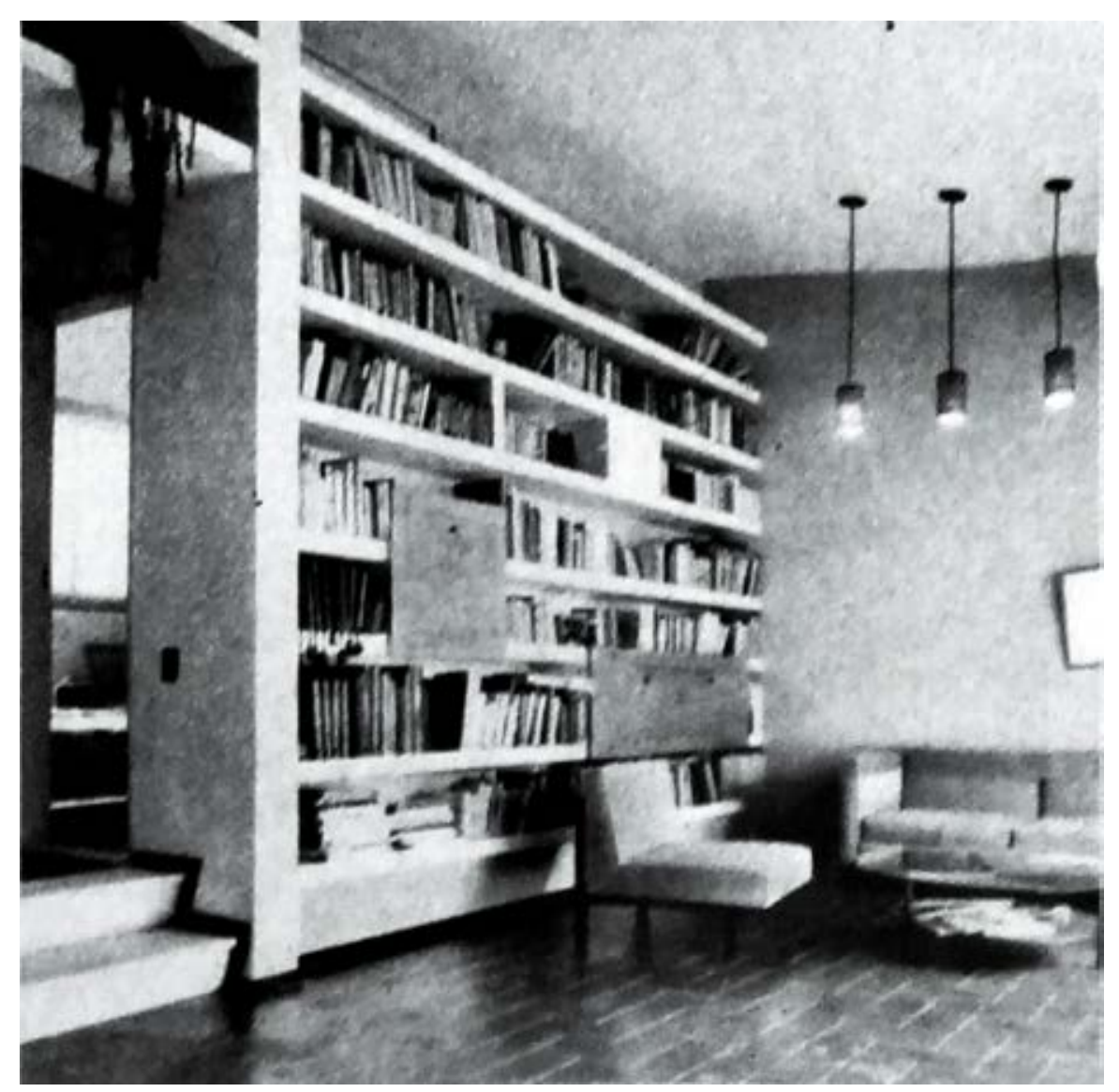

Fig.2.17 - Decoração moderna na pequena casa, do arquiteto Mauro Müller.

Em outro artigo de Casa e Jardim, Denby (1958, p.8) descreve uma "casa mínima," que poderia ser utilizada por recém-casados e casais de mais idade, pois muitas "pessoas têm um capital disponível muito pequeno, e entretanto gostariam de morar numa casa construída para eles e não naquelas feitas em série. (...) as casas feitas sob encomenda terão muito mais atrativos que as casas-padrão mesmo se for necessário diminuir o espaço em vista do preço mais elevado."

Uma reflexão possível sobre a ideia da "casa mínima" são seus paralelos com a "existência mínima" do Movimento Moderno, entre eles as soluções espaciais, como o número limitado de cômodos, ambientes integrados, com poucas divisões fixas, cozinhas pequenas, mas planejadas, banheiros subdivididos. Ou ainda, elementos como móveis embutidos, sofás-camas, eletrodomésticos, etc.

Porém, uma das diferenças básicas entre a casa positivista, a Existenzminimum, ou "mínimo de habitação" (Wonhnungsminimum) e a "casa mínima," do "bem viver," é em relação à estandardização.

Uma das questões centrais para o arquiteto racionalista era o desenvolvimento do "tipo," devido à sua essencialidade e à sua possibilidade de repetição, entre outros 
aspectos. Mas, em relação à "casa mínima," o "fazer em série" não era uma alternativa, pois a casa deveria adaptar-se ao seu usuário, deveria ser única. $A$ escolha e o toque pessoal eram desejados. Apenas materiais de acabamento, móveis e objetos poderiam ser fabricados em série.

"O conforto e a intimidade contra o estandardismo,"11 mostra as dificuldades para transformar-se um "apartamento (cada dia mais estandardizado) num ambiente capaz de proporcionar intimidade e conforto." (O CONFORTO..., 1959, p.49)

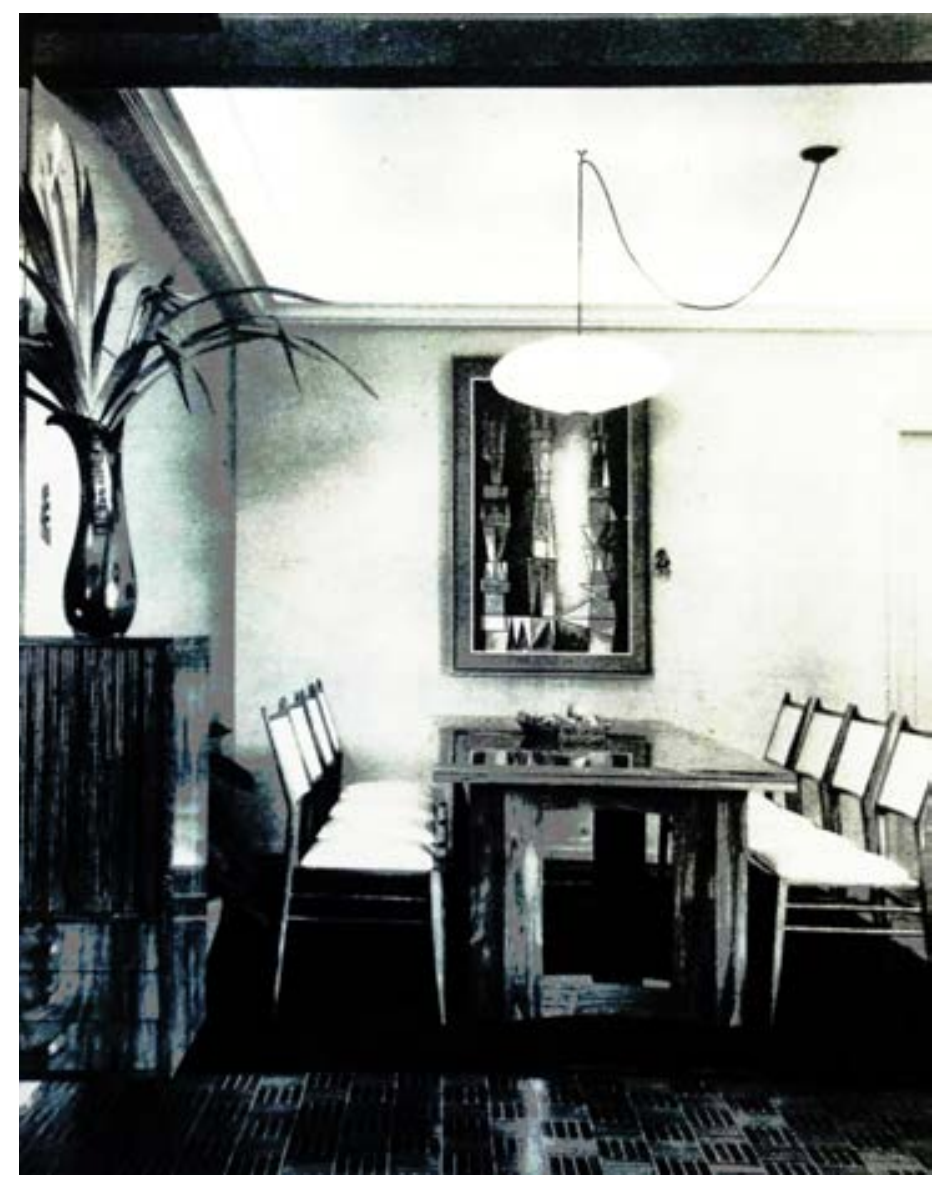

Fig.2.18 - Apartamento mostrado em O CONFORTO...

Mas, apesar das abordagens diversas em relação a alguns aspectos, ainda assim podem-se traçar alguns paralelos entre as casas do "bem viver" e as habitações positivistas, do Movimento Moderno, principalmente nos anos 1920.

Para constituir a Existenzminimum, a "habitação para o nível mínimo de vida," a casa foi esquadrinhada, medida, analisada de todas as formas. A ideia não era

\footnotetext{
${ }^{11}$ Decorador Jean Gillon, móveis Fortalit, proprietário Dan Landwehr
} 
atingir o mínimo absoluto, já suficientemente utilizado pelos especuladores imobiliários, mas o mínimo relativo. Não se tratava apenas de diminuir a área da habitação e baratear seus custos, mas racionalizar o espaço de maneira que, mesmo com uma pequena extensão, ele ainda tivesse qualidade e as funções pudessem ser satisfatoriamente desempenhadas. Aspectos que também são observados nas habitações do bem viver.

Nesse sentido, o arquiteto Alexander Klein ${ }^{12}$ tentava encontrar instrumentos precisos para a avaliação do projeto da habitação, que não se vinculassem apenas a padrões dimensionais e constituíssem um sistema de validações qualitativas. Procurava equacionar o problema da habitação com todas as suas variáveis e suas relações; em toda a sua complexidade.

A elaboração da planta baixa exigia um trabalho muito preciso, em que nenhum centímetro quadrado poderia ser desperdiçado. Analisava-se, de forma extremamente racional, os mínimos movimentos e percursos necessários à execução das várias funções. A partir desse estudo, desenhavam-se os ambientes.

Não se deve utilizar aqui a denominação "cômodo," pois este supõe a separação dos vários ambientes em compartimentos fechados. Klein, de forma diversa, aconselhava que se concentrassem várias atividades em grandes espaços, com divisões provisórias, como biombos. A sala de estar, por exemplo, à noite poderia ser utilizada como dormitório. Armários embutidos também funcionavam como divisórias. Os espaços de circulação eram racionalizados e a mobília era embutida ou encostada às paredes, para que fossem mantidas amplas superfícies livres. ${ }^{13}$

Pode-se dizer que estas estratégias estão presentes nas casas do "bem viver." Talvez o rigor e a precisão racionalistas, na elaboração da planta baixa, não sejam levados tão longe. E a versatilidade na utilização dos ambientes não seja tão acentuada, mas, em linhas gerais, as estratégias são praticamente as mesmas. Um legado do Movimento Moderno que foi mantido.

\footnotetext{
${ }^{12}$ Klein desenvolveu estudos para a agência de habitação alemã, a Reichsforschungsgesellschaft für Wirtschaftlichkeit im Bau - und Wohnungswesen, (conhecida como Rfg). Russo, ele chegara à Alemanha em 1920. O método desenvolvido pelo arquiteto foi publicado em 1928 sob o título de "Elaboração de Plantas e configuração de Espaços em Pequenas Habitações e novos Métodos de Avaliação." E, em 1934, surge seu estudo sobre a casa unifamiliar, uma aplicação parcial de seu método de projeto, que apresentara em Paris, no Congresso Internacional das Habitações e Planos de Ordenação.

${ }^{13}$ Cf. capítulo 4 de Klein, 1980.
} 


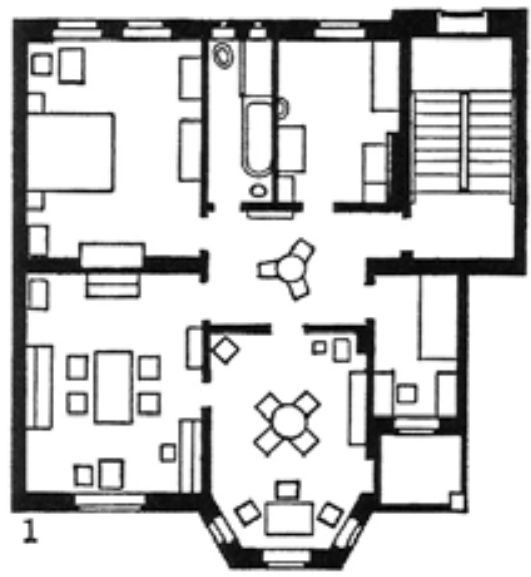

A. Bad Example

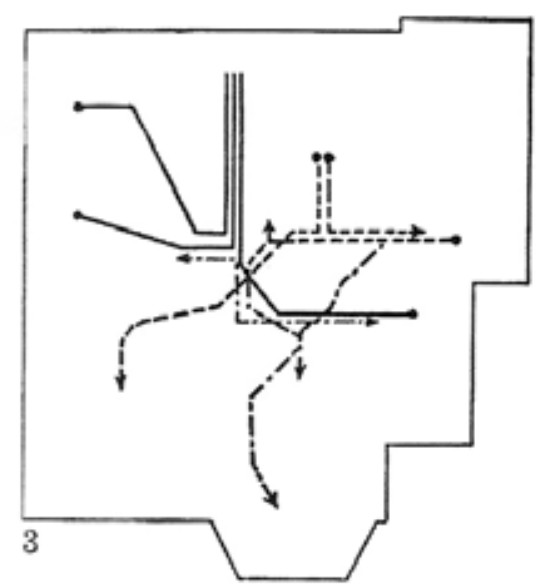

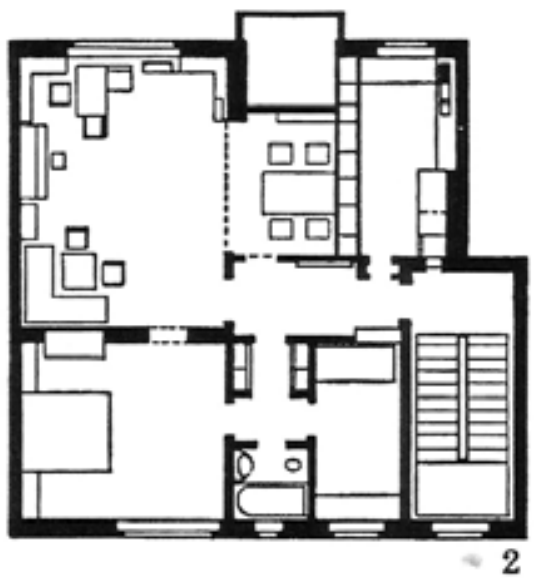

B. Good Example

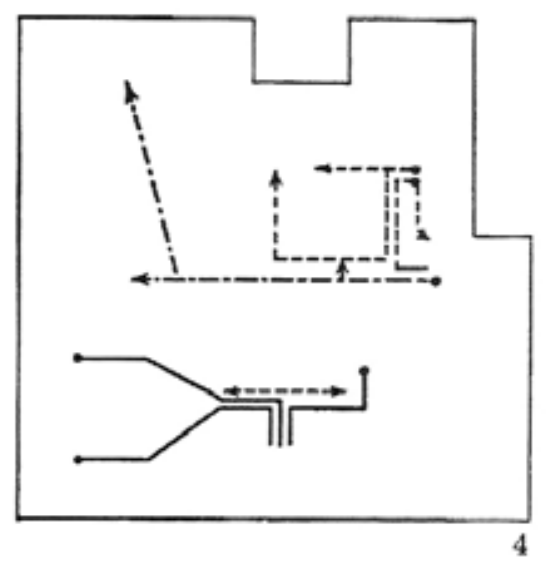

Fig. 2.19 - Análise de percursos para a avaliação da qualidade do espaço.

As experiências com pequenas habitações, de maneira a reduzir sua área, mas mantendo a qualidade do espaço, já vinham desenvolvendo-se há certo tempo. Elas estão presentes no trabalho de muitos arquitetos e não arquitetos. Podem ser encontradas ainda no século XIX, nos Estados Unidos, ligada à tradição doméstica americana, quando as feministas desejavam mais eficiência no lar, para que a mulher pudesse dedicar-se a outras atividades fora da casa.

Ainda no início do século XX, deve-se destacar o trabalho de Heinrich Tessenow, elogiado por Klein (1980, p.52) Antes da Primeira Guerra Mundial, o arquiteto trabalhou com pequenas habitações, projetando em conjunto a mobília adequada a elas, de maneira que elementos supérfluos fossem eliminados, para uma vida mais simples.

Klein ainda enumera, em suas experiências para a racionalização da habitação, algumas estratégias para se evitar a sensação de limitação do espaço decorrente da 
redução da área útil da casa. Entre elas, a integração entre o interior e o exterior através da colocação adequada das janelas e portas de correr, aproveitando também a insolação e a iluminação natural. Os ambientes integrados também auxiliariam na diminuição da área.

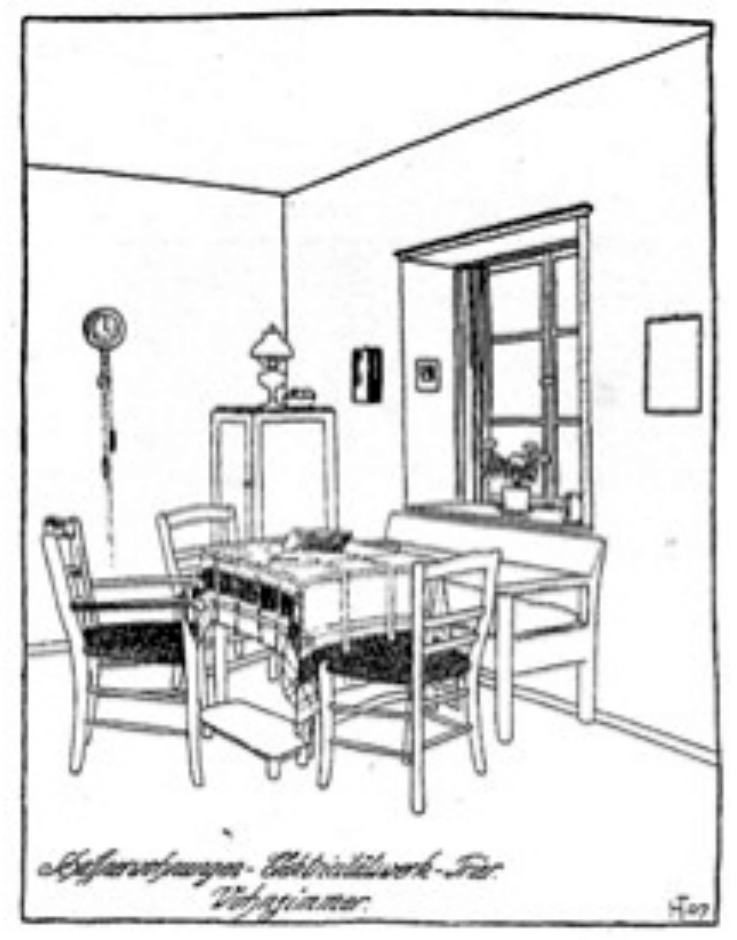

Fig.2.20 - Desenhos de Tessenow.

Algumas dessas estratégias, desenvolvidas por arquitetos como Klein e Tessenow, realmente modificam o espaço, porém outras apenas conferem uma sensação de amplidão.

Tais observações são muito próximas daquelas encontradas em Casa e Jardim, onde apresentam-se várias possibilidades para aperfeiçoar-se o espaço real ou apenas a percepção deste. "Em arquitetura interior é possível encontrar solução para problemas aparentemente insolúveis. Assim, as próprias proporções de uma moradia podem ser transformadas, pelo menos em aparência. (...) a discrepância entre as medidas concretas e a impressão subjetiva. $O$ aparente milagre se explica pela criação de novos planos, artificiais, e uma combinação de cores que rebaixam os tetos, afastam as paredes e aproximam as janelas." (JEAN, 1956, p.34) ${ }^{14}$

\footnotetext{
${ }^{14}$ Outro artigo sobre decoração de apartamentos, desta vez com um caso real, na rua Vieira de Carvalho. A proprietária era Helena Mindlin, que teve a ajuda do decorador Norman Westwater.
} 
Ou os móveis poderiam ser "incorporados à parede, para acentuar ilusão de espaço." (DECORAÇÃO..., n.41, p.10) ${ }^{15}$

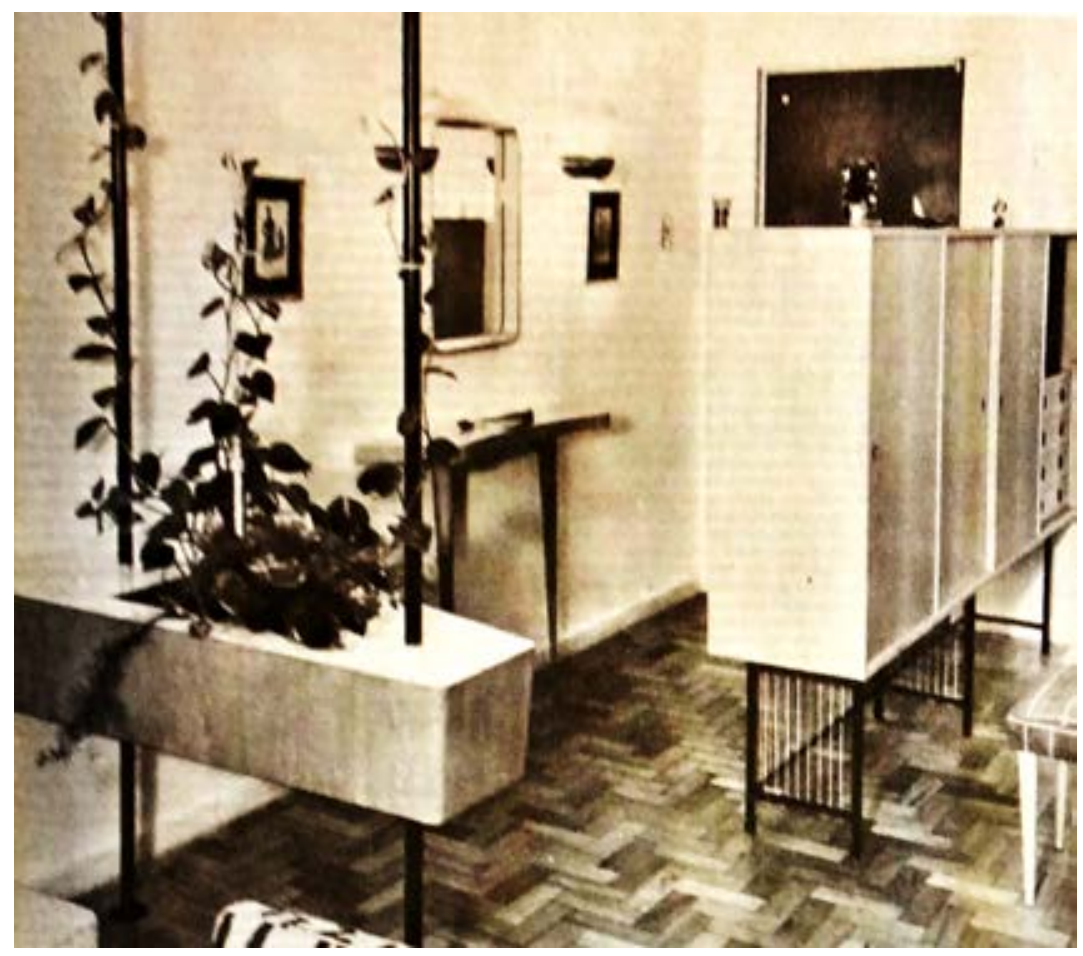

Fig.2.21 - Estratégias para a "ampliação" do espaço.

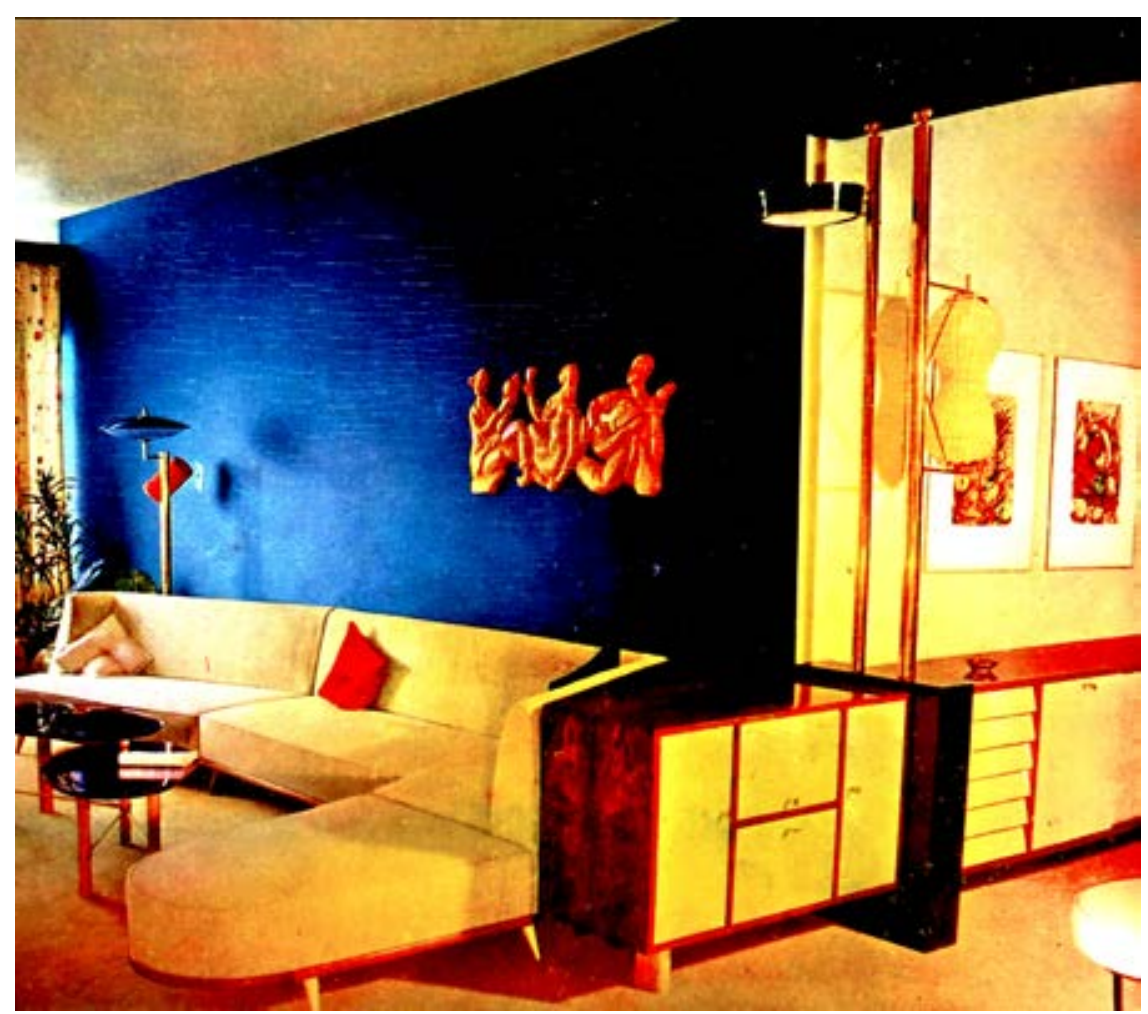

Fig.2.22 - Cores, móveis sob medida, outras maneiras de se ampliar o espaço.

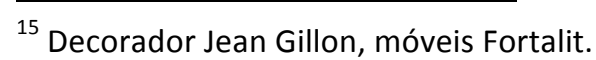




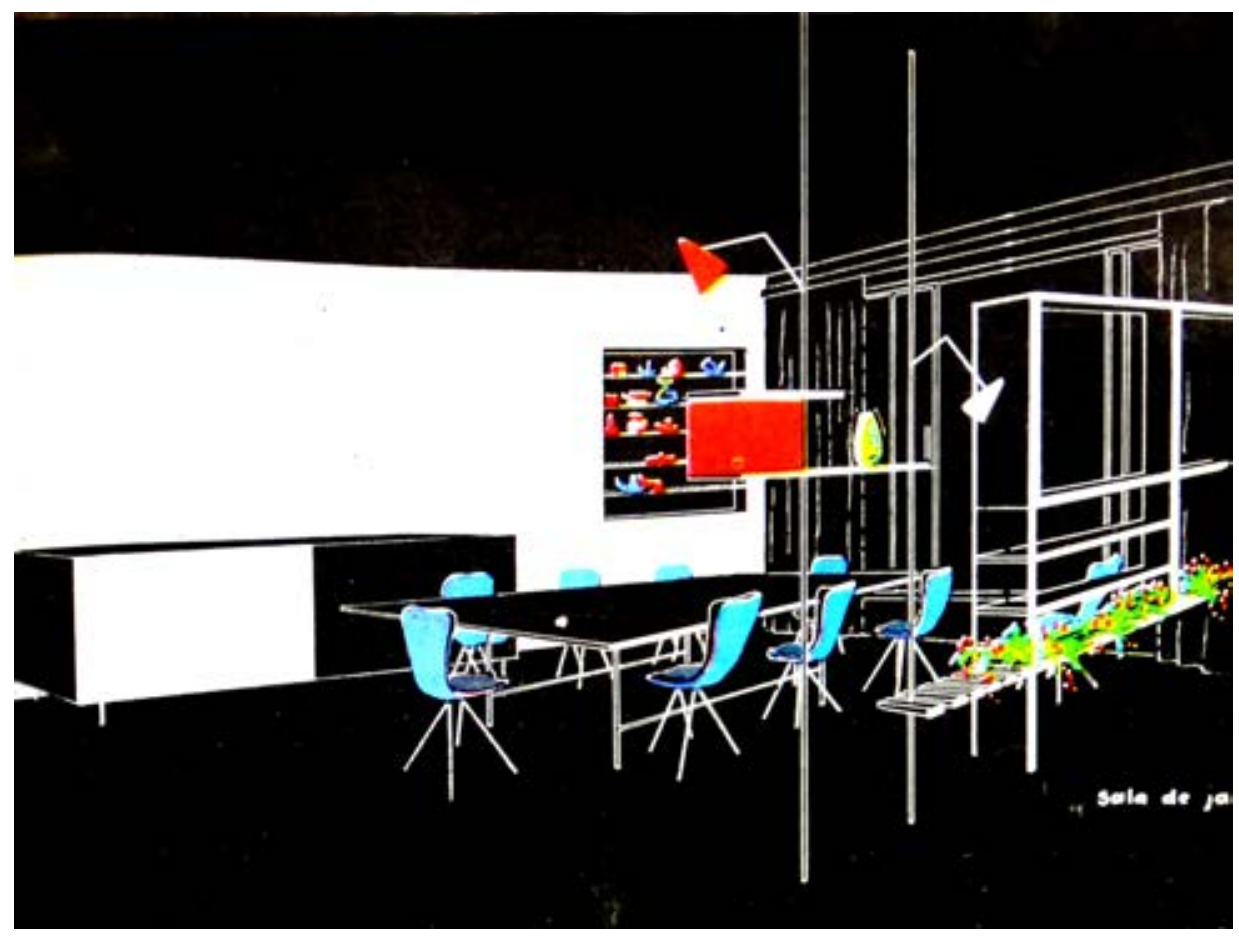

Fig.2.23 - Móveis modernos, “leves," e vazados.

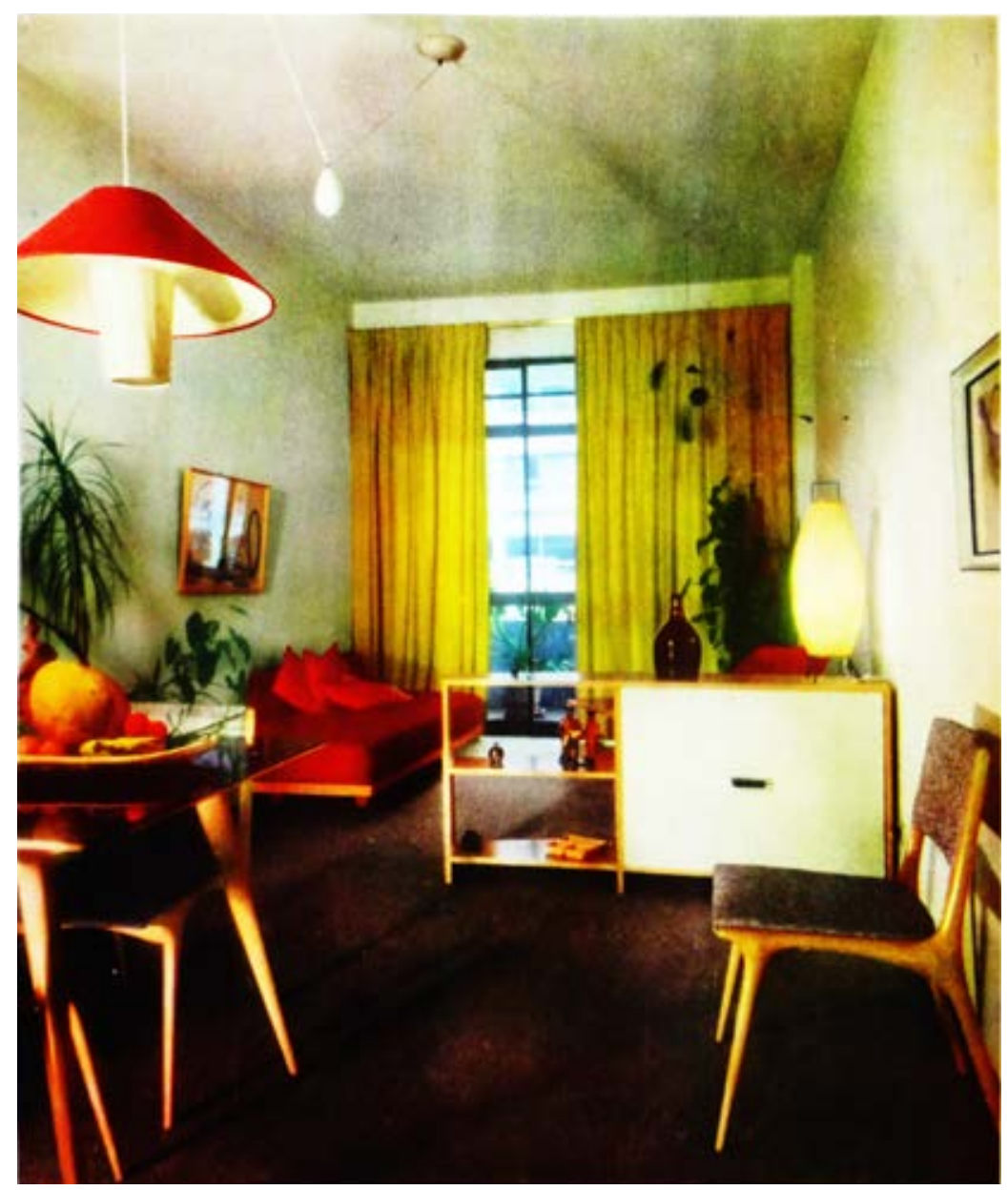

Fig.2.24 - Pequeno apartamento, com o mesmo tipo de móvel anterior. 
Na revista, vê-se a utilização de móveis em metal ou madeira clara, mais "leves" visualmente, vazados ou suspensos do chão por apoios. Ou mais baixos do que o pé direito. Prateleiras também eram outro recurso.

Para o aperfeiçoamento do espaço real, havia ainda a possibilidade de integraremse dois ambientes em um, demolindo uma parede ou criando um arco. O resultado seria uma sensação de espaço maior, ventilação e iluminação mais eficientes. ${ }^{16}$

Mesmo com pequena área, uma casa poderia ser confortável, com um número reduzido de ambientes, porém amplos. Em uma casa americana, mostrada em Casa e Jardim, um balcão separa a pequena cozinha do living, integrando-os e aumentando a sensação de amplidão, reforçada pelas grandes janelas panorâmicas que permitem a visão da paisagem. O arquiteto "procurou proporcionar o máximo de conforto em sua limitada área." (NÃO..., 1953, p.27) ${ }^{17}$

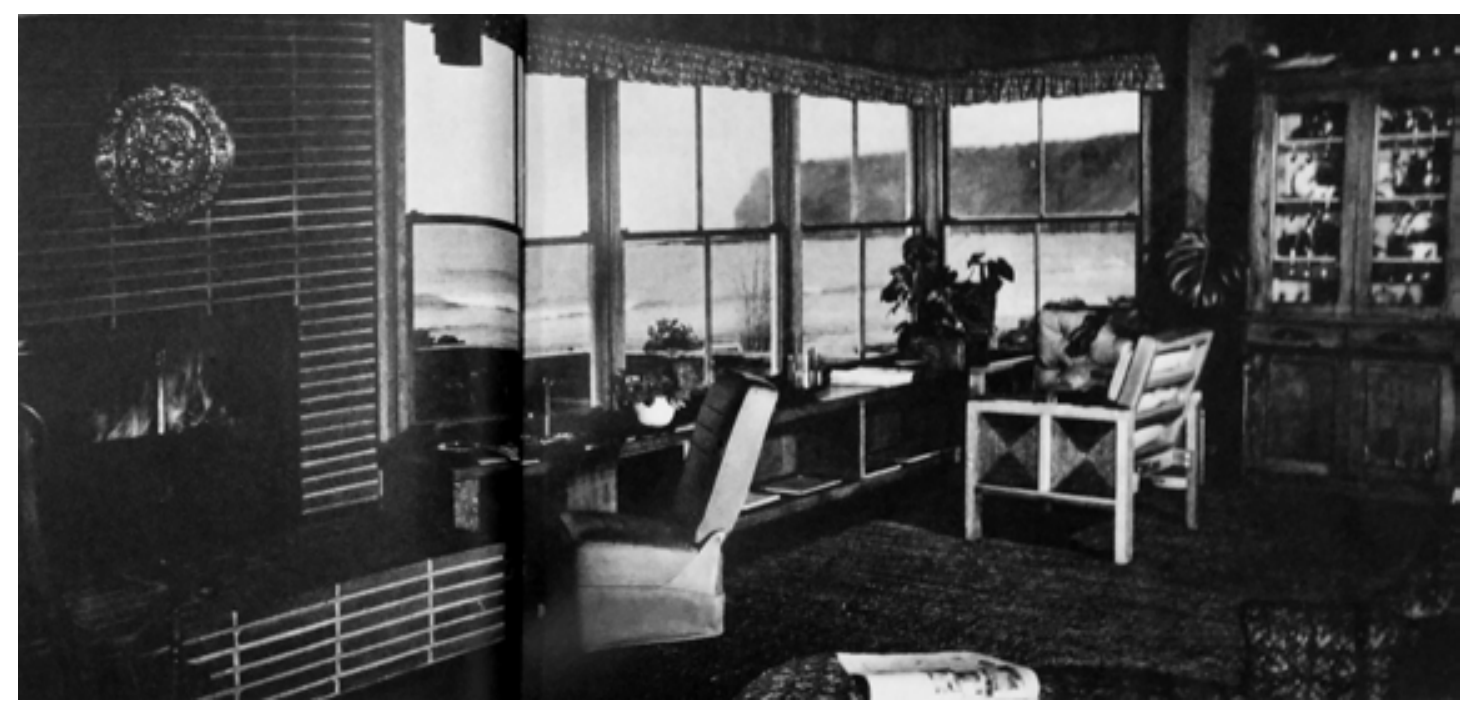

Fig.2.25 - Living da casa americana.

Vistas panorâmicas eram também um recurso muito utilizado, para fazer o espaço parecer maior. Na pequena casa do "bem viver," prática e confortável, localizada na Serra da Cantareira, utilizada para o repouso em família nos fins de semana, “(...) tudo foi solucionado com muito senso prático (...) dentro dos limites do necessário e sem sacrifício de comodidade; o maior cuidado foi dispensando ao aproveitamento da natureza. (HUBERTO, 1959a, p.20) ${ }^{18}$ No terraço, mobiliado com peças de vime,

\footnotetext{
${ }^{16}$ QUANDO..., 1958.

${ }^{17}$ Trata-se de uma casa de veraneio, em uma praia de Los Angeles, mostrada como modelo.

${ }^{18}$ Arquiteto Nicoleff.
} 
pode-se ficar em paz e calma, "enchendo a vista e os pulmões com os dons ímpares da natureza, relaxando o corpo num silêncio reparador." (HUBERTO, 1959a, p.19).

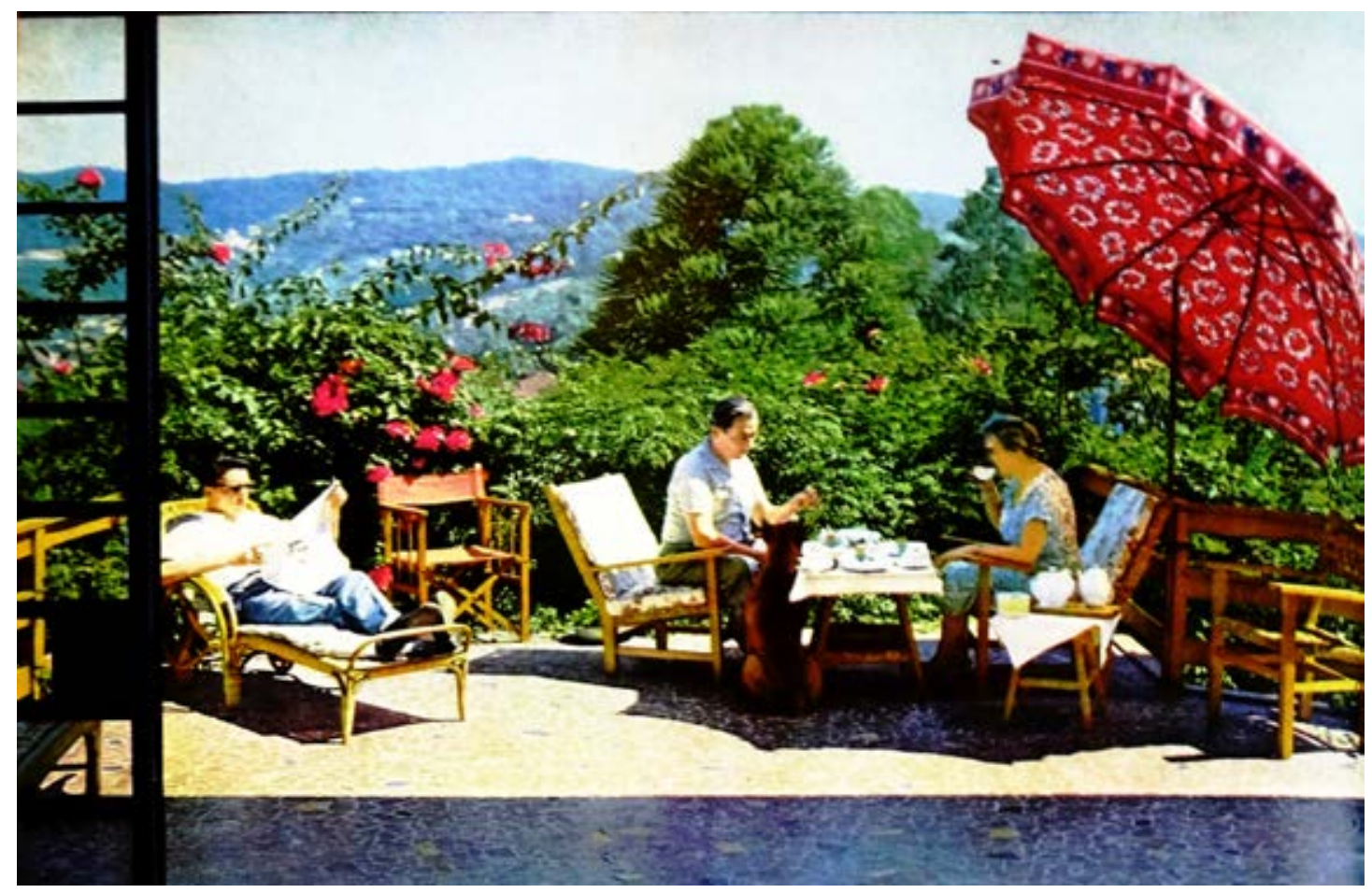

Fig.2.26 - Casa na Serra da Cantareira.

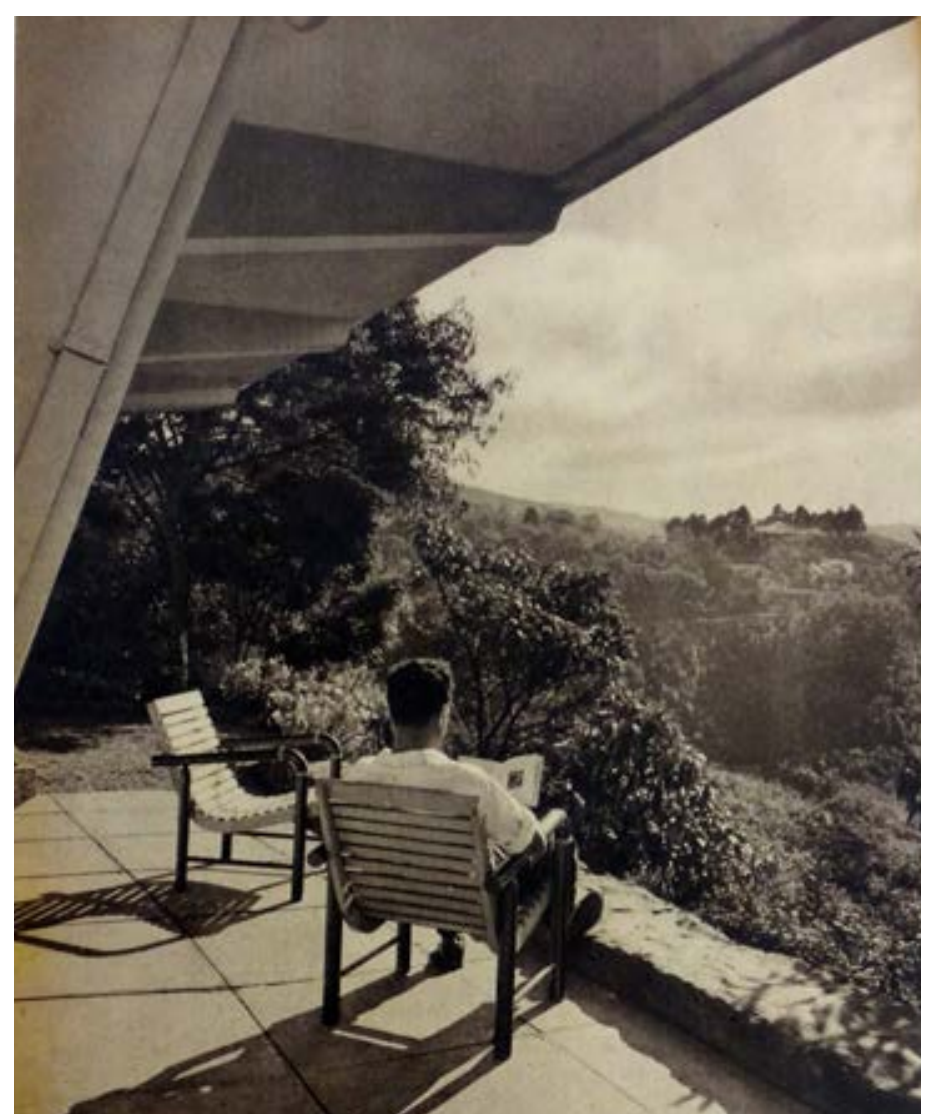

Fig.2.27 - Outra casa na Cantareira, projeto do Escritório Arquitetônico Bresslau e Bastian. 
Em outra casa pequena, no mesmo local, ${ }^{19}$ também procura-se criar a sensação de um amplo espaço, através das vistas panorâmicas. O terreno tem declive acentuado, aproveitado através do balanço de parte da casa.

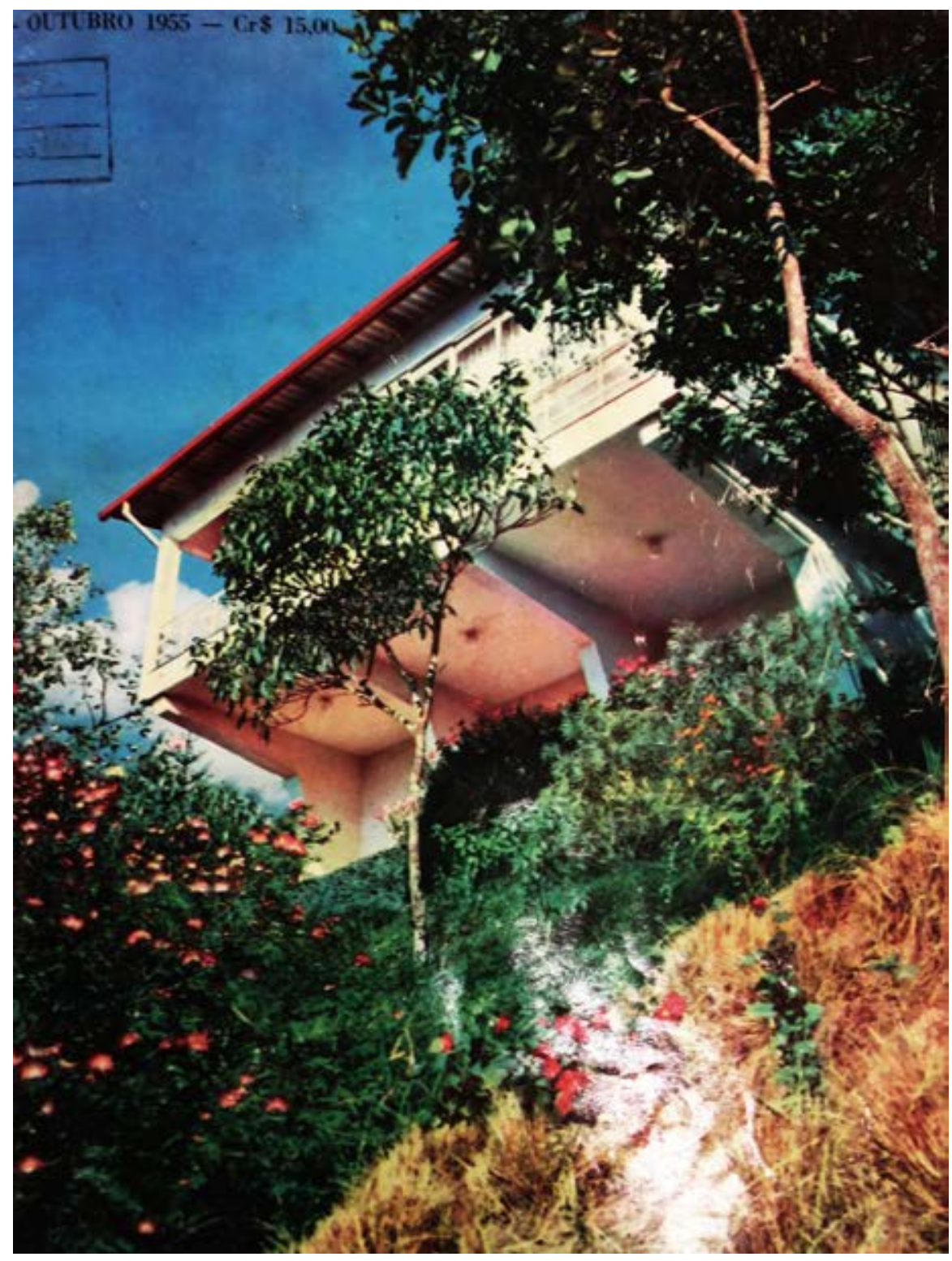

Fig.2.28 - Casa anterior mostrando o grande balanço.

Ainda segundo Casa e Jardim, a psicologia apontaria a necessidade desses grandes espaços abertos e áreas vazias e silenciosas. ${ }^{20} \mathrm{~A}$ utilização do vidro seria

\footnotetext{
${ }^{19}$ NO ALTO..., 1955. Projeto do Escritório Arquitetônico Bresslau e Bastian, paisagismo de Paul Leibküchler, decoração de Jean Muller, proprietário Werner Rosenfeld. A casa é mostrada também na capa desse número.

${ }^{20} \mathrm{O}$ artigo menciona Frank Lloyd Wright.
} 
uma espécie de "libertação de barreiras (...). Nossa tendência de fazer o interior e o exterior se fundirem, não será porventura o reflexo da nossa sede de espaço vital?" (VILLELA, 1959b, p.10) As grandes janelas fariam o horizonte ampliar-se, indo além das dimensões do ambiente. A simplificação dos ambientes internos, com a diminuição do número de móveis e outros elementos, possibilitaria a mesma sensação de amplidão.

Além dessa sensação, os espaços envidraçados permitiriam o contato com a natureza.

Janelas enormes do teto até o soalho ligam a natureza, seja de plantas (...), seja marítima (...), aos interiores. A residência fica maior, o bem estar aumenta" (COMPLETE..., 1959, p.10)

seja como for, sempre vamos desejar incluir a natureza na nossa vida e convidá-la a entrar em nosso lar. Grandes janelas nos deixam participar de paisagens como parques, florestas ou mesmo mares; aí, fenestrais dão a impressão de emoldurar um quadro maravilhoso. Se não temos a sorte - e não podemos conseguir um lar com vistas deslumbrantes - tentamos então produzir no pátio um encantamento particular, um mundo somente nosso, onde as plantas e flores crescem, e os peixes brincam no tanque 'mignon' que é o seu pequeno mundo. (Ibid., p.11) ${ }^{21}$

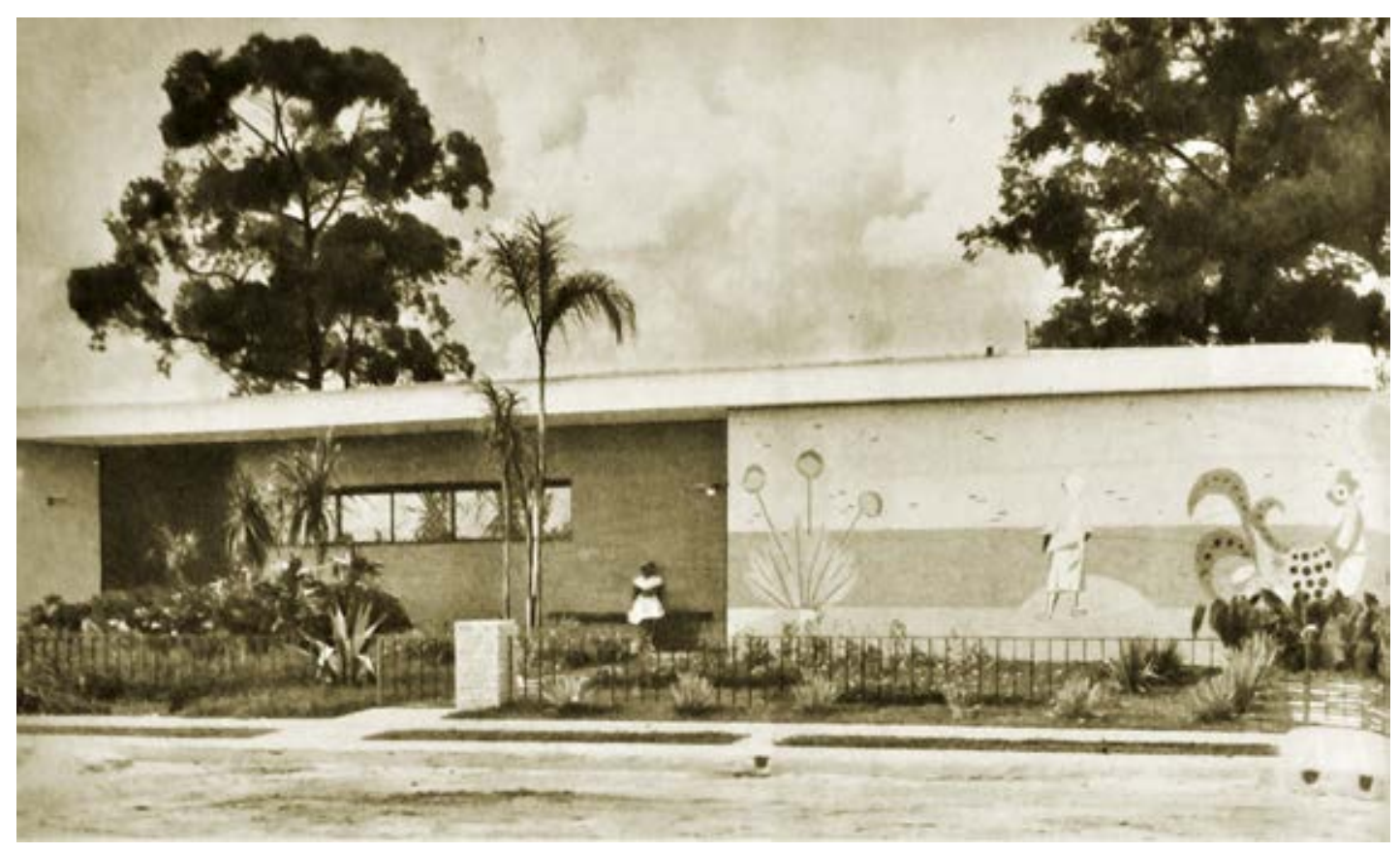

Fig.2.29 - A "casa do galo."

\footnotetext{
${ }^{21}$ No artigo, é feita uma espécie de balanço dessas ideias, aproveitando imagens já publicadas.
} 
Podia-se criar uma "natureza particular," ainda que fosse apenas um gramado com caminhos pavimentados e algumas massas de vegetação, como nessa casa, mostrada na revista, apelidada "casa do galo." 22 "Desde o 'living', temos o prolongamento da paisagem e a ligação direta com a natureza, o que, sem dúvida, é uma das condições essenciais da habitação moderna. O 'living', de fato, forma parte com o exterior por intermédio do terraço (...)." (CAMPOBELO, 1956, p.16)

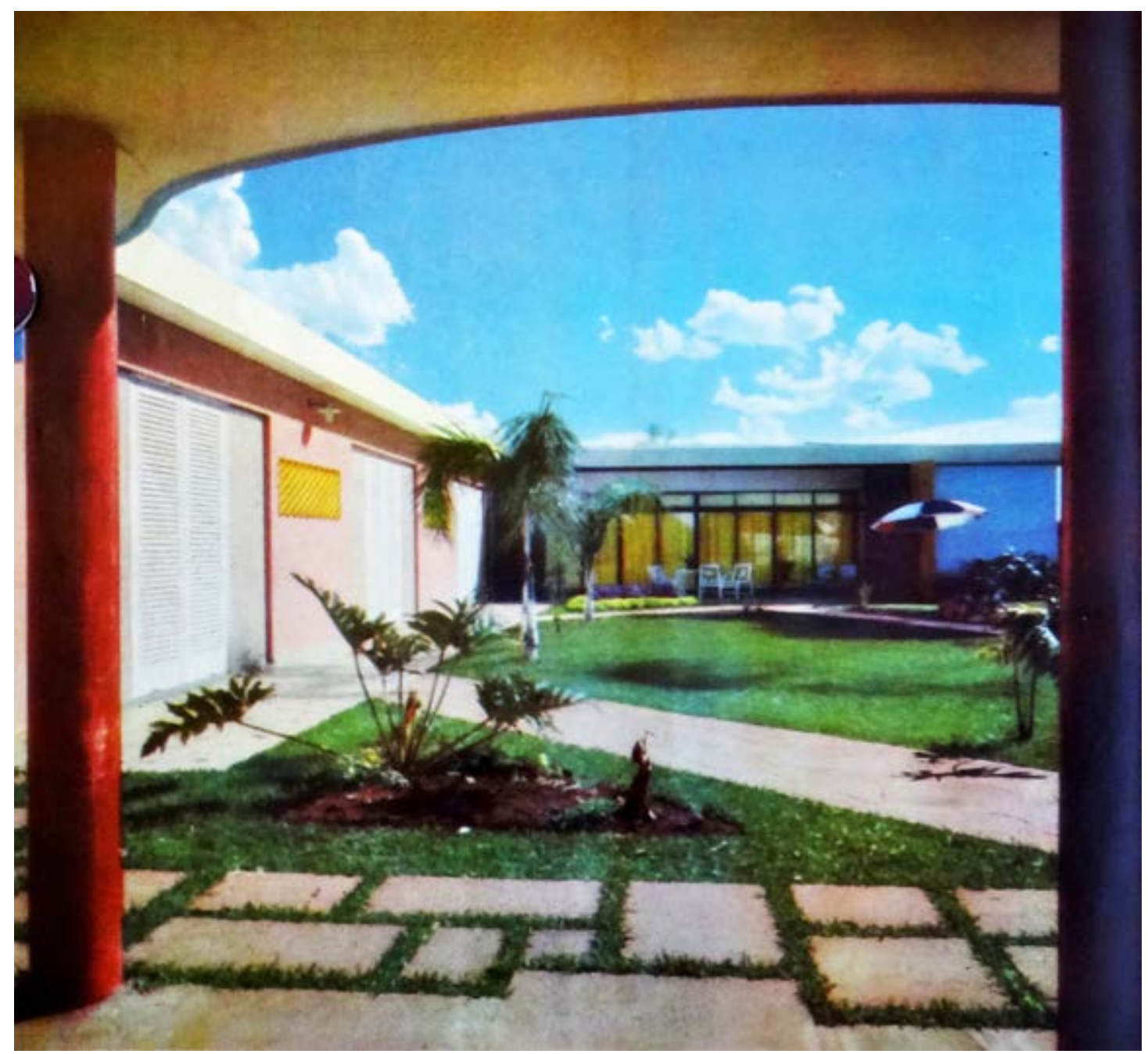

Fig.2.30 - Ambiente externo da “casa do galo."

\footnotetext{
22 "A Casa do Galo" é assim chamada porque o artista plástico Aldemir Martins fez um mural para a fachada, com um grande galo à beira mar. Projeto do arquiteto Eduardo Corona, no Brooklin Paulista. Paisagismo Jardins de Vanguarda Ltda. Alguns móveis de Joaquim Tenreiro. O texto diz que o jardim da frente foi resolvido pelo paisagista-pintor Waldemar Cordeiro.
} 


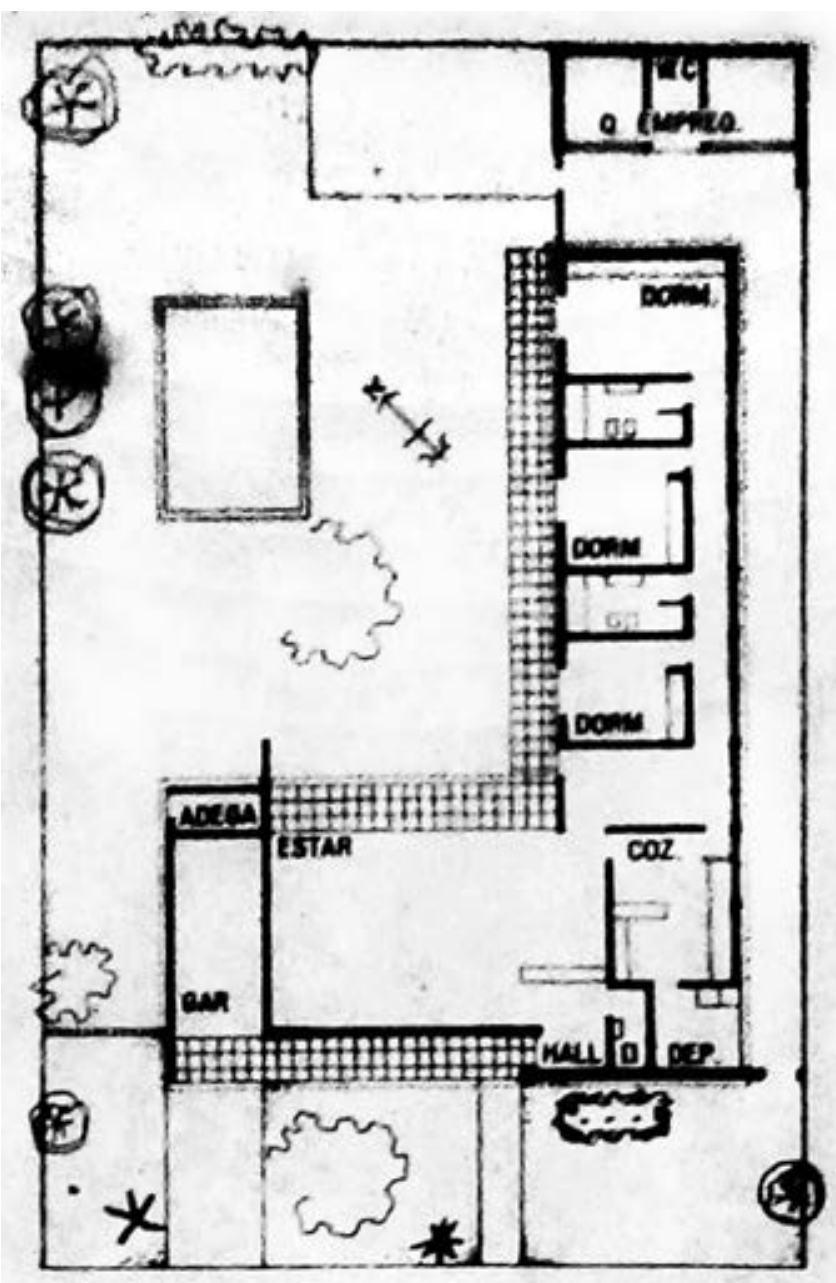

Fig.2.31 - Planta baixa da casa anterior.

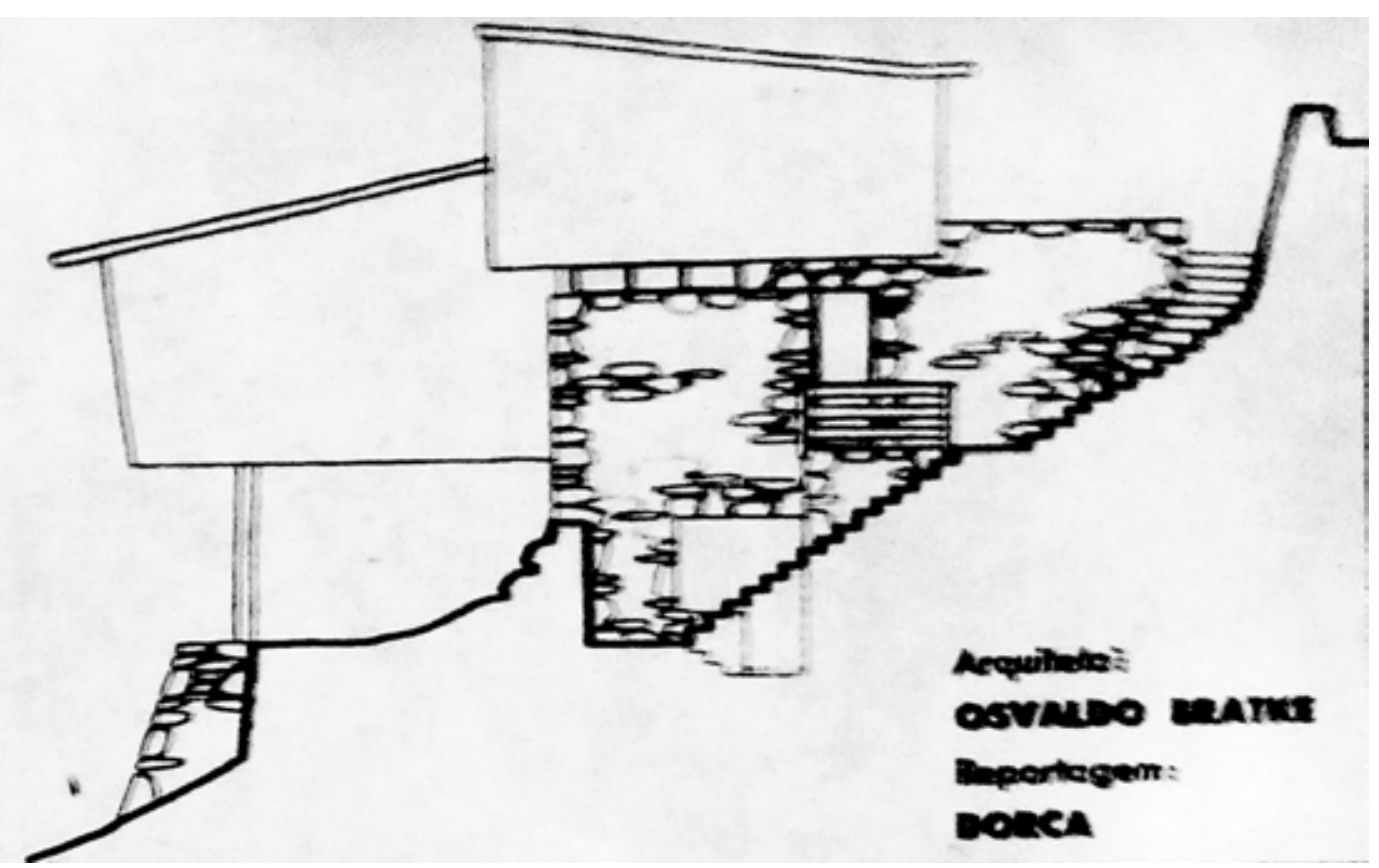

Fig.2.32 - Corte do projeto de residência, projetada por Bratke, na Ilha Porchat. 


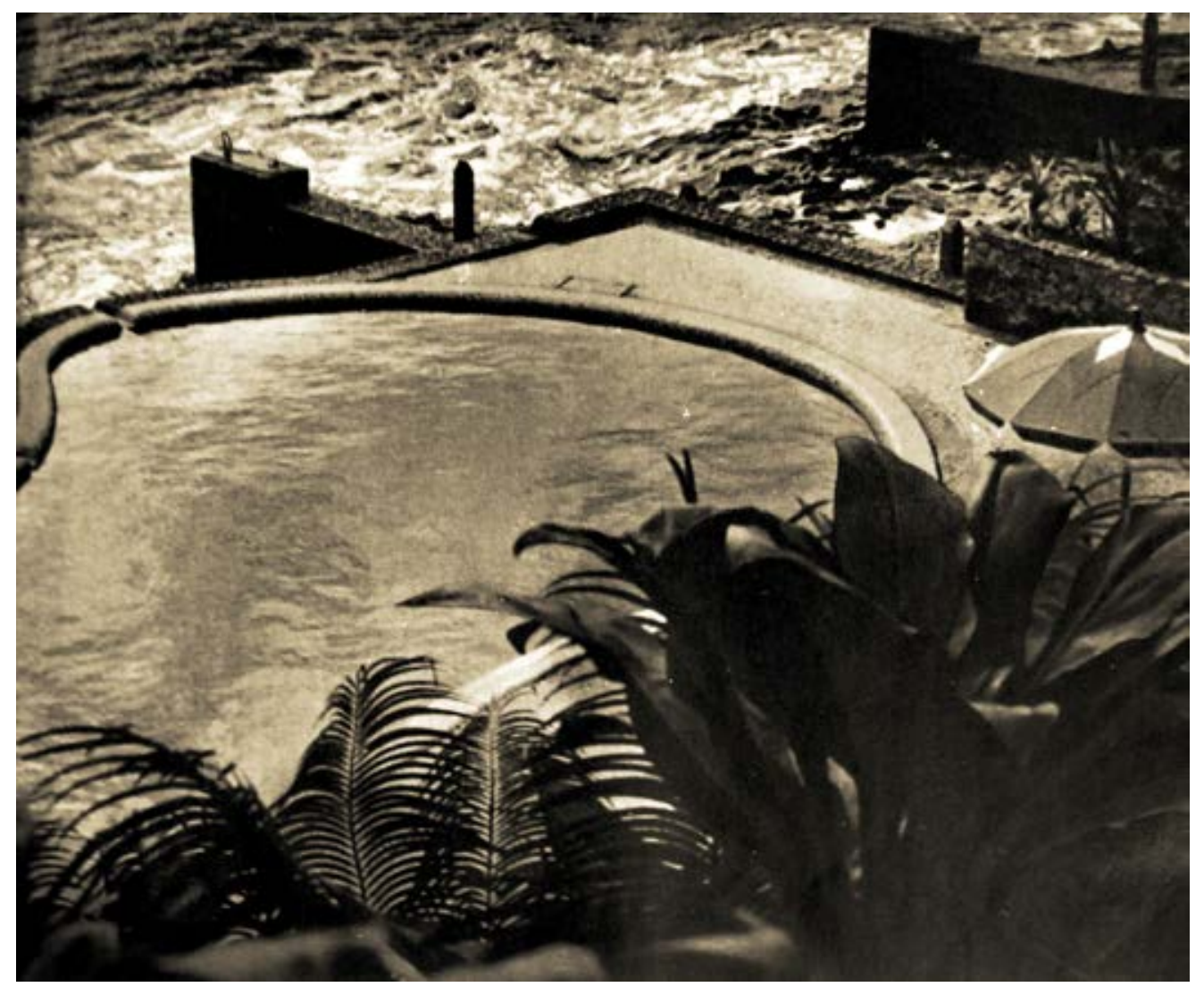

Fig.2.33 - Vista da piscina da casa anterior.

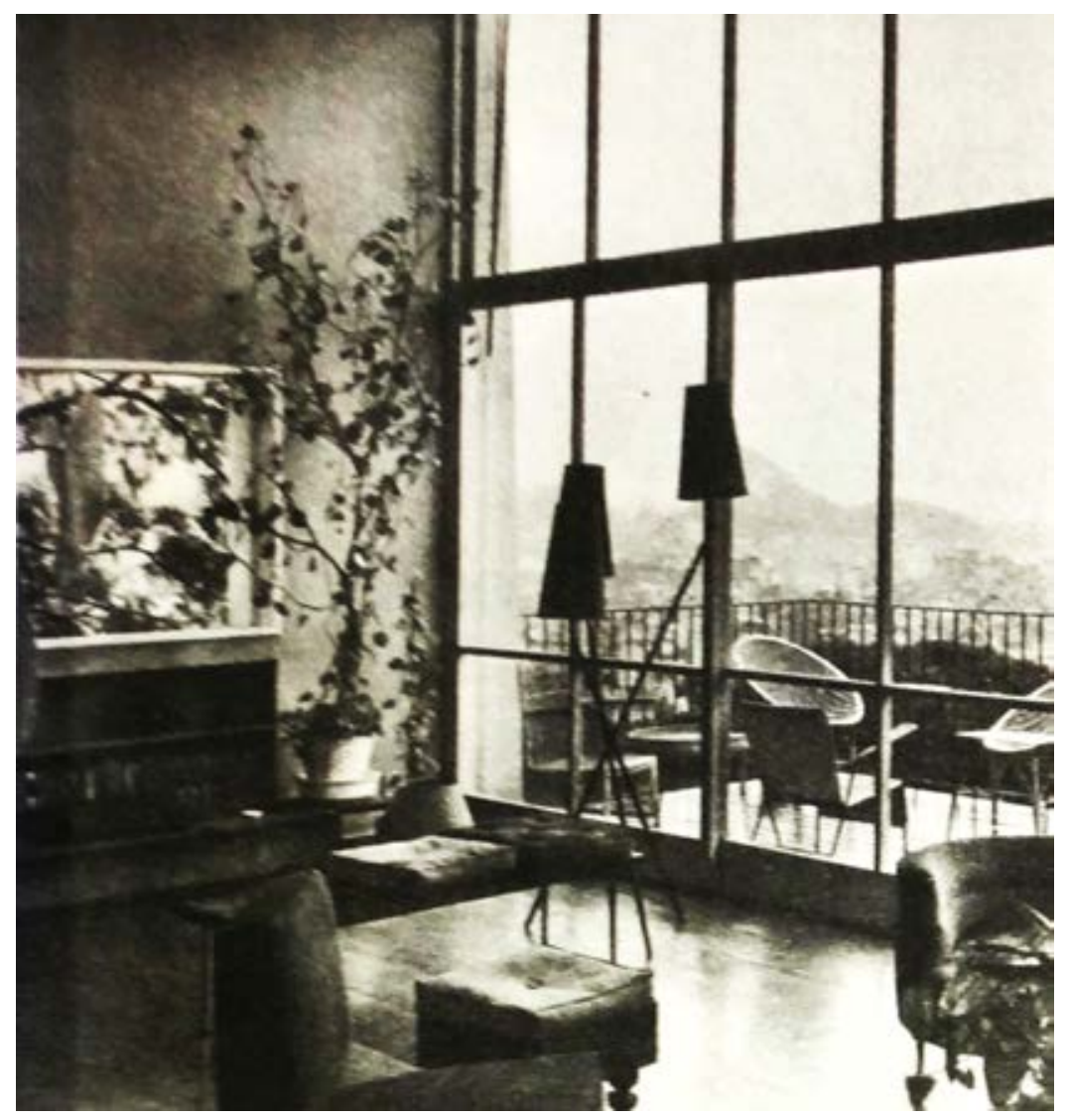

Fig.2.34 - Residência projetada por Henrique Mindlin. 
A ligação com a natureza era tão importante para o "bem viver" que a arquitetura, às vezes, pouco aparecia. ${ }^{23} \mathrm{Na}$ llha Porchat, a residência projetada por Oswaldo Bratke, à beira-mar, construída sobre as pedras e adaptada ao terreno íngreme, parece resumir-se aos ambientes externos e às vistas panorâmicas possíveis.

No projeto de Henrique Mindlin, a vista do mar é emoldurada pela "grande janela que forma a moldura para um quadro natural, trazendo para dentro da casa a natureza com toda sua exuberância." (A PAISAGEM...1956, p.30) "A cavalo no morro, a casa domina a paisagem carioca." (Ibid., p.31)

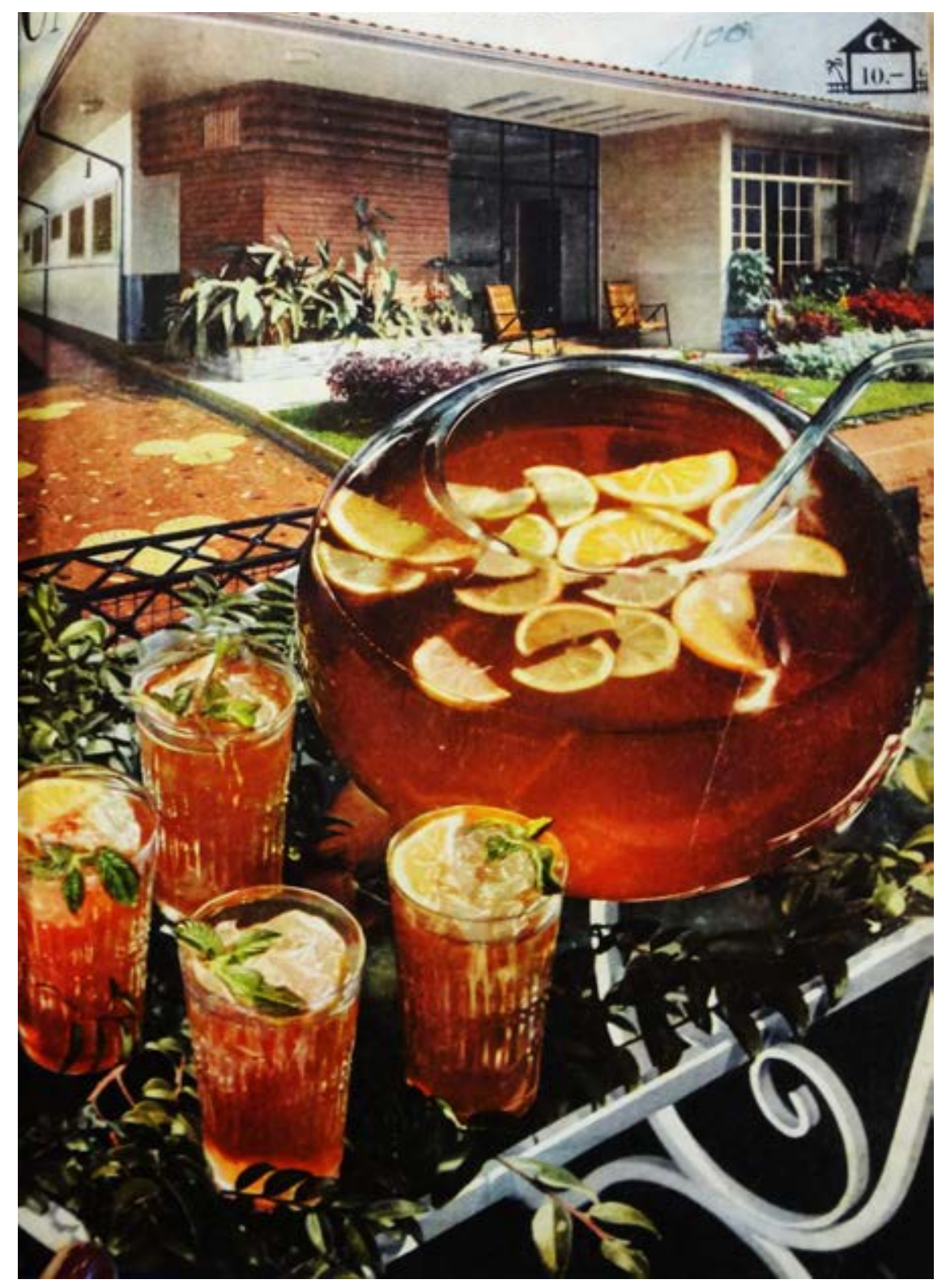

Fig.2.35 - Jardim de residência mostrada em Casa e Jardim.

\footnotetext{
${ }^{23}$ Dorca, 1956.
} 
Quanto ao jardim, ele chegava a influir na definição do projeto das casas do "bem viver": "O jardim, que o arquiteto tornou dono da casa, entra pelas janelas adentro, comunicando ao morador (...) a fresca e repousante sensação do campo. ("PRESENÇA"..., 1953, p.11) ${ }^{24}$

As janelas, muitas vezes, ocupavam grandes extensões das paredes e eram chamadas panorâmicas, "janelas-quadro" ou "janelas-moldura." 25

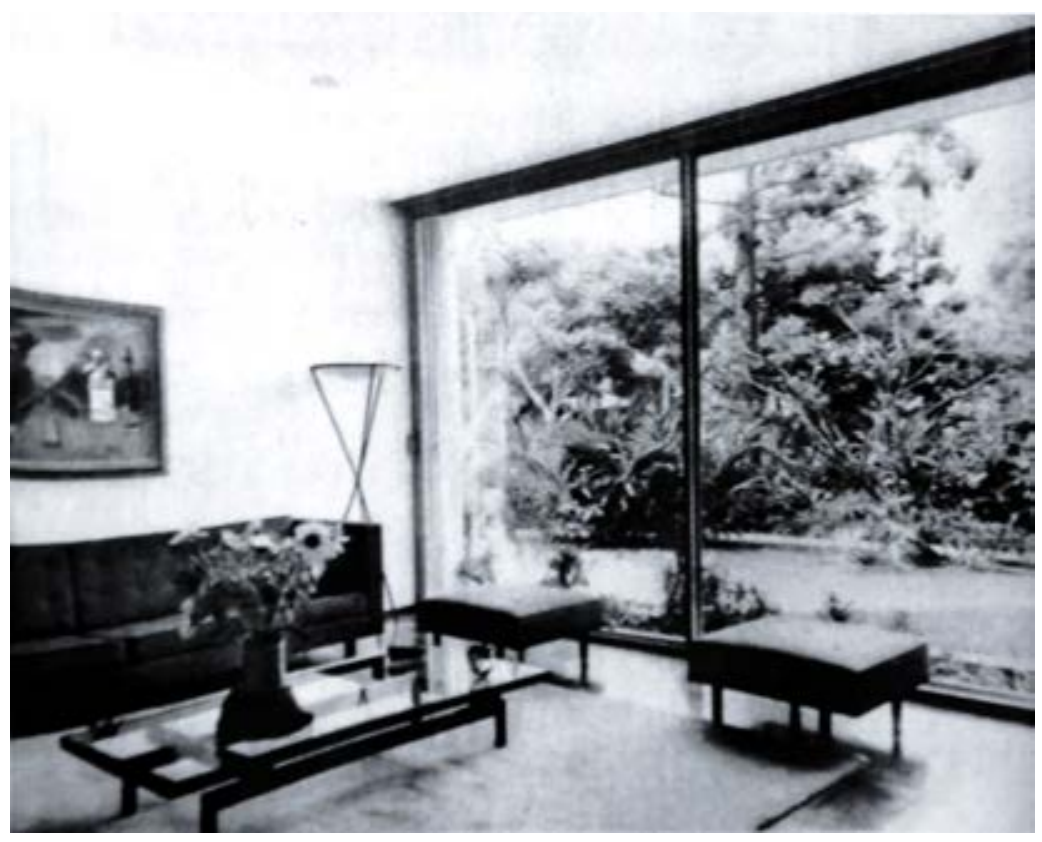

Fig.2.36 - "Janela-moldura."

E assim, da ânsia de luz e ar, da rebelião contra as habitações cada vez menores e a vida cada vez mais agitada e frenética, foi surgindo, fruto dessa ânsia, a forma de criar a ilusão da amplitude, mesmo num quarto pequeno, trazendo para nosso convívio a natureza, o ar livre, tudo que é belo. (...) Nalguns casos, o quadro já existia e a janela-moldura apenas o captou. (METZENER, 1955, p.36)

Mas, apesar dos elogios às grandes superfícies de vidro, havia ainda, no Brasil, à época, dificuldades técnicas e em relação ao custo na utilização dessas grandes esquadrias. Além disso, segundo Bratke (1988, p.159), a preocupação em relação à segurança provocava relutância nos proprietários: "abrir mais a casa para o exterior"

\footnotetext{
24 “Arquiteto Zeno Wolanski. A casa localizava-se na Rua Primavera, 60, em São Paulo e, possivelmente, ainda existe.

${ }^{25}$ METZENER, 1955. Projeto de Lucjan Korngold.
} 
era uma ousadia, pois "o cliente queria uma casa trancada, fechada, quase uma fortaleza. (...) Você punha vidros e o homem dizia: 'Ah, pelo amor de Deus, precisa grade!' (...) Até eu ter coragem de recomendar vidro temperado de $10 \mathrm{~mm}$ demorou muito, porque eu estaria assumindo uma grande responsabilidade, dada a confiança que o cliente depositava em mim."

Apesar disso, Casa e Jardim mostrava várias casas com grandes panos de vidro, como aquela projetada pelo arquiteto Rino Levi: ${ }^{26}$ "Nota-se a interligação interiorexterior obtida por grande porta envidraçada e acentuada pelo prolongamento do forro sobre o jardim, com pérgula de cimento armado." (O ARQUITETO..., 1954, p.12)

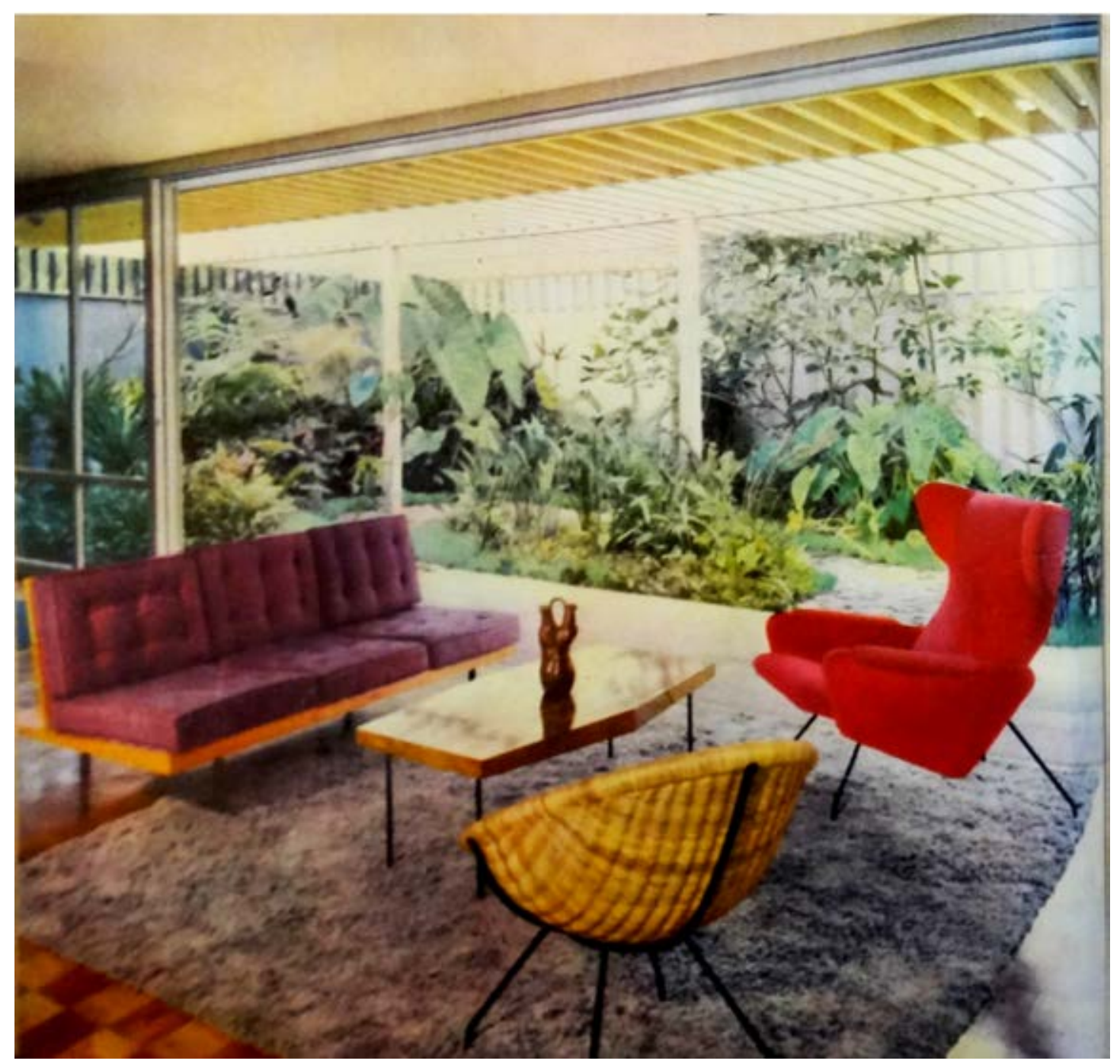

Fig.2.37 - Residência projetada pelo arquiteto Rino Levi.

\footnotetext{
${ }^{26}$ Com a colaboração do arquiteto Roberto Cerqueira César. Proprietário Milton Guper.
} 
Esse prolongamento criava um plano alongado que transpassava o encontro com outro plano - das portas de vidro - e a ele ficava perpendicular. A continuidade do plano, além da transparência do vidro, "relevava" a separação entre interior e exterior, que se ampliavam mutuamente. Existia uma relação ambígua entre ambos; um estava sutilmente ligado ao outro através de interpenetrações recíprocas.

Além do forro, a parede lateral também se prolongava ao exterior. As massas verdes de plantas tropicais, que escondiam o muro dos fundos, auxiliavam nessa sensação de amplidão. E a sala parecia transbordar para o jardim.

As portas de correr separavam fisicamente, apenas quando necessário, o pátio da área social interna, que incluía o jantar e outro ambiente com piano e lareira. ${ }^{27}$

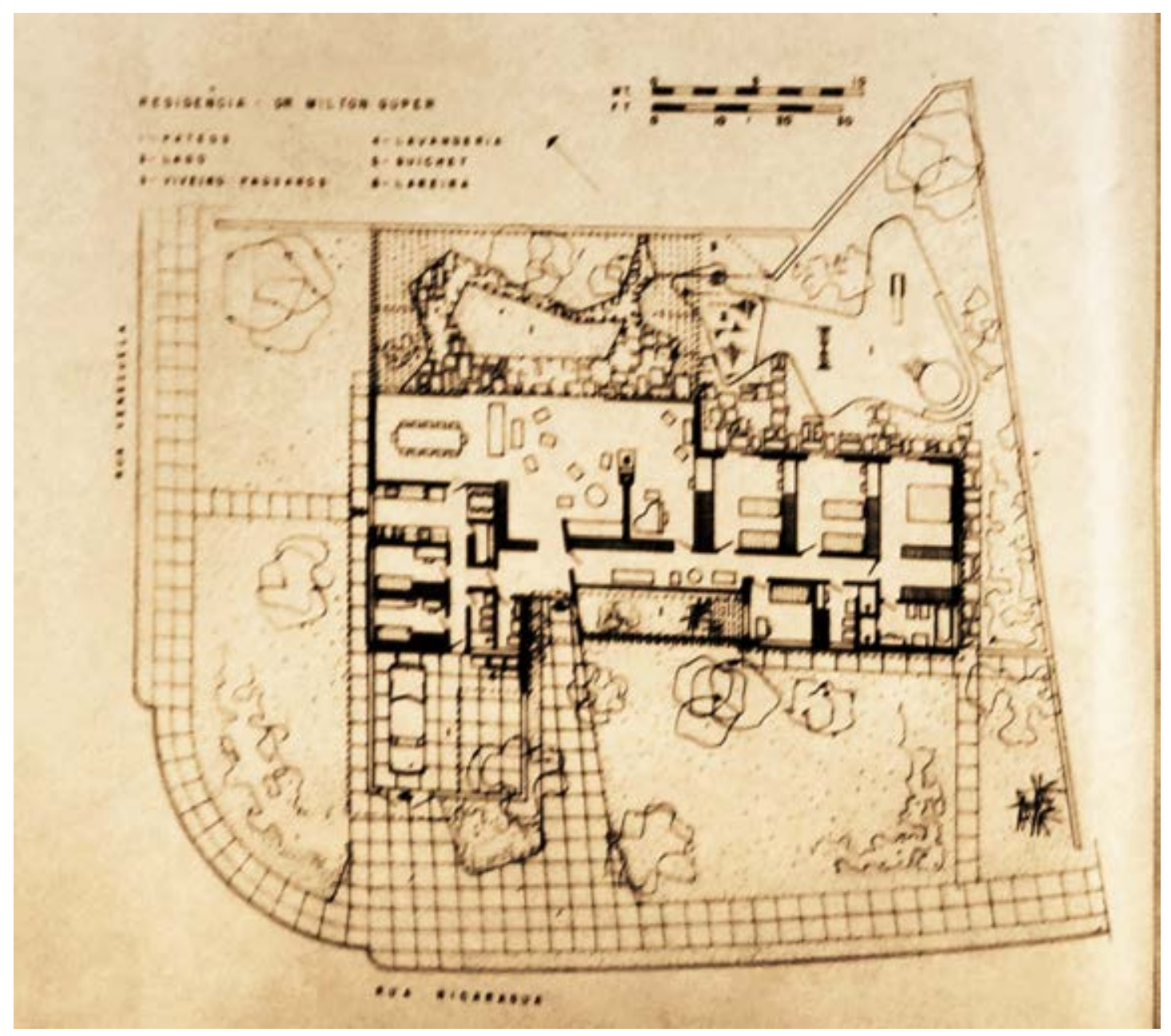

Fig.2.38 - Residência projetada pelo arquiteto Rino Levi, planta baixa.

${ }^{27}$ Os móveis, em cores variadas, são modernos, assim como a iluminação e as obras de arte. 
Além dessa relação com os espaços internos, os espaços externos dividem-se em vários setores, com funções definidas, sendo um deles o jardim frontal, que faz a transição entre a rua e a casa. Essa separação era comum e criavam-se vários pátios, às vezes a partir de uma planta baixa desenvolvida em várias alas.

$\mathrm{Na}$ residência seguinte, mostrada na revista Casa e Jardim, projetada em duas alas, ${ }^{28}$ uma térrea, outra assobradada, existe um pátio de serviço e um pátio para a área social. Nesse caso, os dormitórios situam-se no pavimento superior, gozando de privacidade. Porém, em vários projetos, estes localizam-se no térreo, existindo uma área externa específica para eles.

Esses vários pátios permitem uma espécie de "integração funcional" interna-externa, quando a atividade que se desenvolve em determinado ambiente pode também ocupar o espaço externo contiguo.

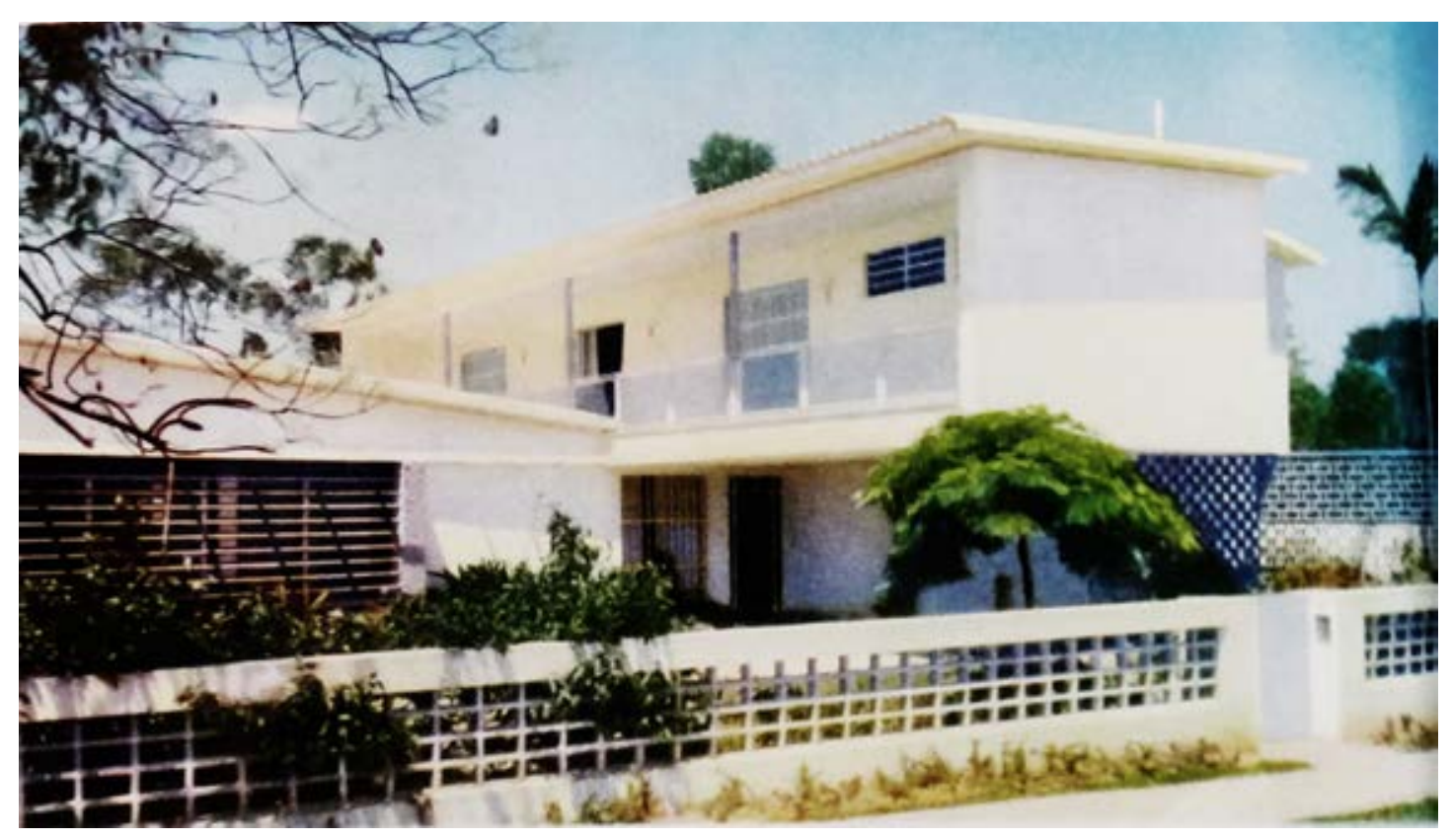

Fig.2.39 - Casa em duas alas.

O pátio social está sempre resguardado, pois geralmente volta-se para os fundos do lote ou para as suas laterais. Quando isso não acontece, como nesse projeto em particular, criam-se barreiras visuais. Nesse caso, a proteção para o jardim de inverno e a sala de estar é constituída por lâminas de concreto inclinadas. Essa preocupação com a manutenção da privacidade no jardim mostra a sua valorização

\footnotetext{
${ }^{28}$ EM TERRENO..., 1953. Projeto do engenheiro Saul Renato Serson, da Construtora Serson.
} 
como área de convívio. Existe, ainda, um cuidado especial em seu desenho, nas casas do "bem viver," mostrando o trabalho de outro profissional, o paisagista. ${ }^{29}$

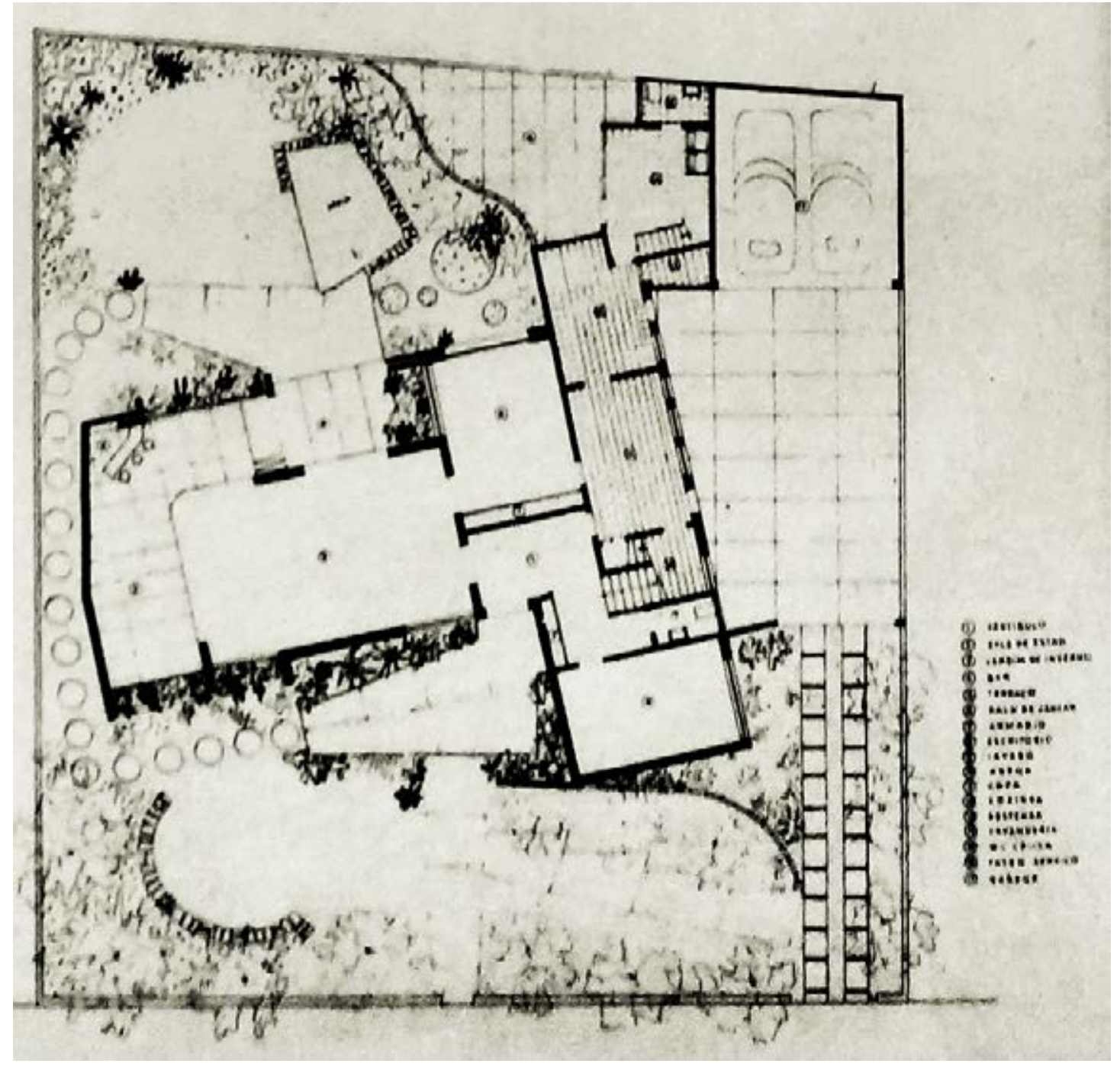

Fig.2.40 - Planta baixa da casa anterior.

\footnotetext{
${ }^{29}$ Havia, ainda, a possibilidade de se manter a privacidade com a utilização de cortinas. UMA RESIDÊNCIA..., 1954. Arquiteto José Carlos Maya.
} 


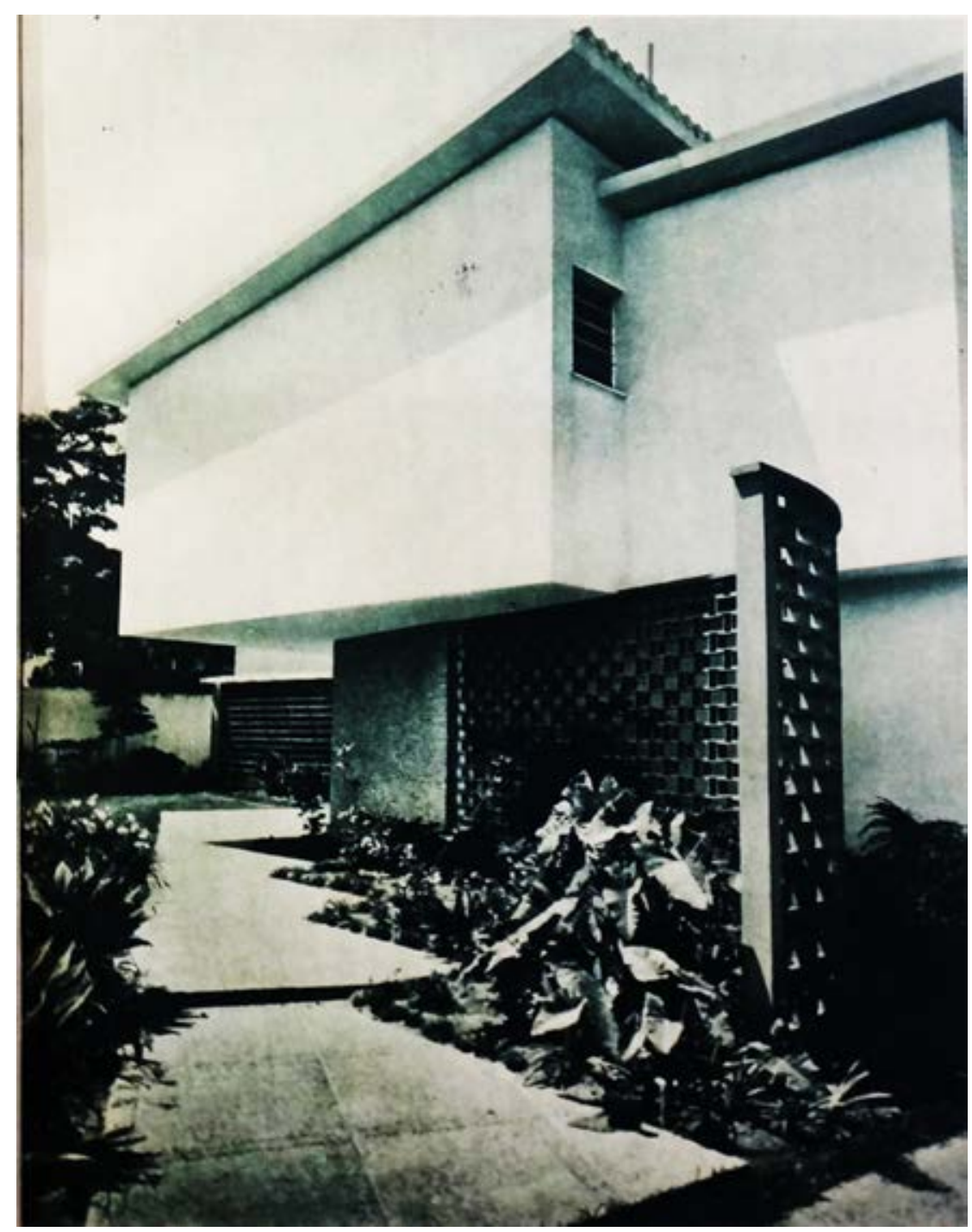

Fig.2.41 - Ainda na mesma casa, observa-se o cuidado no desenho dos jardins.

\subsection{Totalidade}

Outro aspecto da arquitetura do "bem viver" que pode ser analisado a partir dessas interpenetrações mútuas entre ambientes internos e externos é a ideia de integração. Podem-se utilizar, nessa leitura, os conceitos de unidade e de totalidade. Como quando menciona-se a "perfeita unificação da casa com o jardim, trazendo este para dentro da residência com a sua continuação lógica, com áreas verdes na própria sala de estar." (AS NECESSIDADES..., 1954, p.7) ${ }^{30}$

\footnotetext{
${ }^{30}$ Ainda que tais áreas verdes internas se resumissem a uma pequena floreira embaixo da escada. Reforma e decoração do Escritório Técnico Bernardo Rzezak. Paisagismo do arquiteto Roberto Cardoso Coelho.
} 
Em outra casa, "foram estudados grandes vãos que permitissem maior visibilidade dos jardins, para que estes formassem um todo único com os interiores." (EM TERRENO..., 1953, p.12)

Assim, a sensação de totalidade estética inclui a casa em si, o jardim e os interiores. "A integridade vai ainda mais longe, abrangendo cores, contrates de luz e sombra, detalhes unitários." (MERAVIGLIA, 1956, p.17)

Aqui está implícita a ideia do arquiteto concebendo o projeto arquitetônico e comandando paisagismo e desenho dos interiores, em conjunto com paisagista e decorador. Ele é o responsável pela unidade de projeto. ${ }^{31}$

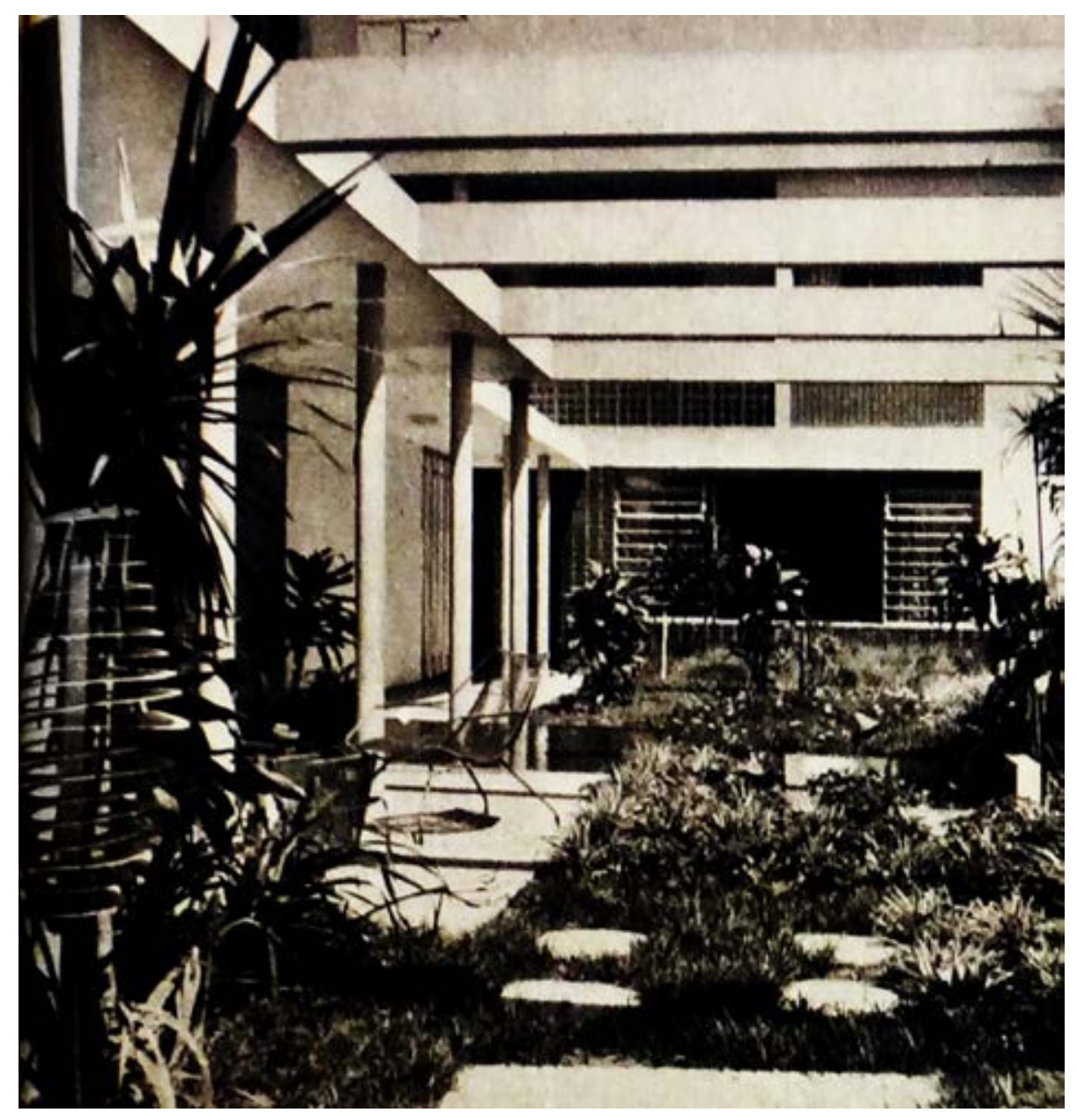

Fig.2.42 - Detalhes da casa e dos jardins concebidos conjuntamente.

Esse todo, segundo Casa e Jardim, não é mera junção de partes, pois "quando todos os fatores individuais são corretos, o todo torna-se maior do que a soma das

\footnotetext{
${ }^{31}$ Arquiteto Victor Relf, Paisagismo Jardim Vanguarda. Proprietário Schill Kuperman.
} 
partes." (VOCÊ..., 1959, p.7) Cada etapa do projeto poderia estar correta - o terreno, os detalhes, o espaço, o trabalho do arquiteto, a atitude dos clientes, a capacidade do construtor -, mas "o total é ainda maior do que se estatísticas e lógicas constituíssem fatores controladores." (Ibid., p.7)

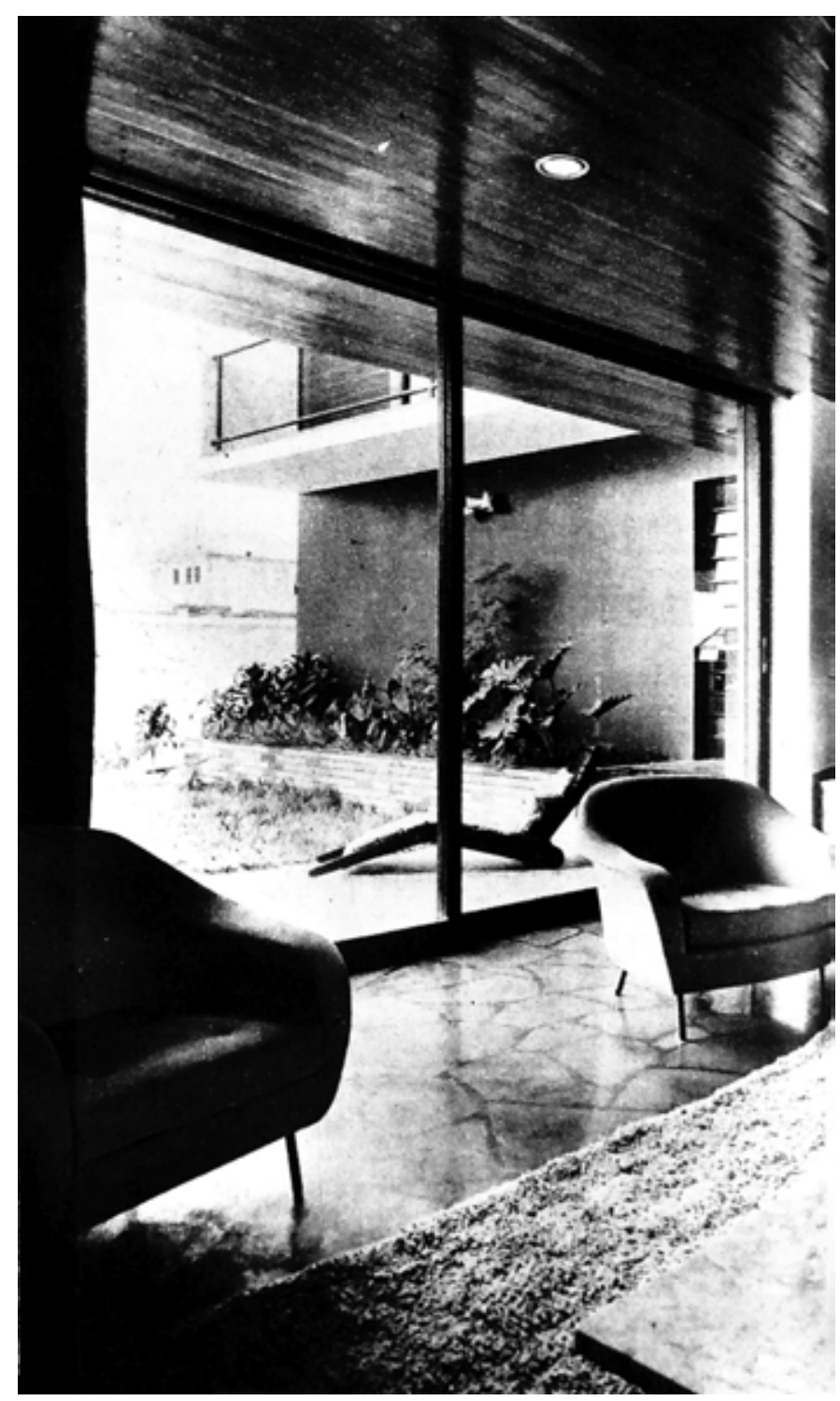

Fig.2.43 - Esse pequeno canto do living estabelece relações com o exterior, mas a unidade inclui também o mobiliário, externo e interno, a vegetação e, até mesmo, o forro em madeira .

Além da totalidade, deveriam ser consideradas as questões relacionadas ao conforto e à funcionalidade: "Cada cômodo deve ter sua função certa e cada móvel sua utilidade, formando um conjunto funcional. (...) (Assim,) consegue-se o efeito desejado, tornando a casa íntima e agradável e dando-lhe alma e personalidade." (AS NECESSIDADES..., 1954, p.9). 


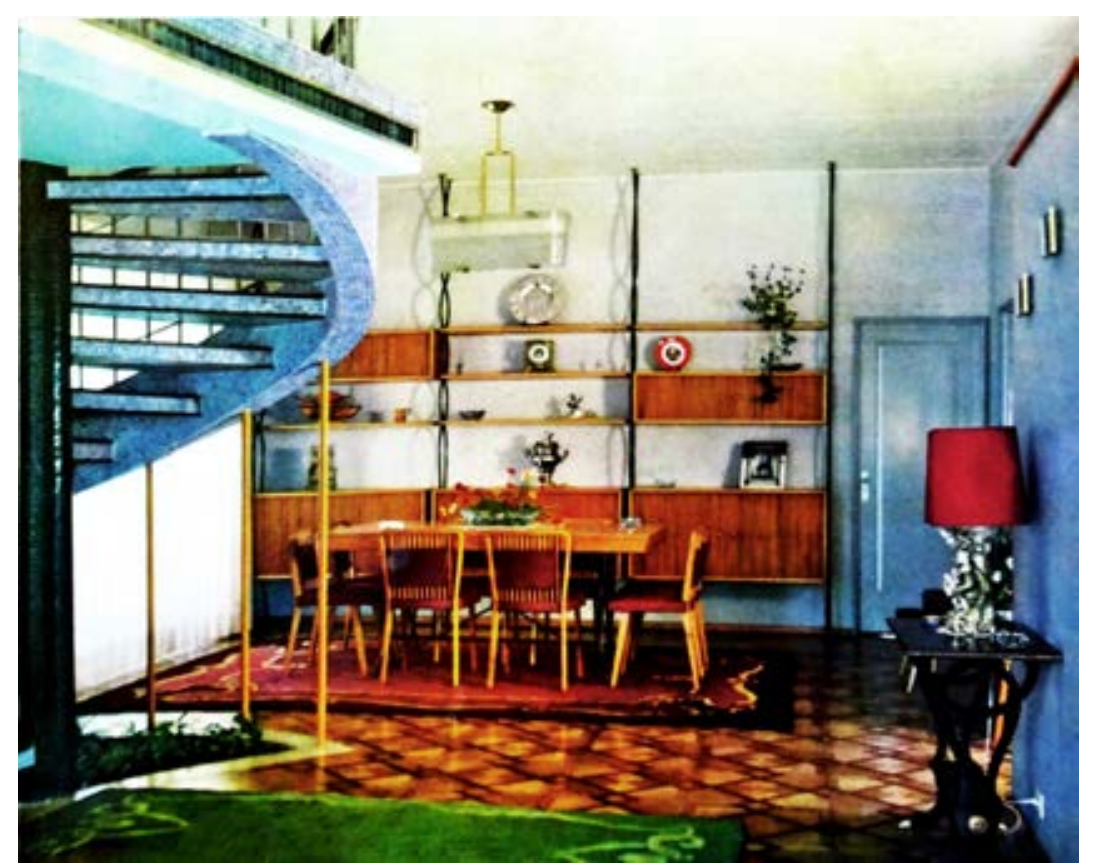

Fig.2.44 - Ambiente com "alma e personalidade."

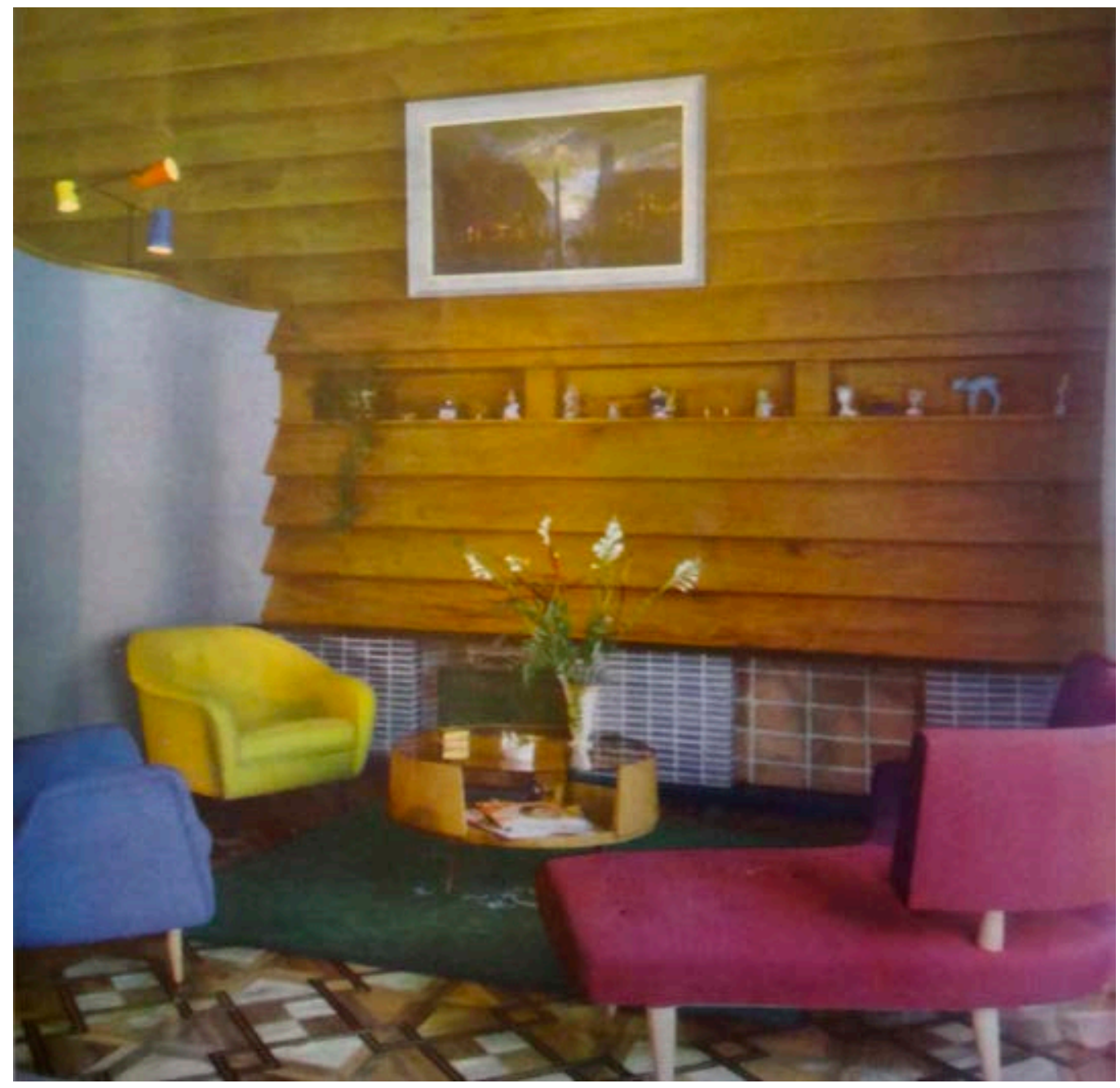

Fig.2.45 - "Dança de cores contrastantes." 
O conforto envolvia as necessidades materiais de cada um dos habitantes da casa. Dessa forma, cada um poderia desenvolver as atividades que desejasse, da forma que the conviesse: o espaço e o mobiliário deveriam ser considerados para formar "um conjunto harmonioso que (evitasse) colisões de interesses e tendências. (...) Cada um terá o seu móvel preferido no lugar adequado, sem contrariar a 'esfera' do outro." (HEDVIG, 1953, p.24) 32

Mas, esse processo vai além dos aspectos materiais ou funcionais da arquitetura. Esta casa é parte de um conjunto dinâmico, com elementos que se relacionam inclusive as pessoas. O conjunto circunscreve-se ao espaço daquela residência e liga-se ao tempo cotidiano, às refeições, à rotina da família, às preocupações prosaicas: "a simplicidade de linhas modernas nos móveis é a nota marcante," (além da) "dança de cores contrastantes (que) convida a alegres refeições." (AS NECESSIDADES..., 1954, p.4)

Pois, ainda segundo a revista, a vida diária não precisaria caracterizar-se por "uma monotonia cansativa: ela poderia ser cheia de variedades, estímulos e prazeres maravilhosos." (O SEGREDO..., 1954, p.20)

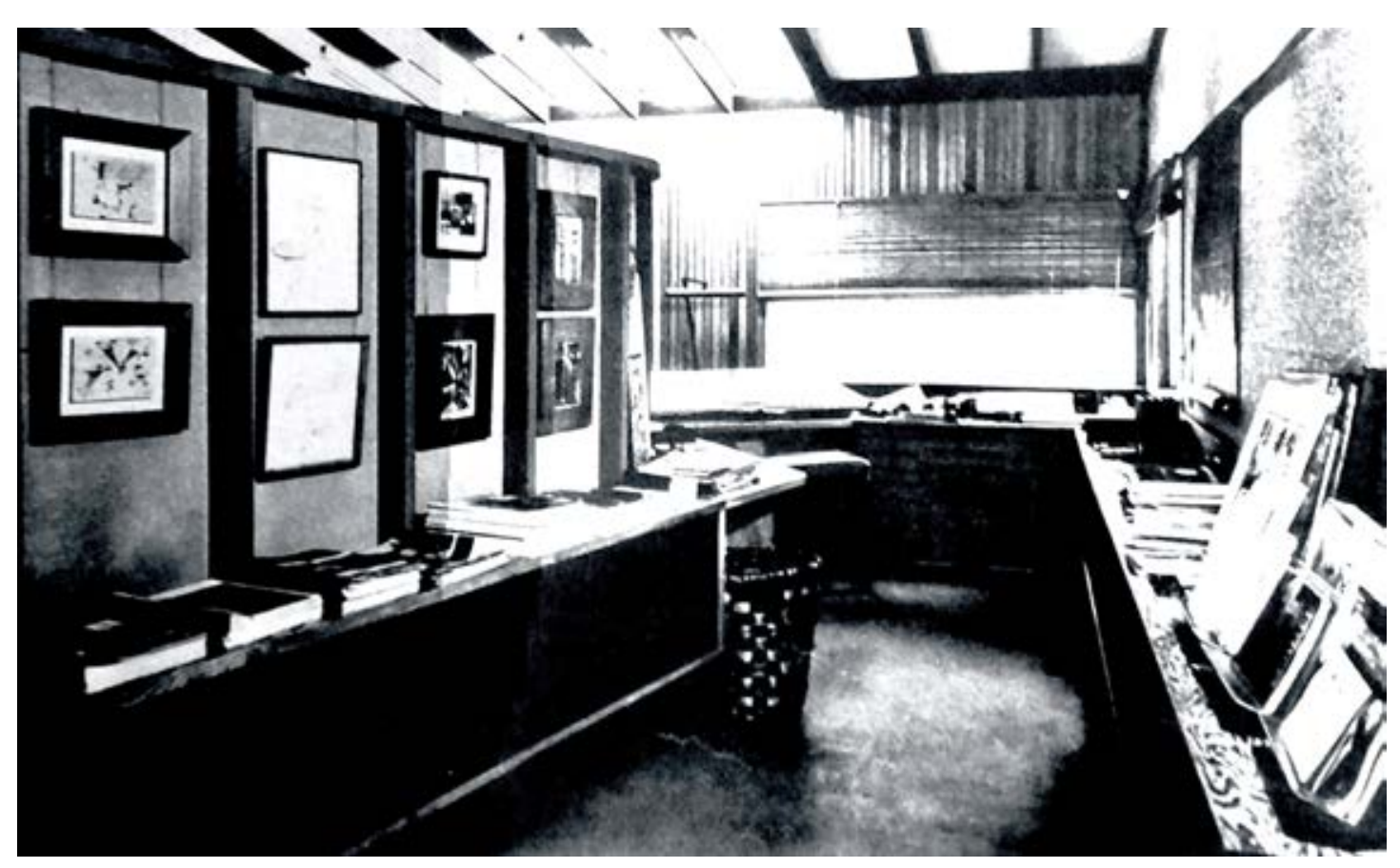

Fig.2.46 - Através de uma divisória em “Z,” mobiliário e objetos variados criaram-se vários ambientes para os diversos moradores desenvolverem suas atividades.

\footnotetext{
${ }^{32}$ Existem vários artigos sobre decoração para dormitórios, direcionada ao tipo de ocupante: AQUI DORME UMA SENHORA, 1959; AQUI DORME UM HOMEM, 1959; AQUI DORMEM CRIANÇAS, 1959; AQUI DORMEM OS PAIS, 1959.
} 


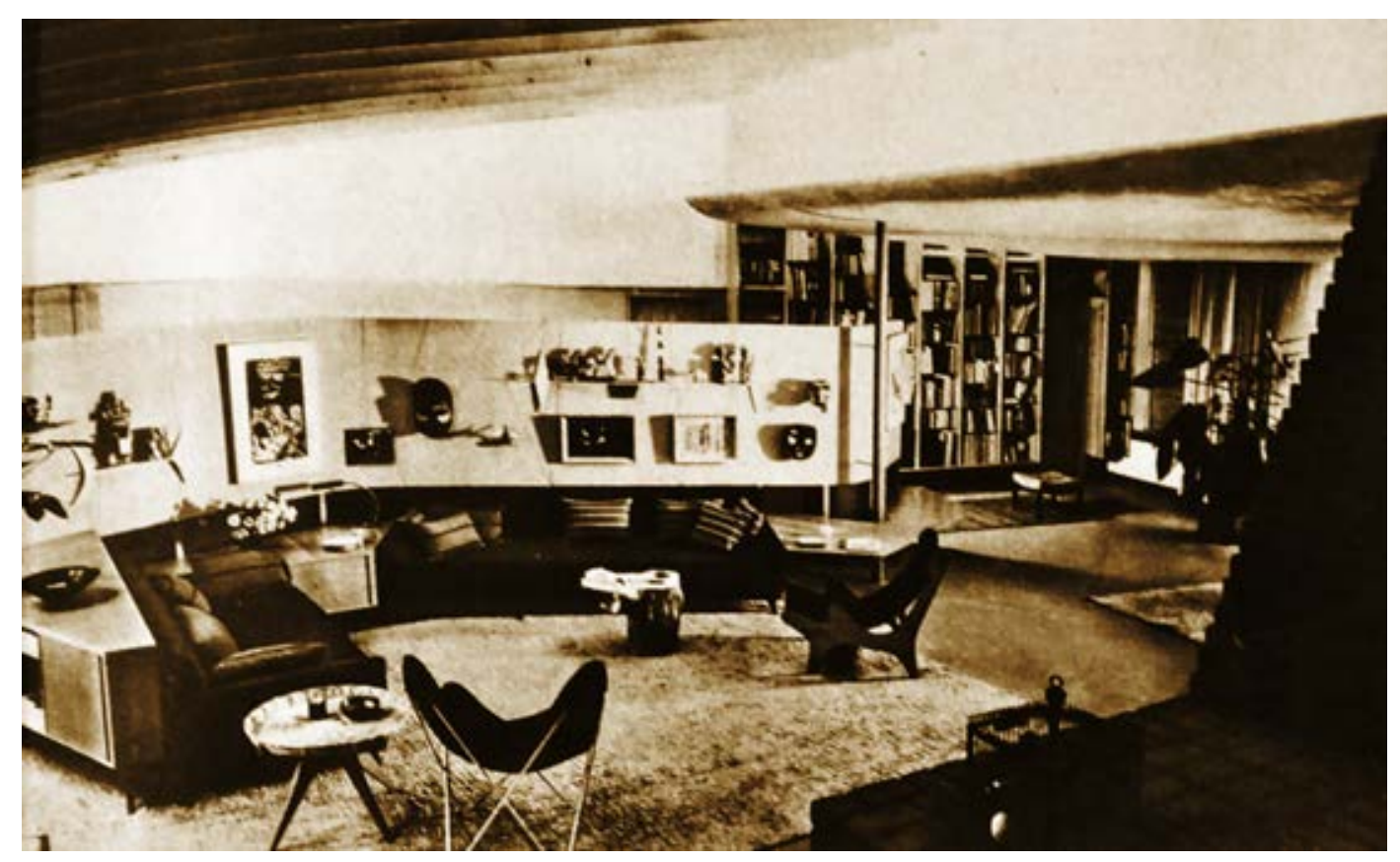

Fig.2.47 - 0 ambiente anterior visto do lado do living.

Utilizando a leitura de Ábalos (2000), que analisa várias casas do século XX, relacionadas a modos diversos de se pensar o mundo e de se viver, pode-se dizer que esta é uma casa pragmática.

"O sujeito pragmático é uma criação artística individual de cada um sobre si mesmo; uma sucessão de experiências, metáforas e linguagens que constituem a própria identidade e em cuja maior riqueza reside sua realização plena." (ÁBALOS, 2000, p.175) O "pragmatismo contrapõe uma concepção individual e subjetiva do mundo à grande máquina social positivista." (Ibid., p.175)

Essa concepção de vida, do "bem viver," também não se liga a um projeto coletivo. É relevante o presente, o individualismo, a subjetividade: "a residência (...) tornou-se um sistema de vida, planejado para eles, por eles, mas com um fator intangível adicional que não sabiam iriam encontrar (...). Além dos prazeres que advêm de participar na criação de alguma coisa, tiveram todas as recompensas de um estudo e compreensão de si próprios, todas as alegrias que vêm ao aprender coisas novas." (VOCÊ...,1959, p.7)

Para interpretar as questões da totalidade e da subjetividade no "bem viver," podemos utilizar o conceito da obra de arte total, aplicada ao objeto arquitetônico, apesar deste termo não ser mencionado em Casa e Jardim.

Segundo esse conceito, a "obra de arte é, dentre todas as obras humanas, a 
unidade mais acabada, a totalidade que se basta a si mesma." ${ }^{33} \mathrm{O}$ que concede à obra de arte sua beleza é a unidade, a sua essência.

Ainda de acordo com esse conceito, se a unidade estiver fechada "em si," exclui o morador. Mas, quando o próprio indivíduo compõe o ambiente com objetos variados, segundo o seu gosto, resulta uma unidade subjetiva, um novo todo, cuja síntese e forma total é adaptada a apenas uma personalidade determinada. Assim, sendo a obra de arte única, trata-se de um mecanismo de diferenciação e individualização.

Dessa forma, apesar dos objetos e elementos serem fabricados em série, o ambiente criado com eles poderia ser exclusivo. Apesar de não serem únicos, a síntese, obtida por eles e com eles, é.

Trata-se de uma totalidade constituída por muitas partes que se relacionam, um ambiente criado "sob medida" para seu morador. Esta síntese é a obra de arte total. Acaba por se constituir uma espécie de cenário - a casa com seus móveis, objetos, elementos - para o cultivo da vida. Segundo Casa e Jardim: "Objetos de várias procedências, épocas e estilos, formam um todo muito bem equilibrado." (A PAISAGEM..., 1956, p.31)

Outro aspecto a ser ressaltado é que o conceito de totalidade quase sempre é entendido como soma das partes, mas é mais que isso, é necessário analisar as relações entre as partes e o todo. Ambos se opõem, mas as partes só podem ser consideradas como tal se relacionarem-se com o todo, que lhes confere seu significado.

Assim, a beleza do ambiente viria das relações estabelecidas entre suas partes móveis, quadros, objetos, elementos construtivos - e entre cada parte e o todo.

Pode-se fazer também um paralelo entre o conceito de obra de arte total e o método orgânico de projeto, ${ }^{34}$ que tem sua origem na Escola de Chicago, de Louis Sullivan e Frank Lloyd Wright. ${ }^{35}$

De acordo com a revista, o cerne do problema da casa seria a dupla função, a orgânica e a estética. "Funcionalismo é o termo de uma teoria estética adotada em arquitetura. (...) Baseada no principio de que a forma deve seguir a função. (...)

\footnotetext{
${ }^{33}$ SIMMEL, Georg, Philosophie des Gelds (Filosofia do Dinheiro, 1900), Gesamtausgabe vol.VI, organização de D.P.Frisby e K.C. Köhnke, 2ª ed., Frankfurt/M, Suhrkamp: 1991, p.629 apud WAIZBORT, 2000, p.180.

${ }^{34}$ Cf. De Carlo (2008) e Rebecchini (1985) sobre o método orgânico de projeto,.

${ }^{35}$ Ambos são citados em Casa e Jardim, além de seu lema "Form follows function." (VILLELA, 1959b, p.10)
} 
funcionalismo corresponde à perfeita integração de utilidade e beleza. Quando dizemos função, (...) entendemos a organização do espaço e as relações dimensionais segundo a utilidade e o melhor serviço que exigimos nos prestem estas e aquele." (BIANCHI; LANDERSET, 1959, p.4) ${ }^{36}$

Dentro dessa concepção "moderna, funcional ou orgânica" (VILLELA, 1959b, p.11), para Casa e Jardim, um objeto deveria ser planejado para determinada finalidade, fabricado com material e processos adequados à sua forma. Além disso, deveria ser considerada sua beleza.

Assim, função e forma deveriam ser consideradas conjuntamente para o "bem viver:" "Morar bem nada mais é do que a combinação entre o conforto e o efeito. Há pessoas que vivem sem conforto dentro de um purismo absoluto. Outras há que vivem bem instaladas dentro da ausência do estilo. O difícil é encontrar uma casa que nos assente que nem uma luva, e que seja ao mesmo tempo, obra-prima de arquitetura." (MARGÔ, 1957b, p.15) 37

Ainda segundo a revista, na "natureza, a utilidade e aspecto, função e forma, são tão estritamente entrelaçados que dão a ideia de ser uma só coisa." (COMO DESENVOLVER..., 1956, p.6) Dessa forma, o "empenho de toda a arte é unir a forma à função, da mesma maneira como elas são unidas na natureza; fazer uma expressar a outra. Esta integração é a marca do verdadeiro estilo." (Ibid., 1956, p.69)

Segundo Rebecchini (1985, p.64-5), em sua análise dos métodos de projeto, a tese orgânica diz que a função nasce com a forma e é inseparável desta, assim, na natureza, a "função-árvore" não pode ser separada da "forma-árvore." "Entre forma e função não existe uma relação de consequência, mas de contemporaneidade. A função não existe a priori sem uma forma." ${ }^{38}$

Segundo a ideologia orgânica, o homem pode encontrar apenas na natureza uma referência constante, espontaneamente dirigida ao bem. Mas, para isto, deve superar barreiras que a própria civilização impõe. Nesse processo, não é suficiente o uso da razão, que, mesmo com seu poder dedutivo baseado na lógica, não

\footnotetext{
${ }^{36}$ Segundo o artigo, Bianchi e Landerset seriam diretores do Instituto de Arte e Decoração, "único no gênero, oficializado pelo governo." (BIANCHI; LANDERSET, 1959, p.3)

${ }^{37}$ Refere-se a casa na Alameda Rio Claro, em São Paulo.

${ }^{38}$ Esta é outra questão fundamental sobre a qual divergem os métodos racionalista e orgânico: o do momento da definição da forma e da função. Segundo a lógica racionalista, a função é definida inicialmente e a ela corresponde apenas uma forma, a única capaz de satisfazê-la plenamente. Essa passagem da função à forma é, em ultima instância, dedutiva.
} 
consegue atingir o essencial. É necessária a intuição, a imaginação poética. No entanto, essa intuição não é individualizada, mas fruto de uma pesquisa rigorosa sobre o homem e sua ligação com a natureza. ${ }^{39}$

Essa ligação com a natureza está presente na arquitetura do "bem viver," como vimos. Ainda que seja uma natureza adaptada, "recortada," cultivada, como um pequeno jardim.

Além disso, a prática orgânica parte de um esforço inicial de síntese da forma, de uma ideia do todo, imediata e intuitiva, que é analisada para se verificar a possibilidade de seu desenvolvimento.

Essa síntese inicial é um fio condutor em torno do qual se materializa o edifício. Uma ideia dominante, que estrutura a unidade. Esse todo conceitual não é mera junção de partes, existe uma intenção implícita. Entre as partes, existe uma conexão e entre essas e o todo. Não se trata apenas de uma justaposição de formas.

Nos textos de Luiz Saia, que analisam a prática projetual, ${ }^{40}$ também podemos perceber referências ao método de projeto orgânico. Segundo ele, nesse processo, estariam presentes operações irreversíveis, da "pura atividade criadora" do arquiteto, fruto de inspiração poética pré-existente, que antecipa as outras etapas projetuais e se constitui em um norte, um caminho que dirige o processo que estrutura a arquitetura.

Ele refere-se ao esforço inicial de síntese da forma. A partir de então, ocorreriam "operações simultâneas," envolvendo o partido, o programa, a técnica, a definição do espaço, a escolha dos materiais, o sítio.

Ou seja, a ideia do todo, onde existe uma intenção implícita, sempre iniciaria o processo.

Com esse conceito de "unidade inicial" como ponto de partida, a casa é vista como um todo orgânico, do qual emergem os elementos. Elementos do edifício, do mobiliário e do paisagismo, com os quais pretende-se obter o "efeito final," muito próximo da "ideia inicial."

Essa ideia do todo contraposto às partes está presente em Casa e Jardim: "Qualquer atividade, em que estejamos absorvidos, desperta em nós uma sensação estética. (...) E estas nos levam à percepção do todo, bem como aos detalhes em

\footnotetext{
${ }^{39}$ Motivações análogas encontram-se na arquitetura produzida na Escandinávia, por Aalto, e também em algumas vertentes holandesas.

${ }^{40}$ Entre eles, SAIA, 1957a.
} 
separado. Podemos gostar de uma coisa como um todo e, ao mesmo tempo, de suas particularidades. (...) O constante e eterno desejo de alcançar a totalidade - de combinar o inteiro com o unitário, de forma que se crie uma perfeição estética constitui os segredos da arte e, por conseguinte, também, os segredos da arte moderna de construir." (MERAVIGLIA, 1956, p.15)

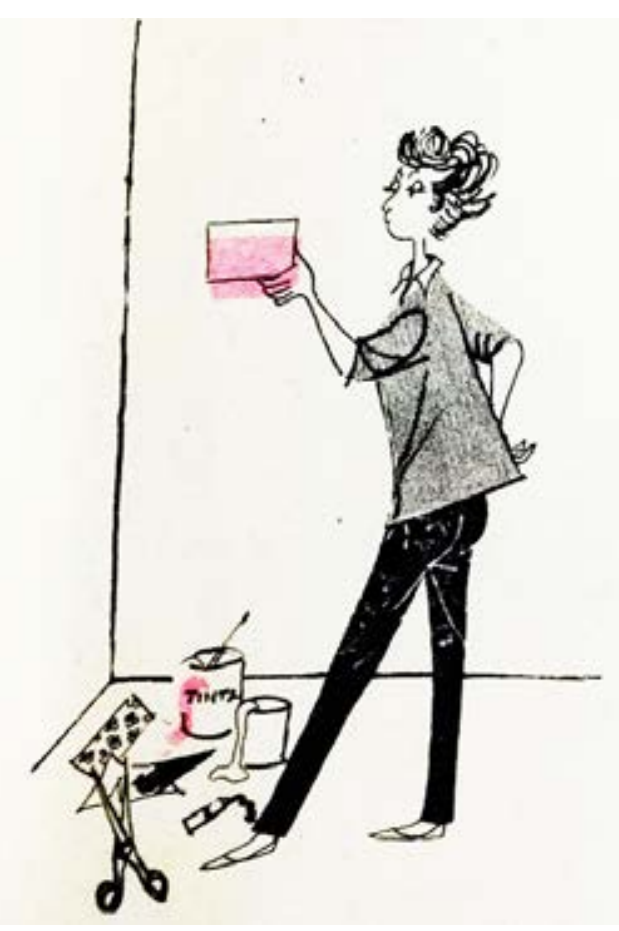

Fig.2.48 - Dona de casa com talento para a decoração.

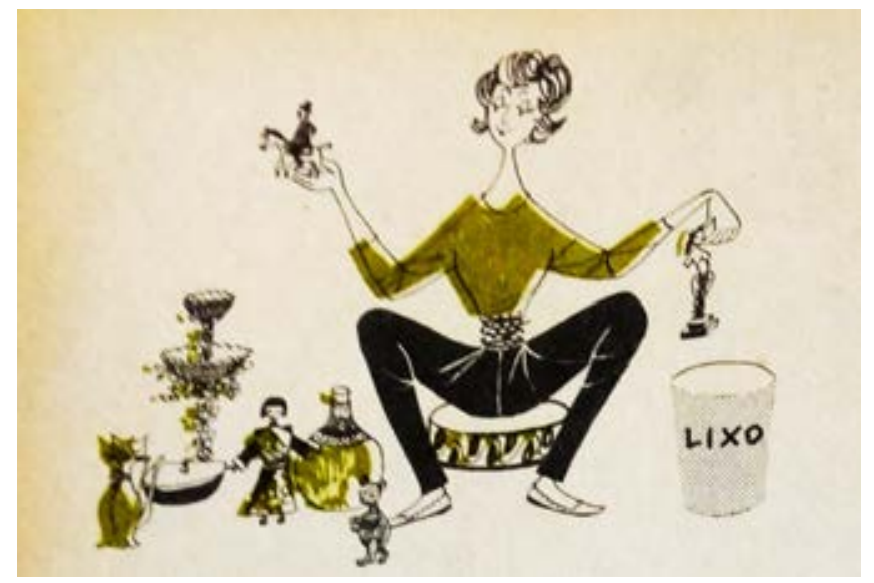

Fig.2.49 - "Faça você mesma."

E a questão do todo, da síntese inicial, é traduzida para o leitor: "Depois de o esquema geral estar pronto, você tem paciência de ir até o fim com o mesmo gosto, 
cuidando inclusive dos detalhes que não estão à vista?" Ou, ainda: "Tem capacidade técnica suficiente para saber como cuidar desses detalhes, de modo a serem consentâneos com o caráter geral do esquema?" (VAMOS TESTAR..., 1959, p. $56)^{41}$

\subsection{Subjetividade}

Como dissemos, a partir do conceito de obra de arte total, resulta uma unidade subjetiva, adaptada a uma personalidade determinada, um ambiente exclusivo. Pois, a "(...) coesão da obra de arte significa que uma unidade anímica subjetiva se exprime nela; a obra de arte exige apenas um homem, mas o exige por completo e de acordo com sua interioridade mais central: ela justifica isso pelo fato de que sua forma lhe permite ser o mais puro espelho e expressão do sujeito." ${ }^{42}$

Da mesma forma, na arquitetura do "bem viver," outra questão que se coloca, ao lado da totalidade, é a da subjetividade. Tais residências deveriam ser a expressão do sujeito que as iria habitar.

Segundo Villela (1959b, p.11), em artigo de Casa e Jardim, uma das particularidades da época seria a valorização do ser humano, a partir da liberdade de se viver do modo preferido. Assim, ligando a decoração à personalidade do individuo, ela se tornaria o "símbolo da liberdade individual que nos oferece a democracia." (Ibid., p.11)

Para expressar a individualidade, o projeto deveria basear-se em necessidades reais, no modo de viver da família, chegando a uma solução funcional, sem ambientes supérfluos. Qualquer item que encarecesse a construção ou dificultasse a manutenção, deveria ser banido, evitando fazer "da dona de casa a sua escrava ao invés de sua maior beneficiada." (AS NECESSIDADES..., 1954, p.9)

Porém, à "primeira vista pode parecer que a finalidade de nossa casa seja apenas, ou principalmente, a de nos proporcionar conforto físico. Na verdade, o ambiente material tem papel vital sobre nossa psicologia - é fator preponderante na vida emocional e, ao mesmo tempo, uma expressão de individualidade." (VILLELA,

\footnotetext{
${ }^{41}$ O leitor poderia verificar sua aptidão para a arte de construir e decorar em "Vamos testar seu talento para decoração?"(VAMOS TESTAR...,1959, p.55-56.).

${ }^{42}$ SIMMEL, Georg, Philosophie des Gelds, op.cit., p.630 apud WAIZBORT, 2000, p.180.
} 
1959a, p,4) Nossa personalidade estaria refletida em nossas escolhas a respeito de móveis, cores e outros aspectos.

Assim, além dos aspectos práticos, seria fundamental compreender a personalidade do morador: suas características, aspirações e desejos mais íntimos. Elaborar quase um estudo psicológico do individuo. (HEDVIG, 1953, p.24)

Mas, esse "estudo psicológico" não seria uma indagação que se faz diretamente ao usuário, já que este ainda não está consciente de suas escolhas. $\mathrm{O}$ arquiteto faria essa análise.

Segundo o método orgânico de projeto, ficaria a cargo da cultura do arquiteto, da sua capacidade intuitiva, perceber as exigências íntimas de um indivíduo. Deveriam ser pesquisadas suas aspirações, mesmo que não conscientes, em uma investigação profundamente intuitiva. ${ }^{43}$

Para Rebecchini $(1985$, p.63) tal alternativa seria "mais incerta, mas admite a possibilidade de um maior sucesso, de uma contribuição culturalmente mais válida." As exigências psicológicas e ideológicas sobrepõem-se às praticas e materiais.

Mas, na verdade, o que acaba por acontecer na arquitetura do "bem viver" é que a cultura do arquiteto - ou aquela veiculada pela revista - acaba por influenciar os desejos e aspirações do morador, fazendo com que ele adote, de forma naturalizada, gostos e padrões - do arquiteto ou da revista - como se fossem seus.

$\mathrm{Na}$ revista, existe uma tentativa de se transmitir a linguagem moderna e alterar o gosto do leitor. Busca-se atribuir-lhe desejos, alterar-se suas escolhas. De forma natural, como se esse "cultivo" do gosto fosse escolha própria.

Segundo Casa e Jardim, as preferências estéticas, apesar de vistas como intrínsecas ao homem, poderiam sofrer alterações, a partir das novas informações: "O gosto é, de algum modo, uma particularidade inflexível e rígida de nossa

\footnotetext{
${ }^{43}$ A tese "racionalista" choca-se com a "orgânica" neste aspecto, pois no caso da primeira, as exigências a serem consideradas são aquelas expressadas de forma evidente, manifesta, pelos usuários. Existe uma indagação mais objetiva.

De acordo com o método racional de projeto, desenvolvido pelo Movimento Moderno, para se definirem as necessidades do usuário deveriam ser examinadas as exigências coletivas, trazendo-se os elementos comuns e descartando-se os excepcionais. $O$ intuito era a satisfação equilibrada das exigências vitais do maior número possível de pessoas, com o menor esforço econômico e produtivo. O valor médio era o que contava. Assim, acabam por prevalecer as exigências práticas, mais facilmente controláveis de que as psicológicas e ideológicas. Devemos nos lembrar que, com esse método de projeto, foram concebidos grandes conjuntos habitacionais, como as Siedlungen alemãs.
} 
natureza. A par disto, porém, ele é suscetível às novidades, sempre que estas satisfaçam os seus pendores estéticos". (MERAVIGLIA, 1956, p.15) ${ }^{44}$

Podemos considerar que, apesar de o morador ser, teoricamente, a fonte das aspirações, na verdade, na medida em que se tenta modificar seu "gosto," transmitindo-Ihe "lições da linguagem moderna," não se trata realmente de seus anseios. Trata-se de um paradoxo: devemos exprimir o que somos, mas antes devemos nos modificar, nos cultivar, educar nossa personalidade.

Ainda em artigo da revista, o decorador, "íntimo com a alma do futuro dono da casa (...) usará o seu bom senso estético, para aproveitar-se das novas ideias, de uma maneira que reflita perfeitamente a compreensão pessoal do proprietário." (A CULTURA..., 1954, p.13) Seriam essenciais "um gosto cultivado, um espírito sensível para objetos finos e harmonias felizes e a abominação contra cada exagero em qualquer sentido." (Ibid., p,13 e 78).

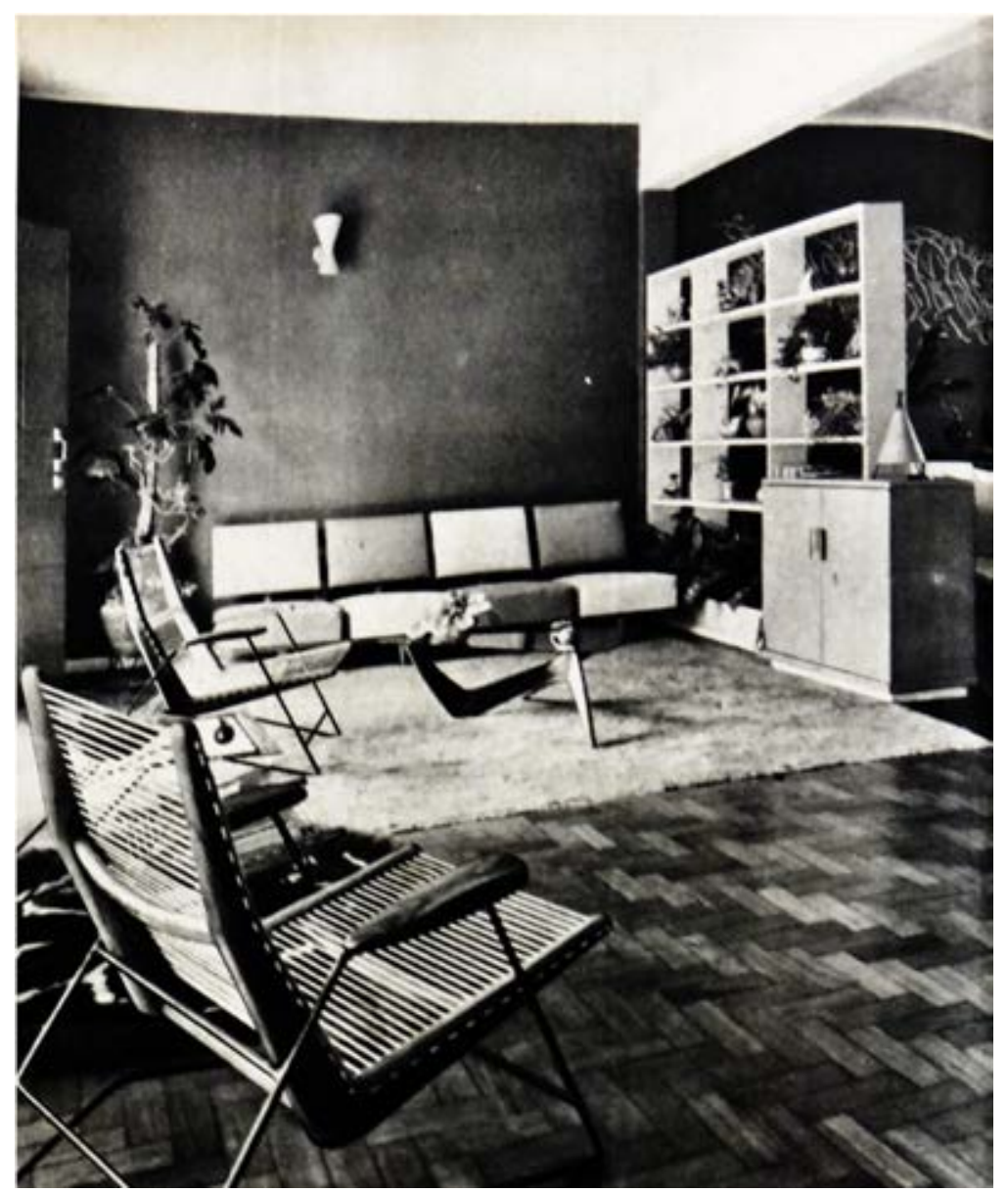

Fig.2.50 - 0 móvel baixo, fechado seria um conjunto de radio vitrola, que não estaria à altura do ambiente: pesado demais, de desenho antiestético - nada teria a ver com o "estilo."

\footnotetext{
${ }^{44}$ Casa no Jardim América, na rua Cuba, em São Paulo. Arquiteto Victor Reif, paisagismo Jardim Vanguarda.
} 
"A casa, já que é feita sobre (sic) medida, como no caso presente, deve manter-se dentro das normas do bom gosto, da moderação, refletindo o caráter e as preferências do seu dono."(MARGÔ, 1957b, p.11)

Ou, ainda: "não podemos (...) deixar de pensar na harmonia que por certo existiu entre o seu proprietário e o arquiteto para que se criasse obra tão perfeita e estética - síntese de uma personalidade bem definida, que encontrou na obra projetada sua exata interpretação." (HUBERTO, 1959b, p.41) ${ }^{45}$

Sempre, com a "ajuda dos arquitetos competentes e decoradores hábeis, (haveria) a ambição de morar, não somente entre quatro paredes e com móveis impessoais, mas, em um ambiente que reflita a personalidade dos moradores." (UMA RESIDÊNCIA ..., 1954, p.20)

Mas, quando não existe arquiteto nem decorador, a revista dá conselhos sobre construção e decoração diretamente ao leitor que, nesse caso, seria o responsável pela criação de seu lar.

Isso poderia ser feito de várias formas: adquirindo os materiais, móveis e objetos, trazendo lembranças de viagem, ou reformando peças que já possuísse. Poderia até mesmo adotar o "do it yourself" tão comum aos americanos, na forma de pinturas nas paredes, esculturas e trabalhos artesanais. ${ }^{46}$

No limite, a personalidade do morador era fisicamente imprimida à casa, garantindose sua originalidade: "Nesta casa não se encontra quase nenhum objeto sem a marca característica da Sra. Troje que longe de ser uma profissional nas artes manuais, gosta de gravar, nos objetos de sua vida diária, a originalidade, acentuando que 'esta casa é minha' e criando um ambiente que corresponde à sua personalidade." (UMA CASA..., 1954, p.20) Percebe-se, mesmo, certo elogio do amadorismo dessas realizações. O lar seria o local onde o homem poderia se expressar.

\footnotetext{
${ }^{45}$ Paisagismo de Leibkuechler.

${ }^{46}$ Além de anunciar cursos de decoração, Casa e Jardim apresenta inúmeros artigos sobre como fazer e reformar móveis e objetos.
} 


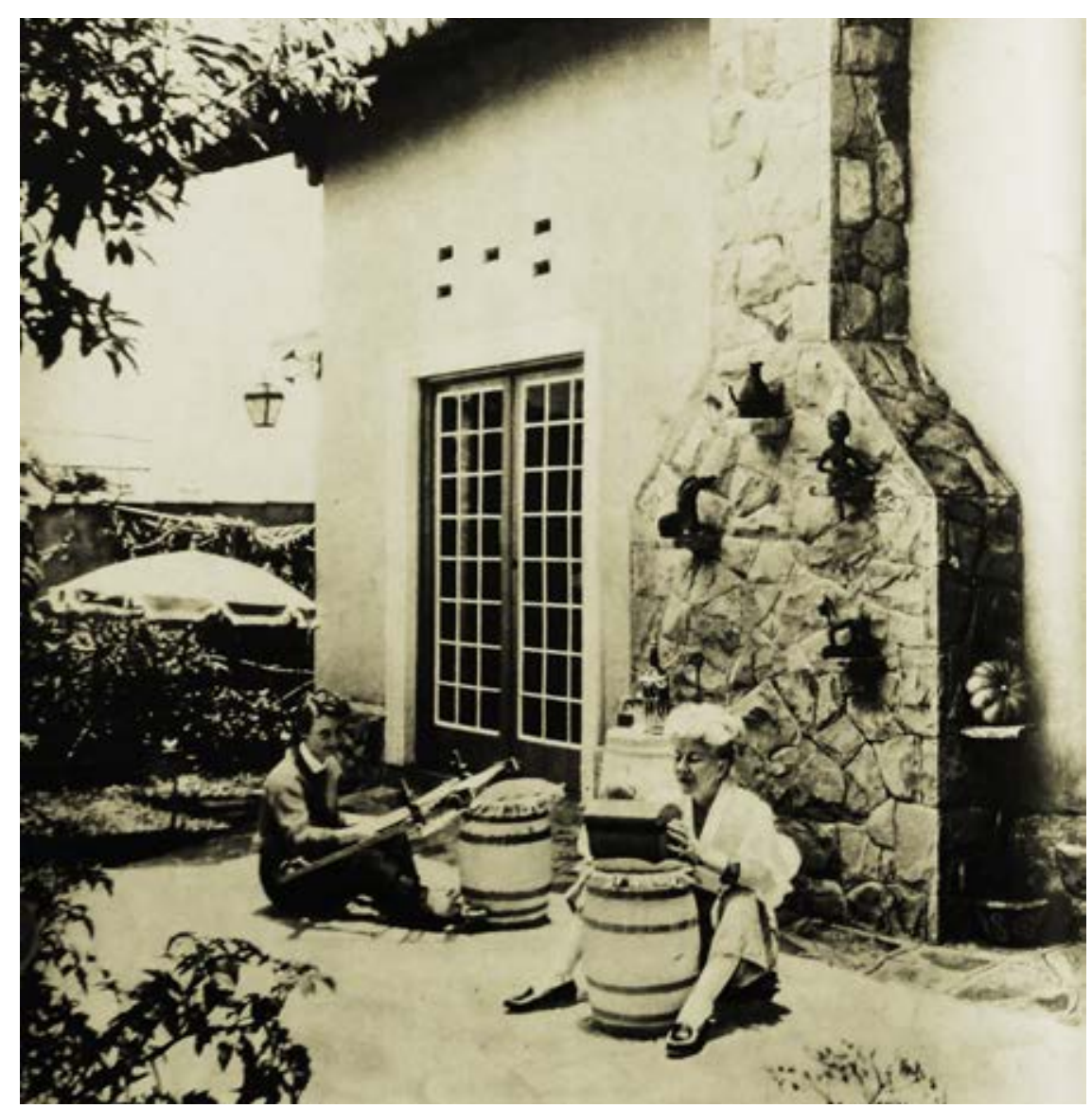

Fig.2.51 - Em frente à chaminé que decorou com figuras de sua autoria, a Sra. Troje pinta, enquanto sua amiga tece.

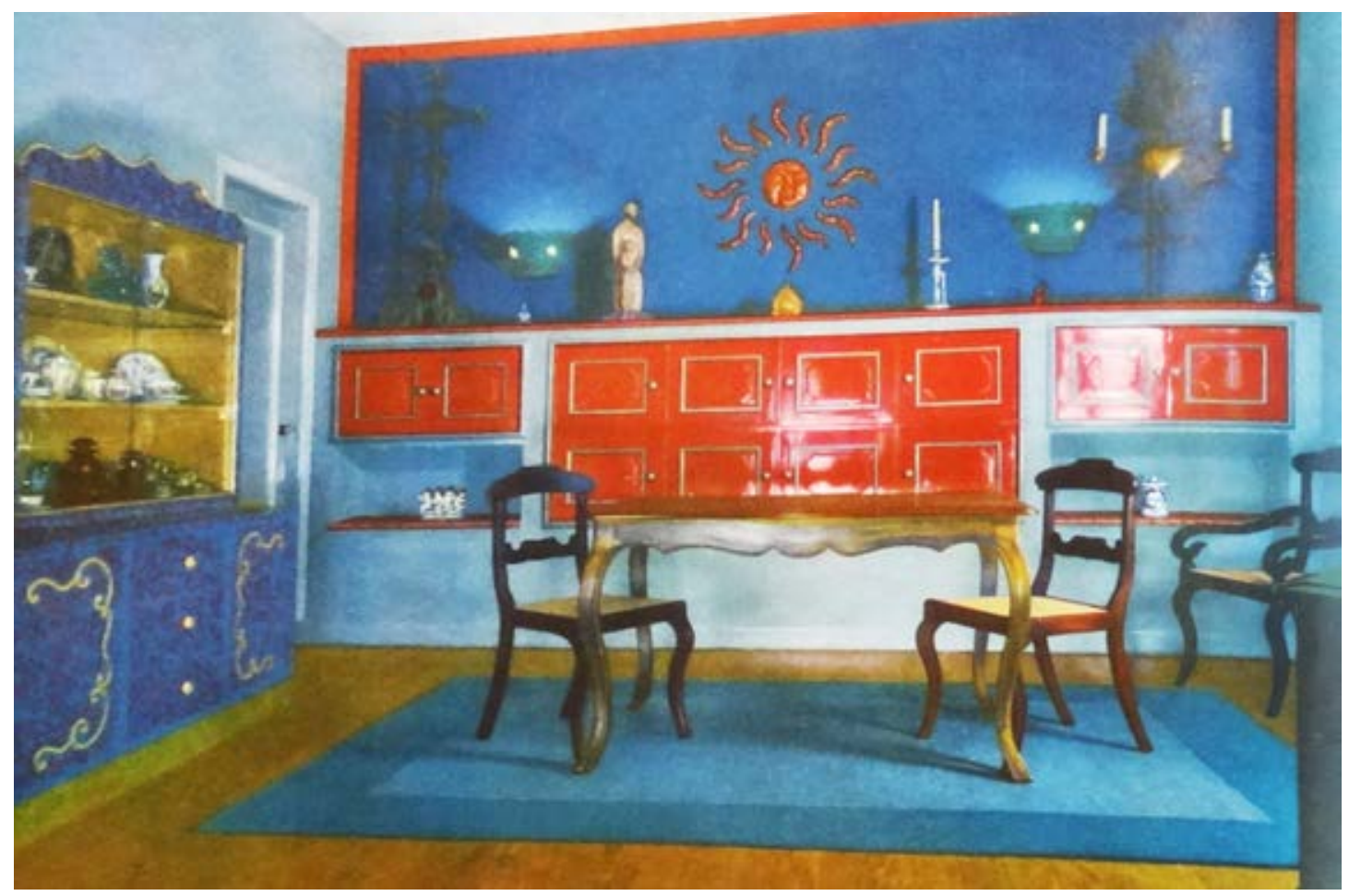

Fig.2.52 - Sala de jantar elaborada pela Sra. Troje. 
Para isso, deveríamos ter uma personalidade independente para cultivar o lar, um "gosto livre, desprendido." (O SEGREDO..., 1954, p.17) Pois: "Abrindo os nossos olhos, verificando as probabilidades que dormem em tudo o que nos rodeia, saber como por poesia em nossa vida diária, isto é o segredo de sentir-se beatificado." (Ibid., p.16-17) Dessa forma, era preferível "o lar estrondoso de um homem desembaraçado do que o produto uniforme de uma pessoa convencional." (Ibid., p.18) Não sem alguns riscos, pois, assumindo essa liberdade, poderíamos ser chamados "peculiar." (sic) (Ibid., p.18) Poderíamos, assim, chegar a uma "cultura pessoal," (Ibid., p.18) satisfazendo-nos por conservar nossa personalidade.

Pode-se dizer que, para o "bem viver," cultivar nosso lar dessa maneira nos daria o prazer do "fazer," mas também o de permanecer nesse ambiente "artístico," com o qual entramos em consonância, já que ele é um desdobramento de nossa personalidade.

Pois, a satisfação proporcionada pela casa poderia "variar de um simples prazer físico até uma exultação de complacências estéticas, incluindo todas as escalas, do útil ao espiritual." (COM..., 1959, n.55, p.3)

Para se chegar a esses efeitos, ainda segundo Casa e Jardim, a educação do gosto poderia ser feita a partir da observação e da análise dos edifícios, avaliando-se, entre outros aspectos, se o interior e o exterior apresentavam as mesmas linhas e cores, se os detalhes unitários haviam sido bem escolhidos, se cada aposento se ajustava a sua finalidade. Dessa forma, poderíamos "aquilatar os nossos sentidos para reflexões estéticas (...)." (MERAVIGLIA, 1956, p.17) A recompensa viria na forma do prazer estético, do cultivo de nossa personalidade. "Através do hábito de ver, observar, criticar e ouvir é que cultivamos e apuramos o nosso gosto o qual, depois, nos dará uma imensidade de alegria e prazer." (Ibid., p.17)

Exemplos negativos também eram mostrados, como o canto "de um apartamento onde o dono não fez questão de escolher com cuidado peças que formam uma unidade. São assentos, postos sem gosto, onde nada combina com nada." (ONDE..., 1959, p.33)

Na revista, percebe-se que o ensino do "bom gosto" é recorrente, pois, apenas com a educação correta, seria possível a compreensão da linguagem moderna e suas sutilezas, como o refinamento e a simplicidade.

"Para isto chamamos a atenção do leitor que poderá procurar desenvolver uma análise da residência a partir dos pontos de vista que apresentamos. Analisando as soluções da planta, seja na distribuição dos aposentos e recantos, bem como até 
mesmo no arranjo dos mínimos detalhes, podemos constatar o esforço que cada elemento por sua vez representa no sentido de concorrer para a formação de um conjunto capaz de traduzir todo um programa de vida residencial." (SOUZA, H., 1956, p.18-20) “(...) O arquiteto conseguiu linhas retas e simples. Com não muitos elementos decorativos atingiu a serenidade e equilíbrio." (Ibid., p.17)

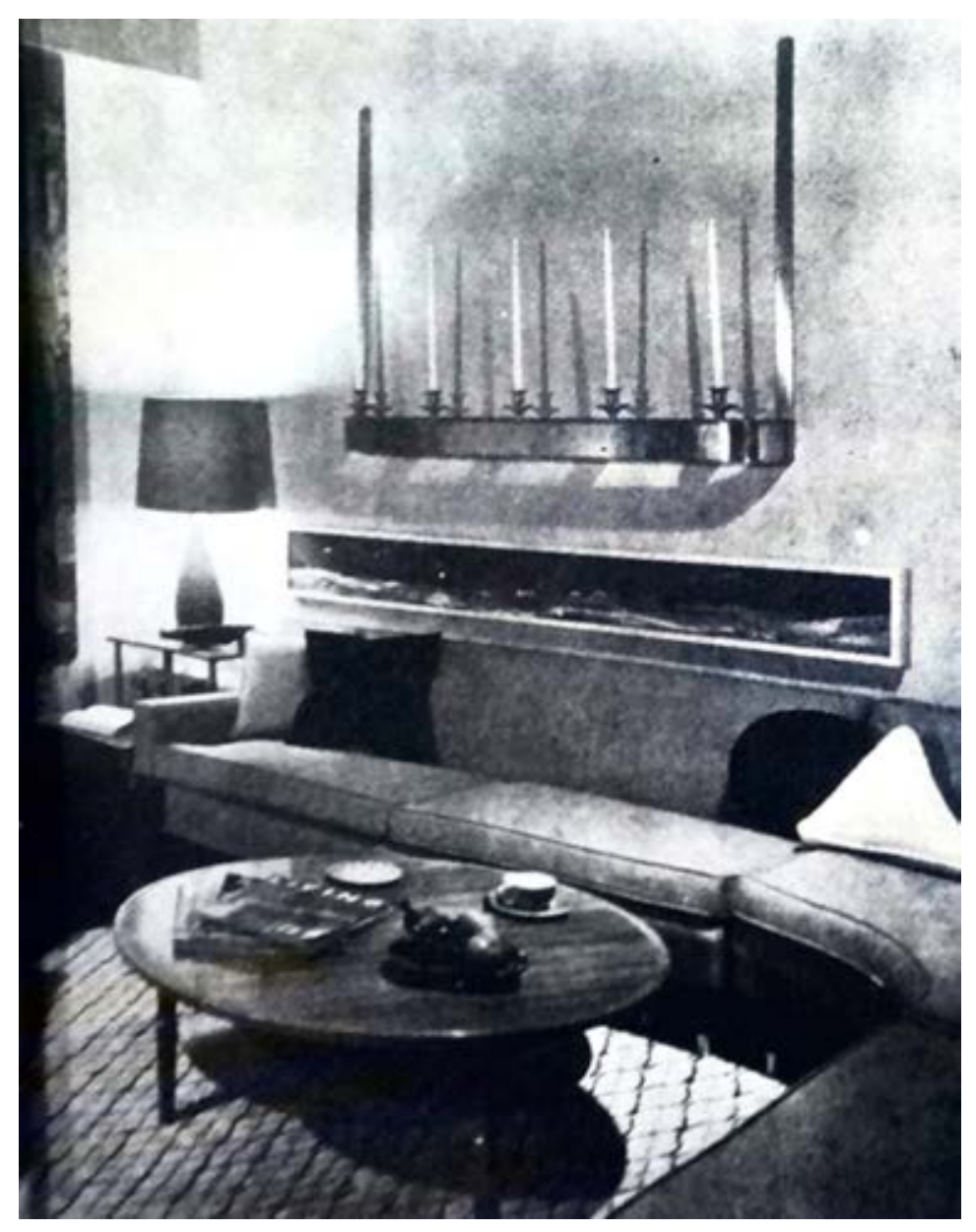

Fig.2.53 - Decoração “descuidada."

Julgando a forma e a funcionalidade de um objeto, conseguiríamos compreender o conceito de estilo, que seria: "aquela forma que expressa o caráter inato do objeto. É o resultado total dos elementos reunidos em conjunto. É a forma tomada por todas as inerentes características do objeto. É a expressão de todas estas características: o material, a fabricação, as cores, o desenho, a elevação, a execução. (...) Se um objeto possui características - mesmo que sejam poucas - não próprias do seu caráter, não mais o podemos considerar um objeto de estilo." (COMO DESENVOLVER..., 1956, p.6) 


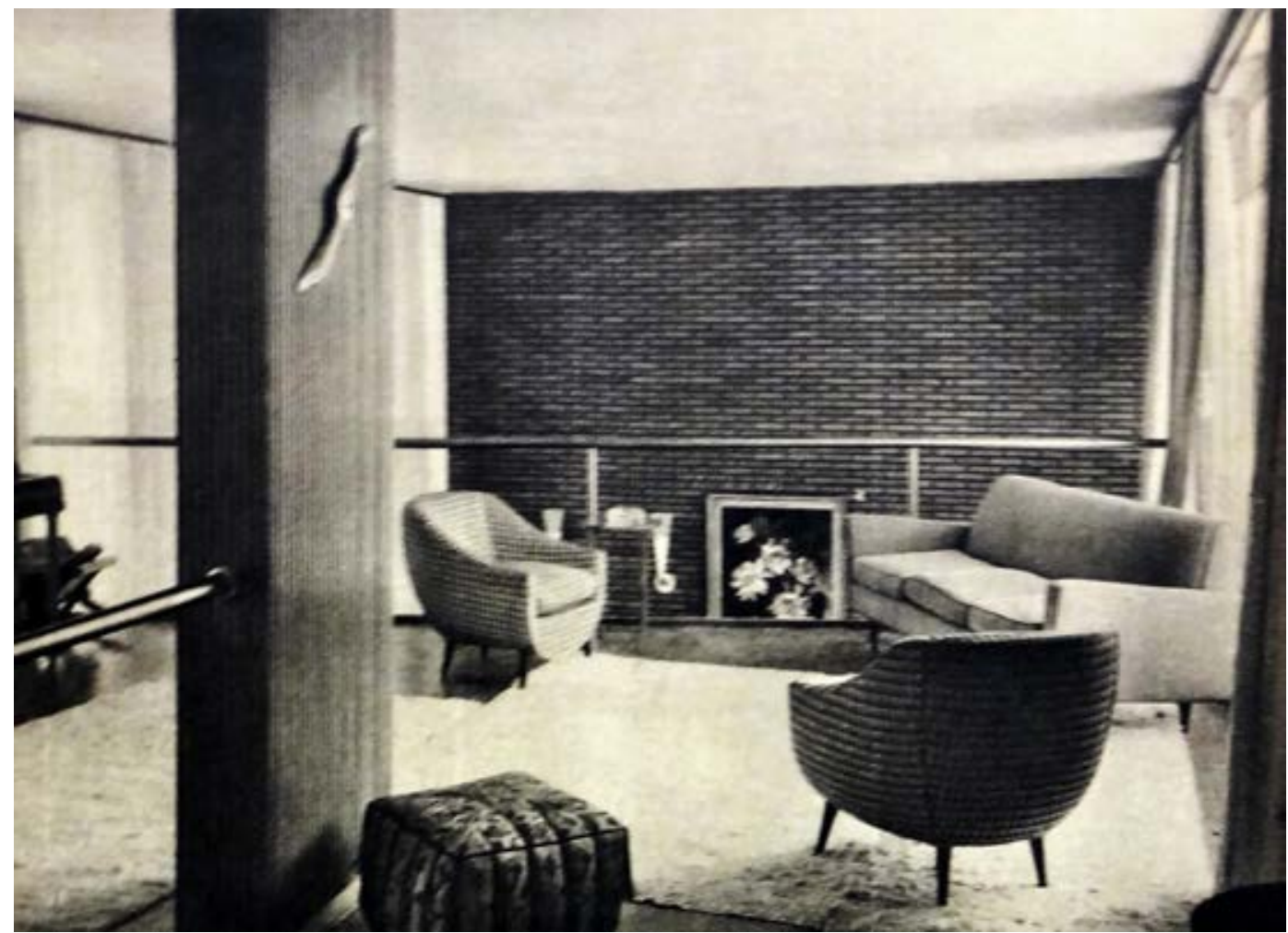

Fig.2.54 - “Conjunto” com serenidade e equilíbrio.

"Quanto ao aspecto, você critica as proporções das partes unitárias em relação ao todo e a proporção do conjunto." (COMO DESENVOLVER..., 1956, p,8) Deveriam ser analisadas, também, as relações entre o móvel, o ambiente e o usuário, além de cores e texturas.

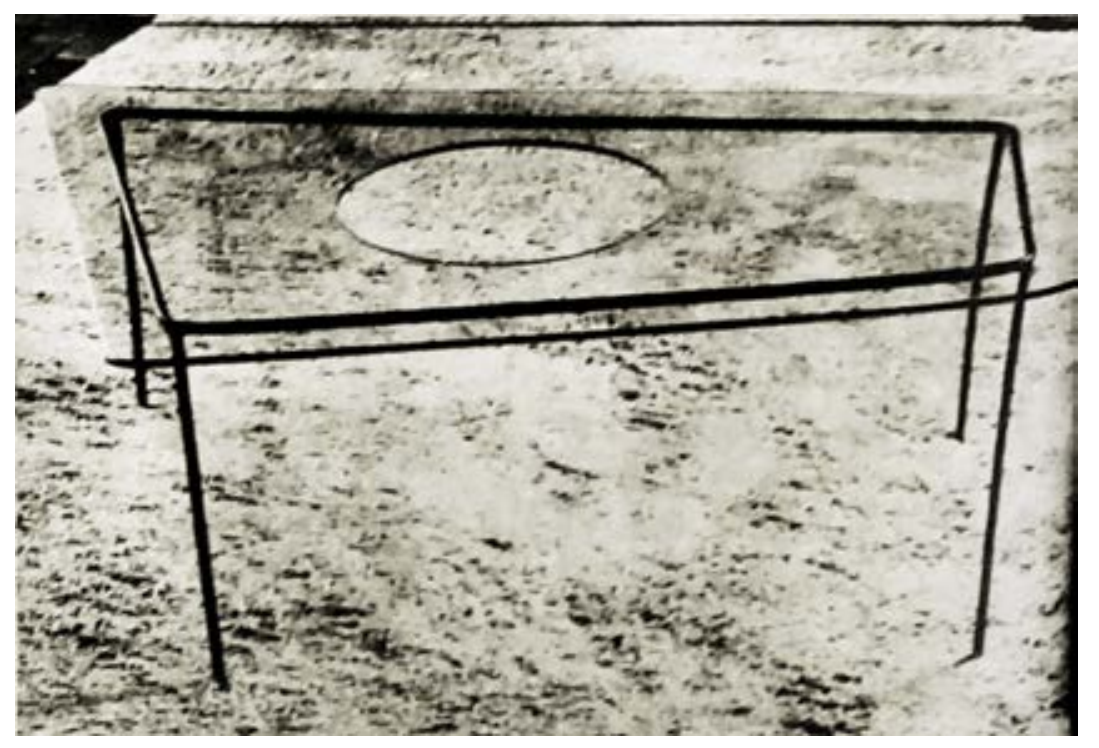

Fig.2.55 - Segundo Casa e Jardim, nessa mesa deveria ser observada sua simplicidade, tanto nas linhas quanto no material usado. 


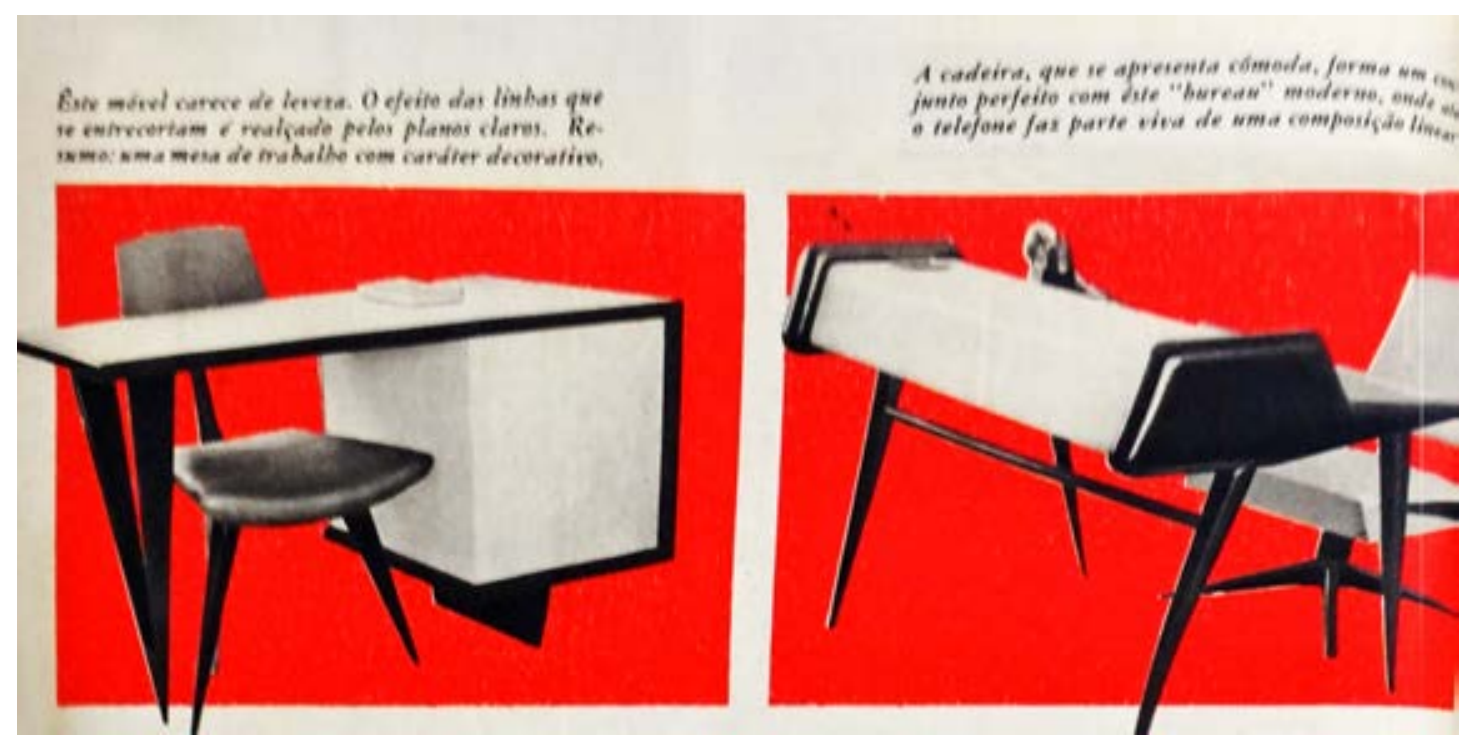

Fig.2.56- Nas comparações, apesar de não explicitada, percebe-se a preocupação com o conforto do usuário.

Esse processo de educação do gosto poderia se dar a partir de algo próximo ao leitor, como uma fachada, para facilitar a compreensão de aspectos como o peso de determinadas massas, as diversas linhas, o ritmo do conjunto, a limpeza e leveza dos detalhes: "Partiremos sempre da aceitação de uma determinada obra para nela indicar uma parte - um detalhe - que escapa à lógica do conjunto. Queremos, assim, chamar a atenção para a importância da coerência nas linhas, no colorido e nos materiais empregados. Queremos contribuir para evitar que detalhes menos felizes possam estragar uma bela fachada." (EVITE..., 1953, p.27)

Em Casa e Jardim, conceitos sofisticados, como o da obra de arte total - da unidade em contraponto às partes - são utilizados, no âmbito de um projeto, chamando a atenção para detalhes determinados que deveriam harmonizar-se com o todo. Partindo da abstração dos conceitos, tenta-se aplicá-los aos diversos elementos da casa:

Quer olhemos a construção em seu todo ou somente analisemos um detalhe, descobrimos que graça e harmonia inspiraram o criador na construção e decoração. Encontramos luxo discreto na simplicidade uniforme. Observamos elegância sem enleios e proporções sem exageros. Os detalhes, adaptando-se harmoniosamente ao todo, são limitados ao indispensável, conquanto essa pequena parcela chame a atenção para o seu especial encanto e delicadeza. (...) Não é necessário mencionar a 
perfeita combinação de cores das paredes, mobílias e cortinas com todo o interior. (CRIVELLI, 1955a, p.21-2) ${ }^{47}$

Pois, segundo o conceito de obra de arte total, a beleza é o resultado da totalidade que é configurada quando elementos singulares são colocados em relação entre si. Esta beleza não seria, assim, atributo de nenhum elemento isolado, mas do seu relacionamento. E seu significado cresceria quanto maior a pluralidade dos elementos e mais forte a unidade na qual a obra de arte seria capaz de os circunscrever.

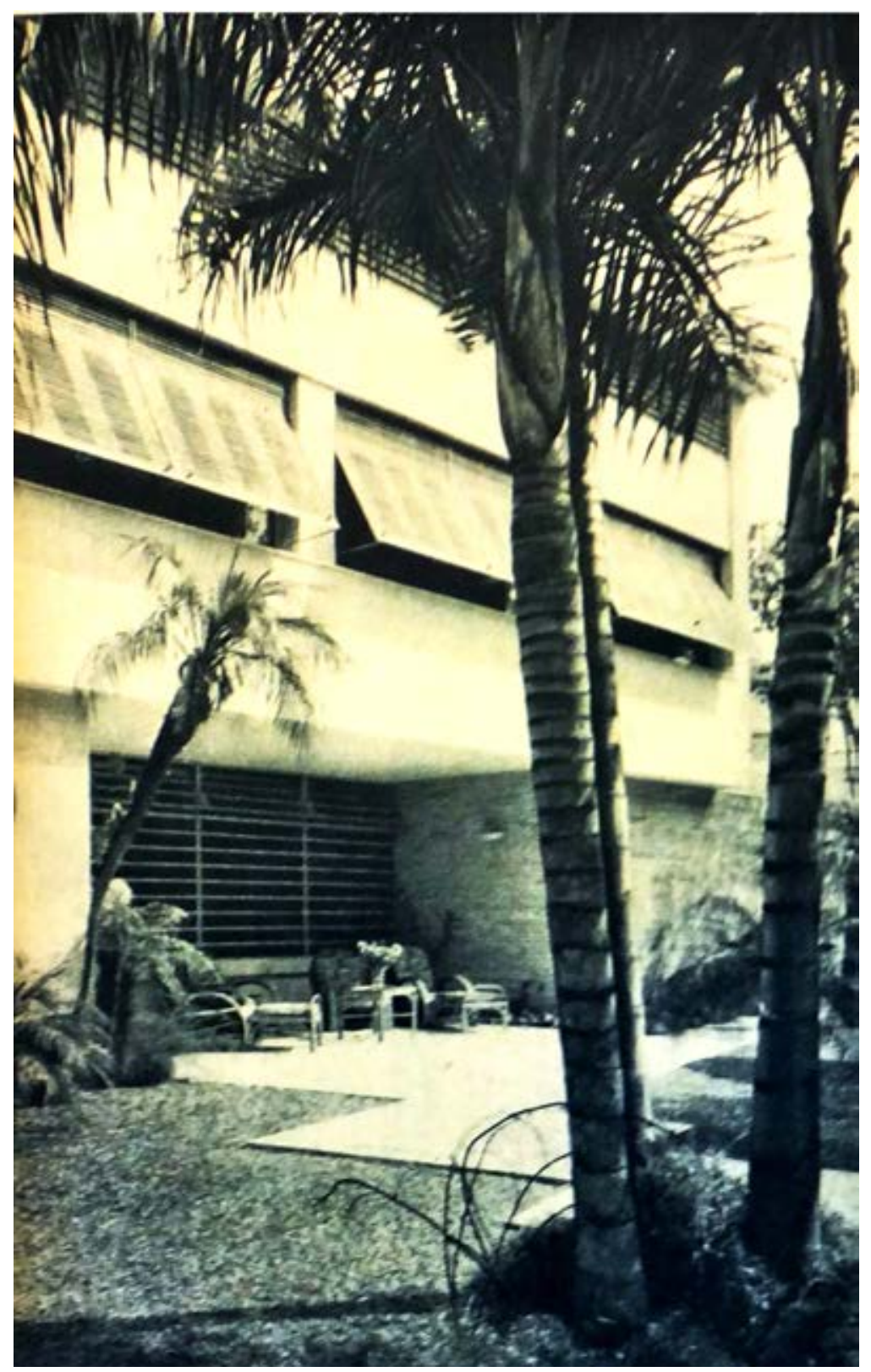

Fig.2.57- Harmonia no todo e nos detalhes da fachada, mostrada como exemplo.

\footnotetext{
${ }^{47}$ Projeto do arquiteto Lucjan Korngold.
} 


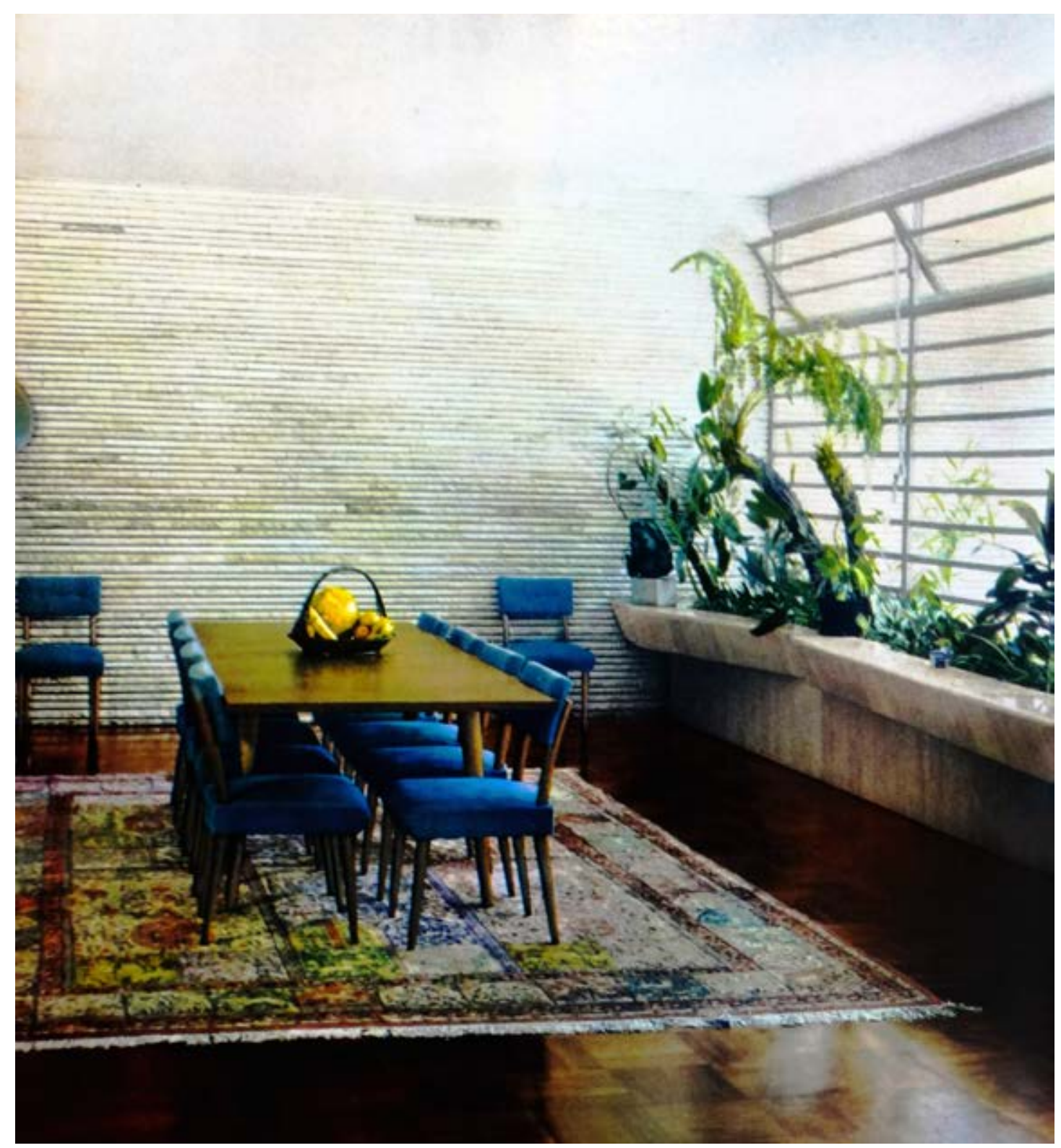

Fig.2.58- "Luxo discreto na simplicidade uniforme." Detalhes adaptados ao todo, delicados, combinação de cores perfeita, segundo a revista.

\subsection{Uma arquitetura cheia de contrastes: cores, materiais, luzes, sólidos, vazios.}

Nas casas do "bem viver," como dissemos, está presente a ideia do todo que envolve as várias partes em sua unidade, através de relações múltiplas.

Estas relações se dão entre vários elementos: cores; materiais texturizados e lisos; volumes e planos; materiais "quentes" e materiais "frios;" transparências, vazios e sólidos; luzes e sombras. 
No caso das texturas, elas ajudam a criar uma arquitetura expressiva de percepção visual, mas também tátil. A visão nos incita ao toque dos materiais distribuídos pelo edifício.

Planos e volumes são definidos por uma disposição geométrica de linhas que reforça o efeito de dinamismo da linguagem moderna. Em alguns casos, cria-se um equilíbrio dinâmico muito agradável e uma sensação de harmonia.

Mas, nas casas mostradas em Casa e Jardim, nem sempre existe esse arranjo harmônico. O grande volume em forma de caixa, dos arquitetos Binat Fonyat e Tercio Fontana, por exemplo, constituído por materiais diversos e contrastantes, ${ }^{48}$ apresenta na fachada: "tijolos expostos e revestidos, elementos vazados e madeira, mosaicos nas colunas e outros." (RESIDÊNCIA..., 1956, p.16)

Esses e outros detalhes "desafiam" a unidade da caixa. Mas, seus contornos elementos da estrutura, na cor branca - mantêm a força desse volume. ${ }^{49}$ No entanto, existe uma exacerbação do contraste entre planos, materiais e cores, e um efeito pinturesco exagerado. Provavelmente, a síntese inicial, a ideia do todo, que "amarra" os elementos, não foi bem constituída, ou não foi seguida.

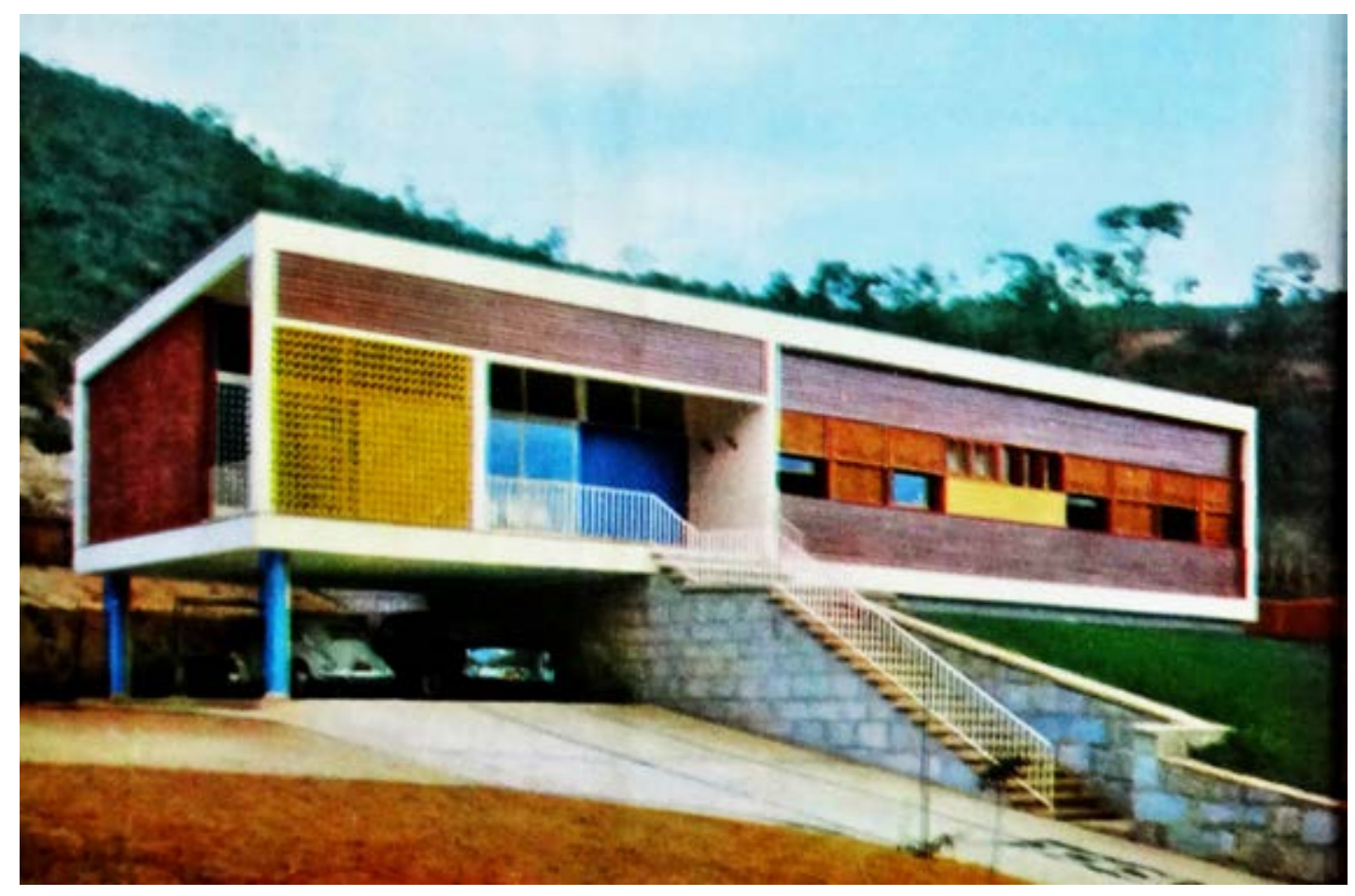

Fig.2.59- Casa dos arquitetos Binat Fonyat e Tercio Fontana.

\footnotetext{
${ }^{48}$ Localizada em Petrópolis. Proprietário João Antero de Carvalho.

${ }^{49}$ Parte da casa está apoiada em pilotis, resolvendo o desnível do terreno, situado em ponto elevado.
} 


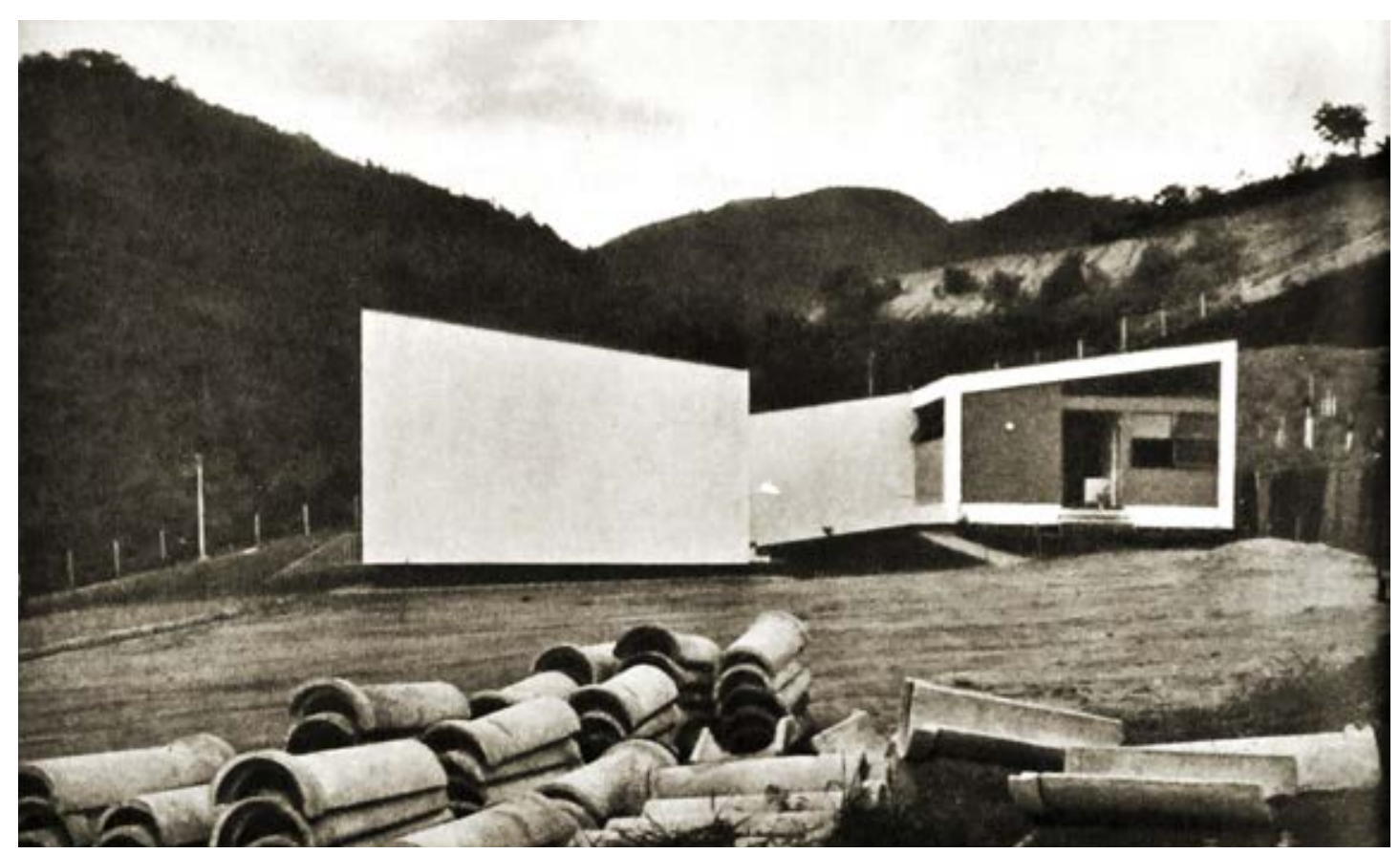

Fig.2.60 - Vista lateral da casa, mostrando a adaptação ao terreno em desnível.

Os dois blocos - um com área de estar e dormitórios e outro com serviço e salão de jogos - são ligados por uma espécie de passarela. Percebe-se certa referência à arquitetura de Oswaldo Bratke em seus volumes requadrados pela estrutura e fachadas com vários detalhes. Ou às casas americanas de Marcel Breuer, com sua geometria precisa, pousada levemente no solo. Essa autonomia do volume é recorrente também na obra de Bratke.

$\mathrm{Na}$ arquitetura de Bratke, a estrutura está sempre à vista, impõe-se, e percebe-se uma preocupação com sua modulação, compositiva e construtiva. Os detalhes variados e harmoniosos não chegam a desafiar a totalidade e com ela convivem.

Em seus projetos, alguns planos verticais são opacos, outros transparentes, outros, ainda, apenas sugeridos, como nos terraços. Neles, ele se utiliza de materiais diversos, como o tijolo à vista, elementos vazados, vidros.

Existem, ainda, contrastes entre luz e sombra, texturas e acabamentos lisos, surpreendendo o usuário com muitos detalhes, em uma concepção pinturesca que se opõe à organização geral clássica, definida pela estrutura. ${ }^{50}$

\footnotetext{
${ }^{50}$ Não devemos nos esquecer da formação clássica que o arquiteto recebeu no curso do Mackenzie.
} 


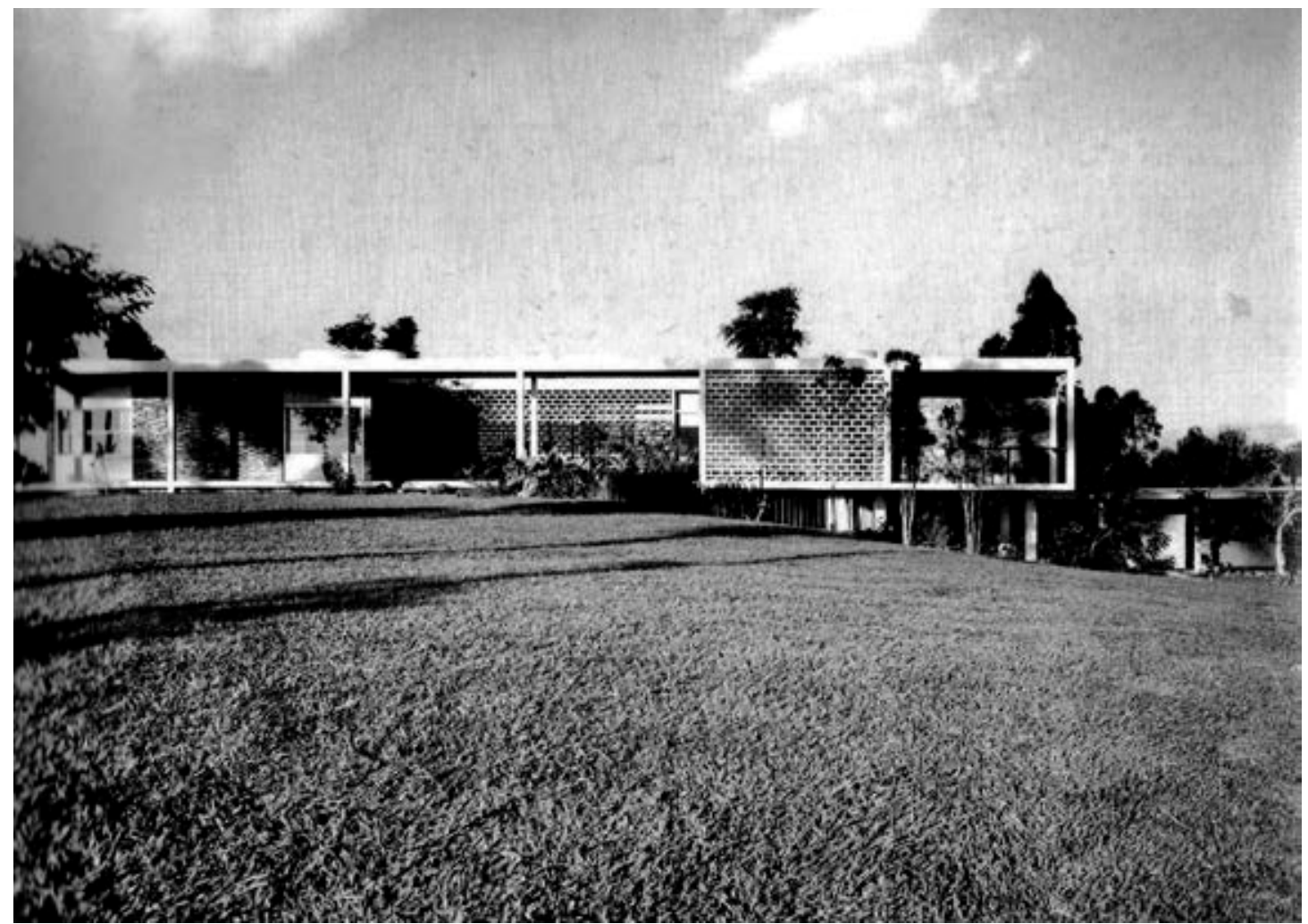

Fig.2.61- Bratke, residência do arquiteto.

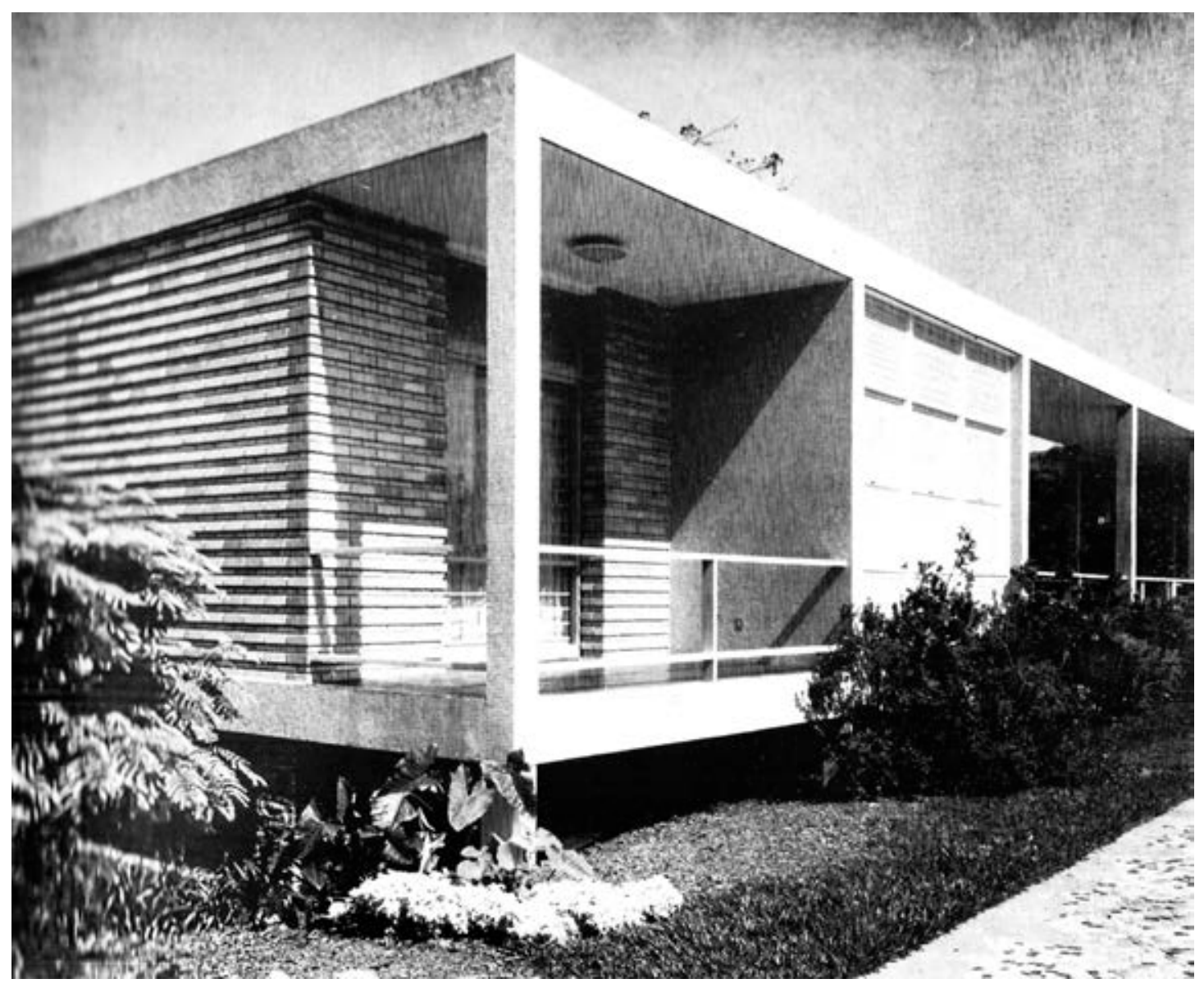

Fig.2.62- Residência Oscar Americano. 
As casas de Bratke, principalmente sua residência ${ }^{51}$ e a de Oscar Americano, ambas no Morumbi, com sua geometria precisa, "pousam" em um ponto elevado do sítio e desfrutam das vistas panorâmicas dos jardins e do horizonte. A vegetação e o edifício não se "misturam."

A questão da concepção clássica é apontada na residência Oscar Americano, em artigo de Casa e Jardim: "obra-prima da arquitetura moderna do arquiteto Oswaldo Bratke, (...). O que surpreende em meio à grande calma é a beleza clássica, consequência das proporções perfeitas e da coloração discreta." (DORCA, 1959, p.11)

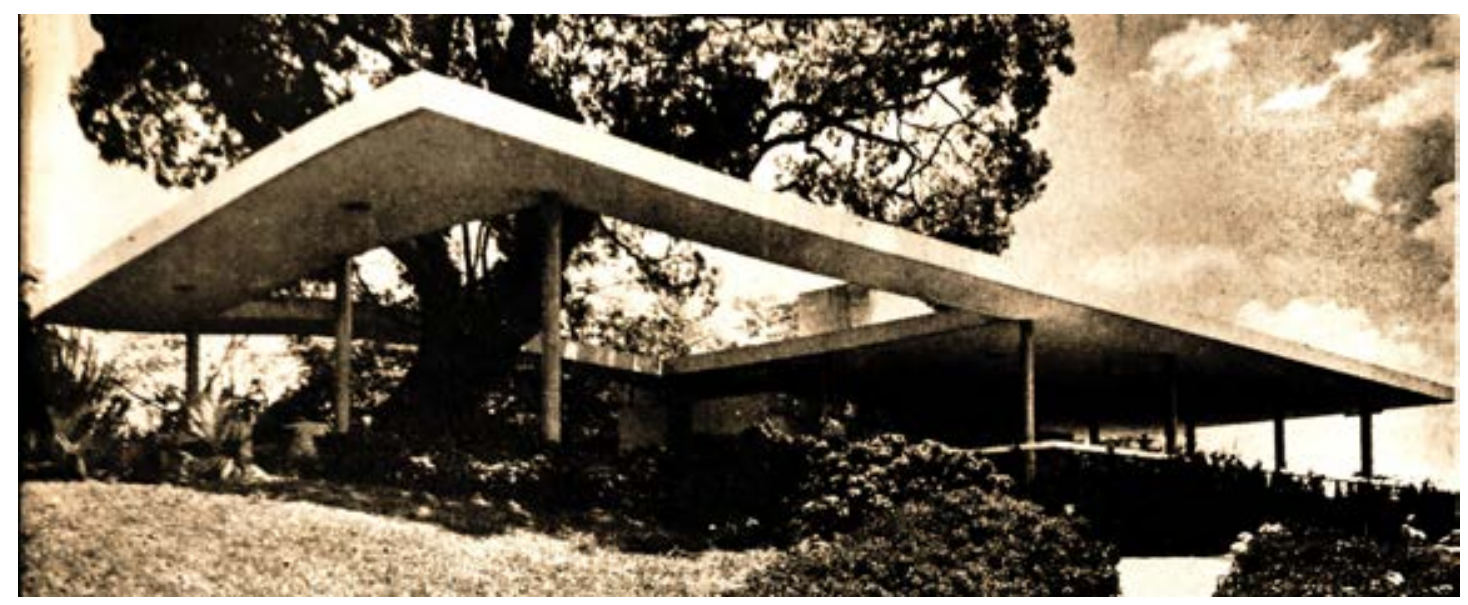

Fig.2.63- Residência Oscar Americano, pavilhão.

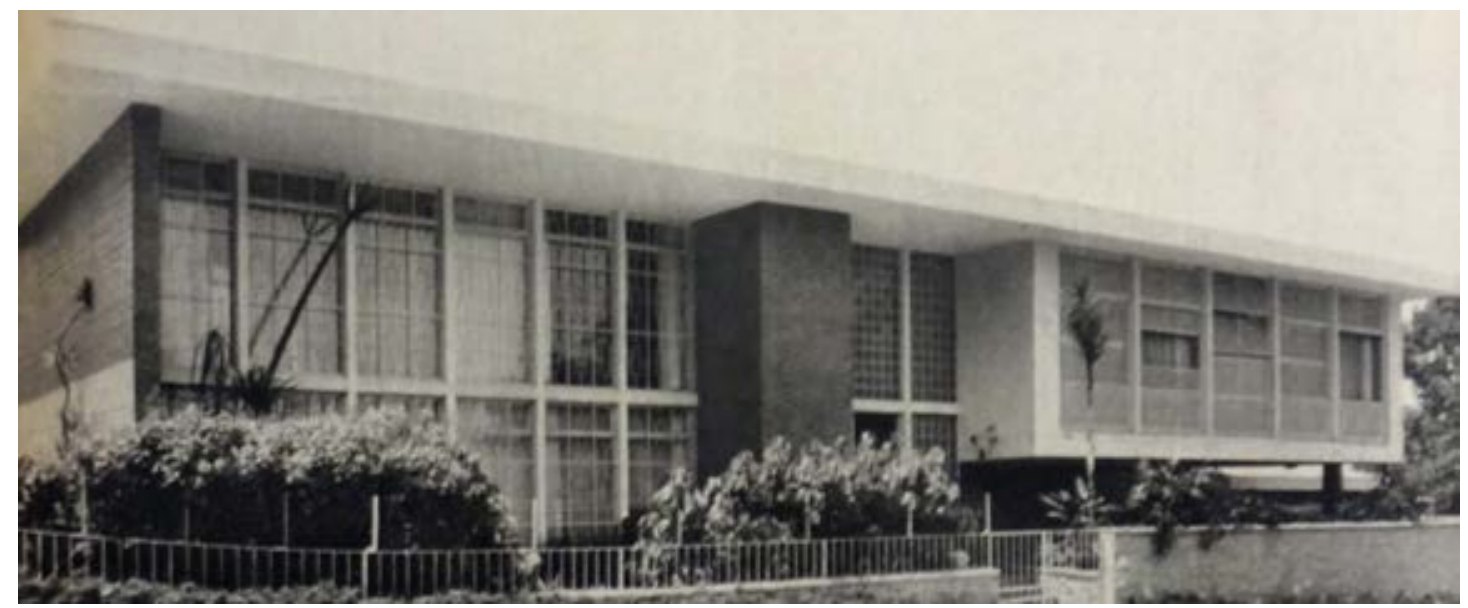

Fig.2.64- Residência projetada pelo arquiteto Miguel Badra Júnior.

\footnotetext{
${ }^{51}$ Mostrada em LUCKMANN, 1958, artigo sobre as vantagens e desvantagens de casas térreas e sobrados.
} 


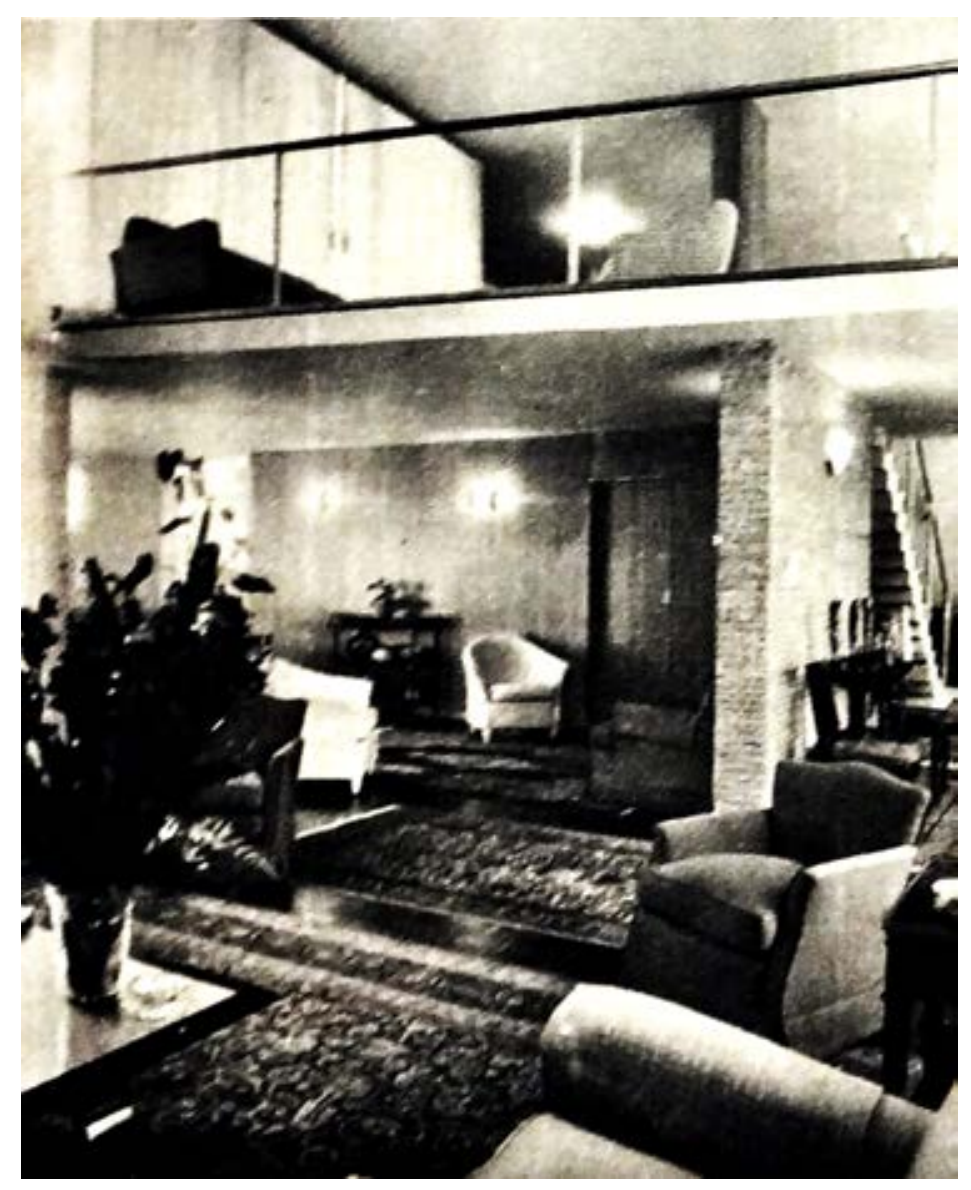

Fig.2.65- Interior da residência anterior, mostrando o mezanino.

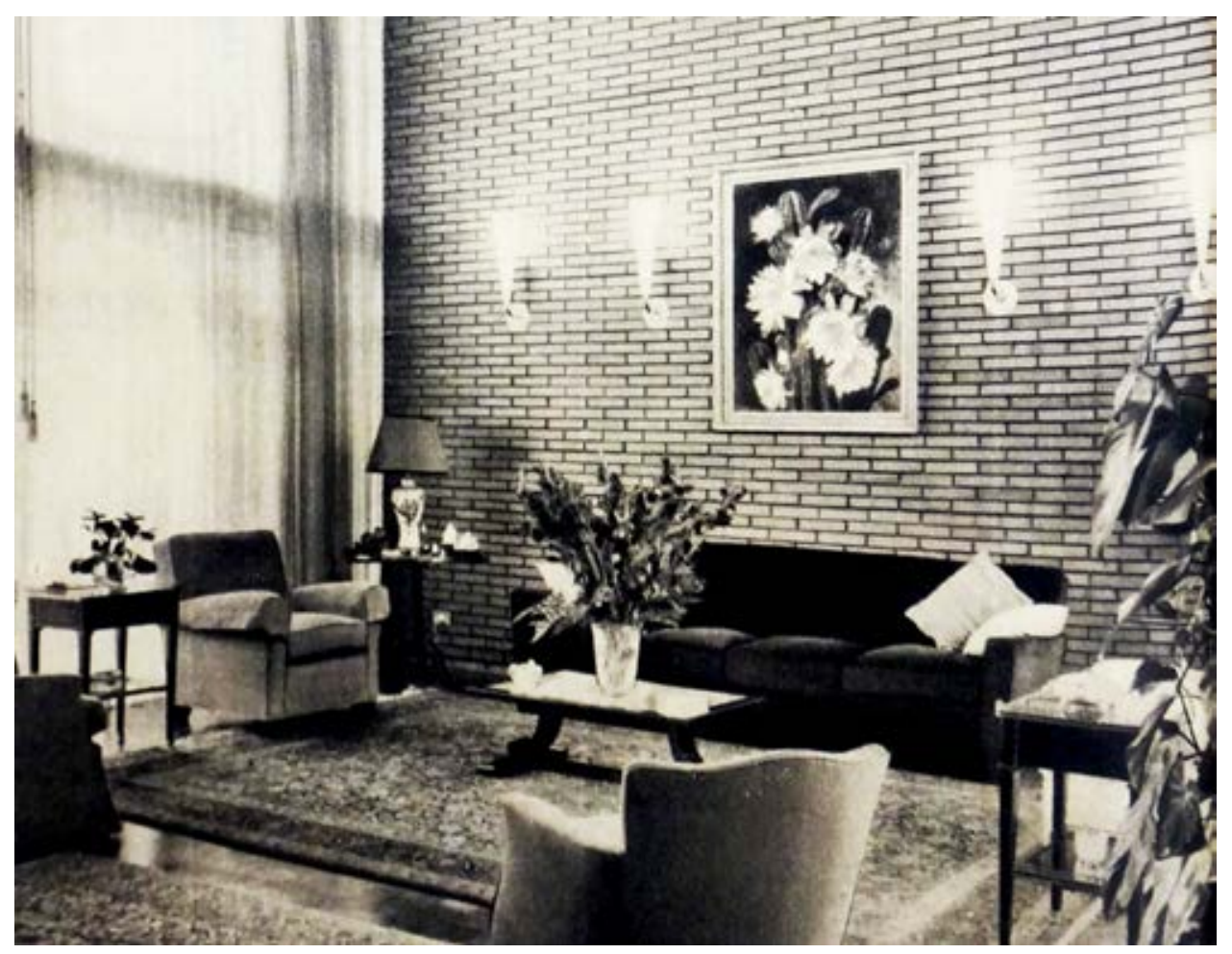

Fig.2.66- Living da mesma residência. 
Ainda na revista, a casa projetada pelo arquiteto Miguel Badra Júnior também se constitui em um grande volume, completado por espessa laje plana com beirais, mas as paredes laterais em tijolo aparente e grandes áreas envidraçadas na fachada principal o "suavizam."

A composição apresenta ${ }^{52}$ detalhes interessantes que se relacionam, como os guarda corpos, os lambris e as paredes em tijolo aparente. Os espaços internos conectam-se, possibilitando permeabilidade e sofisticação espacial, apesar da simplicidade de projeto. "Muita luz e conforto num recanto original (...). A parede de tijolos à vista com seu tom quente acentua a sensação de quietude. (...) O equilíbrio entre o artificial e o natural é prova de bom gosto.” (SOUZA, H., 1956, p.19) E “(...) o 'living', cuja parede principal de tijolos expostos e a sinfonia de linhas que paira no espaço dão ao todo um ar de ousada originalidade." (Ibid., p.17) ${ }^{53}$

Apesar dos inúmeros contrastes, harmonia e equilíbrio são qualidades sempre buscadas no "bem viver." Prochnik (1954b, p.14), no entanto, afirma que "o equilíbrio é obtido antes pela contraposição de elementos de caráter diverso que pela justaposição de elementos análogos."

Essas contraposições estão presentes também na arquitetura de Sérgio Bernardes. A esse respeito, Prochnik (1956a, p.18) diz: "suas casas são bem colocadas no terreno, embora - no que pode servir de exemplo - jamais procure obter uma harmonia entre a arquitetura e a natureza por meio de efeitos rustidos ou falsamente locais." 54

\footnotetext{
${ }^{52}$ Residência na Granja Julieta, em São Paulo.

${ }^{53} \mathrm{Em}$ Casa e Jardim, conceitos originalmente ligados à composição musical associam-se constantemente à composição arquitetônica. $E$, ainda em relação à arte, vários trabalhos são mostrados, como o de Alexander Calder, em RESIDÊNCIA EM..., 1958, reportagem sobre a residência projetada por Henrique Mindlin, Prêmio de Habitação na primeira bienal, localizada em Bonclima, no Rio de Janeiro. Paisagismo de Roberto Burle Marx. Além do mobile de Calder, feito para o local, falase das influências recebidas pelo artista: de Mondrian, na criação de formas abstratas, e de Miró, nas diferentes fases de sua carreira. Segundo a revista, para os leitores que compareceram à Bienal de 1955, os mobiles já não seriam novidade.

${ }^{54}$ No caso desse projeto, trata-se de um grande volume compacto, parte sobre pilotis. Existem grandes panos de vidro e integração entre ambientes, com mobiliário e luminárias contemporâneos e leves.
} 


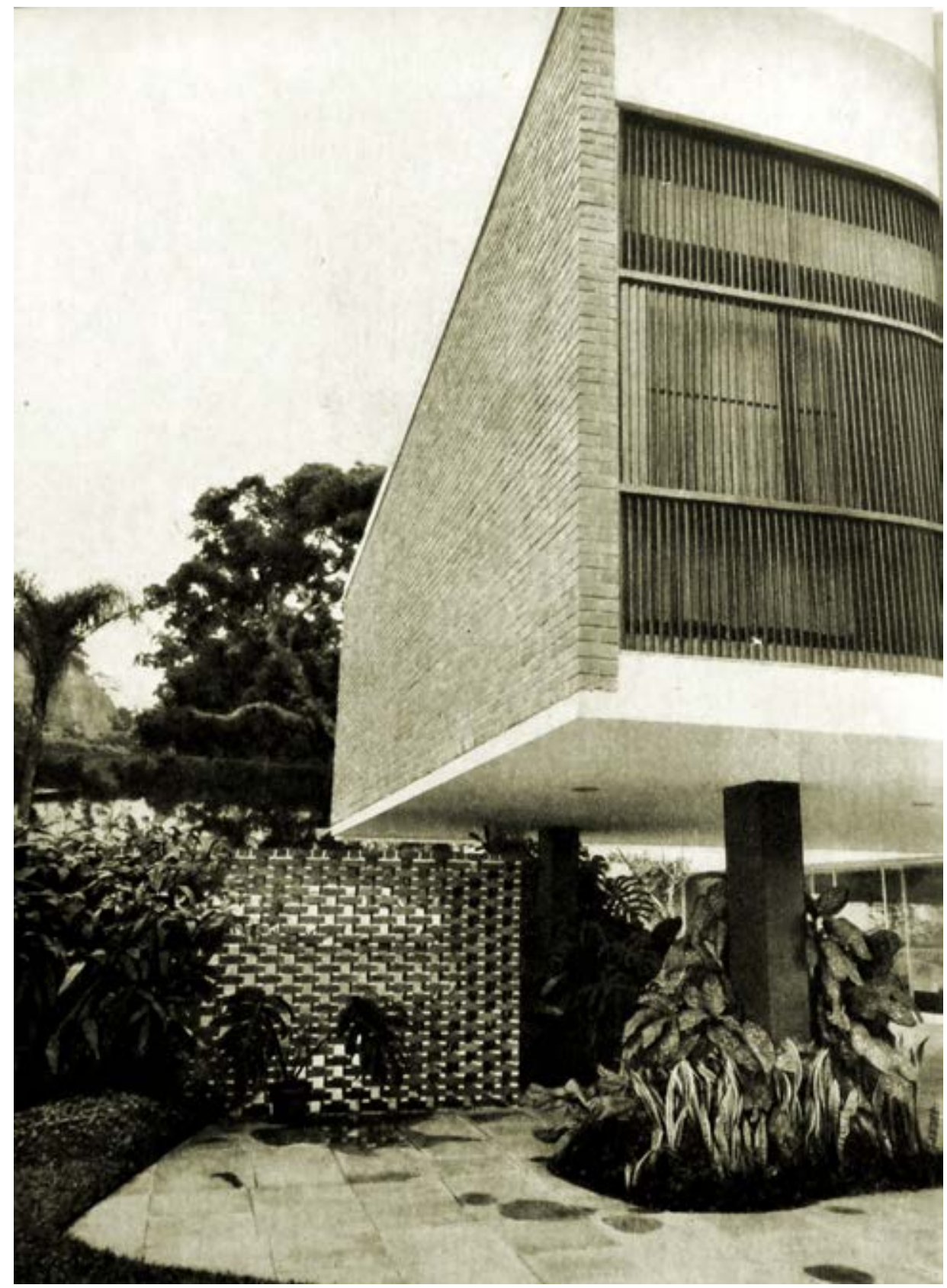

Fig.2.67- Segundo Casa e Jardim, nesta residência de Sérgio Bernardes, existe um jogo interessante entre superfícies foscas e brilhantes, lisas e ásperas, transparentes e opacas, inteiras e fracionadas.

Outra residência do arquiteto apresenta o mesmo efeito: também destaca-se em meio à vegetação. ${ }^{55}$ Resolvida igualmente em um único volume, existem nela vários tipos de contrastes, como o do segundo pavimento, em tijolo aparente, em balanço sobre o térreo envidraçado. Ou entre os materiais e as cores.

${ }^{55}$ PROCHNIK, 1957b. 


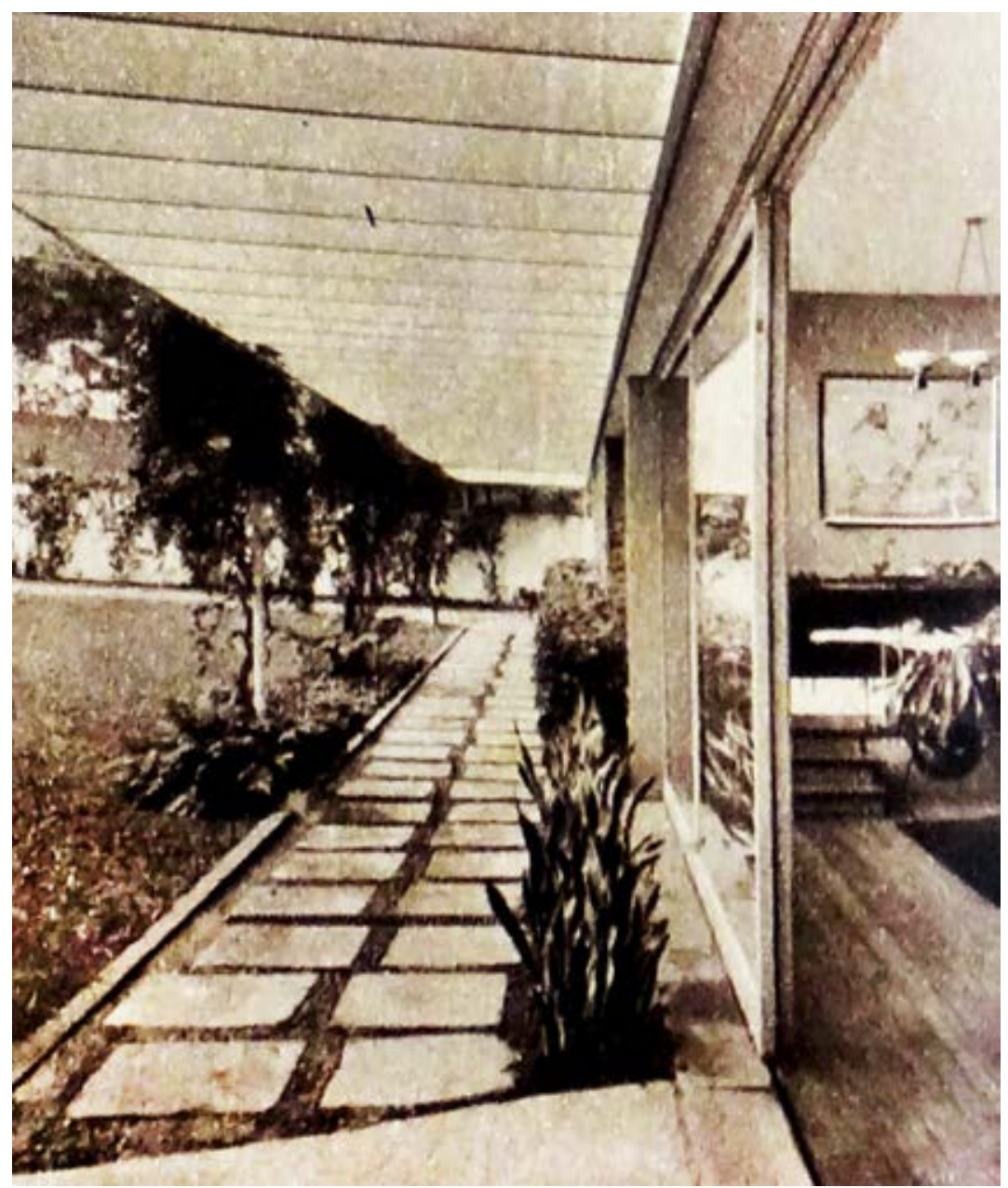

Fig.2.68- A mesma residência.

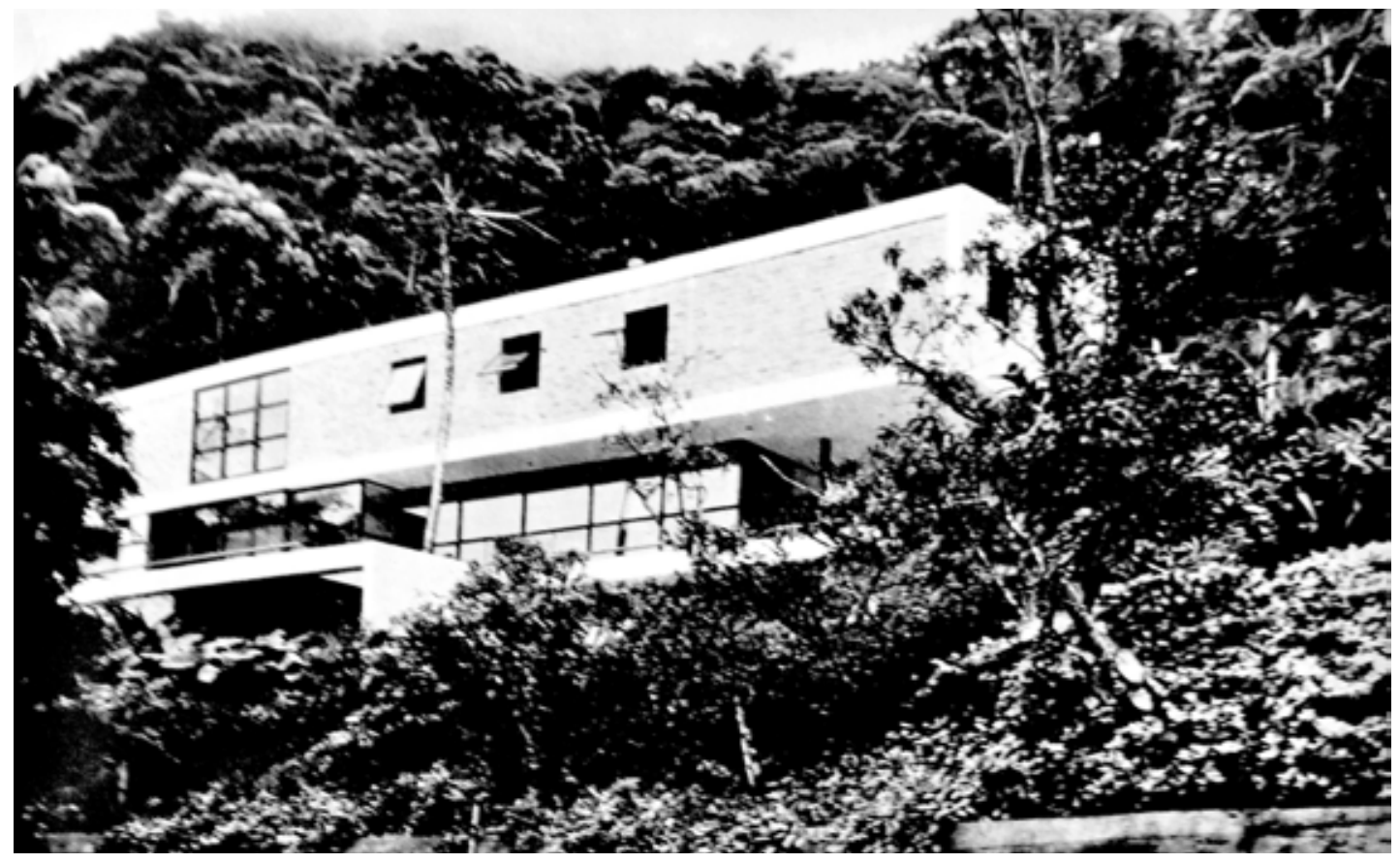

Fig.2.69- Outra residência de Sérgio Bernardes, com colunas metálicas. 
O uso de materiais aparentes e cores vivas também ocorre em três residências, projetadas por David Libeskind, mostradas em Casa e Jardim. ${ }^{56}$ Percebe-se uma "evolução (...), através dos materiais empregados. No mais recente, esses materiais são apresentados em sua textura natural, deixando transparecer o seu colorido e demais propriedades estéticas." (ARQUITETURA..., 1958, p.18). Além dos contrastes entre cores e materiais, existe outro, entre o pavimento térreo, recuado e revestido por elementos cerâmicos texturizados, e o piso superior, com cobertura plana. ${ }^{57}$ As esquadrias do térreo, que seguem até a altura da laje, reforçam a autonomia plástica e leveza do volume superior. No térreo, o revestimento texturizado e o pé direito menor reforçam a ideia de uma base sólida, que "emerge" da terra.

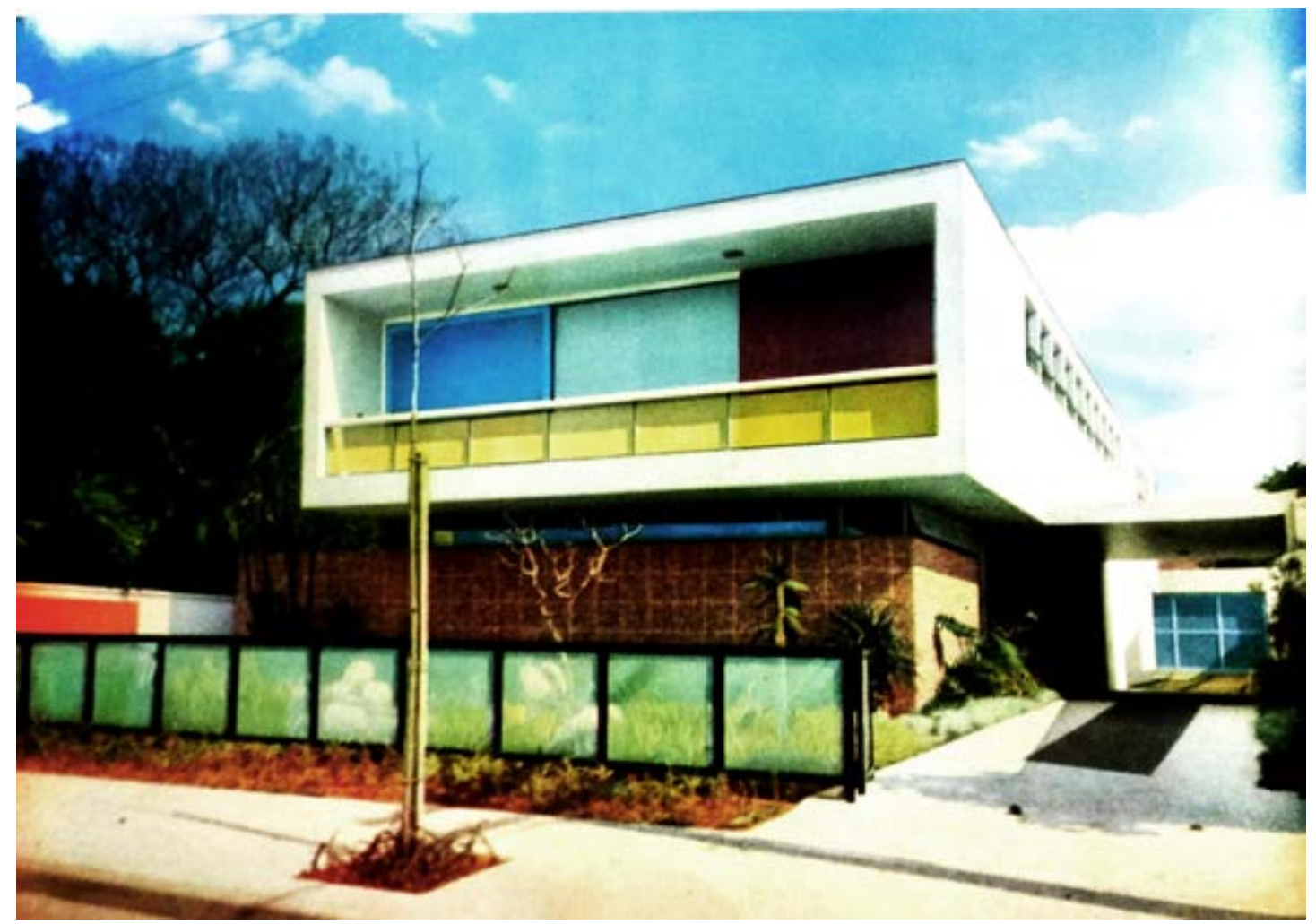

Fig.2.70- Residência de David Libeskind, em São Paulo.

\footnotetext{
${ }^{56}$ Localizadas em Belo Horizonte (1950), Goiânia (1952) e São Paulo (1956). Junto ao artigo, é publicado anúncio da Construtora Libeskind \& Schainberg, em São Paulo.

57 A casa apresenta laje impermeabilizada, com uma camada de pedregulho, para isolamento térmico. Localizada no Ibirapuera, em São Paulo, sua planta baixa mostra uma resolução com geometria precisa, poucas paredes e ambientes amplos. Os pilares da estrutura descolam-se da alvenaria e podem ser percebidos nos espaços internos, mas sem comprometê-los. A fachada envidraçada está à frente da estrutura.
} 
Na casa de Goiânia, também existem contraposições. Entre planos, entre materiais, e entre a solidez das paredes e a permeabilidade dos elementos vazados.

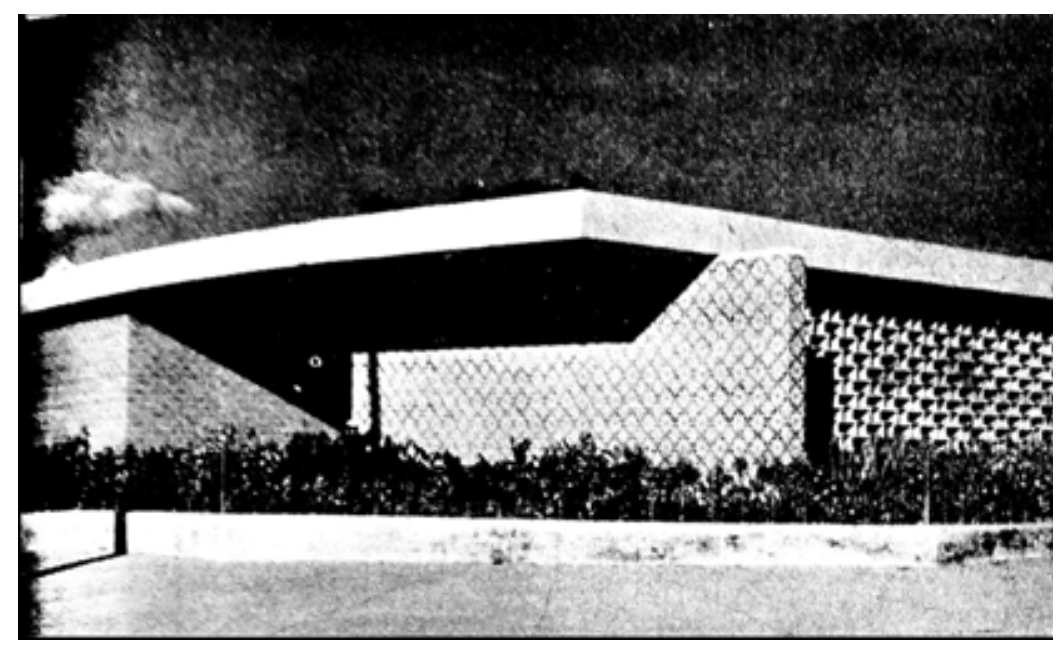

Fig.2.71- Residência de David Libeskind, em Goiânia.

A "residência bi nuclear" (CARNEIRO, 1957, p.29), mostrada na revista, apresenta as mesmas características de contraposição, inclusive entre a casa e o jardim. ${ }^{58}$ Neste, cria-se um ambiente íntimo, cercado pelas duas áreas da residência," velado dos olhares estranhos." (Ibid., p.29) ${ }^{59}$

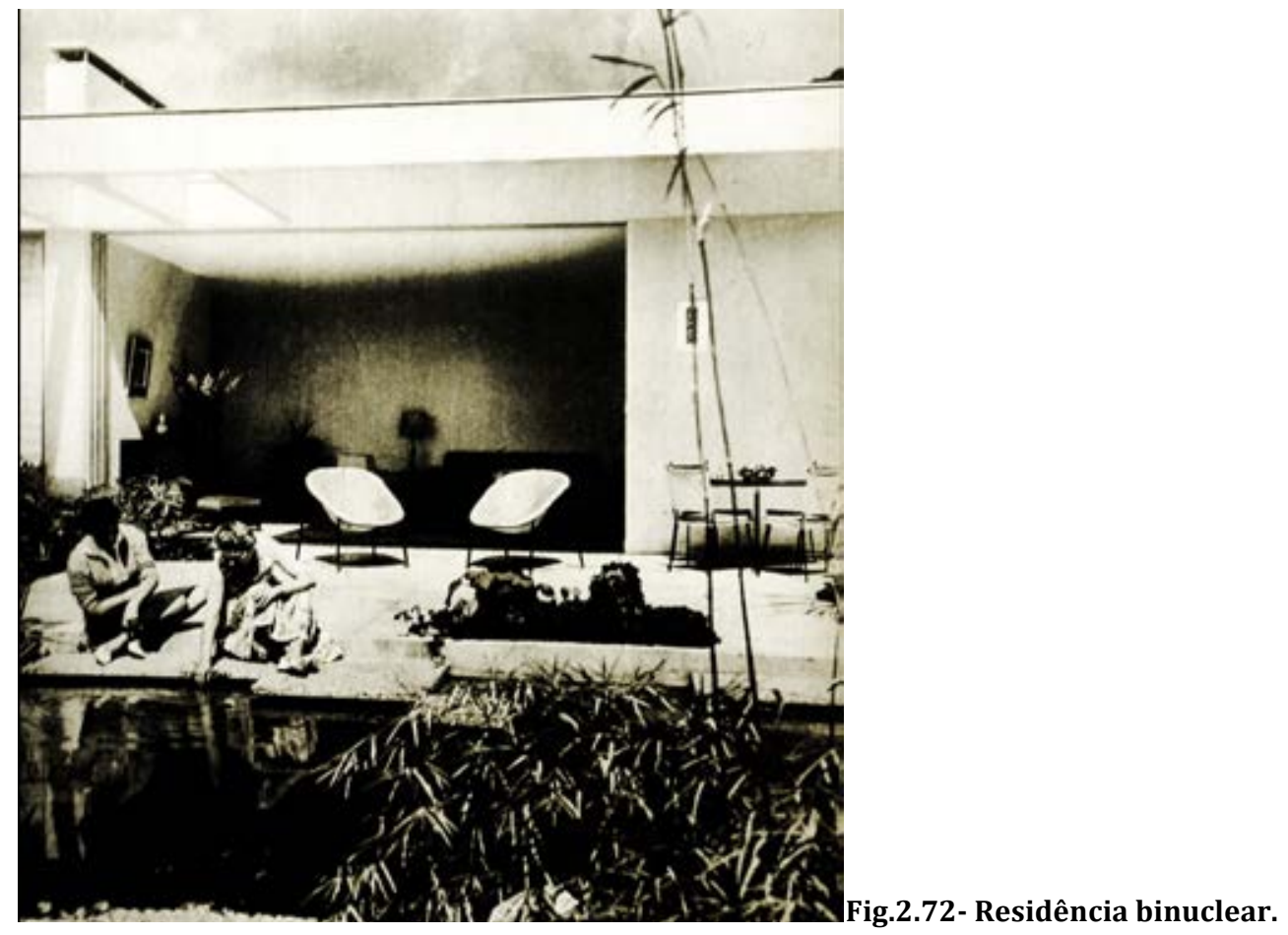

\footnotetext{
${ }^{58}$ Mas, apesar dessa oposição jardim-casa, eles se completam e formam um conjunto.

${ }^{59} \mathrm{Na}$ Rua Martim Francisco, no Brooklyn. Arquiteto Jorge Zalszupin, paisagista Roberto Coelho Cardoso. Proprietário Henrique Flatauer.
} 

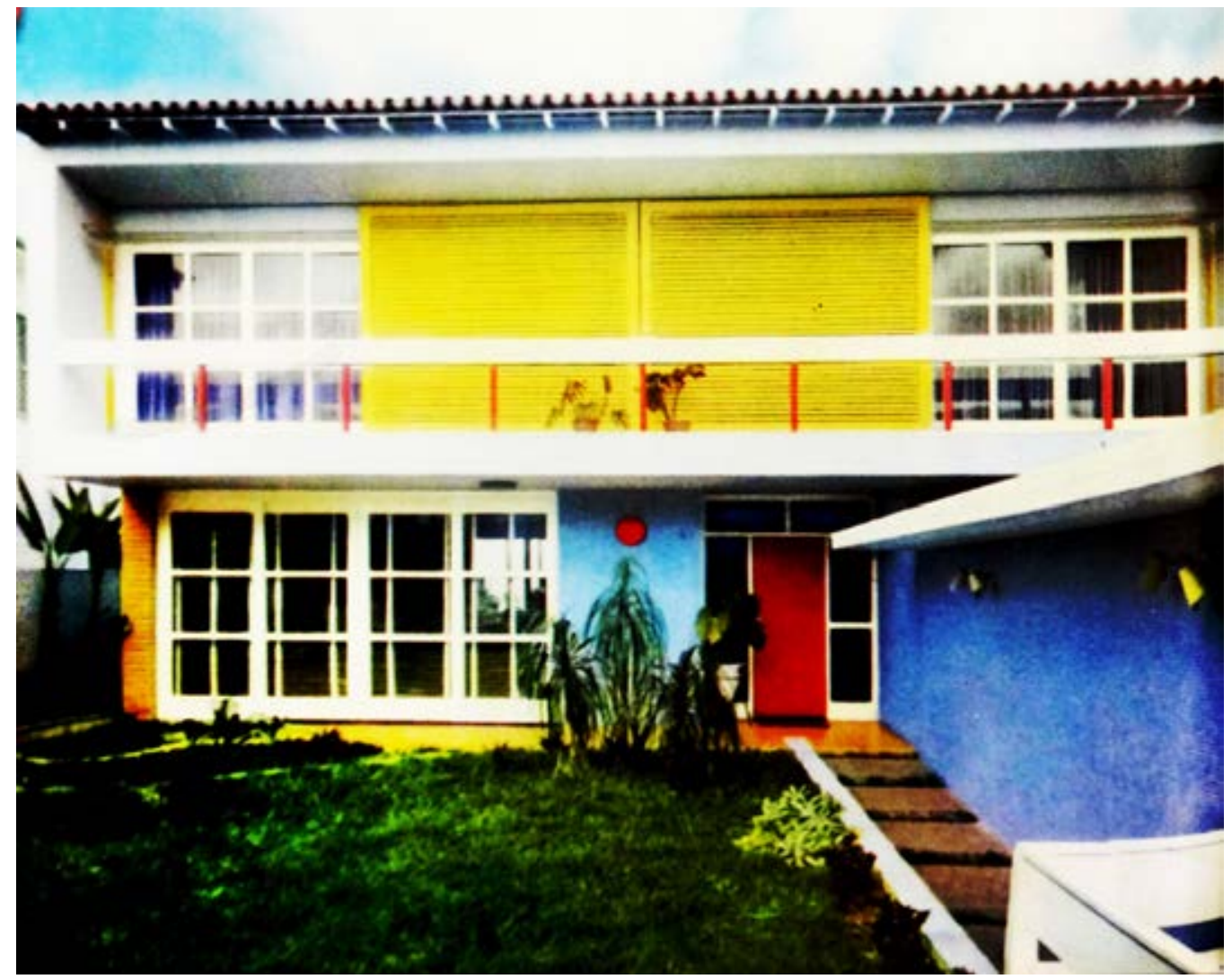

Fig.2.73- Residência projetada por Rubens Viana e Ricardo Sievers.

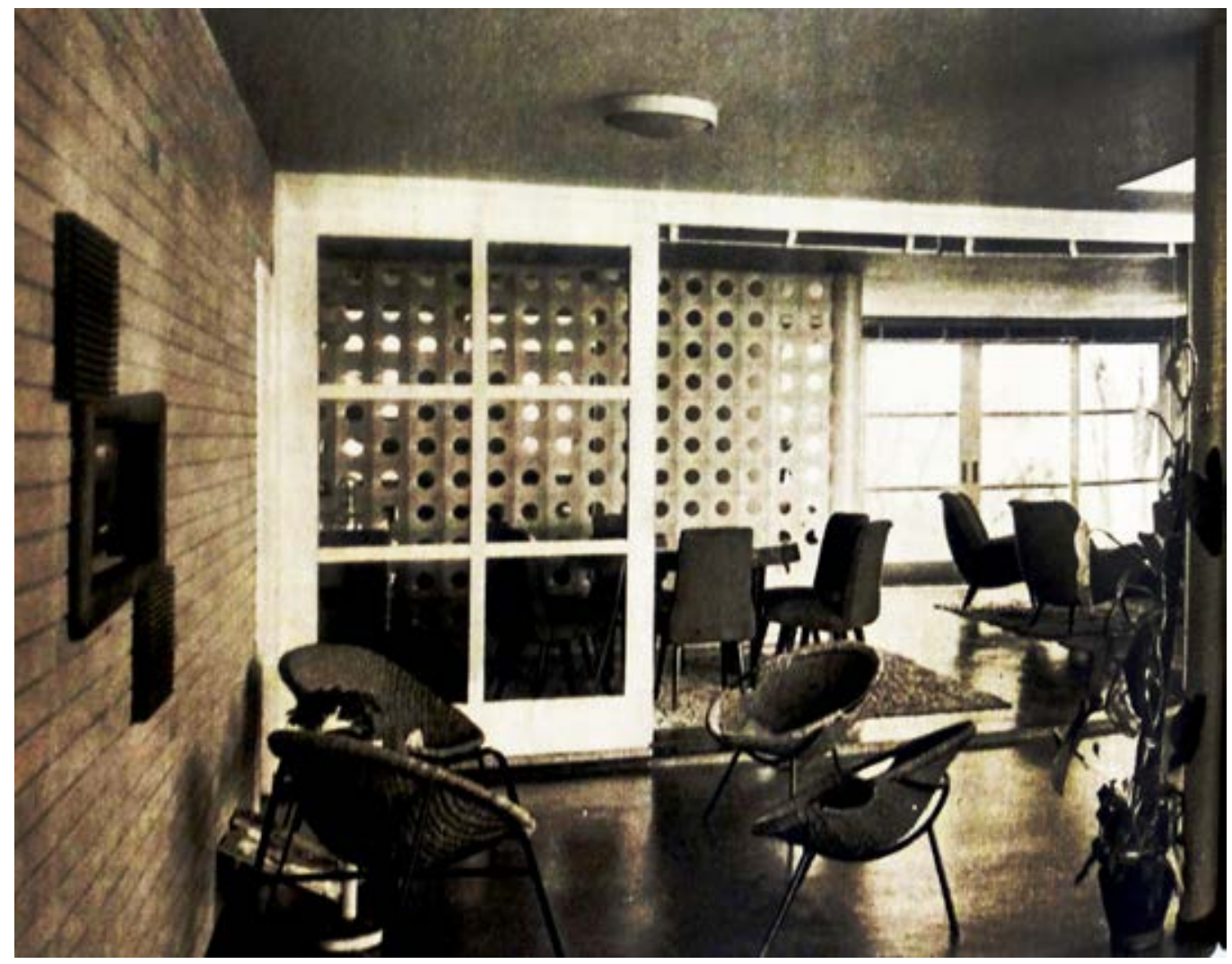

Fig.2.74- Vista interna da mesma residência. 
Em outra casa, projetada por Rubens Viana e Ricardo Sievers, ${ }^{60}$ a "fachada mostra um belo jogo de cores; nos detalhes construtivos e na aplicação dos materiais, em sua forma natural - como telha aparente, madeira, pedra ${ }^{61}$ e a vegetação (...)." (UMA CASA HOJE..., 1957, p.39)

Existe, ainda, uma permeabilidade, um fluxo de espaço, através dos vários ambientes e dos materiais contrastantes. Na área social, as "cortinas de vidro" permitem uma continuidade entre o jardim frontal e o íntimo, formando "um conjunto de efeito visual variável e de grande amplitude espacial." (Ibid., p.39)

\subsection{Adaptações: culturais, regionais, ao sítio e clima.}

É interessante analisar um comentário, em artigo de Casa e Jardim, sobre a casa anterior. $\mathrm{O}$ "acabamento, detalhes e o uso de materiais de construção em sua forma natural, como telhas aparentes, tijolos, pedra e vegetação imprimem à residência o sabor de nossa arquitetura colonial.“ (Ibid., p.41)

O sabor nos remete ao alimento, que é um dos elementos mais simbólicos e típicos em determinada cultura. Na verdade, a revista está se utilizando dessa imagem e desse discurso para tratar da arquitetura.

$\mathrm{Na}$ verdade, este é um discurso sobre a tradição. Esta refere-se a diversos aspectos culturais de uma sociedade, como hábitos, costumes e, mesmo, as formas construtivas.

Dessa forma, na arquitetura do "bem viver," além da linguagem moderna, podem ser encontradas referências à tradição. Principalmente à tradição pinturesca, ${ }^{62}$ românti-

\footnotetext{
${ }^{60}$ Também em duas alas.

${ }^{61}$ A utilização de pedras como material aparente é constante, em Casa e Jardim. LUCKMANN, 1957 mostra os vários tipos, sua procedência e destaca seu emprego crescente na arquitetura moderna, como revestimento e constituindo muros, destacando a resistência e a facilidade de manutenção. A "pedra da moda" (LUCKMANN, 1957, p.23) seria a pedra mineira que, aplicada em tiras finas, era chamada Califórnia.

$62 \mathrm{O}$ pinturesco olha o edifício e seu entorno como uma sequência de perspectivas e estimula uma nova sensibilidade visual. Assim, outro recurso do qual se utiliza o pinturesco é o aproveitamento das localizações privilegiadas da topografia e da paisagem. Outra característica vista em Casa e Jardim, a valorização das vistas e da paisagem acidentada e da vegetação.

O pinturesco pode ser entendido, no sentido mais amplo, como um ponto de vista, um modo ou uma intencionalidade do desenho arquitetônico, como um nível supra estilístico que transborda os limites cronológicos e geográficos, competindo com os modos acadêmicos, canônicos, clássicos ou hieráticos. (CRESPO; COVA, 1982, p.9).
} 
ca ou regionalista, que envolve a transmissão de valores e outras questões em um fluxo contínuo de uma comunidade homogênea pertencente a um território. Esse território pode ter a abrangência de um país.

O conceito de regionalismo baseia-se em um modelo social ideal, segundo o qual todas as sociedades possuem um cerne, uma essência, que devem ser descobertos e preservados. Entre eles, estão os aspectos geográficos e climáticos e os hábitos, que envolvem o uso e a transformação de materiais locais, naturais. (COULQHOUN, 2007b, p.150)

Essa tradição também é chamada pinturesca ${ }^{63}$ porque envolve, na arquitetura, a assimetria forçada, as volumetrias complexas, os recursos ao cromatismo e à textura e as composições aditivas.

“(...) a paisagem pinturesca seleciona e recorta o campo de visão pelo que nele se destaca, o inusitado da varietà (que só pode ser apreendido 'em relação a algo', ao qual se opõe como 'novidade')" (PINHEIRO; D'AGOSTINO, 2004, p.339). O conceito do pinturesco também pode ser aplicado à escala do edifício. Nesse caso, os detalhes contrastam entre si e relacionam-se.

Trata-se de uma arquitetura espontânea, que opõe-se à volumetria da linguagem moderna, tendente à pureza prismática.

Assim, pode-se dizer que as casas do "bem viver" são pinturescas. E a utilização de materiais naturais, texturização e cores criam uma ligação com o local, constituindo uma arquitetura regionalista, teoricamente.

Mas, apesar da variedade, nas casas mostradas em Casa e Jardim, procura-se manter a unidade do edifício. A ideia inicial, a síntese, "controla" essas "experiências," irregularidades, impetuosidades e detalhes inesperados, através da linguagem moderna. Os detalhes e o todo contrapõem-se, mas o último deve preponderar.

A presença da tradição na arquitetura do "bem viver" se dá de várias formas.

Em primeiro lugar, através da procura por soluções "caracteristicamente regionais" (SCHULTZ; SCHULTZ, 1956, p.37), que ainda persistiam nos locais afastados das

\footnotetext{
${ }^{63} \mathrm{O}$ vocábulo pitoresco, usual na linguagem cotidiana em inúmeras acepções tomadas por analogia de seu sentido etimológico - pittoresco, no italiano, deriva de pittura, significando "próprio para ser pintado" - está vinculado a um conceito que, a despeito da aparente superficialidade, acarretou profundas transformações no pensamento estético ocidental, tais como a crítica à rigidez geométrica clássica (simetria, axialidade, etc.) e ao ideal de imitação dos antigos (mímesis); em suma, o pinturesco traz a concepção de arte como expressão autêntica, livre do artificialismo das convenções estilísticas.
} 
grandes cidades. "Para a decoração do lar, o folclore foi a última descoberta. Desde os confins da Amazônia, Bahia, Mato Grosso, até a terra gaúcha, o regional se oferece variado e rico em formas exóticas, na exuberância ingênua das cores." (SCHULTZ; SCHULTZ, 1956, p.39)

Ao voltarem-se os olhos para a arte popular, para a "atividade espiritual do homem simples," (Ibid., p.38) ainda não "corrompido," seria possível aproximar-se da essência da cultura, com um novo conceito de beleza, que em nosso caso, deriva dessa mistura de raças. Pois, com a presença do negro no Brasil, "novas concepções e outras ideias sobre o belo foram-se difundindo, criando raízes ao lado do que havia do indígena e do populário português." (Ibid., p.38)

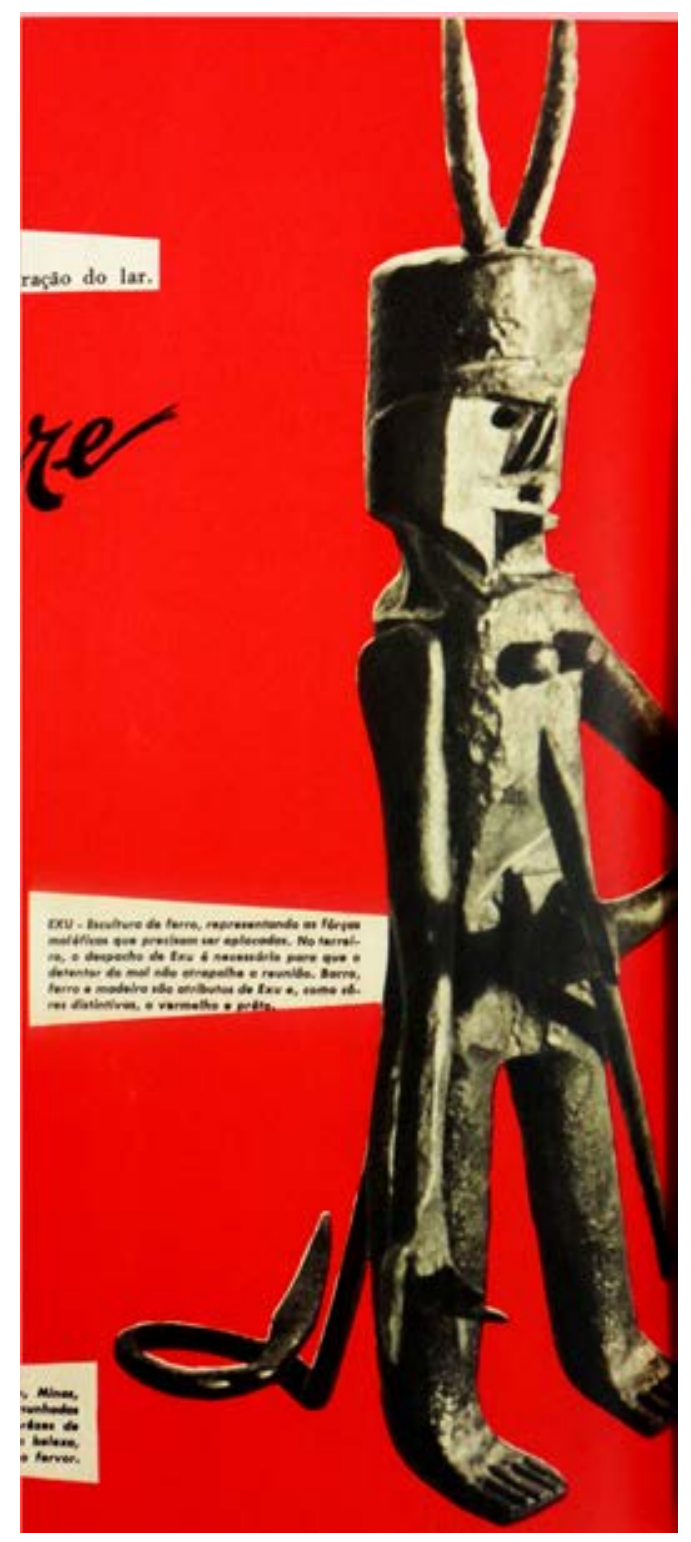

Fig.2.75- Escultura representando Exu, peça do folclore. 
$\mathrm{Na}$ verdade, as "soluções regionais" se constituíam em peças "folclóricas" adicionadas à decoração, na tentativa de conferir-se um "toque regional" ao ambiente.

No apartamento da decoradora Claudia H. Andujar, por exemplo, mostrado em Casa e Jardim, são encontrados objetos de várias procedências: artesanato indígena, objetos da Bahia, pedra-sabão de Minas, boneca de Pernambuco, prato boliviano. "Consegui isto não com móveis caros, mas sim por meio de objetos úteis e decorativos que colecionei com carinho durante minhas viagens pelo país e no exterior." (ANDUJAR apud CAMPOBELO, 1958, p.20) Forma-se um conjunto porque a moradora os escolheu e os dispôs pelo interior do apartamento. A “'mistura' não planejada (...) empresta ao apartamento a nota toda pessoal, e que o torna tão agradável para nele viver." (Ibid., p.21)

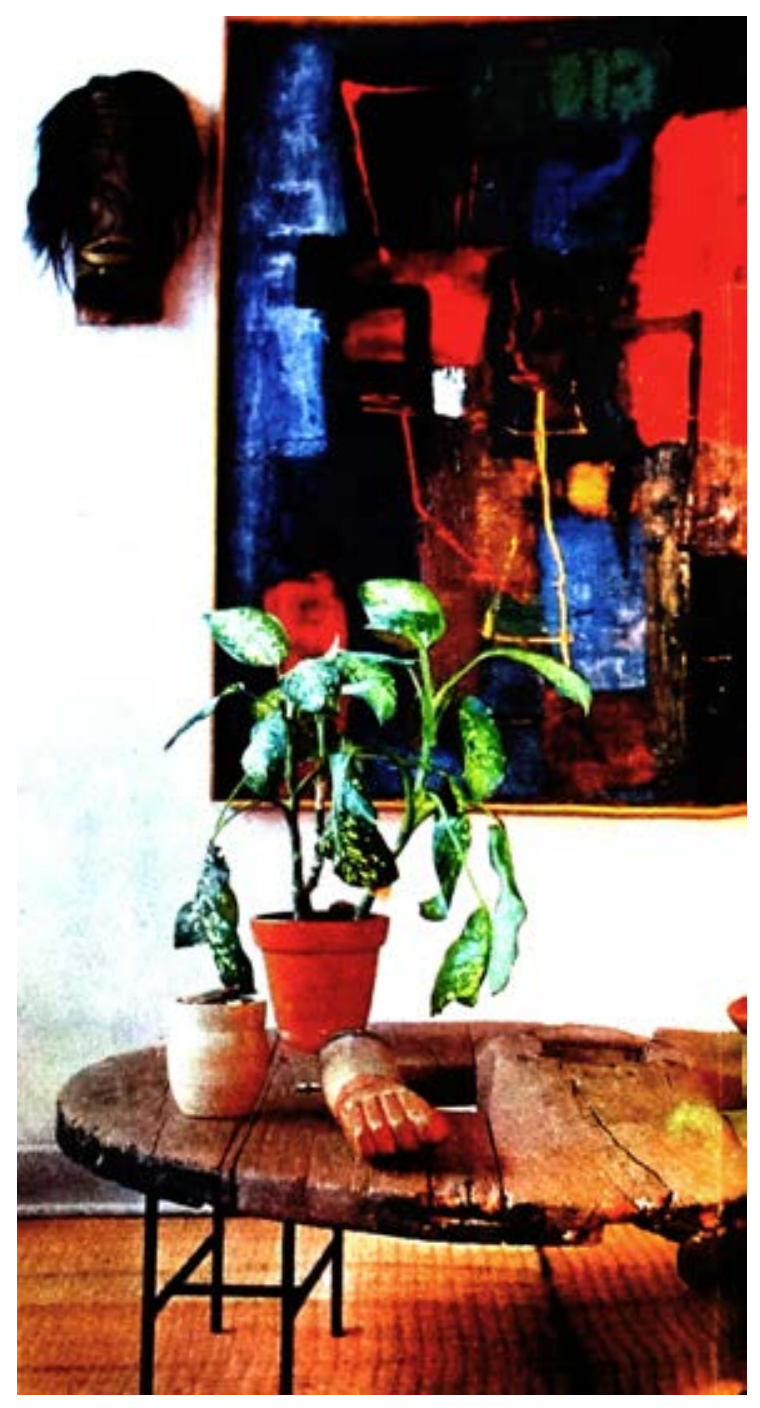

Fig.2.76- Decoração com lembranças de viagem, de várias procedências, da decoradora Claudia Andujar. 
Na decoração, a tradição está presente, também, na revista, em outros elementos típicos brasileiros, como redes, plantas e móveis em fibras variadas, que criam esse "ambiente tradicional ou regional." A rede cearense, por exemplo, "contribui para a sensação de repouso." (JARDIM..., 1955, p.16) Há plantas como samambaias, begônias, orquídeas ou um "recanto pitoresco da vivenda." (Ibid., p.47) ${ }^{64}$

Existem, ainda, pequenos detalhes prosaicos, "tradicionais," em Casa e Jardim, como os talheres inspirados na cultura Marajoara ou no Barroco Moderno. ${ }^{65}$

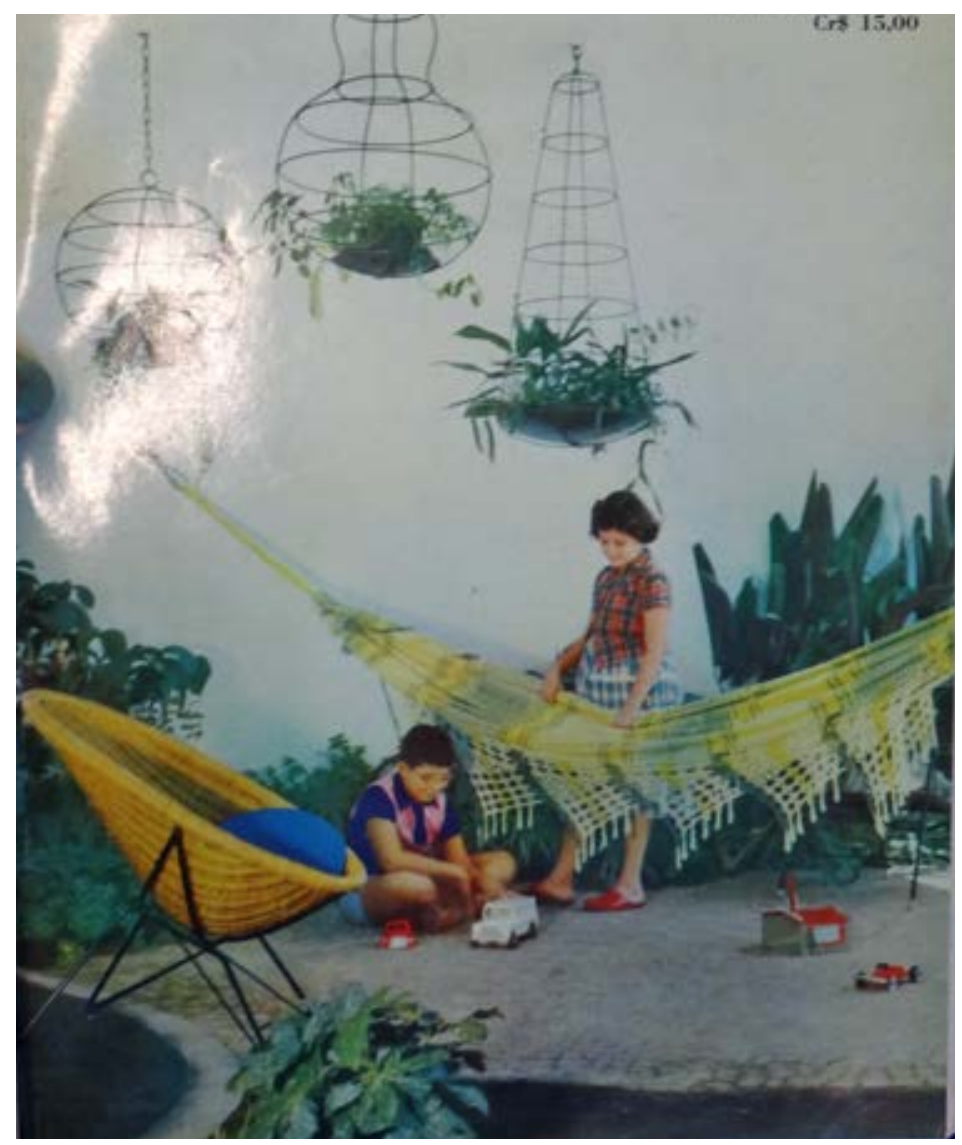

Fig.2.77- Objetos e plantas tradicionais brasileiros criam um "ambiente regional."

E a defesa do regional prossegue, em Casa e Jardim. Esse tipo de decoração com elementos de nossa cultura poderia ser ensinado, ${ }^{66} \mathrm{em}$ "escolas de 'bom gosto', apoiando aberta e espontaneamente o típico, o regional, o muito nosso, que

\footnotetext{
${ }^{64}$ Em uma edição de Casa e Jardim, em especial, a de número 41, de mar./abril 1958, a questão da tradição está presente em vários projetos e textos.

${ }^{65}$ PARA ELA..., 1954, p.61. Anúncio de talheres de prata Wolff.

${ }^{66} \mathrm{O}$ artigo refere-se a curso sobre "a decoração artística e econômica," chamado "Modelo para a vida cotidiana," que o Instituto Nacional de Educação Popular do Ministério da Educação da França teria elaborado.
} 
atualmente vive de experiências estrangeiras, em prejuízo da imaginação e da inteligência brasileiras" (...) (para os mais jovens realizarem) "algo diferente, sem os plágios alienígenas." (BERNARDES FILHO, 1958, p.2)

Mas, a questão da tradição extrapola a decoração e envolve o projeto do edifício, não se apresentando em apenas uma tipologia de casa. Essa fusão tradiçãomoderno pode ter muitas feições, em diversas tentativas de adaptação da arquitetura aos múltiplos contextos brasileiros: praia, cidade ou campo. Nordeste, Sul, Sudeste. Variam os climas, as paisagens, os modos de vida e os materiais.

No entanto, essas adaptações regionais podem surgir apenas como uma espécie de "acessório," que confere um toque local ou pitoresco à arquitetura. Algo puramente formal.

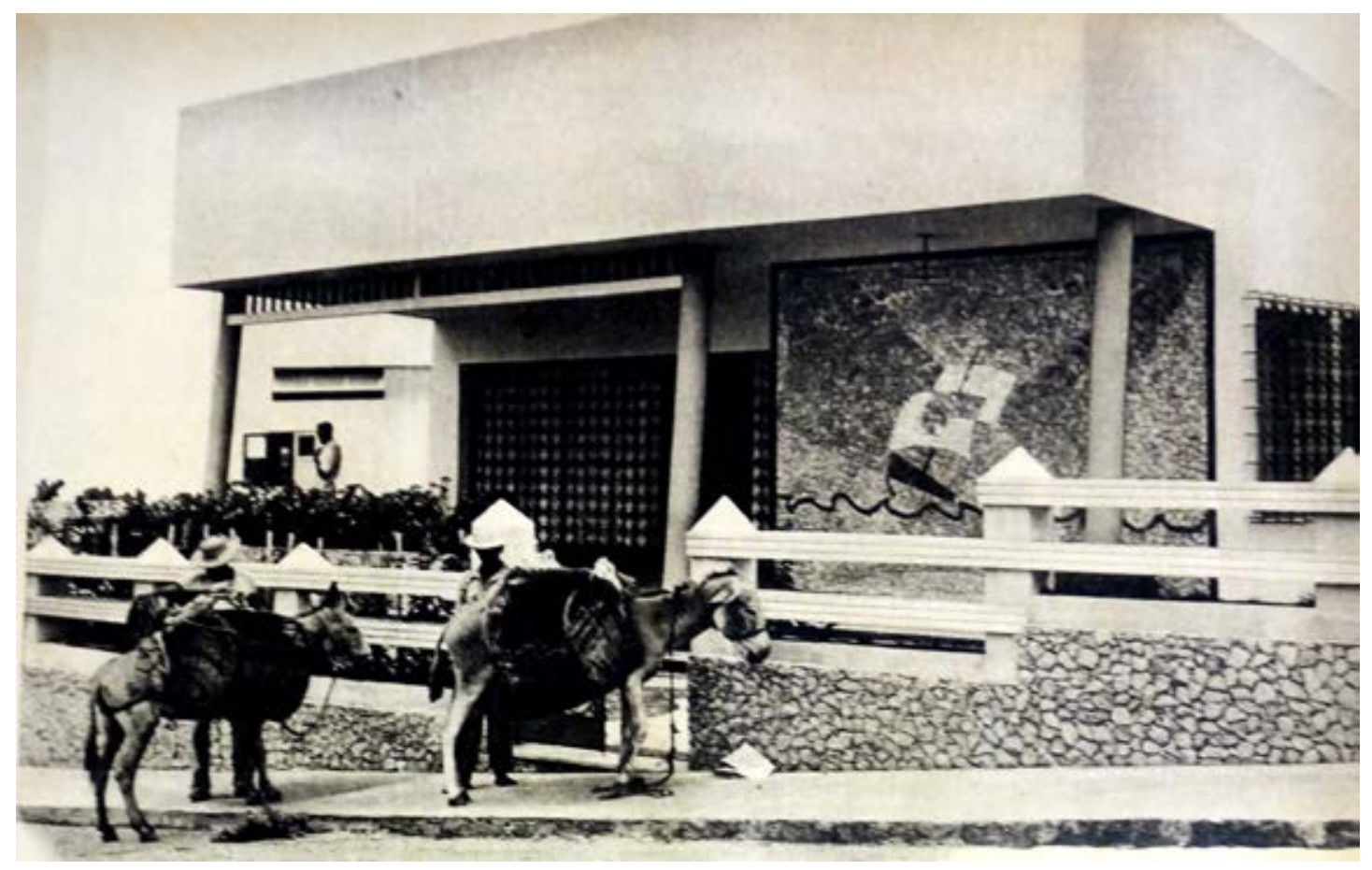

Fig.2.78- Casa em Salvador, sem autoria definida.

É o que se vê na casa localizada em Salvador, ${ }^{67}$ publicada na revista. Painéis colocados na fachada, retratando barcos no mar, seriam algo "que remonta às antigas civilizações, mas é também um traço de arquitetura contemporânea. Com a pedra, elemento natural, (...) criou-se uma fisionomia da casa, como expressão

\footnotetext{
${ }^{67}$ A residência, exemplar do "bem viver," sem autoria definida, teria sido inspirada em fotografias da revista Casa e Jardim.
} 
típica de sua belíssima paisagem." (PASTILHAS, 1956, n.29, p.6) Uma pérgola em madeira trançada evoca as antigas varandas. Outra nota pitoresca é dada pelos jumentos fotografados à porta da casa.

Esses elementos mesclam-se à linguagem moderna, presente na platibanda, desproporcional, apoiada em pilares cilíndricos inclinados.

Outra casa, ${ }^{68}$ projetada pelo arquiteto Lev Smarcevscki, ${ }^{69}$ mostrada em Casa e Jardim, também apresenta linhas modernas, com teto plano, grande marquise e pilares cilíndricos. Os aspectos "típicos" regionais acrescentados são o muro de pedras coloridas - "pedraria baiana," (DUTRA, nov.1956, n.30, p.18) as conchas retiradas do mar, os elementos vazados e um painel com motivos da vida local. "O grande painel de Maria Célia que serve de fundo, é em cerâmica vermelha, representando o feirante da Água de Meninos. Aqui tudo lembra a Bahia." (Ibid., p.18)

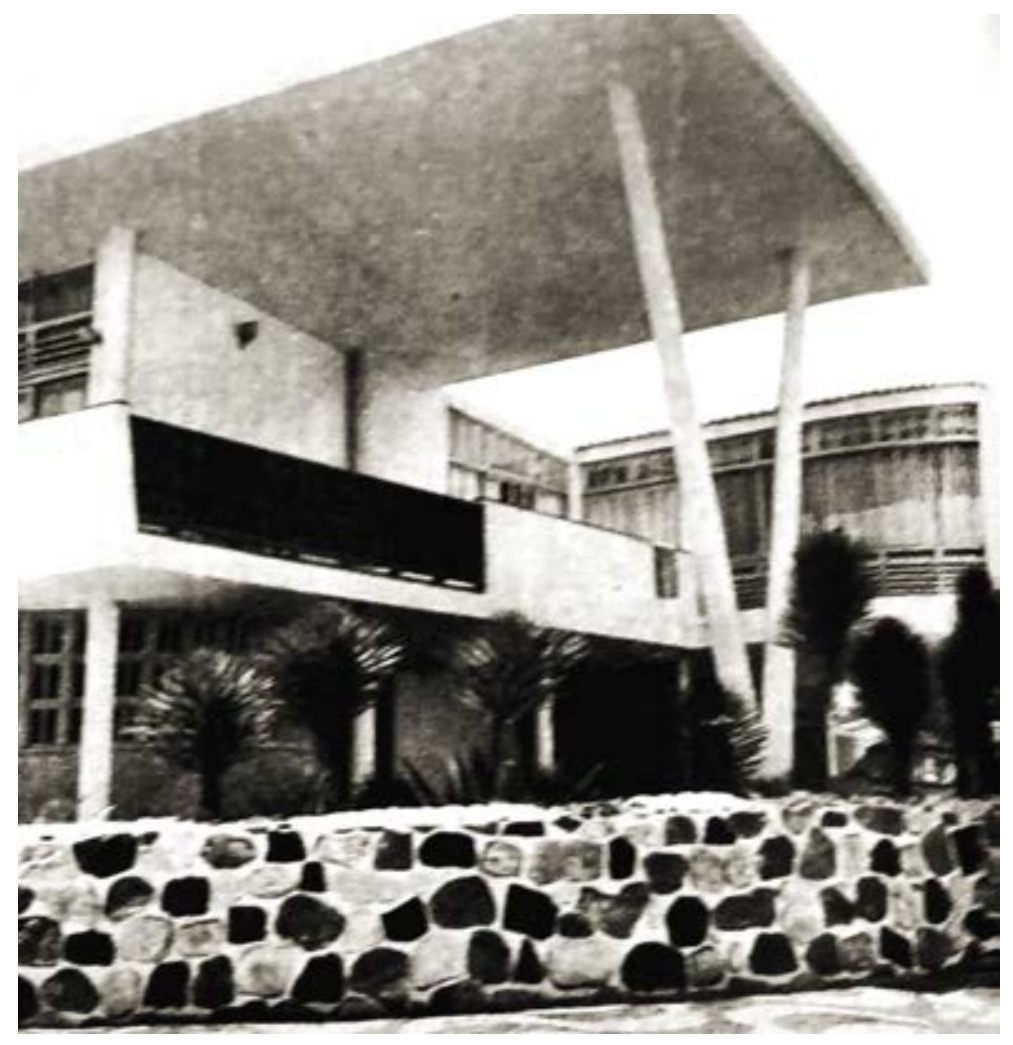

Fig.2.79- Casa do arquiteto Lev Smarcevscki, na Bahia.

\footnotetext{
${ }^{68} \mathrm{O}$ artigo fala sobre as tradições baianas, sua arquitetura colonial e a chegada da linguagem moderna.

${ }^{69}$ Lev Smarcevscki (1924-2004) foi arquiteto, pintor, escultor, navegador e inventor. Apesar de haver nascido na Ucrânia, considerava-se baiano de criação e dedicou sua vida inteira ao mar. Smarcevscki foi dos primeiros a perceber a importância dos saveiros como patrimônios históricos e navais Projetou o Edifício Jequitaia, um importante marco do modernismo na capital baiana, construído em 1961.
} 
No entanto, em várias outras casas mostradas na revista, a tradição é tratada de forma diversa, como espécie de "inspiração" para a constituição da ideia de projeto, da síntese inicial.

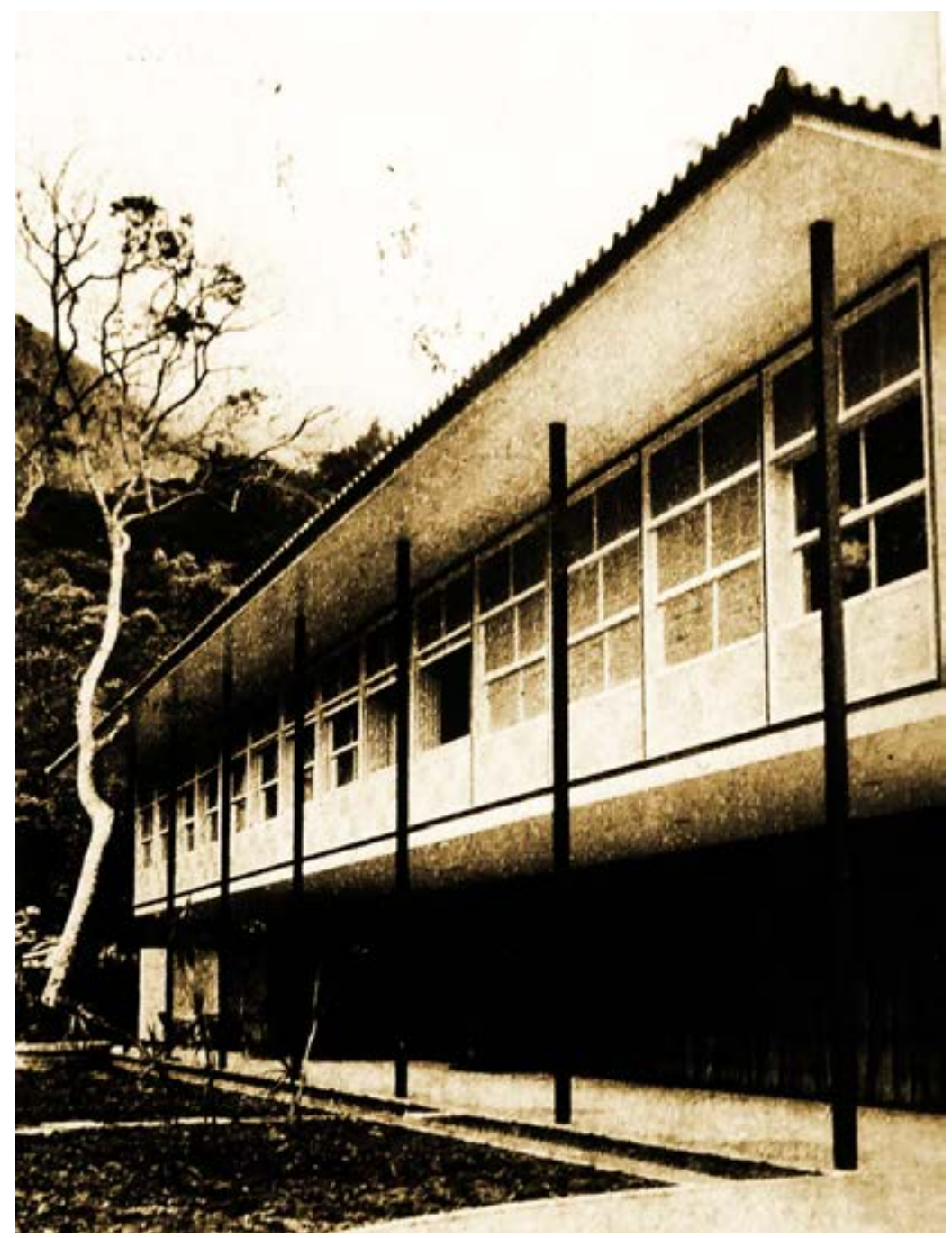

Fig.2.80- Casa dos arquitetos Paulo F. Santos e Paulo E. Pires.

Entre elas, está o projeto de Paulo F. Santos e Paulo E. Pires. ${ }^{70}$ Nela, os elementos tradicionais não parecem simplesmente "acrescentados," posteriormente ao projeto.

A cobertura é aparente com telhas de barro e as esquadrias são tradicionais. Mas, o terraço e as portas de vidro são modernas. No interior, os móveis e outros elementos modernos, como uma escada vazada, mesclam-se a peças antigas. Percebe-se que se tentou utilizar aspectos tradicionais da nossa arquitetura, como as venezianas e as telhas de barro, apropriadas ao clima, mas com técnicas adequadas à época.

\footnotetext{
${ }^{70}$ REIS, 1957.
} 
A residência projetada por Jon A.V. Maitre Jean e Keiko Matsudo, ${ }^{71}$ também mostrada em Casa e Jardim, apresenta, da mesma forma, feições da arquitetura tradicional: tesouras e forro em madeira aparente e cobertura em telhas de barro. Os materiais são naturais e a vegetação é nativa. "Os detalhes que embelezam decorrem do modo de usar o material. A madeira, esta nossa riqueza natural, cujas qualidades infinitas poucos sabem explorar, empregou-se largamente nesta residência (...). Vista de fora, a casa nada tem de incomum. As linhas são singelas e perfeitamente adequadas ao tijolo e à madeira." (ZONTA, 1956, p.5)

As técnicas, os materiais, a linguagem utilizada, são harmônicos e adequam-se ao local. No entanto, trata-se de um programa moderno - uma casa de veraneio no litoral.

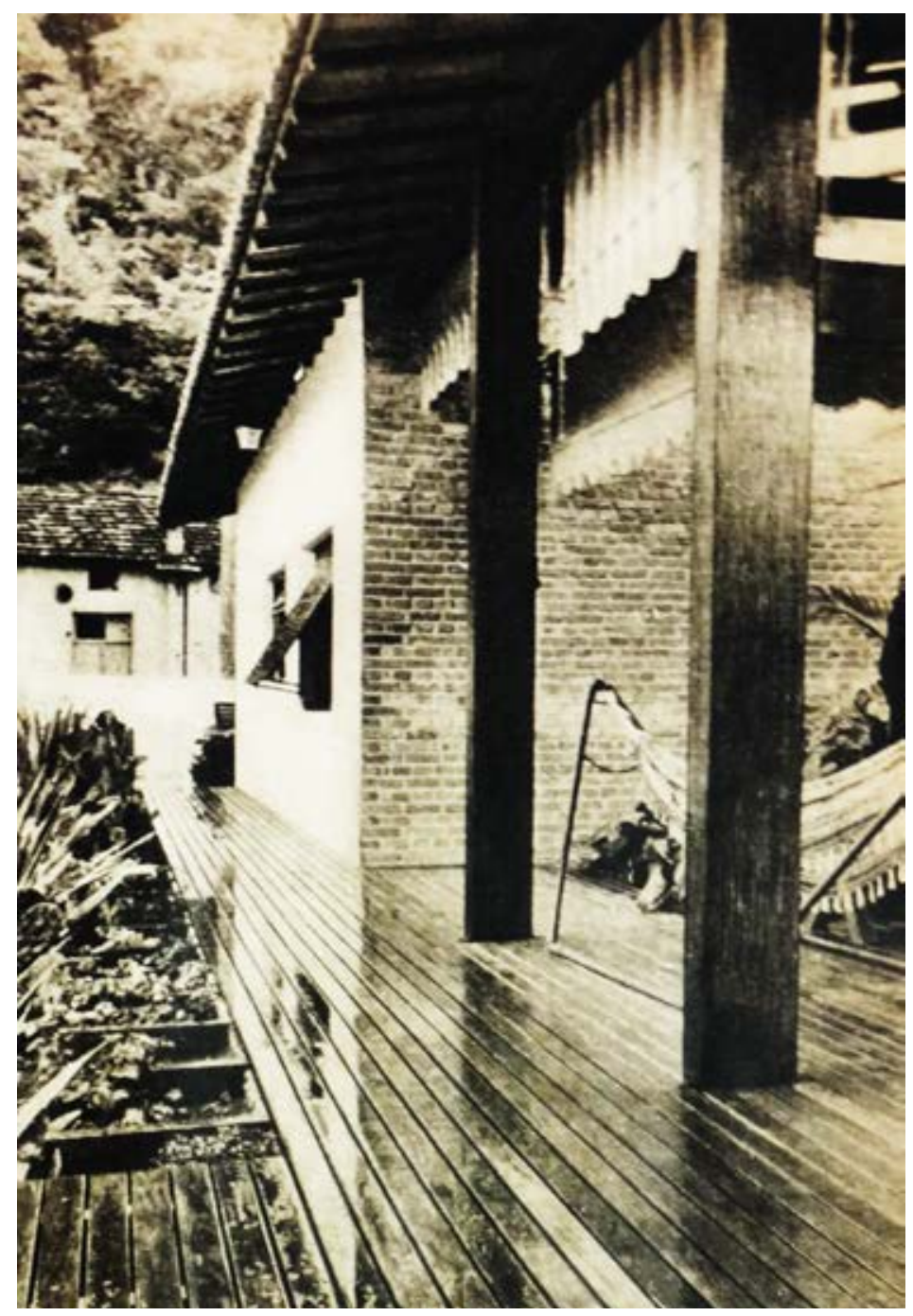

Fig.2.81- Casa de Jon A.V. Maitre Jean e Keiko Matsudo

\footnotetext{
${ }^{71}$ Paisagismo de Osborn Coelho Cardoso.
} 


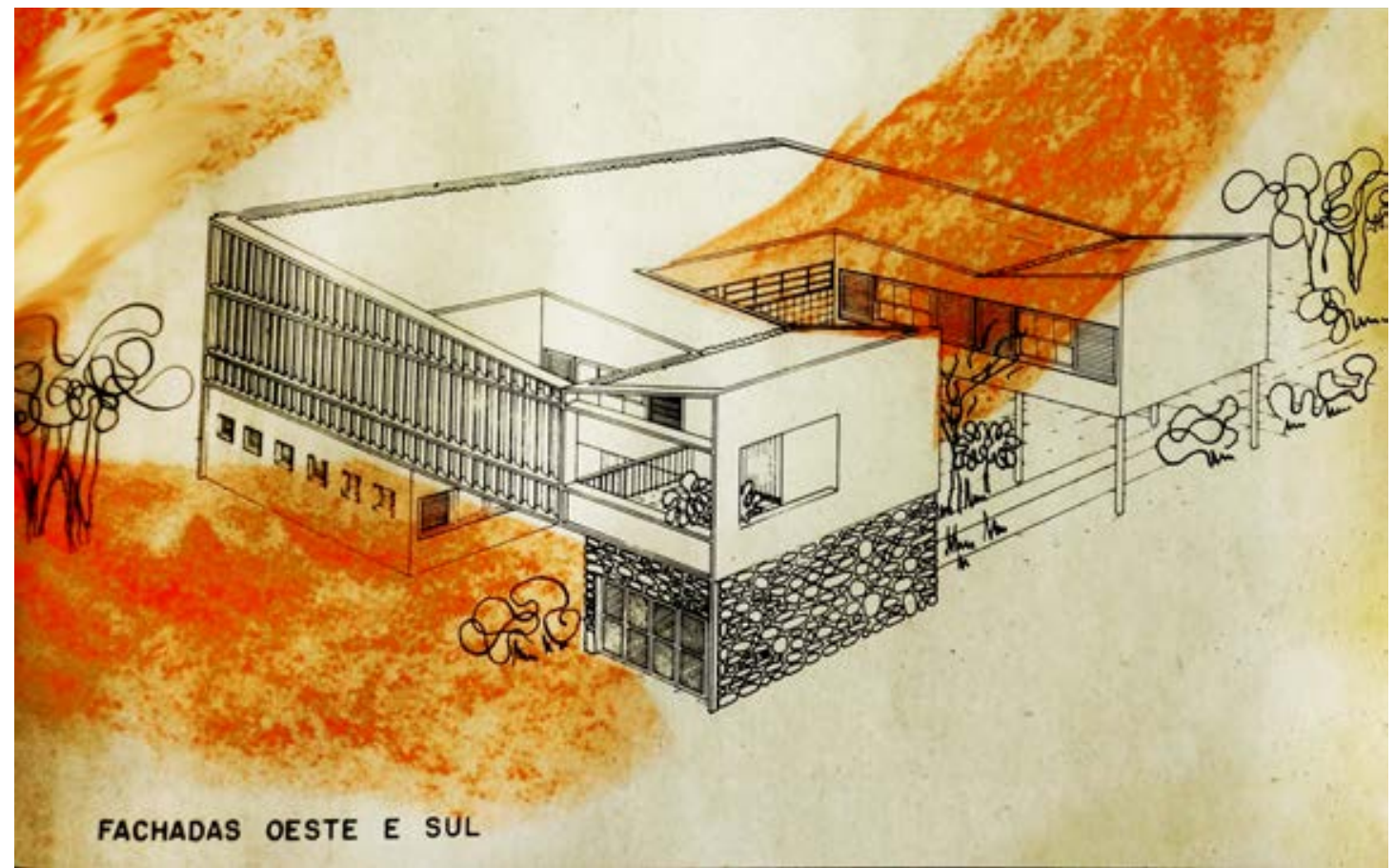

Fig.2.82- projeto da arquiteta Lygia Fernandes.

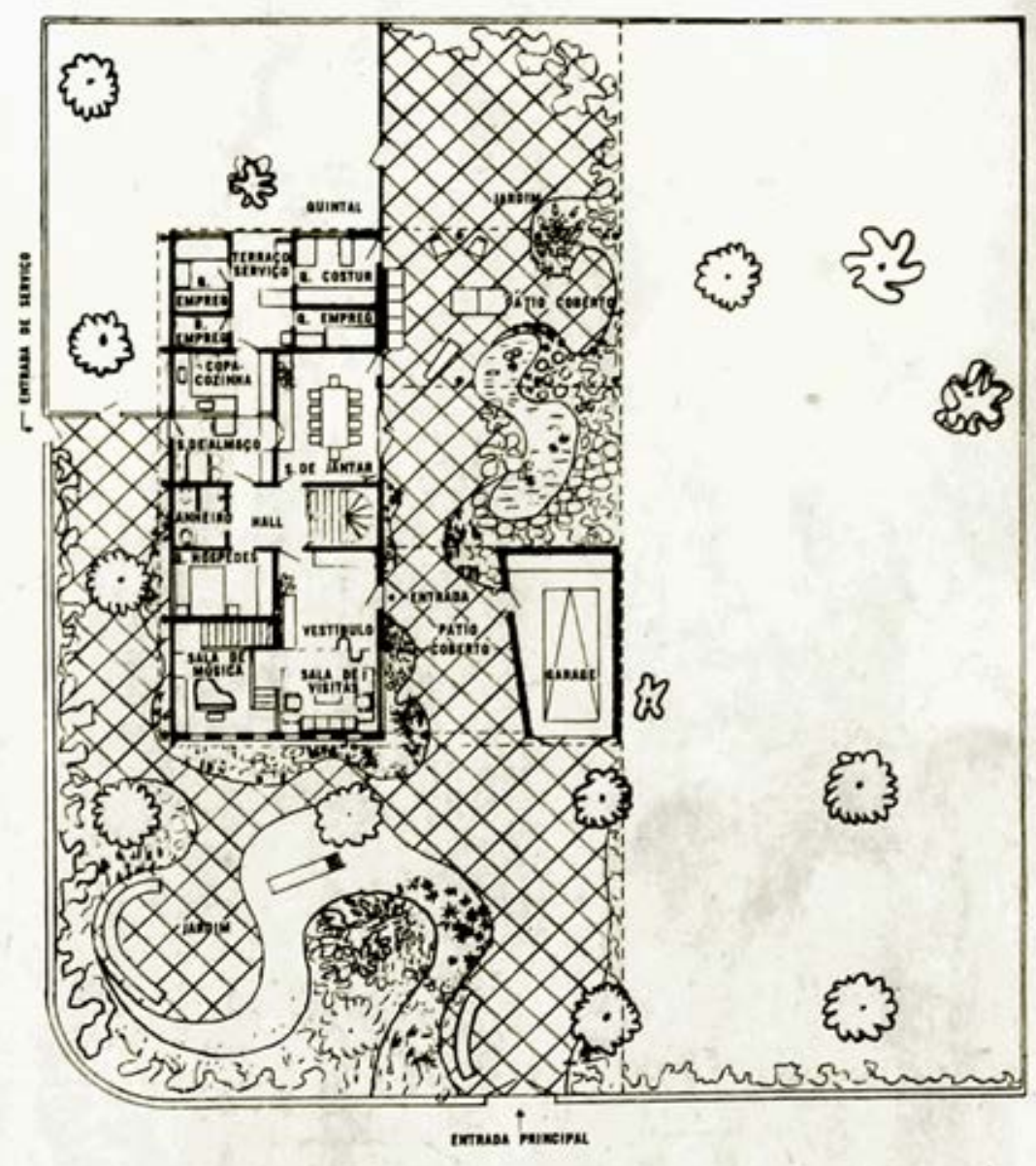

Fig.2.83- Planta baixa da mesma casa. 
Mas, outra casa do "bem viver" mostra uma abordagem diversa em relação à tradição. Projeto da arquiteta Lygia Fernandes, ${ }^{72} \mathrm{em}$ Alagoas, utiliza-se da linguagem moderna, sem telhado aparente. A proteção contra o calor é feita através da ventilação cruzada, com venezianas fixas e móveis; da correta orientação solar e do emprego de brise-soleils: "uma casa simpática, arejada e bem estudada, própria para o clima do lugar em que foi construída (...)." (PROCHNIK, 1956b, p.11) Além disso, os pilotis criam recantos sombreados e ajardinados, como um pátio das casas tradicionais.

A casa projetada por Oscar Niemeyer, no entanto, adapta-se ao local, à própria paisagem: ${ }^{73}$ "A cobertura do teto entra em harmonia formal com a paisagem parece ter sido moldada pelo próprio vale onde se encontra como se estivesse suspensa de morro a morro." (PROCHNIK, 1957a, p.12) ${ }^{74}$

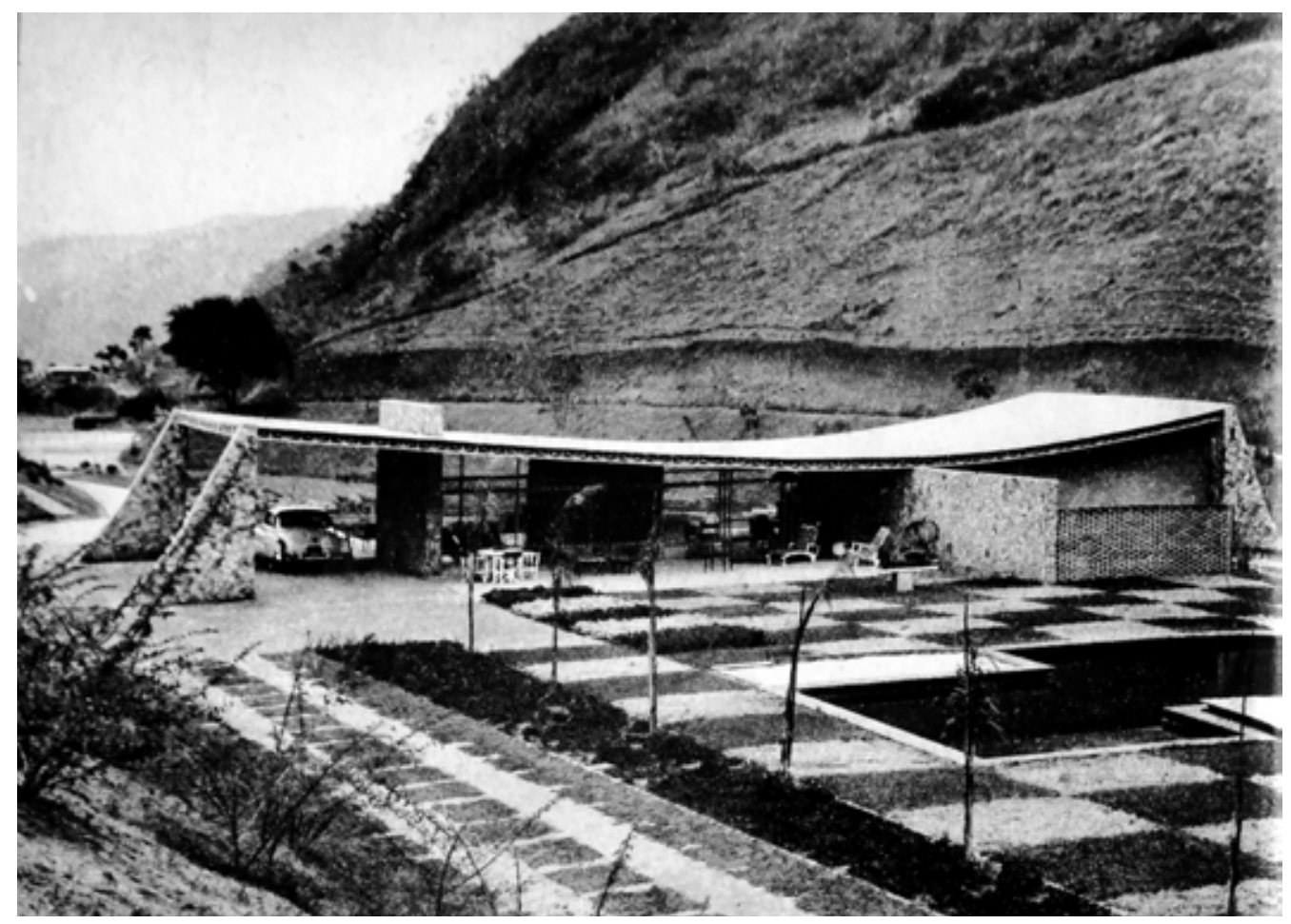

Fig.2.84- Projeto de Oscar Niemeyer.

\footnotetext{
${ }^{72}$ Proprietário José Lyra. A arquiteta Lygia Fernandes formou-se em 1945 pela Escola Nacional de Arquitetura. Trabalhou com Henrique Mindlin e Jorge Moreira. Entrou para o DHP em 1948. É autora de vários projetos de habitação padrão do DHP. Atuou também na fiscalização das obras dos conjuntos Pedregulho e Paquetá e de diversas habitações padrão.

${ }^{73}$ Paisagismo de Burle Marx. A casa, também mostrada na capa dessa edição, fica próxima a Petrópolis. Proprietário Edmundo Cavanelas.

${ }^{74}$ Mostrada em Casa e Jardim, encontram-se aqui algumas das características da arquitetura do "bem viver:" grande lareira em pedra, portas de vidro que tornam o forro de madeira contínuo entre exterior e interior, pedras portuguesas e mármores no piso, cores variadas, móveis contemporâneos, inclusive uma poltrona Saarinen.
} 


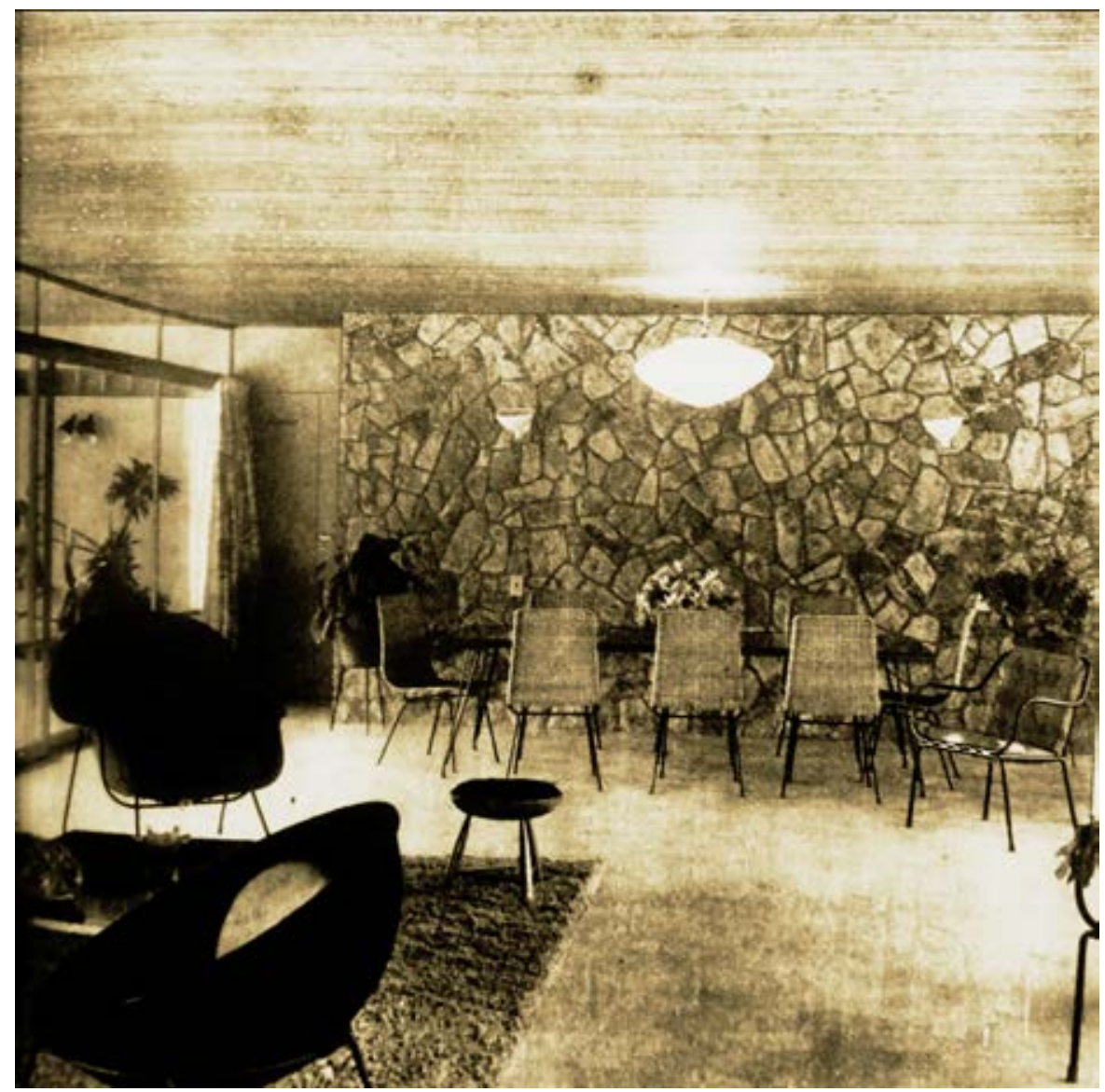

Fig.2.85- Ambiente interno da casa projetada por Niemeyer.

Em outra casa baiana, mostrada na revista, ${ }^{75}$ suspensa sobre pilotis, com elementos vazados, existe um "belo muro, construído de grandes pedras de tonalidades contrastantes. Símbolo de tradição, uma varanda se estende à frente dos quartos." (ZONTA, 1958, p.29) O antigo caramanchão é revisitado, agora com pilares cilíndricos e laje plana: “(...) uma nova concepção do nosso antigo caramanchão, embelezada por um painel de Caribé, executado com pastilhas, forma um recanto agradável e dá uma nota alegre ao jardim." (Ibid., p.30) Vários painéis estilizados mostram cenas do trabalho dos pescadores.

(...) nossa arquitetura atual, conhecida e admirada em todo o mundo, e na qual a tradição está representada não na forma, mas sim no uso dos novos materiais - de acordo com as condições do meio e no entrosamento perfeito da arquitetura com a natureza. (...) À sua forma moderna, condicionada aos novos materiais, se justapõem elementos tradicionais: as grandes varandas que aí

\footnotetext{
${ }^{75}$ O proprietário é Manuel Marques de Souza. O autor do projeto não é mencionado na reportagem da revista.
} 
aparecem são lembranças da nossa velha casa-grande. (ZONTA, 1958, p.31)

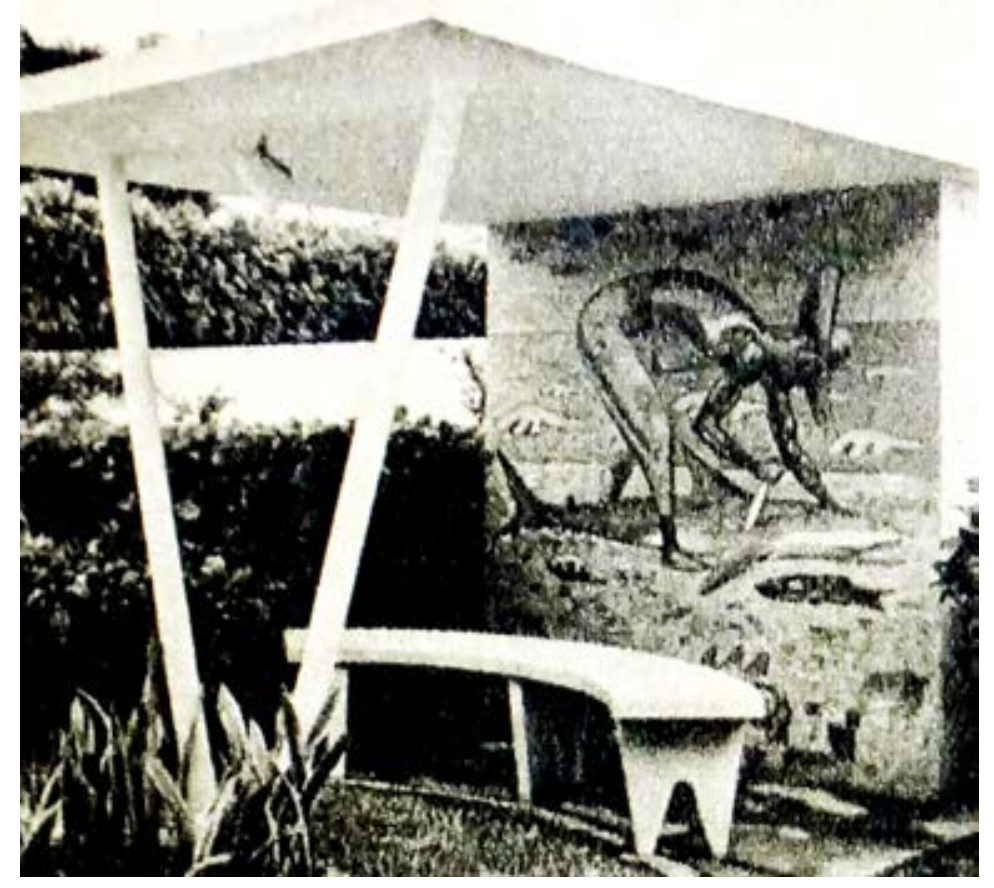

Fig.2.86 - Caramanchão revisitado.

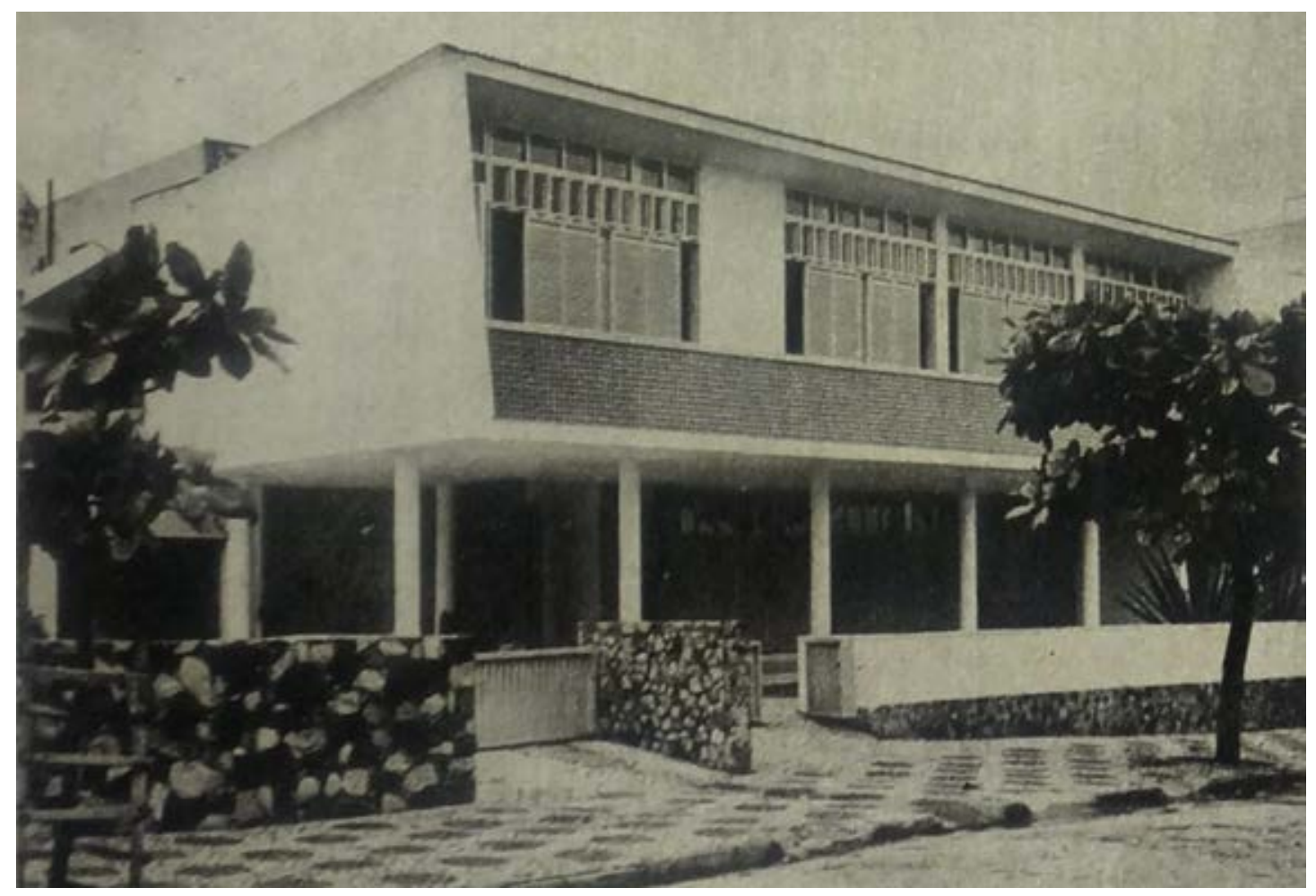

Fig.2.87 - Outra residência baiana. 
$\mathrm{Na}$ arquitetura de Luiz Saia, também está presente a ideia de uma nova forma para elementos tradicionais. Na residência projetada por ele no bairro do Morumbi, ${ }^{76}$ uma casa do "bem viver," nota-se a presença de objetos típicos, como rede, pilão, cestas, cortinas de bambu e outras peças antigas.

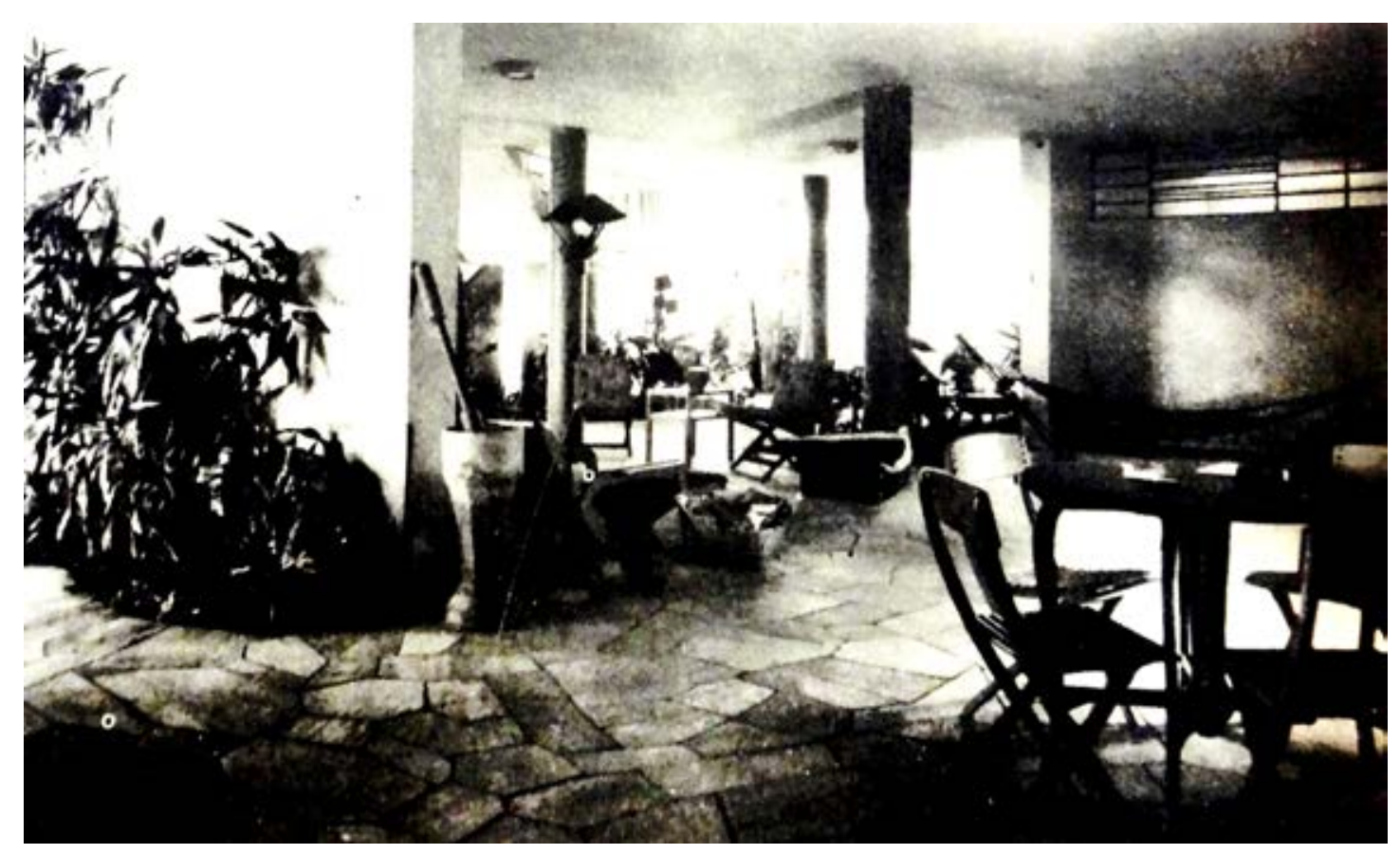

Fig.2.88 - Grande espaço de estar, abaixo do térreo, na casa do Morumbi, projetada por Luiz Saia.

Mas, podemos perceber algumas referências não tão explícitas à tradição. Entre elas, os caixilhos de concreto, que escondem o setor de serviço. É um recurso que remete às antigas rótulas em madeira, que protegiam a casa dos olhares estranhos. Além disso, a sala de estar liga-se ao jardim interno, dotado de uma pérgula. Esta é uma solução que lembra as varandas das casas urbanas coloniais, um local reservado à família e resguardado da rua.

\footnotetext{
${ }^{76}$ Publicada em Casa e Jardim e também na revista Acrópole: M., 1961 e RESIDÊNCIA NO MORUMBI..., 1956. Proprietário Guilherme Hannud. Destaca-se, na casa, o grande espaço de estar, espécie de varanda, em uma espécie de subsolo, permitido pelos pilotis que suportam parte do pavimento térreo, resolvendo a questão do terreno inclinado. No térreo, o living tem vários ambientes e portas de vidro o comunicam com o jardim. Os dormitórios apresentam um pátio externo privativo.
} 


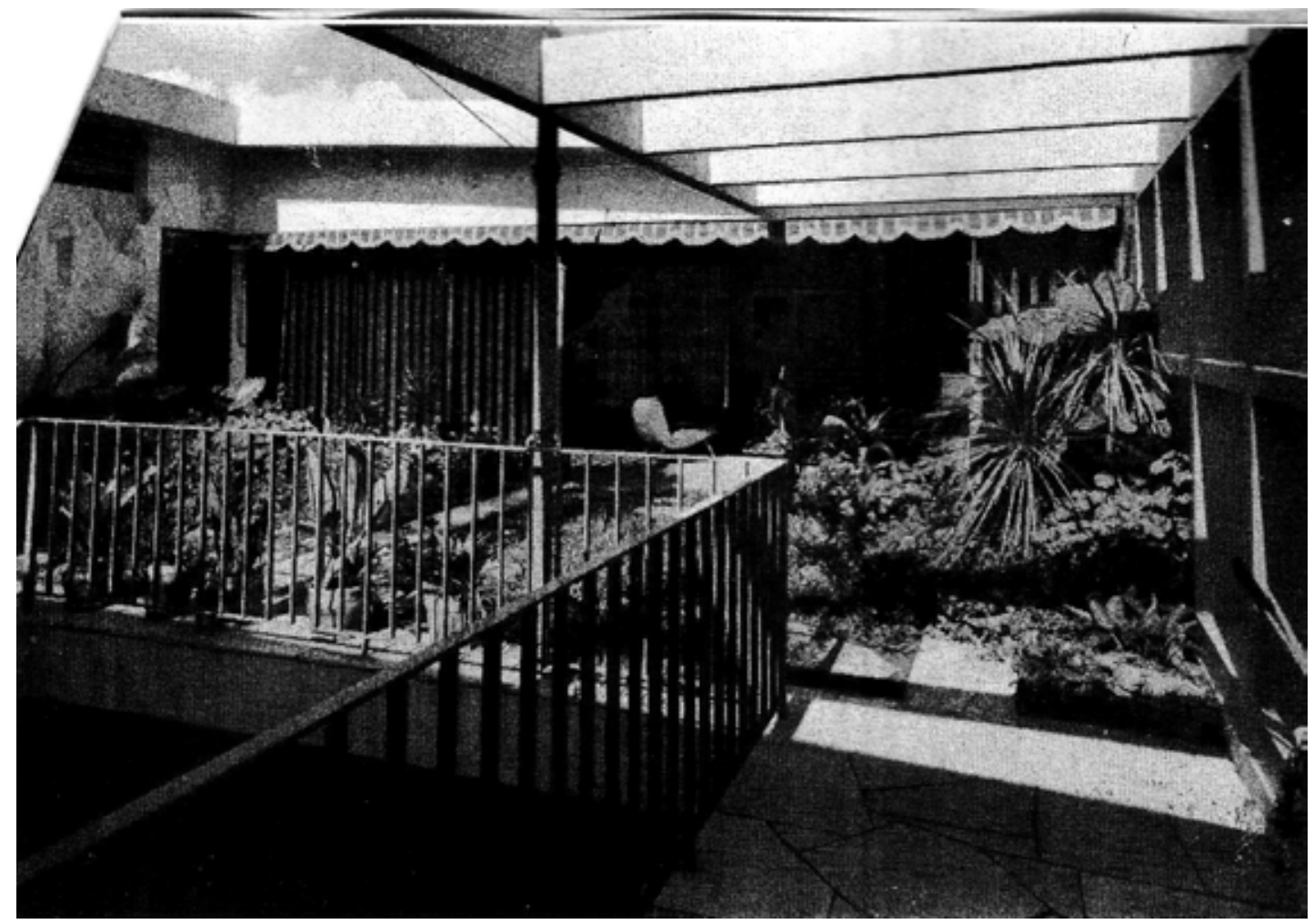

Fig.2.89 - Jardim interno com pérgola, da mesma casa.

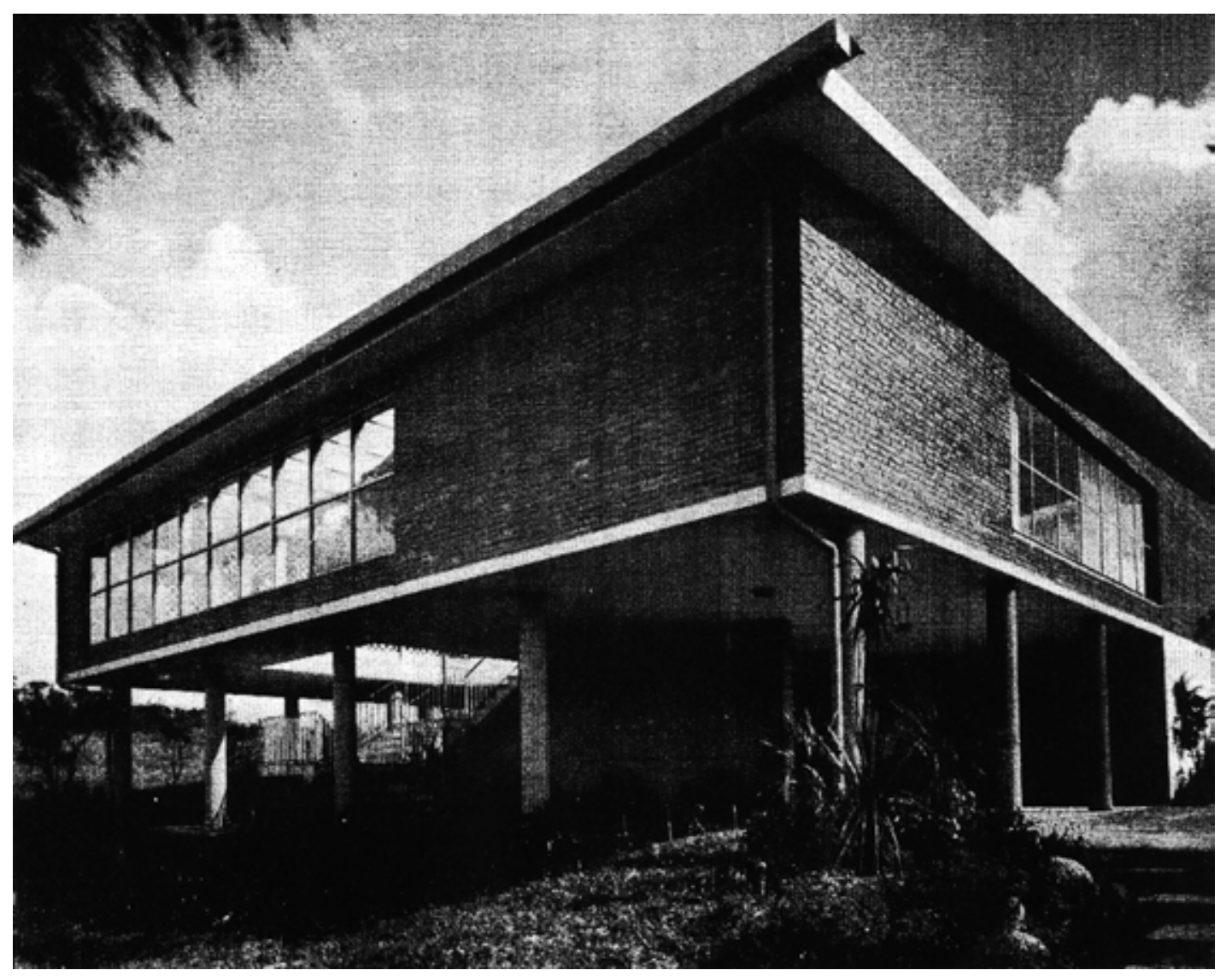

Fig.2.90 - Vista posterior da mesma casa no Morumbi. 
Saia projetou ao menos outra residência em São Paulo, no Alto de Pinheiros. ${ }^{77}$ Nesta, a área de estar é constituída por dois grandes ambientes conjugados, além de uma espécie de alpendre, que é chamado de hall, fechado com "balaústres de seção quadrada, dispostos diagonalmente, solução esta que 'persegue' a arquitetura paulista de residências desde o século XVII." (RESIDÊNCIA NO ALTO..., 1957, p.280)

O alpendre das casas paulistas coloniais rurais localizava-se na fachada frontal, entre a capela e o quarto de hóspedes, funcionando como anteparo, espécie de transição entre o espaço exterior e a residência em si. Estão implícitos aí traços do caráter do paulista, como a hospitalidade, mas também certa reserva em relação aos visitantes. Saia procura preservar esses hábitos, em sua arquitetura.

Ele recria seu uso, para a recepção de visitantes, neste "hall-alpendre," que confere certa proteção, impedindo o contato direto com a rua. Pois, a preocupação com a segurança das residências já estava presente na metrópole paulistana nos anos 1950. E o arquiteto procura conformar seus projetos ao modo de vida moderno, às questões que inquietavam o homem da época.

Saia (1957a, p.42) lembra que os fazendeiros de café "trouxeram para a residência urbana certas soluções de agenciamento e de organização do espaço, como é o caso do alpendre, cujo recobrimento plástico pôde aceitar diferentes formas." Os esquemas antigos poderiam ser acolhidos, desde que aplicados "com espírito peculiar da época." (Ibid. p.38)

Ele já encontrara na arquitetura do passado um "fenômeno muito preciso de regionalização de arquitetura residencial." (SAIA, 1957b, p.6) Os paulistas haviam adotado um tipo de habitação com um programa, um sistema construtivo e resultados plásticos em pleno acordo com o estilo de vida que levavam.

Nessas residências, Saia se utiliza de uma linguagem comum: "fundem-se" materiais tradicionais, como o tijolo maciço de barro, em grande parte deixado aparente, e contemporâneos. Saia (1957a, p.35) dizia que a arquitetura contemporânea levaria a uma atualização plástica, técnica e funcional dos materiais tradicionais. Os "materiais antigos vistos sob novo ponto de vista."

Assim, o arquiteto indica um caminho para se buscarem referências na arquitetura tradicional, sem enfatizar apenas seu aspecto formal. Esse tipo de abordagem não

\footnotetext{
${ }^{77}$ RESIDÊNCIA NO ALTO..., 1957, mostrada na revista Acrópole, mas não em Casa e Jardim. No entanto, pode ser considerada uma casa do "bem viver."
} 
considera a tradição apenas como inspiração plástica. Ou em desacordo com o material, a técnica ou a finalidade. Para isso, Saia dizia que o arquiteto contemporâneo deveria abrir-se ao conhecimento e interpretação das questões regionais.

Saia estava especialmente preparado para tratar desse tema, a partir de seus estudos sobre o patrimônio. Em sua arquitetura, ele reelabora a tradição vernácula, adequando o edifício a climas, culturas e lugares diversos.

Como em outras casas do "bem viver," vê-se no trabalho do arquiteto a utilização da linguagem moderna, com linhas e volumes definidos, mas também o tratamento de superfícies com texturas e cores e a valorização dos detalhes.

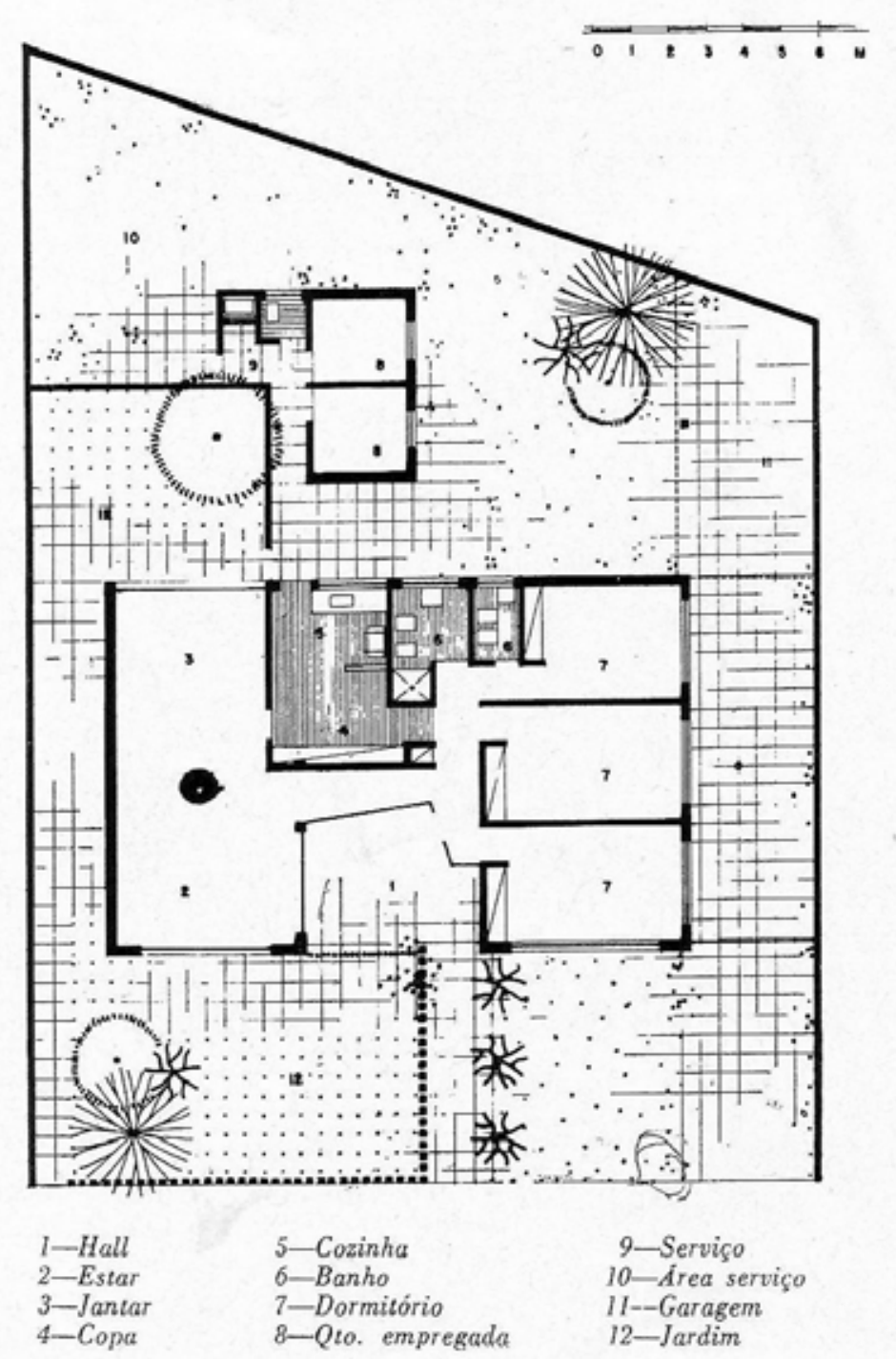

Fig.2.91 - Planta baixa da casa projetada por Luiz Saia, no Alto de Pinheiros. 


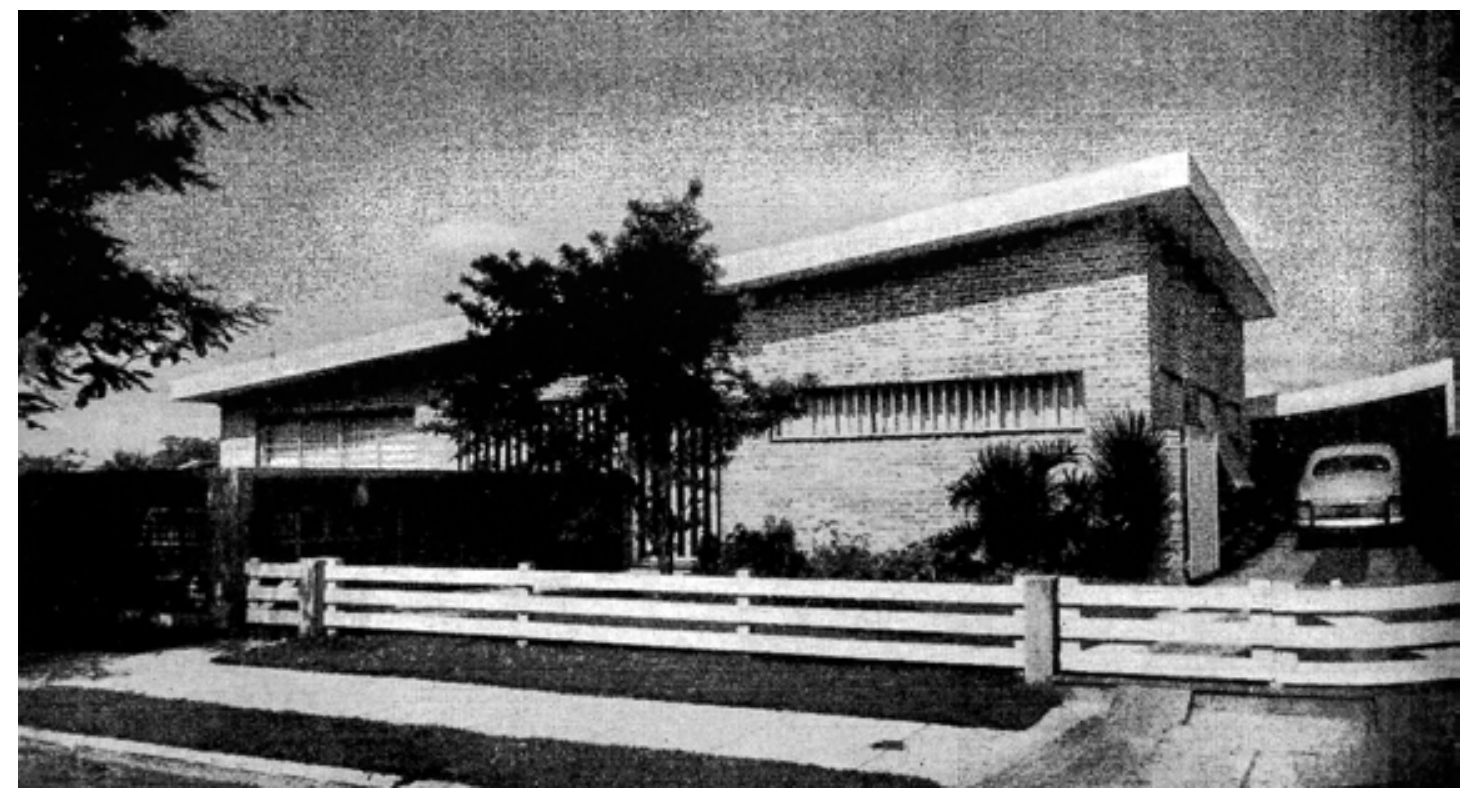

Fig.2.92 - Fachada da mesma casa.

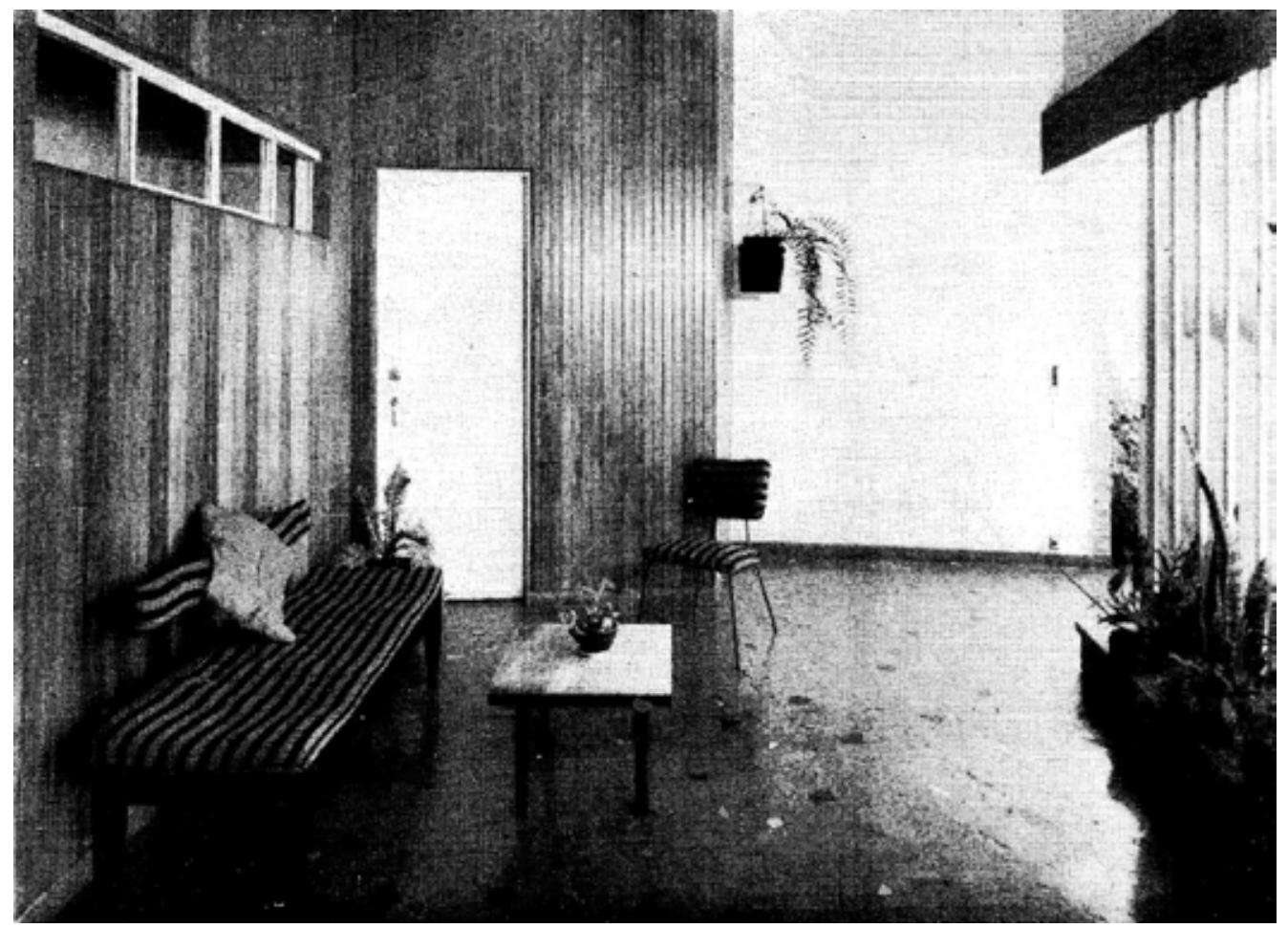

Fig.2.93 - 0 alpendre da casa no Alto de Pinheiros.

Pode-se afirmar que existe uma sintonia entre as reflexões de Saia e as transformações pelas quais passava a arquitetura nos anos 1950, entre as quais, as críticas que se faziam ao Movimento Moderno, particularmente nos CIAMs.

Essa crítica interna do Movimento Moderno foi levada à frente principalmente pelo 
Team $\mathrm{X}$, questionando as limitações e deficiências dos princípios originais do movimento. Entre elas, a falta de atenção a elementos culturais específicos, relacionados a determinada região. ${ }^{78}$

Tentou-se, dessa forma, assimilar elementos estranhos à tradição da arquitetura erudita, provenientes da arquitetura vernácula.

O Team X mostra, também, a necessidade de novas ferramentas analíticas e conceituais. O conhecimento não é mais visto como tautológico e absoluto, mas como analítico e relacionado a determinada estrutura. Trata-se de uma nova abordagem para a arquitetura, baseada no conhecimento dos objetos, processos e estruturas do mundo real. Ocorre uma transição, no CIAM, entre 1928 e 1947, entre valores absolutos e a análise de fatos empíricos. (AVERMAETE, 2005, p.63)

No CIAM de Otterlo na Holanda, em 1959, Aldo Van Eyck coloca-se contra "a antitética compreensão das três tradições que pertencem ao campo da arquitetura: a tradição clássica, a tradição da construção espontânea e a tradição moderna." (Ibid., p.18-9) Apesar de, normalmente, serem consideradas mutuamente exclusivas, Van Eyck argumenta que todas incorporam valores fundamentais da arquitetura. Seriam realidades a serem reconciliadas, fontes produtivas de saber arquitetônico. ${ }^{79}$

Acabaram por ocorrer adequações aos vários contextos nacionais e, mesmo, regionais, considerando-se o clima e outras características naturais e sociais. Uma espécie de regionalização do Estilo Internacional.

$\mathrm{Na}$ exposição Brazil Builds, em 1943, no MOMA, ${ }^{80}$ a colocação lado a lado da arquitetura moderna brasileira e da arquitetura tradicional não deixa de ser uma tentativa de se legitimarem os exemplares modernos, reconciliando-os com o clima e o contexto cultural. (QUEZADO DECKKER, 2001, p.127)

Principalmente a partir dos anos 1950, percebe-se uma preocupação constante com a noção de "lugar" e um senso de materialidade. Essa inspiração em realidades tangíveis acabou por produzir resultados interessantes.

\footnotetext{
${ }^{78}$ Esse processo já se iniciara nos anos 1930, em uma espécie de "adaptação" do Movimento Moderno a valores arquitetônicos perenes, implícitos nos materiais e nos hábitos regionais de culturas diversos, com tradições distintas.

${ }^{79}$ A "tradição da construção espontânea," a que Van Eyck refere-se, é a que chamamos pinturesca, romântica ou regionalista.

${ }^{80}$ Foram selecionados e apresentados, como uma contribuição original à arquitetura moderna, um grupo de edifícios modernos no Brasil. A exposição apresentava fotografias, plantas, modelos, mapas e slides e esteve aberta entre 13 de janeiro e 28 de fevereiro de 1943. Era composta de duas partes, uma relacionada à arquitetura tradicional, a partir de 1652, e a outra à arquitetura moderna, da década anterior, o foco da exposição.
} 
Para Coulqhoun (2007a, p.141), o discurso sobre o regionalismo pressupõe que os valores culturais, inclusive a arquitetura, não são, a priori, imutáveis e universais mas dependem do particular, do específico, do local, de experiências que são herdadas. No regional, está implícita a diferença, que rejeita as tentativas de se sistematizarem os valores culturais, baseados nas leis naturais ou em outras teorias universalizantes.

Adaptação é uma das palavras de ordem, também, na arquitetura do "bem viver." A adequação a um morador específico, através de uma casa feita sob medida, e, teoricamente, conformada à sua cultura e local.

\subsection{Por quê a linguagem moderna?}

Até que ponto pode-se dizer que existe uma estética comum às casas do "bem viver"? Que trata-se realmente da linguagem moderna? Pois, no geral, quem olhasse tais casas, em princípio não veria uma linguagem comum. Quais são os princípios que norteiam seu desenho?

As casas, à primeira vista, não parecem "rigorosamente" modernas. Algumas são bangalôs com telhados tradicionais, pois “(...) é bem (sic) de ver, que não pretendemos nos arvorar em mentores unicamente da arquitetura moderna, condenando tudo o que for antiquado ou tradicional - por isso que existem casas antigas, inúmeras até, muito mais bonitas, do que algumas de um modernismo mal compreendido. Nosso desejo, por conseguinte, é tão somente o de chamar a atenção dos nossos leitores para a racionalização inteligente relativa às soluções das plantas baixas, sugeridas (...)." (DO RASCUNHO..., 1956, p.68)

Porém, em outras, vê-se a utilização da linguagem do Movimento Moderno, de forma mais "pura." No entanto, os grandes volumes, do início do Movimento Moderno, são decompostos em planos, tratados com diferentes materiais e cores, para ressaltá-los.

Entretanto, mesmo quando não apresentam "feições" típicas da arquitetura moderna, existem, nas casas do "bem viver," alguns "elementos-tipo," ${ }^{11}$ como pilotis,

\footnotetext{
81 "Elementos-tipo" porque não são meros objetos para serem chamados "objetos-tipo," mas partes do edifício como pilotis, pilotis em $\mathrm{V}$, janelas em faixa, rampas, lajes em balanço, etc.
} 
alguns em V, "brotando" de floreiras, rampas circulares e outros, que são utilizados de forma recorrente.

Apesar do discurso valorizando a simplicidade e a eliminação de detalhes supérfluos, inúmeros projetos com tais detalhes são mostrados em Casa e Jardim e, nos textos, é elogiada sua utilização.

Porém, em outros casos, criticam-se tais exageros, afirmando-se que constituíam mero formalismo: "Vemos às vezes pequenas residências nas quais vão penduradas as várias 'marcas registradas' do 'estilo moderno', numa superabundância de arcos, 'marquises', apoios em V, acabamentos em cerâmica, canjiquinha e mosaico de vidro, como se materiais ou formas bem integradas, numa ou noutra obra famosa, garantissem reunidos um efeito ainda mais favorável..." (PROCHNIK, 1954a, p.8) ${ }^{82}$

Esse era um tema em discussão, à época. Saia (1957a, p.46-7) criticava a utilização de tais elementos em situações em que não caberiam, transformando-os, em muitos casos, em solução autônoma. Os pilotis teriam se reduzido a um modelo ideal, interpretado de forma plástica, apenas.

Com efeito, as cartas do atual baralho são poucas e fáceis, eficientes e rendosas: meia dúzia de soluções formais e algumas palavras de poder mágico: "brise-soleil," "colunas em V," "pilotis," "amebas," "panos contínuos de vidro," "moderno," "funcional," etc. O prestígio dessas formas e palavras e o seu abuso sonegam a consideração justa dos problemas que realmente são propostos pelo trato mais consentâneo da nossa arquitetura. (SAIA, 1987, p.200) ${ }^{83}$

As críticas de Saia são semelhantes às de Max Bill, em relação à arquitetura formalista europeia, americana e brasileira. Ele condenava suas formas e sua modernidade superficial. Bill (1954, p.28) descreve assim um edifício visitado por ele em São Paulo: “(...) uma formidável mistura de sistemas de construção, de pilotis largos, de pilotis finos, de pilotis de formas fantásticas, sem nenhuma finalidade construtiva, colocados em diferentes direções (...)."

\footnotetext{
${ }^{82}$ Rachel E. Prochnik era correspondente da revista no Rio de Janeiro. Essa casa, mostrada em Casa e Jardim, localizava-se na llha do Governador, no Rio de Janeiro.

${ }^{83}$ Artigo publicado originalmente em 1954: SAIA, Luís. A fase heroica da Arquitetura Contemporânea Brasileira já foi esgotada há alguns anos. Arte em Revista. n.4, p. 51.
} 


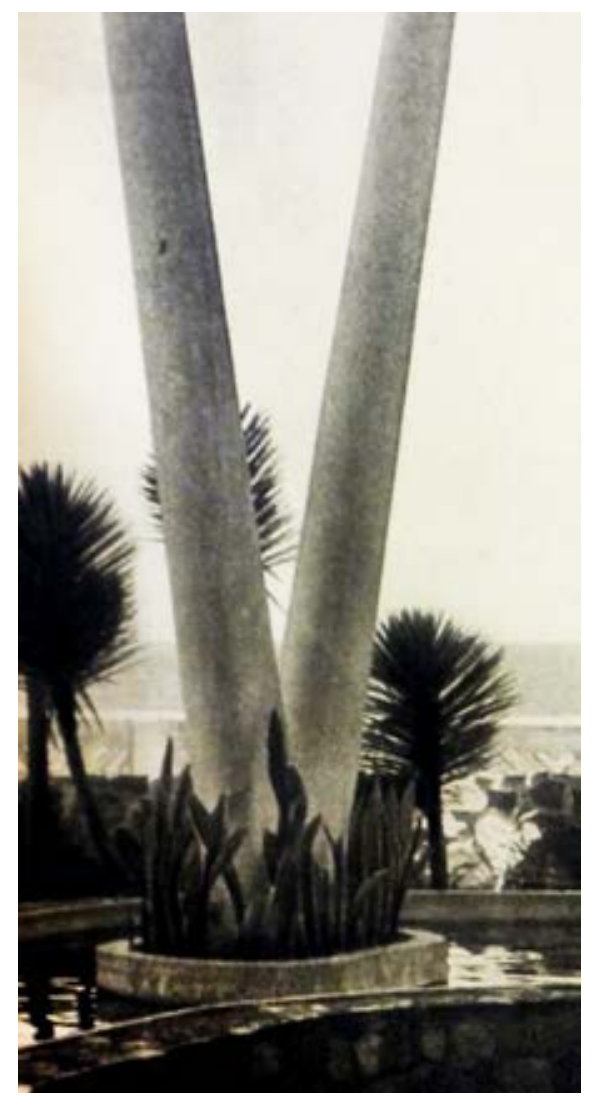

Fig.2.94 - Pilotis em “V”, na residência do arquiteto Lev Smarcevscki.

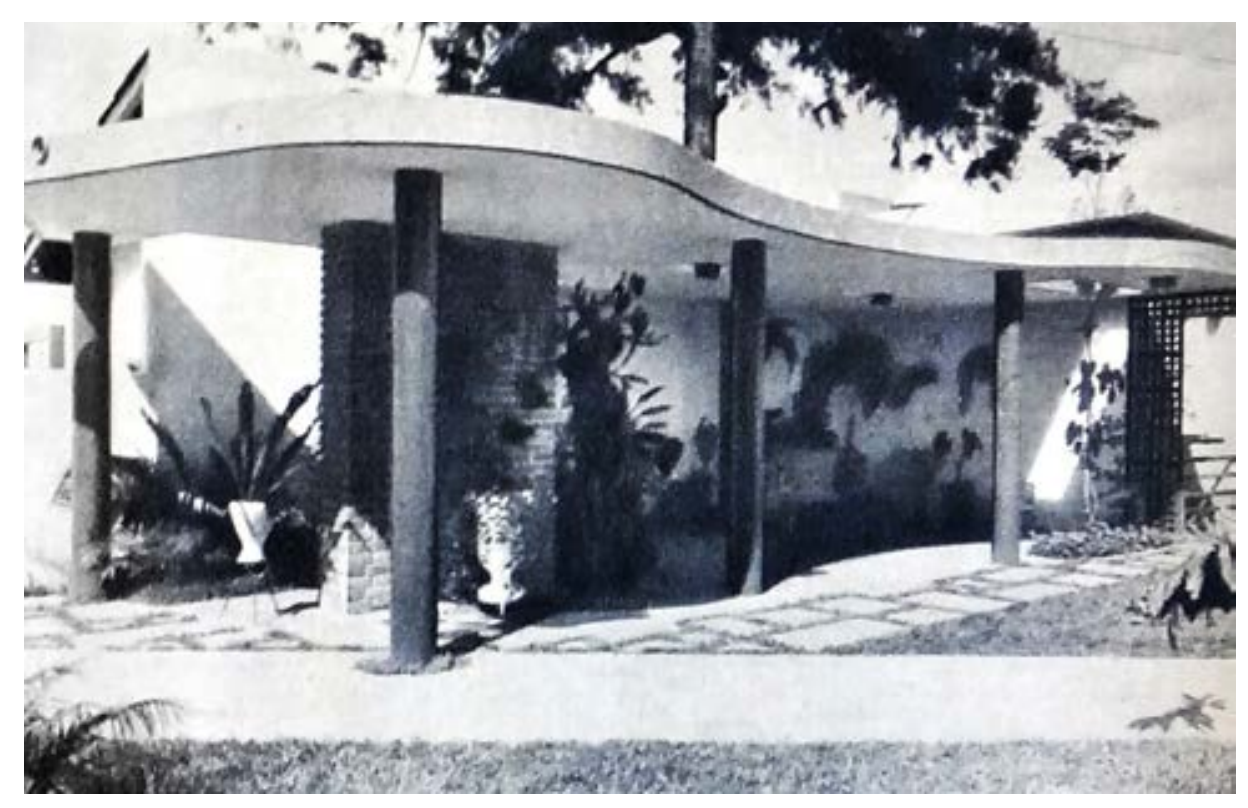

Fig.2.95 - Pilotis em profusão na residência do arquiteto Eduardo Corona, a “casa do galo.”

A partir da valorização da produção da "escola carioca," não se levaram em consideração as discussões europeias sobre aspectos contrários à Carta de Atenas. Os arquitetos brasileiros, no pós-guerra, não participaram dos debates nos CIAMs, 
de forma coletiva, onde ganhavam relevo as críticas aos princípios da arquitetura moderna. (BUZZAR, 1996, p.1)

Tudo isso tornou mais difícil uma discussão profunda sobre nossa arquitetura e sobre aspectos como o formalismo de parte da produção brasileira. Esta questão reflete-se na arquitetura do "bem viver," nos "elementos-tipo" mencionados e em tipologias recorrentes, por exemplo.

Uma destas tipologias é o volume suspenso do solo, com cobertura em uma água, onde estão os principais ambientes. ${ }^{84} \mathrm{O}$ acesso a esse piso é feito por uma rampa circular, sendo o pavimento térreo reservado para garagem e serviço.

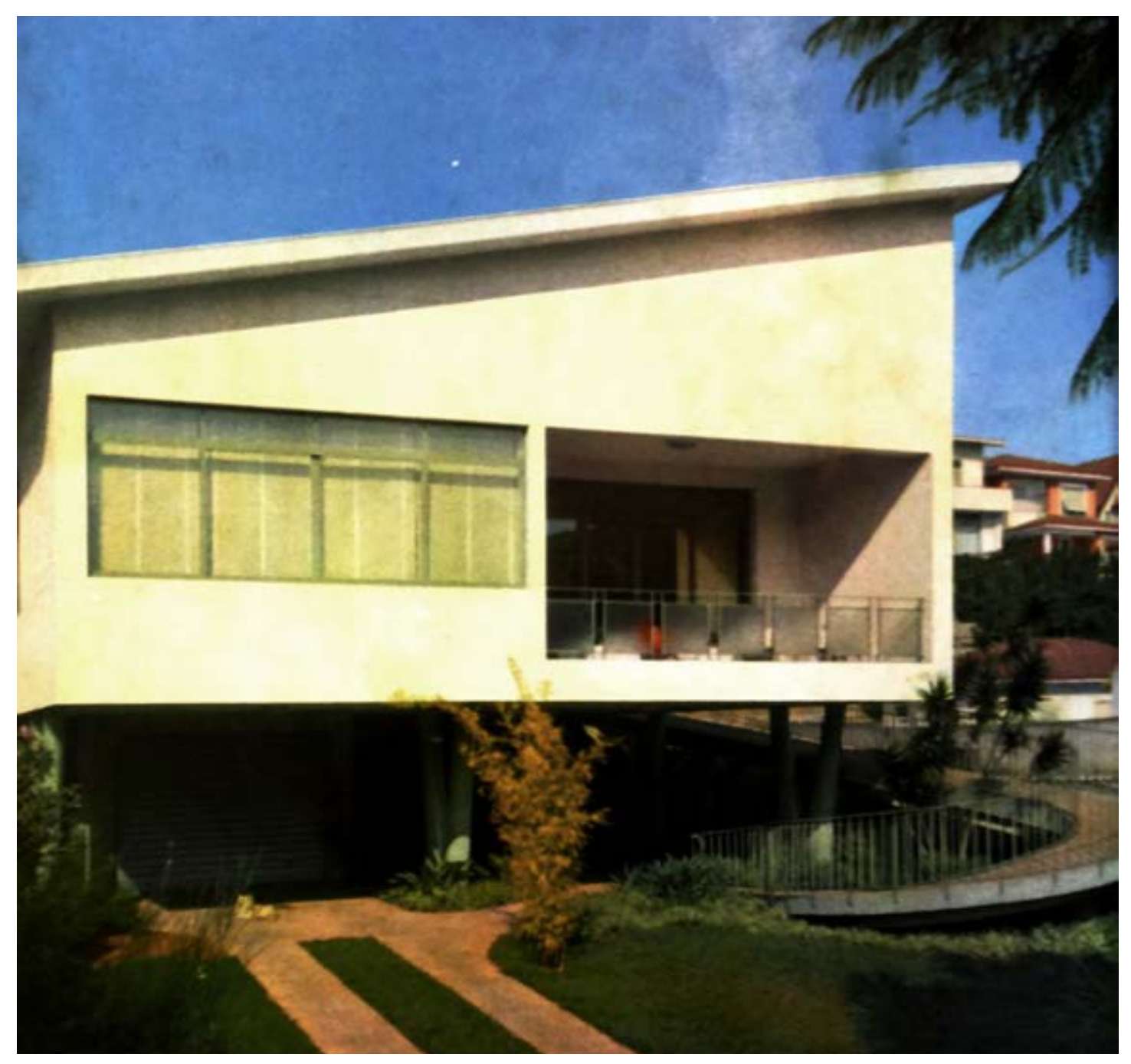

Fig.2.96 - Casa na Avenida Pacaembu.

\footnotetext{
${ }^{84}$ A HABITAÇÃO, 1955. Não consta o autor do projeto da residência localizada na Avenida Pacaembu, em São Paulo.
} 


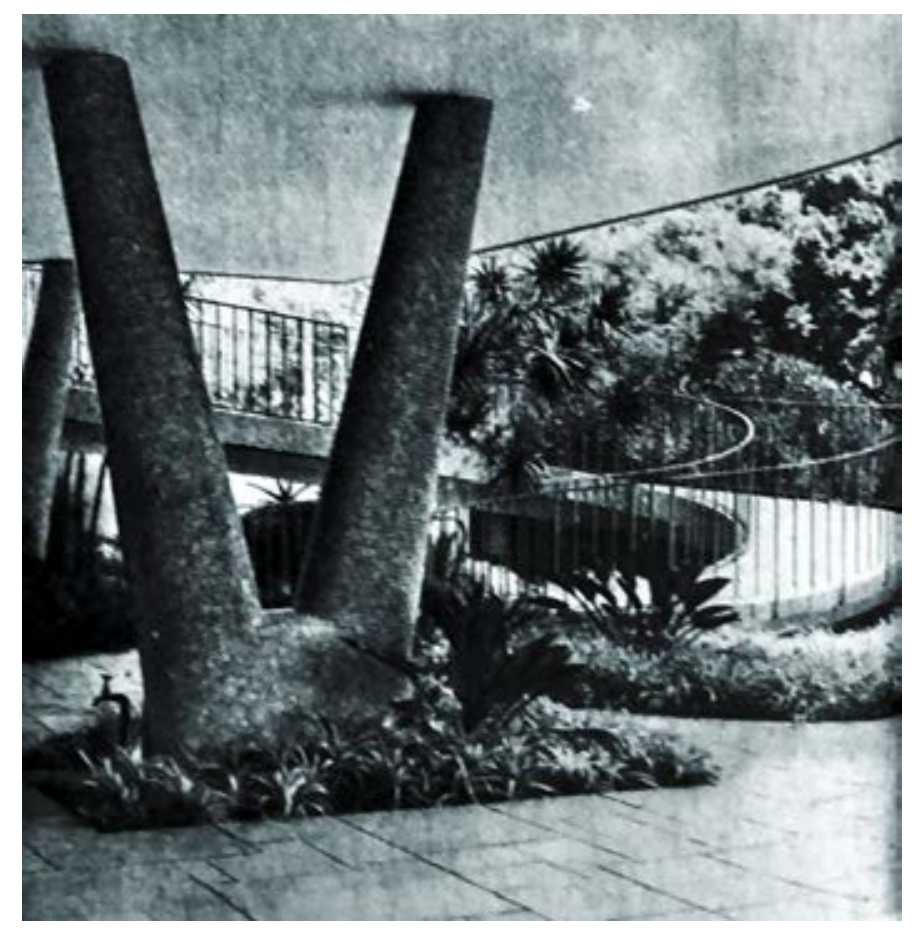

Fig.2.97 - Pavimento térreo da casa anterior.

As reportagens da revista, geralmente, mostram os projetos sem as plantas baixas, o que dificulta sua compreensão. Além disso, os edifícios são expostos a partir de ângulos que não permitem sua percepção real, mas valorizam-se aspectos ressaltados no texto. As fotos corroboram o discurso.

Entre os aspectos ressaltados em relação à linguagem utilizada na arquitetura do "bem viver," está a afirmação da horizontalidade dos edifícios. Para isso, mesmo que as coberturas não sejam planas, são mostradas sob determinadas perspectivas que levam a essa percepção.

Nos textos que acompanham os projetos, repetem-se ideias e considerações. E a qualidade do projeto, muitas vezes, não corresponde à que é descrita. Frequentemente, determinados atributos são ressaltados excessivamente.

Todas essas observações, esse discurso, levam quase sempre ao moderno. Mas, que "moderno"? Às vezes, parece algo difuso, como uma "sensação," que opõe-se ao tradicional, que seria algo estabelecido e desgastado.

Outras vezes, menciona-se uma maneira ultrapassada de se viver, à qual o moderno se contrapõe.

Em outras situações, moderno corresponde a um novo estilo arquitetônico, que contrasta com uma arquitetura que é necessário desestabilizar e remover. 
Nessa espécie de "campanha" contra o que é ultrapassado, em Casa e Jardim, às vezes, comparam-se soluções boas e ruins: "Assim como simpatizamos mais com esta ou aquela pessoa, o mesmo se dá com referência às casas. (...) Nem sempre conseguimos definir as razões por que gostamos desta ou desgostamos daquela residência." (PORQUE GOSTAMOS..., 1954, p.5 e 64)

As fotos que ilustram esse texto mostram, em primeiro lugar, uma casa com feições modernas: vigas que reforçam a horizontalidade, muro e embasamento em pedras, grandes janelas. A segunda casa apresenta arquitetura tradicional, com detalhes decorativos variados. Esta seria "antipática (e) completamente desequilibrada." (Ibid., p.64)
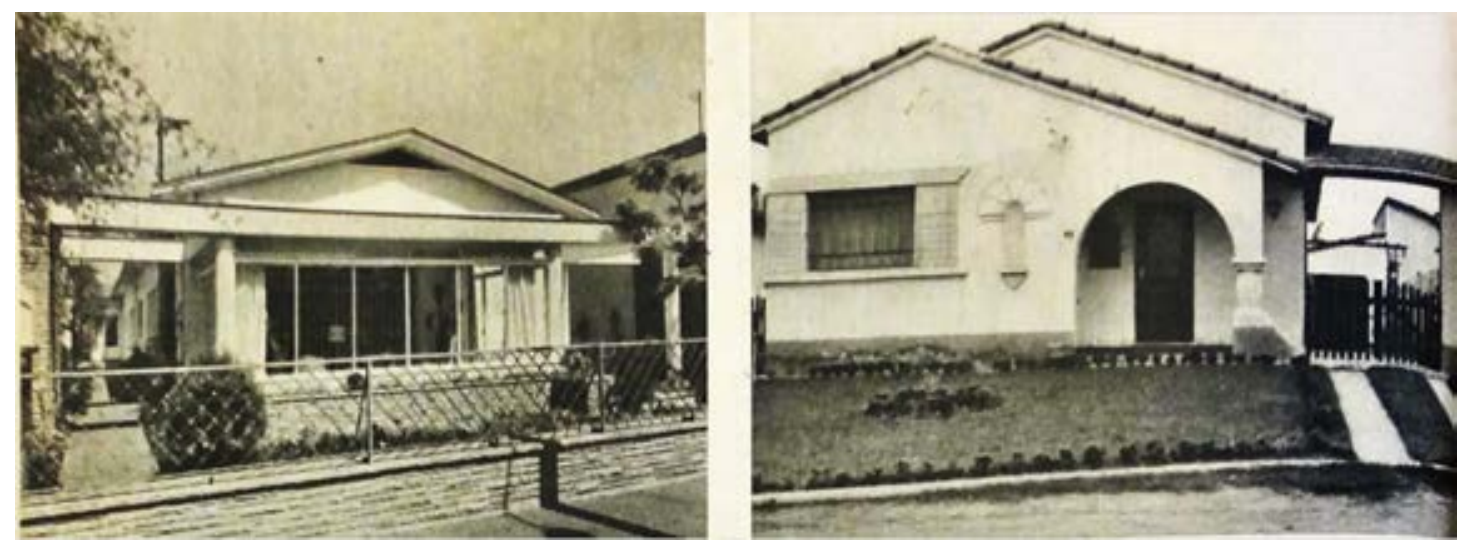

Fig.2.98 - Casa moderna e casa "antipática," comparação entre soluções boas e ruins.

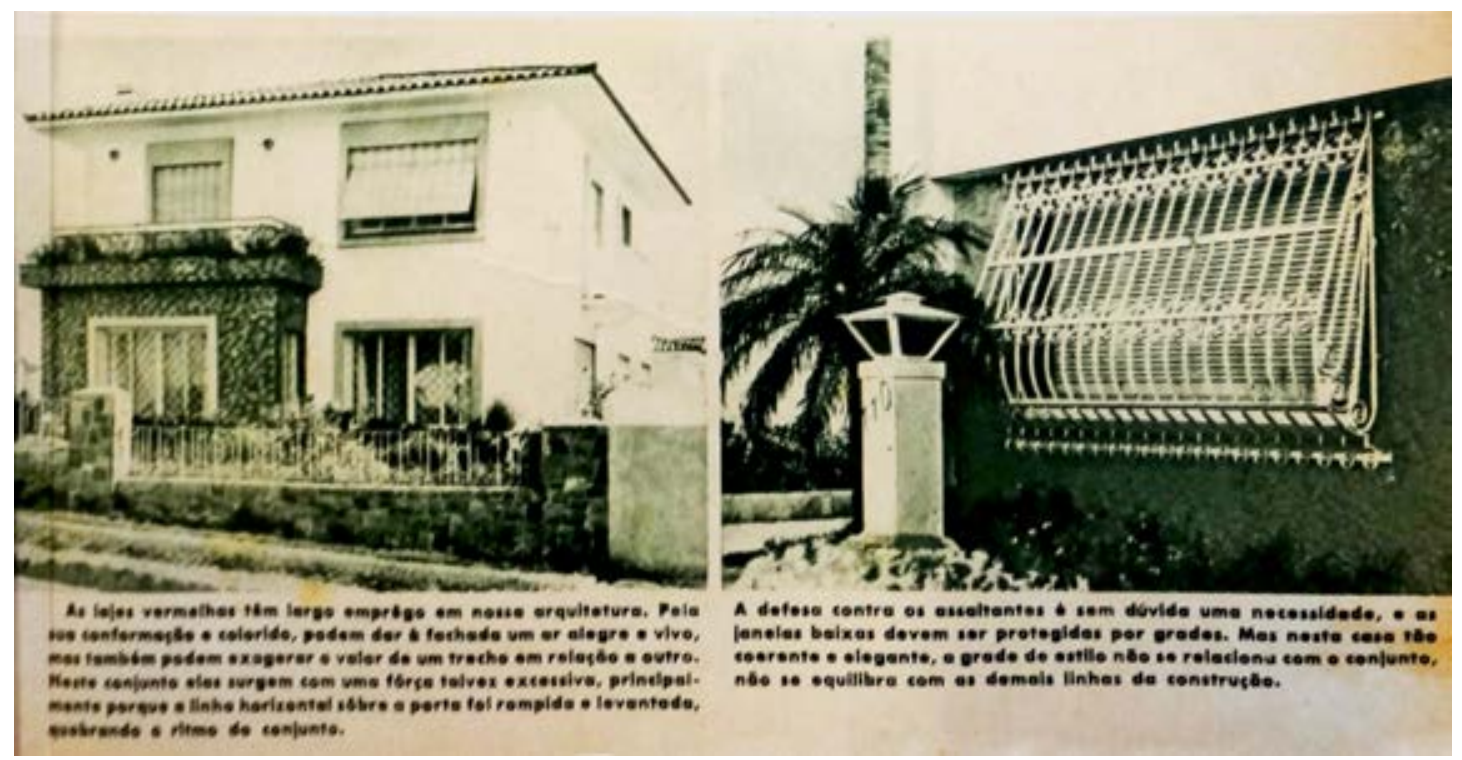

Fig.2.99 - Aulas de estética moderna. 
Procura-se reafirmar a racionalidade da arquitetura moderna, contraposta ao gosto "variável" tradicional: "A arquitetura é uma ciência e uma arte. Há requisitos a que ela deve ater-se necessariamente, e outros que se subordinam ao gosto variável dos construtores e dos proprietários. (...) Muitos estilos se alinham uns ao lado de outros, testemunhas de modas que já passaram, de tendências que hoje predominam, de rumos que vão sendo abertos." (EVITE..., 1953, p.26)

Porém, essa defesa da linguagem moderna não era assim tão rígida: "não vamos, aqui, adotar uma 'escola', e condenar tudo o que a ela escape." (Ibid., p.26)

Outra questão importante é a associação da linguagem moderna a características como juventude e informalidade. Procura-se diferencia-la do que está estabelecido mostrado como velho e em desuso.

Associa-se, por exemplo, em Casa e Jardim, a preferência pela estética tradicional aos membros mais velhos da família - que utilizam o termo sala de visitas. Enquanto as gerações mais jovens optam por uma casa com living, moderna no "estilo," na tipologia - térrea -, no projeto e na decoração. ${ }^{85}$

Quanto aos arquitetos, quando estes são jovens, este fato é sublinhado e considerado positivo. Pois juventude é associada a qualidades como moderno, atual, contemporâneo. Além disso, significa que a formação do profissional também é moderna: "Simplicidade construtiva, fácil manutenção, materiais simpáticos, reunidos pelo jovem arquiteto num conjunto despretensioso, saúdam à primeira vista o visitante com um amável 'à vontade'. Tudo isso - e a serra também!" (PROCHNIK, 1956c, p.22) ${ }^{86}$ Percebe-se, no trecho citado, confiança e informalidade, contrapondo-se, implicitamente, ao que é antigo, formal, complicado.

No entanto, informalidade em excesso também poderia afastar o público de Casa e Jardim. "Moderno é sinônimo de informal?"87 questiona-se. Segundo o texto, apesar de o moderno geralmente ser associado ao informal, esse vínculo não seria indissociável, mas apenas uma afinidade. Pois, de qualquer forma, "os ideais de vida do homem evoluíam na direção de maior simplicidade, maior facilidade, melhor nível para maior número." (PROCHNIK, 1958, p.24) Não seria necessário evitar o

\footnotetext{
${ }^{85}$ LUCKMANN, 1957.

${ }^{86} \mathrm{O}$ jovem arquiteto é Marcello Fragelli. Proprietário E. de Mello Costa. A casa localizava-se em Petrópolis.

${ }^{87}$ Projeto de Sérgio Bernardes. Interessante notar que são utilizadas esquadrias em alumínio anodizado.
} 
contemporâneo para fugir do informal, bastaria uma correta definição dos espaços e das formas e um adequado uso dos materiais, entre outros aspectos.

Outra questão levantada pela revista era o cansaço do público em relação à "limpeza decorativa" moderna. Esse fato poderia levar, em contrapartida, ao exagero na arquitetura e na decoração. Pois, após um período em que "as formas funcionais se impunham pela sua nua beleza," novamente se notava "a tendência aos enfeites, talvez por estarmos enfastiados com a sólida objetividade do construtivismo." (SUHR, 1955, p.4) Pedia-se "Qualidade, não quantidade!." (Ibid., p.71)

Mas, os excessos da "limpeza moderna" também deveriam ser evitados: "existem revolucionários que creem poder com a palavra 'funcional' desculpar e, ainda, encorajar excrescências as mais feias em gostos e ideias. É verdadeiramente inconcebível que pessoas de muito bom senso (...) deponham as armas diante de um pseudomodernismo que nem é sentido, nem sabido e nem mesmo compreendido pelos seus autores próprios." (A CULTURA..., 1954, p.13) ${ }^{88}$

Os custos em relação à utilização da linguagem moderna também eram objeto de discussão, em Casa e Jardim. Era necessário afastar a falsa impressão de que seriam menores, mas deveria ser ressaltada a qualidade dos materiais - pastilhas, cerâmicas, elementos vazados, etc. Estes seriam mais caros que um simples reboco, porém a economia apareceria com o tempo, devido à sua durabilidade, lembrando, ainda, que eram fundamentais para o efeito pretendido.

Em arquitetura moderna não são somente as linhas simples e funcionais que the dão os efeitos desejados e sim também a utilização harmoniosa dos materiais modernos de construção, nem sempre baratos. (...) Nem sempre as coisas por serem simples se tornam mais baratas, pelo contrário, em geral as coisas simples brilham por sua qualidade via de regra mais onerosa. (sic) (LUCKMANN, 1959, p.44) ${ }^{89}$

Porém, outros aspectos da linguagem moderna não são discutidos, como o fato da retirada dos beirais do telhado ${ }^{90}$ - que protegiam a fachada - não apresentarem realmente uma justificativa prática, mas apenas estética. Seriam necessárias, nesse caso, esquadrias mais resistentes e persianas, que teriam um custo maior. $\mathrm{E}$, em uma arquitetura para a classe média, esta questão é fundamental.

\footnotetext{
${ }^{88}$ Projeto e execução do "Studio Lar Moderno," de Henrique Alexander.

${ }^{89}$ Publicado na seção Conselho C e J.

${ }^{90}$ No entanto, grande parte das casas do "bem viver" apresenta telhado aparente com beirais.
} 
Stevens (2003, p.118) lembra que os que estão estabelecidos no campo da arquitetura devem evitar a possibilidade de que se revele "a arbitrariedade essencial de sua estética." Podemos utilizar sua interpretação para analisar a escolha da linguagem moderna para a arquitetura do "bem viver."

Ele adota, em boa parte de seu trabalho, o aparato analítico do sociólogo francês Pierre Bourdieu, ${ }^{91}$ que considera a sociedade um espaço relacional, ocupado por pessoas e instituições, cada qual competindo a seu favor. Essas "pessoas estão sempre em algum tipo de relação com todas as demais, seja ela superior, inferior ou igual." (STEVENS, 2003, p.62) ${ }^{92}$

Nos vários campos ${ }^{93}$ abrangidos pela sociedade e que se intersectam, alguns grupos são subordinados e outros dominantes, pois conseguem promover melhor seus interesses. Pois, entre outros aspectos, controlam mais recursos.

Esses recursos são de vários tipos. O tipo de poder mais óbvio é a força física. Outro é o econômico, conceito utilizado pela teoria marxista. Bourdieu, ampliando a teoria de Max Weber, demonstra que existe um terceiro tipo de poder, o simbólico, que envolve a manipulação de conceitos, símbolos e ideias para se atingir um fim.

O poder simbólico compreende a posse de capital cultural ${ }^{94}$ e atua de forma muito mais eficaz porque convence os "subordinados" a serem cúmplices em sua própria sujeição. Pois, ele é percebido, de forma equivocada, como legítimo e natural.

O campo no qual este poder atua é a cultura. Ele legitima a cultura dominante, valorizando seus bens e práticas simbólicas, em detrimento de outras. Nesse

\footnotetext{
${ }^{91}$ Existem dificuldades em relação a seu estilo, prolixo, discursivo, complexo e formal, de difícil compreensão. Por isso, utilizaremos a leitura de Stevens (2003), inclusive pelo fato deste autor aplicar diretamente as análises de Bourdieu ao campo da arquitetura.

${ }^{92}$ Para Bourdieu, "uma classe é um grupo de pessoas que ocupa posições similares no espaço social".P.Bourdieu, "What Makes a Social Class? On Theoretical and Practical Existence of Groups", Berkeley Journal of Sociology 32 (1987):1-16 apud STEVENS, 2003, p.80

${ }^{93}$ Um campo seria um "conjunto de instituições sociais, indivíduos e discursos que se suportam mutuamente." (Ibid., p.90) A sociedade é constituída por muitos campos que podem se sobrepor, como o da religião e o da educação. O da arquitetura é constituído por arquitetos, críticos, professores de arquitetura, construtores, todo tipo de clientes, uma parcela do Estado envolvida com a construção, instituições financeiras, o discurso arquitetônico, as exigências legais, etc.

${ }^{94}$ As outras formas de capital cultural, segundo Bourdieu, seriam: institucional -as qualificações acadêmicas e realizações educacionais-; objetivado - constituído por objetos ou bens culturais como obras de arte -; social -redes de pessoas com as quais se pode contar. (Ibid., p.76)
} 
campo, "são travadas as batalhas simbólicas da sociedade," (STEVENS, 2003, p.94) muito mais complexas. ${ }^{95}$

O campo é um espaço dinâmico e a posição de um indivíduo é definida de modo relativo. Isso acontece porque o valor do capital que este individuo possui depende do estado do todo e está sujeito a desvalorizações e reavaliações, na medida em que muda o estado do campo.

No caso do capital simbólico, seu valor, estabelecido pelo campo, é arbitrário e pode mudar ao longo do tempo. Foi o que aconteceu quando a valorização do capital do Movimento Moderno acabou por ocasionar a desvalorização do capital das beauxarts.

Algo similar acontece no campo da arquitetura em São Paulo entre os anos 1920 e 1940. O capital simbólico e econômico que a arquitetura tradicional possuía era muito relevante ${ }^{96}$ e foi, aos poucos, sendo desvalorizado, na medida em que a linguagem moderna conquistava espaço.

Pois, o motor que impulsiona o campo é o conflito entre os que alcançaram o topo, a fração dominante, a linguagem estabelecida, e os que ainda não conseguiram, a fração subordinada dos recém chegados, a vanguarda.

Isso não significa que a arquitetura moderna passa a predominar, a apresentar uma presença maciça na cidade. Ela apenas passa a ser, no campo da arquitetura e mesmo da cultura como um todo, valorizada como a linguagem dominante, cujas práticas e escolhas são apreciadas.

É importante lembrar que a adoção da linguagem moderna aconteceu, no contexto paulistano, de forma diversa do Rio de Janeiro. Foi um processo mais lento e a formação do núcleo paulista do IAB teve papel fundamental.

Pois, apesar do vanguardismo de Warchavchik, em São Paulo não chegou a se formar, de início, um grupo coeso como o do Rio de Janeiro. ${ }^{97}$

E, a posição de ponta dos paulistanos em busca de uma modernidade, nos anos 1920, foi transferida para o Rio de Janeiro na década seguinte. ${ }^{98}$ Pois, ainda que no

\footnotetext{
${ }^{95}$ Pois, a palavra campo indica também um campo de batalha e um campo de forças. E a posição dos indivíduos no campo se altera pela totalidade das linhas de forças que ali atua. (STEVENS, 2003, p.91)

${ }^{96}$ Em suas diversas vertentes, inclusive àquela ligada às belas artes.

${ }^{97}$ Devemos ressaltar que o episódio do Ministério da Educação, que impulsionou a formação da Escola Carioca e o prestígio internacional decorrente, não pode ser generalizado para todo o país.

${ }^{98}$ Sintomático disso foi o Salão Moderno de 1931, organizado por Lúcio Costa frente a ENBA, e a formação de entidades intelectuais de perfil moderno enquanto esvaziava-se o movimento paulista.
} 
ambiente carioca a linguagem moderna também não predominasse, ela já estava presente, a partir dos anos $1930 .{ }^{99}$

Assim, a arquitetura moderna carioca tornava-se o exemplo a ser seguido. Enquanto que, em São Paulo, a maior parte dos arquitetos atuantes, entre os anos 1930 e 1940, permanecia alheio às questões levantadas pela arquitetura moderna. Havia ali um panorama bastante indefinido, em que várias linguagens arquitetônicas ainda eram utilizadas.

Oswaldo Bratke (1988, p.158), um dos arquitetos mais ativos na profissão entre 1930 e 1960 na cidade de São Paulo, lembra que, na época, a arquitetura paulistana mostrava-se diversa dos modelos modernos europeus, mas apresentava boas soluções, preferíveis a certos exemplares modernistas importados e inabitáveis.

As modificações nessa arquitetura aconteciam aos poucos, de forma lenta, refletindo transformações na forma de se viver. ${ }^{100}$ Eram mudanças no arranjo das plantas, nas técnicas construtivas e nos materiais utilizados. ${ }^{101}$

Nesse momento, as camadas médias da população, formadas por profissionais liberais e empresários, principalmente, expandiam-se, constituindo uma clientela potencial para os arquitetos, sobretudo após a Segunda Guerra Mundial. E, desejavam moradias modernas e personalizadas. Tinham, no entanto, recursos limitados, o que "casava" com a situação dos arquitetos mais jovens, não muito conhecidos, ainda sem clientes.

Apesar de que, para Bruand (2005, p.76), a “passagem do plano teórico para o prático" apenas teria sido possível com o contato direto com Le Corbusier, permitido com sua segunda visita. Essa "trama montada" para a narrativa sobre a arquitetura moderna brasileira já foi bem analisada por Martins (1987), para quem (2006, p.15), a narrativa que "prioriza o caráter brasileiro da arquitetura moderna desenvolvida a partir dos episódios-chave do Ministério e da Pampulha" tem seu início na publicação do livro Brazil Builds, de 1943.

${ }^{99}$ Em 1933, por exemplo, aconteceu o $1^{\circ}$ Salão de Arquitetura Tropical. No catálogo da exposição, são publicados o Manifesto de La Sarraz, informações sobre a fundação dos CIAMs e um pequeno texto de Walter Gropius, sobre o evento. Também são mostradas obras realizadas por Afonso Reidy, Marcello Roberto e pelo próprio Warchavchik, entre outros. (FERRAZ, 1965, p.193)

${ }^{100}$ Um viver de forma mais simples, principalmente na classe média, em torno da família, em casas menores, nos subúrbios.

${ }^{101}$ Em relação às técnicas e materiais, eles podem ser analisados através dos memoriais descritivos de construção, encontrados nos arquivos da Companhia City. Entre eles, a alvenaria aparente era muito utilizada, com embasamento e faixa junto ao beiral, pintados, para proteção contras as chuvas e a infiltração de águas no piso. As lajes de concreto, inicialmente aparecem apenas nos banheiros do pavimento superior, mas nos anos 1930, já são usadas em outros ambientes da casa e na cobertura. Vigas metálicas sob as paredes do pavimento superior permitiam grandes vãos nos ambientes do térreo. Assim, as estruturas eram usualmente mistas: alvenaria estrutural, vigas metálicas e lajes de concreto armado. Cf. JANJULIO, 2009, capítulo 5. 
Segundo Camargo (2000, p.78), Bratke conseguiu conquistar essa classe média para a arquitetura moderna, até então restrita a pequeno grupo de intelectuais, profissionais liberais e iniciados na arte moderna.

Estes novos clientes ocuparam, principalmente, os novos bairros jardins; e muitas das casas do "bem viver" foram construídas no Jardim América ${ }^{102}$ e em outros bairros novos, em direção e na outra margem do Rio Pinheiros.

A Escola Carioca manteve-se dominante, inspirada no modelo corbusiano até o fim dos anos 1950. Um modelo que propunha uma expressão nativa, uma manifestação da personalidade nacional e uma liberdade formal sem restrições. À margem do sucesso carioca, a arquitetura paulista teve um papel secundário durante os anos 1930 e 1940. Porém, a metrópole paulistana progredia rapidamente e a arquitetura acaba por se beneficiar desse crescimento econômico. Esse, entre outros aspectos, altera a hegemonia carioca, que é transferida para a arquitetura paulista. (LUCCAS, 2010, p.35) $)^{103}$

Os pioneiros na primeira etapa de assimilação da linguagem moderna no contexto paulistano seriam Henrique Mindlin, ${ }^{104}$ Rino Levi, Eduardo Kneese de Mello e Oswaldo Bratke. Além da atividade projetual de todos no período, deve ser lembrada sua participação na fundação do IAB-SP, em $1943 .{ }^{105}$ Com a constituição desse

\footnotetext{
${ }^{102}$ O Jardim América foi implantado pela Companhia City, começando a ser ocupado na segunda metade dos anos 1910. Não era um bairro da elite, ao menos em seus primeiros tempos. A companhia vendia os terrenos a prazo e também concedia financiamentos para a construção, tornando o loteamento acessível às camadas medias. Sobre a arquitetura e os arquitetos do Jardim América nos anos 1920, Cf. JANJULIO, 2009 e WOLFF, 2000.

${ }^{103}$ Dessa forma, a participação de São Paulo no cenário intelectual e artístico nacional cresce e tornase marcante, principalmente nos anos 1950, tendo os industriais paulistas assumido a iniciativa de fomentar cultura, após a Segunda Guerra Mundial.

${ }^{104}$ A trajetória de Mindlin caracteriza-se pela busca da racionalidade que caracteriza a arquitetura moderna, por exemplo, através de pesquisas relativas ao esquema de distribuição interna das edificações. Desvincula-se de qualquer preocupação formalista. Seu texto, "Análise Racional do Projeto (Método Klein)", publicado em Acrópole, n.3, ano I, julho 1938, p.39-46, relaciona-se diretamente às experiências dos arquitetos modernos, discutidas nos primeiros CIAMs, que envolvem a necessidade de uma avaliação objetiva do projeto arquitetônico. Segundo o texto, tal avaliação seria feita através do método desenvolvido por Alexander Klein.

${ }^{105}$ Os primeiros presidentes do IAB-SP foram: Eduardo Kneese de Mello (1943-50), Oswaldo Bratke (1950-52), Rino Levi (gestão iniciada em 1952). Henrique Mindlin, que se estabeleceu no Rio de Janeiro após uma estadia nos Estados Unidos (1943-1944), participou do Conselho Diretivo do IAB entre 1944 e 1946 e do Conselho Fiscal entre 1945 e 1947.
} 
núcleo, forma-se um grupo com princípios e objetivos comuns, entre eles, a construção de sua sede, através de um concurso em $1948 .{ }^{106}$

Bratke descreve assim o novo núcleo: "o IAB/SP estava ligado aos arquitetos modernos. Determinados arquitetos eram delicadamente afastados, uma vez que não eram reconhecidos por este time como arquitetos de vanguarda. E o IAB era, sem dúvida nenhuma, para os de vanguarda."107

A questão central na entidade era a arquitetura moderna. "Nós todos ficamos modernos, os que não eram foram se tornando... Dentro do IAB, só pensávamos a arquitetura contemporânea." (MELLO, Eduardo Kneese, 1985, p.9 apud FICHER, 2005, p. 249)

Adotada pelos jovens arquitetos, a tarefa era conquistar público para a arquitetura moderna. Não se pode deixar de pensar no IAB como um "campo de batalha," com fileiras cerradas em sua nova sede - instalada em um edifício emblemático.

E a formação dos primeiros profissionais nos cursos autônomos de arquitetura - no Mackenzie e na USP - estimulou também o florescimento da linguagem moderna em São Paulo.

Dessa forma, a cultura dominante passa a ser a desses grupos, desses pioneiros modernos, que conseguem ter sua cultura valorizada.

Pois, aqueles que constituem a vanguarda procuram distinguir seus produtos de outros, classificando-os como valiosos, consagrando-os e, como diz Bourdieu, impondo um principio de dominação. (STEVENS, 2003, p.92)

Deve-se ressaltar que o capital simbólico não é propriedade apenas de arquitetos, mas de críticos, comentaristas, escritórios, escolas, revistas, editoras, museus e galerias. É importante mencionar, aqui, os dois grandes museus, fundados nos anos 1940, o MAM - com suas bienais - e o MASP. E Lina Bo Bardi e a revista Habitat e, ainda, a revista Acrópole, entre outras forças que se contrapunham à supremacia da arquitetura produzida no Rio de Janeiro e à arquitetura tradicional.

Stevens (2003, p.120) afirma que o objetivo central de exposições como as que fazia o MOMA em Nova York, nos anos 1930 e 1940, é "fazer com que o público perceba semelhanças, é criar uma escola ou um movimento no qual antes havia

\footnotetext{
${ }^{106}$ Uma das primeiras realizações do IAB/SP foi o I Congresso Brasileiro de Arquitetos, que aconteceu em São Paulo, em janeiro de 1945. Outro evento muito importante foi a exposição Brazil Builds, que passou por São Paulo em janeiro de 1945, e teve lugar na Galeria Prestes Maia.

107 BRATKE, Oswaldo, depoimento gravado prestado a Sylvia Ficher. São Paulo, 31 out. e 12 nov. 1985, vol.2, p.2 apud FICHER, 2005, p.247-8.
} 
apenas indivíduos isolados, multiplicando assim o capital simbólico de cada um pela mobilização do capital coletivo do todo."

O mesmo se dá com instituições como o IAB. Nosso período de estudo inicia-se dez anos após sua fundação e muita coisa aconteceu nesse período, no campo da arquitetura, em São Paulo. Pode-se localizar em Casa e Jardim, nos anos 1950, um avanço real desse grupo pioneiro. É digno de nota que vários projetos de Mindlin ${ }^{108}$ e Levi são publicados, desde o início, e de Bratke, principalmente na segunda metade dos anos 1950.

\footnotetext{
${ }^{108}$ Autor da obra fundamental Modern Architecture in Brazil (1956), Henrique Mindlin (1911-1971) graduou-se como engenheiro-arquiteto pelo Mackenzie em 1932, trabalhando em São Paulo até 1941, quando foi para o Rio de Janeiro. Produziu obras como a Casa George Hime (1949), em Petrópolis, onde utilizou materiais e elementos tradicionais, com uma linguagem moderna. $\mathrm{Na}$ metade da década de 1950, Mindlin associou-se ao italiano Giancarlo Palanti (1906-1977) e iniciou uma nova fase em São Paulo. Ali desenvolveu programas corporativos, em obras como The First National City Bank (1957, Recife), o edifício Avenida Central (1958, Rio de Janeiro), o Bank of London \& South America (1959, São Paulo), difundindo as novas tendências provenientes dos Estados Unidos.
} 
192 


\section{Capítulo 3}

\section{O Good-Life Modernism}

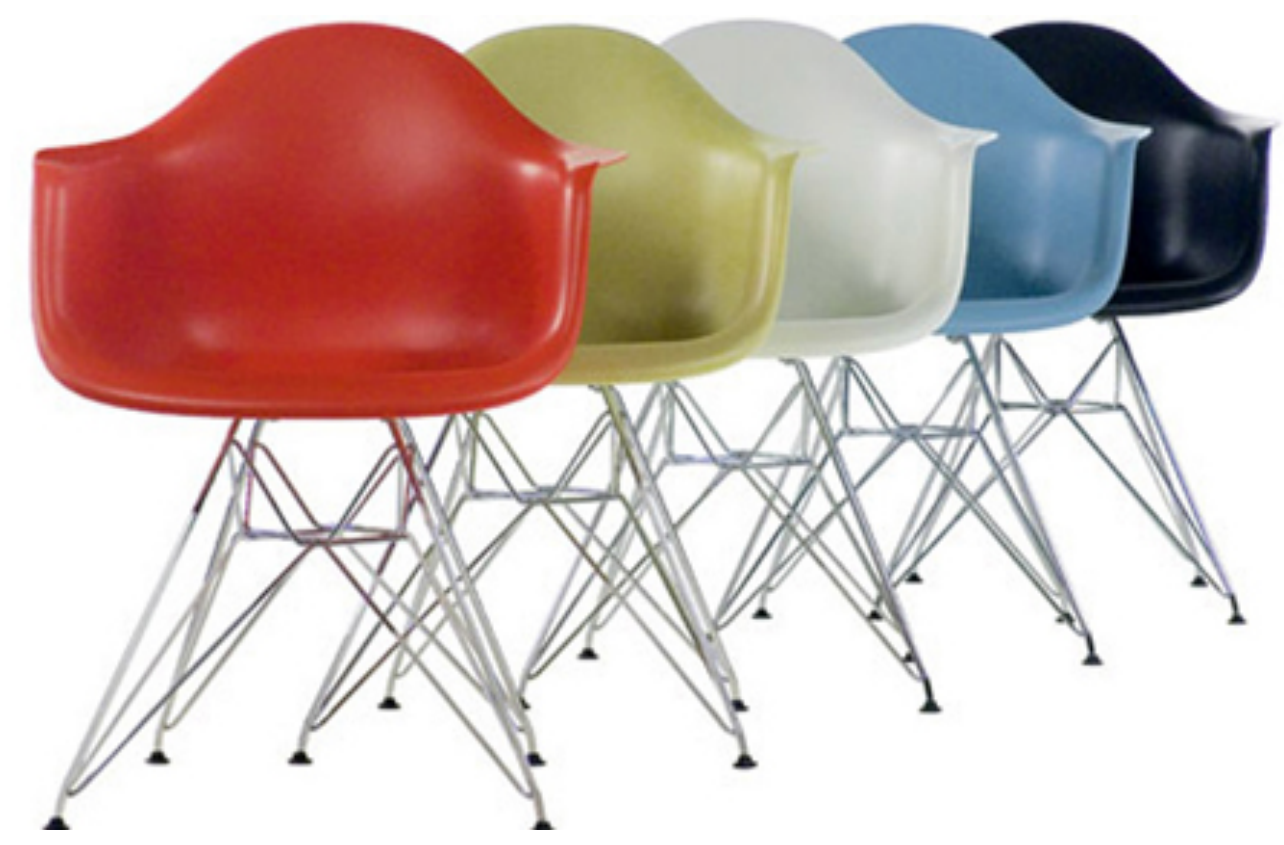

Fig.3.1 - Cadeiras do casal Eames.

O esforço de ampliação da influência econômica, política e ideológica dos EUA no pós-guerra resultou na penetração da cultura norte-americana não apenas em países latino-americanos, como o Brasil, mas também na Europa. Difundia-se em todo o mundo ocidental um novo modo de vida, propiciado pela produção em massa de bens manufaturados, de uso pessoal e doméstico.

Pois, como dissemos, durante a Guerra Fria, os Estados Unidos adotaram a diplomacia cultural como uma arma explícita no arsenal anticomunismo. A política cultural tornou-se intrinsicamente ligada aos objetivos da política externa, o maior deles, a segurança nacional. (HAINES, 1989, p.159) 
A arquitetura americana era vista como outro produto cultural, que deveria ser exportado. ${ }^{1}$ Em uma sequência infindável de imagens domésticas, ela torna-se o cenário para a exposição de produtos atraentes, em inúmeras reportagens e anúncios publicitários.

Para Colomina (2007, p.12), a nova forma de domesticidade era uma poderosa arma, cujas imagens de felicidade cuidadosamente definidas "eram lançadas por todo o mundo como parte de uma campanha de propaganda cuidadosamente orquestrada." ${ }^{2}$ Era uma arquitetura destituída de conotações politicas ou sociais. Não se questionava a ideologia da Guerra Fria.

Havia um fascínio pelo novo "modelo" americano, mostrado pelas revistas de arquitetura, da mesma forma como absorviam-se outros produtos dos Estados Unidos no pós-guerra. ${ }^{3}$

Nesse terceiro capítulo, analisamos a arquitetura americana do pós-guerra, mais especificamente, a doméstica, que teve importantes ressonâncias em nossa arquitetura.

\subsection{Uma crítica interna ao Movimento Moderno}

No estudo dessa arquitetura, é interessante um olhar cuidadoso aos arquitetos da época, inicialmente aos imigrantes europeus. Pela sua presença constante em revistas da época, Marcel Breuer nos ajuda a levantar algumas questões.

\footnotetext{
${ }^{1}$ Além da arquitetura doméstica, a linguagem utilizada em prédios comerciais e institucionais também era "exportada." Utilizava-se uma técnica cada vez mais desenvolvida e uma estética abstrata, refinada, com fachadas de vidro e aço. De acordo com a politica cultural do governo dos Estados Unidos, os edifícios das embaixadas americanas ao redor do mundo, nos anos 1950 e inicio dos 1960's, deveriam seguir a nova estética. Ver US Building Abroad: in Doing its Share of $\$ 100$ Bilion Postwar Job, the Building Industry Has Become a World-Wide Embassador. Architectural Forum, p.98-119, jan.1955.

${ }^{2}$ Estas imagens idealizadas acabaram por se tornar um tema de interesse por todo o país. Uma questão de identidade nacional. (COLOMINA, 2007, p.54-5) Emblemático da relevância do assunto foram as discussões que se travaram em torno da cozinha, em julho de 1959. Em plena guerra fria, o vice-presidente Richard Nixon, abriu a Exposição Nacional Americana em Moscou, onde se envolveu em um acalorado debate com o premier Nikita Khrushchev sobre o modo de vida americano. Para Nixon, a superioridade americana repousaria não em armas, mas na estável e abundante vida familiar nos modernos subúrbios americanos, em casas equipadas com eletrodomésticos modernos e diferentes papéis para homens e mulheres.

${ }^{3}$ Esse fascínio pelos produtos atrativos e coloridos da "Boa Vida" envolve até mesmo a comida, racionada no Reino Unido até os anos 1950.
} 
Sua arquitetura, depois da mudança para os Estados Unidos, parece pautada pelo equilíbrio, com uma crítica ao Movimento Moderno. Questionam-se alguns elementos do movimento, mas sem negá-lo:

Breuer francamente apoia uma estética baseada na geometria clara das formas da máquina: o retângulo é o módulo de suas plantas e fachadas. Mas, Breuer evita usar as superfícies duras que se associam às formas da máquina. Ele gosta de usar materiais naturais como a madeira e a pedra devido ao calor que emprestam a uma casa planejada para uma vida confortável. (...) Reconciliando essas duas tendências - o amor pela simplicidade e o amor pelo conforto - Breuer consegue manter-se afastado de um tipo de romantismo de Hansel-and-Gretel por um lado e, por outro, evitar a cintilante aparência de laboratório. Suas casas são "humanas" sem serem "sentimentais." (MARCEL..., 1952, p.106)

Suas casas seriam, "acima de tudo, lugares para um bom viver (negrito nosso, no original good living) e Breuer gostaria que fossem julgadas nesses termos." (Ibid., p.114)

Não se poderia imaginar uma casa do Movimento Moderno vista, antes de tudo, como um local confortável para se viver e que seria avaliada, principalmente, em relação a essa questão.

Além da evidente transformação da linguagem, em uma "suavização" das formas da máquina, com "calor", existe a questão do modo de vida, do conforto, que é o grande propósito dessa habitação.

O projeto iniciava-se com um bom planejamento das funções a serem desempenhadas pela casa. "A coisa mais importante que Breuer tem a dizer sobre a planta da casa é que certas funções são tão incompatíveis que deveriam ser mantidas claramente separadas," como os espaços de vida diurna e aqueles destinados ao repouso. A solução mais comum para o arquiteto era construir a casa como duas unidades separadas, conectadas em uma planta $\mathrm{H}$, com a ligação servindo como hall, criando-se dois pequenos pátios. Eram as casas binucleadas.

Apesar dessa separação, Breuer utilizava-se de vários artifícios - como telas transparentes e divisórias baixas - para manter os espaços abertos e fluidos mas, conferindo-Ihes privacidade.

Ele seria "um dos arquitetos criativos que estão revitalizando a arquitetura doméstica - para resgatar a casa americana do antiquário, e incorporar a ela os materiais, 
métodos construtivos e o modo de vida atuais (...)." (SYMMETRICAL..., 1952, p.121) Um novo tipo de vida para o homem do pós-guerra.

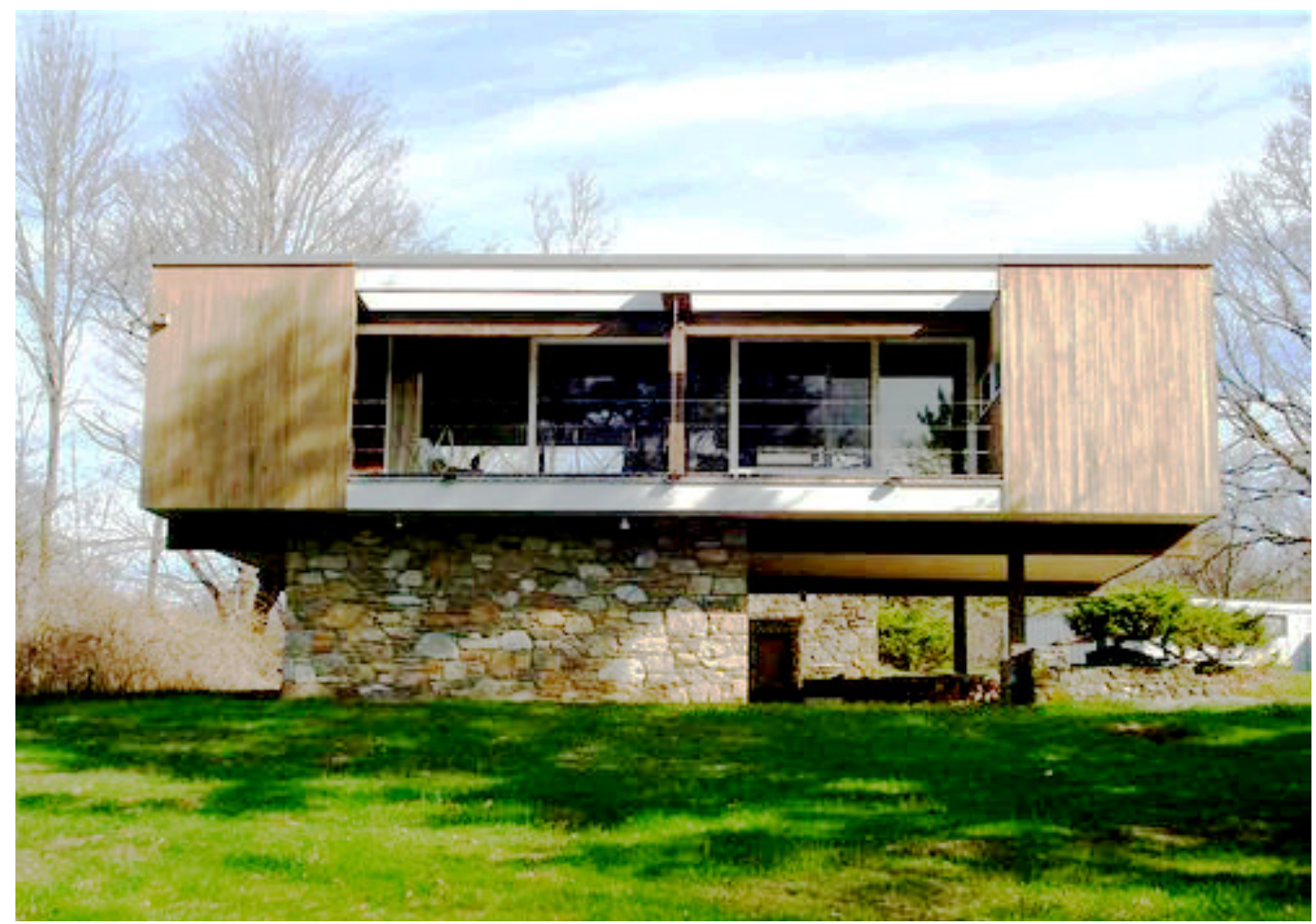

Fig.3.2 - Wolfson Trailer House, ${ }^{4}$ de Marcel Breuer.

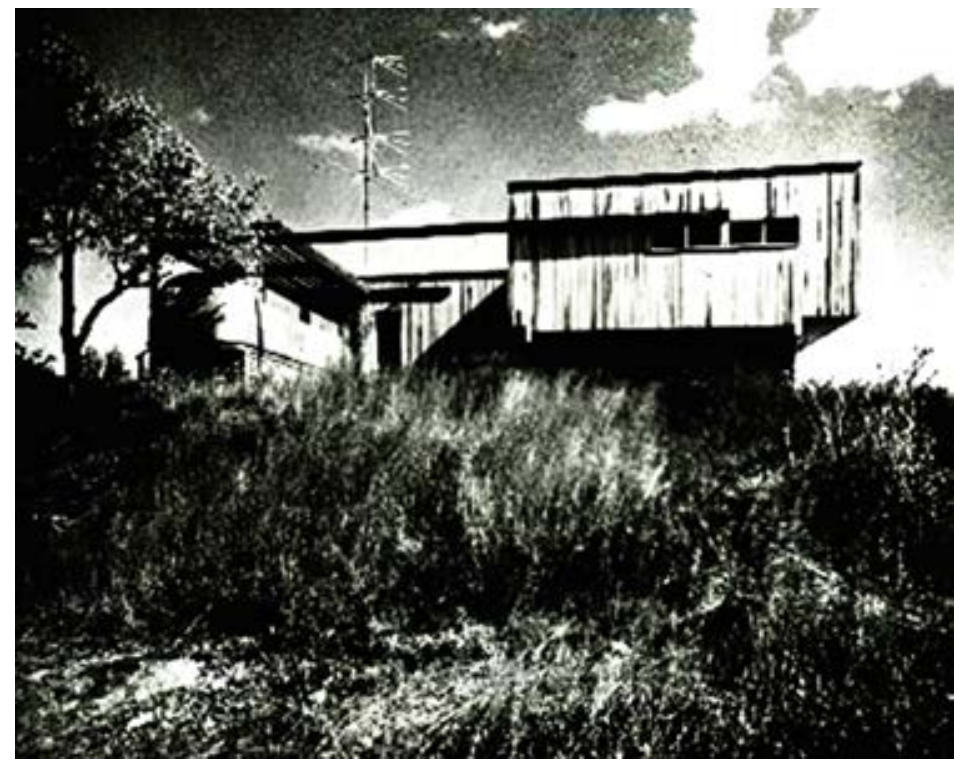

Fig.3.3 - Wolfson Trailer House, vista lateral.

\footnotetext{
${ }^{4} \mathrm{O}$ ponto de partida para a casa foi um trailer comprado por seu proprietário, um artista, e fixado sobre blocos de concreto, onde ele viveu por três anos. A casa de Breuer, um espaço para trabalhar, dormir e estar, "nasce" desse trailer e a ele se liga através de uma "ponte" fechada. Antecipa suas casas binucleadas.
} 
Desenho dramático e excitação visual seriam outros atributos da casa, percebidos no contraste entre os grandes panos de vidro, madeira e pedras. Ou ainda, no balanço avantajado do segundo pavimento, que confere uma sensação de leveza e precisão a esse piso, que se contrapõe à base em pedras que "surge" do chão e penetra no segundo pavimento na forma de uma lareira. Os "acessórios" de suas casas, lareiras e escadas, tornam-se pontos focais.

O balanço, a leveza e a precisão ainda são parte da linguagem do Movimento Moderno. A base em pedras, no entanto, contrasta com o edifício e o transforma.

A partir das janelas e das varandas, espaços para contemplação, desfrutavam-se as vistas panorâmicas. Pois, a

atitude de Breuer em relação à natureza é a de um observador, de um homem por trás da câmera: ele gosta de olhá-la. (...) Suas casas são postos de observação de onde admirar o que nenhum homem pode imitar. (...) Arquitetura, para ele, é uma coisa - a natureza outra. Suas casas nunca se fundem com seu ambiente natural. (...) são modernas, lares civilizados para homens civilizados, modernos - não refúgios nos quais os moradores do subúrbio $^{5}$ podem fingir ser Tarzan. (MARCEL, 1952, p.114)

Percebem-se certas adaptações ao modo de vida americano, mas em alguns aspectos, Breuer não se "aclimatou." Existe uma clara distinção entre arquitetura e natureza.

Podemos questionar como seria, então, a arquitetura doméstica praticada por um "nativo." Na capa do primeiro número de House \& Home, é mostrada "A Traditional House in the Modern Idiom:"

Alguns dizem que esta é uma casa tradicional realizada no estilo moderno. Outros, que trata-se de uma casa moderna permeada com tradição. Os conservadores de New Canaan, ainda perplexos com tais trabalhos de vanguarda, como as casas de Marcel Breuer, Philip Johnson e John Johansen, usam uma frase mais coloquial. Eles a chamam 'uma casa moderna que realmente parece uma casa.' (A TRADITIONAL..., 1952, p.109)

A tradição faria da casa moderna, uma verdadeira casa. Transformaria a "máquina de viver" industrializada, tornando-a mais aceitável para o público em geral que as

\footnotetext{
${ }^{5}$ No original, commuters, termo que não apresenta uma tradução precisa para o português, significando a pessoa que viaja diariamente entre seu trabalho e sua moradia.
} 
"casas de vidro" do Movimento Moderno. Criando uma arquitetura que questiona e "suaviza" os princípios modernos e se "afasta conscientemente" de vanguardismos.

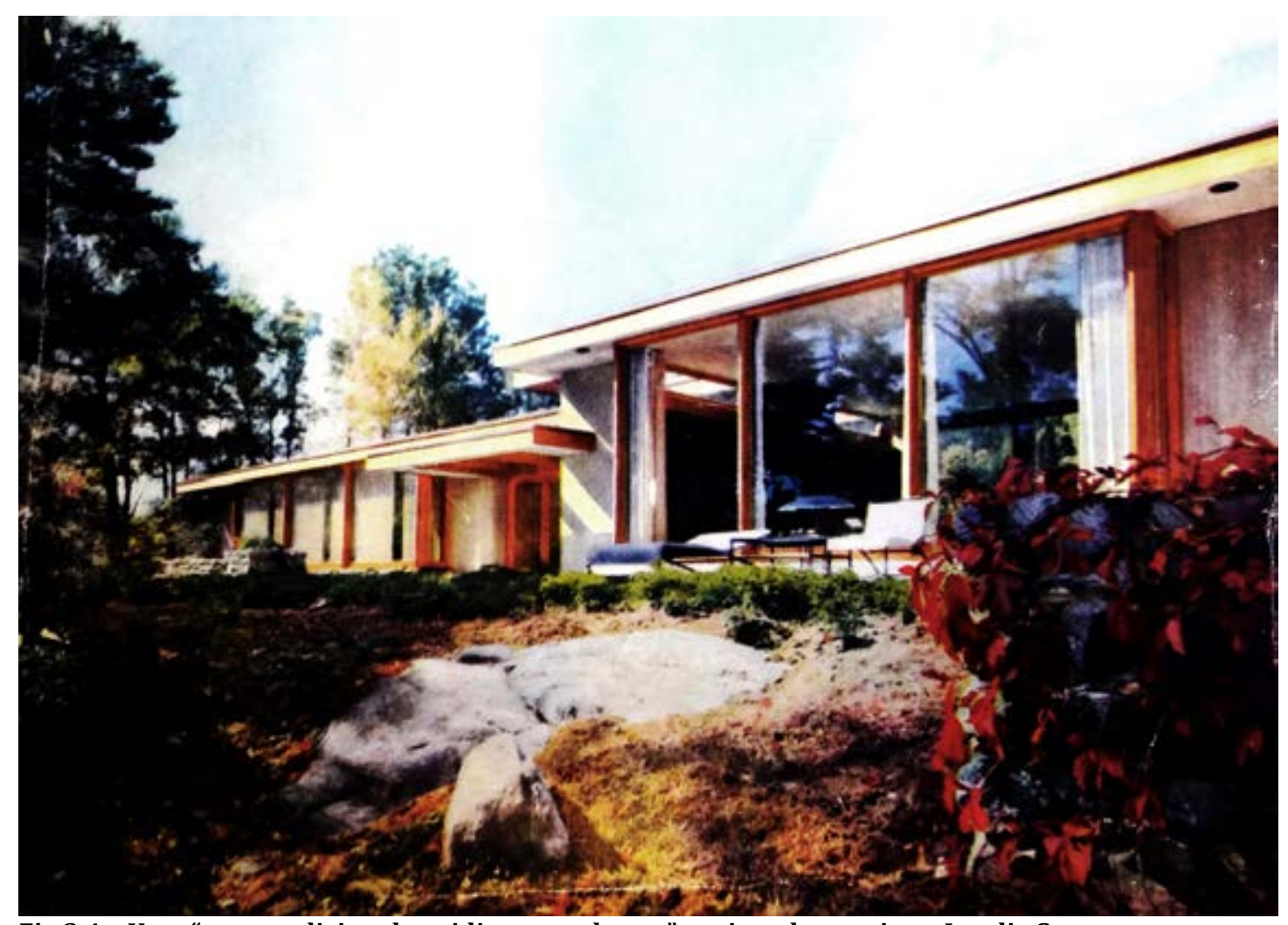

Fig.3.4 - Uma “casa tradicional, no idioma moderno," projeto do arquiteto Landis Gores.

A casa foi projetada por Landis Gores. E sua escolha para ilustrar o primeiro número dessa revista diz muito sobre a arquitetura mostrada. Ele faz parte de uma nova geração de arquitetos americanos, com uma nova formação. No caso de Gores, isso inclui certo tempo em Princeton, onde teria aprendido a disciplina e a linguagem clássica, antes de ir para Harvard, para estudar arquitetura com Gropius e Breuer.

$O$ arquiteto seria "um criativo jovem moderado entre seus contemporâneos vanguardistas (...)." (A TRADITIONAL...,1952, p.114)

A planta aberta, os espaços dinâmicos e arrojados, detalhes claros e simples, os telhados planos e os grandes panos de vidro, estariam permeados da "tradição viva da arquitetura doméstica americana," assimilando essa tradição a partir da Coonley Playhouse de Frank Lloyd Wright, de $1912 .{ }^{6}$ Dessa forma, Influências tão diversas

\footnotetext{
${ }^{6}$ O Avery Coonley Playhouse foi desenhado por Wright próximo à Avery Coonley House, em 1912, como uma espécie de jardim de infância para a filha dos Coonley e outras crianças da vizinhança. Os vitrais do Coonley Playhouse apresentam alguns dos desenhos mais conhecidos de Frank Lloyd Wright, mostrando balões e confetes.
} 
como Gropius, Breuer, Mies van de Rohe e Wright poderiam conciliar-se na mesma tendência. (A TRADITIONAL..., 1952, p.109)

Tem-se, na casa de Gores, a presença de artesãos experientes na execução de detalhes de acabamento específicos do desenho moderno, sendo que os grandes panos de vidro teriam sido os aspectos técnicos mais desafiadores da construção. Apesar disso, há materiais tradicionais americanos, naturais, utilizados também por Wright, como pedras, em estado natural, e madeira.

A localização da casa é emblemática, pois na metade do século $X X$, New Canaan tornou-se uma espécie de laboratório para a arquitetura moderna doméstica nos EUA. Isso acontece após a chegada dos "Harvard Five" - Landis Gores, Phillip Johnson, Marcel Breuer, Eliot Noyes e John Johansen - a essa área praticamente rural, onde construíram suas casas. A residência de Gores é uma das primeiras a utilizar a estética moderna e uma das seis originais do primeiro circuito de casas modernas, organizada pelos "Harvard Five", em maio de 1949. A cidade acabou transformando-se em uma espécie de vitrine para o Movimento Moderno.

A casa, longa, marcada pela horizontalidade, é dividida em alas e tem no living room, mais alto, ${ }^{7}$ o centro da composição, quase simétrica. Esse ambiente apresenta duas laterais em vidro - que o fazem parecer maior do que é, na realidade, confundindo os limites entre exterior e interior - e janelas próximas ao teto, trazendo abundância de luz à casa, que se situa em meio a jardins e terraços.

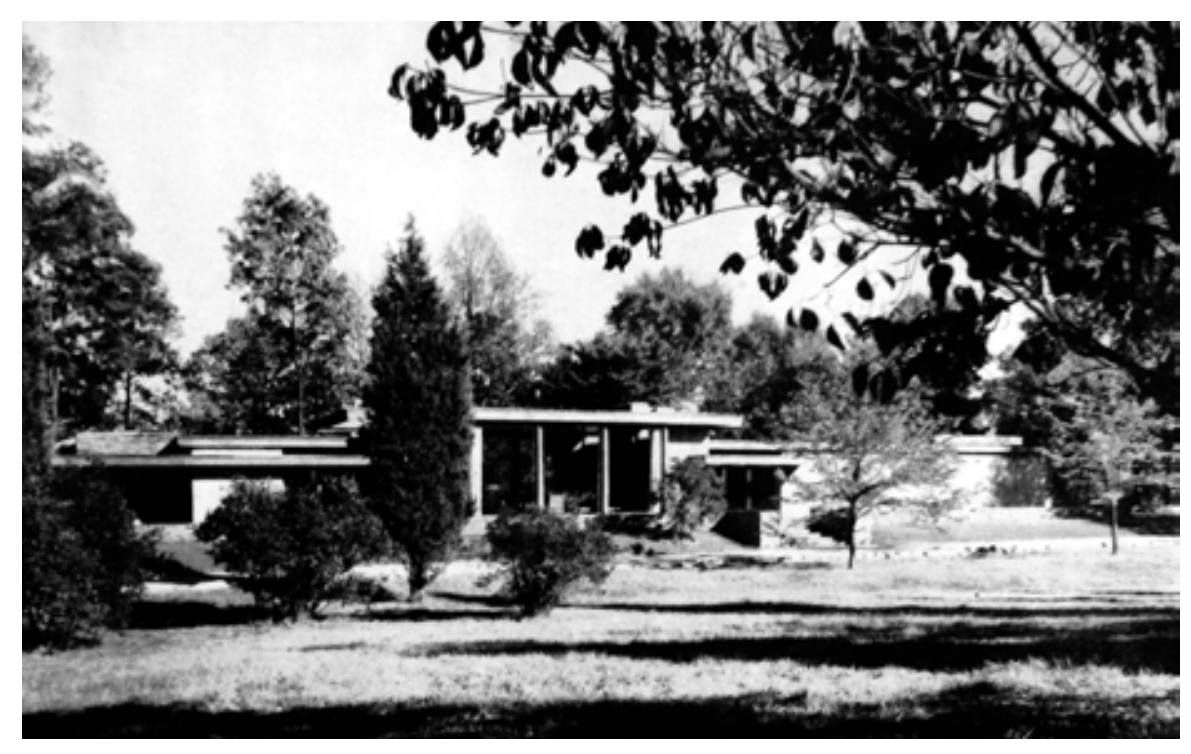

Fig.3.5 - Casa de Gores.

\footnotetext{
${ }^{7}$ Com 11 pés de altura, correspondentes a cerca de $3.55 \mathrm{~m}$.
} 


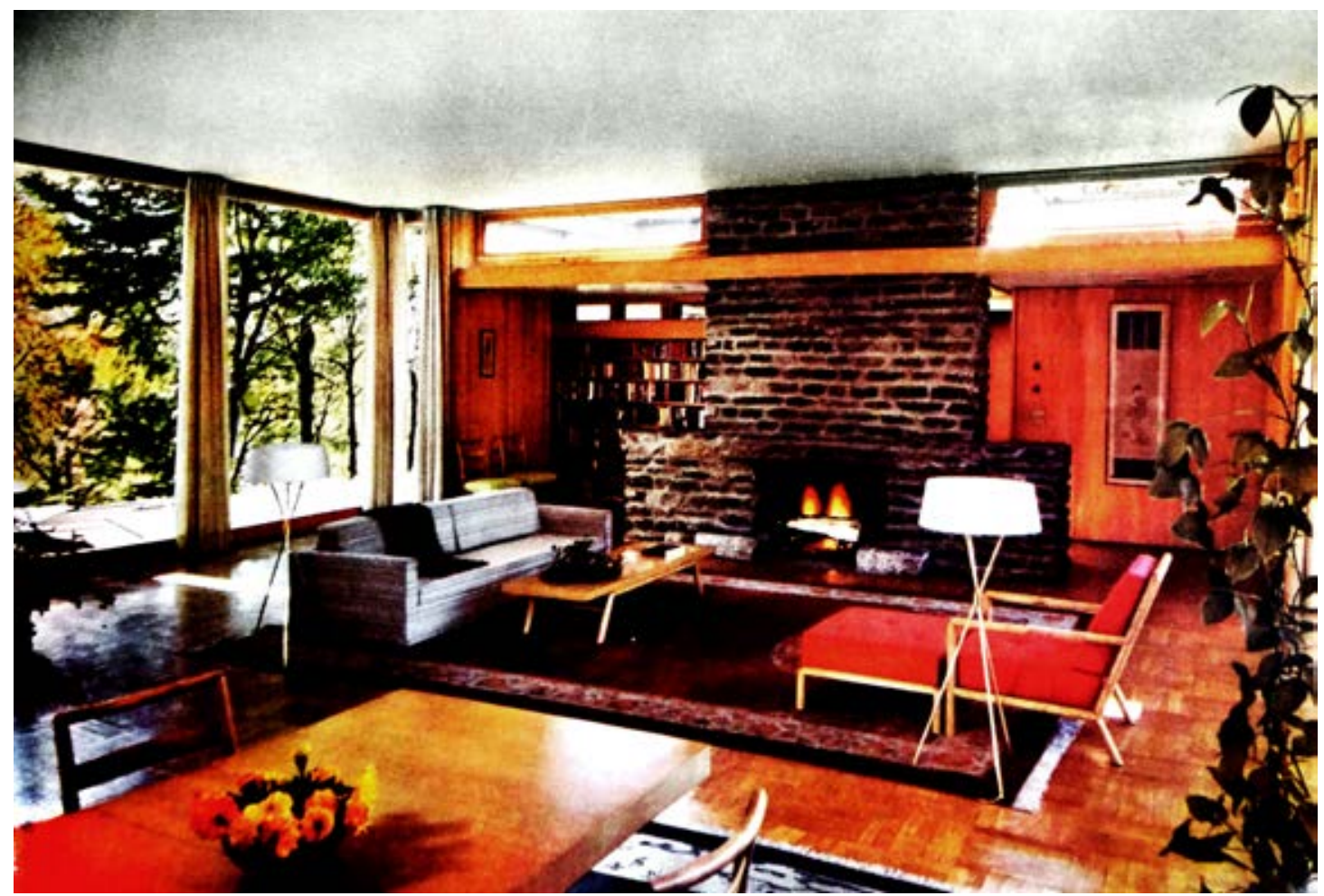

Fig.3.6 - Interior da casa de Gores.

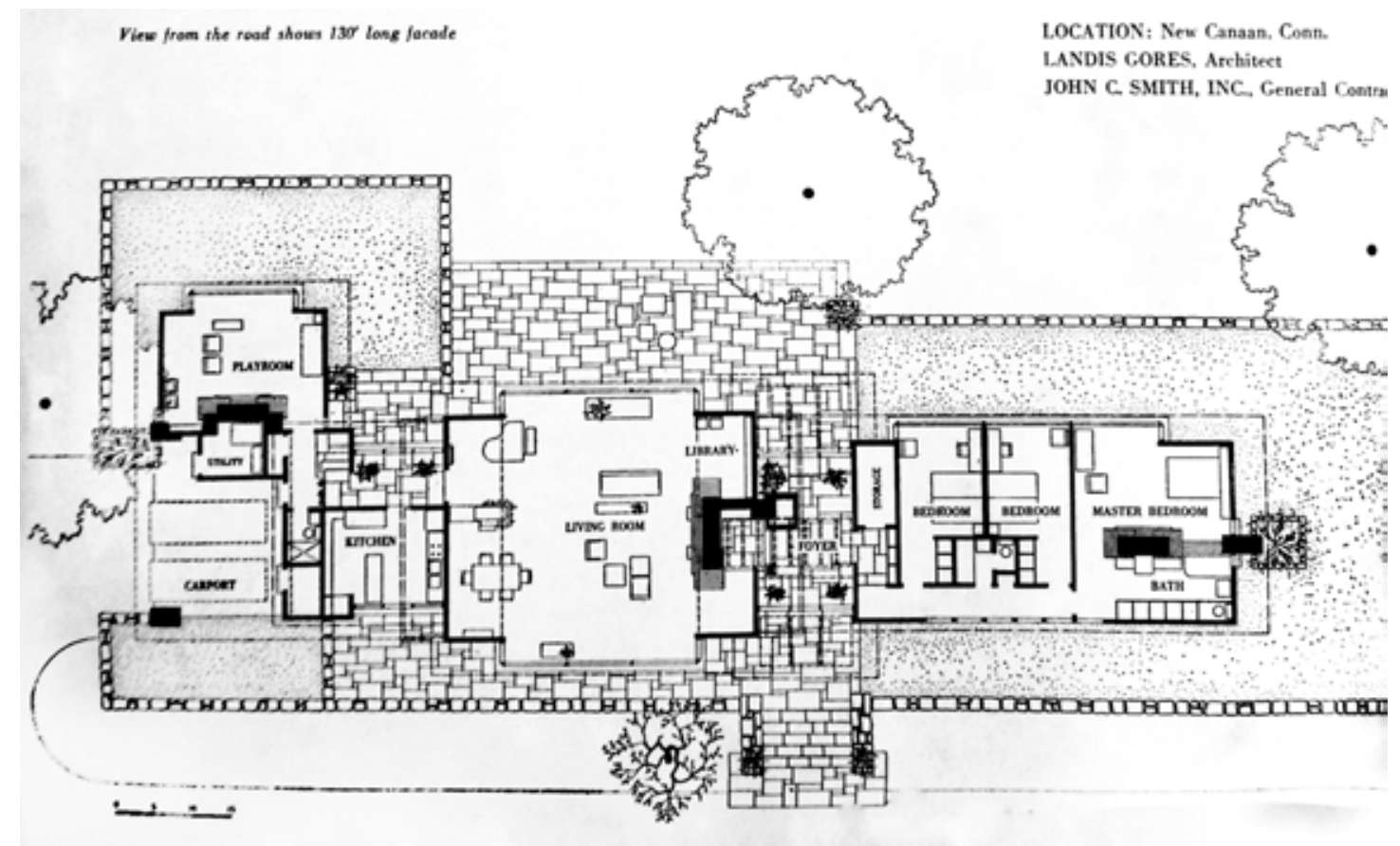

Fig.3.7 - Planta baixa da mesma casa.

Internamente, existe variedade de cores e uma grande lareira em pedra maciça. Os móveis são leves, modernos e variados. 
A planta apresenta um espaço fluido, com voltas, desvios, diferentes pés direitos e níveis na tradição wrightiana.

Gores conecta a casa a seu site, também de forma wrightiana, no ponto mais alto de um terreno acidentado e estreito, procurando integrá-la à natureza; o outdoor living é possibilitado por vários equipamentos.

Na casa de Breuer, no entanto, existem "postos de observação," locais descobertos, sem sombreamento, para fruir, de longe, a paisagem.

Outro aspecto que diferencia as duas casas é o desenvolvimento da planta baixa. A de Breuer é mais rigorosa, as figuras geométricas são melhor definidas, claras e se sobressaem, demarcando os diversos setores. A de Gores, no entanto, apresenta mais fluidez e sensação de continuidade.

Apesar de Breuer haver se adaptado aos EUA e de seus projetos serem bastante apreciados pela classe média americana, sua arquitetura está mais próxima ao International Style do que a de Gores.

No entanto, as casas de Breuer representavam uma "modernidade confortável" (FULLAONDO, 2010, p.171), ele conseguia esclarecer o público sobre esse tema. Uma arquitetura didática, clara, passível de ser reproduzida, sempre levando em consideração a questão do conforto. Acessível à família média americana.

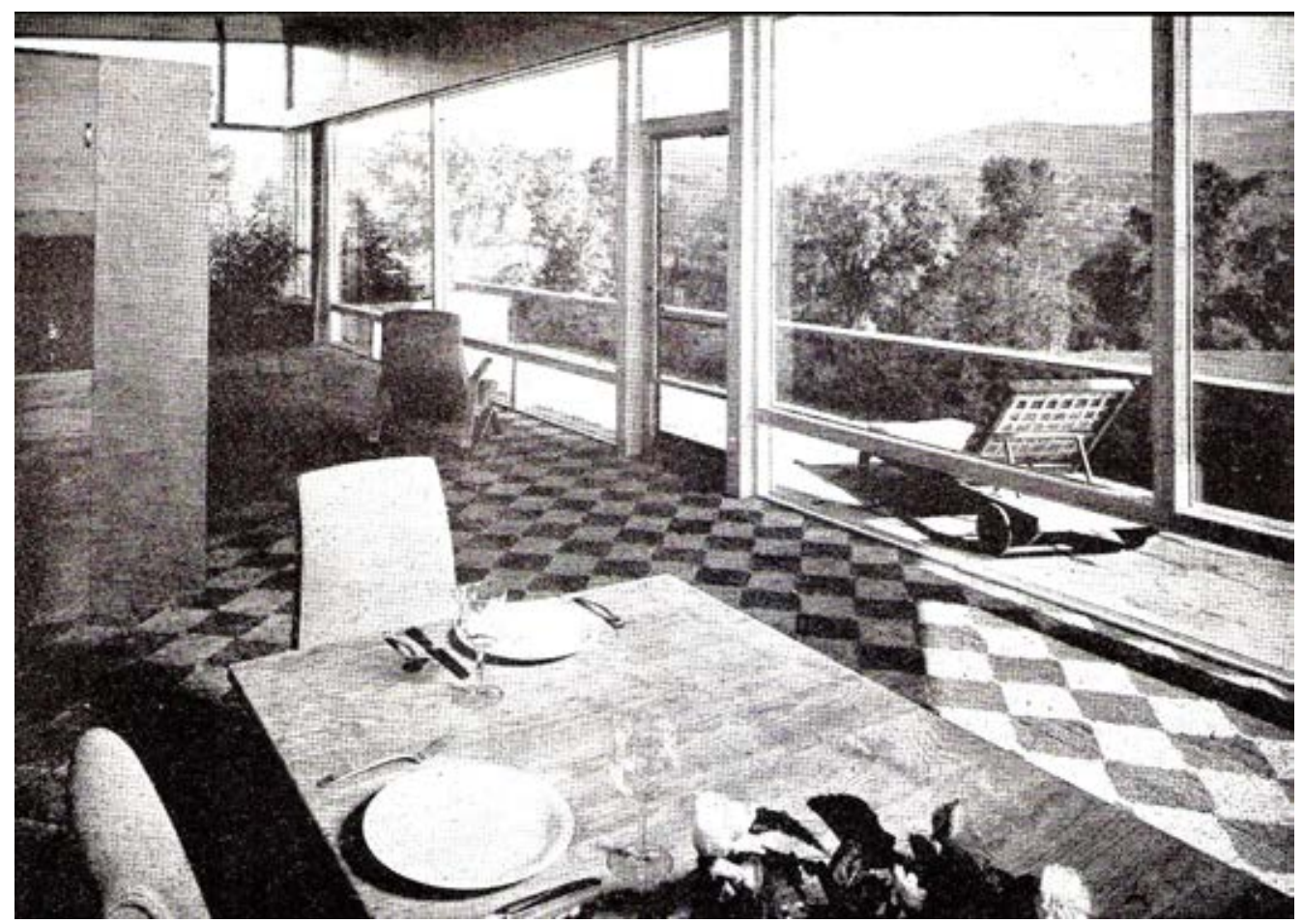

Fig.3.8 - "Posto de observação," na casa projetada por Breuer, em Williamstown. 


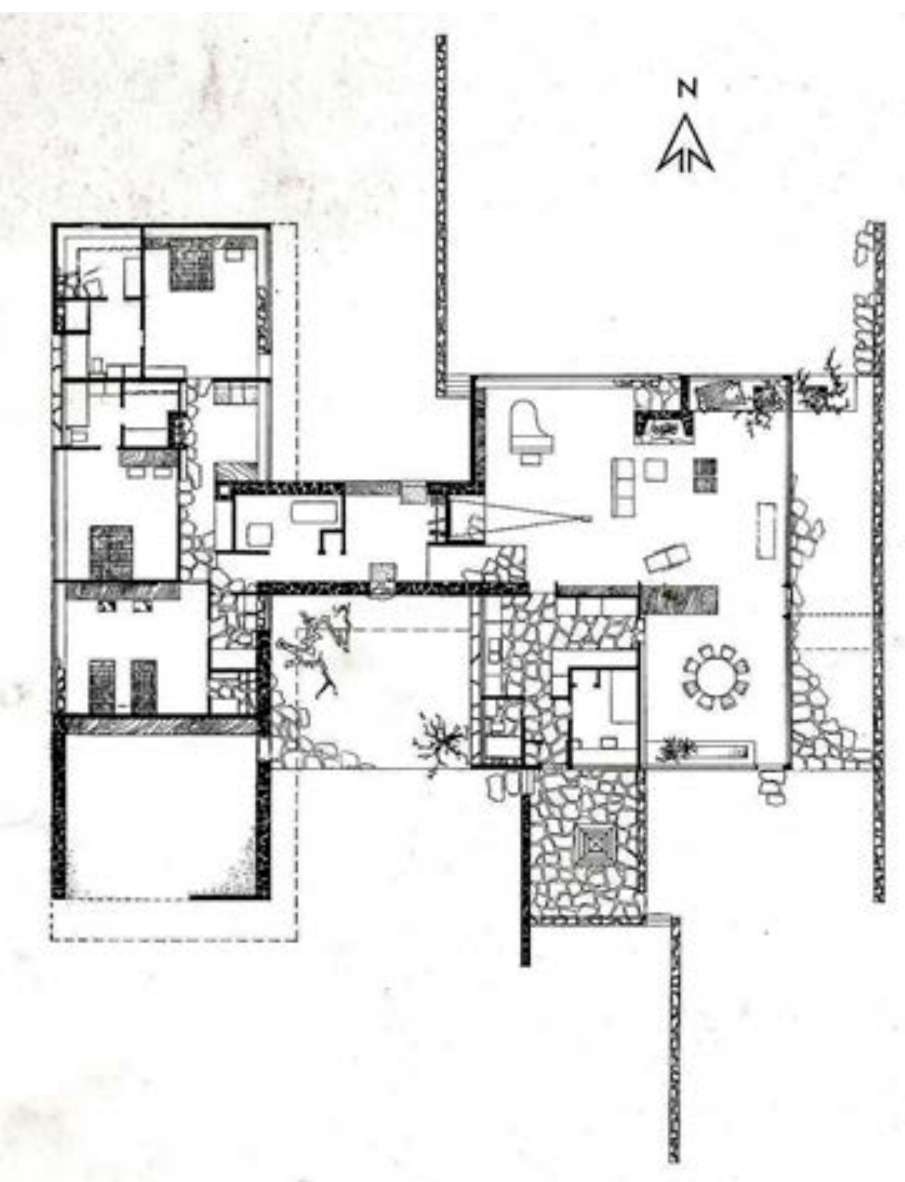

Fig.3.9 - Planta baixa da mesma casa, binucleada.

\subsection{Uma seleção de casas modernas}

No mesmo ano em que começa a ser publicada a revista House \& Home - 1952 -, surge uma coletânea de projetos já publicados pela revista Architectural Record, o álbum 82 Distinctive Houses from Architectural Record. ${ }^{8}$

Ao contrário de House \& Home, esta é uma revista técnica. Apresenta variedade de casas, algumas mais simples, outras para um público de maior poder aquisitivo, ${ }^{9}$ mas sempre com a presença do arquiteto. Destina-se ao profissional ou a seu cliente.

Aqui está registrado o trabalho de muitos de nossos principais arquitetos de residências, uma amostragem de costa a costa que

\footnotetext{
${ }^{8}$ Em 1954, a revista publicou uma nova lista de residências, levando em consideração os mesmos princípios.

${ }^{9}$ Chegando a apresentar dormitórios para empregados.
} 
exibe, acredito, um panorama significativo do trabalho contemporâneo. (MASON, 1952, s.n.p.)

House \& Home, no entanto, apresenta empreendimentos com grande número de casas, dirigindo-se, ora ao empreendedor, ora ao comprador - o "consumidor."

A amostragem de Architectural Record contempla a produção das várias regiões americanas. Uma das questões levantadas a partir dessa produção é a noção de lugar. ${ }^{10}$ Vê-se a inspiração em realidades diversas. São casas feitas sob medida e conformadas a várias culturas e locais, inclusive em relação aos materiais.

Ainda que se perceba a tentativa de se utilizar a linguagem moderna para o desenho, existe uma clara diferenciação de acordo com a região, clima, paisagem, hábitos e tradição construtiva.

No caso da Flórida, planeja-se uma casa que resista a furacões, ${ }^{11}$ mas, ainda assim, aberta ao exterior, franca, com grandes área envidraçadas, que a "envelopam." As áreas de estar se desenvolvem ao redor da piscina.

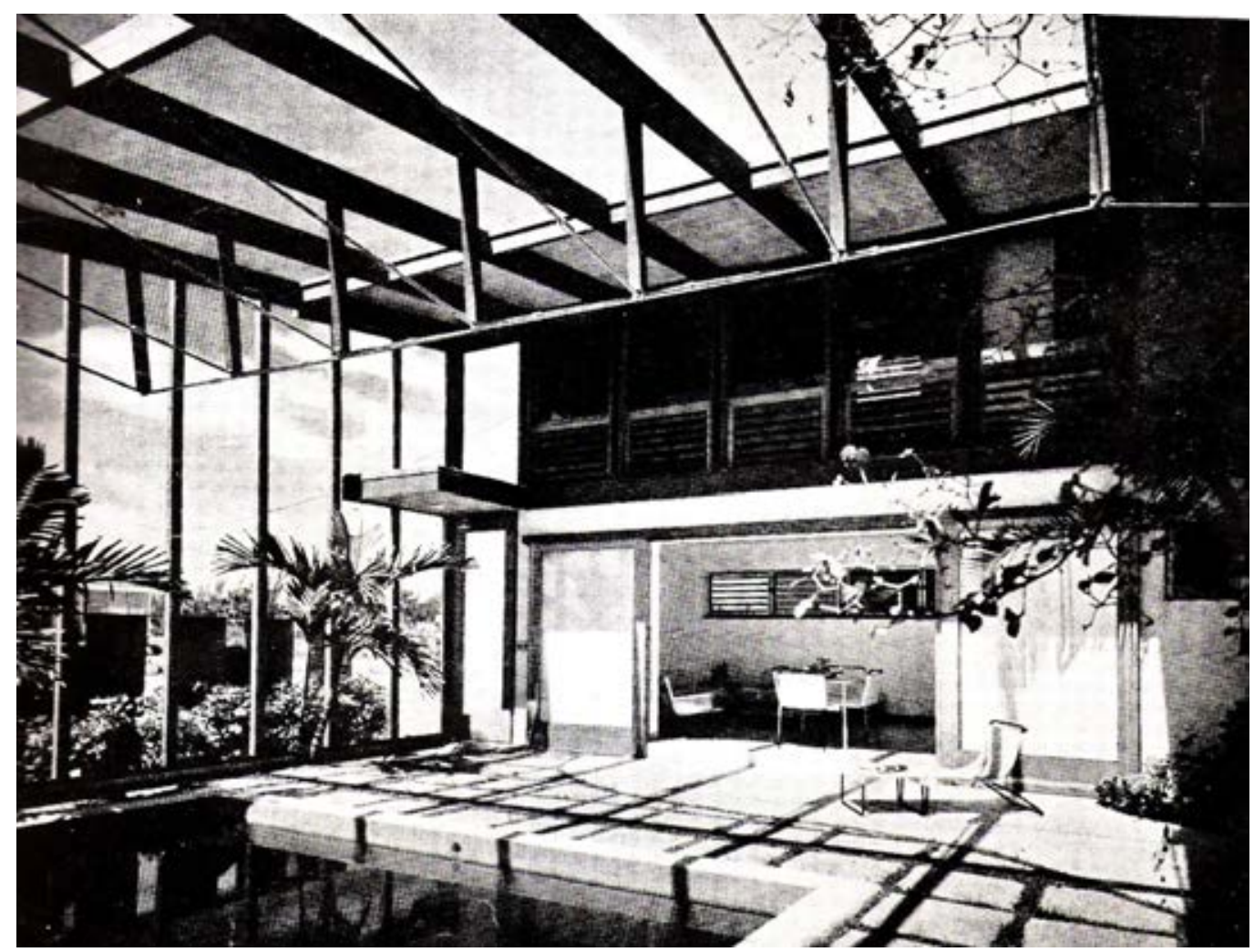

Fig.3.10 - Casa na Flórida.

\footnotetext{
${ }^{10}$ Tema já tratado em relação à arquitetura do "bem viver," no capítulo 2.

${ }^{11} 82$ Distinctive Houses from Architectural Record, casa n.15, do arquiteto Igor B. Polevitsky, em Miami, Fl., publicada em Junho, 1952, p. 62-5.
} 


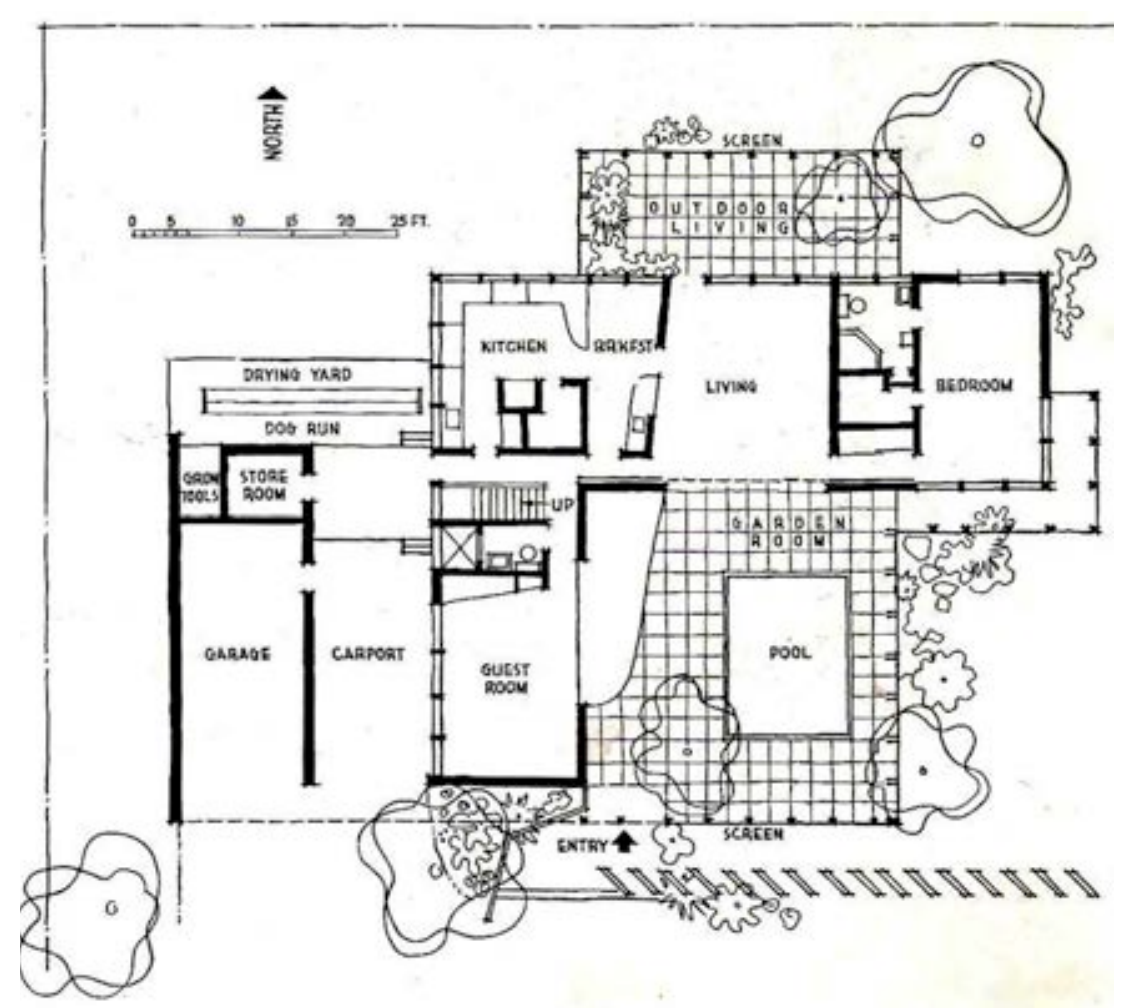

Fig.3.11 - Casa na Flórida - planta baixa.

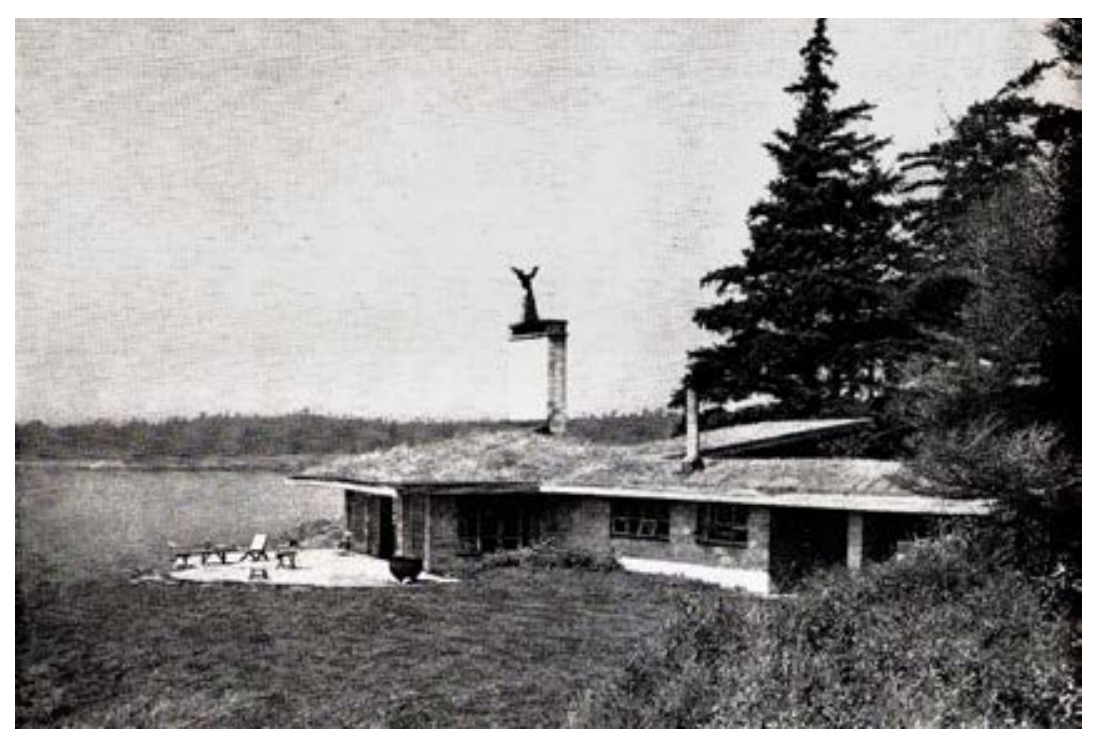

Fig.3.12 - Casa no Pacífico Noroeste.

A casa do Pacífico Noroeste ${ }^{12}$ apresenta certa inspiração na tradição do movimento Arts and Crafts, muito presente naquela região. O telhado, que ajuda a ligar a casa,

\footnotetext{
${ }^{12} 82$ Distinctive Houses from Architectural Record, casa n.16, do arquiteto Lionel H. Pries, em San Juan Group., Wash., publicada em Abril 1952, p.66-8.
} 
baixa, ao site e à paisagem, é coberto com vegetação. Existem elementos decorativos, como a escultura na chaminé e motivos pintados na entrada.

Outra casa da região localiza-se em Seattle. ${ }^{13}$ Trata-se de um cottage, com telhado inclinado, bay windows e janelas panorâmicas.

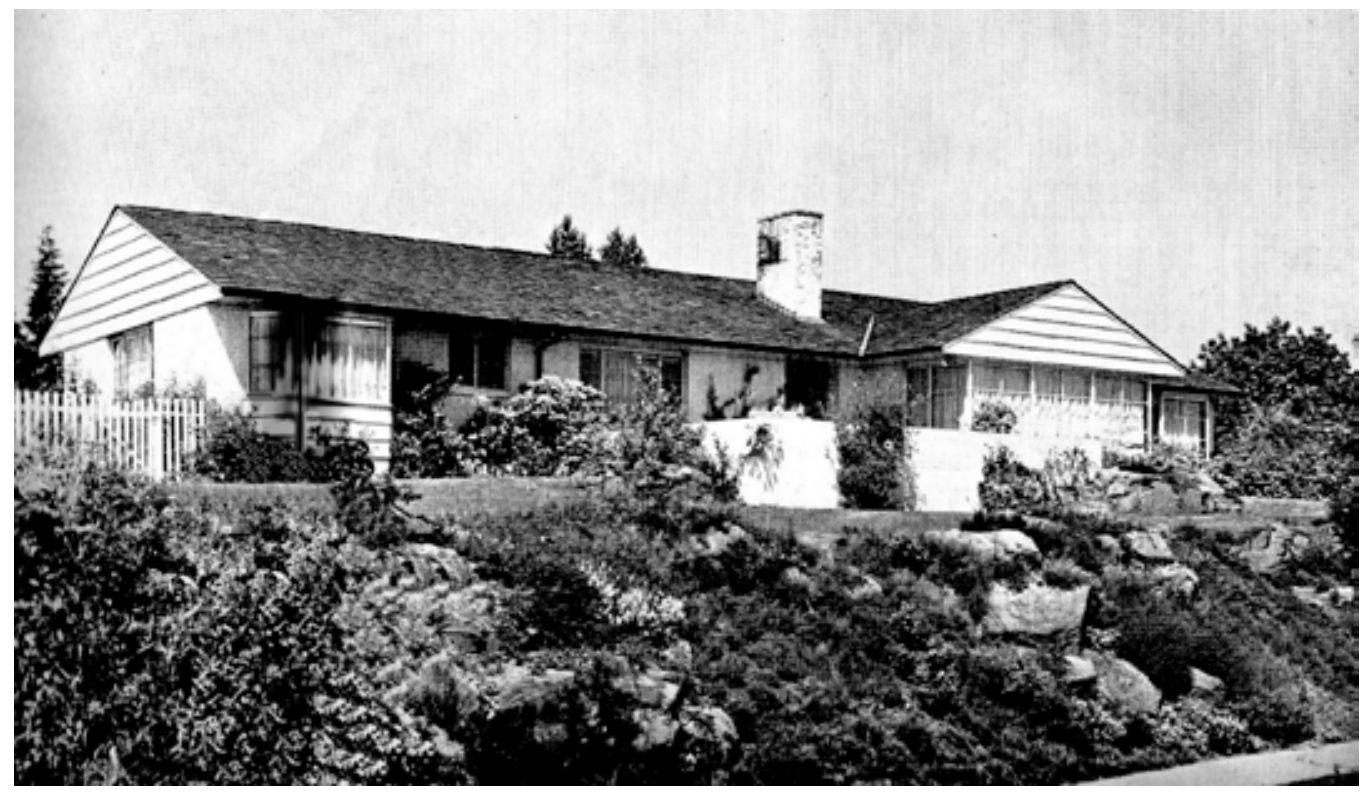

Fig.3.13 - Casa em Seattle.

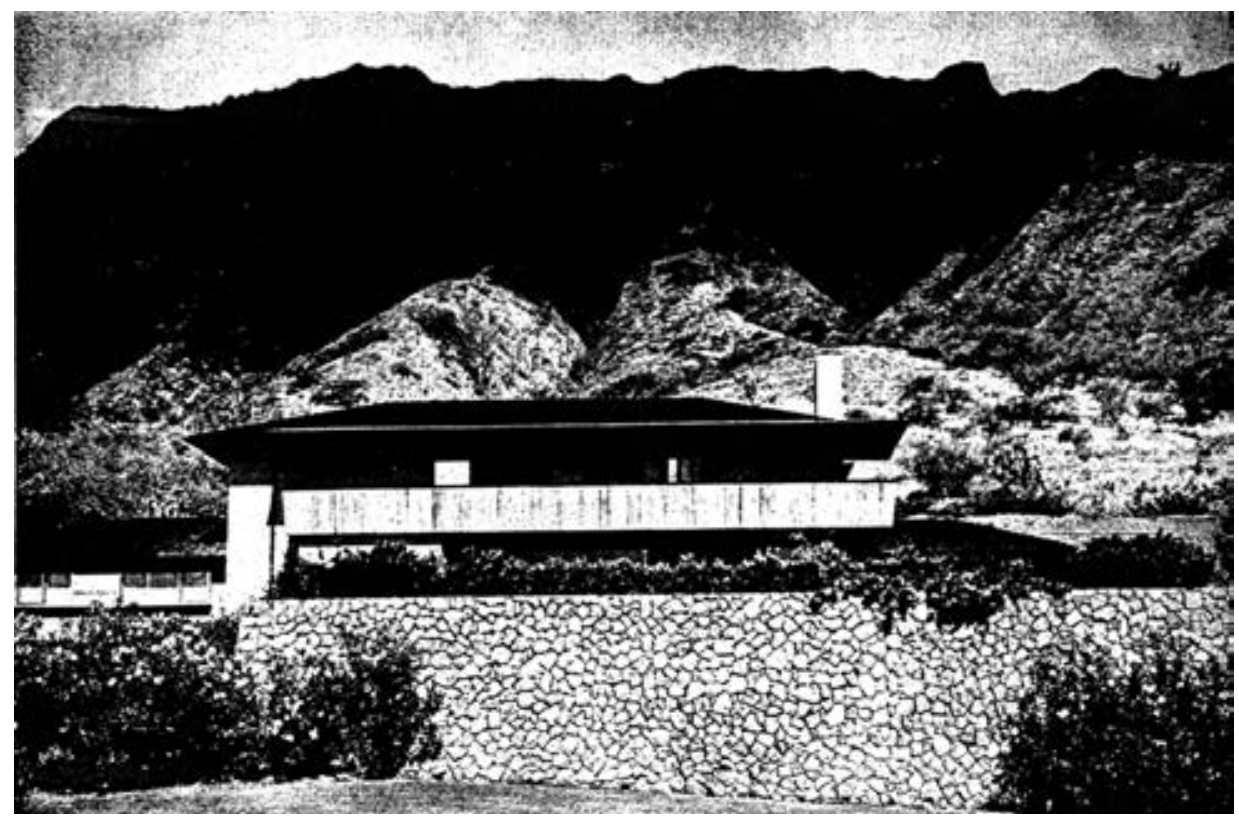

Fig.3.14 - Casa no Havaí.

\footnotetext{
${ }^{13} 82$ Distinctive Houses from Architectural Record, casa n. 62, dos arquitetos Bain, Overturf, Turner \& Associates, em Seattle, Wash., publicada em Set. 1950, p.268-271
} 
No Havaí, ${ }^{14}$ utilizam-se materiais naturais - pedras retiradas do próprio site - para executar os muros de arrimo, além das madeiras locais. O terraço - fundamental nesse clima - avista o mar, e a casa, marcada pela horizontalidade, contrapõe-se ao contorno das montanhas.

A casa da Califórnia ${ }^{15}$ utiliza a linguagem do bangalô. Baixa, com predomínio da horizontalidade, telhado em duas grandes águas e paredes externas em madeira, ajusta-se ao seu site, um canyon. Parte da sala é coberta em vidro, para aproveitamento da iluminação natural e da vista do topo da vegetação.

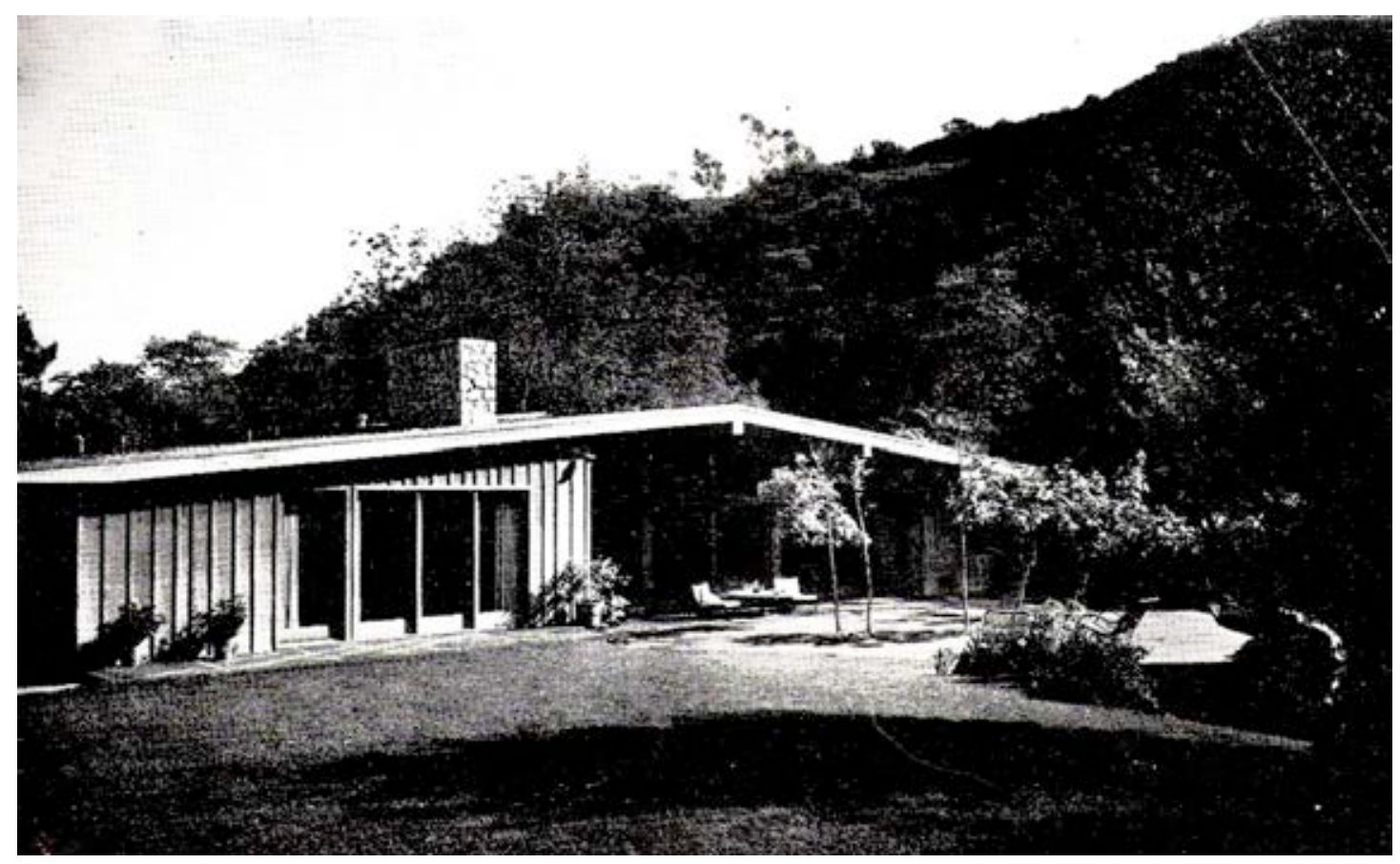

Fig.3.15 - Bangalô na Califórnia.

Uma casa, em especial, chama a atenção nessa coletânea. Construída na Califórnia, ${ }^{16}$ sua locação foi determinada pela presença de vários carvalhos, o que leva Callender (1952, p.117) a dizer: "(...) casa, árvore e terraço são esteticamente e funcionalmente partes integrais de uma composição única."

\footnotetext{
${ }^{14} 82$ Distinctive Houses from Architectural Record, casa n.17, arquiteto Vladimir Ossipoff, em Honolulu, T.H., publicada em Jan.1952, p.69-73

${ }^{15} 82$ Distinctive Houses from Architectural Record, casa de n.19, da arquiteta Edla Muir, em Los Angeles, publicada em Março 1952, p.80-83.

${ }^{16} 82$ Distinctive Houses from Architectural Record, casa de número 27, arquiteto Joseph Allen Stein, em Atherton, Cal., publicada em Nov.1951, p.116-9.
} 
As linhas claras e concisas, a leveza e precisão geométrica, apresentam um contraste com o rústico e áspero carvalho.

O pátio é protegido pela casa e sombreado pelas árvores.

Vistas inesperadas são possíveis a partir da entrada, através dos panos de vidro do living room, dos terraços e jardins além.

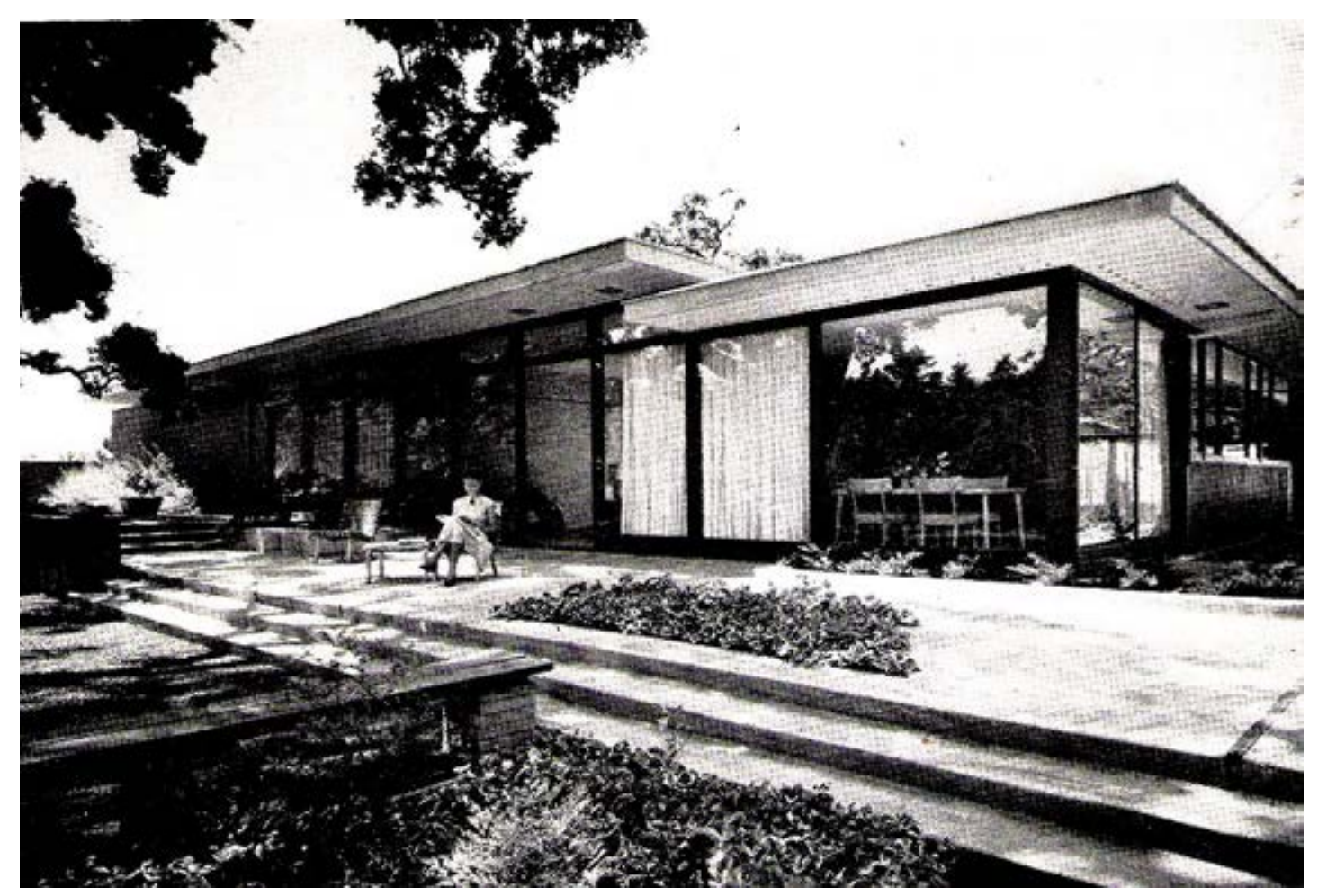

Fig.3.16- Casa dos carvalhos na Califórnia

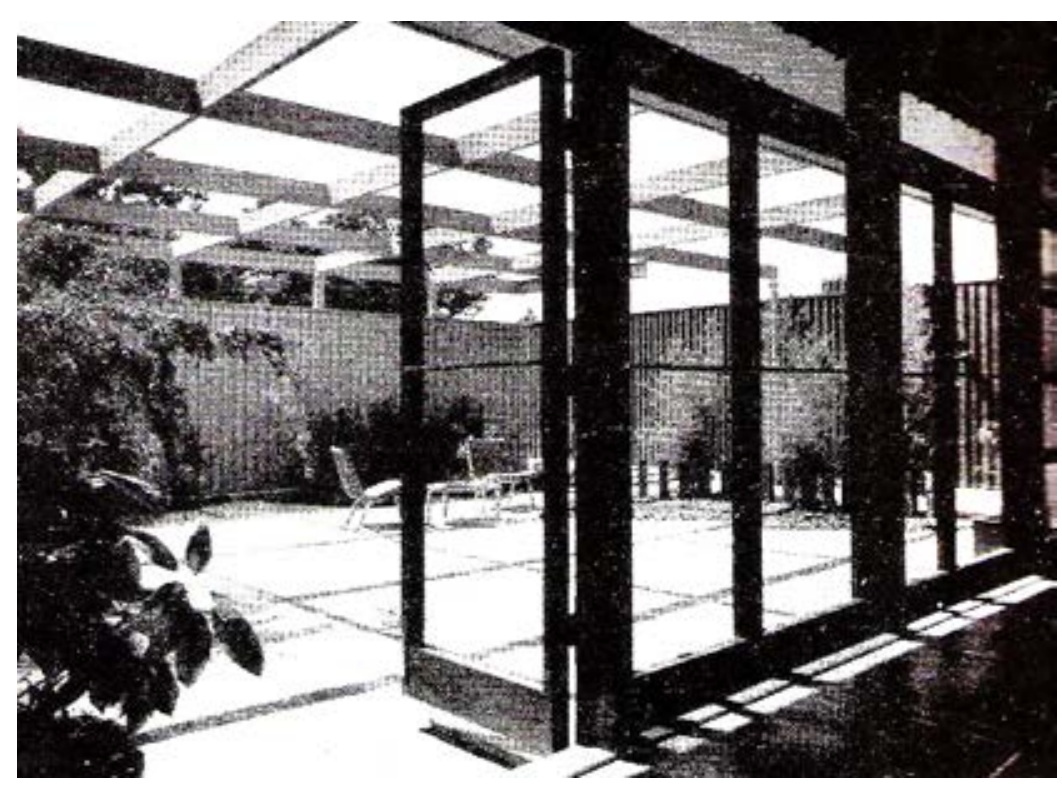

Fig.3.17 - Casa anterior. 
A casa em si não é muito grande, mas o espaço utilizável estende-se além das paredes, tendo cada cômodo seu próprio terraço pavimentado. A privacidade dos ocupantes, apesar do espaço generosamente aberto, é preservada.

"Ainda assim, esta casa proporciona um tipo de vida suntuosa que normalmente se associa a moradias muito mais elaboradas." (CALLENDER, 1952, p.117) Novamente, aparece aqui a questão do modo de vida, do cotidiano.

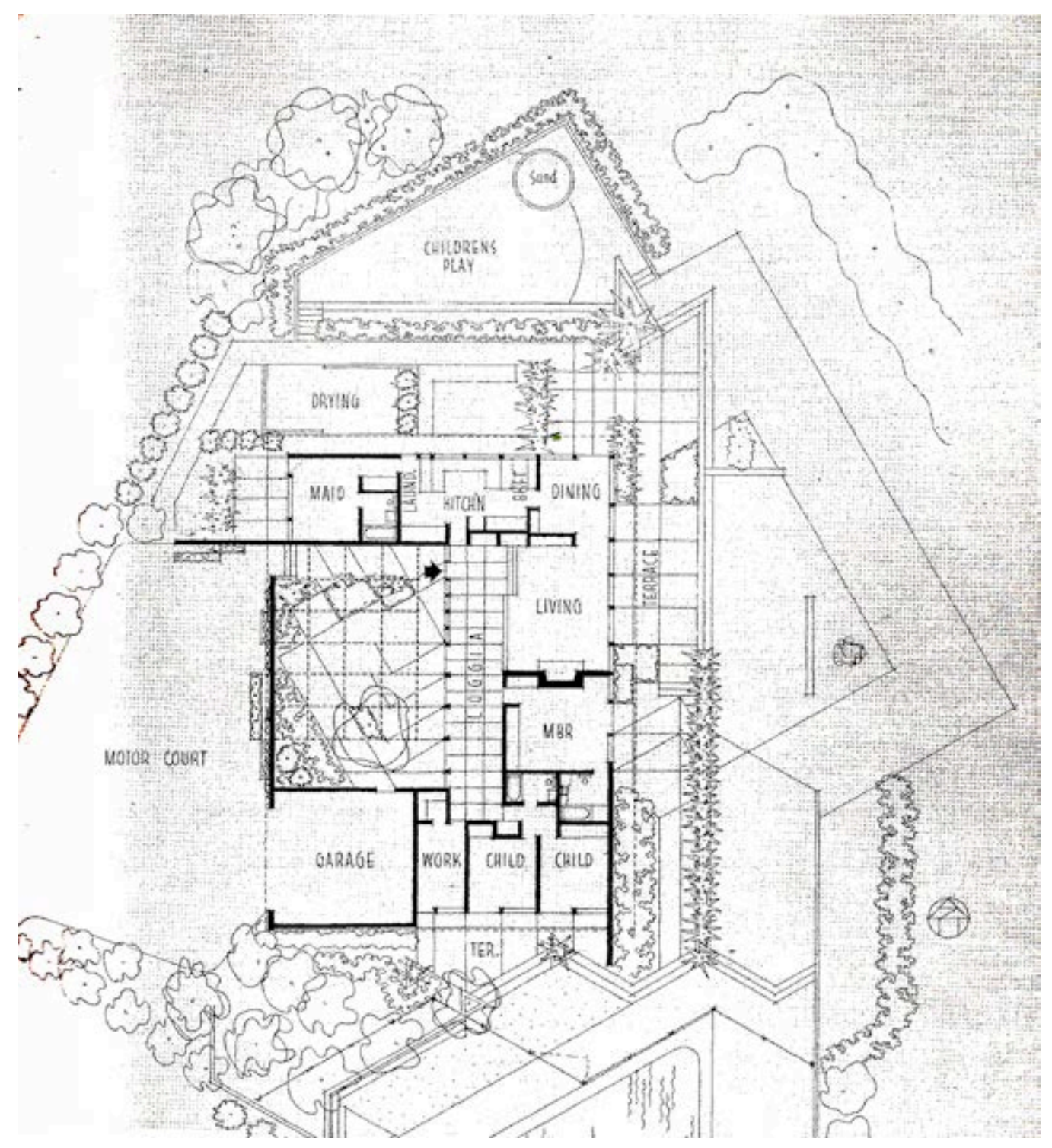

Fig.3.18 - Planta baixa da casa anterior.

A cobertura é plana, com grandes beirais que reforçam a horizontalidade. A geometria definida e os materiais contemporâneos utilizados transmitem a 
impressão de leveza, simplicidade e requinte. Como as casas do Movimento Moderno.

Essas características visuais estão presentes em muitas dessas casas, além de elementos verticais que pontuam as linhas horizontais.

$E$, quando os telhados não são totalmente planos, apresentam pequena inclinação, mas o ângulo das fotos não permite diferenciá-los. Os grandes beirais e outros elementos, como varandas e calhas, salientam essa horizontalidade. Que reforça a ideia de abrigo, repouso, e proteção, que remete à Wright.

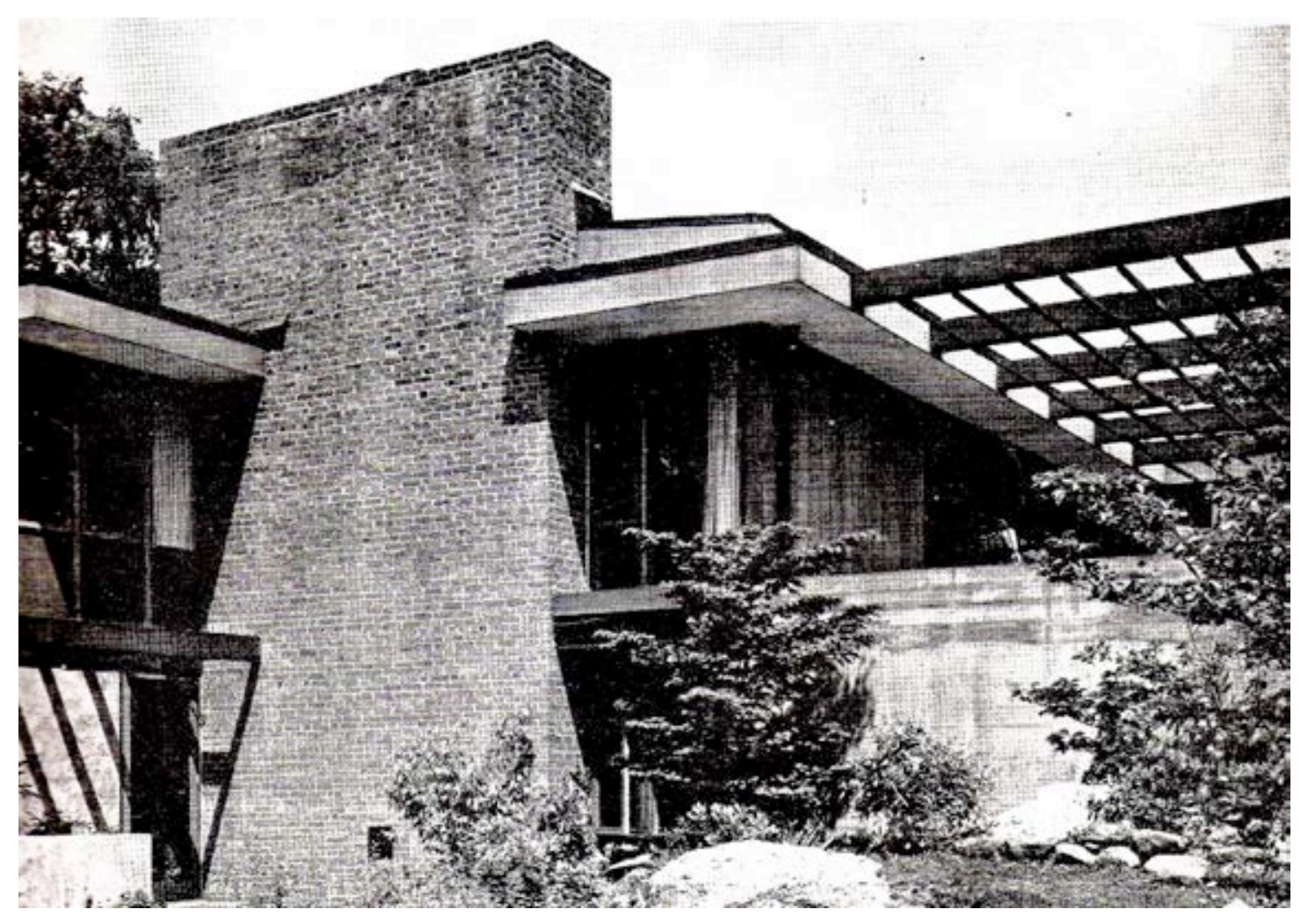

Fig.3.19 - Elementos verticais, como pilares ou lareiras, contrapõem-se à horizontalidade.

Ainda que parte das casas não apresente tais características formais, existe uma preocupação em lhes atribuir qualidades comuns, seja através de um discurso que aponta para uma "ideia de casa" ou da manipulação das imagens. As fotos em branco e preto ressaltam tais características 


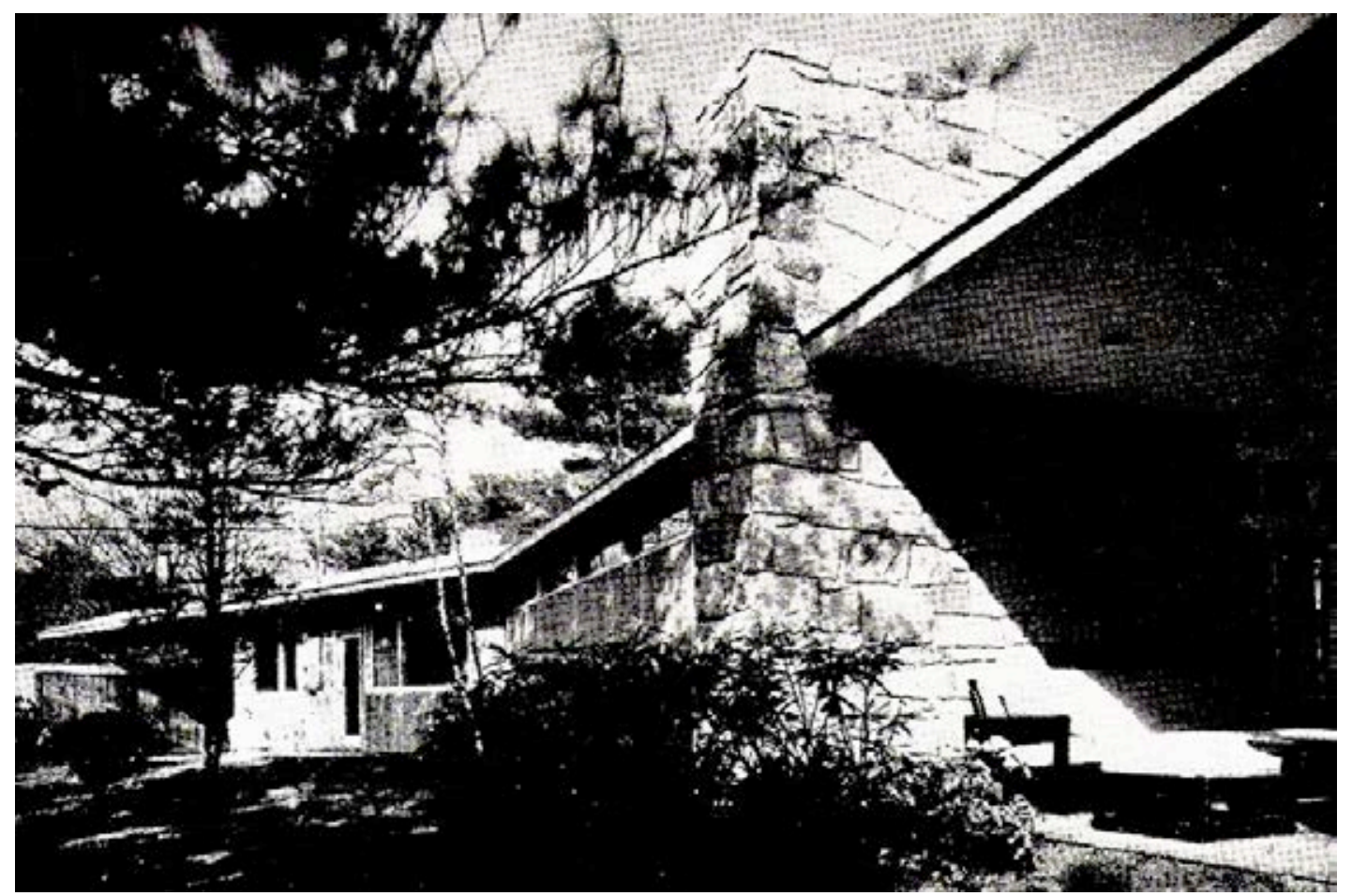

Fig.3.20 - Beirais reforçam a percepção da horizontalidade.

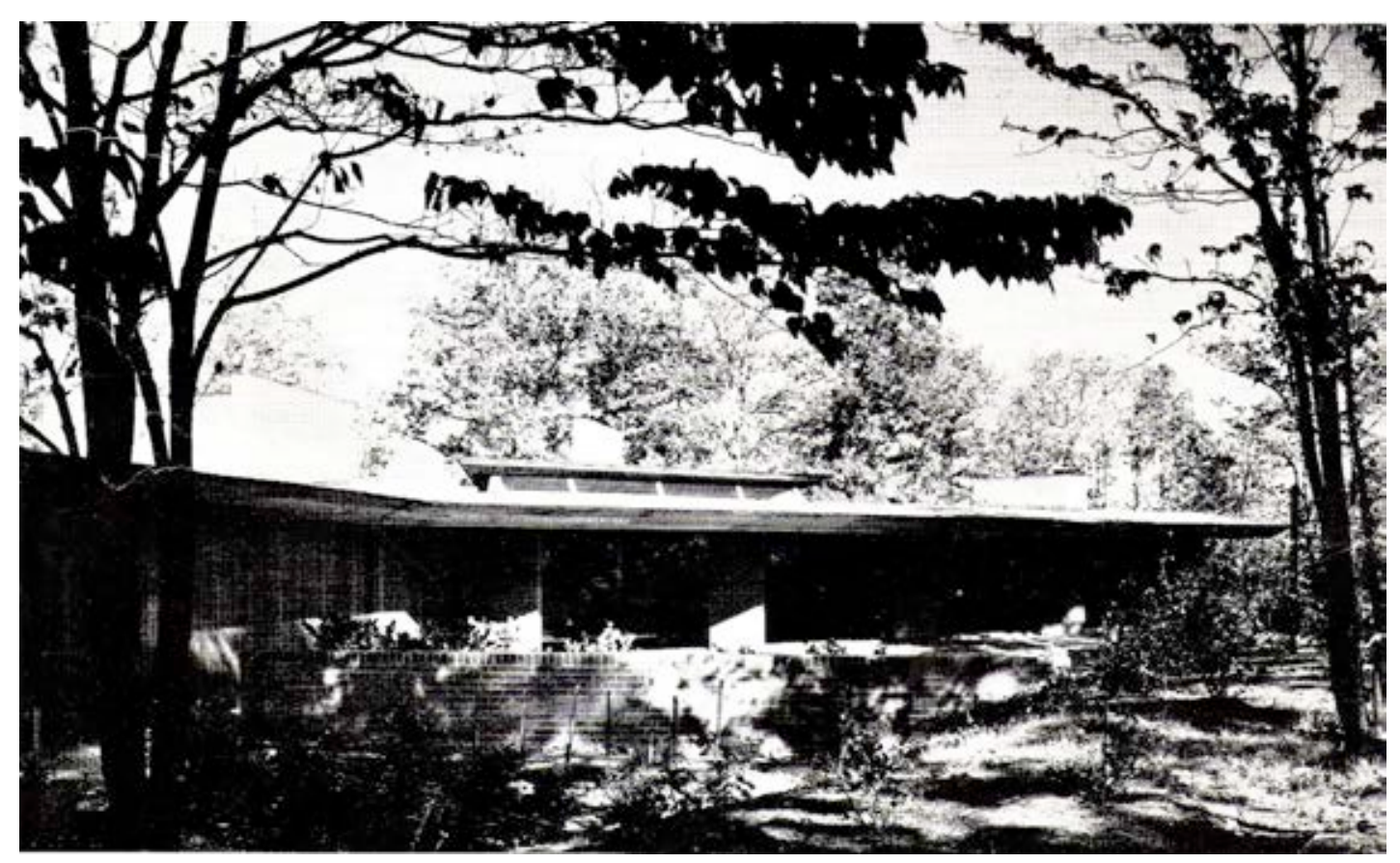

Fig.3.21 - Perfis baixos e horizontais estão presentes em grande parte das casas.

\subsubsection{Totalidade e fluidez}


Outro aspecto, presente nessas casas, é uma noção de totalidade que as vê como um conjunto que vai além dos limites de seus fechamentos, incluindo as áreas de estar ao ar livre, o site e as vistas.

Como afirmara Callender (1952, p.117) que “(...) casa, árvore e terraço são esteticamente e funcionalmente partes integrais de uma composição única."

A integração externo-interno se dá, principalmente, através das aberturas. São portas de correr - presentes em praticamente todas as casas - ou grandes janelas em vidro - as janelas panorâmicas.

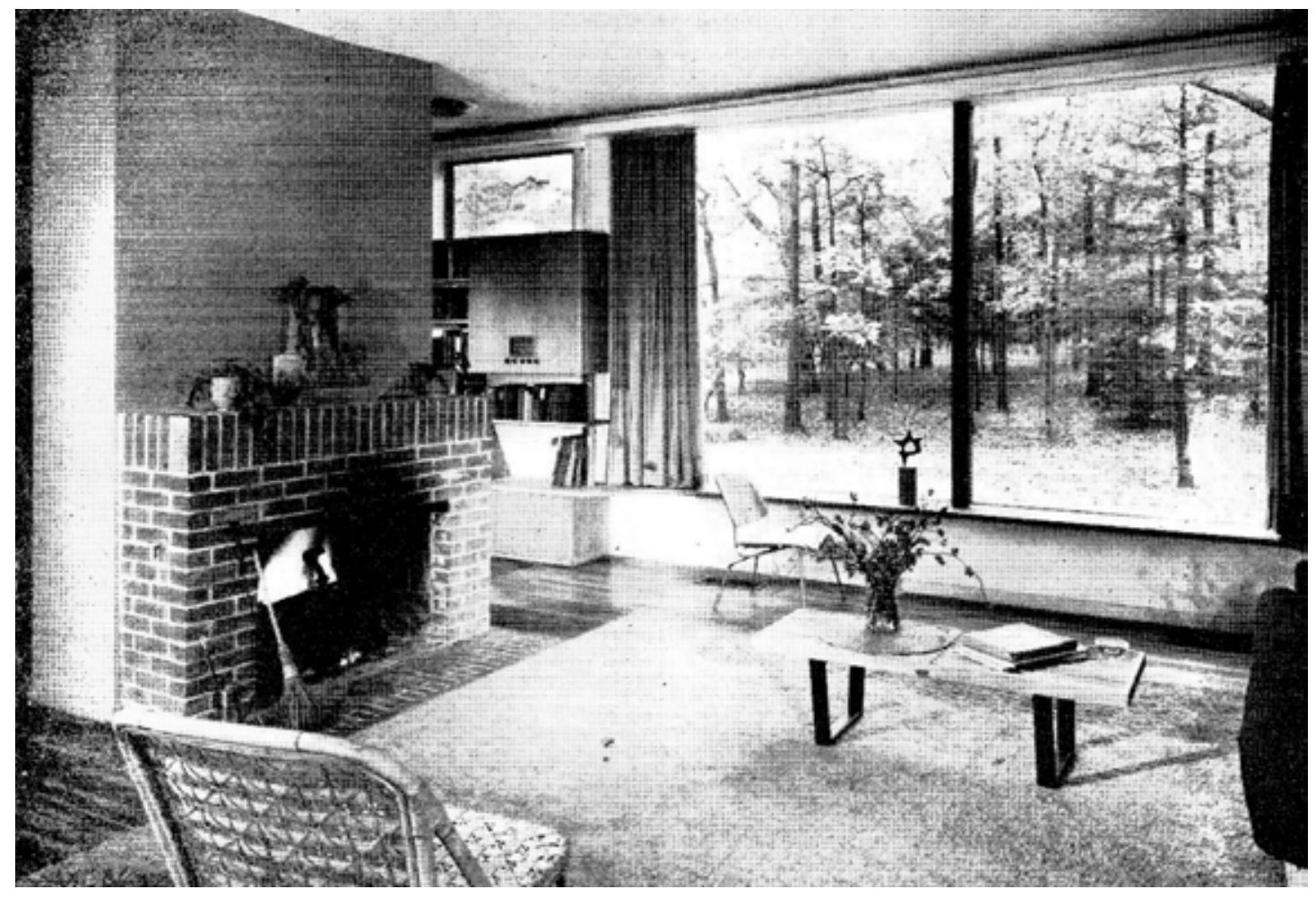

Fig.3.22 - Integração através de janelas panorâmicas.

Nessas casas modernas, o outdoor living é visto como um complemento para os ambientes internos. Mas em uma casa de praia mostrada, esse aspecto se inverte, sendo a casa um mero "auxílio" para o viver fora: "O coração da casa, o verdadeiro 'living room' não está dentro, mas fora." ${ }^{17}$ (CALLENDER, 1953, p.124) O centro da casa é externo a ela.

\footnotetext{
${ }^{17}$ Em relação à casa n. 29, 82 Distinctive Houses from Architectural Record, dos arquitetos Hervey Parke Clark \& John F Beuttler, em Aptos, Cal., publicada em Nov.1951, p.124-6.
} 


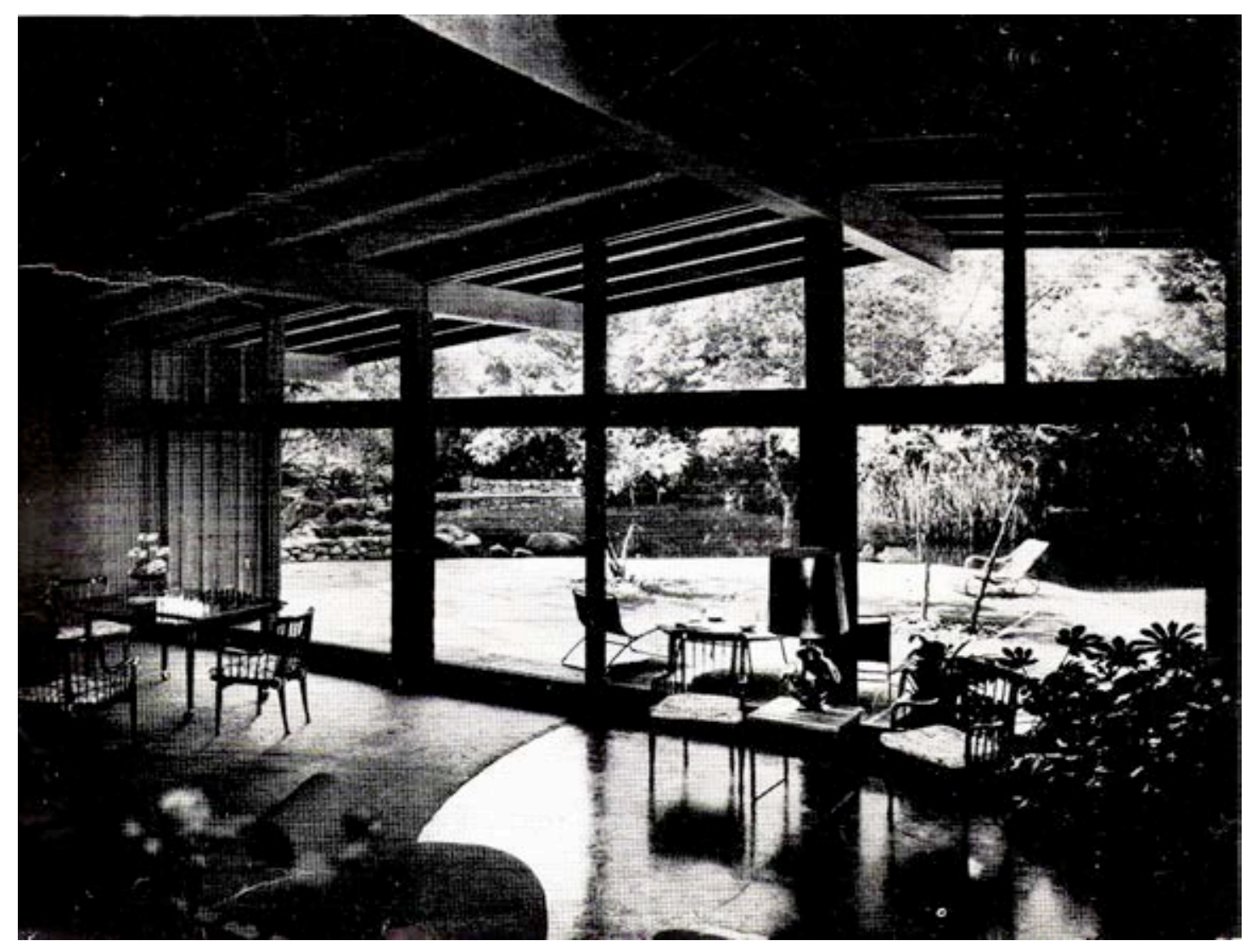

Fig.3.23 - Grandes superfícies envidraçadas.

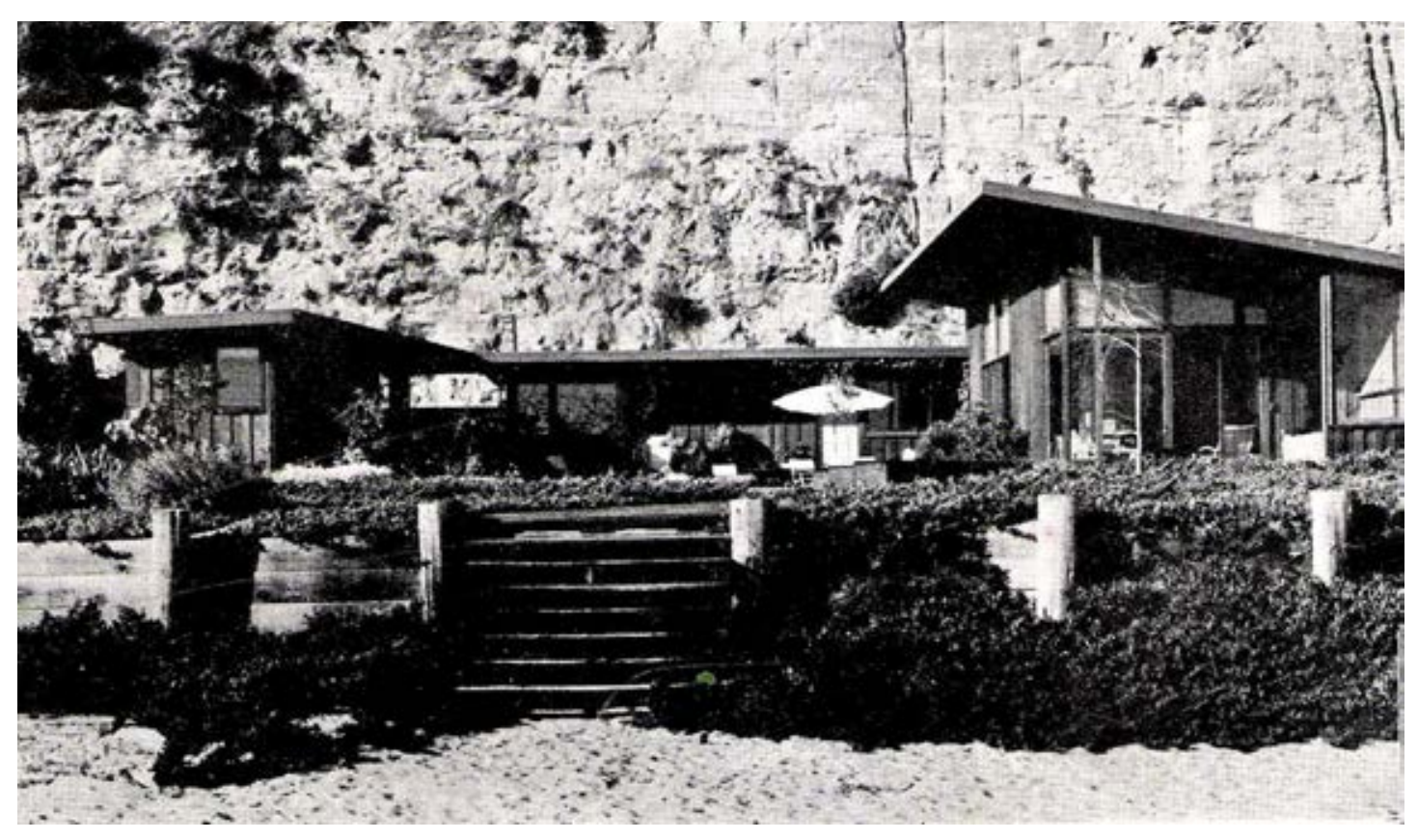

Fig.3.24 - Casa de praia. 


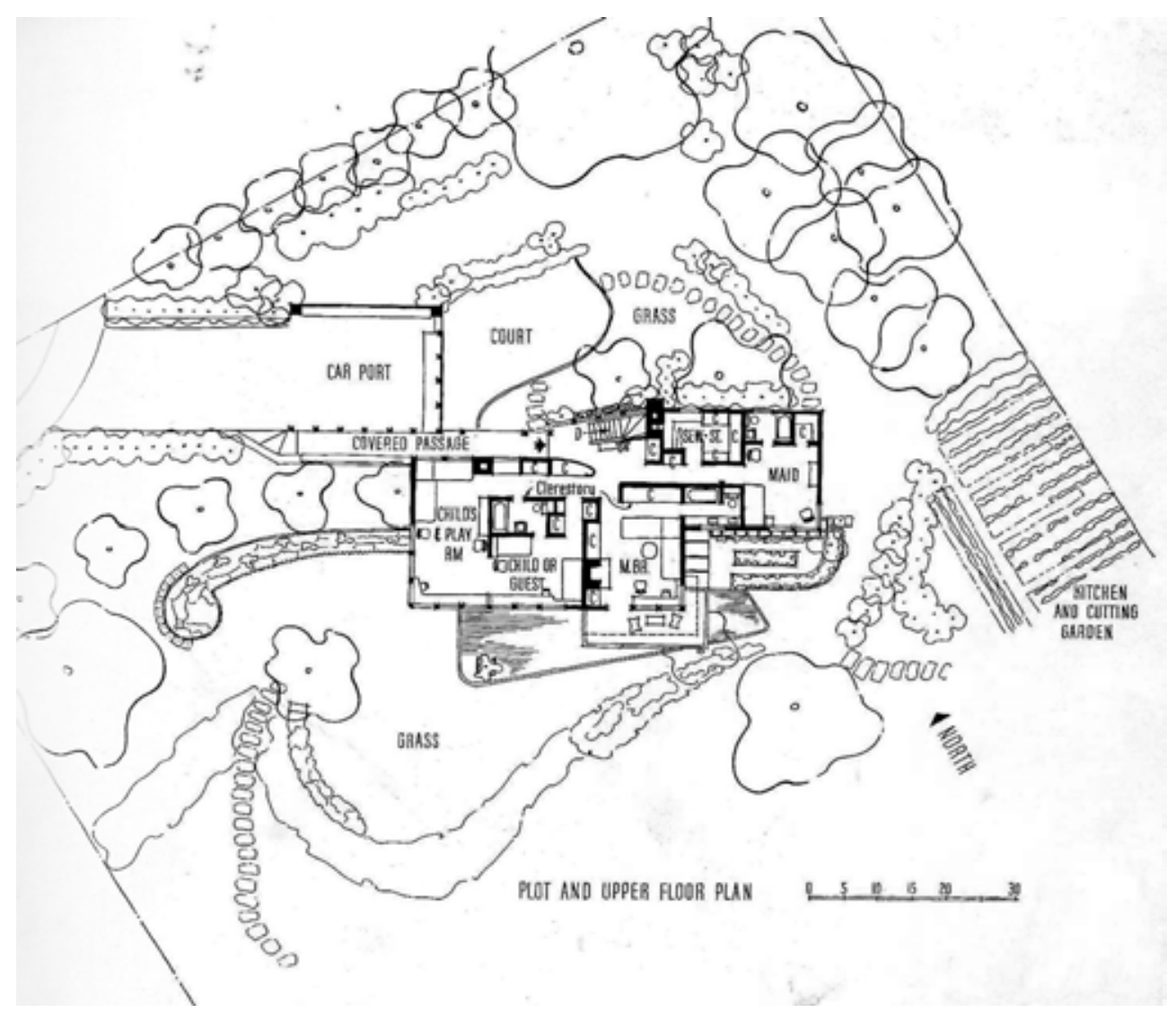

Fig.3.25 - Cuidado no desenho das áreas externas.

A importância da área externa pode ser percebida no cuidado com seu desenho. As plantas das áreas externas mostram pisos, vegetação e outros elementos para o outdoor living.

Esse desenho considera o existente, sempre que possível mantendo a vegetação nativa. Há uma adaptação ao site, mesmo quando são terrenos bastante acidentados, com grandes declives que são, inclusive, preferidos, devido às vistas e à privacidade proporcionadas. A locação da casa e o desenvolvimento da planta baixa levam todos esses aspectos em consideração.

Na casa da Califórnia, ${ }^{18}$ o site é meio natural, meio planejado, mas casa e paisagem formam uma unidade que parece sempre ter existido.

Quando a vegetação nativa é mantida, mescla-se aos jardins planejados por paisagistas - presentes em grande parte dos projetos. Muitas vezes, o paisagismo se "contém" para permitir o desfrute da natureza. É o caso do terraço, "sombreado por uma pérgola com uma parreira, que, no inverno, quando as folhas caem, permite

${ }^{18} 82$ Distinctive Houses from Architectural Record, casa n.19, da arquiteta Edla Muir, já mencionada. 
que o living room seja bastante ensolarado. O paisagismo, ilusoriamente simples, liga a casa a seu site, mas também torna visível e abraça a vista do terraço, através de um vale arborizado." (HOUSE IN..., 1952, p.197) ${ }^{19}$

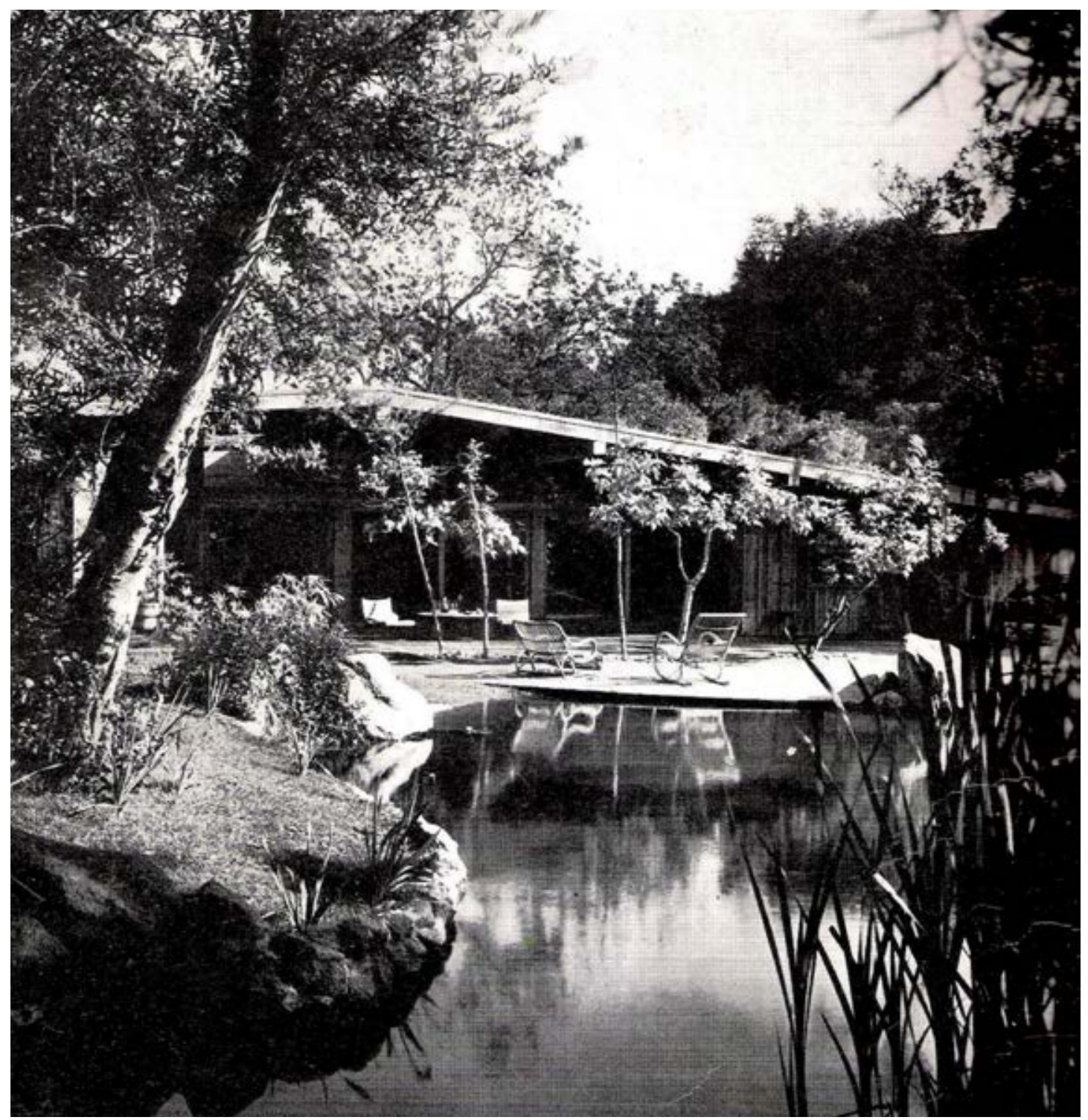

Fig.3.26 - Unidade entre casa e site na Califórnia.

\footnotetext{
${ }^{19} 82$ Distinctive Houses from Architectural Record, casa n. 45, arquiteto Bernard Kessler, em Andover, Massach., publicada em Nov.1950, p.195-9.
} 


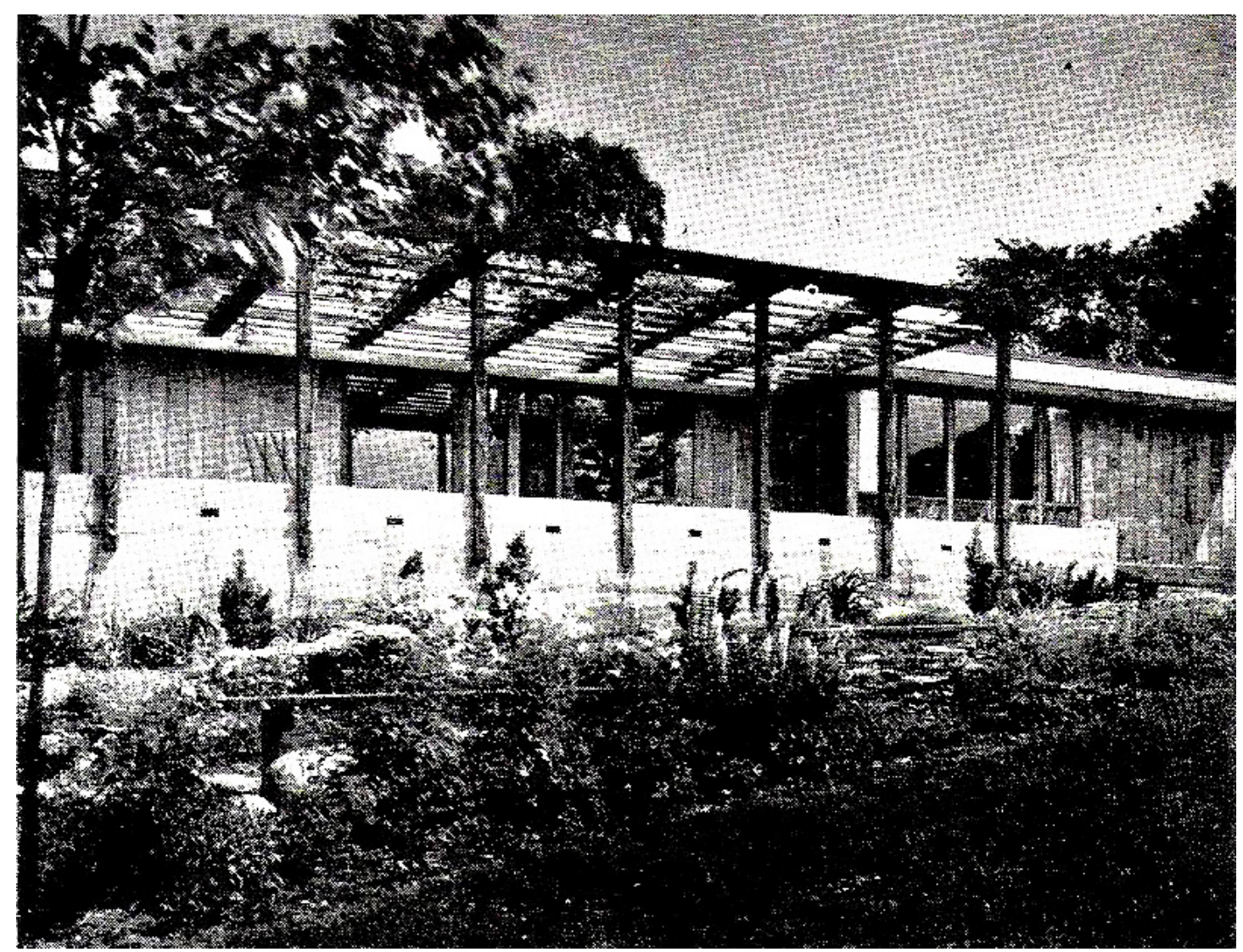

Fig.3.27 - Terraço com pérgola.

A casa do arquiteto John Lloyd Wright ${ }^{20}$ é outro exemplo de fusão casa-site. É difícil identificar o edifício em meio à vegetação do site "luxuriante."

Situada na borda de um penhasco, outra casa também praticamente desaparece em meio à vegetação nativa. ${ }^{21}$

A casa, projetada pelo arquiteto Pietro Belluschi, ${ }^{22}$ apresenta outro tipo de relação com o local onde se situa, um vale, cercado por montanhas com pouca vegetação. Existe, ali, uma interação entre o "vazio" dos amplos horizontes da paisagem e as linhas claras e concisas da edificação.

\footnotetext{
${ }^{20} 82$ Distinctive Houses from Architectural Record, casa n.71, em Del Mar, Califórnia, publicada em Out.1948, p.310-3

${ }^{21} 82$ Distinctive Houses from Architectural Record, casa n. 21, arquitetos Turner \& Northington, em Florence, Alabama, publicada em Mar.1952, p.89-91.

2282 Distinctive Houses from Architectural Record, casa n. 37, em Warm Springs, publicada em Julh.1951, p.156-165.
} 


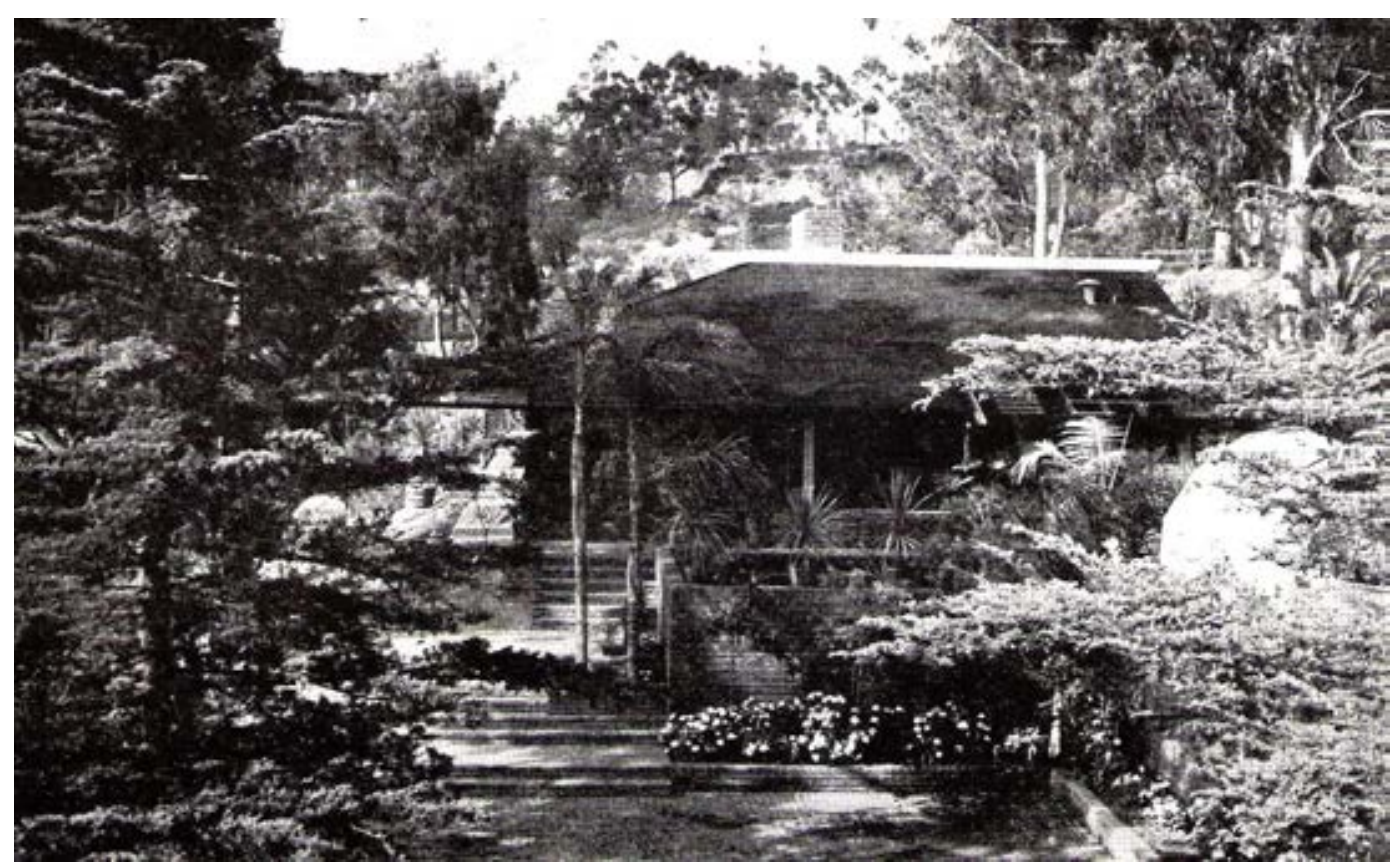

Fig.3.28 - Casa do arquiteto John Lloyd Wright.

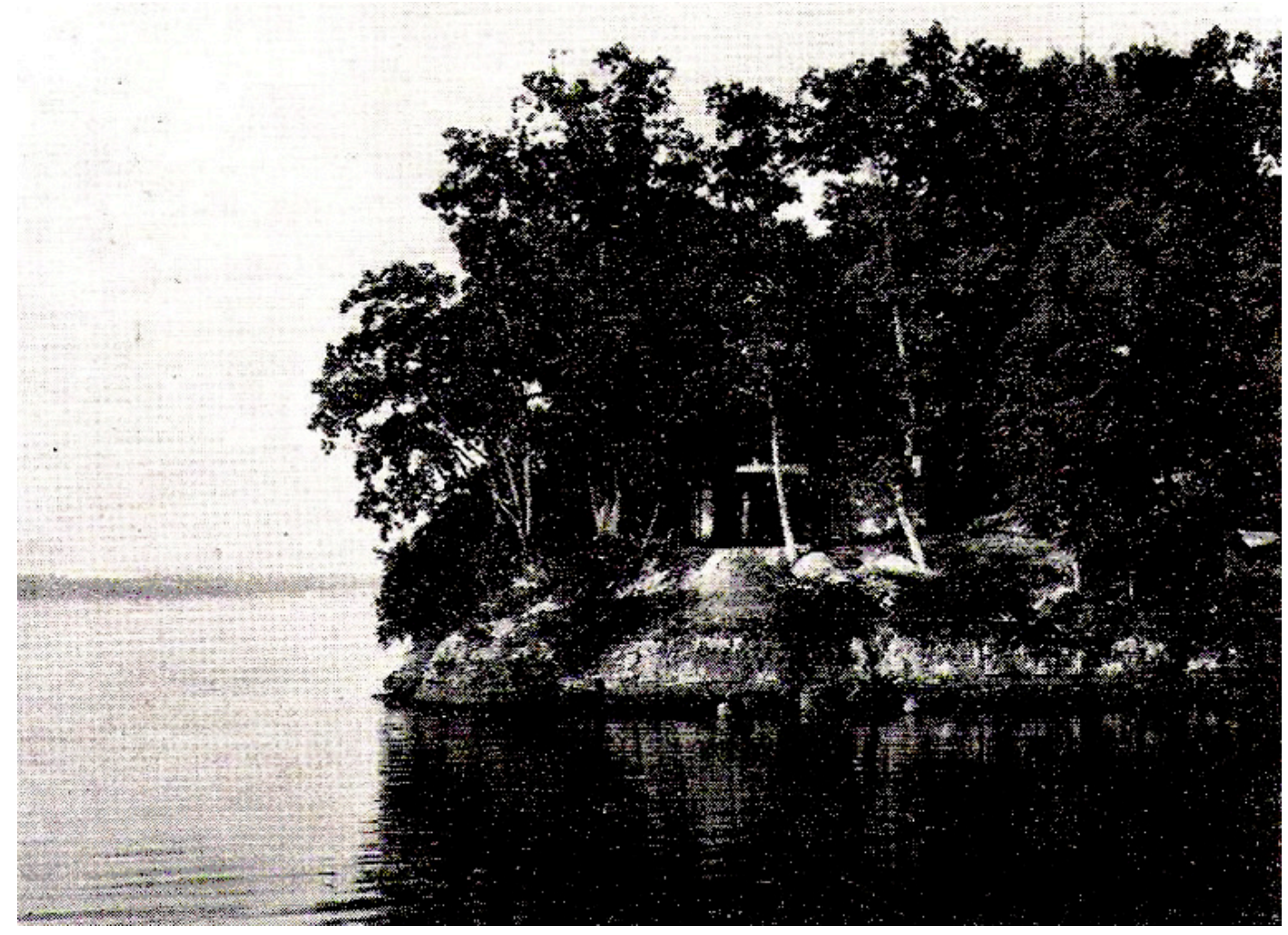

Fig.3.29 - Casa em meio à vegetação nativa. 


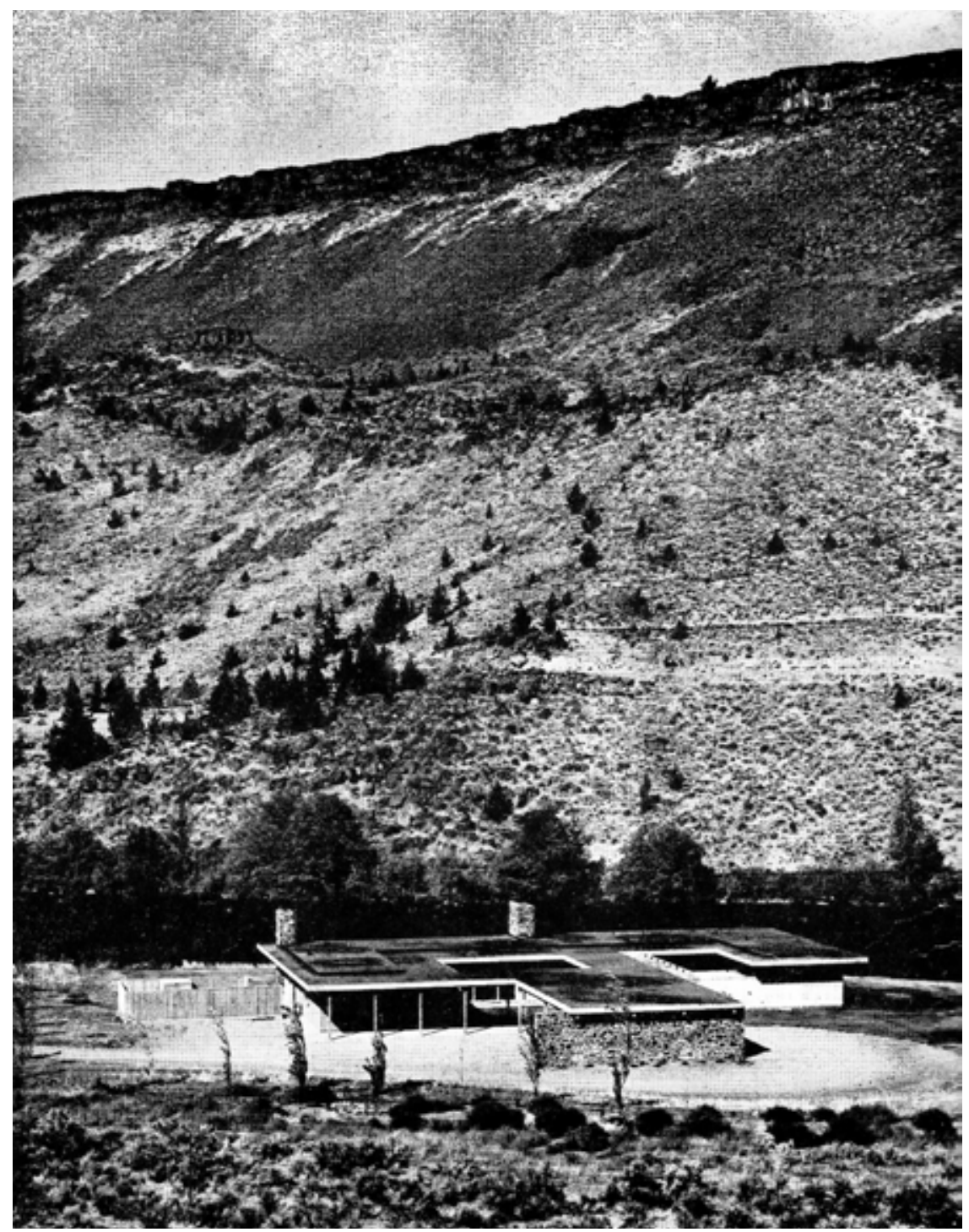

Fig.3.30 - Casa projetada pelo arquiteto Pietro Belluschi.

Essa questão está presente na tradição doméstica americana. Mumford (1952, p.10) aponta uma crescente percepção das qualidades da paisagem, desde Andrew Jackson Downing. ${ }^{23}$ A partir dessa concepção, edifício e paisagem formam um todo harmonioso, que envolve a adequada locação do edifício para "dominar" uma vista e atrair as brisas do verão. ${ }^{24}$

\footnotetext{
${ }^{23}$ A.J. Downing (1815 - 1852) começou sua carreira como paisagista. Em 1842, colaborou com Alexander Jackson Davis no livro de modelos Cottage Residences, com aspectos da arquitetura romântica e pinturesca do campo inglês, que ele acreditava ser um ambiente adequado ao homem. Downing defendia também grandes parques nas cidades, vendo um "aspecto civilizador nos grandes espaços abertos." ${ }^{24}$ Essa teatralidade e dramaticidade das vistas, apesar de Mumford não mencionar, está presente na
arquitetura inglesa, de Norman Shaw.
} 
Assim, quando cria-se uma unidade entre a casa e o espaço circundante, essa conexão não acontece apenas entre materiais, texturas, volumes, mas refere-se ao próprio espaço, que flui e faz essa junção. Um open flow of space. O espaço se derrama, flui, tem continuidade, movimento, vida.

Na casa binuclear de Breuer, ${ }^{25}$ no entanto, o espaço interno é contido e "escapa" em determinados pontos, nas aberturas, chegando até os terraços ou até os pequenos muros de pedra.

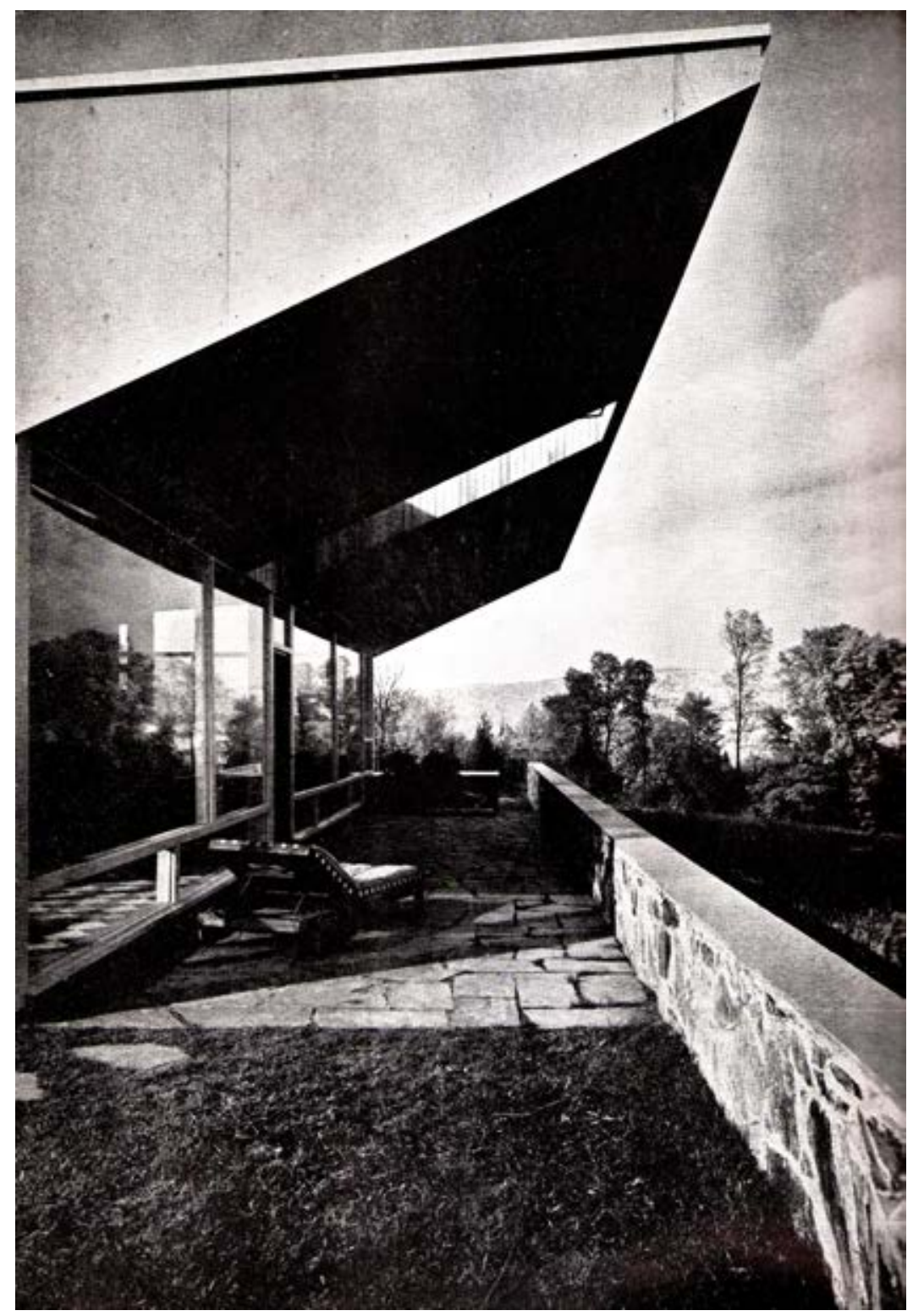

Fig.3.31 -Terraço em casa de Marcel Breuer.

\footnotetext{
${ }^{25} 82$ Distinctive Houses from Architectural Record, casa n.66, do arquiteto Marcel Breuer, em Williamstown, Mass., publicada em Fev.1949, p.283-9. Planta baixa e vista do terraço já mostradas, nas páginas 185 e 186.
} 
Sente-se que o propósito de uma casa não é reprimir ou cercar, mas libertar e ser franca. O espaço é dividido levemente com ambientes separados dos jardins, árvores e gramados por finos painéis de vidro. Existe uma maior flexibilidade de planejamento e uso - e um abandono da caixa fechada e das tradições restritivas. (MASON,1952, s.n.p.)

Essa ideia de fluidez está também presente em uma tradição que vem do século XIX e que prossegue com Wright. Para Scully (1971, p.155), nos "anos 1870, um novo senso de espaço e de fluidez das superfícies desenvolveu-se nos EUA, inicialmente com Richardson, e disseminou-se amplamente, após uma assimilação de influências do colonial americano e do Queen Anne inglês."

Essas mudanças, que adaptam a casa americana às condições locais, necessidades funcionais e materiais, a diferenciam do modelo inglês. A abertura e o fluxo de espaço também são americanos e, por volta dos anos 1880 , já estão amadurecidos.

Trata-se de uma espécie de continuidade plástica em que os contornos das superfícies ficam indistintos e a forma sólida tende a se dissolver na luz.

Scully (1971, p.88) vê diferenças substanciais na constituição dos espaços de uma casa $^{26}$ de William Ralph Emerson ${ }^{27}$ e de uma casa inglesa da época. Nesta, cada cômodo é uma entidade separada, um cubo de espaço fechado, enquanto a americana é aberta, sendo a varanda, uma extensão dela. ${ }^{28}$

Sobre outra casa de Emerson, Scully (1971, p.110) diz: "A planta da Loring House (...) abre-se facilmente; existe uma sensação de uma agradável expansão e um fluxo de espaço através da casa e em direção ao exterior."

Além das modificações na concepção espacial, aconteceu um ajuste às condições de vida americanas. Pode-se falar em uma nova informalidade no viver, que se manifestaria em um tipo peculiar de planta aberta com a junção de ambientes de estar e jantar em um mesmo cômodo, tendo uma grande lareira e uma varanda ao redor. Além disso, havia janelas maiores, mais numerosas, e poucas portas no

\footnotetext{
${ }^{26}$ Em Mount Desert, Maine, de 1879.

${ }^{27}$ William Ralph Emerson (1833-1917) foi um arquiteto americano conhecido por suas casas filiadas ao Shingle Style.

${ }^{28}$ No entanto, o movimento Arts and Crafts inglês apresenta várias casas com cômodos integrados através de portas de correr ou de mezaninos e outras soluções espaciais.
} 
pavimento térreo. ${ }^{29}$ Isso acontece certo tempo antes de Wright levar a cabo sua própria reorganização do espaço interno.

O movimento do espaço não era apenas do interior para o exterior. Em relação à outra casa de Emerson, a W.B. Howard House, suas "vistas (...) 'arrastavam' visualmente a grande extensão do terreno circundante para a casa, acolhendo as montanhas e o mar. Como em muitas das melhores casas consideradas, havia uma grande sensação de abertura para o panorama, de um mergulho no vazio do espaço." (SCULLY, 1971, p.111)

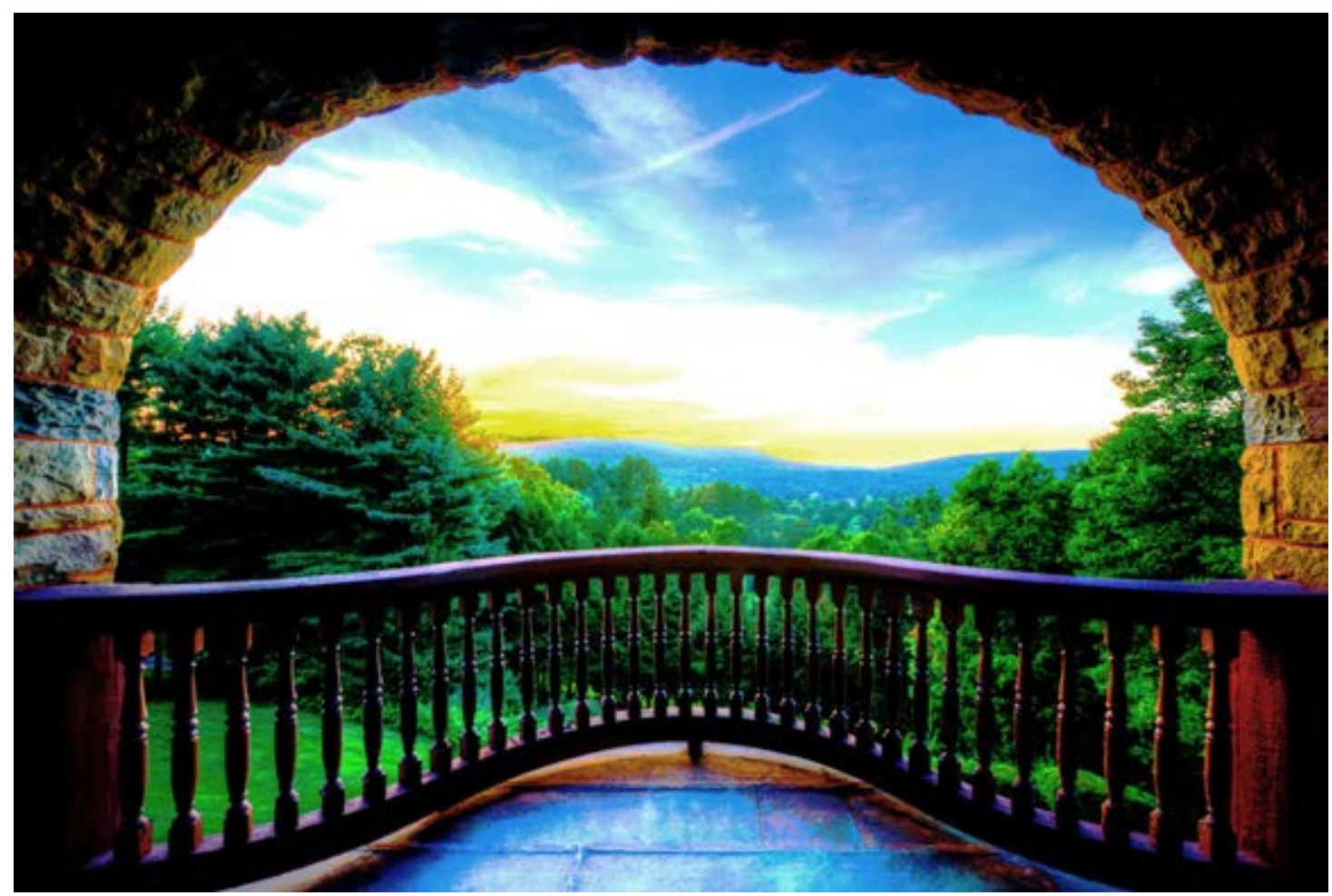

Fig.3.32 - Tianderah, uma Brownstone Baronial Manor, projeto de William Ralph Emerson, 18851887, em Gilbertsville, NY.

Dessa forma, a integração do exterior ao interior está intimamente ligada à importância do espaço aberto para os americanos e do contato com a natureza.

Uma das grandes crenças da América é, justamente, de que se trata de uma nação espaçosa, vasta, sem limites, com recursos naturais inesgotáveis. Desde o tempo dos pioneiros, na medida em que se deslocavam para o oeste, surgiam grandes extensões de terra, vistas intermináveis, uma após a outra. Tudo isso ficou gravado

\footnotetext{
${ }^{29}$ Esses aspectos podem ser vistos em pequenos cottages, simples e despretensiosos, localizados no subúrbio ou na praia.
} 
na memória coletiva da nação e reaparece constantemente em sua cultura. Um dos aspectos dessa questão, como lembra Isenstadt (2006, p.1), é que americanos, em geral, não gostam de se sentir confinados.

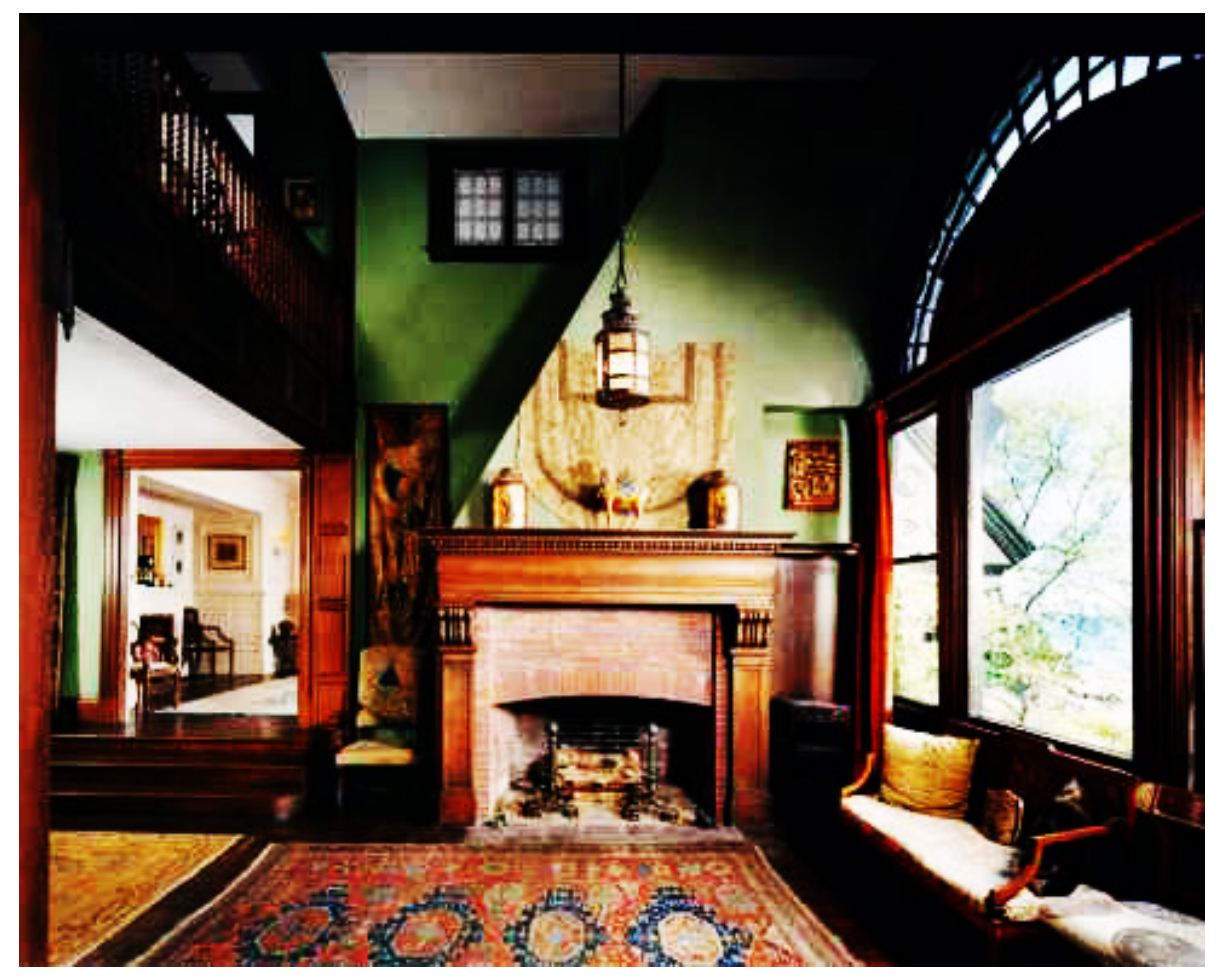

Fig.3.33 - Interior da Loring House.

\subsubsection{Spaciousness, o espaço psicológico.}

Mas, como nem sempre existem recursos para a posse de uma grande casa em um vasto lote, desde o inicio do século $X X$, arquitetos e outros profissionais têm tentado criar um senso de amplidão nas casas, através de várias estratégias ao alcance da arquitetura, do paisagismo e do design de interiores.

Principalmente na pequena casa de classe média, passou-se a trabalhar com dois conceitos de espaço, o "real" e o "percebido" ou "virtual". O primeiro poderia ser medido, o segundo apenas sentido e apreciado. Este, etéreo, leve, porém ilusório, extrapola o espaço físico, real. Está além das dimensões verdadeiras e de seus custos reais. Podia-se "criar" amplidão - spaciousness.

$\mathrm{Na}$ metade do século $\mathrm{XX}$, uma série de elementos da arquitetura da casa foram afetados por esse conceito. Para Isenstadt (2006, p.4), essa é uma questão central 
na concepção da arquitetura doméstica moderna americana, que auxilia na tomada de decisões projetuais. ${ }^{30}$

A janela panorâmica, por exemplo, estabelece a possibilidade de "trazer o exterior para o interior," uma frase pronunciada repetidamente nos anos do pós-guerra. "Compacidade com a ilusão de amplidão" foi um conceito que associou-se à pequena casa moderna - publicado em inumeráveis revistas, profissionais ou não -, e fixou-se no imaginário da classe média. Essas grandes janelas atraíam o olhar para além dos limites da pequena casa. ${ }^{31}$ Eram utilizadas pelo menos desde o início do século $X X$.

Outro recurso utilizado para fazer o espaço parecer maior era o pé direito baixo, aliado ao prolongamento das paredes ou do forro ao exterior. As réguas de madeira, nesse caso, ampliam visualmente o espaço, com um efeito de movimento.

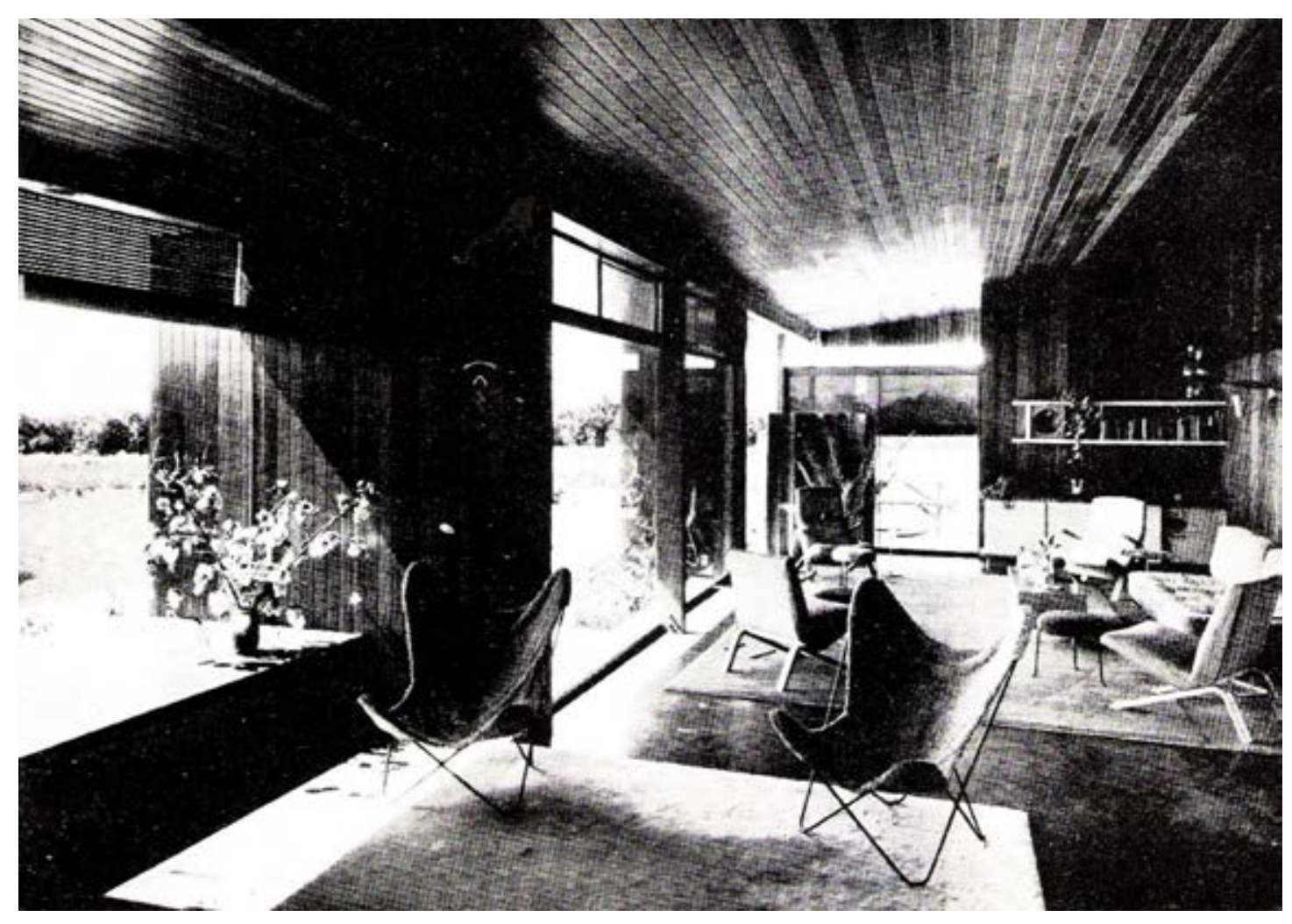

Fig.3.34 - As réguas do forro ampliam o espaço e conferem sensação de movimento.

\footnotetext{
${ }^{30}$ Este ponto está intimamente ligado às preocupações que tocavam a classe média americana. Está ausente dos debates relativos à habitação para famílias de baixa renda e nas casas da elite, onde o espaço real já é generoso, mostra-se desnecessário. (ISENSTADT, 2006, p.4)

${ }^{31}$ Os espelhos também eram utilizados para aumentar o sentido de amplidão e de luz. Poderiam intensificar a profundidade.
} 
Os ambientes internos integrados da planta aberta, com menor quantidade de cômodos fechados, ajudam nessa percepção de um espaço mais extenso. Móveis mais baixos ou vazados, lareiras, paredes com grandes aberturas e painéis deslizantes - todos elementos que não dividem totalmente o espaço - também contribuem para esse efeito.

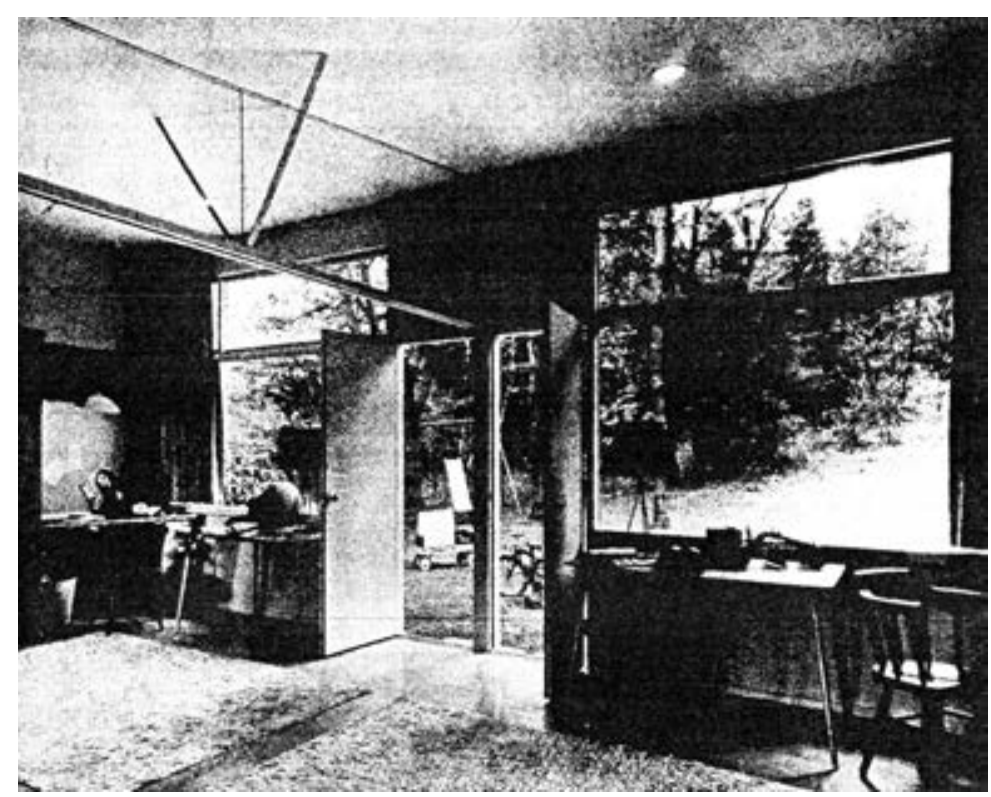

Fig.3.35 - Dormitório dividido por painéis deslizantes.

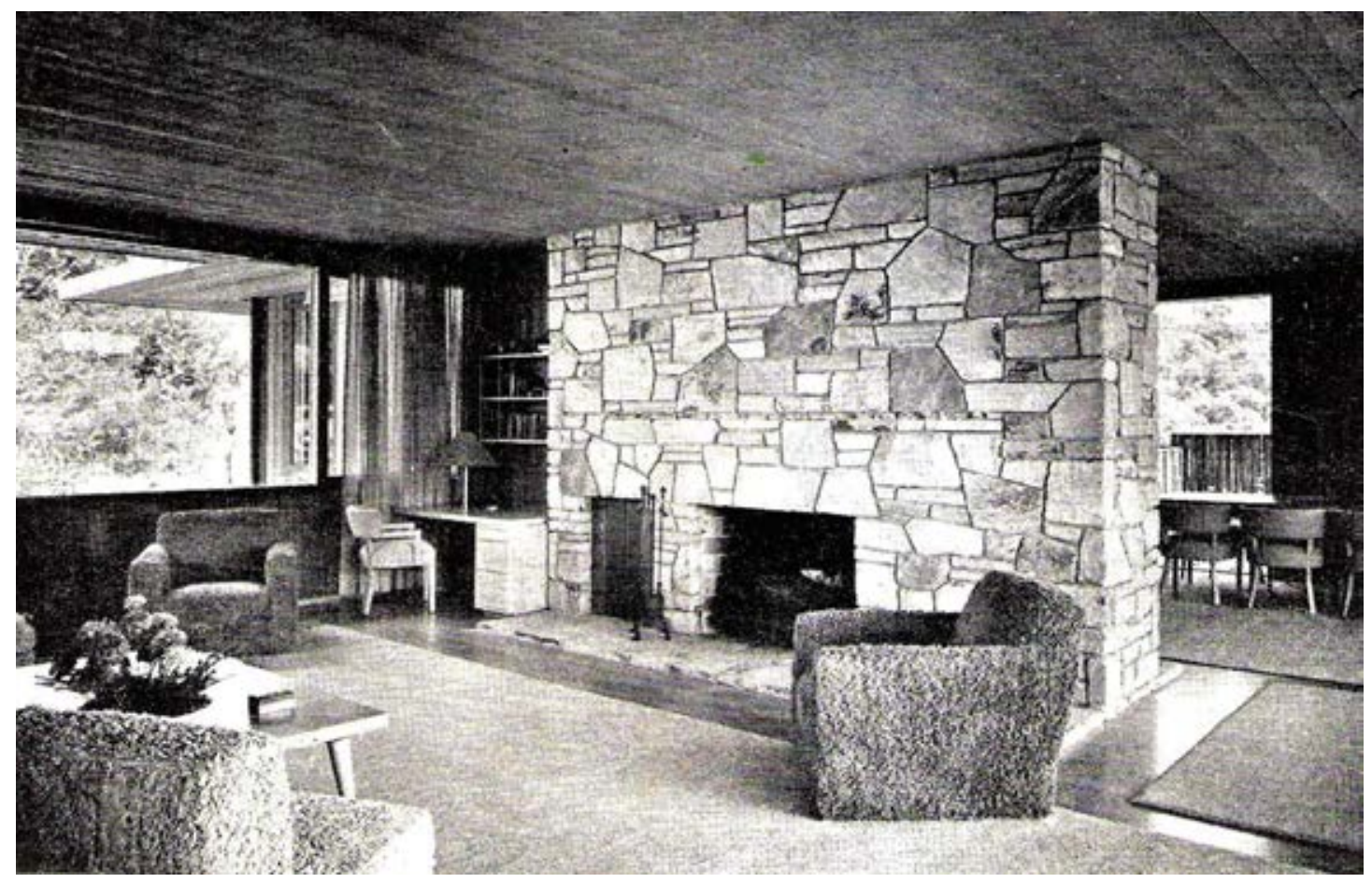

Fig.3.36 - Lareira separando parcialmente o espaço. 
A amplidão pode ser observada em uma pequena casa, ${ }^{32}$ onde os arquitetos Gregory Ain, ${ }^{33}$ Joseph Johnson e Alfred Day - conseguiram, através de vários artifícios, obter essa sensação. Painéis deslizantes permitem a utilização flexível do espaço disponível, escondendo o estúdio e separando os dormitórios apenas quando a privacidade é necessária. O teto quase contínuo e uma grande janela no living também proporcionam essa percepção de um espaço maior do que o real.

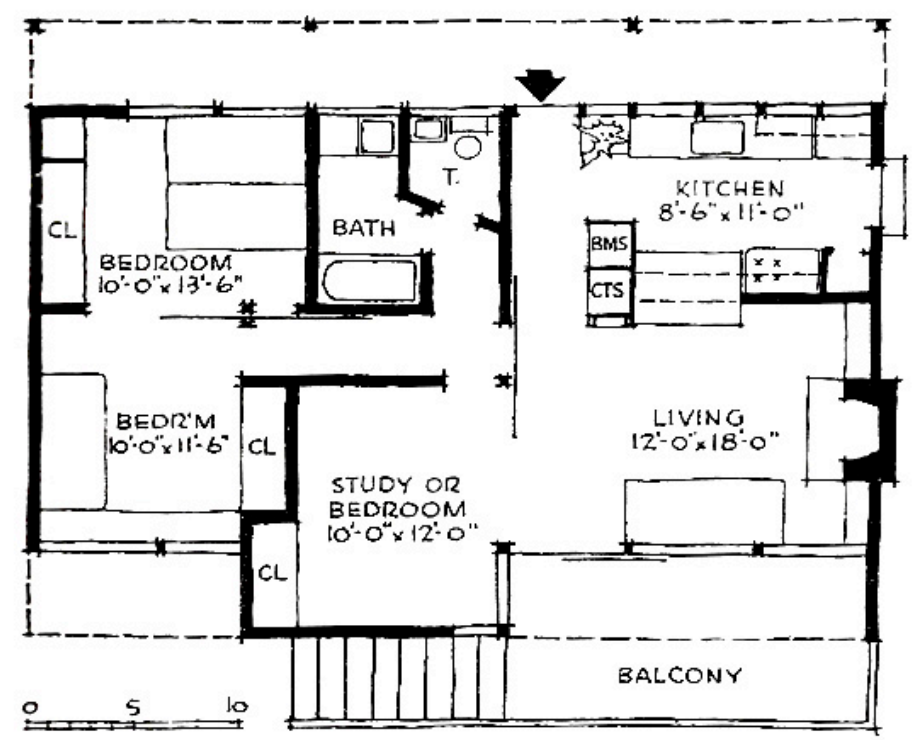

Fig.3.37 - Planta baixa da casa de Gregory Ain, Joseph Johnson e Alfred Day.
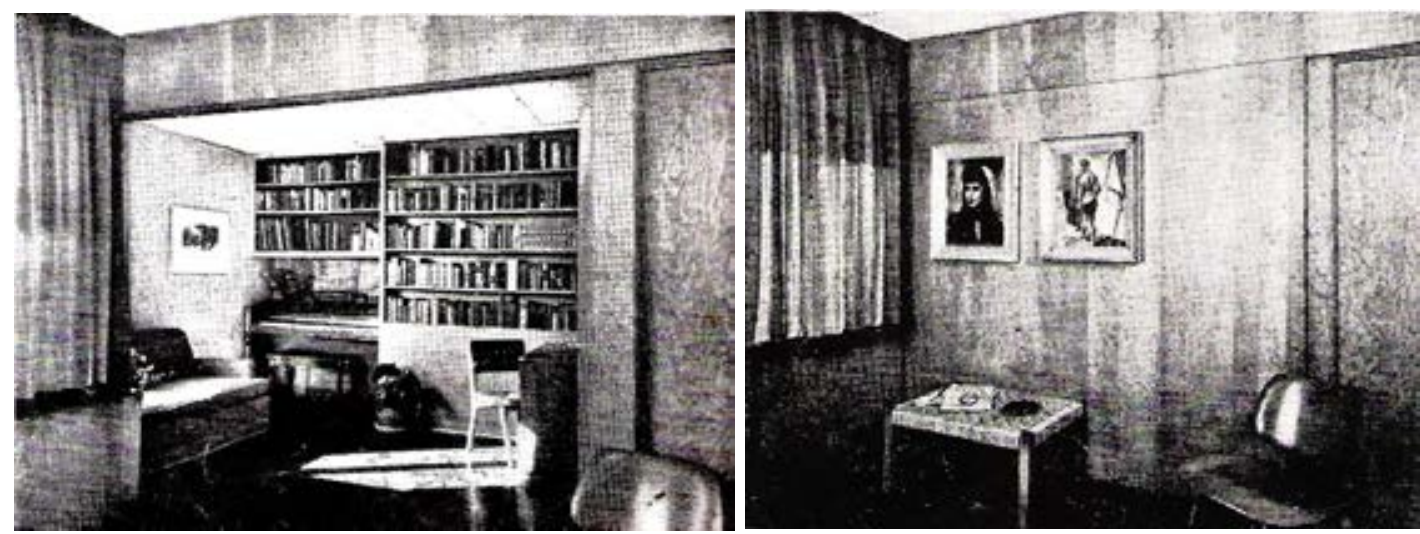

Fig.3.38 - Casa anterior, mostrando o painel deslizante, que esconde o estúdio quando necessário.

\footnotetext{
${ }^{32}$ Com área de $908 \mathrm{ft} 2$, que correspondem a 84,356 $\mathrm{m}^{2}$. "Engenhosidade proporciona amplidão," Casa n.77, em Los Angeles, Cal., publicada em Set. 1948, p.333-5.

${ }^{33}$ Ain projetou uma das casas construídas nos jardins do MOMA.
} 
Observando-se o terreno, vê-se que a opção por uma casa pequena não se deve à falta de espaço no lote. Provavelmente, é uma questão de diminuição de custos e de preservação de uma grande área livre. Além do fato de haver restrições governamentais no pós-guerra em relação à área máxima construída.

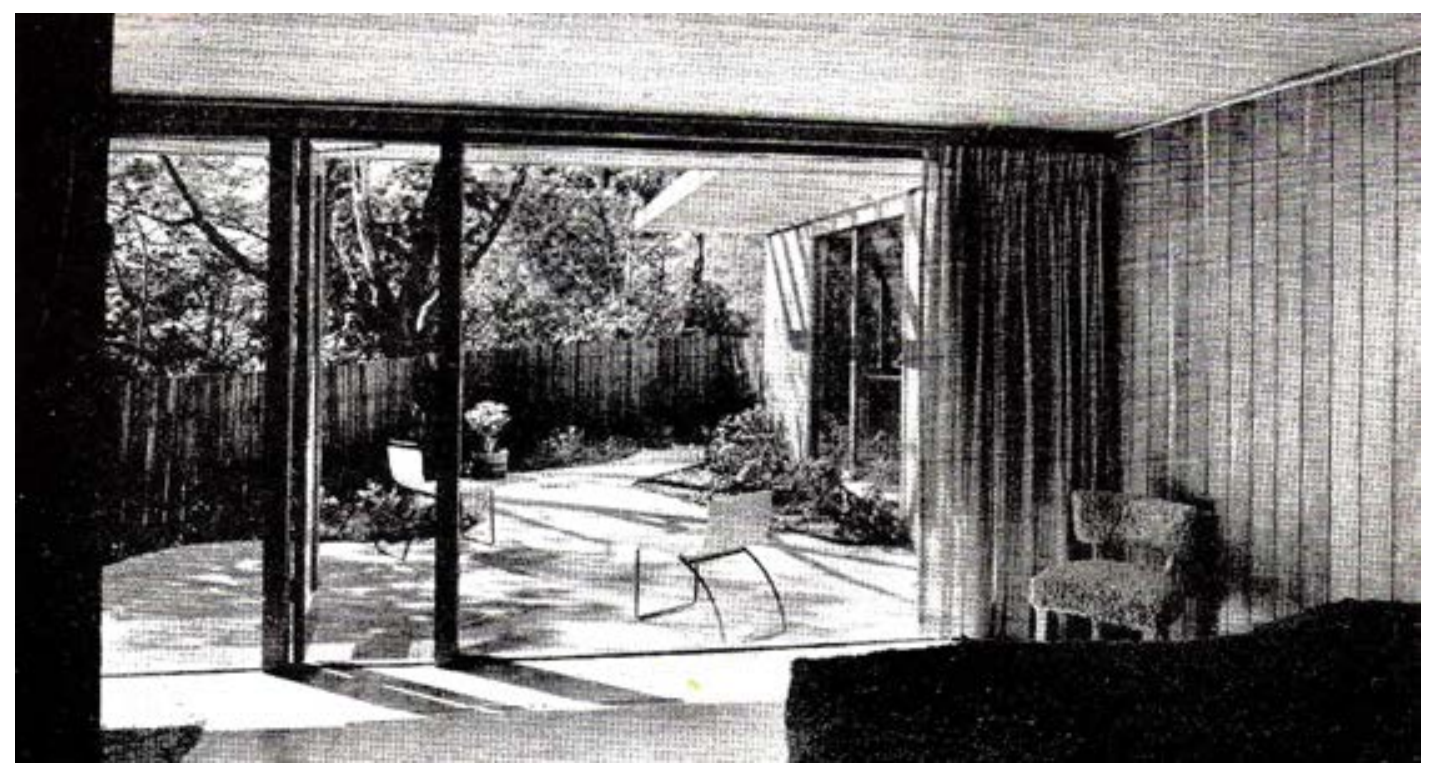

Fig.3.39 - Dormitório da casa projetada pelo arquiteto Henry Hill..

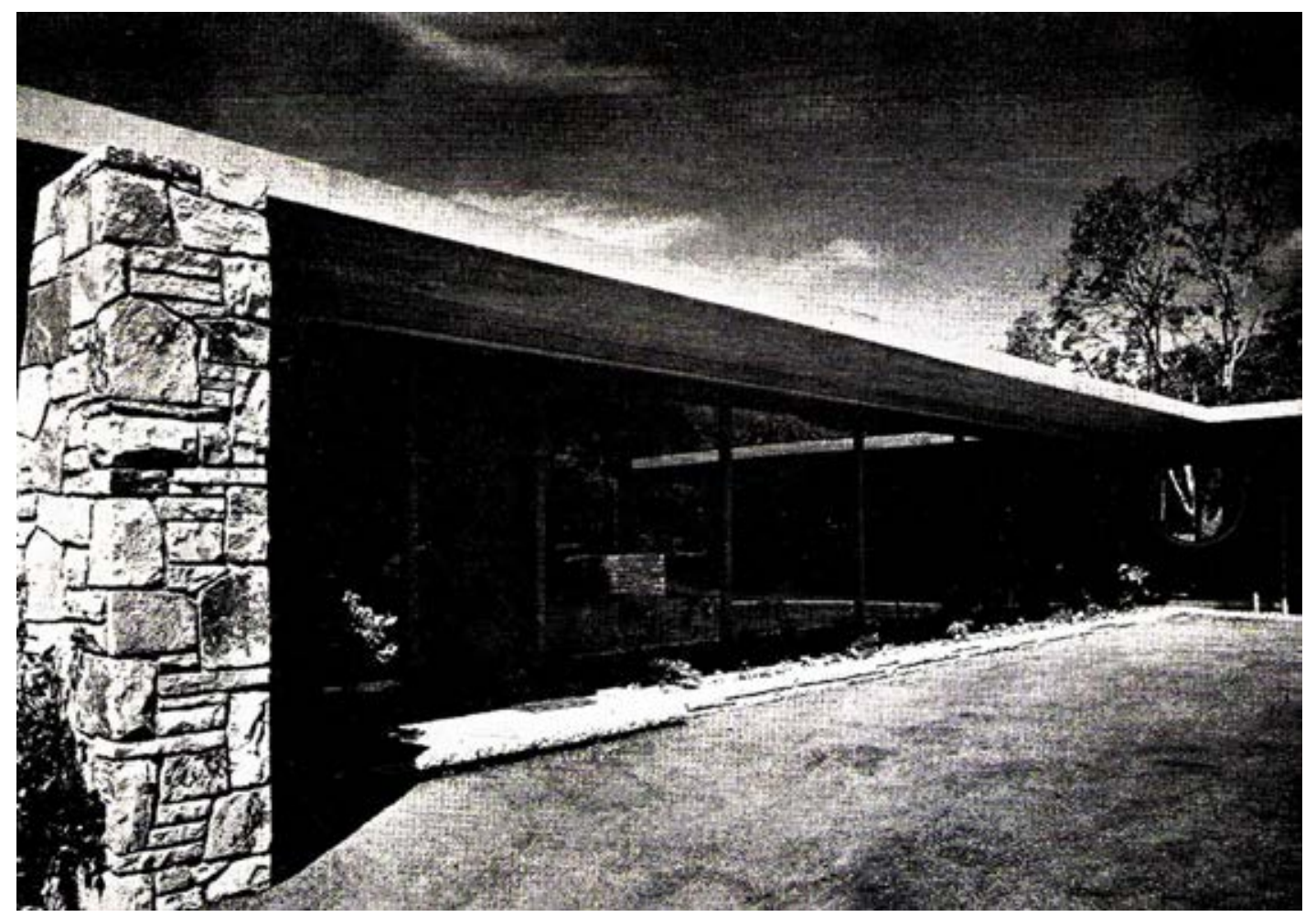

Fig.3.40 - Acesso à casa do arquiteto Henry Hill. 
$\mathrm{Na}$ casa projetada pelo arquiteto Henry Hill, ${ }^{34}$ a amplidão é proporcionada pelos panos de vidro e pelo forro em madeira. Apesar das grandes aberturas, existe sempre a preocupação com a privacidade. A parede maciça em pedra e a vegetação protegem a lateral onde está o acesso à casa, de olhares estranhos. Além disso, o dormitório principal abre-se para um pequeno pátio e cercas protegem a grande área externa e a piscina. ${ }^{35}$

Como essa, a maioria das casas é térrea, com plantas abertas, poucos cômodos, com várias funções. Geralmente estar e jantar são integrados e a cozinha, também, em parte dos projetos.

As plantas, muitas vezes, são resolvidas em várias alas. Constituem-se, assim, vários pátios, de estar e de serviço. Isso é possível porque os terrenos são muito grandes. Essas casas quase se "derramam."

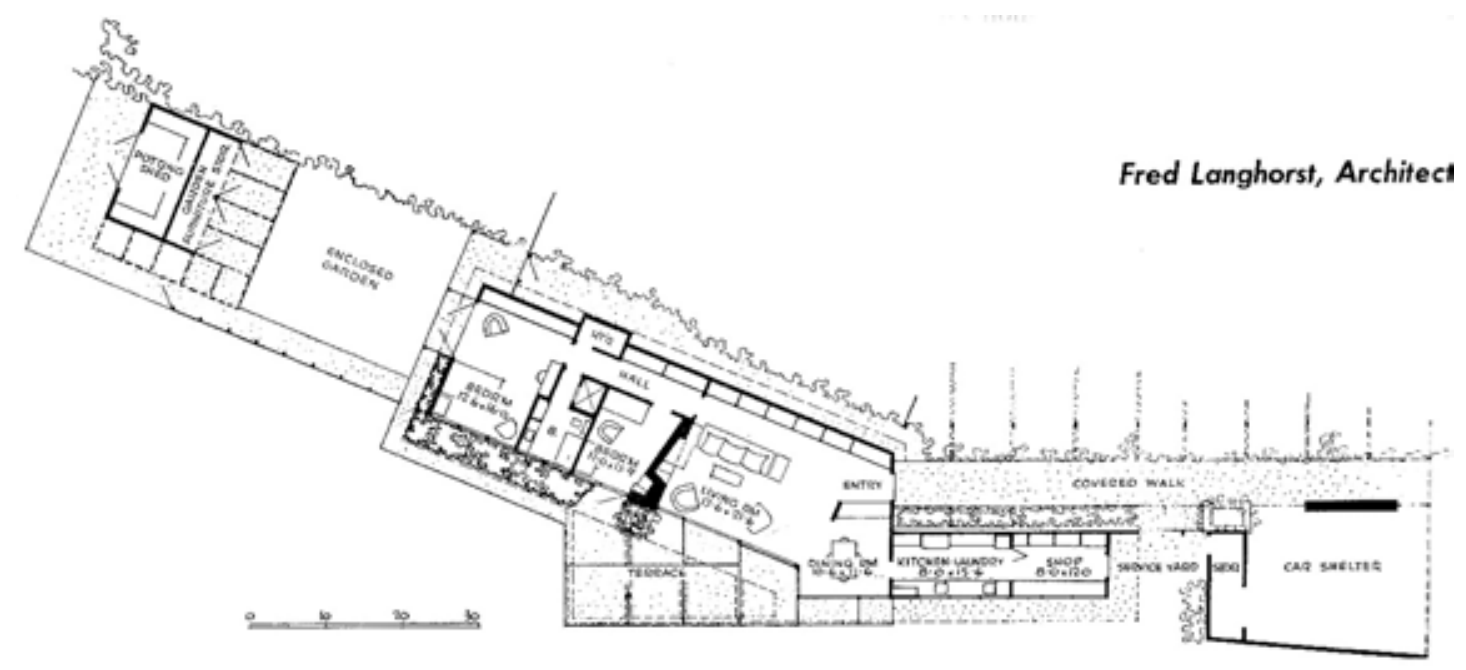

Fig.3.41 - Casa em alas.

\footnotetext{
${ }^{34} 82$ Distinctive Houses from Architectural Record, casa n. 52, em São Francisco, publicada em Jun. 1949, p.230-5.

${ }^{35}$ A casa está localizada de acordo com a melhor orientação solar e desfrutando as vistas das montanhas. Grandes beirais protegem as janelas do sol oeste de verão, mas permitem a insolação no inverno.
} 


\section{A GAZINE CLIENT}

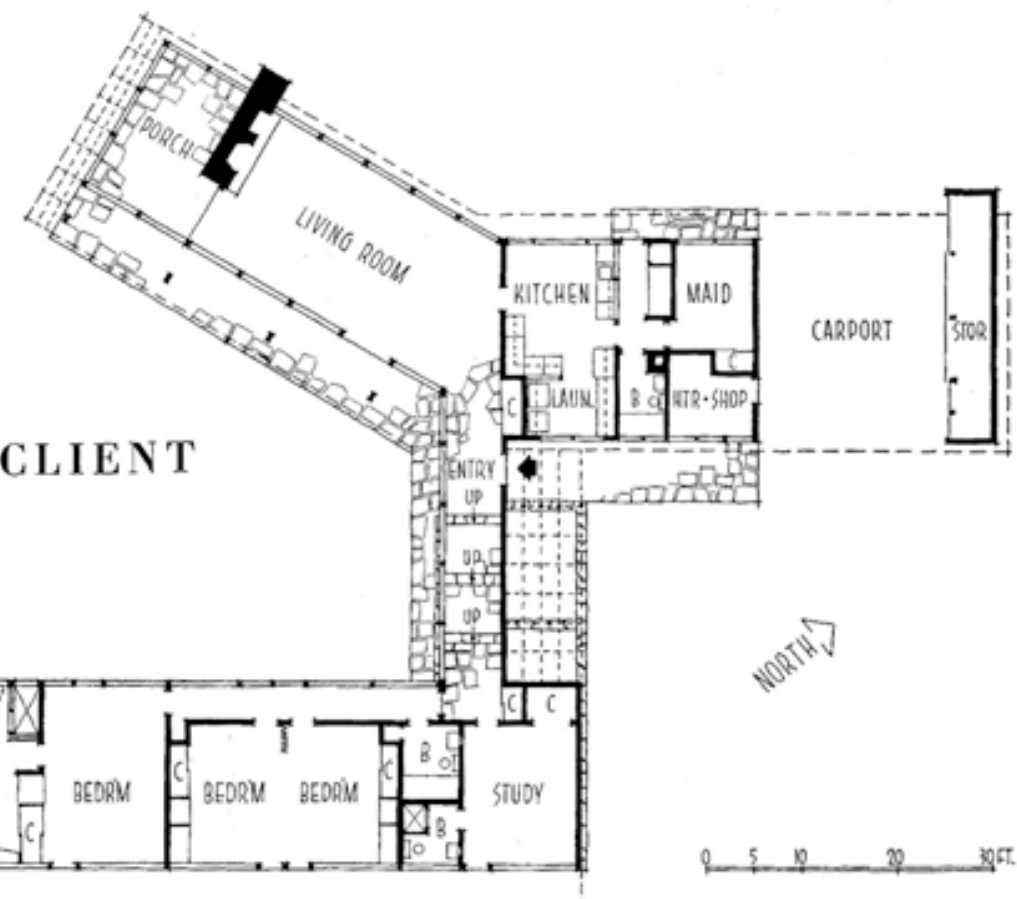

Fig.3.42 - Outra casa com planta baixa desenvolvida em várias alas.

Outra mudança foi a localização das principais áreas de estar da casa em direção aos fundos do lote ou às laterais, ${ }^{36}$ baseada na ideia de que as vistas mais interessantes seriam a de um local privado, fugindo à rua e aos vizinhos. Pois, apesar da sensação de amplidão, as grande janelas também favoreciam a perda da privacidade.

Em 1935, quando tudo isso já se estabelecera, "era visto por muitos, decididamente, como um traço da arquitetura moderna." ${ }^{37} \mathrm{O}$ pensamento moderno era considerado uma rejeição da tradição e uma recusa ao ornamento. Planejavam-se interiores abertos, girava-se "a casa no lote" ${ }^{38}$ e orientavam-se as janelas para cenários privados. Onde os proprietários queriam.

Além da manutenção da privacidade, favorecia-se a proteção contra os ventos e a correta orientação solar. Mas, algumas vezes, havia conflito entre a melhor

\footnotetext{
${ }^{36}$ Essa reorientação da casa já era vista nas primeiras décadas do século, na medida em que as ruas tinham seu tráfego de pessoas e veículos aumentado, mais barulho e sujeira. Significa também que os valores individuais ganhavam importância, em detrimento do lado cívico, da participação em uma rede de valores sociais, coletivos.

${ }^{37}$ Small House Number. Architectural Forum, out. 1935, p.230 apud ISENSTADT, 2006, p.136.

${ }^{38}$ The Small House: 1935. Architectural Forum, out. 1935, p.230 apud ISENSTADT, 2006, p.142.
} 
incidência solar e a procura por privacidade. Isto se resolveu com o aquecimento mecânico, libertando a casa para encarar as vistas mais interessantes.

\subsubsection{Contrastes: texturas e cores}

Outra característica dessa arquitetura doméstica americana é que ela "fala aos sentidos." Ao tato, nas texturas dos materiais. À visão, nas cores quentes, variadas, na frieza do vidro e de outros materiais, e no contraste entre ambos. E, mesmo ao olfato e à audição, nos jardins e seus espelhos d'água.

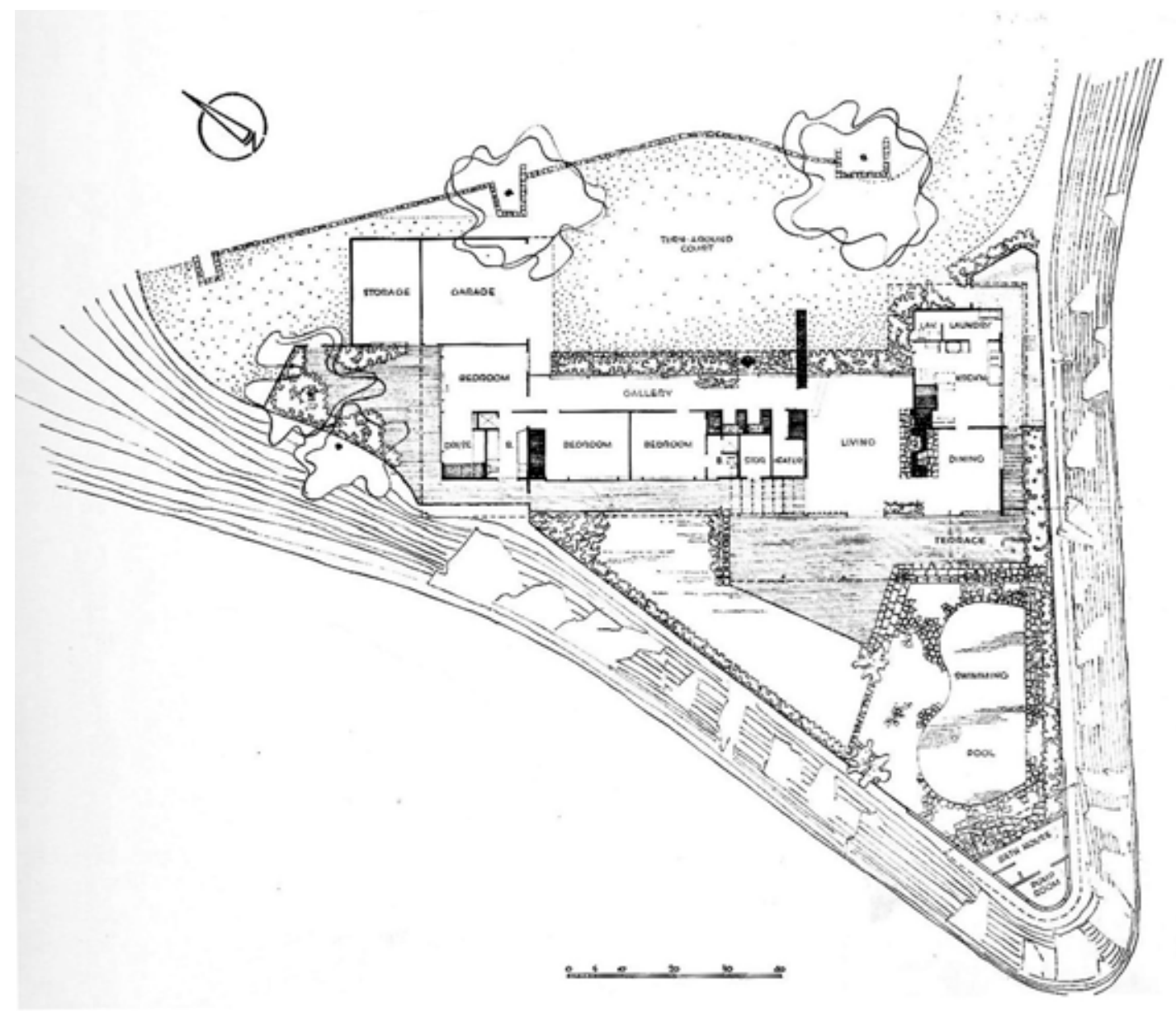

Fig.3.43 - Contraste entre desenho da casa e site no projeto de Henry Hill.

São inúmeros contrastes que podem se dar, por exemplo, entre o desenho da casa ordenado, organizado, claro e conciso - e o site irregular e natural, como na casa já 
mostrada do arquiteto Henry Hill. ${ }^{39}$ A construção leve, de cobertura pouca espessa e plana, que utiliza extensamente a madeira, contrasta com o pilar externo. A grande lareira maciça em pedra, que divide parcialmente as salas de estar e de jantar, e a parede em pedra também contrapõem-se aos detalhes internos modernos e limpos.

Esses contrastes são sempre enfatizados no texto, sendo os mais comuns aqueles que ocorrem entre as lareiras em pedra e as grandes superfícies envidraçadas: "A pedra áspera da parede da lareira foi escolhida para contrastar com as extensões em vidro liso, e a borda em pedra do piso, para enfatizar a textura do tapete e dos tecidos. ${ }^{40}$

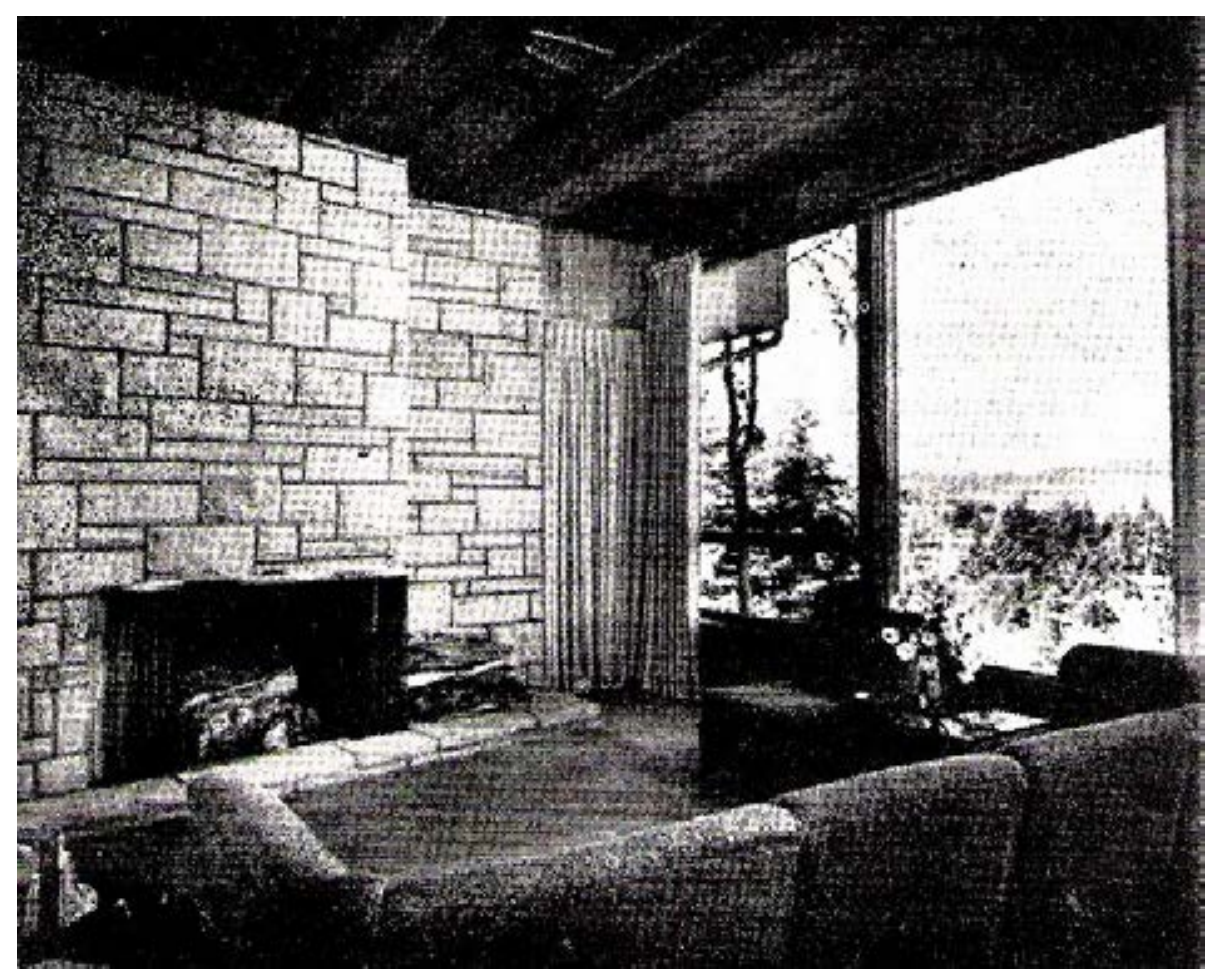

Fig.3.44 - Contraste entre lareira e panos de vidro.

Seria o "desenvolvimento de ideias solares," de "percepção espacial para evitar a monotonia de unidades retangulares," "de cores, tons e formas esculturais." (KECK apud A HOUSE..., 1952, p.170) "41"Recentemente, as palavras 'calor' e 'conteúdo

\footnotetext{
${ }^{39}$ Fig. 3.36 e 3.40 .

4082 Distinctive Houses from Architectural Record, casa n. 22, dos arquitetos Edelbaum \&Webster, em Westchester County, N.Y., publicada em Mar.1952, p.92-5.

${ }^{41}$ George Fred Keck fala sobre a casa n. 39, projeto dele, em parceria com William Keck, em Lake Forest, Illinois, publicada em 82 Distinctive Houses from Architectural Record, Mar.1951, p.169-174.
} 
emocional', outrora heréticas, têm aparecido mais frequentemente nas discussões familiares sobre arquitetura." (Ibid., p.170)

Os interiores dessas casas são limpos, modernos, com poucos elementos, de design também moderno, contido. Mas, existe uma variedade de cores e texturas, utilizadas com grande liberdade. Que, às vezes, exacerbam-se. A casa de John Lloyd Wright apresenta shingles vermelhos no telhado, que mesclam-se ao laranjaterracota dos tijolos de adobe de um canyon próximo. Na cozinha, amarelo, verde e azul; por toda a casa, materiais, mobília, objetos, murais, plantas misturam-se, segundo a descrição, provavelmente tornando os ambientes internos exagerados.

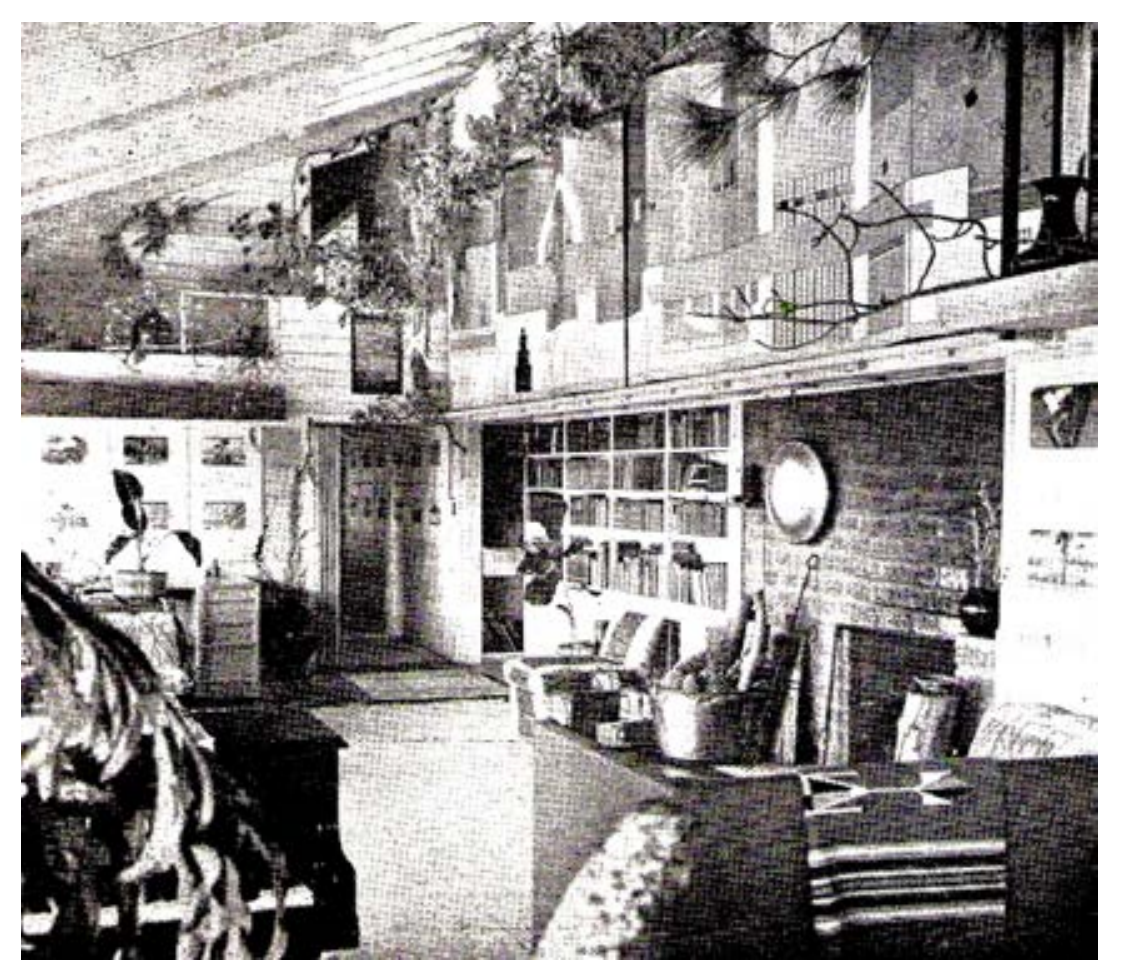

Fig.3.45 - Casa de John Lloyd Wright.

Pode-se falar em utilização do vernacular, com materiais naturais, texturas e certa qualidade pinturesca. A tradição doméstica americana apresentaria uma atração pela cor, pela textura e pela utilização dos materiais - como madeira e pedra - em sua forma natural, sem acabamentos ou modificações, inclusive em interiores. ${ }^{42}$ Mumford (1952, p.12) aponta o Japão como um das origens dessa preferência, ainda nos anos 1880

\footnotetext{
${ }^{42}$ Sendo a madeira avermelhada, utilizada em sua forma natural, uma das favoritas.
} 


\subsubsection{Um manifesto}

Como coletânea de projetos já publicados na revista, o álbum da Architectural Record é uma "construção," um manifesto. Na introdução, enfatiza-se que, com essa "coleção de casas," não se teria tentado evidenciar uma "tendência" ou "movimento" no desenho da casa americana. Mas, seria evidente que uma mudança significativa ocorrera.

A linguagem do International Style está ali, na limpeza, clareza, rigor da planta, nos materiais de acabamento liso, na técnica, mas, como já se disse, existe uma preocupação em "suavizá-la," trazê-la ao público americano de forma mais palatável, mais compreensível. Em uma espécie de "cruzamento" entre a linguagem moderna e a tradição doméstica americana.

Já no final da década de 1930, em editorial da Architectural Forum, Myers (1939, p.2) descreve essa "nova" arquitetura moderna, não mais como um "dogmático ensaio geométrico rebocado e com janelas nos cantos, mas cálida, tolerante, em sua escolha de materiais e mobiliário, indiferente ao grau de inclinação de seu telhado, espontânea e variada, ao proporcionar um abrigo."

Um processo que também envolve uma espécie de regionalização da arquitetura do Movimento Moderno, adaptando o "estilo único." Hibridismos e não purismos, amalgamando tradição e inovação. Nesse processo, criam-se casas pinturescas. Os detalhes e o conjunto contrapõem-se.

Várias casas-modelo procuravam demonstrar a nova linguagem para o público. Eram iniciativas de revistas, museus ou simplesmente executadas para se vender um empreendimento. Pode-se imaginar seu impacto pelo país, na "educação" do público, mostrando arquitetura e desenho modernos.

A "Casa Conceito da House \& Garden,"43 por exemplo, visitada por milhares de pessoas, fora concebida e patrocinada por esta revista, em 1951, em Long Island, em colaboração com os arquitetos e uma construtora. ${ }^{44}$

Seu desenho parece indicar uma cuidadosa fusão de muitas das melhores qualidades de duas influências de estilo muito difundidas - as linhas claras e concisas do International Style, e a sinuosa abertura e liberdade do popular Ranch House Style. Também,

\footnotetext{
${ }^{43} 82$ Distinctive Houses from Architectural Record, casa n.25, dos arquitetos John Hancock Callender e Allen \& Edwin Kramer, em Long Island, N.Y., publicada em Fev.1952, p.104-9.

${ }^{44}$ O mobiliário era da Macy's, a loja de departamentos de Nova York.
} 
eliminou o rigor do primeiro e a deselegante e inadequada combinação de materiais frequentemente encontrada no segundo. (HOUSE..., 1952, p.105).

Suaviza-se o rigor da linguagem moderna e confere-se elegância à confusa mistura de materiais do estilo Ranch House. A "sinuosa abertura e liberdade" provém da tradição americana, como mostramos anteriormente.

O progresso nesse campo, que está tão intimamente ligado aos hábitos, costumes e tradições das pessoas, é necessariamente algo contínuo e fluido. Esta seleção indica uma direção que se manterá - um percurso que conduz a casas mais agradáveis, sincera e cuidadosamente adequadas ao modo de vida americano. (MASON, 1952, s.n.p.)

O progresso é visto como algo contínuo, pois ligado à tradição e hábitos, que se alteram aos poucos, lenta, mas continuamente. Não diz respeito apenas ao modo de se construir, mas relaciona-se firmemente ao modo de vida, ao cotidiano das pessoas.

Porém, a guerra e o período posterior trazem algo como uma revolução na sociedade e na arquitetura. Grandes transformações em um curto período de tempo. Dessa forma, essa nova casa está intimamente ligada ao modo de vida americano e ao contexto do pós guerra.

A evolução, ou talvez revolução, ${ }^{45}$ que está ocorrendo no desenho da casa americana reflete-se nesse livro. (Ibid., s.n.p.)

Nas raízes dessa tradição americana estariam um modo de pensar, sentir, planejar, organizar e construir que se constitui após sua independência política, estabelecendo um novo tipo de vida, com novos hábitos.

\footnotetext{
${ }^{45} \mathrm{O}$ olhar tradicional abarca um grande arco temporal, percebendo os ciclos que se sucedem na história. Ele vê seu próprio tempo como uma evolução do tempo anterior, mas carregando sua bagagem, na qual haverá pequenas alterações. Pois, o presente não é totalmente novo, mas uma continuação do passado imediatamente anterior. Assim, a ideia de evolução faz parte do tradicionalismo, ao invés da ruptura que defendem os modernos. Estes, por sua vez, querem uma forma totalmente original pois cada forma pertence totalmente ao próprio tempo. Para eles, existe uma ligação direta entre a forma e o contexto que a gerou.

A posição tradicionalista, na verdade, não coloca uma pausa no desenrolar do tempo. O presente não é, para eles, uma decisiva e irreversível revolução, mas supõe um movimento que vem do passado e levará ao futuro. Nessa atitude, está implícita a aceitação da herança das gerações precedentes.

Para o pensamento tradicional, nenhum "salto" é concebível também em direção ao futuro. Não se nega o caminho em direção à modernidade; apenas deve ser lento e contínuo. O pensamento moderno, em contrapartida, ressalta a importância da revolução, que anula os traços do passado, afirmando-se o presente e a modernidade projetada em direção ao futuro.
} 
Existe a procura por uma vida mais simples, informal e ativa, em contato com a natureza, mas com o conforto proporcionado pelos equipamentos e máquinas. $A$ arquitetura da casa, principalmente a de classe média, altera-se para responder a mudanças na sociedade, acompanhada de inovações técnicas, desde o século XIX. E uma casa modernizada era considerada, por profissionais e leigos, a chave para todas as reformas: politica, social e estética. ${ }^{46}$

Colunas com conselhos domésticos em revistas e jornais enfatizavam, por volta de 1914, que uma casa moderna deveria responder a duas questões: a recreação coletiva e o crescimento individual. ${ }^{47}$ Conceber a casa como mera vitrine para a exibição de objetos era considerado inadequado para uma boa e confortável vida familiar.

Era necessária a eliminação de tarefas desnecessárias, em resposta à falta de empregados domésticos. Assim, uma simplicidade austera tornou-se a base do desenho e da decoração da casa. Detalhes simples e retilíneos eram usados para o ataque a todo tipo de sujeira e cantos escuros.

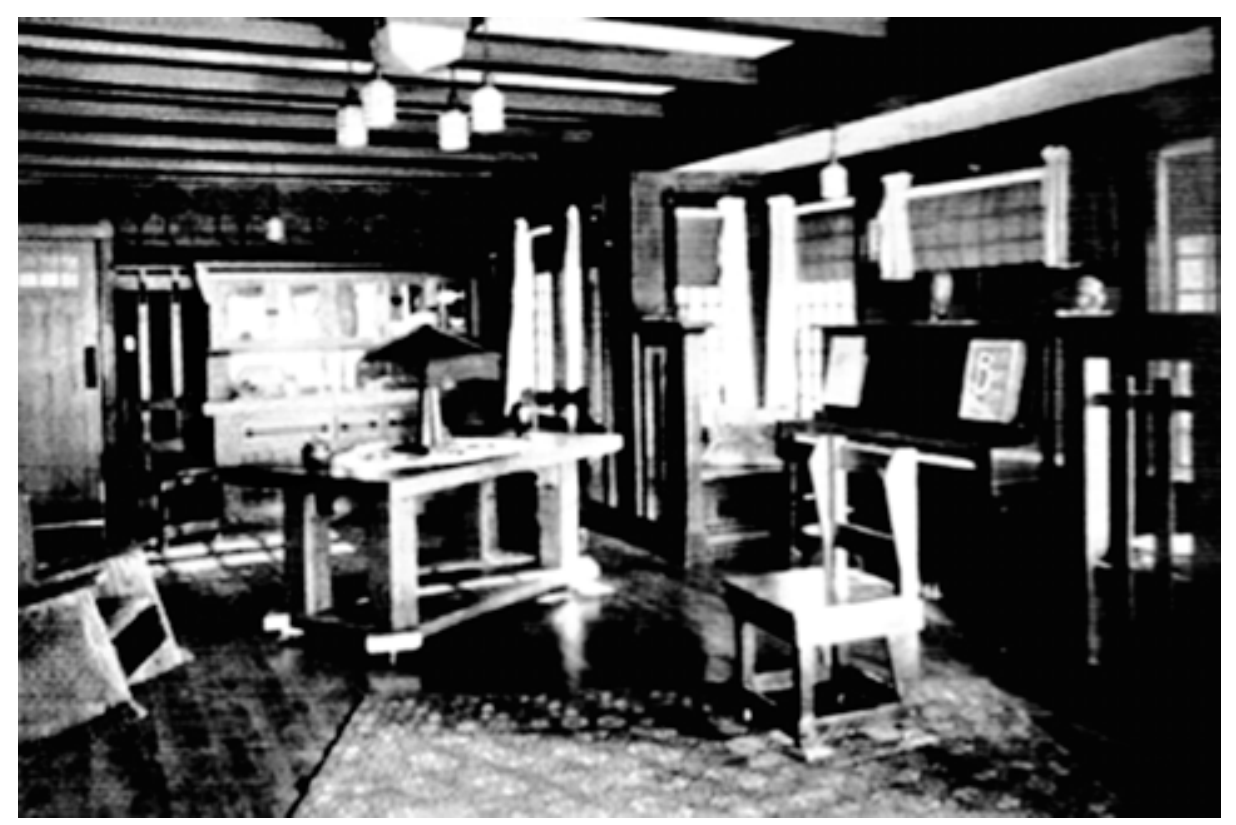

Fig.3.46 - Interior de um bangalô do início do século XX.

\footnotetext{
${ }^{46}$ Mencionamos esse assunto no capítulo 2. Em 1893, formou-se a National Household Economics Association para promover essas questões, que passaram a ser discutidas nas maiores universidades e colleges. Em 1916, 195 instituições estudavam os vários aspectos das tarefas domésticas. (WRIGHT, 1992, p.159)

${ }^{47}$ O living room era o espaço para a reunião da família, enquanto, para o cultivo pessoal e privacidade, eram necessários quartos separados para filhos e filhas e um pequeno gabinete para o marido.
} 
O número de cômodos também se reduziu: na casa de classe média, a sala de visitas como principal ambiente de recepção desapareceu e foi substituída por um grande living room, bem iluminado e ventilado, que absorveu o hall e o jantar.

A eficiência era outro conceito importante. A casa deveria ser administrada como uma fábrica. O gerenciamento científico era recomendado em todos os aspectos da vida moderna. ${ }^{48}$ A cozinha deveria funcionar como um laboratório; iluminada, limpa e eficiente. E um grande número de utilidades domésticas tornou-se acessível à classe média.

Além da participação dos movimentos de mulheres, entre os arquitetos responsáveis por essas transformações na casa americana, devem-se lembrar os irmãos Greene, Bernard Maybeck e Irving Gill, no final do XIX e início do XX, na Califórnia. O desenvolvimento do bangalô, muito popular entre a classe média, também se deu ali. Ainda deve ser lembrada a influência do movimento Arts and Crafts. E, ligado a ele, as Craftsman Homes de Gustav Stickley, por volta de 1910.

Mas, a mais importante contribuição a esse desenvolvimento da arquitetura doméstica americana, no início do século XX, é o trabalho de Frank Lloyd Wright, simbolizado pelas Prairie Houses. "(...) os espaços articulados e interligados da casa de Wright prosseguem o ordenamento do espaço dos cottages do início dos anos 1880." (SCULLY, 1971, p.159) ${ }^{49}$

E, em outra dimensão do trabalho de Wright, está presente a crença de que o homem deve viver de forma livre, em estreito contato com a natureza, para desenvolver seu potencial. Ele tentou manter viva a sensação de união com a terra, presente desde o tempo de Andrew Jackson Downing.

Nesse período, também pode-se notar uma diferenciação por regiões. "Esse elemento de auto-respeito e amor regionais, associados principalmente com os aspectos mais domésticos da vida, é seguramente um dos legados permanentes da tradição americana, como deve ser de qualquer outra tradição viva que constrói em solo nativo e conforme as maneiras e hábitos das pessoas." (MUMFORD, 1952, p.18)

\footnotetext{
${ }^{48}$ O gerenciamento científico foi desenvolvido por Frederick Taylor. E, Christine Frederick, em 1913, publica o livro The New Housekeeping, onde aplica as ideias tayloristas ao trabalho doméstico, para poupar tempo e esforço.

${ }^{49}$ Como no Shingle Style, nas casas de Wright as varandas são claramente constituídas como extensões contínuas do espaço interior e dos planos. A isso deve-se acrescentar a disciplina clássica em seu trabalho: "(...) a tradição amalgamou-se nele, e através dele formou-se uma das bases da arquitetura moderna do século XX." (Ibid., p.164)
} 


\subsection{O International Style e outras experiências modernas}

O outro aspecto da arquitetura doméstica americana do pós-guerra é a adoção da linguagem do International Style.

Essa linguagem teria chegado aos EUA através da exposição Modern Architecture de Hitchcock e Johnson, no MOMA, em 1932, que pretendia trazer a arquitetura moderna europeia ao conhecimento dos arquitetos americanos e do público. Seus organizadores acreditavam que a arquitetura americana precisava de disciplina e de um estilo unificado e controlador. Sem individualismos, ou questões sociais.

Assim, seu conteúdo social e político, potencialmente revolucionário no contexto europeu, foi esvaziado. E, ressaltando seu aspecto estético, conseguiu-se tornar a arquitetura moderna "segura para o capitalismo."

Mostrando o que seria um fenômeno incontestável internacionalmente, a exposição fixou-se em trabalhos que preenchiam o critério formal dos curadores, com três princípios básicos: volume, ao invés de massa; regularidade sem simetria axial; proibição de ornamentos aplicados.

O termo International Style, cunhado por Hitchcock, Johnson e Alfred Barr, refere-se a uma linguagem estética comum, "destilada" a partir de vários movimentos europeus. Muitos críticos americanos da época a consideraram redutivista formalmente e ressaltaram a falta de envolvimento com questões sociais e políticas.

Para determinar este novo estilo moderno, os autores estavam determinados a ignorar singularidades como Wright e o Expressionismo. Enfatizou-se o geral, o compartilhado e o típico. Porém, ao considerar tudo como um fenômeno único, o International Style correu o risco de desconsiderar diferenças marcantes, não apenas visuais, mas de conceituação. Muitos dos adeptos do International Style entendiam, apenas em parte, os princípios da nova arquitetura e adotavam as formas modernas apenas como uma aplicação cosmética, ao invés de uma expressão com significado profundo. Este era um dos perigos de se considerar a nova arquitetura como um "estilo".

Para Stevens(2003, p.124),

quando os heróis do Movimento Moderno cruzaram o Atlântico e foram parar no alto da hierarquia do campo arquitetônico americano em fins da década de 1930 e após a guerra, sua defesa

\footnotetext{
${ }^{50}$ ROWE, Colin, introdução para Five Architects: Eisenman, Graves, Gwathmey, Hejduk, Meier, New York: Wittenborn, 1972, p.4 apud Ockman, 1997, p.124.
} 
de soluções socialistas para as habitações populares foi discretamente deixada cair no esquecimento e seus objetivos sociais desapareceram. (...) E o velho pacto de aliança de dois segmentos das classes dominantes pôde ser reafirmado pela colocação desse estilo a serviço da América capitalista.

Muito do que poderia ser também considerado moderno, na Europa e nos EUA, foi desqualificado, em benefício da constituição de um estilo unificado.

Ainda na década de 1930, afirmava-se que o moderno já era uma realidade e que se “o termo 'International Style' não é amplo o suficiente para incluí-lo, esta é a falta do termo; não da realidade. (...) A questão a que devemos responder hoje não é 'O que é moderno?', mas 'Onde está o moderno agora?’' (WHERE..., 1938, p.467)

Entre as inúmeras experiências modernas expurgadas, estão os avanços da arquitetura doméstica americana no entre-guerras, principalmente na Califórnia. Rudolf M. Schindler, Richard Neutra - ambos imigrantes austríacos -, Wright e seu filho Lloyd Wright trabalharam na região de Los Angeles e desenvolveram sistemas construtivos com o concreto, que pretendiam ser protótipos para a construção em massa. $^{51}$

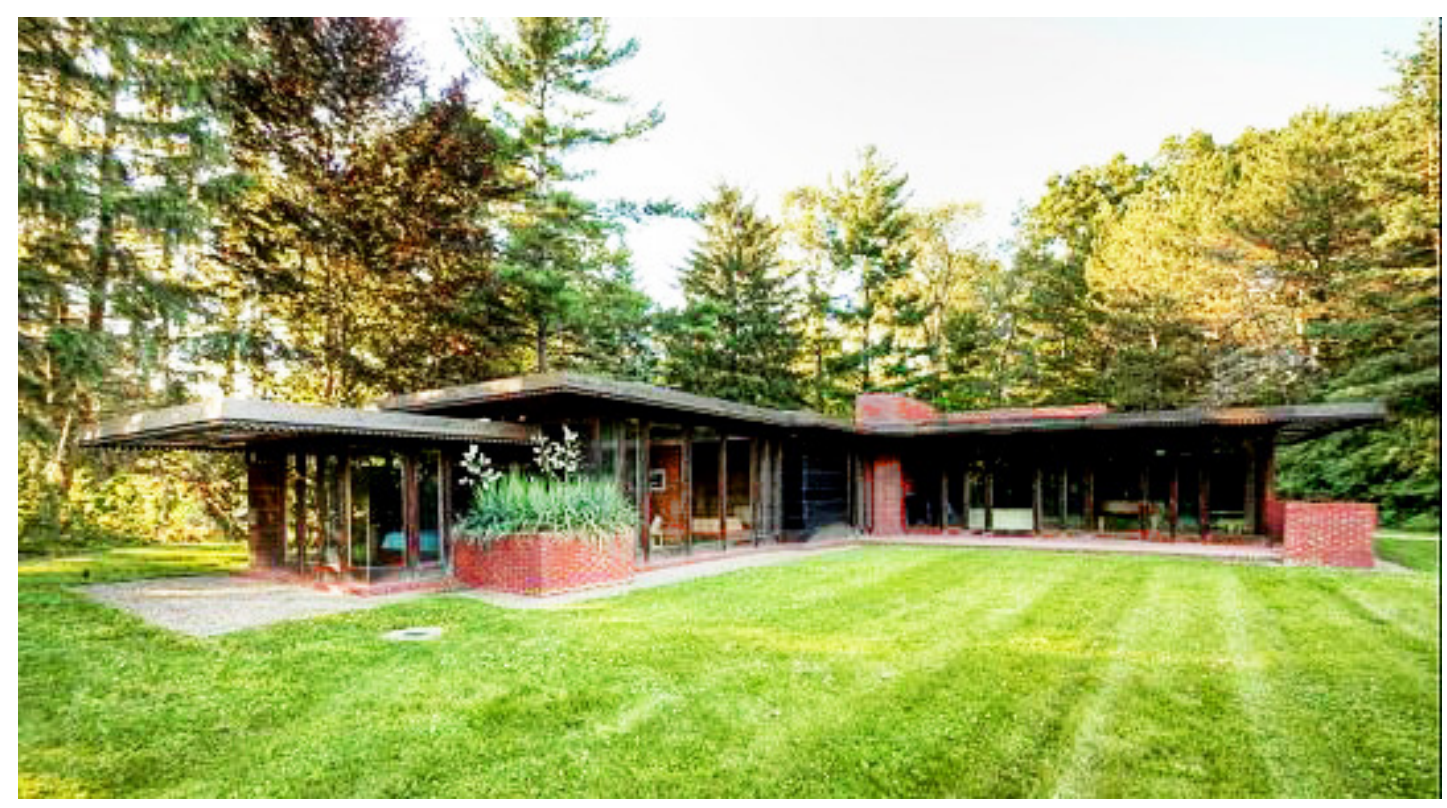

Fig.3.47 - Jacob's House, casa usoniana de Wright.

\footnotetext{
${ }^{51}$ Deve-se lembrar que esses arquitetos conseguiram manter um escritório, nessa época, com trabalhos apenas modernos, o que era muito difícil.
} 
Outras experiências wrightianas a serem lembradas, nos anos 1930, são as casas usonianas, de área reduzida e baixo custo, com vários modelos básicos. Eram modernas, econômicas e flexíveis, considerando o conforto da família. O arquiteto utilizou uma grelha modular e lajes de piso com aquecimento. Madeira, tijolos e outros materiais naturais foram deixados aparentes. Grandes panos de vidro na área de estar; um pequeno núcleo de serviço, que incluía a cozinha, substituindo a lareira como centro da habitação; mobília fixa; o carport, espécie de abrigo para o automóvel. São características que antecipam alguns atributos da casa moderna americana dos anos 1940 e 1950.

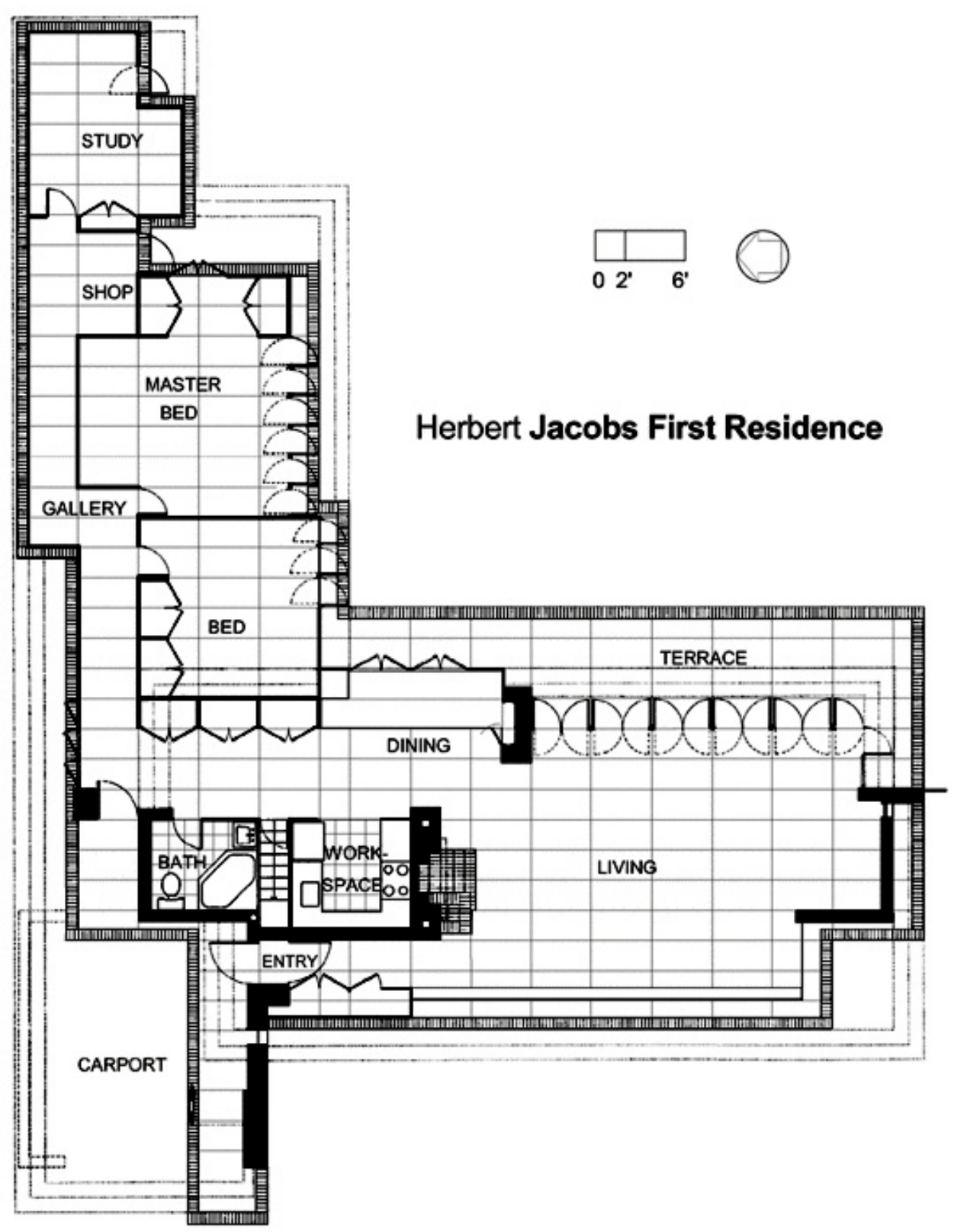

Fig.3.48 - Jacob's House, planta baixa. 
Na década de 1930, essa arquitetura moderna doméstica americana está em fase embrionária, é a época da depressão econômica nos EUA e pouco se constrói. ${ }^{52}$ Além disso, o processo de maturação dessa linguagem é interrompido pela Segunda Guerra Mundial, em 1939.

"Hoje o moderno não é exatamente o que os funcionalistas dos anos 1920 profetizaram. Mas, tem a tremenda vantagem de ser tijolos e aço e vidro, ao invés de ideias e argumentos e - na melhor das hipóteses - exemplos europeus ou transplantados. (...) o tempo mostrou que a maneira de domesticar um funcionalista inflexível é dar a ele edifícios para construir. (...)" (WHERE..., 1938, p.466-7)

Com tantas experiências acumulando-se, Wright (2008, p.84) questiona o papel definidor da exposição do MOMA na história da arquitetura moderna americana. $O$ impacto teria sido limitado, tanto para o público quanto para os profissionais. As discussões sobre o moderno, na época, raramente a citavam.

Teria sido Modern Housing, de Catherine Bauer, ${ }^{53}$ de 1934 , que informou os americanos sobre a arquitetura progressista na Europa. Bauer rejeitava fórmulas simplistas, mostrando de forma crítica, os pontos positivos e negativos de realizações europeias como as Siedlungen. Para ela, os americanos não deveriam aceitar fórmulas estrangeiras prontas e deveriam pensar em "Modernismos," no plural, em resposta às contingências e à diversidade cultural. (Ibid., p.114)

Assim, a adoção da linguagem do Movimento Moderno foi lenta. A respeito das casas modernas, ainda insignificantes em número, Myers (1939, p.2) diz: "Elas são importantes, não apenas como indicadoras de uma tendência, mas como exemplos notáveis de uma poderosa influência que está vagarosamente, mas inevitavelmente, mudando a aparência do cenário residencial americano."

\footnotetext{
${ }^{52}$ Mesmo assim, ainda nos anos 1930, agências governamentais disponibilizaram muitos serviços públicos e uma larga rede de infraestrutura, que incluía sistemas viários e tratamento de água, e que utilizavam uma linguagem moderna nos edifícios. Arquitetos trabalharam em colaboração estreita com engenheiros e paisagistas, tendo cuidado especial quanto ao planejamento dos sites, para a preservação do ambiente natural e sua beleza. Eram grandes estruturas, que incluíam também edifícios para fábricas.

${ }^{53}$ Uma grande promotora do aperfeiçoamento da vida urbana, por meio de habitação de baixo custo funcional e atrativa, Bauer (depois Wurster, após casar-se com o arquiteto William Wurster) associou-se ao MOMA pela primeira vez em 1932, quando participou da elaboração da seção de habitação da exposição International Style. Ela colaborou no catálogo da exposição do museu America Can't Have Housing (1934), e escreveu o prefácio do catálogo da exposição Architecture in Government Housing (1936). Ainda naquele ano, ela se juntou ao conselho de arquitetura do museu, onde permaneceu por seis anos.
} 
"O que era apenas uma controvérsia tornou-se, quase sem percebermos, parte do nosso ambiente cotidiano. (...) Dez anos atrás, toda discussão sobre o moderno partia de uma definição; (...) hoje é possível começar descobrindo o que é e onde o moderno está (...)." (WHERE...,1938, p.466)

A linguagem moderna foi aceita com mais facilidade nas casas maiores, onde o proprietário poderia pagar um arquiteto e desfazer-se de grande parte de sua antiga mobília. O proprietário da casa comum, no entanto, dependia de construtores práticos, cujos empreendimentos deveriam se sujeitar a cautelosas normas dos bancos. Estes temiam a rejeição da nova linguagem, principalmente na costa leste, mais conservadora. Apesar do interesse pela arquitetura moderna mostrado nas revistas e concursos, esse panorama alterava-se lentamente.

Os bancos locais que controlavam os empréstimos, muitas vezes, dificultavam-nos para casas modernas. ${ }^{54}$ Os escritórios do FHA preocupavam-se com o valor de venda dessas habitações não tradicionais mas, segundo Myers (1939, p.2), o gosto do público mudava e passava a ver tais casas modernas não mais como "o símbolo frio e branco de um pequeno culto."

Em 1949, o Time anunciava: "Gostem ou não, as casas modernas chegaram para ficar (com) praticidade e, algumas vezes, aparência espetacular."

Apelava-se também ao caráter internacional da arquitetura moderna: "Não existe um país no mundo onde o processo não esteja em curso." (WHERE..., junho 1938, p.470) ${ }^{56}$

Outro aspecto dos anos 1930 a ser considerado é a correlação entre os idiomas formal e político, que traz a interpretação de que o modernismo é inerentemente progressista enquanto as linguagens tradicionais e clássicas são intrinsicamente fascistas. Em um contexto de ascensão dos regimes fascistas na Europa, essa questão é de fundamental importância.

Nessa "guinada" moderna, deve-se ser considerado outro fator: a mudança de orientação em muitas das escolas de arquitetura americanas, iniciada nos anos

\footnotetext{
${ }^{54}$ Ainda em 1946, essa era uma dificuldade. O escritório central do FHA (Federal Housing Administration) publicara um panfleto sobre o "Desenho Moderno" - FHA Technical Bulletin 2 - para tentar resolver essa questão. (MOCK, 1946, p.94)

55 “New Shells," Time, 15 de Agosto de 1949, p.60 apud Wright, 2008, p.167.

${ }^{56}$ Não é possível avaliar essa mudança nas preferências do público. Esse é o discurso das revistas e jornais, que se manteve nos anos 1940 e 1950, nos vários veículos, tentando alterar as preferências dos consumidores em relação à arquitetura moderna. $\mathrm{E}$, a preponderância em todo o mundo é mera retórica, pois pode-se falar, no máximo, em países ocidentais.
} 
1930, reforçada com a vinda dos arquitetos imigrantes. No entanto, essa questão é mais complexa do que parece.

O contexto alemão em que a Bauhaus surgiu era muito diferente do americano e acabou por ocorrer uma adaptação e hibridização nos Estados Unidos, que apresentou diferentes formas, sob Gropius, em Harvard, Mies no Illinois Institute of Technology, László Moholy-Nagy no Institute of Design em Chicago, entre outras instituições. Em cada caso, a natureza das mudanças dependia das personalidades envolvidas e do caráter já existente na instituição.

Porém, Gropius permaneceria o preeminente porta-voz da "ideia da Bauhaus," ou ao menos do mito dela, pelas três décadas seguintes. (OCKMAN, 2012, p.21)

Enquanto a Bauhaus geralmente é vista como a primeira instituição de ensino a promover a ligação da aprendizagem da arquitetura com a produção industrial e a prática profissional, exemplos anteriores mostram que os educadores americanos estavam simultaneamente perseguindo objetivos similares, ainda que, de forma diversa.

Uma das escolas que consideravam a importância do trabalho prático era a Universidade de Cincinnati, cujo programa iniciou-se em 1906, mesclando a experiência prática ao ensino acadêmico. ${ }^{57}$

Outra curta iniciativa foi o curso que Richard Neutra ministrou na Academia de Arte Moderna em Los Angeles, em 1928. O "Curso Prático sobre a Moderna Arte de Construir" ${ }^{58}$ atraiu os futuros arquitetos Gregory Ain e Harwell Hamilton Harris. (ALOFSIN, 2012, p.109 e 111)

Experiências práticas também ocorriam na University of Southern Califórnia, a partir de 1930. Maquetes e desenhos muito elaborados eram desencorajados e os estudantes envolviam-se com questões práticas, como custos.

Assim, claramente, no início dos anos 1930, o conceito do arquiteto primeiramente como um esteta estava se transformando. Procurava-se educar os jovens para tornarem-se líderes profissionais em uma sociedade moderna.

\footnotetext{
${ }^{57}$ Em 1922, o programa foi ampliado, criando uma ligação fundamental com o mundo profissional. Os estudantes alternavam o ensino na universidade com o trabalho de campo. Este incluía serviços na construção civil, experiências com técnicas e materiais e prática em escritórios de arquitetura.

${ }^{58}$ Anunciado como "exercícios práticos no desenho e elaboração do projeto arquitetônico, a serem combinados, mais tarde, com aulas expositivas sobre os princípios básicos da arquitetura moderna e sua relação com outras atividades criativas." (ALOFSIN, 2012, p.100)
} 
Joseph Hudnut ${ }^{59}$ tornou-se reitor em Harvard em 1935 e iniciou uma reorganização total da escola. Após esse processo, em 1936, ele viajou à Europa para encontrar um novo líder para o departamento de arquitetura, entrevistando candidatos como Walter Gropius, Mies van der Rohe e J.J.P. Oud. Gropius, que se encontrava em uma situação profissional precária na Inglaterra, foi o escolhido.

O prestigioso programa de Harvard teve repercussão em muitas outras escolas de arquitetura no país, porém, o impacto de Gropius foi, até certo ponto, superestimado. Claramente, a estrutura para uma mudança radical na escola já existia antes de sua chegada e o crédito disso deve-se, em grande parte, a Hudnut. (ALOFSIN, 2012, p.111)

Mesmo nas escolas onde as tradições das Beaux Arts persistiram até muito tarde, a mudança para uma agenda modernista não era associada automaticamente à pedagogia de Gropius ou à Bauhaus. No MIT, por exemplo, Lawrence Anderson procurou no modernismo escandinavo novas ideias, visitando, no final dos anos 1930, Alvar Aalto, junto com William Wurster.

"A difusão de uma agenda modernista mais homogênea depois da Segunda Guerra Mundial e a associação da ideologia da arquitetura moderna especialmente com realizações que tiveram lugar no entre-guerras europeu serviram, em grande parte, para eclipsar as iniciativas reformistas levadas a cabo pelos educadores americanos nos anos 1920 e início dos anos 1930." (Ibid., p.117)

\subsubsection{A linguagem do Movimento Moderno}

Mas, em que se constitui a linguagem moderna? Faz parte dela um vocabulário transformado, onde está presente a simplicidade. Como a imagem que fazemos da máquina, de algo simples e preciso, que utiliza formas geométricas puras.

Mais do que apenas responder à determinada função, o desenho evoca significados externos ao projeto. Assim, essa linguagem apresenta uma dimensão simbólica, que cria associações. "Pode-se ir ainda mais longe e dizer que parte do poder expressivo da nova arquitetura estava na tensão entre os fatos conhecidos, como,

\footnotetext{
${ }^{59}$ Ele já revolucionara o ensino na Columbia University, onde fora escolhido reitor em 1934. E, também desejava basear o ensino nas condições reais e em problemas relacionados à construção. $O$ projeto representava uma abordagem conjunta em relação aos materiais, técnicas e às necessidades da vida moderna.
} 
digamos, uma janela industrial ou uma coluna de concreto armado padronizada, e as associações simbólicas que eles evocam, que parte da capacidade expressiva da nova arquitetura repousa." (CURTIS, 1996, p.266-7) Uma simples pia se transformava, através do "diálogo" com objetos-tipo ao seu redor. As formas representavam "algo maior," que transcendia os meros fatos cotidianos.

O sistema construtivo do Estilo Internacional surgiu a partir das novas funções atribuídas à coluna, à parede e ao teto. $O$ esqueleto do edifício tornava as paredes estruturais obsoletas e, assim, a função de suporte da estrutura deveria ser expressada. Dessa forma, as colunas deveriam separar-se das paredes, que agora eram apenas elementos de fechamento. Essas colunas obtiveram liberdade para erguerem-se no meio do espaço e as paredes poderiam articular-se livremente, como telas.

Reafirma-se, portanto, a independência funcional das partes, dos elementos, como as divisórias, colunas, teto.

Desse modo, nos edifícios de Mies e de Le Corbusier concebidos até 1929, a coluna serve fundamentalmente como pontuação de um espaço de extensão horizontal. (ROWE, 1999, p.140)

Tetos e pisos deveriam apresentar planos ininterruptos, pontuados por cilindros. Para isso, as vigas deveriam permanecer ocultas, sem ligações aparentes com as colunas, conferindo liberdade a elas. Impedindo que o espaço se compartimentasse visualmente, transgredindo o conceito de liberdade da planta livre. Pois, caso contrário, as vigas, aparentes, definiriam posições para as divisórias, que também se alinhariam às colunas.

Em decorrência desse sistema construtivo com elementos independentes, as paredes não apresentavam mais a mesma dupla função, a fachada era livre e poderia haver as longas janelas horizontais - fenêtre en longueur.

As considerações sobre o teto plano também não se limitam a questões práticas. Assim, principalmente por razões simbólicas, a cobertura deveria ser plana. ${ }^{60}$ Podia ser utilizada como jardim e ressaltava o volume da edificação. Substituía a cobertura tradicional e o sótão. Richards (1959, p.46) ressalta que a cobertura horizontal não estaria indissoluvelmente associada ao desenho moderno. Porém, o arquiteto moderno tenderia a evitar o teto inclinado, "talvez porque inconscientemente

\footnotetext{
${ }^{60} \mathrm{~A}$ ideia do teto plano sempre foi controversa. As questões técnicas, ainda que enfrentadas com empenho, só chegaram a garantir resultados satisfatórios muito mais tarde. Em 1931, um jornal de Frankfurt dizia: "umidade, teu nome é May."
} 
perceba que no momento atual o idioma arquitetônico moderno tem que competir com a sobrevivência de outros idiomas. (...) um teto plano tem um caráter em harmonia com esta época científica sumamente mecanizada, possui uma integridade, um repouso e uma lógica que é totalmente diferente, por exemplo, do casual pintoresco (...)."

Essa independência estrutural acabava levando a uma espécie de compromisso a priori com a assimetria. No jogo compositivo moderno, o arquiteto se entregava com liberdade às infinitas combinações de elementos, "objetos-tipo": janelas em faixas, tetos planos, lajes em balanço. E, até mesmo elementos mais abstratos, como volumes retangulares articulados, planos suspensos e espaços que se interpenetram. As relações estabelecidas entre eles traziam a diversidade.

Utiliza-se o conceito de composição como arranjo livre de partes, sem regras definidas a priori. Um procedimento que cria a partir do nada, de acordo com leis "geradas no interior da própria obra." Este fato tornava, muitas vezes, a relação entre as partes incompreensível, segundo as regras do Classicismo. Mas, poderia haver um equilíbrio dinâmico.

No entanto, nesse jogo compositivo, apesar das regras não serem fixas, acabam por ser atribuídos significados simbólicos aos elementos construtivos, da mesma forma como se fazia no classicismo.

\subsection{O Good-Life Modernism}

Esse processo de adaptação da arquitetura moderna ao contexto americano, uma "mescla" de linguagem moderna e tradição doméstica, é analisado por Jarzombek (1991). Segundo o autor, nos anos 1950, o vocabulário formal moderno, desenvolvido nas décadas anteriores por arquitetos como Marcel Breuer, Rudolph Schindler, Richard Neutra, e Gregory Ain, para uma seleta clientela, foi colocado ao alcance de um público muito mais extenso, em uma "versão" que poderia ser chamada Good-Life Modernism. ${ }^{61}$

\footnotetext{
${ }^{61} \mathrm{O}$ termo, cunhado por esse autor, provavelmente deriva de good life, expressão bastante repetida à época, onde está implícita a ideia de uma vida como espécie de recompensa, no pós-guerra, pelos sacrifícios exigidos durante o conflito, além das dificuldades enfrentadas durante os anos da depressão. Em várias citações desse capítulo, de fontes da época, a expressão é utilizada.
} 
Essa "versão" da linguagem moderna teria origem principalmente no trabalho de Frank Lloyd Wright e Mies van der Rohe. Porém, essas referências teriam sido simplificadas.

No caso de Wright, a riqueza dos detalhes e a complexidade espacial mantiveramse, em parte, nas casas mais elaboradas. Enquanto características como os grandes beirais, a lareira central e os planos horizontais e baixos estão sempre presentes, reforçando a ideia de lar, como um local confortável e aconchegante.

Quanto à linguagem de Mies, mudanças na concepção da planta também são observadas. A conexão entre dormitório e estar e a cozinha resguardada, refletindo uma organização doméstica com empregados, alteraram-se. ${ }^{62}$ Nas casas do GoodLife Modernism, vê-se uma clara distinção entre o espaço de estar (que inclui jantar e cozinha) e os dormitórios. Esse desenho do espaço "tornou-se um dos princípios de organização inquestionáveis do Good-Life Modernism." (JARZOMBEK, 1991, p.79) Que é bem exemplificado pelas casas bi-nucleadas de Marcel Breuer.

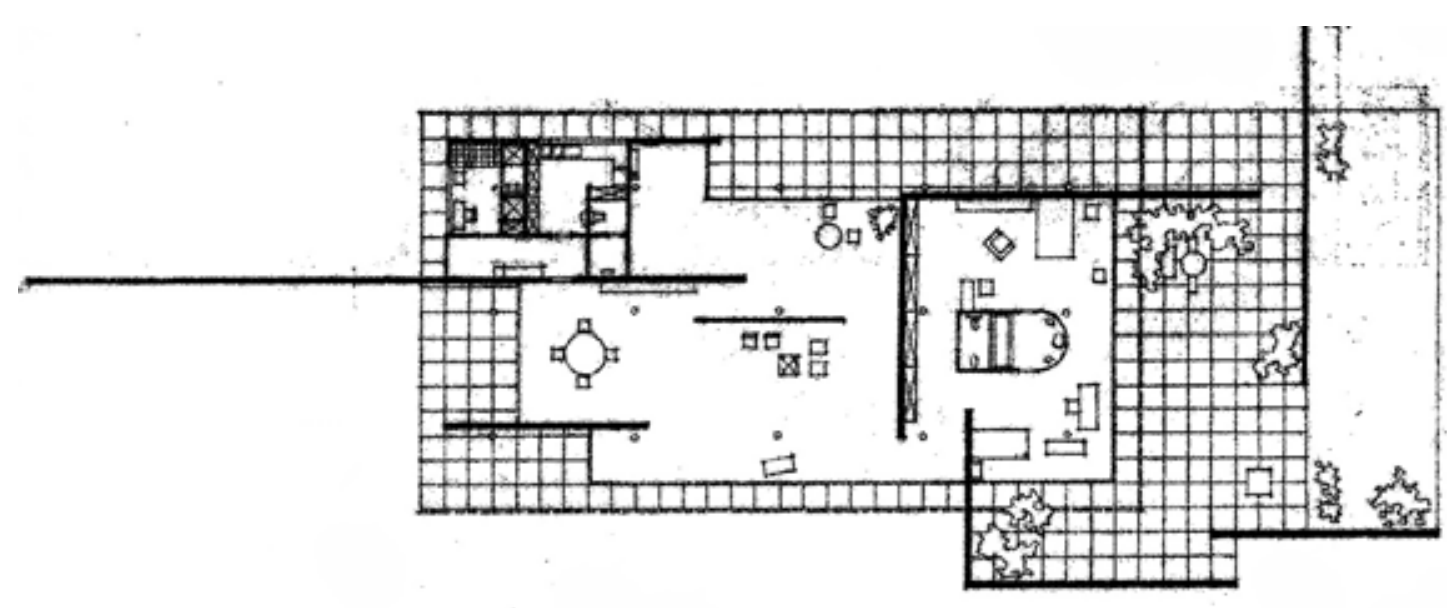

Fig.3.49 - Casa na Berlin Building Exposition, de Mies van der Rohe.

Os princípios modernistas se amalgamaram às qualidades presentes no desenho do ambiente doméstico. Para isso, escritórios de arquitetura, bancos, museus, a indústria da construção, a imprensa especializada, eram chamados a participar.

As revistas precisavam "definir" o que os consumidores "queriam" de forma clara, garantindo que os arquitetos atendessem à nova demanda criada.

\footnotetext{
${ }^{62}$ Arranjos vistos, por exemplo, na Brick House.
} 
Entre as várias revistas que contribuíram para a definição do Good-Life Modernism, a House \& Home foi a mais importante. (Ibid., p.78) O editorial de seu primeiro número dizia:

Esse é o Volume 1, Número 1 de uma nova aventura no jornalismo, uma revista cujo evidente e único propósito é ajudar os americanos a encontrar uma melhor maneira de viver, proporcionando-lhes casas melhores a preços que possam pagar. (...) HOUSE \& HOME toma seu nome da crença de que nossa indústria deve à família americana muito mais do que um abrigo. Se a boa vida deve ser a herança de todo americano, nós devemos construir em nossas casas, (...) todas as alegrias, que fazem de uma casa um lar. (...) Dessa maneira, devemos utilizar o projeto para fazer o lar completo e acrescentar prazer à utilidade. (...) apenas profissionais podem fazer tais casas alcançáveis. Apenas profissionais podem combinar desenho, materiais, métodos e recursos (...) e criar para cada homem um lar para a boa vida. (CORNERSTONE...,1952, p.107) (no original, as expressões em negrito correspondem a good life)

O objetivo era produzir uma arquitetura para uma vida sem aflições, sem angústias ou desejos não atendidos.

O Good-Life Modernism pretendia estabelecer para os americanos uma nova estética, mais limpa, racional, sem ligações com o historicismo. Este era visto como algo negativo do passado, assim, era necessário olhar para o futuro, após todas as dificuldades e tristezas trazidas pela guerra, e criar algo novo, "limpo."

Arquitetos e clientes deveriam reconhecer as esferas sobrepostas da estética e do mercado. E compreender que a expressão arquitetônica não deveria ser vista como um manifesto individual e singular.

Anunciavam-se novas abordagens que trariam vitalidade ao desenho da casa americana. Sem o jargão da vanguarda, House \& Home utilizava uma versão básica, mais acessível do modernismo, dirigindo-se ao público leigo.

Para conseguir penetrar no ambiente doméstico, "o Good-Life Modernism teve que se distanciar do desprezo modernista pela cultura burguesa, anterior à guerra; princípios e estratégias mantiveram-se, mas sem a contaminação de uma teoria que poderia afastar a classe média. (...) A ideologia foi dissimulada pelo pragmatismo." (JARZOMBEK, 1991, p.82)

Entre outros aspectos, a inclinação ao socialismo de muitos dos arquitetos do Movimento Moderno e a discussão sobre questões sociais, na era macarthista, teria 
dificultado a aceitação dessa arquitetura doméstica. Ao invés dessas teorias e história, um novo discurso a respeito da racionalidade introduziu essa linguagem no mercado da habitação.

Além da racionalidade, existia o apelo visual dessa arquitetura. Utilizavam-se palavras como contraste, interesse, drama, imaginação:

o desenho contemporâneo na Califórnia parece determinado por críticos confusos que usam termos como 'nu', 'ascético,' ou 'insípido'. No entanto, essa casa, que venceu o primeiro prêmio em uma recente competição de House and Garden, é uma demonstração mais do que suficiente de que o moderno pode ser tão imaginativo, causar tanta impressão quanto qualquer um possa desejar. (...) contrastando formas e materiais e linhas longas e fortes para criar um interesse dramático." (A SMALL HOUSE..., 1952, p.316) ${ }^{63}$

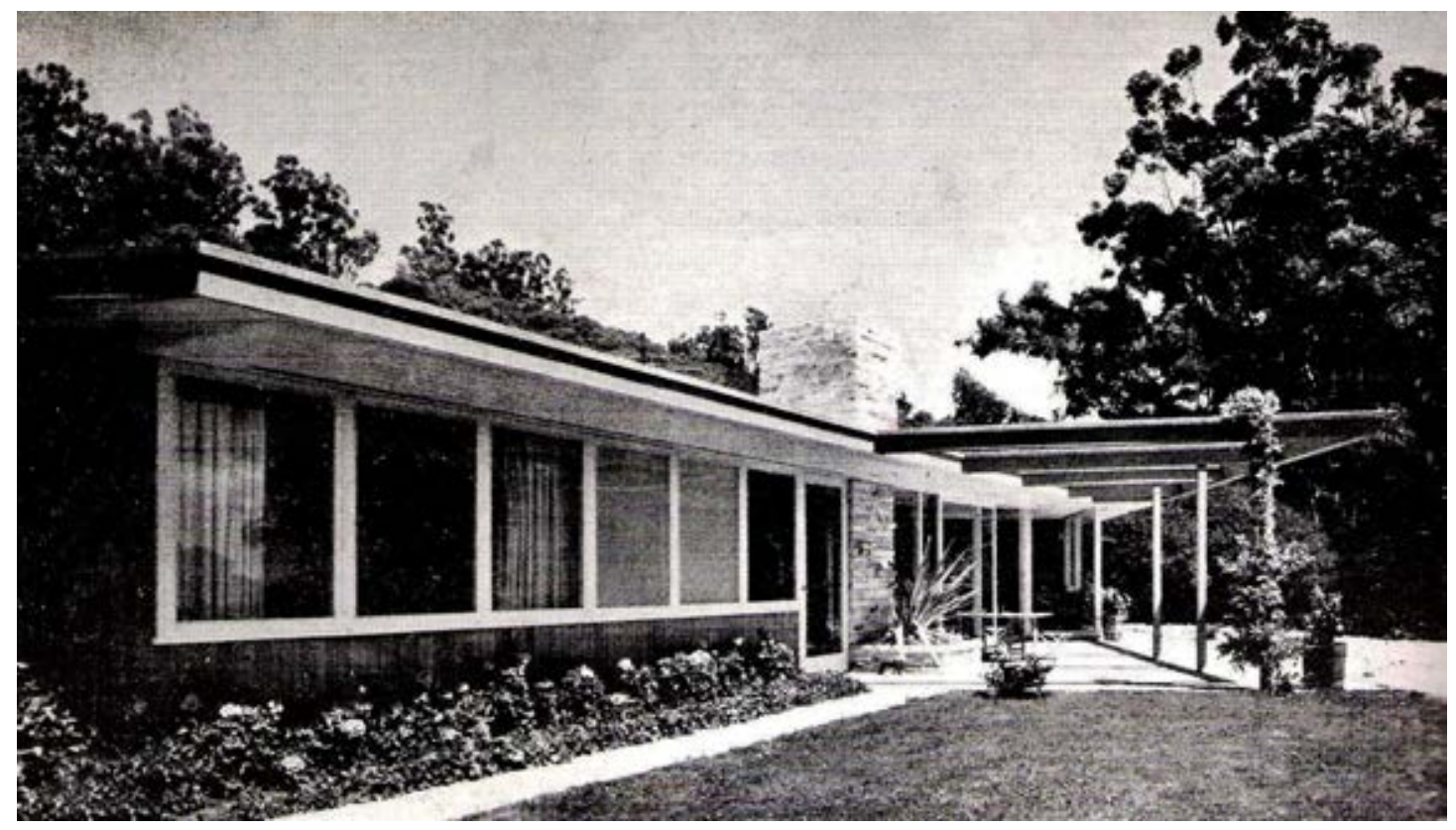

Fig.3.50 - Casa que recebeu o primeiro prêmio em competição de House and Garden.

O Good-Life Modernism não se dirigia às elites, mas ao mercado consumidor de classe média. E, não se tratava de uma abstração, a ideia de se colocar a linguagem moderna ao alcance da família americana média. De forma pragmática e objetiva,

\footnotetext{
6382 Distinctive Houses from Architectural Record, casa n.73, do arquiteto Fred Langhorst, em Marin County, Cal., publicada em Abril 1948, p.316-319.
} 
desejava-se manter o controle de todas as variáveis presentes no lucrativo negócio da habitação no pós-guerra.

House \& Home foi criada como um espaço para a fusão de interesses que incluíam as indústrias da construção, os bancos, escolas de arquitetura, e mesmo museus, todos eles colaborando para gerar a politica cultural que colocaria o Good-Life Modernism no ambiente doméstico. O Good-Life Modernism, longe de florescer espontaneamente, foi definido, patrocinado, e consolidado por um conjunto de interesses nunca visto. (JARZOMBEK, 1991, p.78)

Era um discurso sem nuances ou meias palavras:

(...) esta revista deve ajudar arquitetos a compreender o novo papel do construtor, ajudar os construtores a adquirir um novo conhecimento sobre o desenho, conseguir que cada profissional tenha uma nova percepção sobre as finanças e economia da habitação.(...) (CORNERSTONE..., 1952, n.1, p.107)

Todos esses personagens são mobilizados:

Imagino se você percebe quanto o futuro da casa e do lar americanos repousa em sua mãos reunidas e depende do que você fará a respeito? Entre vocês estão os arquitetos que desenharão essas casas (...). Entre vocês estão os construtores, os incorporadores, os realizadores e os corretores de imóveis que irão patrocinar e construir essas casas (...). Entre vocês estão os banqueiros e financiadores que irão financiar essas casas. Entre vocês estão os fabricantes e fornecedores dos elementos e dos materiais - os homens que mais e mais deverão fornecer as peças pré-dimensionadas e industrializadas a partir das quais a casa melhor do amanhã será montada. (DEAR..., 1952, p.101)

Assim, para muitos americanos, a casa de subúrbio parecia a única maneira de se alcançar uma boa vida familiar. "Isso era o que o governo, os incorporadores, os bancos, e as revistas Ihes diziam, e muitos acreditavam nisso - ou sentiam que deviam." (WRIGHT, 1992, p.258)

\subsubsection{Sonhos de Guerra}


$\mathrm{Na}$ verdade, todo esse processo está profundamente imbricado à guerra. Pois, um dos aspectos dessa questão são as mudanças que levaram da indústria de guerra à "indústria da paz."

O esforço de guerra tornou necessária a união do país em torno de um ideal: a busca por um futuro de paz e prosperidade. As imagens que estavam presentes nos sonhos dos soldados americanos durante a guerra não eram abstratas como as ideias de paz, de liberdade, de amor: “... pelo que lutamos: o lar, a formação de famílias saudáveis, o consumo de produtos. (...) quando perguntados pelas razões pelas quais lutar, os soldados americanos raramente falavam de princípios, ao invés, referiam-se a objetos, atividades e produtos cotidianos - alguns lembrados do passado, outros, os anúncios lhes prometiam para o futuro." (POLAN, 1986, p.6). ${ }^{64}$

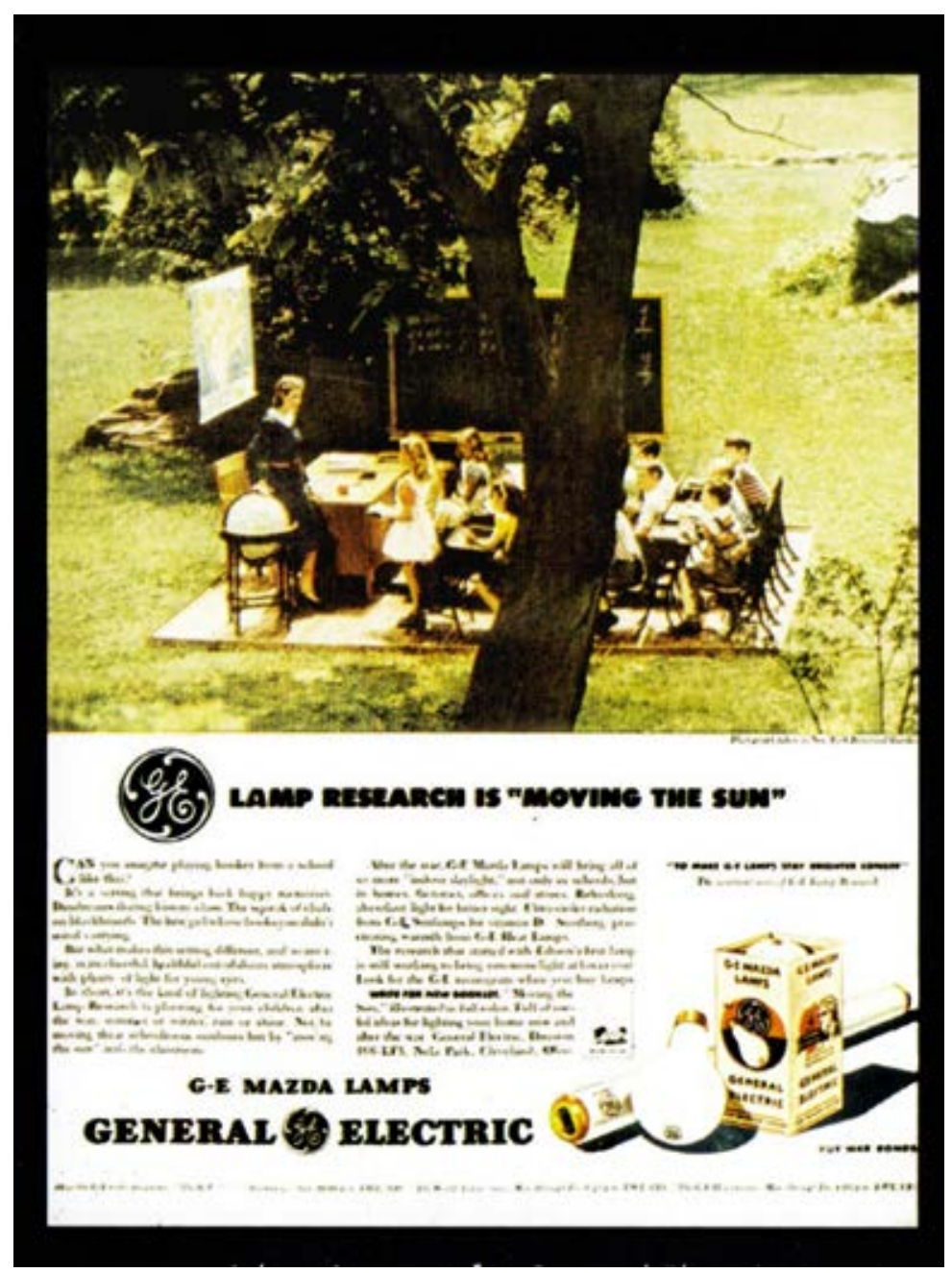

Fig.3.51 - Anúncio da General Electric, ainda da época da guerra.

\footnotetext{
${ }^{64}$ A propaganda de guerra tinha tanta importância que o Office of War Information tinha em um de seus principais cargos o vice-presidente da Coca-Cola.
} 
Ainda durante os anos da guerra, o desejo do público por bens de consumo restritos pela concentração de recursos no esforço de guerra - era alimentado pela mídia e por anúncios sancionados pelo governo. Havia o receio de que a economia, que atingira um pico de produtividade durante os anos do conflito, pudesse enfrentar uma depressão na volta à paz. Falava-se em "mobilização para a abundância." (OCKMAN, 2004, p.345)

Após a guerra, o aumento da produtividade e do consumo eram vistos como essenciais para um contínuo desenvolvimento do capitalismo americano.

Ainda durante o conflito, as empresas fabricantes anunciavam que estavam engajadas no esforço nacional, mas também que as técnicas desenvolvidas durante o conflito seriam revertidas em produtos para o tempo de paz, inclusive artigos para a casa. Assim, a tecnologia, tanto para produção dessas habitações, quanto para as máquinas que facilitavam a vida, ${ }^{65}$ foi herdada dos tempos de guerra.

Sei que será da forma que suas cartas descreveram...uma brilhante casa ensolarada... um jardim que você possa cuidar enquanto o sol o aquece... e uma cozinha para mim, cheia de objetos mágicos (...) um refrigerador ... com prateleiras brilhantes ... Um congelador ... Oh!, é fácil ver como seremos felizes...

Aqui, na Kelvinator, nós garantimos isso. Quando nosso trabalho da guerra estiver terminado - toda nossa força, todas as nossas habilidades nascidas da guerra, serão transformadas em produção para a paz. Esta será nossa parte na construção de uma nação maior e mais feliz. (...) onde homens e mulheres poderão transformar seus sonhos em realidade. ${ }^{66}$

Ao término da Segunda Guerra Mundial, os Estados Unidos consolidaram-se como potência dominante. Sua indústria teve um crescimento acelerado no esforço de guerra e seu território não fora atingido: “(...) as forças militares e comerciais já projetavam tal imperialismo durante a guerra. Realmente, as estratégias de guerra eram planejadas não apenas para a vitória, mas para um tipo de vitória do monopólio capitalista." (POLAN, 1986, p. 41).

Uma transição de uma guerra bem sucedida para uma paz bem sucedida, para as alegrias de uma vida familiar cheia de bens de consumo.

\footnotetext{
${ }^{65}$ Muitas dessas máquinas já existiam, como os eletrodomésticos, mas a tecnologia da época da guerra ajudou a aperfeicoá-los.

${ }^{66}$ Anúncio da companhia Kelvinator, reproduzindo os pensamentos de uma dona de casa americana, Life, 16 de Abril de 1945, p.57 apud COLOMINA, 2007, p.135.
} 
Crucial para a viabilidade do setor econômico era o mercado de habitações de baixo e médio custo. "A obsolescência planejada tornou-se uma importante estratégia econômica depois da guerra; uma abordagem similar àquela usada para vender automóveis foi aplicada ao mercado de habitação em massa." (OCKMAN, 2004, p.347)

$\mathrm{E}$, a arquitetura moderna tem um papel não marginal nesse processo de retomada da prosperidade. Ela está presente, de forma marcante, no boom que se seguiu à guerra, quando o sonho da casa no subúrbio tornou-se uma espécie de compensação pelos sacrifícios exigidos durante o conflito.

\subsubsection{O papel do MOMA e das revistas na constituição do Good Life Modernism.}

É importante compreender quais as forças por trás do Good-Life Modernism, os agentes dessas mudanças fundamentais na maneira de se produzir e de se consumir a arquitetura.

São, como dissemos, revistas de arquitetura, arquitetos, fabricantes de produtos de consumo, mas também instituições, como o Museu de Arte Moderna de Nova York, - MOMA. O sucesso do Good-Life Modernism dependia muito de exposições organizadas por elas.

O papel das revistas de grande circulação, principalmente aquelas dirigidas às mulheres, também foi fundamental na alteração do gosto do americano médio em relação à arquitetura moderna. Os modelos apresentados pelas revistas favoreciam a expressão do proprietário, definindo projetos sem autoria, sem a mão do arquiteto. ${ }^{67}$

Segundo Fullaondo (2010, p.125), as revistas especializadas, como Architectural Forum e Arts \& Architecture, também foram muito importantes nessa transformação, com a publicação, desde meados dos anos 1930, de exemplares de residências modernas.

A Arts \& Architecture, da Califórnia, lançou um concurso em 1943, Design for Postwar Living, cujo objetivo era se chegar a um "modelo de vida para o trabalhador

\footnotetext{
${ }^{67}$ As soluções dadas pelas revistas para determinadas questões geralmente não eram complexas. 0 living room, por exemplo, deveria ser organizado em torno de três elementos: a televisão, a lareira e a grande abertura com vista para o jardim.
} 
americano" e sua família. "Esse trabalhador americano, condicionado pelos anos de guerra (incluídos os membros das forças armadas que se tornarão parte da população trabalhadora) ... está apto a ter um enorme respeito pela máquina, tanto como produtora, quanto como arma de destruição ... e é muito provável que ele não apenas aceitará, como exigirá, simples, direta e honesta eficiência nos aspectos materiais de seu modo de vida." 68

Outra ação perpetrada pela Arts \& Architecture, ${ }^{69}$ de fundamental importância, foi o programa Case Study Houses, iniciado em 1945, cuja força motriz foi seu editor John Entenza. Ele pretendia criar oportunidades para arquitetos modernos e produzir modelos de desenho que impactassem o gosto do público e a indústria da construção. O programa manteve-se por mais de vinte anos. Doze prêmios foram conferidos a ele pelo American Institute of Architects.

Foram encomendados, a certo número de arquitetos, vinte e seis projetos de casas, publicados mensalmente pela revista. Grande parte delas foi construída, ${ }^{70}$ equipada através de um arranjo com fabricantes que participavam do programa e aberta ao público para visitação. Houve também grupos de casas.

Casas "exatas e simples em planta, moduladas na estrutura, classicamente ordenadas na estética." (MCCOY, 1977, p.7)

Nos primeiros anos do programa, entre 1945 e 1949, treze casas foram construídas e sete projetos apresentados. O período termina com a finalização da casa de Charles Eames e a de John Entenza, projetada por Eames e Eero Saarinen.

A primeira casa do programa, construída, era uma "casa mínima" pois, em 1946, ainda havia restrições do governo em relação à área máxima construída permitida: $1100 \mathrm{ft}^{2}$, de espaço fechado. ${ }^{71}$

O segundo período vai de 1950 a 1960. Com exceção de uma, todas as casas apresentavam estrutura em aço. A ênfase era na elaboração de protótipos para a construção industrializada, ao invés de performances únicas.

\footnotetext{
${ }^{68}$ Entenza, John. Competition Designs for Postwar Living. Arts \& Architecture, Abril 1943.

${ }^{69}$ Arts \& Architecture era uma pequena revista que falava a uma audiência de elite, apresentando apenas o trabalho moderno de vanguarda. No final dos anos 1940, era muito conhecida e respeitada na Europa, Japão, América do Sul e EUA. Entenza comprou a revista em 1930, quando ainda se chamava California Arts \& Architecture. Depois, tornou-se seu editor, com grande receptividade aos jovens arquitetos locais.

${ }^{70} \mathrm{O}$ número de visitantes atesta o sucesso da empreitada: quase quatrocentos mil para as seis primeiras casas abertas à visitação. (COLOMINA, 2007, p.27)

${ }^{71}$ Que correspondem a $102,19 \mathrm{~m} .{ }^{2}$
} 
Os interiores eram revolucionários, mobiliados com cadeiras, sofás e mesas leves, com base ou estrutura em aço, "cadeiras borboleta" em metal e lona, mobília para o pátio em tubos e cordas, e, dos Eameses, cadeiras e mesas em madeira compensada moldada. Isso acabou por estimular pequenas fábricas, criadas pelos próprios designers, fabricando vários objetos modernos para a casa, muitos deles escolhidos para os interiores das Case Study Houses. Entre eles, têxteis, luminárias e utensílios de cozinha.

O programa mostrou-se bastante influente, no desenho das casas e dos sites, nas técnicas construtivas e em sua atitude em relação à natureza da vida no pós-guerra. (HINE, 1989, p.167-8)

Focando as luzes sobre o arquiteto, não sobre o cliente ou o incorporador. Esses profissionais não formavam uma "escola," mas foram unidos sob a "bandeira" da Arts \& Architecture.

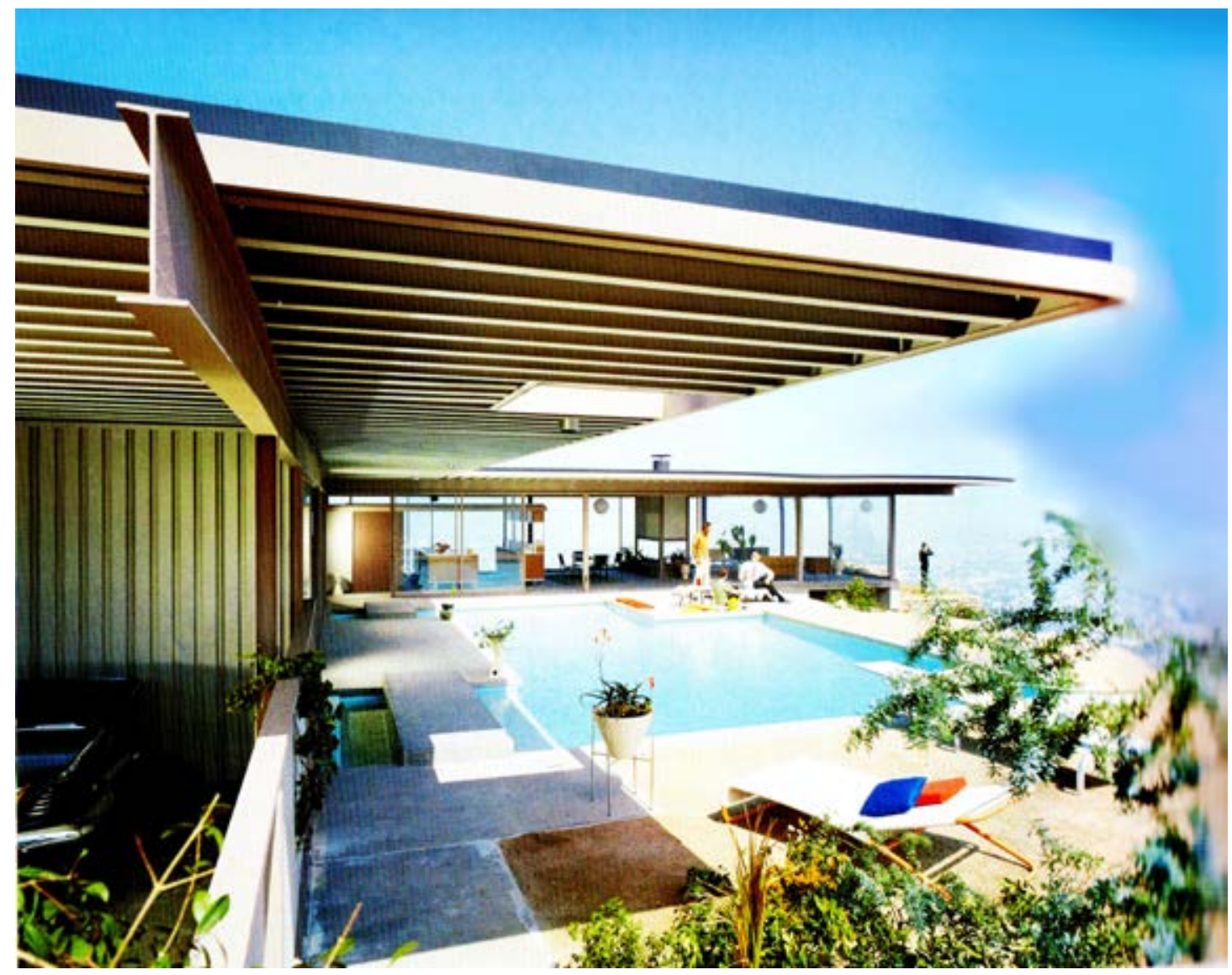

Fig.3.52 - Stahl House, 1960, Case Study, House n.22, de Pierre Koenig. 


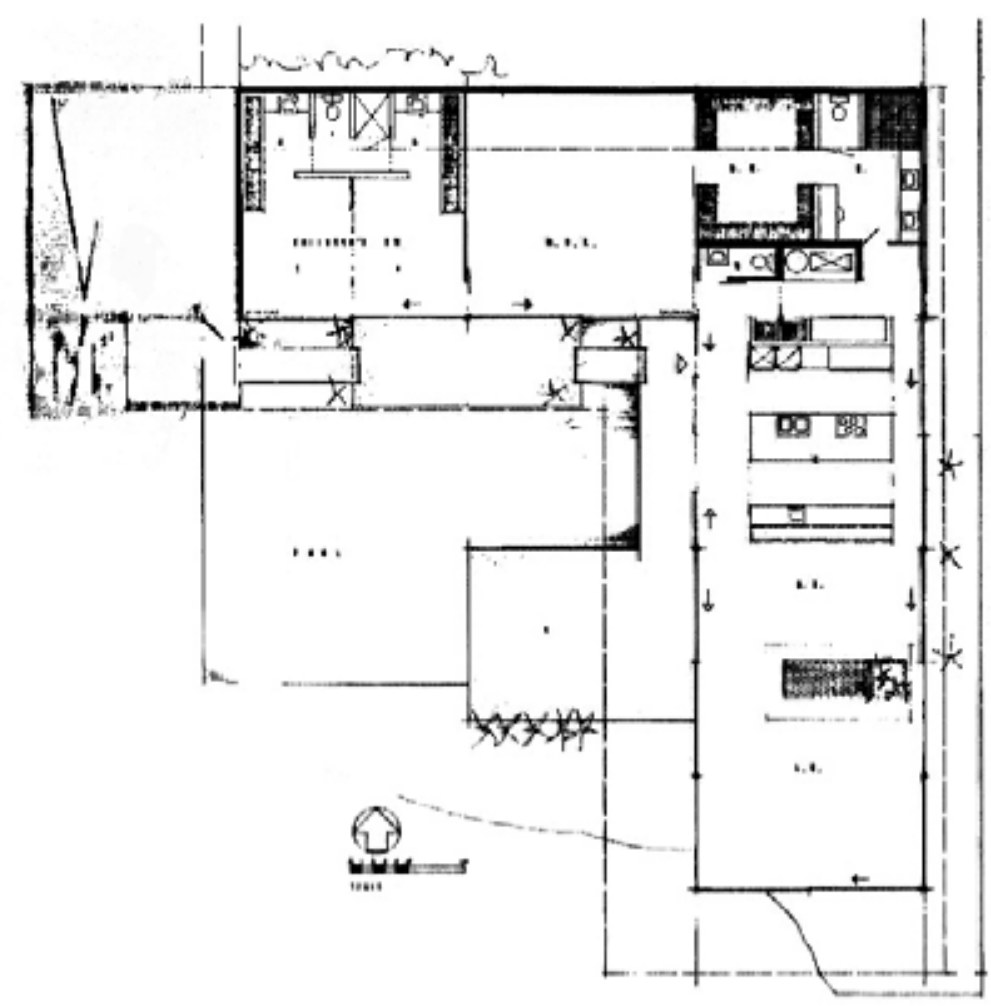

Fig.3.53 - Stahl House, planta baixa.

Mesmo nos anos 1940 e 1950, a Califórnia ainda era um local onde havia muito por se fazer, com possibilidades de progresso em relação ao futuro, diferente da costa leste, um lugar já estabelecido. A região mantinha a ideia da fronteira, de espaço infinito a ser ocupado. Ali, as indústrias do entretenimento e da defesa, concentradas no sul, favoreceram o desenvolvimento econômico.

Além disso, o clima ameno fazia da Califórnia um reduto de vida informal e relaxada, em relação com a natureza. Era um local perfeito para se desenvolver uma nova arquitetura com as características do Good-Life Modernism. Pode-se dizer que ela foi seu principal "polo." A Califórnia, de certa forma, abriu-se ao desenvolvimento da moderna arquitetura doméstica. ${ }^{72}$

Inspirados pelo trabalho de William Wilson Wurster e Gardner Dailey na área de São Francisco, um grupo mais jovem desenvolveu nos anos 1940 o que se tornou conhecido como o estilo Bay Region. Na região de Los Angeles, liderados por

\footnotetext{
72 Deve-se lembrar que, na University of Southern California, após a guerra, foi criado um departamento de desenho industrial, sob a direção de Raymond Loewy, que atraiu lideranças modernistas da Califórnia para a escola. (OCKMAN; SACHS, 2012, p.130)
} 
Neutra, Schindler e Soriano, outro grupo de jovens arquitetos se destacava. Arts and Architecture descobriu e divulgou seu trabalho através do Case Study Houses.

Além da Arts and Architecture, pode-se citar a Ladies' Home Journal, ${ }^{73}$ que lançou, em janeiro de 1944, um concurso para que os arquitetos mais famosos à época concebessem uma pequena residência unifamiliar, considerando o desenho moderno, as novas técnicas e materiais e a possibilidade de produção em série. Em consonância com um modo de vida moderno. ${ }^{74}$

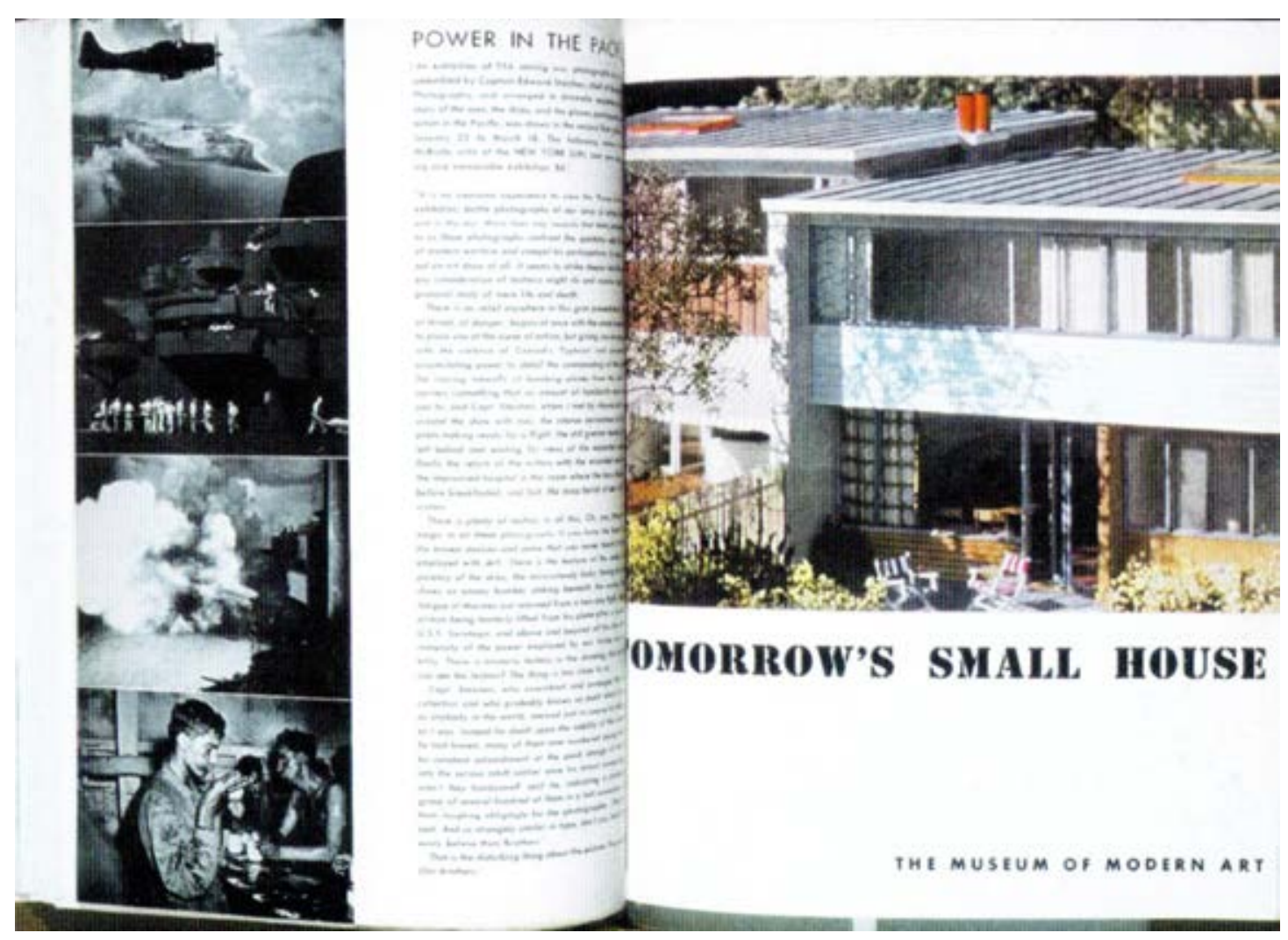

Fig.3.54 - "Power in the Pacific" e "Tomorrow's Small House," no Bulletin of the Museum of Modern Art, Spring/Summer, 1945. Imagens da guerra ao lado das perspectivas para o futuro.

Os projetos apresentados, publicados por mais de um ano pela revista, serviram de base para a exposição do MOMA, Tomorrow's Small House, ${ }^{75}$ realizada entre 20 de maio e 30 de setembro de 1945, que teve como curadora, Elizabeth B. Mock. ${ }^{76}$

\footnotetext{
${ }^{73}$ Que, no início do século XX, publicara muitos dos projetos de residências de Frank Lloyd Wright.

${ }^{74}$ As casas deveriam atender à família média americana, com dois a quatro filhos e renda anual entre 2.000 e 3.000 dólares. Deveria haver 3 dormitórios e, de preferencia, dois banheiros. Outra questão era estar em consonância com os avanços da indústria da construção, atendendo às dimensões estandardizadas dos fabricantes. O custo da casa deveria estar entre 4.000 e 6.000 dólares.
}

${ }^{75}$ Foi elaborado um catálogo - Tomorrow's Small House: Models And Plans. Havia projetos de George 
É possível identificar traços comuns entre os projetos, segundo Fullaondo (2010, p.129), da nova casa americana do pós - guerra. A maior parte era constituída por casas térreas, sem sótãos, nem porões, de planta retangular e cobertura plana, grandes panos de vidro, com vistas para o jardim, pátios e outros espaços de estar externos.

A exposição teve um grande êxito de público, chegando a cerca de 3.500 pessoas em apenas um dia, manifestando o grande interesse que o tema da casa despertava na sociedade. Interesse demonstrado também por parte da imprensa, com artigos e críticas publicadas por todo o pais: “(...) Uma vez terminada a guerra, o público quer uma casa, e vai à exposição para ver ou comprovar se essas casas se ajustam a suas necessidades específicas. As grandes superfícies de vidro, a planta aberta, o uso de parte do terreno para proporcionar espaços externos que complementam os internos são consideradas ideias e todo mundo parece estar de acordo." 77

Um dos aspectos mais criticados foram as coberturas planas, tanto em relação ao aspecto estético, quanto ao técnico e funcional, pois o sótão, até então presente na casa americana, desaparecia. A concepção da casa moderna ainda estava longe de ter uma aprovação unânime.

Dessa forma, os museus colaboraram nesse processo de definição e legitimação do Good-Life Modernism. Tentava-se criar uma nova mentalidade no público, aberta à nova maneira de se viver. Além da arquitetura em si, diversos tipos de objetos ajudavam a criar o novo ambiente, na tentativa de se guiar o público para essa "vida moderna":

O papel do MOMA foi particularmente importante, devido a outra série de exposições, que incluíram protótipos de casas nos jardins do museu, em

Fred Keck, Carl Koch, Philip Johnson, Mario Corbett, Hugh Stubbins Jr., Plan-Tech Associates, Vernon DeMars e Frank Lloyd Wright.

${ }^{76}$ Elizabeth Mock juntou-se ao MOMA, como freelancer, em 1937. Ela estivera em Taliesin. Com John McAndrew, curador de arquitetura e desenho industrial, organizou a exposição What Is Modern Architecture?, em 1938. Em 1940, ela tornou-se assistente de McAndrew e depois de ele haver sido demitido, em 1942, assumiu o Departamento de Arquitetura e Desenho Industrial, dirigindo-o durante os anos da guerra. Realizou várias exposições relacionadas à habitação - Built in the U.S.A.: 1932-1944 (1944), Tomorrow's Small House: Models and Plans (1945) e If You Want to Build a House (1946) - e, através de seus esforços e de sua irmã, Catherine Bauer, o departamento promoveu o planejamento urbano e a habitação nos anos 1930 e 1940. Ficou no museu até 1946.

${ }^{77}$ Roslyn Ittelson, "Report on the Reaction of the Public to the Exhibition of Small Houses at the Museum of Modern Art," Curatorial Exhibition Files, Exh.\#289, The Museum of Modern Art Archives, Nova York. In: Ibid., p.135. 
colaboração com lojas de departamentos e revistas. Esse tipo de exposição tornava a compreensão e o interesse mais intensos.

Em 1949, Marcel Breuer foi responsável por um deles. ${ }^{78}$ Uma das exigências era de que a casa permitisse acréscimos. Além disso, estava implícita a possibilidade dos proprietários serem os responsáveis pela construção, havendo apenas algumas consultas básicas ao arquiteto.

As características são aquelas já apontadas em relação ao Good-Life Modernism. A construção, leve, utilizava estrutura e fechamento em madeira ${ }^{79}$ e cobertura em duas águas, assimétricas. Os vários cômodos prolongavam-se em espaços de estar externos que, na realidade, estabeleciam os limites do espaço doméstico.

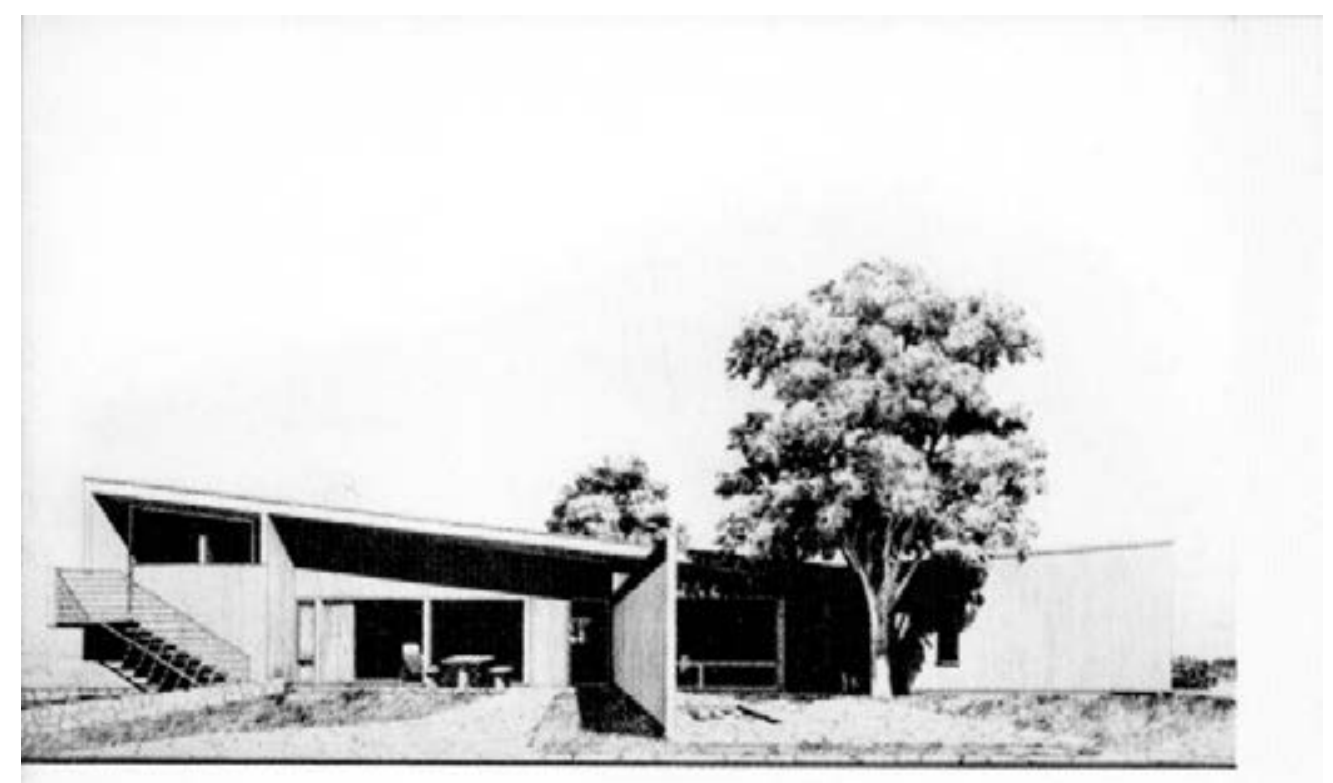

The House in the Museum Garden

Mareel Breuer Arehitect

1 West 34 street

Ine Yer

Fig.3.55 - Casa no jardim do museu, Marcel Breuer.

\footnotetext{
${ }^{78}$ The House in the Museum Garden, aberta entre 12 de abril e 30 de outubro de 1949. O modelo foi totalmente decorado. A casa foi utilizada como cenário para vários anúncios em revistas e jornais.

${ }^{79} \mathrm{O}$ sistema construtivo era o mais comum entre construtores americanos, com o qual Breuer já estava familiarizado.
} 


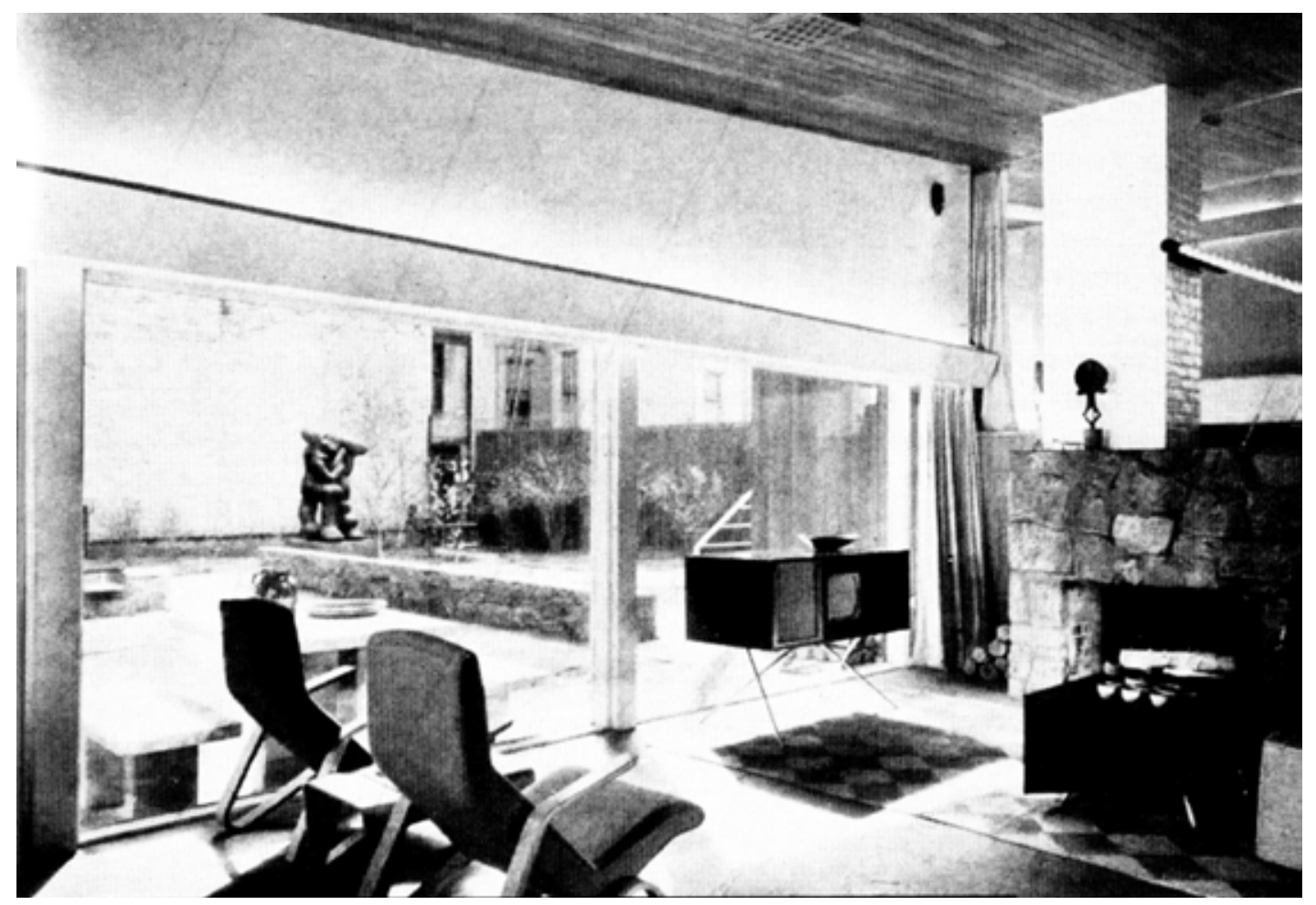

Fig.3.56 - Casa no jardim do museu, Marcel Breuer, interior.

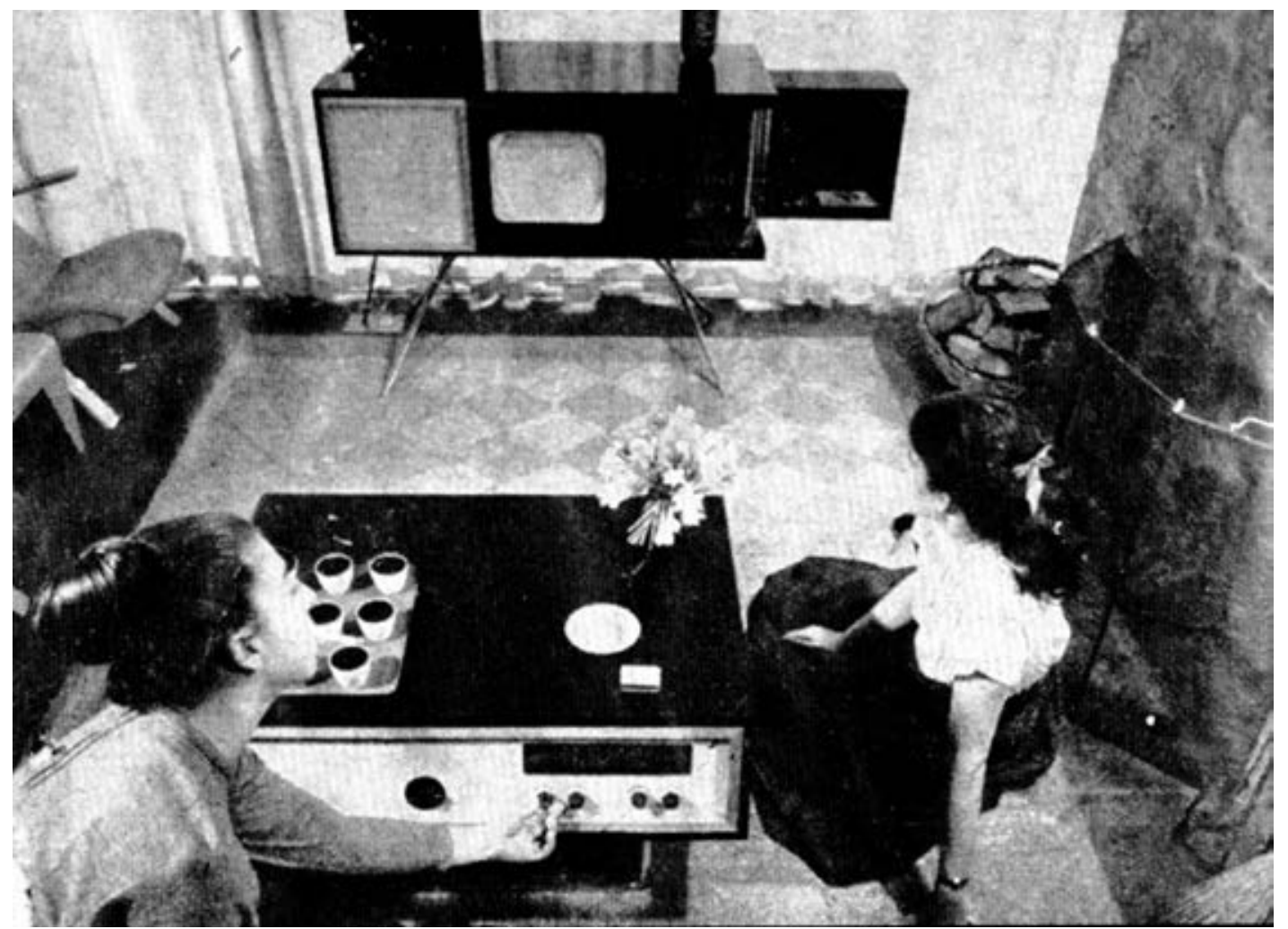

Fig.3.57 - Anúncio que teve a casa de Breuer no jardim do museu como locação. 
No ano seguinte, o arquiteto Gregory Ain, da Califórnia, foi escolhido para elaborar um novo protótipo. ${ }^{80}$ Nessa nova casa, considerava-se a flexibilidade do espaço, através de painéis móveis, que dividiam ou uniam ambientes. Outra vez, as áreas de estar estendiam-se até o espaço externo, através dos grandes panos de vidro. Estes artifícios - como mencionamos anteriormente - conferiam amplidão à pequena casa. Esta, aliás, tinha sido uma das preocupações das três exposições, a de 1945, 1949 e 1950.

A residência era térrea e a cobertura, plana e única, era pontuada pela grande chaminé, em tijolos. Incorporava características da arquitetura moderna, mas o desenho não diferia de tantas outras que se espalhavam pelo país na época, realizações dos incorporadores imobiliários.

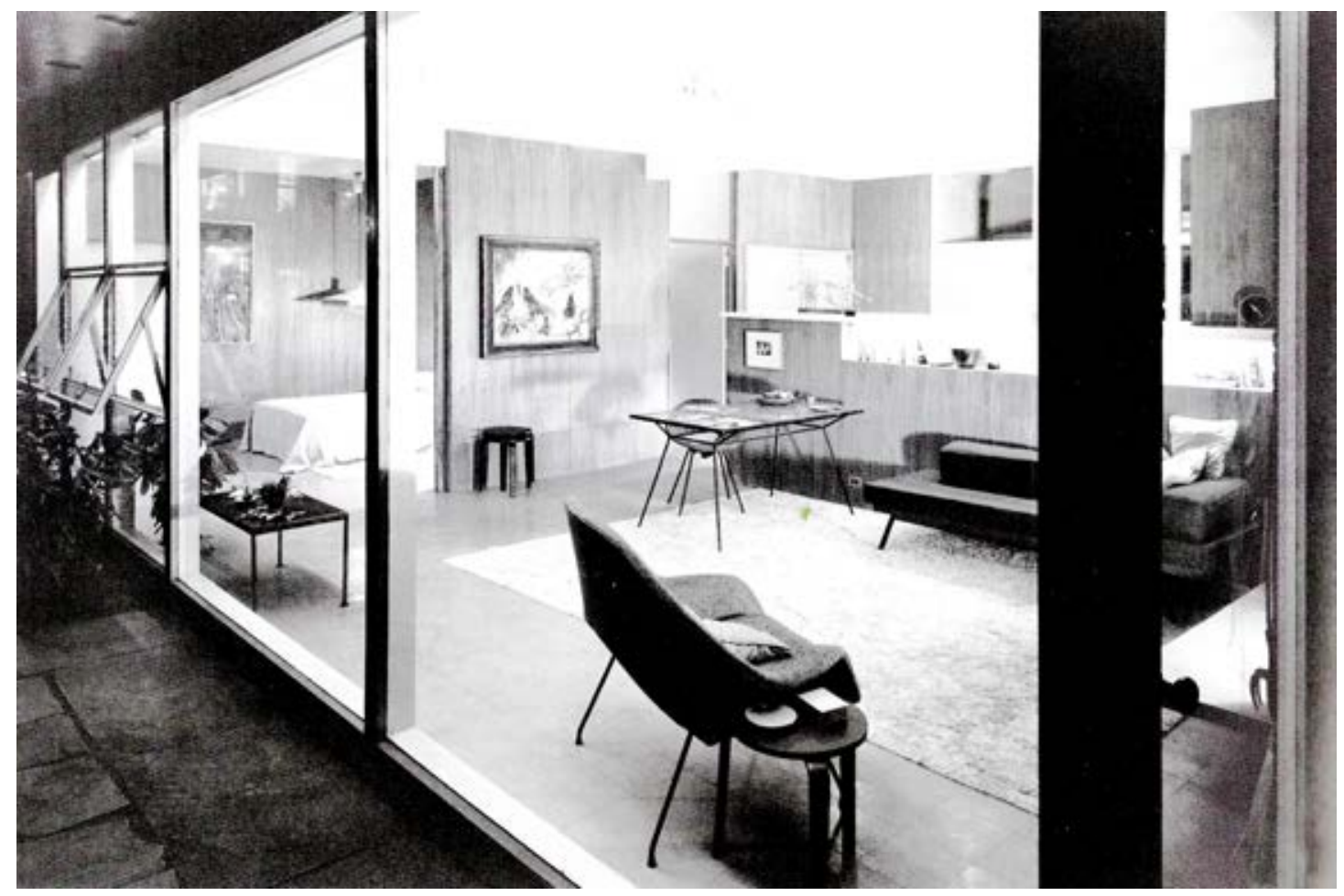

Fig.3.58 - Casa no jardim do Museu de Gregory Ain, interior.

\footnotetext{
${ }^{80}$ Esta exposição intitulou-se Exhibition House e esteve aberta entre 19 de maio e 30 de outubro de 1950. Foi uma parceria entre o museu e a revista Woman's Home Companion. Muitas vezes, o protótipo é chamado de "casa da Woman's Home Companion." Cerca de 300.000 pessoas visitaram a casa de Ain. (COLOMINA, 2007, p.50)
} 


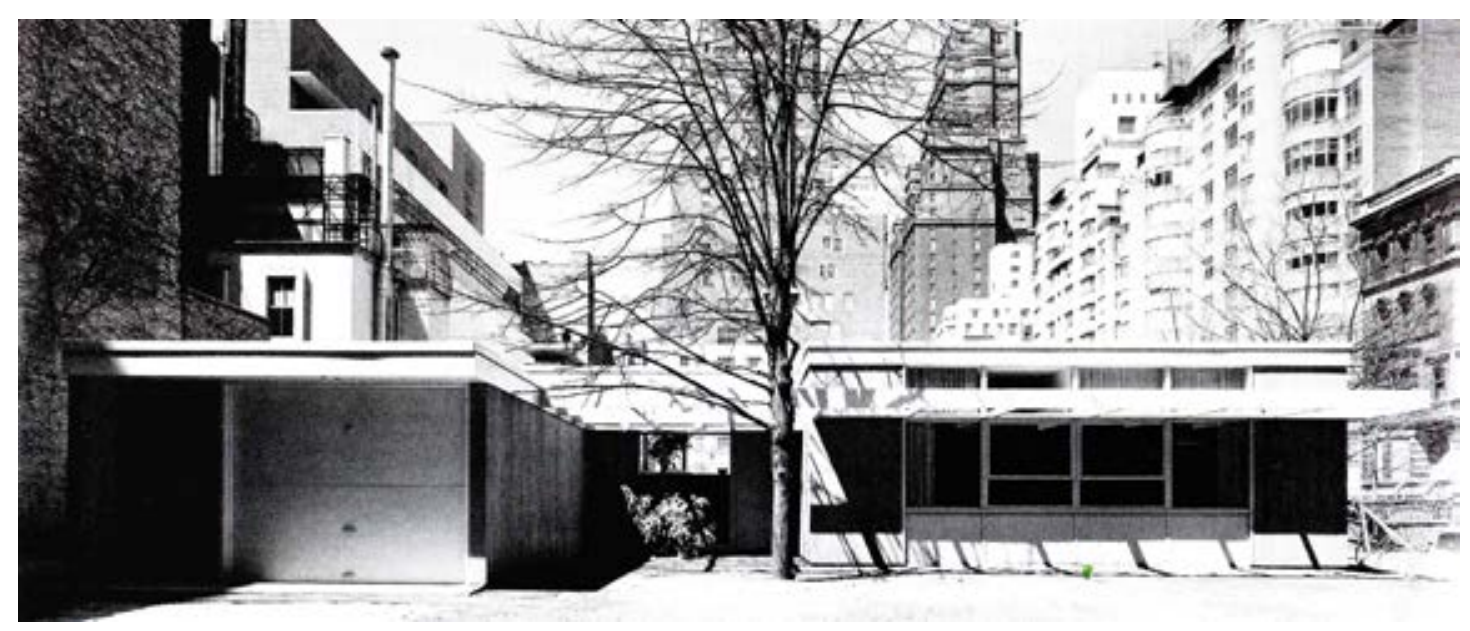

Fig.3.59 - Casa no jardim do Museu de Gregory Ain.

\section{OUR HOUSE}

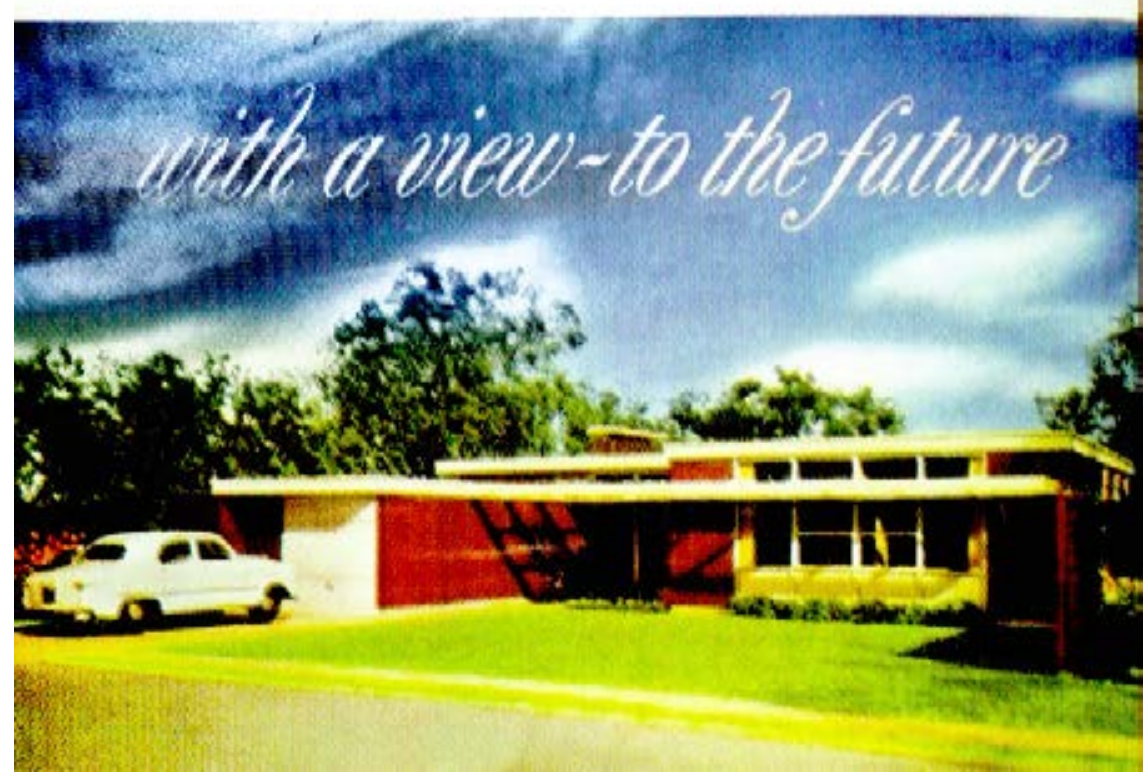

Fig.3.60 - Casa no jardim do Museu de Gregory Ain, foto inserida em site de subúrbio.

Lewis Mumford comentou a esse respeito, em sua coluna do New Yorker:

De forma definitiva, questiona-se que serviço pensava oferecer 0 museu ao emprestar seu prestigio a um modelo de casa com tantos deméritos. Há quinze anos, teríamos agradecido por uma casa assim e com razão seríamos menos rígidos em relação a seus erros, disparates e clichês. Mas, desde então, construíram-se 
centenas de habitações, tão boas como esta, em todo o território nacional, (...). ${ }^{81}$

A investigação e reflexão sobre a arquitetura moderna doméstica marcaram essa preocupação "educativa" do MOMA e de seu departamento de arquitetura, principalmente nos anos posteriores à Segunda Guerra Mundial:

O museu assumiu há certo tempo um papel ativo no incentivo a grandes modelos arquitetônicos e de desenho industrial. A exposição desta casa, além de mostrar o melhor desenho e uma utilização perfeita de materiais e equipamentos, apresenta também uma solução prática e econômica para as necessidades do modo de vida moderno. Os únicos motivos que levam o museu a financiar integralmente este projeto são educativos. ${ }^{82}$

As casas no jardim constituíram, no entanto, uma mudança na politica do departamento de arquitetura do museu, que já se delineava nas exibições da época da guerra. Não é exposta uma arquitetura de vanguarda, mas aponta-se, a partir do que existe no mercado, os pontos positivos e negativos em relação à casa de classe média.

\subsubsection{If you want to build a house}

Geralmente, havia publicações do MOMA, ligadas às exposições. ${ }^{83}$ É o caso de If you want to build a house, de Elizabeth Mock, de 1946, a partir da exposição de mesmo nome, um verdadeiro "manual para a casa moderna." Todos os princípios e preceitos do Good-Life Modernism são enumerados, ensinando ao potencial morador o "viver moderno." 84

De início, apresenta a arquitetura moderna como um "estilo de vida," deixando clara

\footnotetext{
${ }^{81}$ MUMFORD, Lewis. Not for internal use. The New Yorker, vol.26, p.54, ago.1950 apud Fullaondo, 2010, p.191-3.

${ }^{82}$ Museum of Modern Art, Woman's Home Companion Exhibition House, Registration Exhibition files Exh.\#447, The Museum of Modern Art Archives, Nova York apud Ibid., p.181. Aliás, essa questão educativa estende-se à arte moderna como um todo, desde sua fundação, como indica o nome do museu.

${ }^{83}$ As publicações eram muito importantes para o museu. Mais que catálogos de exibição, a maioria era uma monografia sobre seu tema, direcionada tanto a acadêmicos quanto ao público em geral. (QUEZADO DECKKER, 2001, p.90-91)

${ }^{84}$ Até mesmo taxas de juros de empréstimos para construção, praticadas pelo FHA, eram discutidas.
} 
a extrapolação em relação ao campo disciplinar da arquitetura, envolvendo o contexto do pós-guerra e suas inúmeras variáveis.

A arquitetura moderna (...) não é apenas outro estilo imitativo. É uma atitude em relação à vida, uma abordagem que começa com pessoas ativas e suas necessidades, físicas e emocionais, e tenta satisfazê-las o máximo possível, da melhor forma possível. Por outro lado, não há regras. Os resultados serão tão variados quanto o conjunto de materiais oferecidos, os problemas humanos apresentados e os talentos criativos empregados em resolvê-los. (...) A parte mais delicada de nosso trabalho como clientes será a escolha de um arquiteto. (MOCK, 1946, p.6)

De forma sistematizada e didática, Mock (1946, p.7) explica, inicialmente, a necessidade de uma nova abordagem para a casa, distinguindo-a das caixas brancas do International Style com janelas de canto e teto plano, ${ }^{85}$ que teriam se tornado uma fórmula do moderno. Em oposição à essa "receita moderna," expõe-se a possibilidade de adequação da arquitetura moderna aos vários contextos: "Não há casa dos sonhos agradável universalmente, e é essa variedade de interpretações que mantém a arquitetura viva e previne que ela se torne desesperadamente entediante e estandardizada." (MOCK, 1946, p.11)

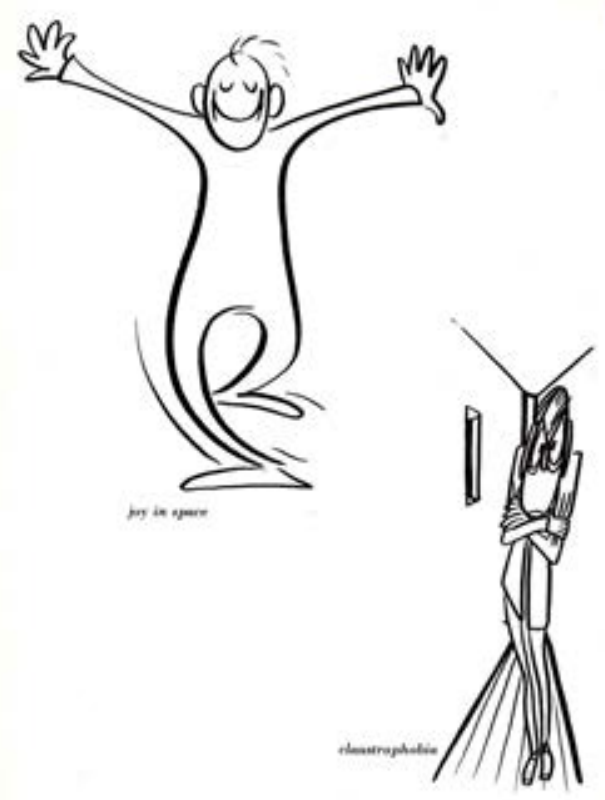

Fig.3.61 - Mock mostra a alegria proporcionada pela amplidão.

\footnotetext{
${ }^{85}$ Esse tipo de expressão, com pequenas variações, era recorrente, um lugar-comum para diferenciar as novas casas modernas das experiências do Movimento Moderno. Como já citado, em editorial da Architectural Forum, Myers (1939, p.2) fala em "dogmático ensaio geométrico rebocado e com janelas nos cantos."
} 
As qualidades que deveriam estar presentes em uma casa - sociabilidade, privacidade, simplicidade, amplidão, luz, possibilidade de vida ao ar livre, conforto físico e psicológico - são descritas.

De certa forma, faz-se uma mediação, adaptando a linguagem moderna e instruindo o morador.

É interessante fazer um paralelo entre If you want to build a house e uma reportagem elaborada a partir de uma mesa redonda, organizada por House \& Home ${ }^{86}$ quase uma década após a publicação do MOMA. Participaram editores ${ }^{87}$ ou assistentes de várias revistas. ${ }^{88}$ Arquitetos e clientes estavam ausentes da mesa.

Ao longo desse número, definem-se os desejos dos compradores. Na verdade, estão muito próximos daqueles apontados por Mock (1946), na tentativa de educar seus leitores.

Mock (1946, p.93) dirige-se aos futuros moradores, ressaltando a importância e as possibilidades do trabalho do arquiteto, no planejamento, no desenho, na utilização de materiais de forma mais econômica e de novos métodos construtivos: "Qualidade no desenho não é um extra luxuoso.(...) e tem muito pouco a ver com custos."

De forma diversa, a mesa redonda de House \& Home dirige-se principalmente aos incorporadores. Deseja-se chegar a um consenso sobre o que é possível proporcionar, entre os itens que as pessoas mais desejam, mantendo os custos baixos: ${ }^{89}$

O conceito desse número de House \& Home é de que o melhor caminho para vender é oferecer às pessoas o que elas querem e então ter certeza de que elas sabem que você lhes está oferecendo aquilo. Assim, esse número é uma lista de características e atrativos para o mercado. Acreditamos que o anseio por uma casa melhor é o mais íntimo e mais forte desejo no coração de toda família. (WHAT DO..., 1954, p.125)

\footnotetext{
${ }^{86}$ WHAT DO..., 1954.

${ }^{87} \mathrm{O}$ moderador foi o editor executivo de House \& Home, Carl Norcross.

${ }^{88}$ Good Housekeeping, House Beautiful, Ladies' Home Journal, Living, McCall's, Parents', Woman's Home Companion, Better Homes and Gardens e representantes da National Association of Home Builders. Todas dedicadas ao público leigo, lidas pelos potenciais compradores das casas. Sua circulação conjunta era de 18 milhões de exemplares. ${ }^{89}$ Algumas casas mostradas na reportagem, localizadas em empreendimentos por todo o país, seriam
recordistas de vendas em suas localidades - uma delas em Levittown.
} 
São considerações bastante pragmáticas. $O$ objetivo é vender as casas rapidamente. Para isso, além das observações sobre o projeto e a construção, aponta-se que os corretores deveriam se valer das casas-modelo, conhecendo seus mínimos detalhes. Inclusive a decoração e os jardins - idealizados por profissionais locais, interessados nos prováveis negócios com os futuros moradores.

\section{What do people want?}

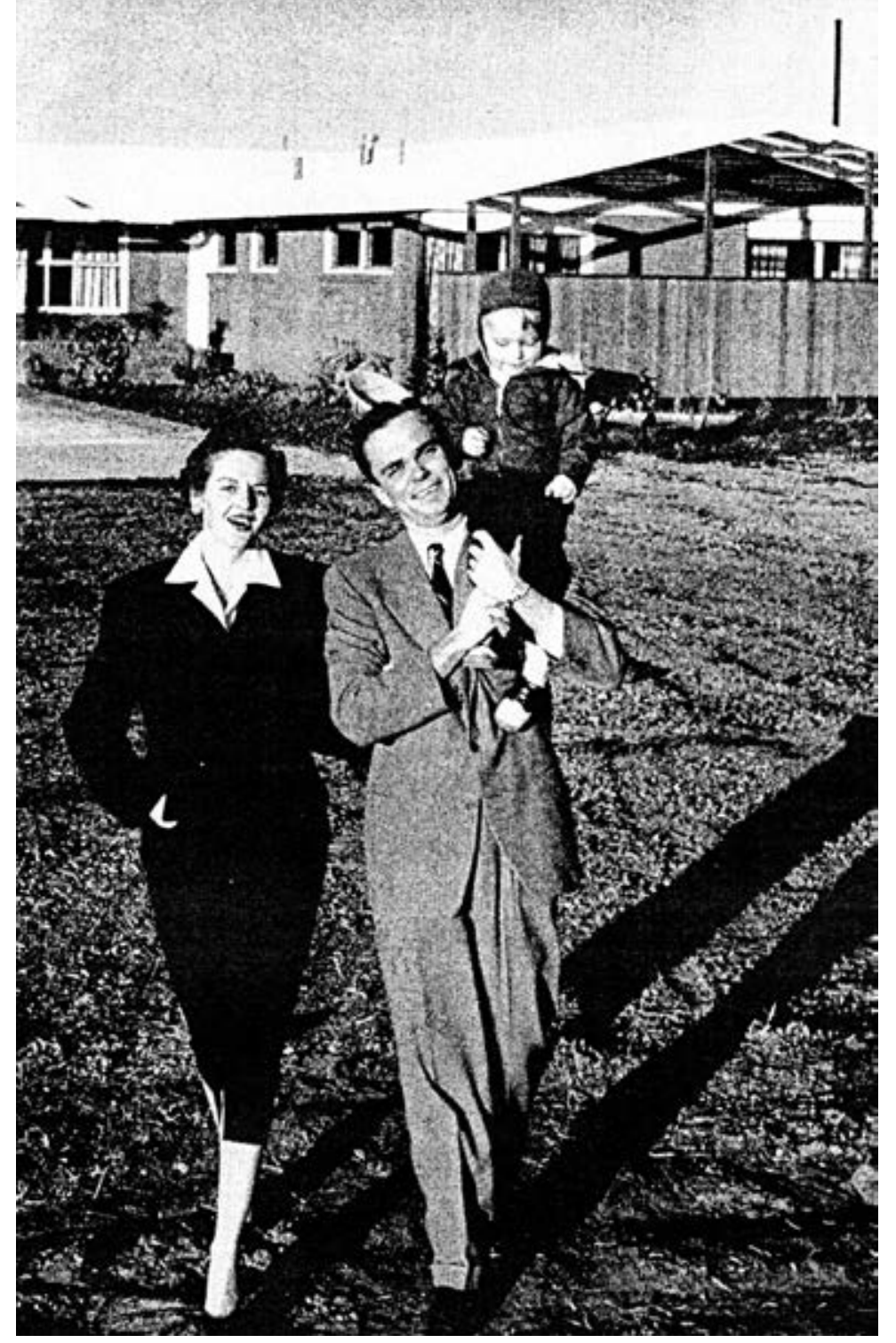

Fig.3.62 - Ilustração da reportagem sobre a mesa redonda, organizada pela House \& Home.

Entre as aspirações dos consumidores, o espaço seria primordial: "a casa com mais espaço é a casa que será vendida mais rapidamente." (Ibid., p.127) 
A sensação de amplidão, com espaço "real" e "psicológico," seria obtida a partir de várias estratégias, como a da "planta aberta, da escolha de cores, e do empréstimo de espaço do exterior (...)." (WHAT DO..., 1954, p.130)

Mock também menciona essa questão, mas fala em fluxo de espaço e fluidez entre as superfícies. A planta aberta transmitiria essa sensação, "permitindo que o espaço flua livremente de uma parte à outra da casa, e do interior para o exterior, ao invés de dividi-la em uma serie inalterável de cubículos em forma de caixas. O olhar não se detém abruptamente nos limites de um cômodo, mas é arrastado pelas ininterruptas superfícies das paredes, piso ou teto." (MOCK, 1946, p.33)

O arquiteto estaria "livre para lhe dar uma sensação de amplidão quando não é possível ser atingida na realidade." (MOCK, 1946, p.9)

A necessidade de "separações," basicamente para proporcionar privacidade e individualidade, está presente em ambas as publicações, mas em House \& Home são apontadas soluções práticas, como o vestíbulo na entrada. A reunião da família é desejada, mas a separação entre gerações, quando necessária, também. Para isso, além do living, é necessária uma family room, uma sala que congrega as funções de vários ambientes - jantar, TV ${ }^{90}$ e jogos.

O espaço para as crianças brincarem e estudarem, devidamente equipado, também era um item importante: "Vender uma casa para uma mãe é fácil: basta mostrar-lhe como você tornou a vida de suas crianças mais agradável." ${ }^{11}$ (WHAT DO..., 1954, p.132) Deveria haver também espaço para os adultos: um "local para gozar o novo tempo livre."92 (Ibid., p.134)

Nas duas publicações, a versatilidade e a praticidade mostram-se aliadas na definição dos ambientes com várias funções, auxiliadas por mobília mais adequada,

\footnotetext{
${ }^{90} \mathrm{O}$ equipamento que mais alterou a vida americana no pós-guerra - tanto no desenho do espaço quanto em relação à mudança de hábitos - foi a televisão. Nos anos 1940 e 1950, ela se tornou acessível ao grande público. Entre 1948 e 1955, perto de dois terços das famílias americanas adquiriram um aparelho de televisão. No entanto, os arquitetos do Case Study Houses, geralmente, a ignoraram. Nas casas da Architectural Record, ela é pouco vista. Apesar disso, os living rooms das casas acabariam por se tornar um local para "ver e ouvir" o que acontecia em outros lugares, ao invés de um centro de atividades familiares. A televisão acabou sendo o centro do ambiente.

${ }^{91}$ Aliás, nessas casas, pode-se dizer que não apenas atendiam-se às necessidades das crianças, mas criavam-se outras. Surgiu, assim, um espaço especial para elas, primeiro chamado o espaço do don'tsay-no ou sala multifuncional, depois chamada de sala da família, muitas vezes apenas uma extensão da cozinha.

${ }^{92}$ Os americanos tinham 1000 horas de lazer a mais, por ano, que seus avós e centenas mais que seus pais, assim, "as pessoas estão gastando milhões em equipamentos para desenvolver seus hobbies." (Ibid., p.134) Esses hobbies eram ouvir o "som Hi-Fi" (high fidelity), marcenaria ou pintura, escultura e costura para as mulheres.
} 
divisórias móveis, e outras peças leves. A mobília fixa e estandardizada é recomendada, por ocupar menos espaço e, também, aumentar a sensação de amplidão.

Para Mock (1946, p.17), o planejamento da casa deveria ser feito com base no individuo e nas inumeráveis e muitas vezes conflitantes atividades que ali acontecem, ao invés da antiga divisão em cômodos específicos.

A otimização da planta recomendava, também, a eliminação de locais supérfluos, como porão e sótão, transferindo a armazenagem para armários ou em locais próximos ao carport.

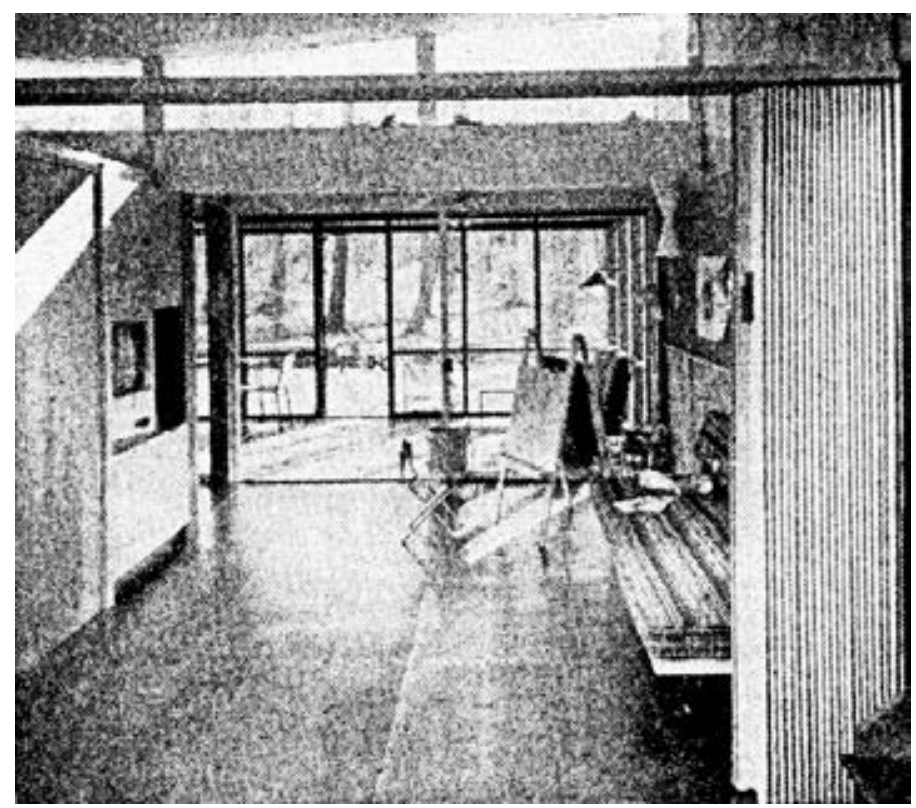

Fig.3.63 - Divisórias móveis para aumentar a sensação de amplidão, em House \& Home.

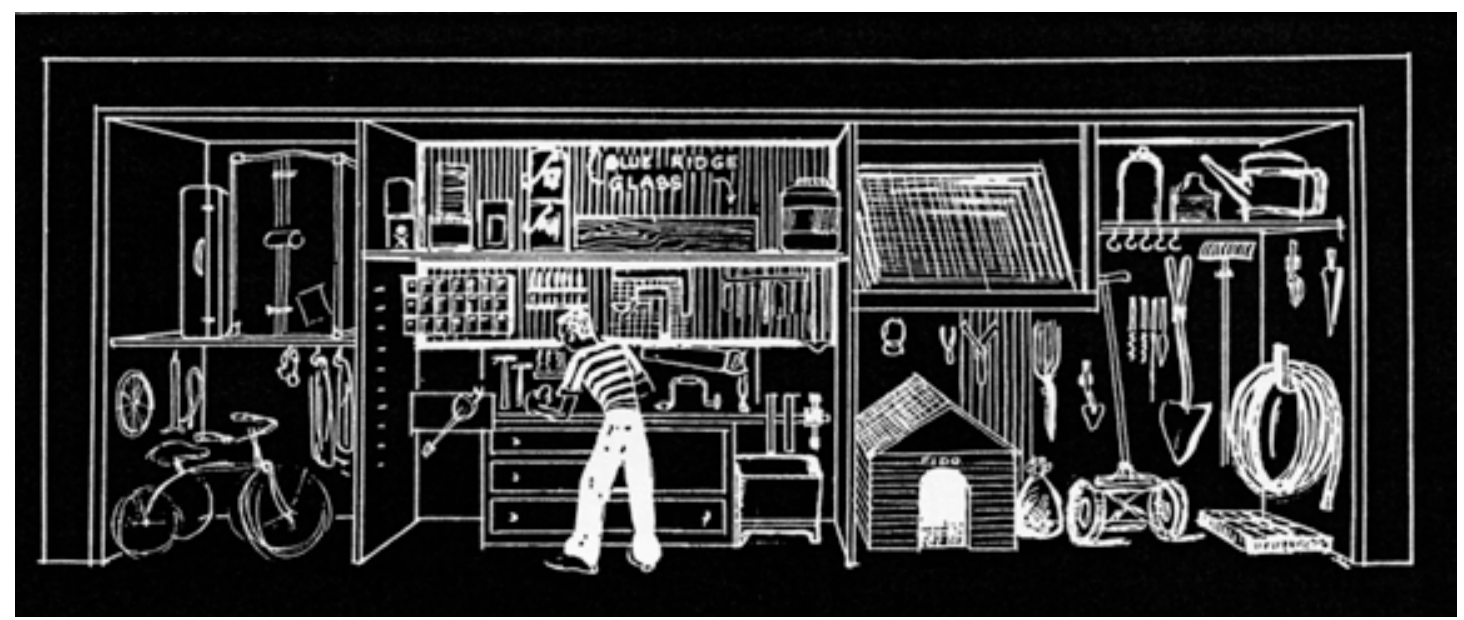

Fig.3.64 - Espaços para armazenagem, em House \& Home. 
Na época em que acontece a mesa redonda de House \& Home, esses espaços já foram eliminados da casa moderna e a armazenagem é definida em detalhes. ${ }^{93} \mathrm{Em}$ espaços pequenos, ela é fundamental na organização, conferindo, ainda, uma sensação de amplidão e de "limpeza" aos ambientes.

Para House \& Home, o espaço externo, integrado ao espaço interno, deveria ser planejado para várias atividades, com equipamentos e vegetação, proporcionando "uma vista com privacidade," através de janelas panorâmicas ou grandes panos de vidro: "Após mais de 15 anos de intensa publicidade, a casa mais envidraçada é agora irrevogavelmente parte do cenário americano. As pessoas em todas as partes do país não apenas a aceitam - elas a exigem." (WHAT DO..., 1954, p.164)

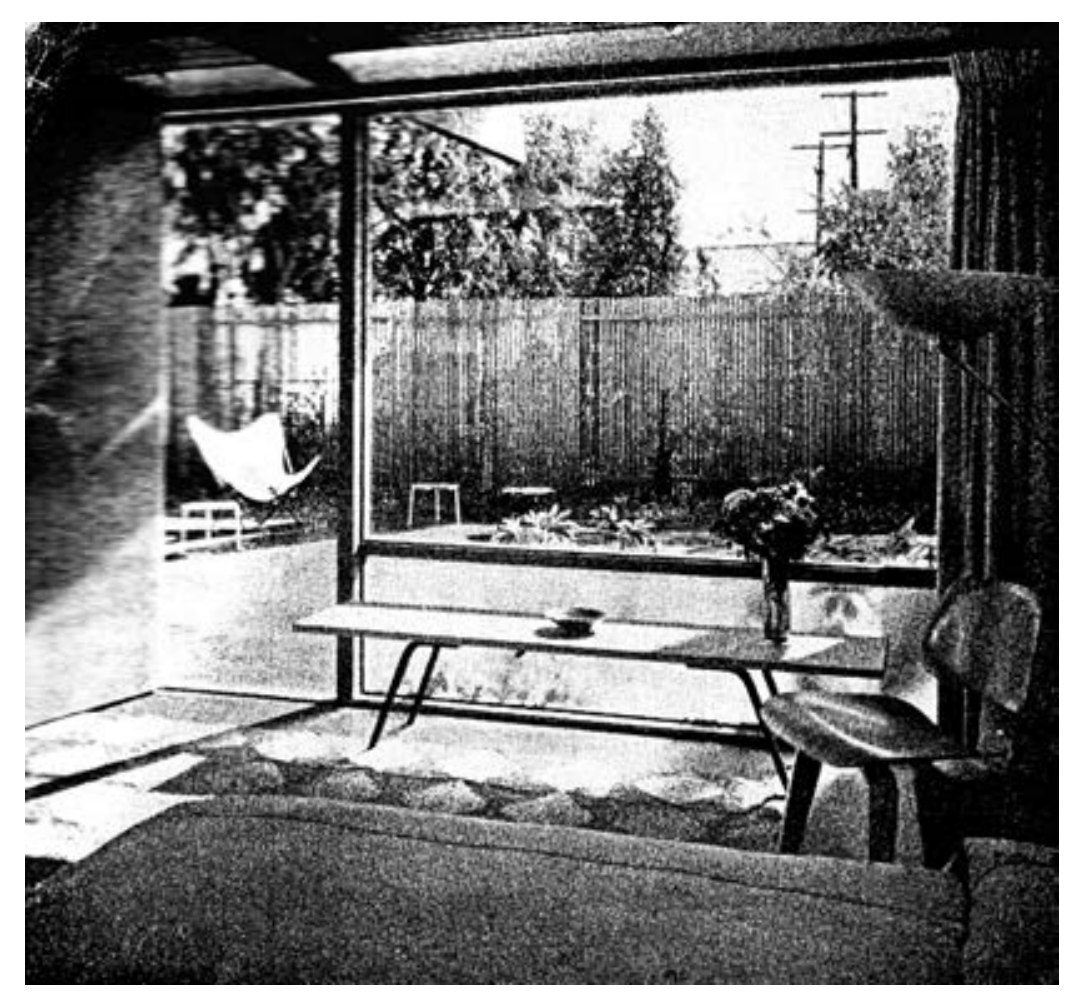

Fig.3.65 - Grandes panos de vidro, em House \& Home.

Havia uma aura de progresso e desenvolvimento tecnológico ao redor do vidro, desde as primeiras décadas do século XX. Além do conforto, apelava-se à satisfação emocional e ao prazer visual que traria ao consumidor. ${ }^{94}$

\footnotetext{
${ }^{93}$ No álbum da Architectural Record, outra característica apontada é a armazenagem em múltiplos tipos de armários e closets que, quando fechados, não são notados."

${ }^{94}$ Além disso, quando a arquitetura do Movimento Moderno atingiu os Estados Unidos, trouxe consigo uma nova ideia da importância do vidro na arquitetura: um "novo" material, com uma lógica
} 
Mock (1946, p.63) fala da necessidade de unidade entre interior e exterior, para que a casa não se tornasse mero agregado de elementos, mas "diferentes aspectos da mesma ideia, frequentemente compostos pelos mesmos materiais;" o jardim penetraria na casa, através do vidro, trazendo "o sol, a luz, a vista, o espaço exterior - quase tudo menos o clima." (Ibid., p.25) O pátio, fechado por muros, cercas ou treliças, seria um "antídoto à vista intensa." (Ibid., p.81).

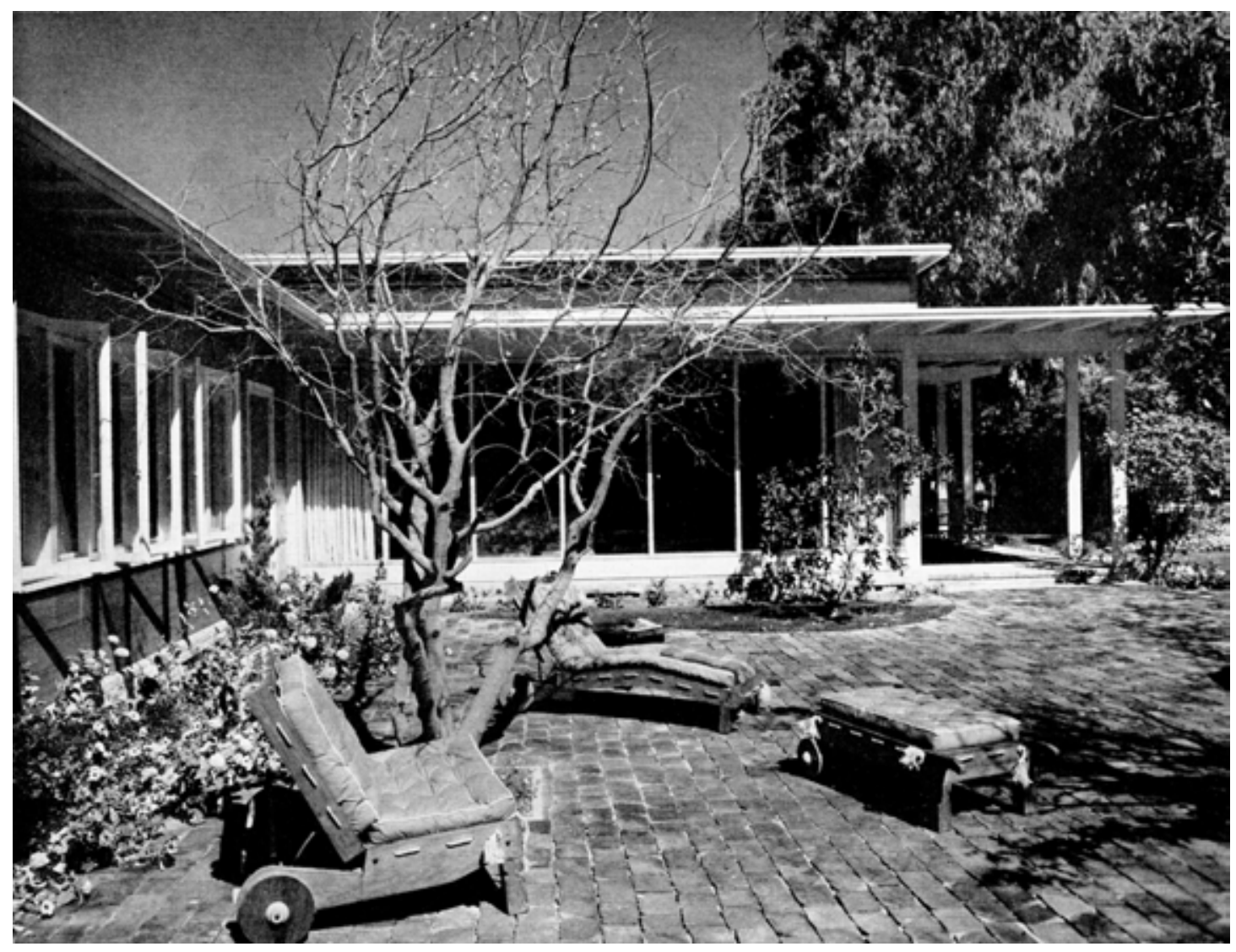

Fig.3.66 - Unidade entre interior e exterior, em Mock.

A cozinha era especialmente relevante. Mock (1946, p.11) aconselhava que não fosse considerada um laboratório, com excessiva atenção a um "planejamento pseudocientífico." Os modelos "modernos" deveriam ser olhados de forma mais crítica. São apresentados modelos integrados aos ambientes sociais.

Em House \& Home, a cozinha era encarada como um centro de controle, para a dona de casa supervisionar os filhos pequenos. Assim, se fosse aberta, seria mais traz consigo a tensão de estar presente e ausente ao mesmo tempo. As paredes de vidro tinham mesmo um efeito moral, a revelação da nova verdade do edifício. 
interessante, pois também proporcionaria um senso de amplidão e iluminação natural. A cozinha poderia estar totalmente integrada à área de estar ou separada por armários, portas de correr ou um balcão.

$\mathrm{Na}$ verdade, a questão mais importante não era o fato da dona de casa ter que cozinhar, mas o isolamento a que era submetida. Tal mudança implica em considerar que o ato de cozinhar não mais necessitava ser desempenhado longe dos olhares da família ou dos hóspedes. Este aspecto está intimamente ligado, também, a uma casa em que não existem empregados.

Questiona-se, assim, se a cozinha deveria ser apenas um espaço de trabalho ou se deveria relacionar-se mais diretamente ao jantar ou estar. ${ }^{95}$ No caso do álbum da Architectural Record, de um total de 82 casas, em 34 existe uma integração total, ou uma abertura - porta ou passa-pratos.

Essa cozinha integrada, uma espécie de living kitchen, ${ }^{96}$ faz desse ambiente o centro da vida familiar, onde se trabalha, joga, brinca, come e de onde a dona de casa pode observar as crianças. Como aponta Giedion (1969, p.625), a living kitchen obtém esse efeito através da combinação de quatro diferentes cômodos: a lavanderia, a cozinha, o jantar e o estar. Para ele, a casa praticamente torna-se uma dependência da cozinha.

Em alguns casos, no entanto, seria preferível uma cozinha pequena e bem planejada, ${ }^{97}$ pois "a dona de casa média anda em torno de 5 milhas, ao redor de sua cozinha todos os dias, para e faz movimentos, como alcançar objetos, levantá-los e carregá-los, suficientes para exaurir um atleta treinado." 98 (WHAT DO..., 1954, p.147)

\footnotetext{
${ }^{95}$ Frank Lloyd Wright, ainda em 1934, na casa Willey, abrira toda uma lateral da cozinha para o grande estar. Na casa Affleck, de 1940, ele os integra totalmente.(Ibid., p.618-9)

${ }^{96}$ No inicio do Movimento Moderno, nos anos 1920, o que se propunha, nas Siedlungen ou em Weissenhof, era o modelo da "Cozinha de Frankfurt," uma working kitchen.

${ }^{97}$ A racionalização do processo de trabalho na cozinha, em uma sequência correta, seguiu as sugestões de gestão científica de Christine Frederick, mas outras mulheres americanas, como Catherine Beecher, ainda no século XIX, haviam começado a desenvolver tais princípios. A partir de 1935, essa organização do processo de trabalho na cozinha é considerada na produção industrial, na estandardização dos componentes, combináveis entre si, vendidos separadamente, pelas grandes companhias ou através do correio. $O$ fogão, a pia e os armários poderiam ser organizados ao longo de uma, duas ou três paredes. Nessa época, passou-se a utilizar as superfícies de trabalho contínuas, que conectavam os armários e a pia .

${ }^{98}$ A lavanderia deveria ser planejada e automatizada, adjacente à cozinha, mas separada, próxima a dormitórios e banheiros. Em outras fontes, ela geralmente aparece como utility room, formando um núcleo de serviço que possibilitava a redução de custos com encanamentos.
} 
$\mathrm{Na}$ área de trabalho deveria ser considerado um triângulo com pia, fogão e refrigerador, encurtando as distâncias, e uma sequência de trabalho, da armazenagem ao local onde seriam servidos os alimentos. ${ }^{99}$ As áreas de balcão eram importantes, sendo que algumas deveriam permitir o trabalho com a dona de casa sentada.

A importância conferida à cozinha também reflete a questão do consumo. Elas eram equipadas com inúmeros eletrodomésticos e equipamentos, como refrigeradores, aquecedores de água, dispositivos para o lixo, lavadoras de louça, fogões, fornos embutidos, etc. A indústria constantemente lançava novos modelos, incentivando a troca. E muitos empreendimentos já vendiam suas casas equipadas, sendo que esse custo era incluído no valor da hipoteca.
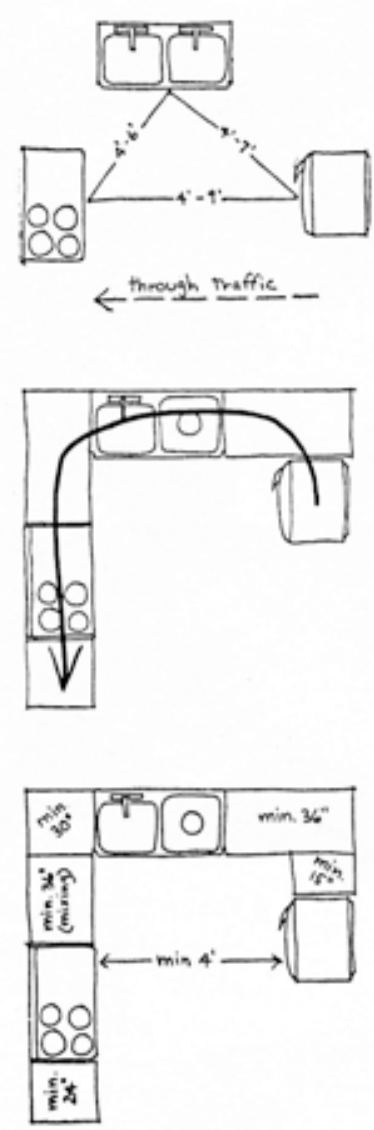

Fig.3.67 - Organização da cozinha em House \& Home.

A facilidade de manutenção era também um item importante, para as duas publicações. Mas, novamente, House \& Home fala de forma mais prática, apontando acabamentos, cores e texturas adequados.

\footnotetext{
${ }^{99} \mathrm{Na}$ casa-modelo tudo isso deveria ser sinalizado.
} 
Flexibilidade era uma questão de fundamental importância. Para que, mesmo não sendo possível ter todos esses ambientes em um primeiro momento, a casa pudesse ser ampliada ou reformada.

Um último desejo, curioso, era "mais cores e glamour," (WHAT DO..., maio 1954, p.157) marcando a diferença entre os dois discursos. O de House \& Home é simplista e pragmático - é preciso saber os desejos do consumidor, atendê-los, na medida do possível, ao menor custo e efetuar uma venda rápida.

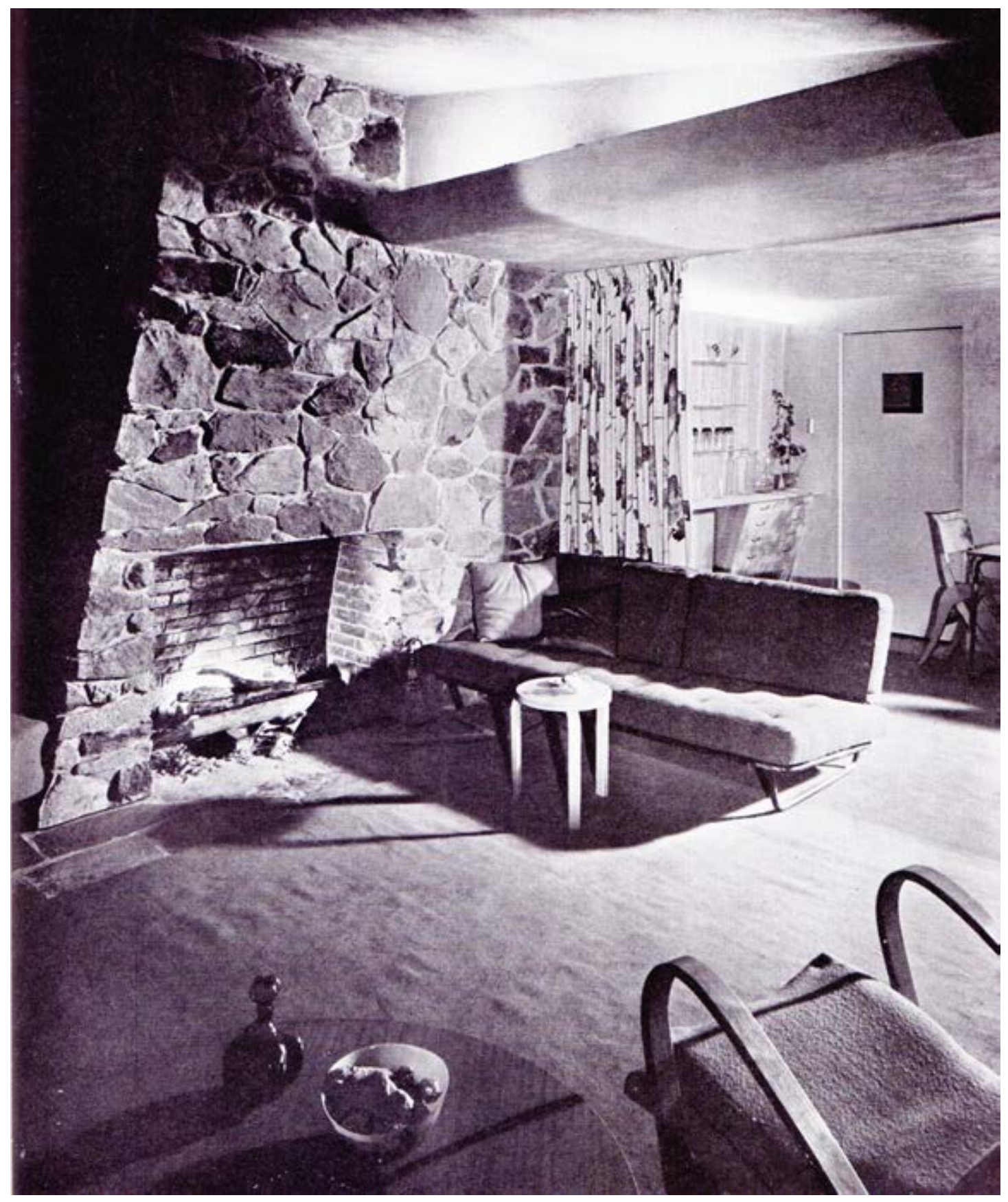

Fig.3.68 - Ambiente mostrado em Mock, de Carl Koch. 
Mock (1946), em contrapartida, discute aspectos interessantes e sofisticados da arquitetura, como a variedade e os contrastes entre luz e sombra, a questão da escala, contrapontos entre abertura e restrição. A lareira, de acordo com a tradição, é mostrada como centro da casa, com seu conteúdo emocional de símbolo da segurança doméstica e de intimidade.

Os materiais deveriam receber uma expressão enfática, utilizados de acordo com seu caráter, mostrando sua verdade. "Materiais, estrutura e forma podem tornar-se um, e um edifício se desenvolve de forma tão inevitável quanto o movimento de uma sinfonia." (MOCK, 1946, p.54)

O olhar poderia passear de forma poética e dinâmica, para a descoberta de novas relações. $O$ arquiteto deveria usar sua sensibilidade, pois a arquitetura, afinal, é arte em três dimensões, em que o espaço deveria ser moldado, construído, interrompido, para deixar de ser apenas um vácuo.

Um discurso muito mais coerente, complexo e elaborado. Em que ela tenta desenvolver o senso crítico do leitor, inclusive em relação a produtos disponíveis no mercado. Não se trata apenas de um incentivo ao consumo.

As informações sobre a casa moderna foram mostradas ao cliente do arquiteto, informando-o sobre o viver moderno, sob todos os seus aspectos. A intenção era educá-lo. O próprio nome da publicação - If you want to build a house - já informa que o futuro morador é o destinatário da mensagem.

Em House \& Home, esse momento já passou. ${ }^{100}$ A dimensão comercial ${ }^{101}$ prepondera e o grande objetivo agora é o consumo - da casa e das appliances.

\subsubsection{Subúrbios}

\footnotetext{
${ }^{100}$ Deve-se considerar, além dos 10 anos que as separam, que uma é uma publicação de um museu e outra, uma revista voltada, principalmente, a incorporadores.

${ }^{101}$ Eram várias as estratégias de convencimento do consumidor, sobre o que ele deveria procurar em uma casa. E com várias formas, como o teste seguinte que a revista Life teria enviado a 26 milhões de leitores, "Can your houses pass this test?" (HOUSE \& HOME, n.6, junh.1954, p.154-5) Havia questões como a presença de: vegetação e outros elementos naturais; ruas curvas; grandes beirais; boa orientação da casa em relação à insolação e ventos; ambientes de estar externos; tamanho do lote; presença de hall; circulação no living; espaço para armazenagem; vários aspectos em relação à cozinha e do serviço; questões sobre os banheiros, etc. Eram atribuídos pontos a cada uma dessas características.
} 
Não se pode pensar o Good-Life Modernism sem se considerar os subúrbios, que no pós-guerra apresentaram uma expansão sem precedentes. Foi ali que ocorreu o boom da habitação, ${ }^{102}$ iniciado por volta de 1949, alterando a periferia das grandes cidades americanas.

Isso foi possível devido, entre outros aspectos, às verbas federais destinadas à construção de autoestradas, que aumentaram nos anos $1950,{ }^{103}$ permitindo a construção do sistema nacional de estradas interestaduais, que criou um ambiente amigável para o carro, fomentando cidades espalhadas e de baixa densidade.

O melhor de nossas residências modernas raramente é visto a partir das rodovias ou das ruas de muito tráfego. Existe mais desse moderno de qualidade do que percebemos porque muito está deliberadamente escondido dos olhos do público. (MASON, 1952, s.n.p.)

Os subúrbios produzidos em massa constituíram uma alternativa para o alto custo da terra em áreas urbanas. As políticas públicas, em cidades como Los Angeles, promoviam a compra de casas nos subúrbios com ofertas de hipotecas de longo prazo e dedutíveis dos impostos.

Esses empreendimentos foram financiados pelo FHA, que concedeu, inclusive, empréstimos para soldados que retornavam da guerra. Aqui, deve-se ressaltar a importância do GI Bill of Rights, ${ }^{104}$ que fez aumentar a demanda por casas. De forma diversa da época da depressão, quando o governo investiu diretamente na construção de habitações públicas, o governo Truman garantiu empréstimos com juros baixos - sem entrada - para veteranos, tornando mais barato, em muitos

\footnotetext{
${ }^{102}$ Entre 1950 e 1960, 11 milhões de casas foram construídas nos subúrbios. (WRIGHT, 2008, p.167)

${ }^{103}$ O New Deal de Roosevelt, depois de 1932, incentivou as hipotecas de 30 anos, que tornaram a casa própria possível para muitas famílias de trabalhadores, apesar de poucos poderem utilizá-la até depois da Segunda Guerra. Em 1939, o presidente assinou a legislação que estabelecia reduções nos juros das hipotecas, estabelecendo um grande subsídio para a suburbanização, para a qual ele também contribuiu através do apoio à construção de rodovias. De 1934 a 1956, a população dos subúrbios americanos aumentou em $75 \%$, em comparação ao aumento de $25 \%$ da população do pais como um todo. (CROSS, 1997, p.119)

${ }^{104}$ A Federal Housing Administration (FHA) concedia empréstimos com prazos longos - até 25 anos - e juros baixos - taxas inferiores a $4 \%$. O próprio governo federal era o fiador das hipotecas. Houve também cooperação da FHA com a Veterans Administration (VA), para a construção de casas para excombatentes, pois $O \mathrm{Gl}$ Bill of Rights prometia habitação, educação e saúde para onze milhões de veteranos. A realidade do pós guerra, no entanto, dificultou esses benefícios, pois foi uma época de inflação severa e falta de empregos. O GI Bill of Rights, oficialmente, Servicemen's Readjustment Act, aprovado ainda durante a guerra, subvencionava veteranos que quisessem estudar antes de voltar ao trabalho, comprar casas ou iniciar negócios, desta forma estimulando a economia. Por volta de 1952, 2.4 milhões de veteranos haviam utilizado esses fundos para comprar casas.
} 
casos, possuir do que alugar uma casa. Essa abordagem, que realmente alavancou o mercado privado de habitação, foi completada pelo Housing Act, de 1949, conhecido como Taft Bill, que, além de outras medidas, determinava um amplo programa de pesquisa tecnológica para a habitação. (OCKMAN; SACHS, 2012, p.129)

Os subúrbios eram locais quase exclusivos para jovens casais brancos que iam formar suas famílias. O desenho das casas e dos bairros, feito para essa "família modelo," excluía interesses e estilos de vida de outras faixas da população. Restrições eram impostas por incorporadores e pelo FHA, que encorajava segregação de classe, raça e religião. ${ }^{105}$ Esse ambiente social pré-fabricado destinava-se aos WASPs - brancos, anglo-saxões, protestantes -, que deixavam áreas nas cidades, vizinhanças antigas e variadas.

Existem ainda dois aspectos a serem considerados na preferência pelos subúrbios. Um deles é o fato, já mencionado, de, em geral, americanos não gostarem de se sentir confinados, preferindo grandes casas, implantadas em grandes áreas, possíveis apenas nesses locais distantes.

Além disso, para a classe média, aglomerações eram associadas à cidade - com seus imigrantes, suas minorias - e a vastidão permitida pelos subúrbios significava distinção social.

Assim, constituiu-se um ambiente para a classe média, com toda a tecnologia possível, do qual os homens deslocavam-se todos os dias ao trabalho, enquanto a esposa permanecia na casa, reforçando a separação física entre o mundo da produção e o mundo do consumo, o doméstico.

Dessa forma, o subúrbio, além de espaço físico, constitui um conjunto de valores e práticas, um modo de vida. Sua cultura característica leva em consideração os gêneros, em uma realidade de domesticação da mulher, alienada pelas exigências domésticas. Para a maior parte, não existe a distinção entre as dimensões pública e privada, entre trabalho e lazer, que marca a experiência masculina. ${ }^{106}$

\footnotetext{
${ }^{105}$ Havia poucos solteiros, viúvos, divorciados e idosos e muitas crianças, em número crescente, pois a taxa de fertilidade nos subúrbios era maior do que nas cidades. Apenas $9 \%$ das moradoras trabalhavam, contra $27 \%$ na população como um todo. Ernest R. Mowrer, "The Family in Suburbia." In: The Suburban Community, ed. William M. Dobriner (New York, G.P. Putnam's Sons, 1958), p.158 apud WRIGHT, 1992, p.256.

${ }^{106}$ Apesar desse período ser visto como de regressão para as mulheres, para muitas delas, o lar era o local onde a modernidade se realizava. A casa não era necessariamente vista como coercitiva e limitadora, mas como parte de um empreendimento que tinha uma "missão civilizadora." (HEYNEN,
} 
Para reter as mulheres no subúrbio, no pós-guerra, e restabelecer os papéis tradicionais, houve uma verdadeira campanha, após um breve período de trabalho fora da casa durante o conflito.

Tratou-se de um esforço conjunto, entre políticas públicas e imagens da mídia, ${ }^{107}$ para reconduzir as mulheres ao lar e ao seio da família nuclear burguesa. (SPIGEL, 2007, p.7) Essa campanha envolvia propaganda do governo, apelos de psicólogos, religiosos e outros profissionais.

Novamente, lançou-se mão do discurso sobre o papel biológico e social da mulher no lar. Mas, foi difícil a aceitação do antigo papel: “(...) de fato, várias pesquisas próximas ao final da guerra mostravam que, em qualquer lugar, de $80 \%$ a $90 \%$ das mulheres empregadas desejavam assim permanecer após o termino do conflito." (POLAN, 1986, p.9)

E, a casa no subúrbio, com todos os bens de consumo ao alcance das consumidoras, foi uma das estratégias de convencimento. Eram incontáveis produtos domésticos, em cores convidativas e design moderno, fabricados continuamente.

Estavam à disposição de uma nova geração de donas de casa, estimuladas pela propaganda, que cresceu de forma decisiva na década de 1950. Esse é outro aspecto da transição da economia de guerra à economia da paz: o ressurgimento dos artigos supérfluos que não podiam ser produzidos durante o conflito.

Os novos eletrodomésticos e inúmeros livros e artigos em revistas femininas, com conselhos variados, deveriam tornar as tarefas domésticas mais fáceis. $\mathrm{E}$ o tempo livre recém adquirido poderia ser utilizado no consumo. Pois, este tipo de vida está intimamente relacionado ao consumo em massa, do qual a economia dependia.

Nos anos 1950, a classe média crescera e abrangia quase metade da população. $O$ aumento da renda, o advento do cartão de crédito e novos bens de consumo promoveram um nível de conforto conhecido como the good life, a boa vida.

2005, p.110) Sob essa perspectiva, modernidade e domesticidade não podem ser vistas em campos opostos, havendo também certa cumplicidade entre elas.

Um exemplo disso são as possibilidades abertas através da venda dos produtos Tupperware, que se dava através da rede de relações sociais das mulheres que viviam nos subúrbios, uma venda "porta-aporta." Em 1954, mais de vinte mil mulheres pertenciam à rede de vendas, como revendedoras, distribuidoras e gerentes, conforme anunciado na capa da revista Tupperware Sparks, de out./nov.de 1954. (CLARKE, 2007, p.138)

${ }^{107}$ O cinema também teve seu papel. Todas as mídias ajudaram a reforçar essa ideologia do subúrbio. 
(WRIGHT, 2008, p.153) Era a promessa de um crédito sem fim, com a mágica de possuir, sem a necessidade de pagamento imediato. A instantaneidade do prazer.

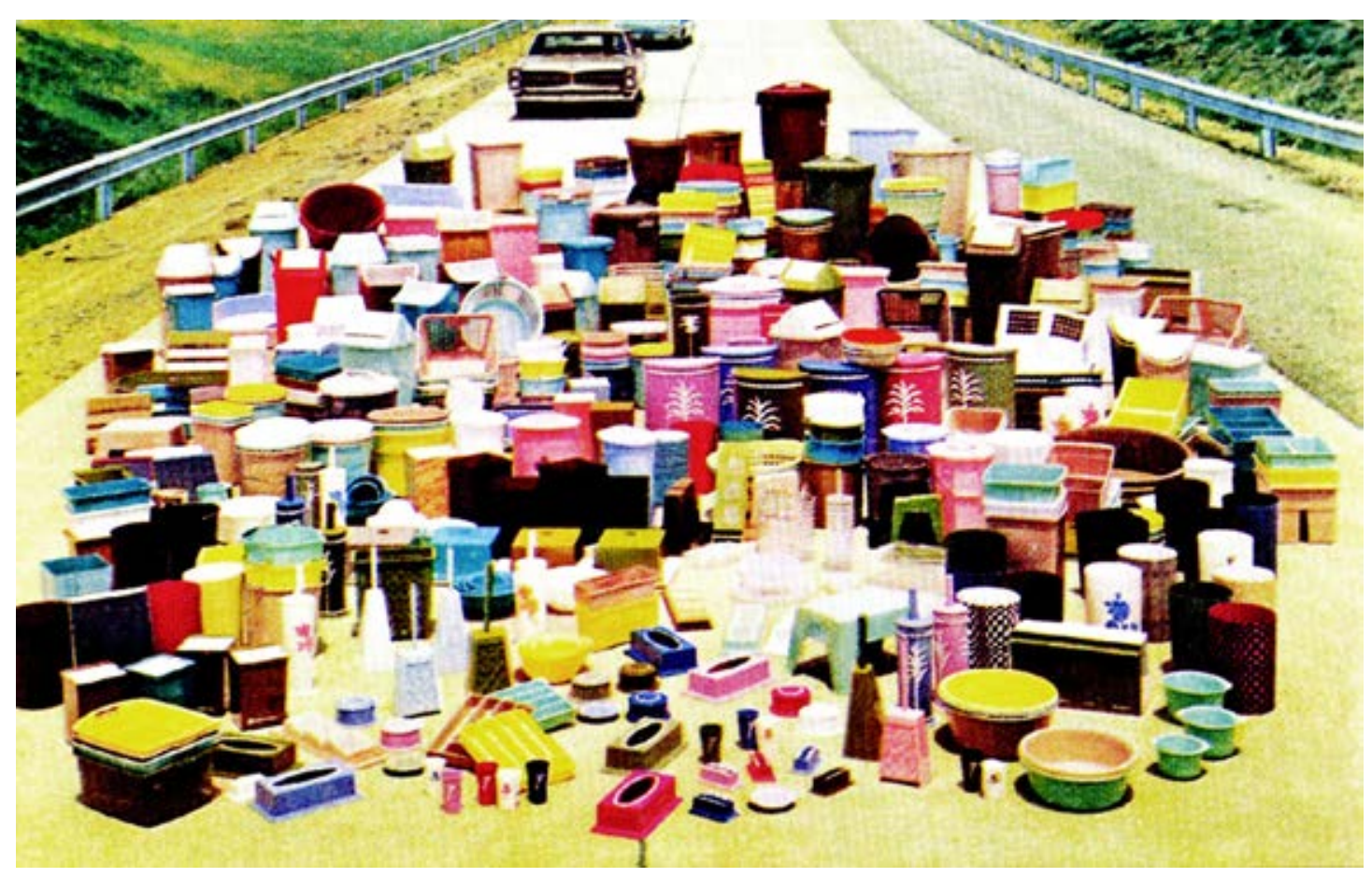

Fig.3.69 - Bens de consumo no pós-guerra.

A casa acaba por confirmar-se como o espaço para o consumo da classe média branca. As famílias decoravam-nas de acordo com anúncios de revistas, com donas de casa visualmente integradas ao "set" doméstico, através de formas, cores e tamanhos.

Segundo sociólogos da época, essas pessoas estavam conscientes de que a vida diária era quase um teatro e a janela panorâmica tornara-se uma espécie de palco. Esse espetáculo da vida cotidiana inspirou séries na televisão, materializando essas fantasias.

A janela panorâmica e as grandes portas de correr em vidro chegaram aos subúrbios nos anos 1950, porém sem as vistas espetaculares da paisagem. A partir do interior, a dona de casa poderia controlar os filhos ou os visitantes. Porém, ao mesmo tempo, havia o medo da perda de privacidade, pois tudo era exposto ao julgamento público, se a família se conformava ao "espirito de comunidade."

Para Colomina (2007, p.168), nessa casa simplesmente não existia interior. O que a grande janela mostrava não era um espaço privado, mas uma representação pública 
de domesticidade. Uma espécie de vitrine vendendo o sonho da classe média americana.

Pois, a prosperidade não conseguia esconder totalmente o lado obscuro desse ambiente - da depressão e das doenças mentais de tantas donas de casa e veteranos. $^{108}$

Grande parte desses problemas era causada pela ansiedade, devido à ameaça de um ataque nuclear. O confronto ideológico entre EUA e União Soviética ${ }^{109}$ fica patente no medo que se espalhou por toda a América. O governo estimulava, inclusive, o crescimento dos subúrbios como forma de proteção contra ataques nucleares. E a construção de abrigos subterrâneos.

Nos anos 1950, a crítica ao subúrbio já se difundira, vendo nesse fenômeno a causa para grande parte das doenças e males americanos. Desde o começo, houve profundas transformações na vida cotidiana.

As Levittowns - os maiores e mais conhecidos subúrbios, que em 1950 proporcionavam moradia para uma em cada duzentas famílias americanas - eram apresentadas como exemplo de organização racional da vida. Utilizava-se a mesma cor para cada oito casas e um salgueiro, três árvores frutíferas, vinte e oito a trinta flores ou arbustos para cada casa. Mas, essas regras serão rapidamente percebidas por seus habitantes como irracionais e arbitrárias ${ }^{110}$ e serão atacadas por toda sorte de subversões estilísticas, entre elas, cômodos extras, novas cores, novas superfícies. (POLAN, 1986, p. 255)

\subsubsection{Grandes e pequenos empreendimentos}

Esses empreendimentos nos subúrbios foram realizados por grandes e pequenos incorporadores, que tentavam produzir e vender as casas desejadas pelas famílias. Foram lançados inúmeros deles, com centenas ou até milhares de casas, praticamente idênticas.

\footnotetext{
${ }^{108}$ Sobre a "neurose de guerra", um manual para famílias de veteranos, When he comes back, dizia: "Quase todos podem desenvolver uma (...) psiconeurose se colocados em circunstâncias com as quais não possam lidar. (...) Nos tempos de paz, tais conflitos frequentemente aparecem conectados aos nossos amores, ódios, e ambições." (POLAN, 1986, p.247)

${ }^{109}$ As primeiras referências à Guerra Fria são de 1948.

110 Outra regra do manual do proprietário de Levittown era que a roupa lavada deveria ser dependurada apenas em varais tipo guarda- chuvas.
} 
A habitação em massa construída no subúrbio "tornou-se" moderna por várias razões. Entre elas, onde um típico construtor colocava cinco casas pouco antes da guerra, os especuladores do pós guerra criavam subdivisões com milhares de casas indistintas umas das outras, que logo respondiam por $80 \%$ da produção americana. ${ }^{111}$ As revistas de arquitetura asseguravam a seus leitores que o modernismo poderia conviver com o mercado de produção em massa.

Em Long Island, na costa leste, a empresa Levitt and Sons lançou a primeira Levittown em 1947, em um antigo campo de batatas. Em 1950, já havia 17.447 casas nesse loteamento, ${ }^{112}$ divididas em vários bairros. ${ }^{113}$ Cerca de 80.000 pessoas viviam ali. ${ }^{114}$

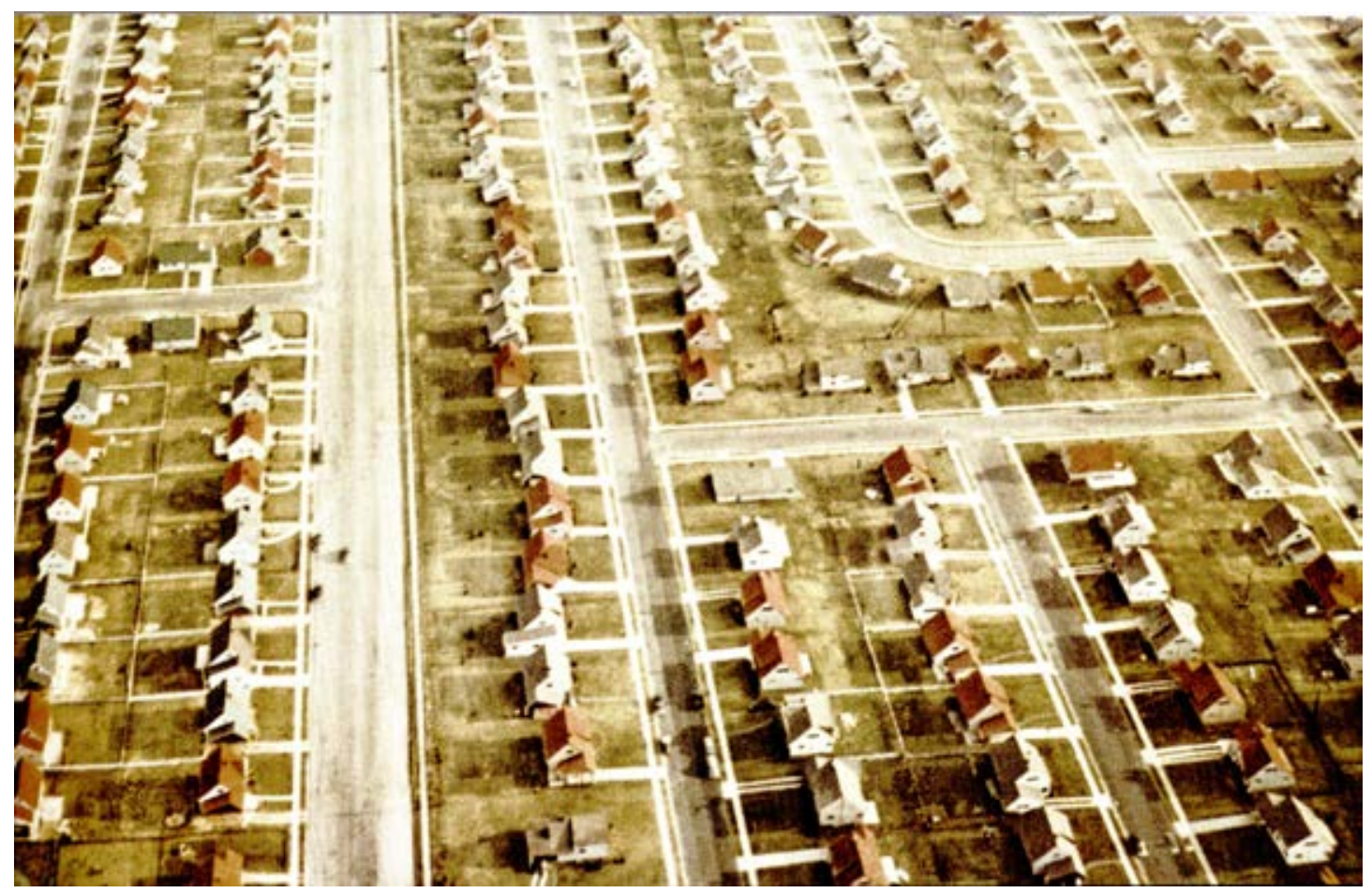

Fig.3.70 -Levittown em Long Island.

\footnotetext{
${ }^{111}$ WEISS, Marc A. The Rise of the Community Builders. New York, 1987, p.161 apud Wright, 2008, p.171.

112 Os preços das casas variavam de $\$ 11,500$ a $\$ 14,500$. A hipoteca era frequentemente mais barata do que o aluguel de um apartamento na cidade, além do fato da nova legislação tributária permitir que os juros das hipotecas fossem dedutíveis dos impostos. Podia-se comprar uma casa Levittown com pequena ou nenhuma entrada.

${ }^{113}$ WATTEL, Harold. Levittown: a suburban community. In: DOBRINER, William (ed.) The suburban community. New York: G.P. Putnam's sons, 1958, p.287-313 apud IRIGOYEN DE TOUCEDA, 2005, p.63.

${ }^{114}$ Essa Levittown tornou-se conhecida como o "Vale da Fertilidade" e "Gaiola de Coelhos," pois muitos dos veteranos que retornavam estavam começando suas famílias e tendo tantos filhos que essa geração passou a ser conhecida como Baby Boom.
} 
A monotonia era combatida, sem grandes resultados, com diversos modelos e cores de fachada, ruas curvas e diferentes recuos frontais. Havia equipamentos como escolas, igrejas, parques, centros comerciais e locais para prática de esportes.

Nesse ano, a companhia estava produzindo uma casa de quatro cômodos a cada 16 minutos. Como a GM, a Levitt and Sons lançava um novo modelo a cada ano. Para isso, a companhia aperfeiçoou a produção em massa de casas, dividindo o processo em 27 etapas diferentes, como uma linha de montagem industrial. Pré-fabricava-se o máximo possível de componentes. Junto com suas subsidiárias, a empresa produzia concreto e outros materiais, cortava a madeira e fabricava eletrodomésticos.

Por trás das fachadas tradicionais, havia conveniências modernas, logo copiadas pelos outros construtores: lajes de piso aquecidas substituindo porões; janelas e portas de correr com vidros duplos que se abriam para pátios; lareiras com três aberturas, como foco das plantas abertas, "emprestadas" de Frank Lloyd Wright; eletrodomésticos.

Mas, havia exceções, incorporadores que tentavam inovar, com qualidade no desenho do site e das habitações, feitos por arquitetos.

Um desses empreendimentos foi Pueblo Gardens, em Tucson, projetado pelo arquiteto A. Quincy Jones. ${ }^{115}$ Havia ali, como era usual, uma casa-modelo decorada. Foi, provavelmente, uma das primeiras a serem mobiliadas com peças de design moderno. ${ }^{116}$ Decorada e "encenada" pelo próprio arquiteto, aparece na capa de House \& Home,${ }^{117}$ com uma longa fila de pessoas esperando para visitá-la.

\footnotetext{
115 Formado na Escola de Arquitetura da Universidade de Washington, em 1936, Jones se tornaria bastante conhecido, ganhando vários prêmios. Trabalhou com os modernistas Douglas Hannold e George Vernon Russell, com Burton A. Schutt e então com Paul R. Williams, entre 1939 e 1940. Durante a Segunda Guerra, com outros profissionais, Paul Williams formou a Allied Engineers, Inc. que prestou serviço em algumas bases navais entre 1941 e 1942. Jones era responsável pela criação do layout das instalações, o que lhe valeu experiência em grandes projetos de desenvolvimento. Trabalhou também em projetos de habitação em grande escala. Depois, serviu como oficial da Marinha. Logo após a guerra, abriu seu escritório, mas ainda associou-se com Williams em cerca de 20 projetos, como o Palm Springs Tennis Club e Pueblo Gardens.

${ }^{116}$ Poltronas de Aalto, cadeiras dos Eameses e luminárias de Greta Magnusson Grossman

${ }^{117}$ V.5, n.5, maio 1954. O final de semana de abertura atraiu 100.000 pessoas, sendo reportagem de capa da revista Time Magazine.
} 


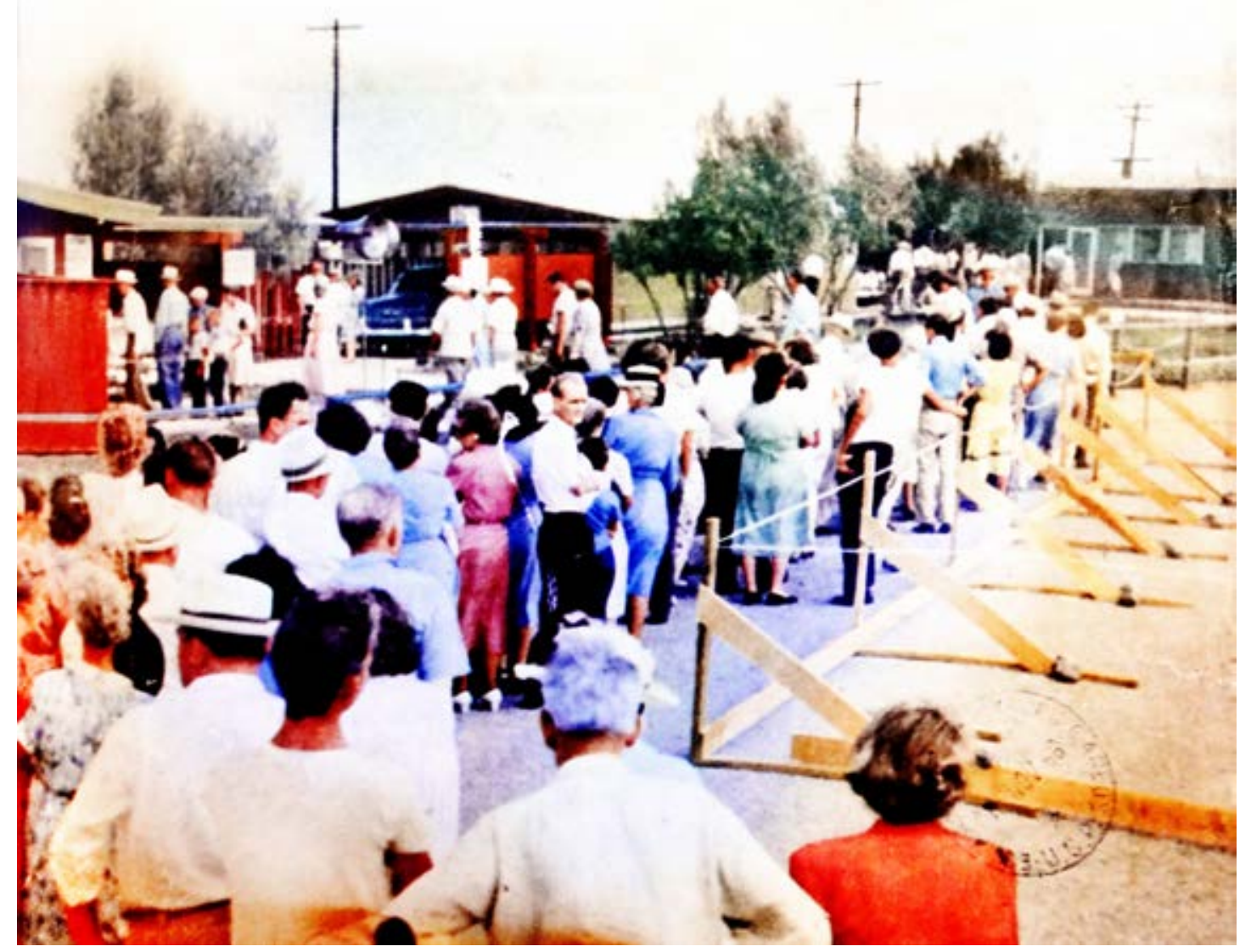

Fig.3.71 - Visita à casa-modelo de Pueblo Gardens.

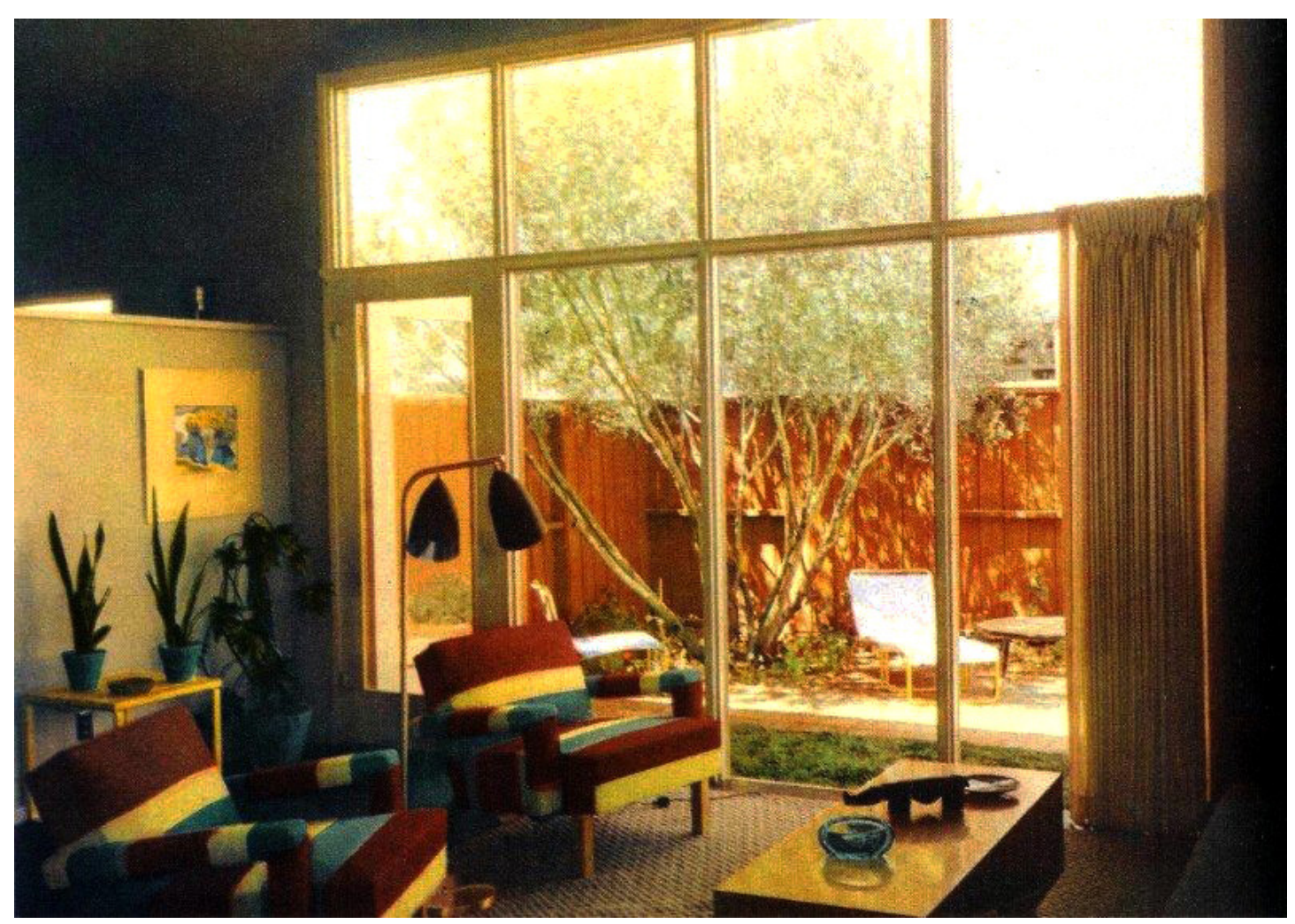

Fig.3.72 - Pueblo Gardens, interior de uma das casas. 


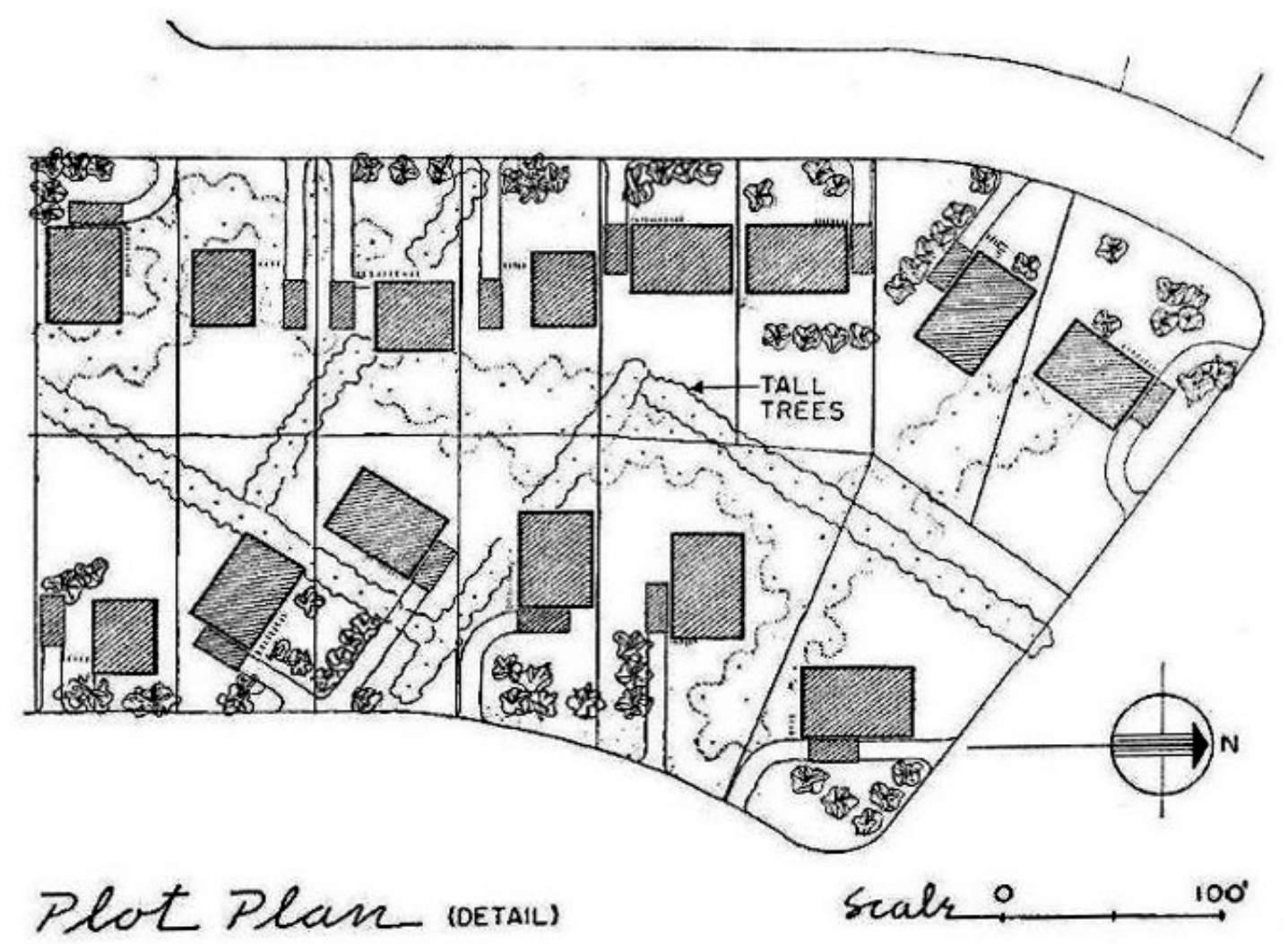

Fig.3.73 - Pueblo Gardens, desenho do site.

Quando Jones foi chamado para discutir o projeto do shopping center que fazia parte do empreendimento, o planejamento do site já havia sido feito e algumas casas aprovadas pelo FHA. No entanto, o arquiteto apresentou desenhos alternativos para as casas, alegando que os princípios modernos poderiam simplificar o projeto e os métodos construtivos, reduzindo custos e "ao mesmo tempo proporcionando mais qualidade de vida para as unidades." (THE SPECULATIVE..., 1950, s.n.p) Apesar das plantas padronizadas, tentou-se obter variedade por meio da locação das casas em ângulos diversos, do contraste de cores e das cercas.

As características das casas são as mesmas já discutidas em relação ao Good-Life Modernism. $\mathrm{Na}$ entrada, o living room é protegido por anteparos. Uma grande área envidraçada abre-se para um pátio. A cozinha integra-se ao living e ao jantar, onde a continuidade do teto aumenta a sensação de amplidão. $O$ arquiteto desenvolveu o paisagismo do conjunto, para proteção contra os ventos e a poeira, e o controle de luz e sombreamento. 


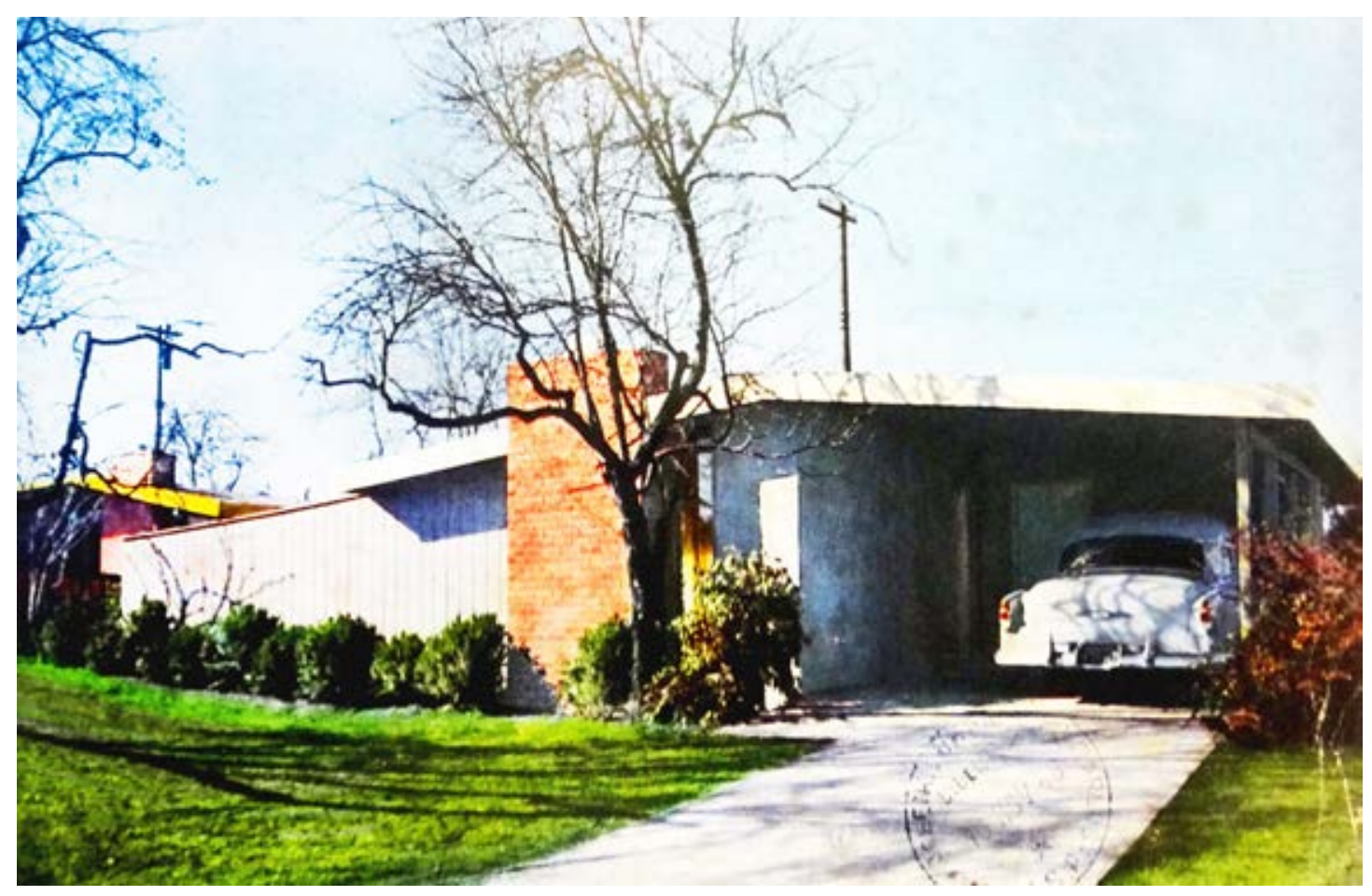

Fig.3.74 - Empreendimento de Eichler, projetado por Anshen \& Allen.

Outro desses empreendimentos foi idealizado por Joseph Eichler, ${ }^{118}$ incorporador de imóveis residenciais. ${ }^{119}$

Eichler encantou-se pela arquitetura, de uma das usonian houses, projetada por Wright, onde viveu. Muitos dos conceitos desenvolvidos pelo arquiteto foram adotados pelo empreendedor. Os bairros desenvolvidos por ele são até hoje reconhecidos por sua qualidade. Ele contratou arquitetos, ${ }^{120}$ o que não era comum nesses empreendimentos, que se encarregavam, também, do planejamento da área, utilizando-se de recursos variados, como os cul de sac, para um desenho mais elaborado, criando vizinhanças aprazíveis. Eichler também recorreu à padronização de componentes.

\footnotetext{
${ }^{118}$ Aparece também na capa de House \& Home, v.5, n.6, jun.1954. As casas, de quatro dormitórios, foram projetadas por Anshen \& Allen. A dupla projetou habitações para Eichler até 1962, e para outros incorporadores. A parceria entre Bob Anshen e Steve Allen's teve início quando estudavam na Escola de Arquitetura da University of Pennsylvania. Depois de formados, envolveram-se com o ambiente da Bay Area, criando importantes edifícios como o International Building, o Bank of Califórnia e o Lawrence Hall of Science.

${ }^{119}$ Eichler construiu 12.000 casas na Califórnia entre 1949 e 1968, modernas, econômicas e com qualidade. (WRIGHT, 2008, p.172)

${ }^{120}$ Raphael Soriano, Quincy Jones, Jones \& Emmons e Pietro Belluschi também trabalharam para Eichler. Jones e Eichler elaboraram o projeto de um bairro de 200 pequenas casas para o programa Case Study Houses, em 1961, não executado.
} 
Suas casas filiam-se ao Good-Life Modernism, apresentando suas características básicas: estrutura independente, plantas abertas, revestimento externo em madeira, fachadas com linhas geométricas limpas e grandes panos de vidro abrindo-se para jardins, pátios e piscinas, integrando ambientes externos e internos.

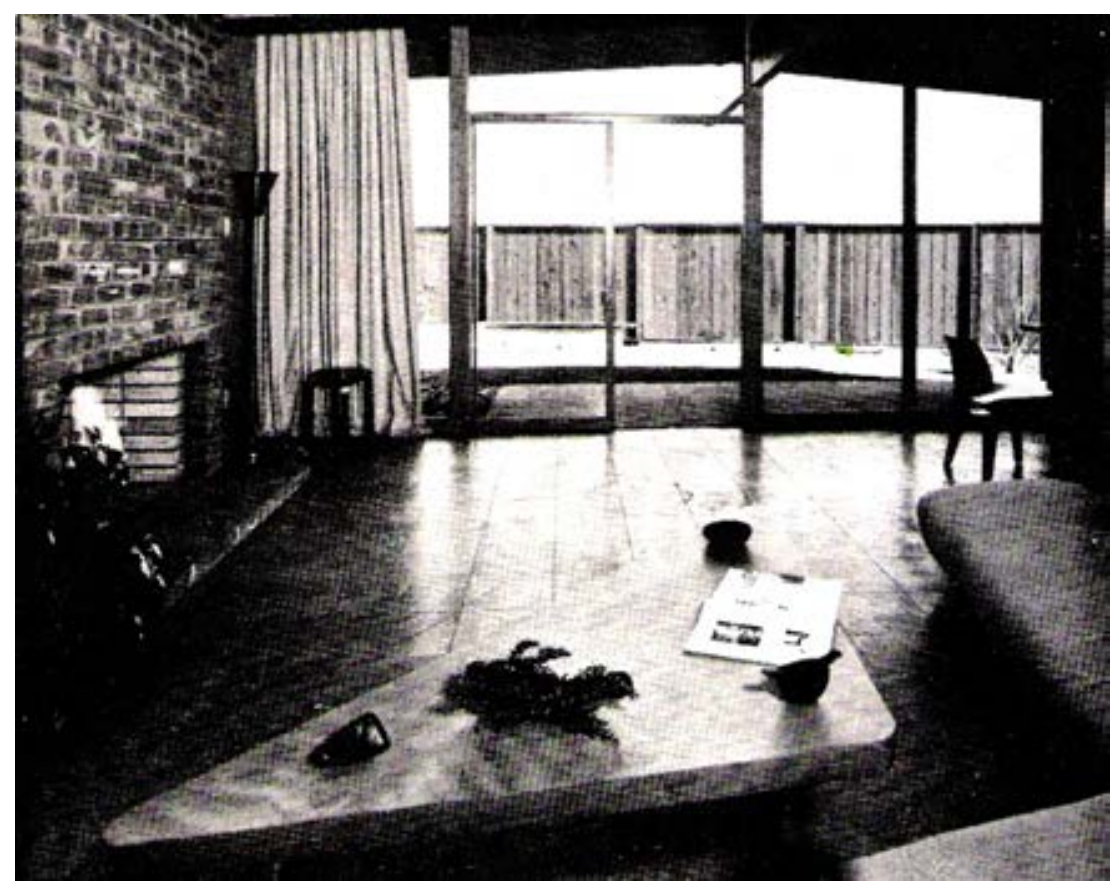

Fig.3.75 - Empreendimento de Eichler, em Palo Alto, na Califórnia, projeto de Frederick E. Emmons e Quincy Jones. Anshen \& Allen, planejamento da área

Fig.3.76 - Planta baixa da casa anterior.

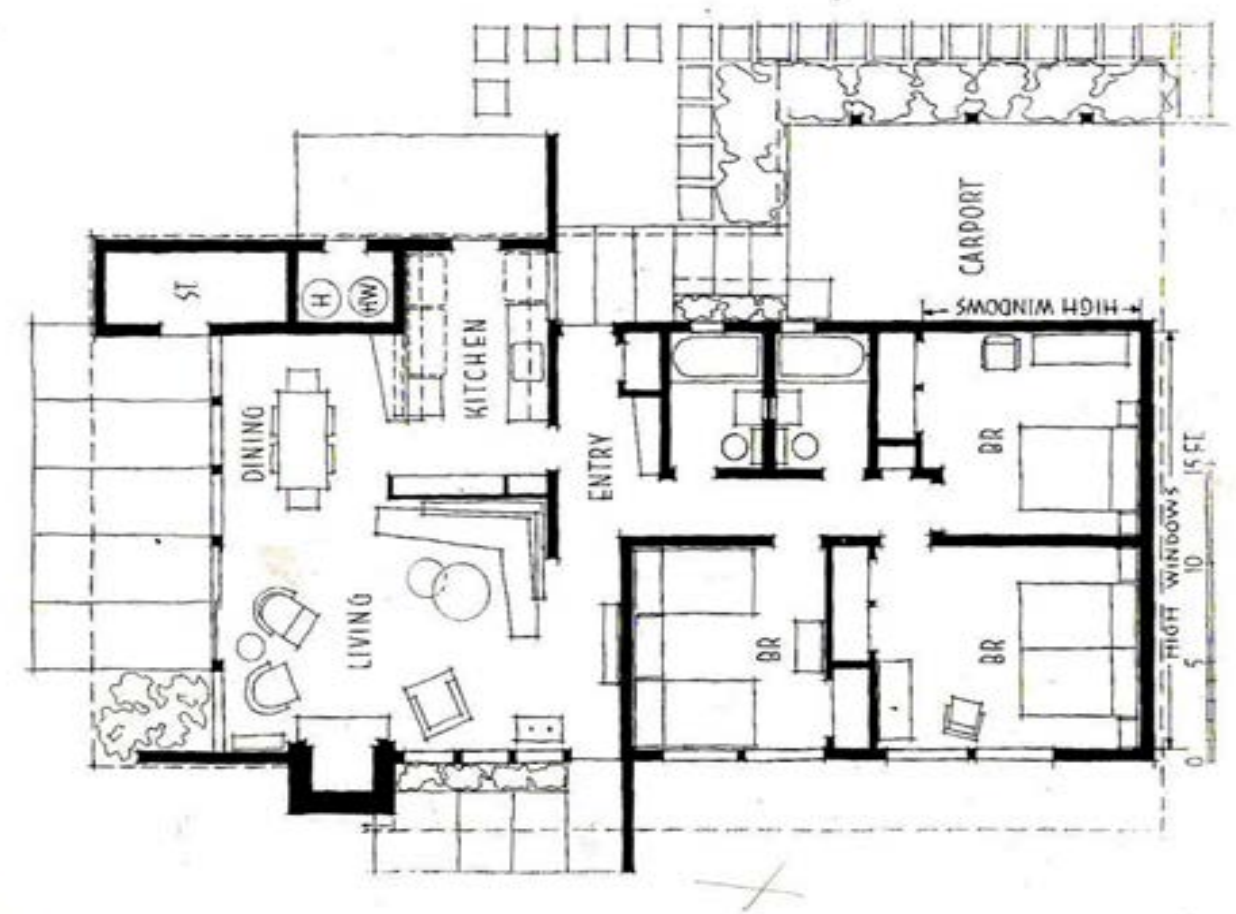


Outro desses empreendimentos habitacionais foi Five Fields, projetado e executado pelo escritório de Walter Gropius, o The Architects Collaborative. ${ }^{121}$ Gropius defendia uma participação mais ativa do arquiteto na construção do edifício.

Os arquitetos teriam utilizado ali "o estilo ranch house com telhado pouco inclinado." (ARCHITECTS..., 1952, p.89) Na verdade, trata-se de um momento na constituição do Good-Life Modernism, de "acomodação" da linguagem moderna. E, tecnicamente mais simples de ser executada, com telhados inclinados. ${ }^{122}$

O desenho é claro, conciso e simples, com detalhamento rigoroso. (ARCHITECTS..., 1952, p.89)

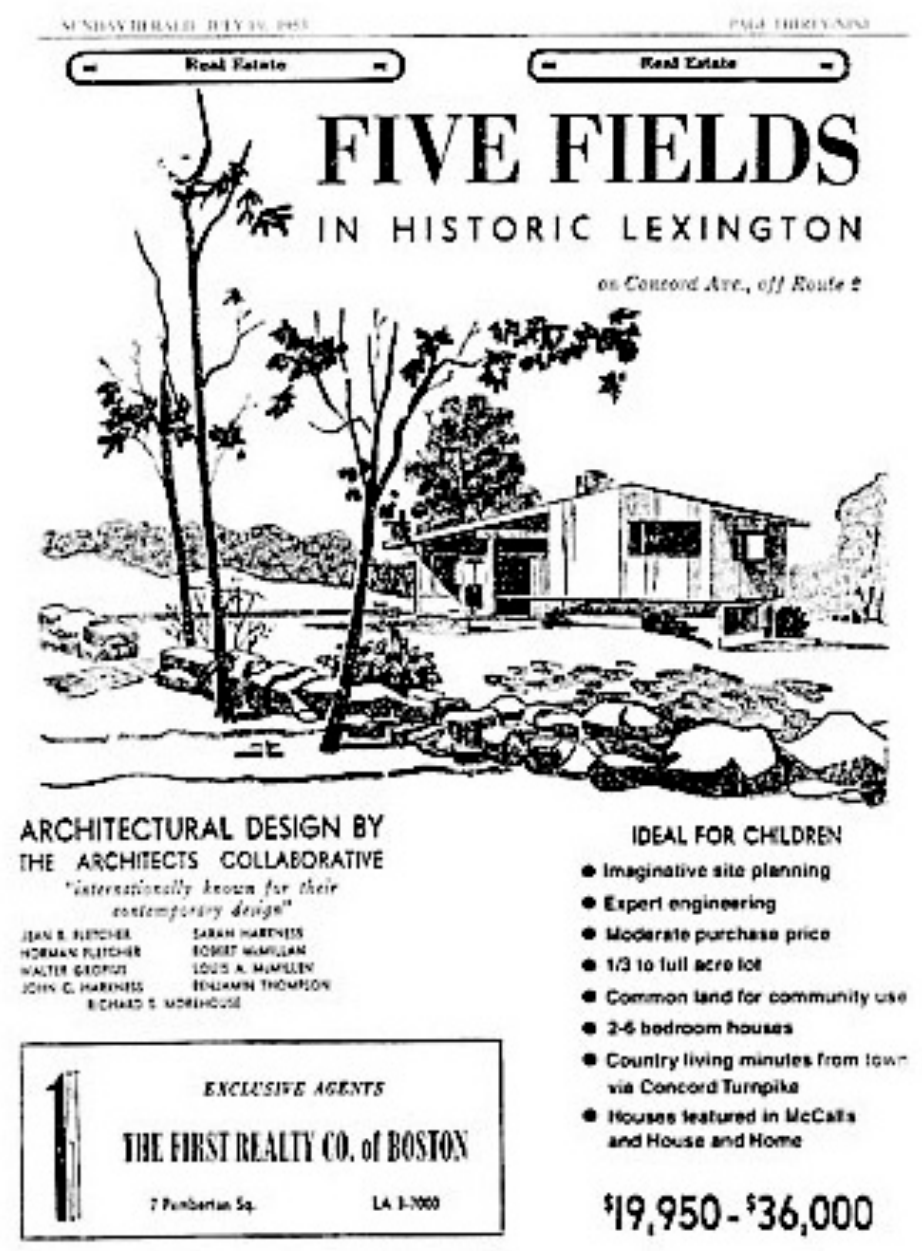

Fig.3.77 - Panfleto de Five Fields.

\footnotetext{
${ }^{121}$ ARCHITECTS..., 1952.

${ }^{122}$ Segundo a revista, a escolha desse tipo de cobertura tentou evitar que se olhasse para uma laje plana a partir de uma casa situada em terreno mais elevado.
} 


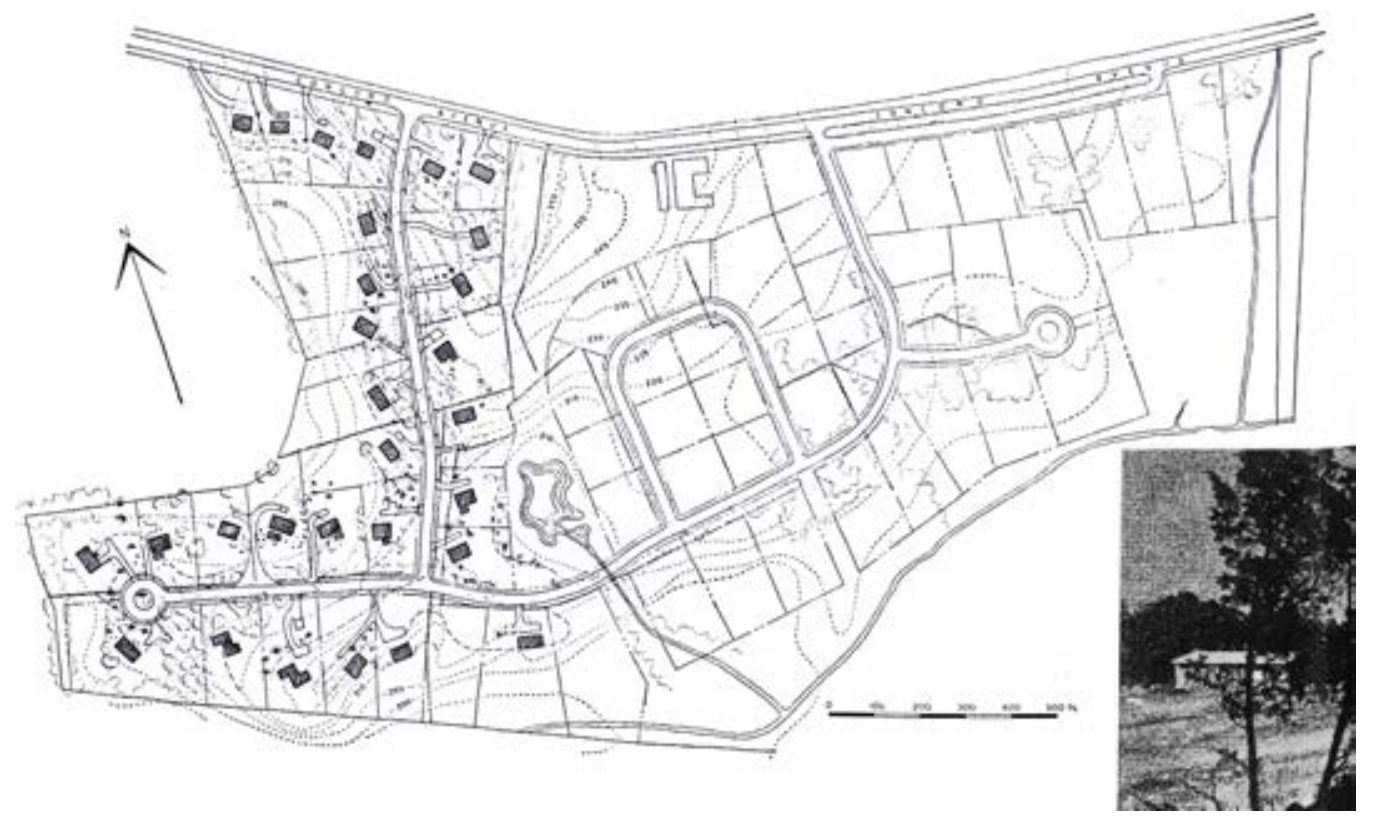

Fig.3.78-- Desenho da área de Five Fields.

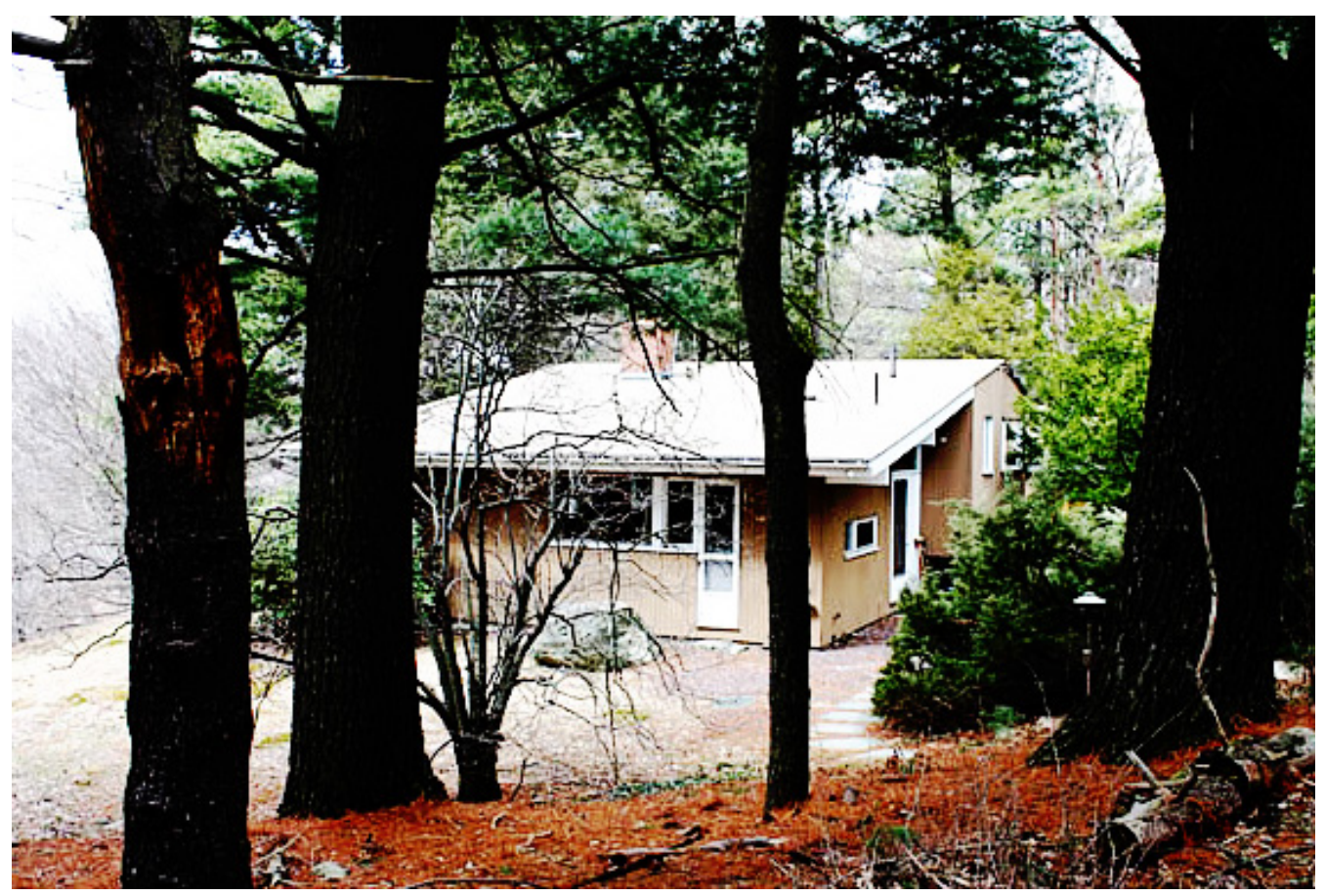

Fig.3.79 - Casa em Five Fields.

A área foi dividida em lotes grandes e preservada a vegetação nativa, o que torna difícil a visualização das casas. ${ }^{123}$ Estas não foram locadas paralelas às ruas, mas de acordo com a melhor orientação solar e dos ventos, e para permitir vistas

\footnotetext{
${ }^{123}$ Vinte e cinco casas haviam sido iniciadas desde o lançamento em junho de 1951 e haveria área para mais trinta. Os arquitetos haviam construído seis e vendido quatro delas.
} 
panorâmicas. Ruas curvas e culs-de-sac trazem variedade e maior segurança ao tráfego. Parte da área foi reservada para uso comunitário.

Existiam várias tipologias de casas, segundo a declividade do terreno: térreas para locais planos, meio níveis para locais com inclinação suave e sobrados para declives maiores. Visualmente, existe variedade, devido aos diferentes materiais empregados, aos telhados inclinados, sacadas e outras áreas em balanço.

As plantas são abertas, com um hall em "T," que leva à cozinha, dormitórios ou living. Com dois, três ou quatro dormitórios, não diferem muito do que se vê em outras casas modernas americanas da época. ${ }^{124}$

Esse empreendimento não foi o único do escritório. Próximo a ele, também em Lexington, foi implementado anteriormente, Six Moon Hill, onde a linguagem do Estilo Internacional se mostra mais característica, mais "pura."

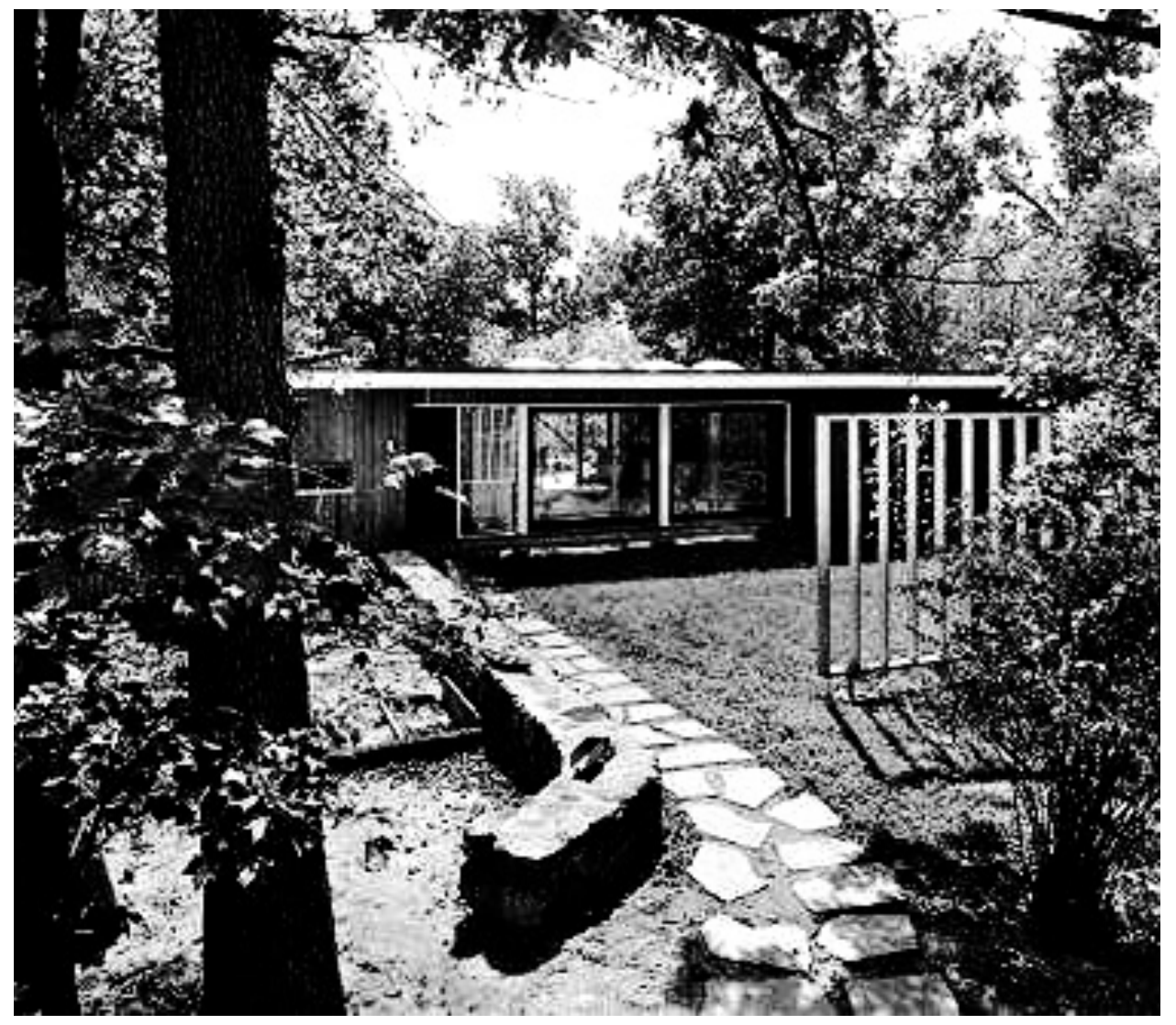

Fig.3.80 - Casa em Moon Hill.

\footnotetext{
${ }^{124}$ Outro dos objetivos do TAC era a habitação a preço razoável, apesar de não ter sido alcançado. A qualidade do desenho e da execução tiveram um custo elevado: US\$15.059,00 seriam um preço excessivo para uma casa de 2 dormitórios de 960 sq.ft., sem porão.
} 
Era constituído de casas de tamanho médio, com fechamento em madeira, áreas envidraçadas e telhados planos com balanços, localizadas em um site arborizado e montanhoso. Six Moon Hill foi planejada para constituir uma comunidade. Em 1948, alguns dos arquitetos do TAC compraram 20 acres de terra, desenharam e construíram as casas onde se estabeleceram. Além delas - vinte e quatro -, havia um cul-de-sac, uma piscina e um pequeno campo comuns. Vários arquitetos em Massachusetts criaram comunidades similares.

\subsubsection{Novas técnicas e materiais}

Alguns aspectos do desenvolvimento da técnica, ligada à construção do edifício, no pós-guerra americano devem ser ressaltados. Como dissemos, muitas técnicas e materiais foram "reciclados" da guerra.

No entanto, desde os anos 1930, por todo o país, a pesquisa sobre habitação já tornara-se sistemática, com vários grupos organizados, como o Architectural Group for Industry and Commerce (AGIC) e algumas iniciativas governamentais. Presidente Herbert Hoover criou, ainda, o Departamento de Comércio, que implementava a estandardização de materiais de construção e laboratórios que desenvolviam produtos, como painéis de madeira compensada.

Durante o conflito, o esforço de guerra foi coordenado em nível nacional e teria um efeito extraordinário na economia e, por extensão, na arquitetura. Todo tipo de produção, do armamento aos materiais de construção, foi alterado. Para isso, grandes corporações receberam encomendas do governo.

A pesquisa científica recebeu verbas de bilhões de dólares, que foram utilizados, por exemplo, na construção de laboratórios sofisticados. (WRIGHT, 2008, p.142) Novos produtos sintéticos substituíram materiais críticos como alumínio, aço e borracha. As companhias químicas desenvolveram produtos como isopor, novos tipos de acrílico e resinas. ${ }^{125}$

A marinha empregou mais de mil arquitetos, que criaram sistemas mais flexíveis, improvisando com os materiais e técnicas disponíveis. A facilidade de montagem e a

\footnotetext{
${ }^{125}$ O plástico pode ser considerado emblemático do otimismo do pós-guerra americano. Seu uso foi intenso em uma variedade de produtos; grande parte deles para consumo doméstico, muitas vezes substituindo materiais tradicionais. Ele refletia o interesse do público pelo progresso tecnológico.
} 
adaptabilidade eram características necessárias. Cada material era reavaliado e usado de novas maneiras. ${ }^{126}$

Havia a necessidade de se criarem habitações para milhões de pessoas que se mudavam para novas áreas, próximas às fábricas ligadas ao esforço de guerra. As próprias Levittowns germinaram nesse contexto: William Levitt desenvolveu casas para oficiais da marinha durante a guerra, com novas técnicas construtivas, utilizando a pré-fabricação e a estandardização, que serviram como protótipo para as casas dos subúrbios do pós guerra.

As universidades também participaram, entre elas o MIT. No pós-guerra, o instituto passou por importantes transformações, devido a seu envolvimento em pesquisas militares durante o conflito, quando a direção iniciou um processo que consolidaria seu papel na educação cientifica e tecnológica.

Ao contrário de seus colegas engenheiros, os arquitetos do MIT não haviam desempenhado um papel crucial no esforço de guerra, o que dificultava seu envolvimento no complexo militar-industrial do pós-guerra. No entanto, os líderes do departamento - William W. Wurster, Lawrence B. Anderson e Pietro Belluschi fizeram um esforço importante para integrá-lo nos planos do instituto.

Introduziu-se a pesquisa sobre habitação no departamento, ${ }^{127}$ com foco na préfabricação de residências. Isto envolveu a utilização dos laboratórios da universidade e a criação de cursos sobre materiais e disciplinas específicas, como hidráulica, acústica, iluminação, aquecimento e ventilação.

A iniciativa mais marcante do MIT, na pesquisa de inovações técnicas junto à indústria, foi o Industrialized House Course, iniciado em 1949. A pesquisa era interdisciplinar, envolvendo múltiplos campos - planejamento, engenharia, sociologia e direito. O trabalho envolvia o planejamento do site, estratégias de marketing, publicidade, casas - modelo e um detalhado plano de financiamento, além das questões técnicas e de desenho.

\footnotetext{
${ }^{126}$ Charles e Ray Eames, junto com John Entenza, desenvolveram uma tala de madeira compensada para a marinha americana, e até peças para aviões, feitas do mesmo material. A tecnologia seria utilizada no pós-guerra, para a produção de armários e moveis. Além dos Eameses, Quincy Jones, Landis Gores, John Hancock Callender, entre outros, também participaram, desenvolvendo técnicas e materiais ou projetando instalações e habitações.

${ }^{127}$ Já em 1940, Alvar Aalto fora nomeado professor de pesquisa e deveria trabalhar com estudantes sobre estandardização flexível em um assentamento urbano experimental na Finlândia. Ele teve pouca chance de implementar o projeto, pois foi chamado de volta a seu país devido à guerra, mas retornaria ao final dela, para lecionar no M.I.T., entre 1945 e 1948, e construir o alojamento Baker House.
} 
A habitação era reconhecida, na época, como um tema de importância nacional e havia uma demanda por experts que associassem o conhecimento científico e a experiência prática. Pois, a crise habitacional mostrava-se mais severa devido aos veteranos que retornavam e aos trabalhadores da defesa que tinham sido deslocados. Era um campo que requeria inovação técnica e conexão com o governo e a indústria. (SACHS, 2013, p.228) Procurava-se a eficiência na produção a custos baixos.

A pesquisa também teve um papel no direcionamento das políticas governamentais. Nos anos do pós-guerra, a produção de habitação colocava-se entre as esferas pública e privada. Concebida como um projeto nacional, muitos fabricantes esperavam que o governo federal os apoiasse nas fases iniciais do desenvolvimento do produto, assumindo os riscos envolvidos.

No entanto, o clima político do pós-guerra favorecia investimentos privados e não do governo - ou qualquer ação que pudesse ser classificada como "socialismo." 128 Investindo em pesquisa, o governo parecia estar apoiando a esfera pública e, ao mesmo tempo, dando suporte à indústria da pré-fabricação, sem investir em uma companhia em particular.

A pré-fabricação da casa, no pós-guerra, capturava a imaginação do púbico americano, simbolizando o poder da tecnologia e da livre iniciativa para desenvolver a economia e também resolver questões sociais. A propriedade da casa surgia como um princípio central na emergente sociedade de consumo. (SACHS, 2013, p.233-4)

No mercado, já havia muitas inovações em uso. Pueblo Gardens apresentava casas com estrutura em madeira, construída sobre uma laje de concreto, solução comum à época. As placas de gesso das paredes eram isoladas com folhas de alumínio. Os telhados, com grandes beirais, também utilizavam um isolamento, em lã. Havia aquecedores e equipamentos para refrigeração. No canteiro de obras, as paredes e outros elementos eram pré-fabricados, o que possibilitava a produção de uma média de 7 casas por dia, no pico da construção. ${ }^{129}$

\footnotetext{
${ }^{128}$ KELLY, Burnham The Prefabrication of Houses: A Study by the Albert Farwell Bemis Foundation of the Prefabrication Industry in the United States. Cambridge, MA, The Technology Press of the Massachusetts Institute of Technology and Wiley, New York, 1951, p.96 apud SACHS, 2013, p.231.

${ }^{129}$ A indústria da construção, atrofiada durante a depressão e a guerra, apresentava escassez de trabalhadores experientes no pós-guerra. Mas, mostrou-se também uma oportunidade para se "reinventar toda a indústria da construção." (HINE, 1989, p.168)
} 
Mock (1946) menciona as técnicas modernas de produção em massa, ressaltando, no entanto, suas limitações. A pré-fabricação era apontada como uma maneira de se baixarem os custos, mas a qualidade dos materiais era preocupante.

Grande parte dos caixilhos ainda era feito artesanalmente. Pois, as portas de correr, presentes em grande parte das casas, ainda não tinham boa qualidade. "Se boas janelas e portas de correr estarão disponíveis, em breve, em madeira ou em metal, os fabricantes estão mantendo esse esplêndido segredo para si mesmos." (MOCK, 1946, p.30)

A técnica do aquecimento do piso já era comum. Embutiam-se canos em uma laje de concreto, onde circulava água quente, ou insuflava-se ar quente através de blocos cerâmicos perfurados. Em ambos os casos, um porão torna-se supérfluo.

A utilização da estrutura metálica, antes da guerra, ainda era proibitiva, pois o metal era muito caro para ser utilizado em residências. Em 1949, teria grande repercussão a primeira Case Study House em estrutura metálica, a Eames House. ${ }^{130}$

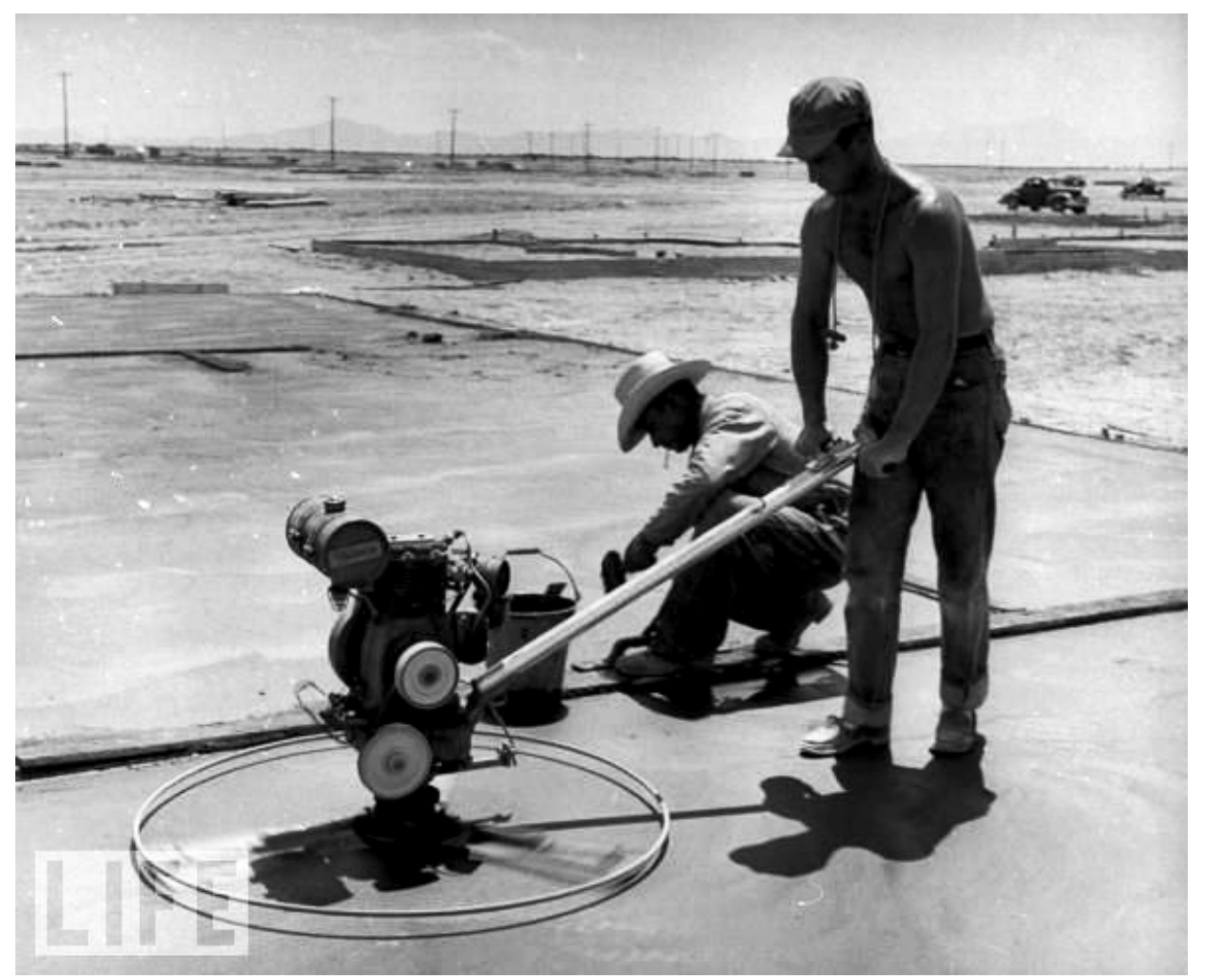

Fig.3.81 - Execução de laje em Pueblo Gardens.

\footnotetext{
${ }^{130}$ Era a casa n.8. A ideia de estandardização também estava presente; os componentes da estrutura foram selecionados a partir de um catálogo de fabricantes de aço e depois montados.
} 

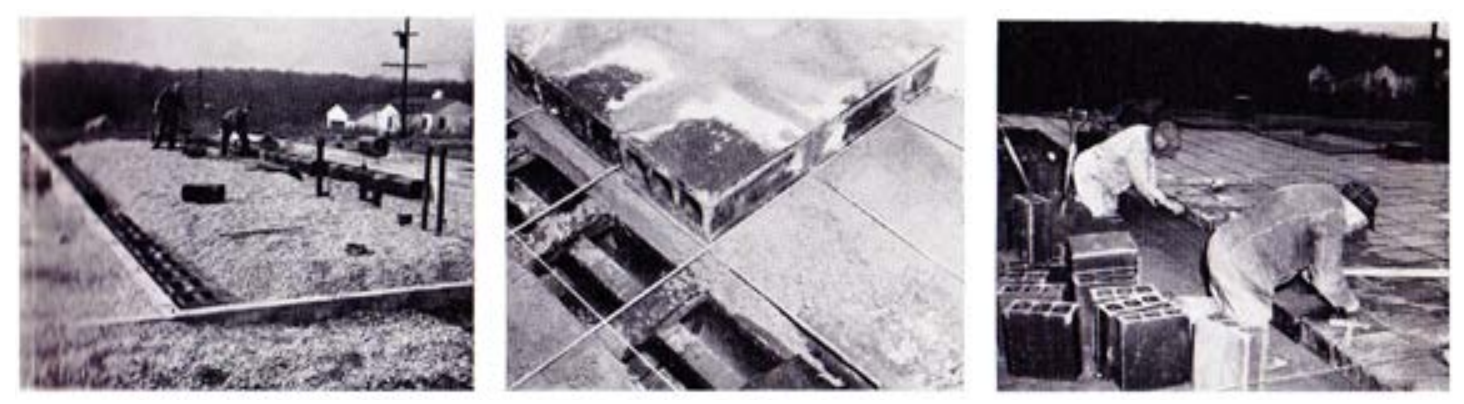

Fig.3.82 - Execução de laje de piso aquecida.

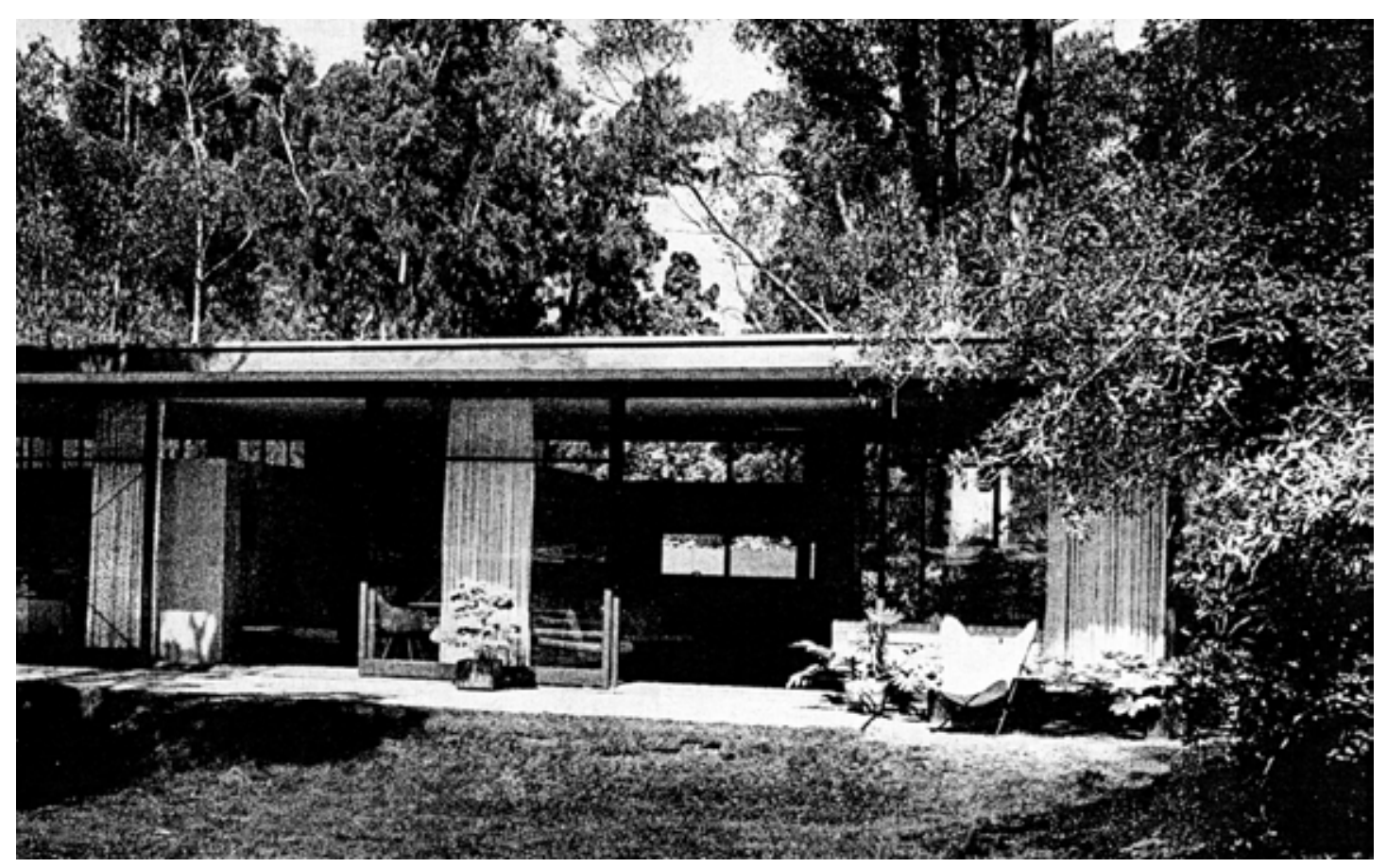

Fig.3.83 - Home show house, do arquiteto Lloyd Ruocco.

Mas, havia experiências com estrutura metálica em aço, que eram mostradas ao público através das home show houses. Uma delas, do arquiteto Lloyd Ruocco, em San Diego, na Califórnia, foi visitada por 60.000 pessoas. ${ }^{131}$ Esse tipo de construção permitia grandes superfícies envidraçadas e divisões internas móveis.

O programa Case Study Houses acabou mostrando-se a grande vitrine para as técnicas modernas. Apesar da maior parte das casas ainda apresentar a tradicional estrutura em madeira, procurava-se utilizar elementos estandardizados, pois eram concebidas como protótipos para a produção em larga escala. As casas projetadas por Raphael Soriano, Craig Ellwood e Pierre Koenig utilizaram a estrutura metálica,

${ }^{131}$ HOME..., 1954. 
que acabou predominando nos anos 1950. O programa acabou enfatizando a experimentação tecnológica em materiais e sistemas construtivos, com clientes abastados que podiam patrocinar esses avanços tecnológicos. 
292 


\section{Capítulo 4 \\ O papel do arquiteto}

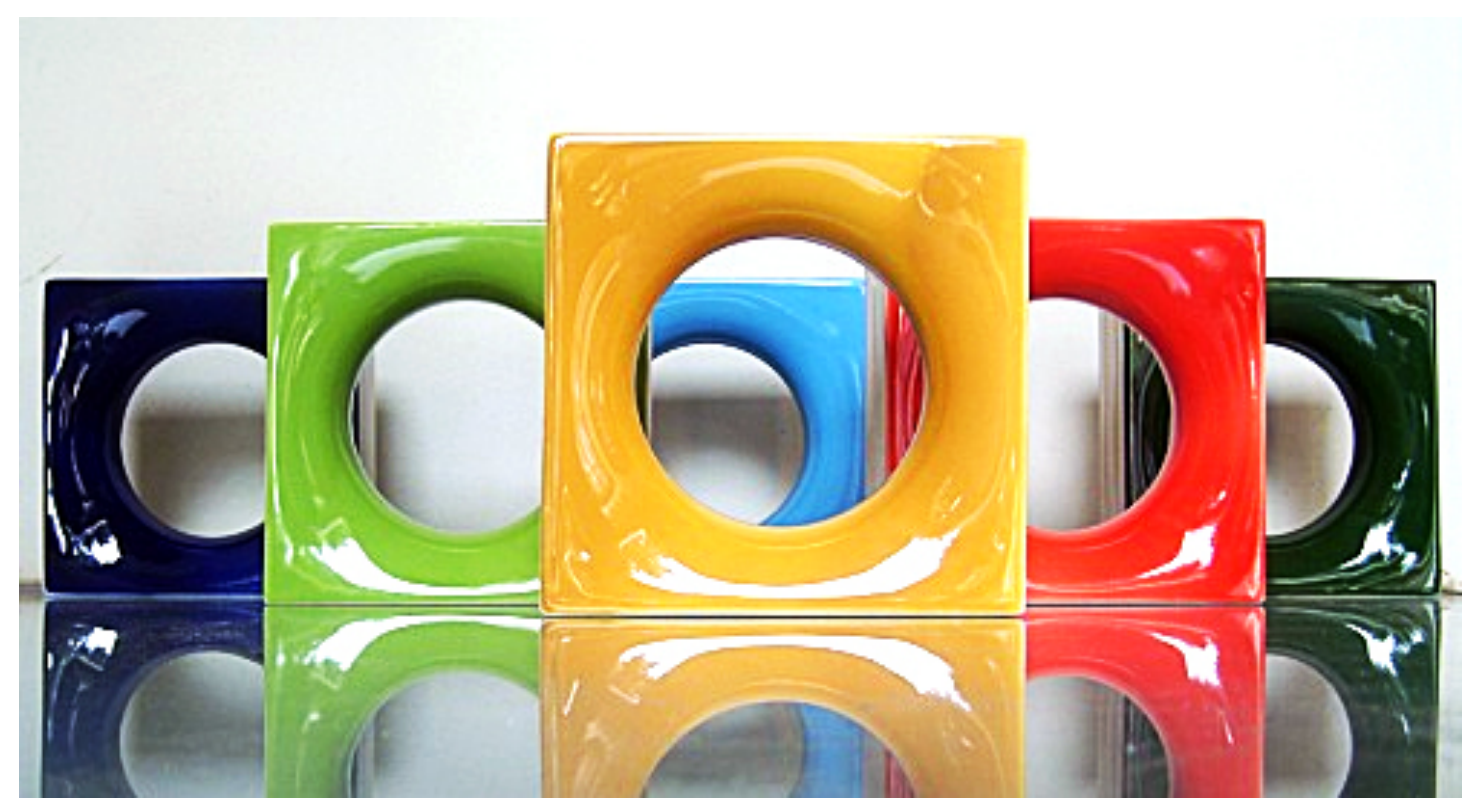

Fig.4.1 - Cobogós

Como dissemos no capítulo 2, o exercício profissional, no ambiente paulistano entre os anos 1920 e 1940, ainda não incorporara a linguagem moderna. A arquitetura remetia a várias linguagens que o profissional deveria dominar, para atender às exigências dos clientes. Inúmeros álbuns de modelos e revistas auxiliavam as futuras moradoras a escolher a casa ideal para a família.

Uma atitude perfeitamente compatível com a época. Projetava-se utilizando-se da linguagem mais adequada à determinada situação, empregando-se o repertório disponível.

Esse panorama modificou-se, como vimos. Assim, outra questão interessante a ser examinada são as mudanças ocorridas na prática profissional, no período analisado, no Brasil e nos Estados Unidos. Este é o tema deste capítulo. 


\subsection{A modernização da arquitetura em São Paulo e a dedicação exclusiva ao projeto}

O exercício da arquitetura nos anos 1920 e 1930, com a utilização de vários estilos, até por um mesmo arquiteto, não era visto como algo negativo. Uma mesma reportagem, nas revistas e outras fontes da época, mostrava obras com "roupagens" diversas. ${ }^{1}$

A utilização da linguagem moderna, em São Paulo, como vimos, apresentou diferenças em relação ao Rio de Janeiro. Bratke (1988, p.158) lembra que, ainda no final dos anos 1930, a arquitetura paulistana não apresentava os padrões estabelecidos na Europa, com o moderno, mas "de boa solução e aspecto. Melhor que os primeiros arremedos importados." ${ }^{2} \mathrm{Em}$ nome dessas "extravagâncias inabitáveis, sem lógica, moradias acompanhadas de 'manual de intrusões de uso'” a que ele chama movimento modernista -, acabou-se por relegar arquitetos com obras menos chamativas, mas honestas, como Victor Dubugras, Antônio Moya, Ademar de Moraes, Bernard Rudofsky e outros. ${ }^{3}$

Assim, pode-se falar em modernização em São Paulo, nessa época, com transformações pequenas e lentas, em relação às técnicas construtivas e materiais.

Como lembra Bratke (1988, p.159): "Assim, com muita cautela íamos avançando, com pequenas modificações: era um pé-direito pouco menor, o telhado com menor ponto, um beiral mais estruturado, uma janela maior."

Outra questão importante em relação à prática profissional é que o arquiteto também construía, ainda nos anos 1920 e $1930 .{ }^{4} \mathrm{E}$, a posterior adoção da atividade exclusiva de projeto traria grandes transformações.

\footnotetext{
${ }^{1}$ Olavo Caiuby, um arquiteto da época, apresenta na Revista de Engenharia do Mackenzie, jun. 1930, p.52-3, duas casas, uma em estilo Neocolonial e outra, destinada a um diretor de banco, clássica. E, ainda, projetos "híbridos," com características do Neocolonial e do Missões. Alfredo Ernesto Becker, outro arquiteto da época, também se utilizava do Neocolonial, Missões e de outros estilos. Cf. JANJULIO, 2009. capítulo 5.

${ }^{2}$ Assunto tratado no capítulo 2.

${ }^{3}$ Em nossa dissertação de mestrado, pudemos observar várias dessas questões colocadas por Bratke. Adhemar de Moraes, por exemplo, fazia pequenos cottages, bangalôs e sobrados maiores, para a classe média, no Jardim América e imediações.

${ }^{4}$ Os memoriais descritivos, encontrados no arquivo da Companhia City, em nossa pesquisa de mestrado, funcionavam como espécie de contrato com o cliente - carimbados por um tabelião - para a construção da casa. Neles, eram apresentados os materiais a serem utilizados, com os preços aproximados, demonstrando que o arquiteto também era o responsável pela construção do edifício. Esses memoriais serviam, também, juntamente com a planta, para que se determinasse o valor do
} 
O projeto, até os anos 1930, constituía apenas uma etapa da atividade conhecida como arquitetura e seu valor comercial praticamente inexistia. Fazia parte, ainda, do exercício da profissão, a construção do edifício. A autoria do projeto de arquitetura era um aspecto secundário, mesmo um projetista contratado pela firma de arquitetura poderia executá-lo.

Assim, mesmo "diplomado, o portador do título de arquiteto continuava identificado com um desenhista de fachadas e plantas (...) sem a deferência social outorgada aos engenheiros por seu alegado domínio da técnica." (FICHER, 2005, p. 243-4). Valorizava-se o saber técnico, mas a arquitetura poderia ter várias formas, seguir vários estilos.

Em consequência, havia a percepção de que o reconhecimento do trabalho do arquiteto passava pela valorização do projeto. O arquiteto Christiano Stockler das Neves, então diretor do curso de engenheiro-arquiteto da Escola de Engenharia do Mackenzie, era um dos que preconizava, ainda nos anos 1920, o projeto arquitetônico como atividade única para os arquitetos. Ele havia estudado nos Estados Unidos, onde já acontecera a separação entre as atividades de construção e de projeto. ${ }^{5}$

Mas, o pioneiro na adoção da atividade projetual única seria o arquiteto RIno Levi. Desde 1928, ele possuía uma empresa ligada à construção e, a partir de meados da década de 1930, passou a se dedicar exclusivamente a projetos completos de execução e fiscalização, tornando-se um profissional liberal, uma atitude temerária para a época, servindo de modelo aos jovens arquitetos. Foi Levi quem encorajou Bratke e outro arquiteto, Eduardo Kneese de Mello, a se dedicarem exclusivamente

financiamento a ser concedido pela City ao proprietário do terreno para a construção. Esse proprietário, muitas vezes, era o próprio arquiteto, pois, provavelmente, em alguns casos, ele iniciava a construção, depois comercializava o imóvel e transferia o financiamento ao novo proprietário.

${ }^{5}$ Já em 1925, uma publicação americana dizia que o American Institute of Architects definira a prática profissional do arquiteto e os valores a serem cobrados. As tarefas incluíam as reuniões necessárias com o cliente, o preparo dos estudos preliminares, o projeto executivo, especificações, detalhes e a administração geral e supervisão do trabalho. Por esse trabalho, ele deveria receber $6 \%$ do total da obra. Não se tratava de um sistema de empreita como no Brasil. WRIGHT, Richard (ed.) House and Garden's Second Book of Houses. New York: The Condé Nast Publications, Inc.1925, p.113. 
ao projeto. Provavelmente, os três primeiros arquitetos paulistanos ${ }^{6}$ a passar por essa experiência. ${ }^{7}$

Havia outros temas em discussão, em relação à atividade profissional. Entre eles, a questão da obrigatoriedade do diploma. Pois, havia profissionais não diplomados, que após cinco anos de exercício da profissão de engenheiro, arquiteto ou agrimensor, no território do Estado, poderia tornar-se um licenciado. ${ }^{8}$

Também debatia-se a diferenciação legal entre as atribuições dos arquitetos e dos engenheiros civis, sendo Levi, também, um dos primeiros a se ocupar dessa questão, defendendo a especificidade da atividade, diversa daquela do engenheiro ou do construtor. ${ }^{9}$

Neves (1929, p.15), igualmente, era contrário às mesmas competências para arquitetos e engenheiros. E avesso ao título de "engenheiro-arquiteto:" "Nós, arquitetos, que já não toleramos que o engenheiro civil faça arquitetura, apesar de conhecer um dos seus ramos - a construção (...)."

Desde o século XIX, os arquitetos tentaram sua profissionalização, ampliando sua autonomia, definindo e controlando um mercado protegido para serviços arquitetônicos, diferenciado dos serviços de construtores e engenheiros. Isso implicava na criação de "competências padronizadas entre seus praticantes para distinguir seus serviços de outras alternativas. A sanção do Estado, o ensino formal e o credenciamento profissional podem satisfazer tais exigências." (STEVENS, 2003, p.31) Pois, dizer que alguém é um arquiteto vai além do fato de possuir um diploma para projetar edifícios; significa que possui um conjunto de atitudes e gostos, formas de capital cultural que o distinguem de um mero construtor. (Ibid., p.97)

A formação das associações profissionais de arquitetos, na primeira metade do

\footnotetext{
${ }^{6} \mathrm{O}$ arquiteto Álvaro Carlos de Arruda Botelho, pesquisado por nós, provavelmente já estava apenas projetando em 1936, pois consta que a Sociedade Construtora e de Imóveis, uma firma construtora da época, havia executado ao menos uma habitação projetada por ele.

${ }^{7}$ Influiu também na decisão de Bratke, a morte de seu sócio, Carlos Botti, em acidente aéreo, em 1942, o que o deixou sobrecarregado de trabalho. Bratke fez uma parceria com o colega Guilherme Corazza, que construía, passando as obras para ele.

${ }^{8}$ Lei Estadual n. 2.022, de 27 de dezembro de 1924, conhecida como Lei Alexandre Albuquerque. (FICHER, 2005, p.179-80)

${ }^{9}$ Aliás, tais discussões não aconteciam apenas a nível nacional. No IV Congresso Pan-Americano de Arquitetos, que se realizara no Rio de Janeiro em junho de 1930, havia teses a respeito da regulamentação profissional, recomendando que os poderes públicos dos diversos países sancionassem tais leis. (IV CONGRESSO..., 1930, p.6)
} 
século XIX, faz parte desse contexto. Assim, como a substituição da pupilagem nas corporações de ofício pelo ensino formal. São tentativas de se construir um monopólio de mercado.

Pois, por quase toda sua história, o campo da arquitetura se reproduziu através da transmissão de capital simbólico por meio de cadeias de mestres e pupilo e de redes de contatos pessoais. No começo do século XIX, o Estado francês criou um novo método de reprodução com a formação de uma escola, a École des Beaux-Arts.

Ao adotar o sistema Beaux Arts, justifica-se a profissão "pela natureza do como fazia o que fazia." (STEVENS, 2003, p.32) Esse método de projeto poderia ser ensinado de maneira formal nas escolas, indicando porque projetos totalmente diversos seguiam os mesmos princípios. Assim, uma base teórica foi criada, envolvendo questões diversas, que não mais seriam solucionadas por outras profissões.

O sistema Beaux Arts seria depois abandonado, aos poucos, em nome da modernização do ensino e de uma formação profissional mais próxima à realidade. Mas, a questão da teoria, que diferencia a disciplina arquitetônica, ainda está presente.

Nesse sentido, outra questão debatida no ambiente paulistano dos anos 1930 era o ensino autônomo de arquitetura. As primeiras escolas independentes do curso de engenharia surgiram apenas na década de $1940 .{ }^{10} \mathrm{Em}$ São Paulo, a Faculdade de Arquitetura do Mackenzie e a Faculdade de Arquitetura e Urbanismo da Universidade de São Paulo, a FAU/USP. ${ }^{11}$

A regulamentação profissional acabou acontecendo em dezembro de 1933, com o Decreto Federal n.23.569, que definiu a proteção ao título acadêmico, tornando o exercício da profissão restrito aos diplomados, mas deixando indefinida a diferenciação entre as atribuições de engenheiros civis e arquitetos.

A partir da regulamentação profissional, os arquitetos procuraram se afastar da imagem dos engenheiros civis, seus colegas no negócio da construção. A médio prazo, haveria a divisão entre as tarefas profissionais do projeto e da execução.

\footnotetext{
${ }^{10} \mathrm{O}$ ensino a que tinham acesso os arquitetos de São Paulo, nas primeiras décadas do século XX, constituía-se dos cursos de engenheiro-arquiteto da Escola Politécnica, que funcionou de 1894 a 1954, e do Mackenzie College, oferecido entre 1917 e 1946, e, ainda, do curso de arquiteto da escola de Belas Artes de São Paulo, que existiu entre 1928 e 1934. (FICHER, 2005, p. 17)

${ }^{11}$ Fundadas, respectivamente, em 7 de Julho de 1947 e 21 de Junho de 1948.
} 
É inegável que isso confere certo prestígio ao arquiteto que, além de tornar-se um profissional liberal, exerce uma atividade exclusiva de diplomados - a regulamentação da profissão não recaía sobre a atividade de construtor.

\subsubsection{O trabalho no escritório}

Abandonando o envolvimento diário na construção, os escritórios de arquitetura passaram a se ocupar apenas do desenho, e as construtoras e seus engenheiros, das obras, com suas questões técnicas e financeiras. Com algumas exceções, pouco a pouco, foi o que aconteceu.

Entre outras questões, isto implicava em diminuir o lucro proveniente da atividade construtiva e fazer com que o cliente remunerasse dois profissionais, um para 0 projeto, outro para a obra, lembrando que, anteriormente, o projeto estava embutido no custo da obra.

Assim, essa dedicação exclusiva ao projeto, inicialmente, só era possível a profissionais conhecidos, "com certo nome."

E envolve um cliente mais exigente, que está pagando pelo "papel" e demanda mais atenção do arquiteto. Bratke ${ }^{12}$ (1988, p.162-3) lembra que: "Para o arquiteto se profissionalizar, precisa ter em mente como conduzir um projeto, de maneira a sobrar tempo para encontros com clientes, visitas a obras, condução do ateliê e estudo dos projetos."

Foram necessários maior precisão e um detalhamento rigoroso do projeto, pois, até então, executavam-se as obras apenas com as plantas de prefeitura. Os detalhes eram resolvidos no canteiro, já que o arquiteto era o próprio construtor.

\footnotetext{
${ }^{12}$ Oswaldo Bratke foi um dos arquitetos mais ativos na profissão, entre 1930 e 1960. Respeitado pelos colegas como um profissional que conhecia a fundo as questões construtivas, ele, no entanto, esteve sempre afastado das discussões teóricas do meio acadêmico. Não esteve presente, por exemplo, no IV Congresso Brasileiro de Arquitetos.

Não era o modelo de profissional que se estabeleceu no imaginário da arquitetura. Negando a genialidade e a inspiração, projetava para atender os requisitos necessários de forma prática e econômica. Evitava a simples busca de soluções diferenciadas e impactantes, de difícil execução, que acabavam por elevar o custo do edifício. Para ele, em uma residência, eram importantes a sensação de segurança e bem estar para seus usuários. Na arquitetura carioca, em contrapartida, o sucesso de Oscar Niemeyer, com soluções plásticas de grande efeito, instaura nos arquitetos essa vontade de ser original, que muitas vezes sacrifica aspectos como o dimensionamento dos espaços e a qualidade da construção.
} 
No caso de Bratke, o projeto era bastante detalhado. Mas, apesar do rigor, havia um método de trabalho que possibilitava rapidez e grande capacidade de produção, permitindo que realizasse um grande número de residências. ${ }^{13}$

Após os estudos preliminares, fazia-se o anteprojeto e, então, passava-se ao projeto executivo. Alguns detalhes construtivos, adotados e testados, acabavam por ser padronizados e reutilizados. E, o projeto desenvolvido por um dos profissionais do escritório era conferido por outros, minimizando os erros. Os desenhos a lápis eram muito utilizados. A seguir, após as consultas referentes à estrutura, instalações, etc., o projeto era entregue.

Esse tempo gasto no detalhamento do projeto diminuía ainda mais a disponibilidade do arquiteto para acompanhar a obra. $O$ afastamento do canteiro de obras, com o abandono do sistema de empreitada, já o privara de um acúmulo de conhecimento, anteriormente possível, através da troca de experiências com a mão-de-obra.

Ainda que continue acompanhando a obra, é diferente da visita diária ao canteiro. Ou do envolvimento nas questões de custos, orçamentos, compras.

Além disso, a ausência no canteiro e um projeto minucioso apresentam o risco de que o último seja encarado como o objetivo final, e não como um meio para a transmissão das ideias e informações ao cliente e ao construtor. O arquiteto Ariosto Mila ressalta a importância desse tipo de percepção. O fato de se separarem obra e projeto pode tornar essa relação entre os dois um tanto confusa.

A técnica dispõe da linguagem figurada, que permite a perfeita descrição dos elementos construtivos. A concepção da obra é transportada do ideal para 0 material mediante apenas 0 conhecimento dessa linguagem. $O$ uso intensivo dessa grafia é tarefa do arquiteto, informando terceiros de tudo quanto imaginou, articulou e projetou ao conceber seu trabalho. Ocorre porém que a arquitetura não se detém nas limitações da dura linguagem, de uma épura geométrica, que, afinal, é o meio e não o fim. A obra de arquitetura se completa apurando os mínimos detalhes na escolha dos quais atuam as faculdades artísticas, examinando os materiais de acabamento (...). A realização da obra, exclusivamente através do projeto, corre o perigo de transformar o trabalho em simples

\footnotetext{
${ }^{13}$ Bratke projetou mais de 450 casas para a classe média e média alta, na região do Jardim América, nos bairros novos do Morumbi e imediações. (CAMARGO, 2000, p.85) Na revista Casa e Jardim, grande parte das residências mostradas localiza-se nesses bairros.
} 
produção mecânica, insuficiente para atender às funções próprias do abrigo do homem. (MILA, 1956, p.2-3)

Deveria haver um "diálogo" entre projeto e obra, com ajustes e interação entre os vários profissionais, permitindo mesmo um aperfeiçoamento do projeto. ${ }^{14}$

No contexto americano, a separação entre projeto e execução acontecera ao menos desde a década de 1920 e teria sacrificado a unidade orgânica entre ambos. Gropius (1954b, p.27) a encarava como uma divisão artificial. O AIA (American Institute of Architects) durante o congresso de 1949, em Houston, no Texas, teria acrescentado a seu regulamento, um novo paragrafo: "Um arquiteto não poderá ser envolvido, direta ou indiretamente no contrato da construção."

Gropius (1954b, p.27) lembra que, no passado, o arquiteto era o "Mestre dos Ofícios" ou o "Mestre Construtor," apresentando papel fundamental no processo de produção do edifício. Após perder essa posição, tornava-se difícil afirmar-se como profissional indispensável, da mesma forma que o construtor e o engenheiro, já que o projeto não apresentava valor de venda, anteriormente.

\subsubsection{O relacionamento com o cliente}

Esse novo tipo de atuação profissional exigia mais cuidado no relacionamento com o cliente. Bratke, que tornou-se um grande projetista de residências, era bastante atencioso no atendimento à família. Procurava compreender seu modo de vida, seus interesses e valores para a definição do projeto. Mas, com discrição.

Um relacionamento não muito formal, porém objetivo. Havia um questionário com questões sobre trabalho, lazer, relações sociais e atividades da família, sendo obtidas, assim, as informações necessárias para estabelecer-se o programa. Pedia

\footnotetext{
${ }^{14}$ Essa discussão, em que, com clareza, percebe-se a função do projeto de arquitetura como meio, na verdade é mais complexa. A disciplina arquitetônica sempre considerou a imagem dos edifícios de fundamental importância, sendo que algumas das mais importantes obras de arquitetura nunca foram construídas.

Um dos aspectos reveladores da importância do aspecto simbólico na arquitetura é o fato dos desenhos de edifícios serem pelo menos tão importantes quanto os objetos que representam. Um projeto não executado pode possuir a mesma força simbólica que um edifício real. Apenas para exemplificar, os arranha-céus de vidro, desenhados por Mies van de Rohe, por volta de 1920, nunca foram construídos.
} 
também à mulher que apontasse as revistas de que gostava, para a compreensão das expectativas familiares. ${ }^{15}$

Essa participação do cliente no processo de projeto era vista como natural, pois envolvia suas necessidades e desejos pessoais: o "arquiteto, por mais dedicado e capacitado seja ele, não pode 'sentir' cada residência com a intensidade e a particularidade com que o fará o proprietário." (CONSELHOS.., 1953, p.62)

Pois, uma das expectativas em relação ao profissional era que satisfizesse as necessidades físicas e espirituais, de forma subjetiva: "o lar ideal deve erguer-se 'sob medida' e nunca pré-fabricado em série." (HEDVIG, 1953, p.23) Assim, uma espécie de parceria deveria ser estabelecida.

Pois, como já dissemos no capítulo 2, uma casa deveria ser a expressão do sujeito que ali iria habitar, com suas aspirações, desejos, necessidades psicológicas, além das materiais. E, no caso de uma família, isso deveria ser feito em relação a cada membro.

Para Mila (1956, p.2): "cada casa é um caso." As soluções dificilmente seriam repetidas, pois eram respostas às questões do cliente e, assim, seriam variáveis como a personalidade humana. As condicionantes do projeto, como o terreno a ser utilizado, tornariam ainda mais particular o projeto.

$\mathrm{E}$, assim, as duas grandes tarefas do arquiteto, segundo Casa e Jardim, eram: a primeira, transpor as necessidades e expectativas subjetivas do cliente para a forma de um projeto "sob medida," objetivo, material.

E, a segunda, traduzir a linguagem moderna, abstrata, para o cliente, ou seja, trazer o moderno, idealizado, ao alcance do homem comum.

Essa tradução significa fazer com que o cliente compreenda o moderno. E, nesse processo, adapta-se, materializa-se essa linguagem moderna na vida cotidiana. Com simplicidade, em uma espécie de modernismo modesto, ambientes singelos, sem espaços supérfluos, e um olhar positivo à vida diária. Informalidade, flexibilidade, essencialidade, vida moderna. A linguagem da arquitetura com linhas puras, mas com contrastes de materiais naturais e cores vivas. A arquitetura do "bem viver."

\footnotetext{
${ }^{15}$ Richard Neutra chegava a observar e dialogar com seus clientes por dias ou semanas no intuito de compreender o verdadeiro tipo de casa que satisfaria seus desejos e hábitos.
} 
Com funcionalidade em relação a cada um de seus ocupantes. Nesse contexto, a "funcionalidade" também é subjetiva.

Com isso você terá uma casa funcional, adaptada às suas contingências de vida, e não uma construção arquitetônica abstrata, talvez muito bela, mas na prática imprestável. (...) $\mathrm{Na}$ arquitetura moderna, a tendência para a simplificação das linhas e a abertura de grandes vãos de iluminação pode resultar em criarIhe uma moradia de difícil utilização. O moderno é sem dúvida o único estilo viável na arquitetura contemporânea, mas cumpre a cada interessado fazer com que ele seja um 'moderno vivo' e não apenas teoricamente certo. (CONSELHOS..., 1953, p.62)

O trabalho do arquiteto seria, então, "a arte de organizar o espaço, de maneira econômica, eficiente e atraente (...) (com) habilidade para sentir todas as necessidades humanas, traduzindo essas necessidades em espaços organizados, que constituam um conjunto harmonioso. (...) (E) fazer uso criador do que há de novo e usos novos dos velhos materiais construtivos, procurando sempre tirar partido técnico e estético destes." (ABREU, 1956, p.3)

Apresentado dessa forma, o arquiteto poderia tornar-se uma figura mais próxima do leitor. Muitas vezes, o profissional mesmo expõe suas habilidades e a necessidade de seu trabalho. ${ }^{16} \mathrm{E}$ o contrapõe à dificuldade da construção da casa por um leigo: ${ }^{17}$

Vale a pena, então, conciliar os desejos particulares com a evolução de nossa era e os ensinamentos que a mesma nos deu. $O$ fato de querermos ser o nosso próprio arquiteto induz-nos, muitas vezes, a cometer graves erros, pois que nos falta a experiência para apontar este ou aquele inconveniente, não se

\footnotetext{
${ }^{16} \mathrm{O}$ arquiteto era figura recorrente na revista, como esperado. Famosos ou não, apresentam seus projetos ou são entrevistados sobre vários temas. Além dos projetos mencionados, de arquitetos conhecidos, existem estes. Lina Bo Bardi mostra sua residência no Morumbi. Entre o céu e a vegetação pousa a casa de dois artistas. Casa e Jardim, São Paulo, n.1, p.8-13, mar./abr. 1953.

Rino Levi também mostra sua residência. A residência do Arquiteto Rino Levi. Casa e Jardim, São Paulo, n.23, p.6-8 e 10-15, mar. 1956.

De Oscar Niemeyer, existe um projeto em Belo Horizonte. Uma residência em Minas de Niemeyer. Casa e Jardim, São Paulo, n. 7, p.26-9, mar./abr. 1954.

Afonso Eduardo Reidy apresenta a casa de Carmem Portinho. PROCHNIK, Rachel E. Eis um sonho realizado... Casa e Jardim, São Paulo, n. 9, p.22-25, jul./ago.1954.

E uma residência da autoria do arquiteto Henrique Mindlin: FRYDMAN, Liba. Quando a arquitetura moderna proporciona um verdadeiro lar. Casa e Jardim, São Paulo, n. 12, p.10-14, jan. /fev. 1955, com paisagismo de Roberto Coelho Cardoso.

Eduardo Kneese de Mello é citado em artigo sobre casas pré-fabricadas. Casas Encaixotadas. Casa e Jardim, São Paulo, n.8, p.24-5, maio/jun.1954, das quais estaria se ocupando.

${ }^{17}$ COMO CONSTRUIR..., 1953.
} 
chegando então a uma residência confortável e condizente com os conceitos atuais da 'arte de morar'." (QUE DIFERENÇA..., 1954, p.96)

Assim, a tarefa mais delicada do cliente seria a escolha do arquiteto. "Não pense que economizará recorrendo diretamente a um construtor e utilizando uma das plantas de seu estoque. Um bom arquiteto Ihe dará uma casa muito melhor, frequentemente por um custo muito menor, mesmo considerando seus honorários." (MOCK, 1946, p.6-7)

Pois, ainda, havia desconhecimento em relação à atuação profissional do arquiteto. Apesar de suas tentativas de se descolar da imagem dos engenheiros, a partir da regulamentação profissional.

Mesmo com a separação projeto-obra já sedimentada e, em várias residências, serem definidos o autor do projeto e o responsável pela construção - geralmente uma firma -, esse autor, muitas vezes, não é um arquiteto. Pode ser um decorador ou um engenheiro.

É o caso de Mieczyslaw Grabowski, engenheiro, apresentado como ${ }^{18}$ "doublé" de arquiteto. Ou, do trabalho de equipe entre a firma construtora - M.A.R.P.A.G. -, o casal de proprietários e Giuseppe Scapinelli, "um dos decoradores que projeta suas decorações antes da casa ser construída, e não depois." (MARGÔ, 1958, p.11)

Os decoradores aparecem com frequência em Casa e Jardim, mas seu trabalho é apresentado de forma confusa. Algumas vezes, diz-se que o arquiteto decora os interiores, como uma continuidade do projeto do edifício, outras vezes, a função do decorador é ressaltada. A série "Passeio pelas vitrinas dos decoradores," depois chamada "Decoradores contemporâneos," ${ }^{19}$ mostra a dimensão do consumo, associada a essa atividade.

A loja do decorador, um misto de comércio e exposição artesanal e artística, seria a "prova da existência de um surto de bom gosto e crescente interesse do nosso povo pelo ambiente em que deve viver." (EGÊ, 1956, p.23) ${ }^{20}$

\footnotetext{
${ }^{18}$ SIMÕES, 1957.

${ }^{19}$ MERAVIGLIA, 1955a.

${ }^{20}$ Essa reportagem apresenta a inauguração da loja do decorador Giuseppe Scapinelli, figura sempre presente na revista.
} 


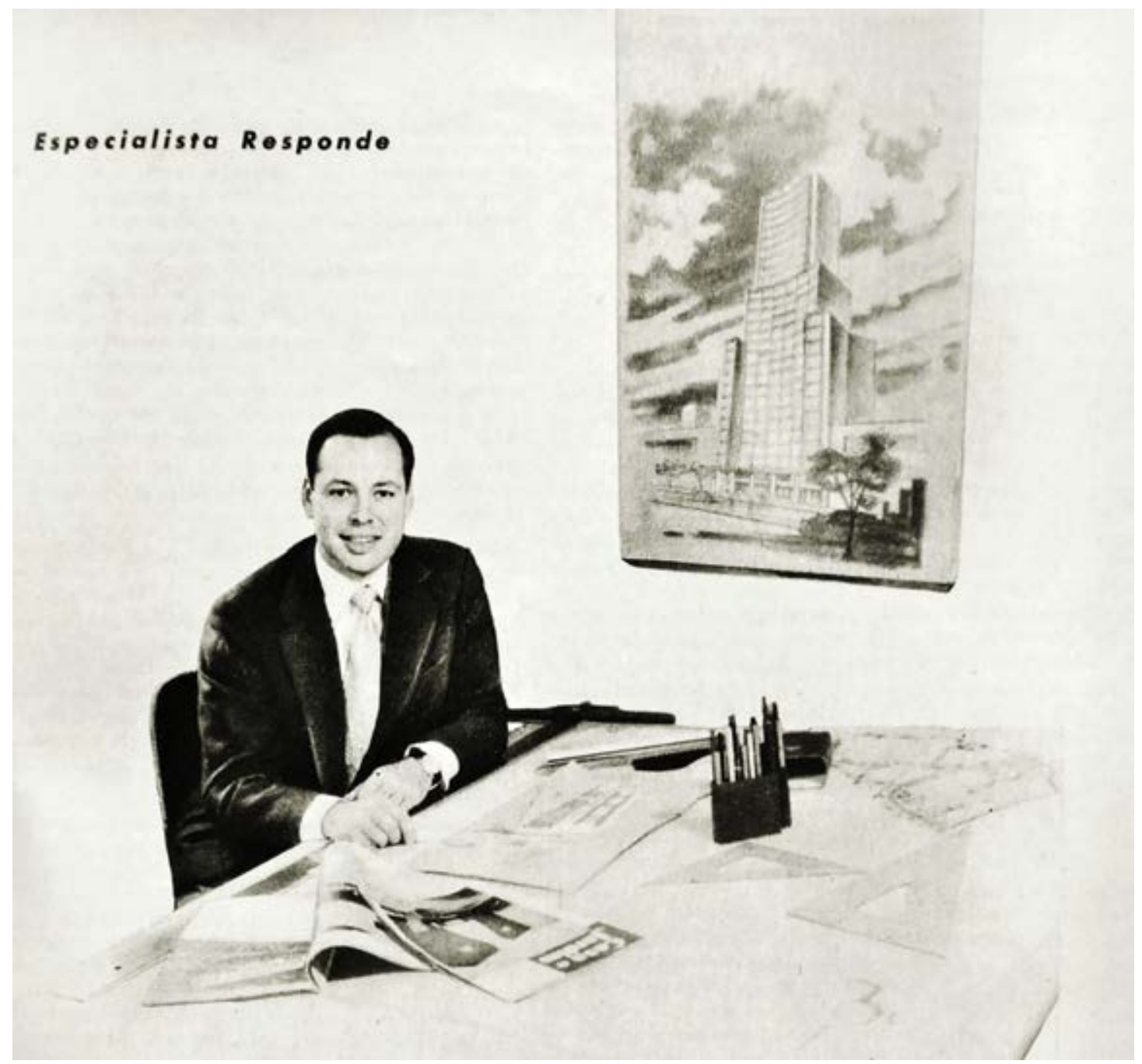

Fig.4.2 - Paulo Martyn Liberman, primeiro entrevistado de uma série de decoradores e "arquitetosdecoradores."

Outra questão sobre a prática profissional envolve o projeto paisagístico. Está implícita aí a ideia da valorização dos ambientes externos como espaço de estar e convivência, desenhados, equipados e utilizados junto com a casa: "A fim de conseguir-se a vivenda ideal, casa e jardim devem ser planejados simultaneamente, conjugando o arquiteto e paisagista, as ideias e conhecimentos técnicos, que a vida está a exigir." (MERAVIGLIA, 1955b, p.48) ${ }^{21}$

O paisagista, inicialmente chamado "jardinista," seria capaz de conseguir essa "intimidade entre as duas peças (...) (trabalhando) em estreita colaboração com o

\footnotetext{
${ }^{21}$ Segundo Callender (1952, p.117), haveria um alto grau de colaboração entre arquitetos e paisagistas, principalmente na região de São Francisco. Citando determinada casa, diz que a colaboração é visível, de forma extraordinária, sendo difícil perceber a linha que separa o trabalho do arquiteto do trabalho do paisagista.
} 
arquiteto, o qual, por sua vez, deverá também possuir bons conhecimentos florísticos." (O JARDIM...,1953, p.47) ${ }^{22}$

Assim, o paisagista teria a ciência e a técnica necessárias para obter a "máxima harmonia entre a casa e o jardim, principalmente pela criteriosa escolha das plantas, cujo aspecto deve concordar com o estilo da moradia. (...) Uma única árvore, por exemplo, cuja fisionomia, formas e crescimento, não estiverem em harmonia com o estilo da casa, pode destruir todo o efeito das linhas arquitetônicas da moradia, (...)." (Ibid., p.47)

São mostrados alguns profissionais, que dão conselhos sobre os vários aspectos a serem considerados, entre eles Roberto Coelho Cardozo, paisagista, professor da FAUUSP, que trabalhou com Garret Eckbo, importante paisagista da costa oeste americana, trazendo, assim, referências californianas. E, também, Osborn Coelho Cardozo. $^{23}$

Roberto Burle Marx, logicamente, é presença obrigatória: são mostrados seus jardins do Ministério da Educação, Aeroporto Santos Dumont e Praia de Botafogo, entre outros. ${ }^{24}$

A atuação do paisagista é descrita em detalhes, como um saber especializado:

Um arquiteto-paisagista não é somente o homem capaz de projetar um jardim, transformando-o em verdadeiro complemento de salubridade e beleza de nossa casa recém-construída; é ainda aquele que seleciona as flores, plantas e árvores apropriadas, colocando-as cada qual em seu lugar mais conveniente, tendo em vista seus conhecimento técnicos no que se refere à vegetação $e$ estrutura. (..) Antes de executar, estuda a melhor locação para o próprio jardim, a linha de água, as combinações de cores e pensa não só em sua aparência momentânea como no efeito futuro e nas despesas. Enfim, aplicando esteticamente o bom, ele consegue atingir o belo.. (...) Ele cuida para que amplos terraços, gramados e

\footnotetext{
22 O paisagista aparece, ainda, em anúncios variados de locais que vendiam plantas, mudas e equipamentos para jardinagem ou de firmas que faziam manutenção de jardins.

${ }^{23}$ Roberto apresenta série de artigos sobre questões ligadas à execução de jardins. Pisos no Jardim. CASA E JARDIM, São Paulo, n. 12, p.51-53, jan./fev.1955, sobre pisos externos para diversos usos. E, também, Biombos como Barreiras. CASA E JARDIM, São Paulo, n.13, p.46-49, mar./abr.1955, sobre a definição de áreas, na parte externa da residência. Osborn também escreve sobre pisos para áreas externas. Pisos: suas preferencias e necessidades. CASA E JARDIM, São Paulo, n. 16, p.50-53 e 73, ago.1955.

${ }^{24}$ PROCHNIK, 1955.
} 
árvores sombrosas sirvam às pessoas que gostem da vida ao ar livre. (MERAVIGLIA, 1955b, p.78)

Mas, apesar dessa especialização, da mesma forma como na arquitetura e decoração, o próprio leitor poderia planejar e cultivar seu jardim: "uma pessoa dotada de intuição estética e possuidora da legendária "mão feliz'" (O JARDIM..., 1953, p.47) poderia transformar um pequeno jardim numa verdadeira joia.

\subsubsection{O processo de projeto}

Como apontamos no capítulo 2, Casa e Jardim inicialmente preparava o leitor, criando-Ihe um repertório de conhecimentos técnicos básicos, transmitindo a linguagem moderna e fazendo-o cultivar seu gosto pessoal.

Pois, era necessário conhecer as alternativas possíveis, para discuti-las em detalhes com o profissional. Mas, antes, o leitor deveria compreender todas as suas necessidades, para deixá-las muito claras para o arquiteto, sendo, assim, possível a participação efetiva nas decisões. "O arquiteto dá-lhe as soluções estéticas, científicas, necessárias ou coerentes com um ponto de vista. Você deverá sempre procurar ver como elas se traduzirão na prática, no seu caso concreto." (CONSELHOS..., 1953, p.62)

Devemos considerar, ainda, que as expectativas iniciais poderiam se alterar no curso do processo de projeto, em consequência da interação com o arquiteto, devido à sua capacidade técnica e sua habilidade de convencimento. Mas, também, é preciso um cliente aberto a novidades, pronto a aceitar algo diverso do que pretendia, de início.

Da "educação" do leitor, fazia parte o conhecimento do processo de projeto. Isso poderia tornar a interação com o profissional mais efetiva. E a compreensão do papel do cliente.

Inicialmente, definia-se o que era "programa": "a série de requisitos a serem satisfeitos no projeto e que são propostos em termos de instalações e ambientes (...). Respeitando as condições do meio e adotando uma determinada técnica, compete ao arquiteto traçar um projeto que satisfaça àquele (o programa)." (PROCHNIK, 1954a, p.7) 
Para se definirem os principais requisitos, uma das questões centrais era o número e tipo de pessoas para quem se projetava, e suas necessidades. "No momento em que o proprietário apresenta ao arquiteto o programa de suas necessidades, está ele traduzindo espontaneamente da maneira mais objetiva o seu comportamento diante das situações, sejam elas as mais quotidianas ou não." (SOUZA, H., 1956, p.17-18) Segundo Mock (1946, p.5), o cliente não deveria pensar em sua casa como um abrigo impessoal de muitos e muitos cômodos colocados atrás de uma fachada, mas como o resultado e a expressão do modo de vida melhor concebido. "Já que a solução satisfatória dependerá, em grande parte, de sua percepção sobre suas próprias necessidades, você deveria fazer seu próprio programa. Um arquiteto é, apenas secundariamente, um psiquiatra."

Tratava-se de uma primeira objetivação dos desejos e necessidades do futuro morador. Uma etapa intermediária, entre os contatos iniciais com o arquiteto e os estudos preliminares.

Parte dessas informações poderia chegar ao profissional na forma de rascunhos feitos pelo cliente e, através deles, seria possível perceber seus desejos. Mas, apenas o arquiteto seria capaz de obter uma planta racional, a partir dos desenhos iniciais, com economia de espaço e diminuição dos custos, entre outros aspectos. Os desenhos do cliente e do arquiteto, colocados lado a lado na revista, ressaltam as diferenças. (DO RASCUNHO..., 1956, p.5)

Além das informações do proprietário, através da psicologia, o arquiteto poderia perceber o modo de viver de todas as pessoas da casa, o que "precede à arte. (...) só depois (o arquiteto) realizará a tarefa, de fato artística, que é a de adaptar o belo ao útil, a arte às necessidades funcionais!" (HEDVIG, 1953, p.24)

Pois, após a primeira etapa, “(...) cabe ao arquiteto tentar traduzir o programa, distribuindo e organizando necessidades dentro de áreas e volumes, dentro de uma operação que poderíamos chamar de amoldamento do espaço (interno-externo e material - psicológico)." (SOUZA, H., 1956, p.17-18)

Para Grabowsky, projetar, para muitos, era como um jogo de palavras cruzadas, em que as alas da casa cruzam-se como as fileiras de palavras. O principal ponto seria a resolução da planta baixa, somado às exigências prosaicas do proprietário. Porém: "Todos estes problemas se resolvem em duas dimensões. E isto diz respeito à arquitetura escrita com 'a' minúsculo. A arquitetura que merece um 'A' maiúsculo, entretanto, começa com a terceira dimensão. E a cultura, a sensibilidade do 
arquiteto que se revelam na solução desses problemas, na penetração dos diversos elementos no espaço, no 'rapport' entre superfícies opacas e transparentes, no jogo das cores." (CAMPOBELO, 1958a, p. 50) ${ }^{25}$
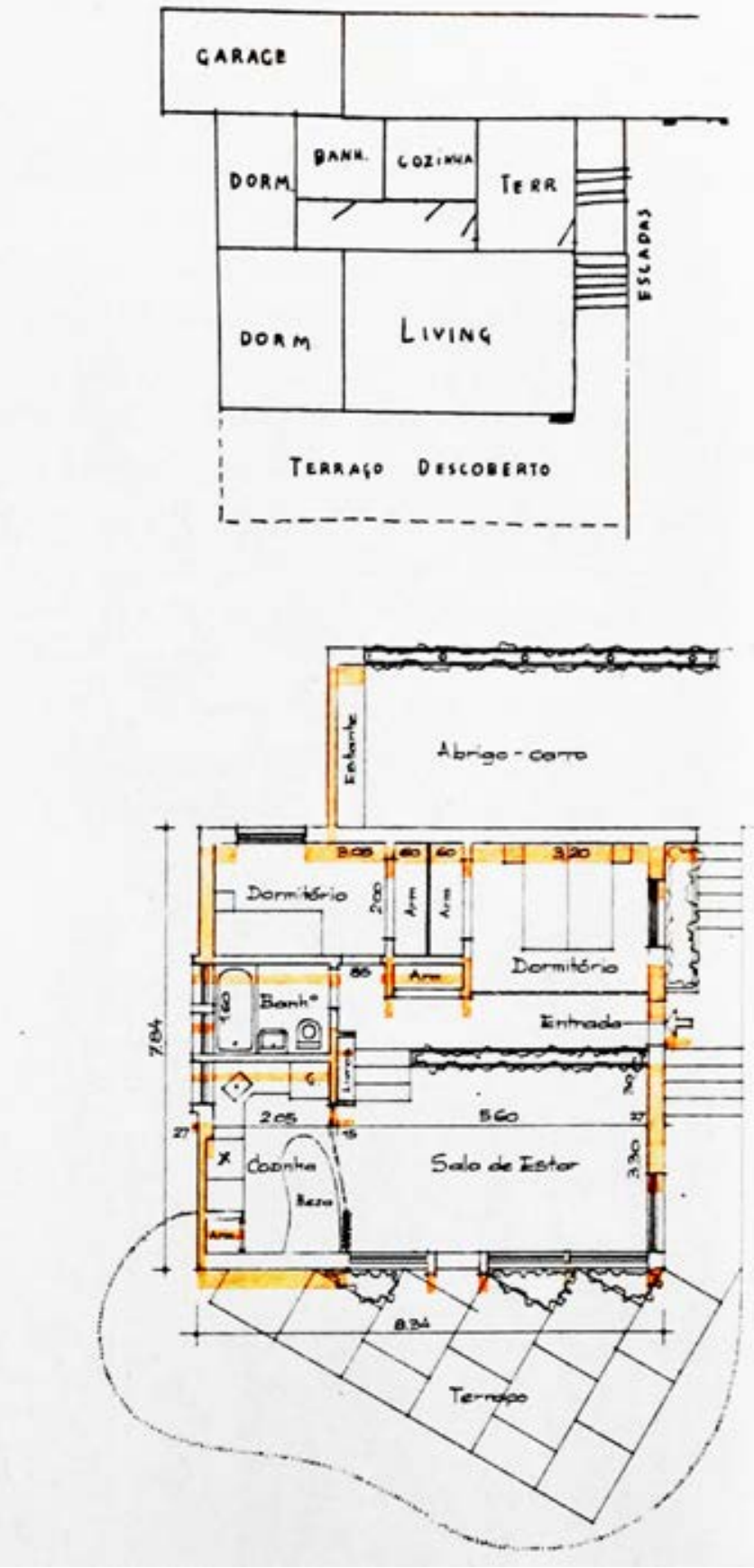

Fig.4.3 - Rascunho do cliente, projeto do arquiteto.

\footnotetext{
${ }^{25}$ Projeto do Escritório Técnico de Engenharia Mieczyslaw Grabowski, paisagismo de Osborn Coelho Cardoso. Grabowski é entrevistado. Proprietário José Marques da Costa.
} 


\subsubsection{Uma relação complexa}

A relação cliente-profissional nem sempre era fácil. Havia desconhecimento mútuo e certa desconfiança do cliente em relação ao trabalho do arquiteto. As inovações sugeridas por ele e o custo de seu trabalho eram algumas das questões problemáticas.

Era necessária empatia entre ambos: "o cliente procura um arquiteto porque tem identidade de pontos de vista. Um bom projeto é produto das aspirações de um cliente postas em prática através dos conhecimentos e personalidade do arquiteto." (BRATKE, 1988, p.162-3)

"Casas são organismos complexos e, para ser boa, deve ser a criação conjunta de um cliente alerta e instruído e de um arquiteto empático e competente." (MOCK, 1946, p.5)

$E$, o profissional deveria estar atento às críticas que o proprietário pudesse fazer e influenciar outros clientes em potencial. "Uma lição aprendemos nesse tempo: dez elogios de clientes satisfeitos se invalidavam com a queixa de um mal atendido..." (Ibid., p.159)

Há grandes exigências que desafiam os arquitetos. Os clientes interferem, os consultores técnicos, as autoridades, os custos. Nenhuma área do campo cultural restrito - escultura, pintura, música, etc. - está tão amarrada a outros campos sociais e é menos autônoma do que a arquitetura. (STEVENS, 2003, p.113)

Por isso, é importante considerar as relações da profissão com outros elementos da sociedade. Caso contrário, acaba-se por relegar outros atores sociais, importantes na arquitetura, para posições marginais.

Além de toda essa "interferência," o relacionamento cliente-arquiteto estende-se por muito tempo, envolvendo o desembolso de verbas crescentes, muitas vezes não previstas.

Essa não era uma questão exclusivamente nossa. Nos EUA, também havia desconfianças do cliente em relação ao arquiteto, supondo que ele aumentasse os custos da construção para elevar seus honorários, fazendo com que, ${ }^{26}$ segundo Gropius (1954b, p.27), 80\% dos edifícios americanos fossem construídos sem arquitetos. O cliente particular médio considerava esse profissional um elemento de luxo, que poderia ser chamado apenas se houvesse verba para "embelezamento."

\footnotetext{
${ }^{26}$ O salário médio do arquiteto seria menor que o de um pedreiro da costa leste dos EUA. (Ibid., p.27)
} 
$\mathrm{E}$, havia, também, preconceito do profissional em relação às escolhas e ao gosto pessoal do cliente. Algumas vezes, temia "o arquiteto pelo eventual mau gosto do futuro proprietário (o que realmente aconteceu), pois achou que não devia haver descontinuidade entre a construção e a decoração. ${ }^{27}$ Na elaboração do projeto, já havia sido prevista a decoração de todos os ambientes, tornando-a um prolongamento da construção, ficando ao decorador o encargo de executá-la sob a orientação do arquiteto. Aliás, é o verdadeiro papel do decorador na arquitetura." (ARQUITETURA..., 1958, p.20)

As intromissões do cliente também eram malvistas. "Para os arquitetos há três espécies de clientes: primeiro, os que não entendem nada de arquitetura e não se metem em nada durante a construção; segundo, os que nada entendem de arquitetura e se metem em tudo durante a construção; e terceiro, os que se consideram entendidos em arquitetura e se intrometem com furor na construção." (GRABOWSKI, 1957, p.28) $^{28}$

Essa visão do cliente, como alguém sempre propenso a intromissões, é manifestada por vários profissionais. Isso reflete, também, o fato de não se tratar de um público desinformado e pronto a aceitar, sem discussões, orientações do arquiteto ou palpites variados de leigos. Ou sem nenhuma noção do que espera de sua habitação.

Trata-se de uma clientela de classe média, como dissemos no capítulo 1, pois Casa e Jardim foi pioneira entre as revistas dedicadas à casa, por se dirigir de forma preferencial ao público leigo dessa camada da população. E a classe média consolidava-se como consumidora de cultura - antes reservada à elite -, com a formação da sociedade de massa no Brasil e a expansão dos meios de comunicação. Era um público com acesso a informações, inclusive de revistas importadas, sobre, por exemplo, a arquitetura doméstica moderna.

Assim, não devemos imaginar que o cliente simplesmente recebia os conselhos dos arquitetos, ou mesmo as informações das revistas, de forma passiva.

Esse cliente, um tanto "rebelde", que não aceitava tudo o que o arquiteto dizia, fazia pedidos variados durante a obra, que perturbavam o trabalho: "Quando nos quer parecer que tudo ficou a contento, evitando todos os erros possíveis, então entram em cena as exigências do respectivo proprietário, que às vezes são das mais

\footnotetext{
${ }^{27} \mathrm{O}$ arquiteto David Libeskind projetara e construíra uma casa que estava à venda.

${ }^{28}$ Grabowski é um dos arquitetos cuja casa é mostrada.
} 
esquisitas. Cada um de nós possui sua personalidade e, quando se trata da casa própria, ideias arraigadas das quais não largamos facilmente." (CAMPOBELO, 1958a, p.49-50)

Mas, o arquiteto via tudo isso como despreparo do cliente, de familiares e amigos: "Nem sempre a sensibilidade do cidadão faculta a melhor solução para os complexos problemas da Arquitetura, principalmente no setor plástico e disto decorre grande parte da responsabilidade pela má arquitetura." (MILA, 1955, p.4) Assim, segunda feira seria o dia das alterações de projetos, pelas visitas feitas à obra no final de semana. Porém, Mila (1955, p.62) diz que é possível modificar, o problema é conservar a unidade do edifício, com o "remendo."29

As modificações eram constantes. As opiniões dos arquitetos a esse respeito divergiam: iam desde a aceitação das sugestões do cliente até a irredutibilidade e as críticas a respeito de "palpites" dados por leigos.

Becker (1955, p.5) - mais conciliador, talvez resultado de sua longa experiência profissional - afirma que uma modificação aparentemente descabida poderia resultar em solução interessante. Afinal, o arquiteto não construía para si próprio. "A obra arquitetônica nada é, senão um organismo que se deve adaptar à vida do cliente." Para não efetuar alterações, o arquiteto deveria convencer o cliente com argumentos reais, usando sua habilidade, devendo sempre haver bom senso e compreensão de ambos os lados.

Uma das justificativas para não haver mudanças era a suposta consonância entre arquiteto e proprietário, durante a elaboração do projeto.

Era a conduta defendida por Levi (1955, p.4), reafirmando a importância da participação do cliente na elaboração do projeto e em todos os detalhes da residência. Conhecendo todos os elementos antecipadamente, ele não arriscaria fazer modificações na construção, pois essas poderiam "prejudicar a unidade do projeto."

Alexander (1955, p.5 e 62) concordava. A cooperação entre arquiteto e cliente levaria a um projeto consonante com os desejos do segundo e as ideias arquitetônicas do primeiro. Não deveria haver alterações, mas ele não descartava "pequenas particularidades que ocorrem a todo 'proprietário'." Ele lembrava, ainda, a

\footnotetext{
${ }^{29}$ Além do depoimento de Ariosto Mila, existem os de Rino Levi, Alfredo Ernesto Becker e Henrique Alexander sobre o tema.
} 
necessidade de se conhecer a fundo os hábitos e interesses dos clientes, talvez passando certo tempo na casa onde viviam.

Bratke, sempre conciliador, achava que, se o projeto fosse bem conduzido, haveria poucas modificações. Seria possível atender às necessidades do cliente, mas também defender os pontos de vista do arquiteto, sem confrontos.

Um aspecto importante em relação à essa questão era a mudança nas expectativas iniciais ou um aumento na "lista de desejos" do proprietário, em consequência de informações novas que ele adquirisse ao longo da obra ou de sugestões de pessoas diversas. Porém, "a última palavra há de ser sempre reservada ao profissional (...)." (MILA, 1955, p.62)

Gropius (1954a, p.178) acreditava que não se devia simplesmente aceitar o ponto de vista do cliente, sem argumentações. "Devemos levá-lo a uma concepção formada a partir de suas necessidades. Se ele nos pede para satisfazer algum capricho ou extravagância sua que não faz sentido, temos que descobrir quais necessidades reais podem estar por trás desses sonhos e tentar guiá-lo em uma abordagem coerente."

Mas, concessões eram necessárias. Pois, havia sempre outro profissional que faria o que o cliente quisesse. "Aquela história do arquiteto que preferiu ir quebrar pedras a fazer pequenas concessões em seu projeto é só para galã de filme americano." 30 (BRATKE, 1988, p.159)

Criticava-se a falta de objetividade nas ideias do cliente, ao trazer rabiscos, revistas e recortes de jornais: "E o pobre do arquiteto, de acordo com a concepção que dele fazem (os poucos que sabem procurá-lo), tem de interpretar a planta apresentada, juntar detalhes, comparar uma série de fotografias e anúncios e, por fim, 'desenhar' tudo direitinho (não esquecendo do sagrado 'Código de Obras'), se não quiser perder o freguês." (SOUZA, A., 1956, p.73)

Discutir os detalhes vistos nas revistas era constante. De forma um tanto pejorativa, Bratke (1988, p.160) diz: "(...) ou pelo menos croquizar sugestões que a amiga da patroa insinuasse..."

Aliás, a respeito da dona de casa, é ressaltado seu papel nas decisões relativas à casa: "Quase nunca acontece de o marido surpreender sua senhora, durante o café

\footnotetext{
${ }^{30}$ Bratke refere-se ao filme The Fountainhead (Vontade Indómita), de 1949. Vagamente inspirado na figura de Frank Lloyd Wright, é a história de um arquiteto que prefere destruir com dinamite um edifício que projetara, a permitir sua adulteração.
} 
da manhã, com a notícia de ter adquirido uma nova residência, a dona de casa sempre tem um papel importantíssimo na escolha do futuro lar. Há lá mil e uma coisas que escapam ao olho masculino e é sempre o espírito feminino quem dá os últimos retoques na harmonia do ambiente." (TOSI, 1954, p.16)

Outro aspecto a ser considerado era que as modificações durante a obra, muitas vezes, deviam-se à dificuldade de entendimento do projeto, apesar das várias peças gráficas.

O cliente pensava que havia entendido, ou ficava com receio ou envergonhado em questionar o arquiteto sobre suas dúvidas. Isso impedia que o projeto fosse bem discutido e elaborado e, na fase de construção, o proprietário se dava conta de vários aspectos que não havia notado antes.

Becker (1955, p.5) é um dos arquitetos que aponta essa dificuldade: "Ademais, em alguns casos, o cliente não sabe ler bem uma planta, escapando-lhe alguns detalhes."

Nesse sentido, Bratke, que tinha grande habilidade para o desenho, fazia croquis de partes do edifício, enquanto mostrava o projeto ao cliente. Isso facilitava a compreensão, possibilitando uma melhor discussão de suas ideias, sem a necessidade de desenhos mais sofisticados e trabalhosos. Além disso, poupava-se tempo que seria gasto com perspectivas mais elaboradas.

Os projetos eram apresentados de forma simplificada, em Casa e Jardim. Muitas vezes, preferiam-se maquetes e perspectivas. As plantas baixas, de compreensão mais difícil, nem sempre eram mostradas. Em algumas situações, as pessoas eram fotografadas manipulando os modelos, para um melhor entendimento dos leitores.

A esse respeito, Mila (1955, p.62) afirma, de forma bem realista: "a experiência espacial só pode ser verificada na realidade concreta da obra realizada. Nenhum desenho, modelo, maqueta ou fotografia tem o poder de transferir a inteira sensação do espaço imaginado arquiteturalmente. (...) e podem ocorrer discrepâncias entre a expectativa elaborada dentro da imaginação e a experiência vivida dentro do real. (...) Se essas surpresas não devem apanhar o arquiteto (...) não se pode exigir isso do leigo que, apreendendo apenas a realidade, prefira conduzir experimentalmente a solução do seu problema." 

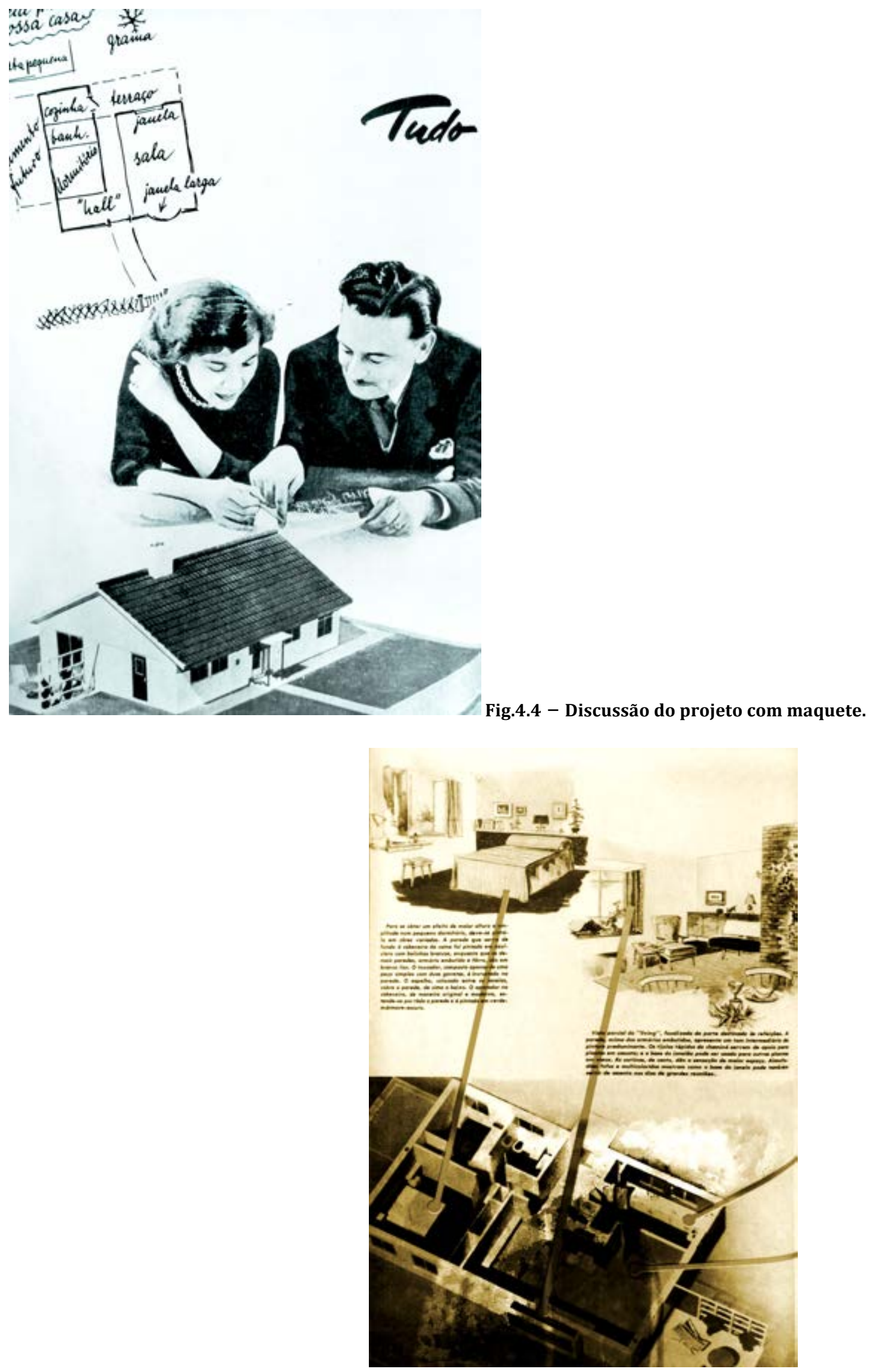

Fig.4.5 - Outra maquete e croquis. 


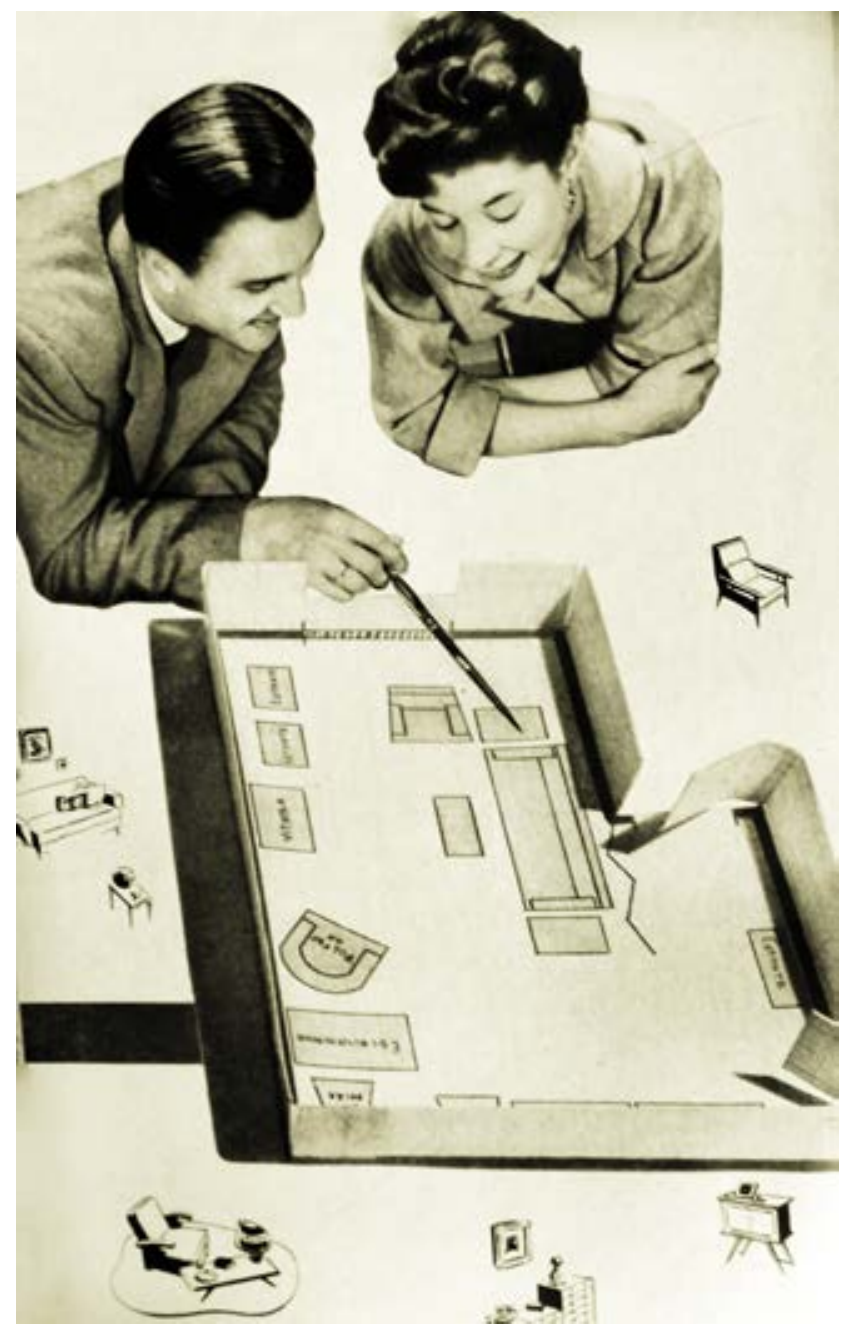

Fig.4.6 - Modelo improvisado.

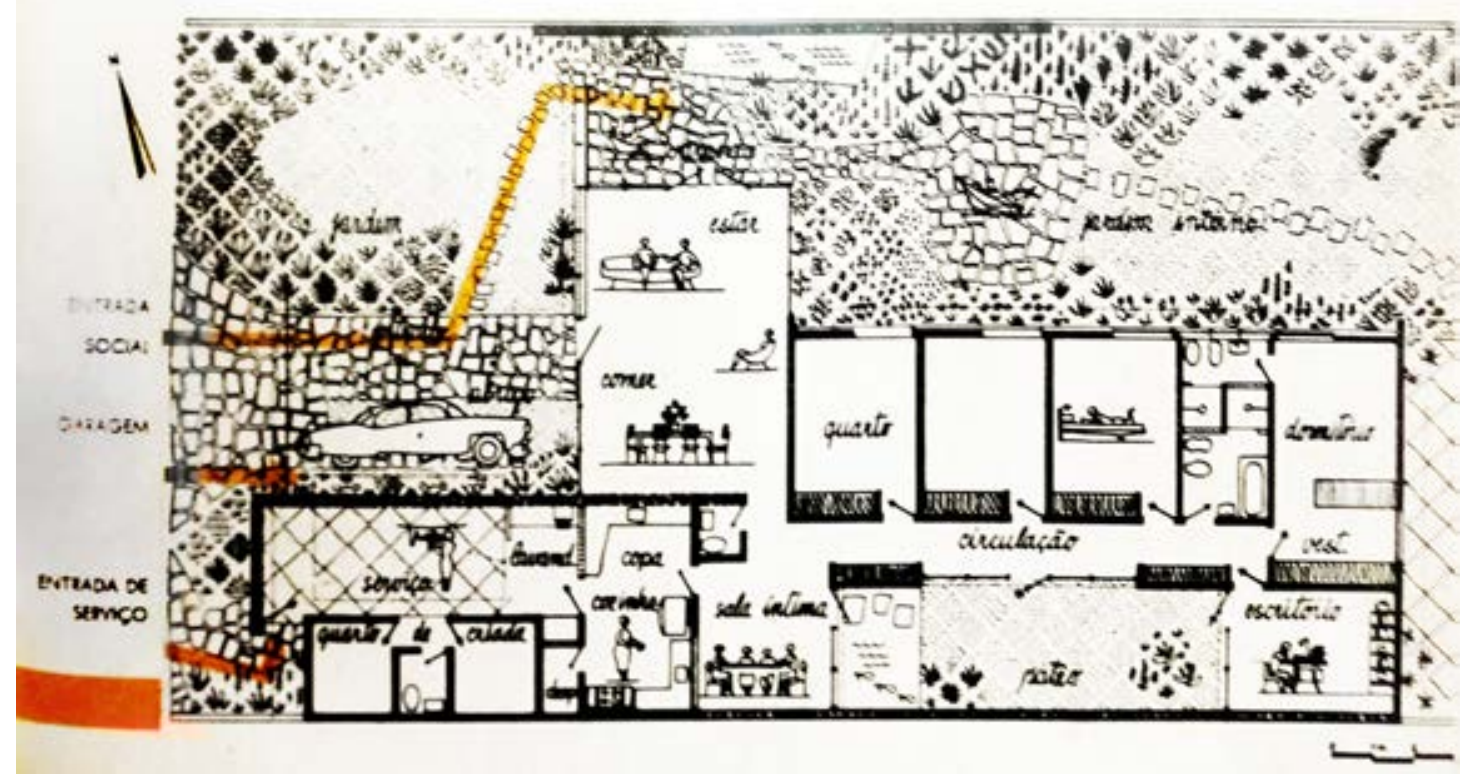

Fig.4.7 - A planta baixa é desenhada de forma descontraída, com indicações de piso e vegetação externos e desenhos alusivos ao tipo de atividade desenvolvida em cada ambiente. 


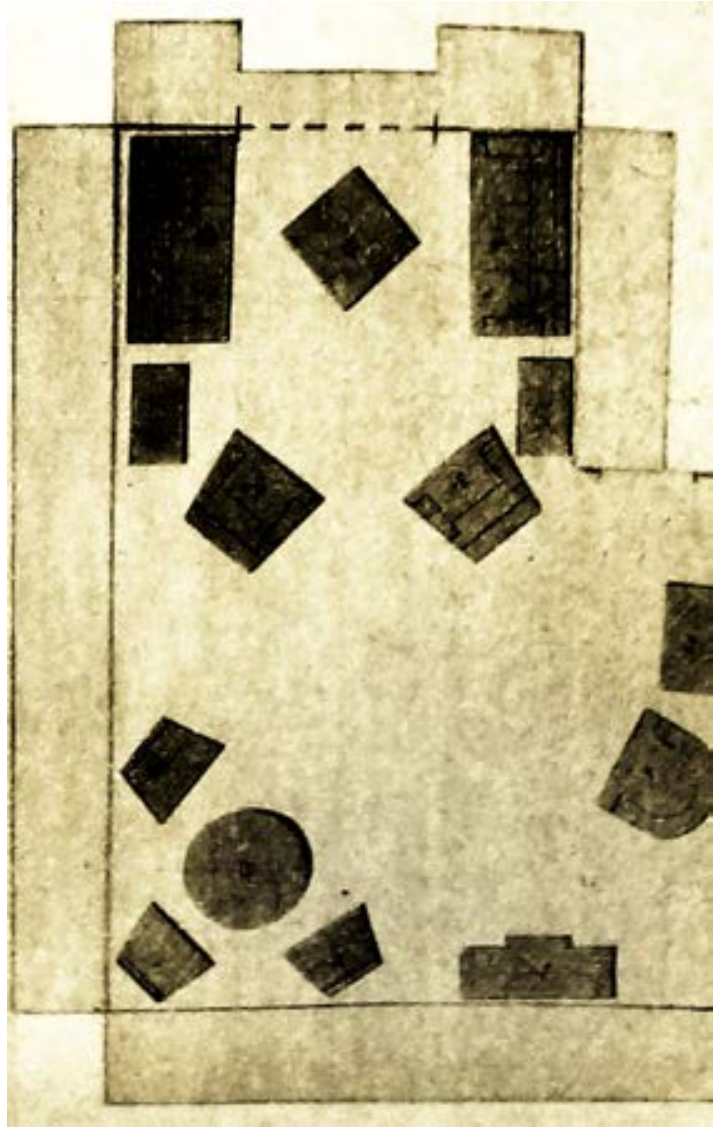

Fig.4.8 - Móveis em papel ajudavam no planejamento da decoração.

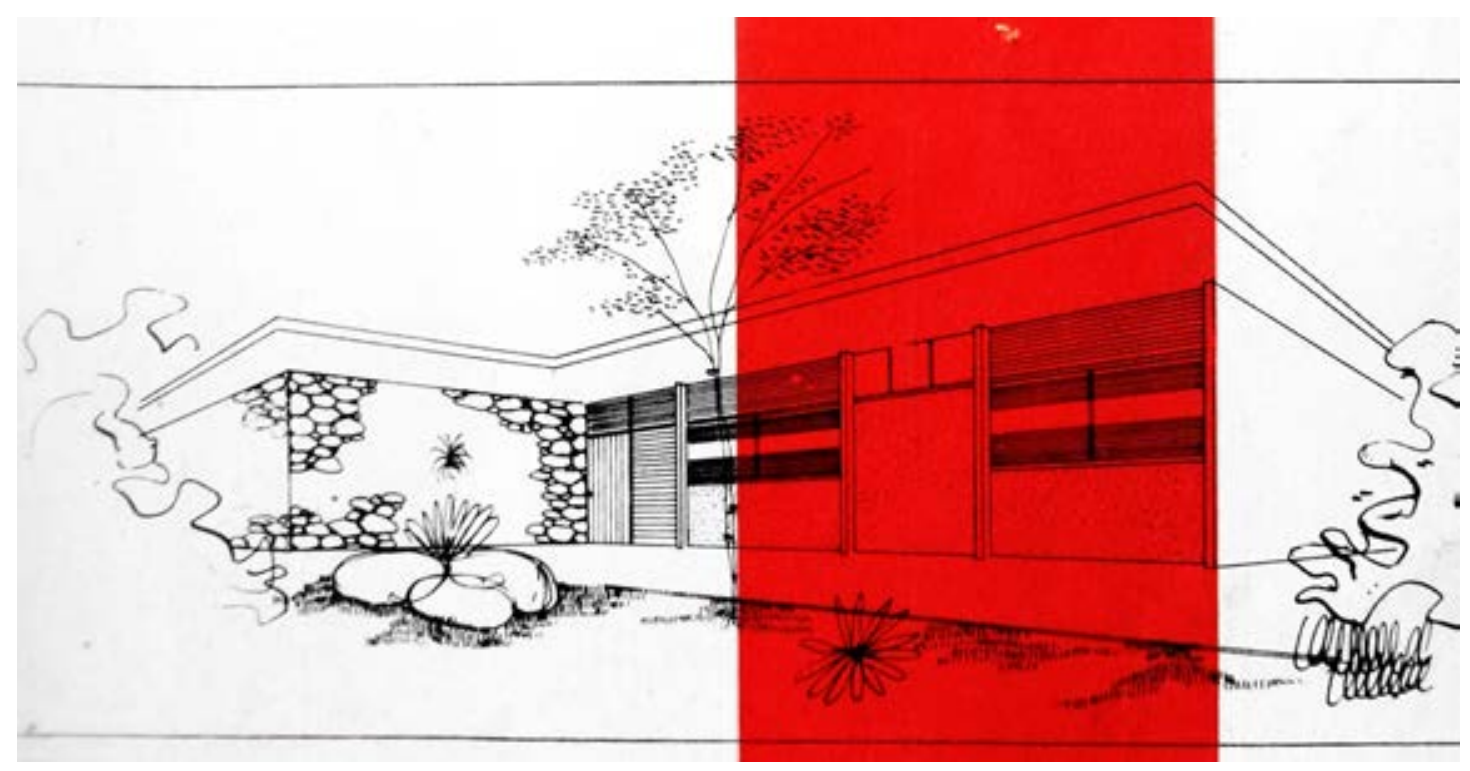

Fig.4.9 - Perspectivas também eram comuns. 


\subsubsection{Após a obra}

Ao tentar explicar todas essas questões, a linguagem moderna, a função do arquiteto, o "código" do desenho, Casa e Jardim atua como espécie de intermediária entre as duas partes, o cliente e o profissional. Em uma relação que pode ou não evoluir de forma satisfatória para um projeto e um edifício que atenda às expectativas iniciais de ambos.

Muitas vezes havia uma cooperação estreita entre profissional ${ }^{31}$ e proprietário: em Campos do Jordão, o "arquiteto Ferdinand Berg em colaboração com o proprietário A. Benetean construiu uma casa ideal para férias." (UMA CASA IDEAL..., 1956, p.30)

Ou, na casa projetada pelo arquiteto Rino Levi, onde aconteceu "um trabalho de estreita colaboração entre o arquiteto e o interessado." (O ARQUITETO..., 1954, p.13)

Às vezes, o cliente apresentava mais do que ideias e recortes de revistas, como aquele que "delineou sozinho o primeiro esboço e planta de sua casa. Chegando a uma conclusão que the pareceu adequada ao sítio e a seus anseios, pediu a um arquiteto que the completasse a planta segundo as regras de arte." (UM SOLTEIRO..., 1954, p. 12)

Havia comentários como: "Se estou satisfeito? - exclamou o dono da residência à Rua Alemanha - minha cara amiga, pode dizer que estou satisfeitíssimo! Este o raro tributo que o proprietário pagou ao seu arquiteto."(MARGÔ, 1957a, p.14) ${ }^{32}$

\footnotetext{
${ }^{31}$ Mas, Casa e Jardim também considera uma "arquitetura sem arquitetos." Quando se prescindia desse profissional, tentava-se orientar o leitor tecnicamente, mas também em relação ao que consumir. São mostradas reportagens em que ele é o responsável pelo projeto e, às vezes, pela obra, como o casal de americanos que comprou uma casa em Santo Amaro, reformou-a e ampliou-a sucessivamente, utilizando-se da mão de obra do proprietário e materiais usados, a fim de "transformar um feio bangalô em residência encantadora, elegante, espaçosa e funcional." (JACKSON, 1954, p.14).

A iniciativa da revista em criar a seção "Equipe 5 responde," formada pelos arquitetos A. Grostein, G. Himmelstein, J.O.Silva, L.A. Teixeira Leite, M.N. Lima, segue por esse caminho: MORE BEM..., 1957. A seção aparece ainda nos números $33,34,36,37,38$, 39 e 40. Eram publicados projetos padrão, elaborados pela "equipe 5," relacionados a programas diversos, em resposta às dúvidas mais frequentes dos leitores. "Esta seção visa a resolver, sempre que possível, os problemas de sua residência moderna." (MORE BEM..., 1957, p.4). Nessa seção, a questão dos custos sempre era considerada aspecto fundamental do projeto, chegando a definir as escolhas técnicas. A partir do n.41, passa a ser chamada "Conselho C e J." Ainda nos números 42, 43, 46, 47, 48, 49, 51, 53, 56, 57 e 58.

${ }^{32}$ Projeto do arquiteto Jorge Zalszupin. Paisagismo de Jardins Tropicais.
} 
E elogios: "Carinho e dedicação dos arquitetos, aliados à compreensão do proprietário levaram para um Uníssono Feliz entre arquitetura e decoração." (UNÍSSONO..., 1955, p.11) ${ }^{33}$.

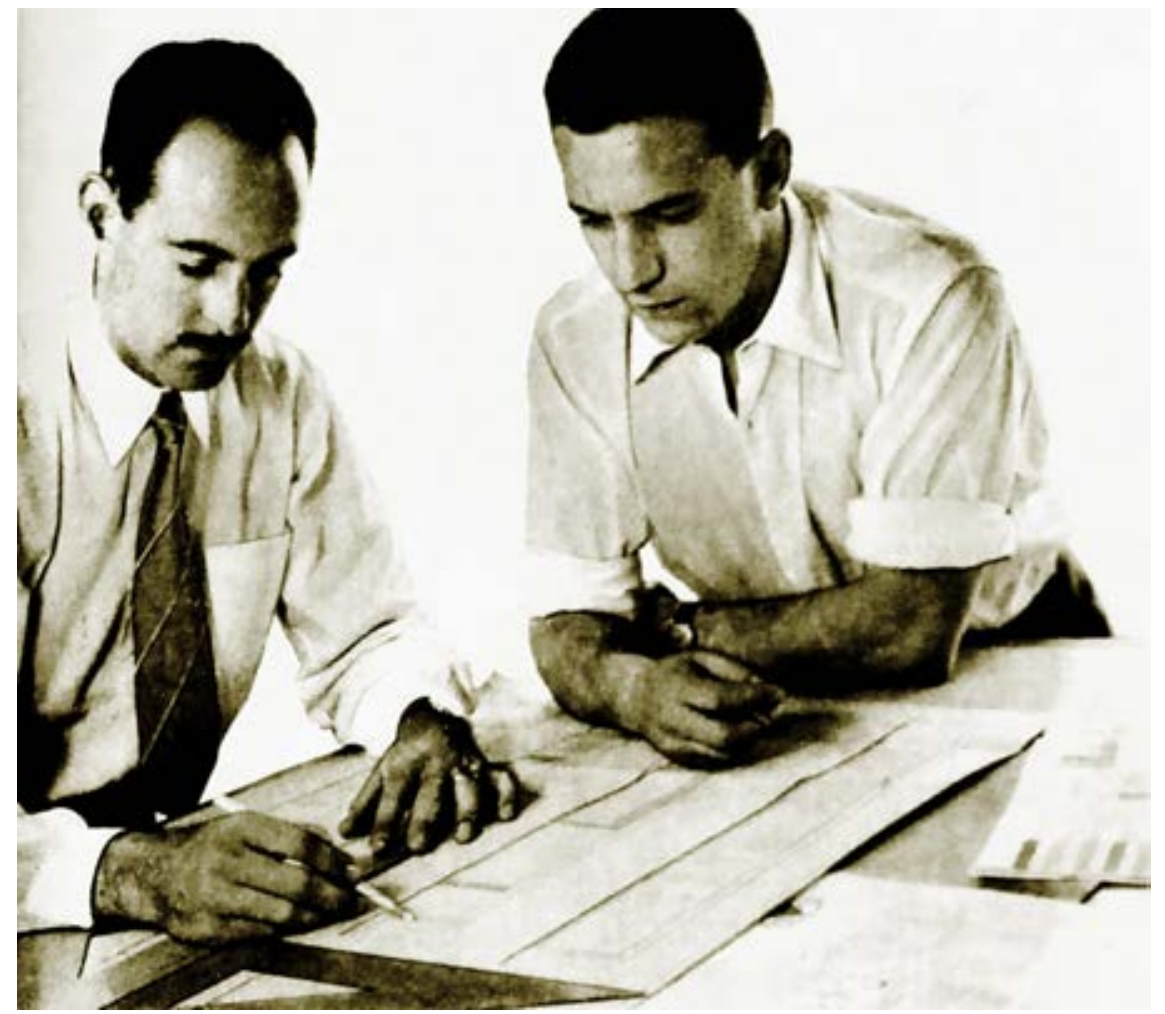

Fig.4.10 - 0 uníssono feliz entre arquiteto e proprietário.

O fato desses "tributos" serem raros mostra quão difícil era essa relação entre o contratante e o contratado.

$\mathrm{Na}$ verdade, o uníssono feliz não se dava com o término da obra. Pois, após a construção, viria a tarefa mais silenciosa, a da "arquitetura humana (...) mostrando a personalidade dos moradores." (M., 1961, p.50) Essa seria uma "combinação de vida e matéria, que lutam desde o primeiro dia, durante meses (...)." (Ibid., p.50) Algo que extrapola o mero projeto e construção: esse "tomar conta da casa" que envolve o morador, e ainda o arquiteto, assim como a etapa anterior também envolvia ambos, mas em proporções diversas, pode ou não vir a constituir um conjunto harmônico. Segundo a revista, certas "realizações tecnicamente perfeitas tanto do decorador como do arquiteto não conseguem entrosar-se com a vida interna da casa

\footnotetext{
${ }^{33}$ Residência no Alto da Lapa, dos arquitetos Hélio Pasta e João Clodomiro B. De Abreu. Construção Boggi \& Mesquita. Proprietário Décimo Mazzocato.
} 
e dessa incompatibilidade nascem sucessivas reformas e mudanças constantes. Quantas vezes também o calor humano duma residência compensa a modéstia da arquitetura, ou supre a deficiência da decoração." (M., 1961, p.50) Para se chegar ao ponto desse morador reconhecer-se nesse ambiente e viver uma vida confortável e plena ali. $^{34}$

Claramente, ao lado da arquitetura, está a vida dos moradores, onde está presente a dimensão cotidiana. A "construção" da casa - ou lar - não se esgota com projeto e obra.

E, essa unidade não pode estar fechada "em si," excluindo o morador, como dissemos no capítulo 2. Deve haver uma unidade subjetiva, um todo, uma síntese adaptada à personalidade do morador. Um ambiente criado "sob medida" para ele.

Pois, quando não existia essa harmonia, havia desenlaces como um "espelho d'água de formas infelizes, que não é da autoria do arquiteto e foi mandado construir pelo proprietário, em época posterior." (CAMPOBELO, 1956, p.16)

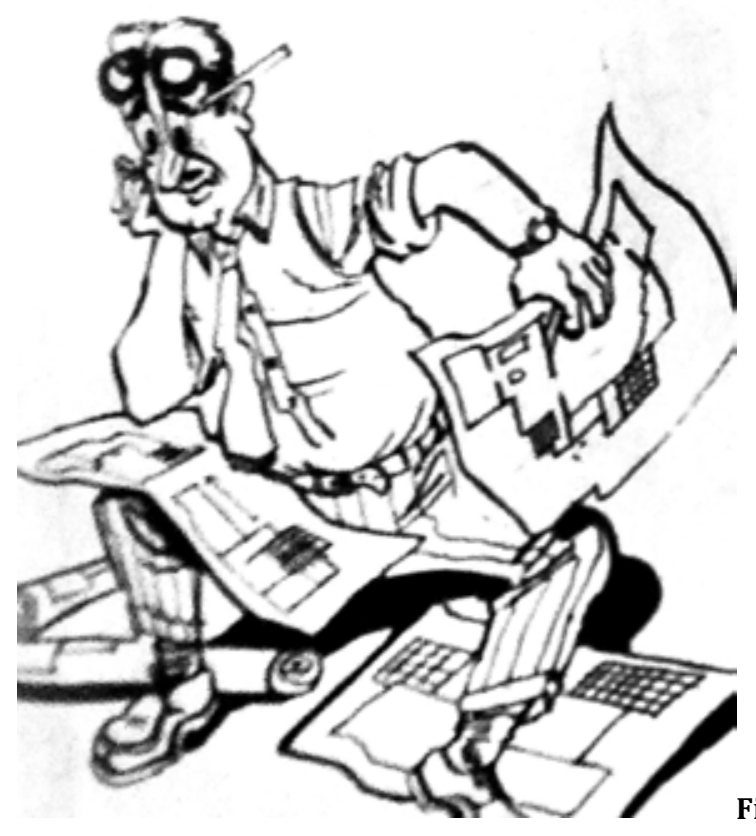

Fig.4.11 - 0 "arquiteto-proprietário."

A situação também seria difícil quando o "proprietário e o arquiteto são a mesma pessoa. É um caso funesto para ambos. O proprietário fica privado da vítima que provocou as falhas e o alto custo da construção, e o arquiteto, privado das desculpas por imperfeições da estética da casa." (GRABOWSKI, 1957, p.33) Nesse

\footnotetext{
${ }^{34}$ Projeto de Luiz Saia. Proprietário. Guilherme Hannud.
} 
caso: "o eterno impasse que costumeiramente surge entre o dono da casa (mais especialmente a dona) e o arquiteto" (SIMÕES, 1957, p.5) não estaria solucionado pois o engenheiro também tem sua esposa, "um amigo que põe a sua "colherzinha"” (lbid., p.5) e a sogra que seria sempre impulsiva.

\subsection{0 arquiteto "menor" nos EUA}

Um profissional "menor", que atende a clientela de classe média ${ }^{35}$ em sua própria residência, ${ }^{36}$ por uma questão de praticidade, mas também, provavelmente, de economia, ${ }^{37}$ pode ser considerado na análise do arquiteto pragmático, que participou da adaptação e utilização da linguagem moderna na arquitetura doméstica dos EUA.

Trata-se de Hugh Stubbins Jr. (1912-2006). Ele estudou no Georgia Institute of Technology, em Atlanta, e no Harvard University Graduate School of Design e, assim, provavelmente, foi aluno de Gropius, onde ele ensinou de 1938 a 1952. Em 1952, Stubbins era professor ali, assim, provavelmente a proximidade entre ambos era efetiva.

Stubbins vivia nos subúrbios, próximo a Harvard. Como a de seus clientes, sua casa fora financiada. Uma pequena casa "espaçosa," um exemplo do Good Life Modernism, adaptada ao site arborizado, com área social integrada, ${ }^{38}$ móveis desenhados pelo arquiteto, uma grande lareira e inúmeros panos de vidro. O teto é plano e são utilizados materiais naturais. O escritório no subsolo, com a metade da área do térreo, adapta a casa ao terreno em desnível. A planta é um retângulo resolvido de forma racional, com paredes alinhadas e banheiros lado a lado. ${ }^{39}$

\footnotetext{
${ }^{35}$ Desde o início do século XX, nos EUA, constitui-se uma ampla classe média, com possibilidade de adquirir sua casa nos subúrbios e decorá-la com produtos disponíveis no mercado, com a ajuda profissional de arquitetos e decoradores.

${ }^{36} 82$ Distinctive Houses from Architectural Record, casa n.78, em Massachus., publicada em Mar.1948, p. 336-344.

${ }^{37} \mathrm{O}$ fato dos arquitetos, em geral, não serem bem pagos é repetido muito vezes no álbum da Architectural Record.

${ }^{38}$ Uma construção modesta, com materiais simples, mas com efeito interessante a US\$ 8,50 o metro quadrado.

${ }^{39}$ Stubbins tem mais duas casas publicadas em 82 Distinctive Houses from Architectural Record. A primeira, n. 48, em. Cohasset, Mass., publicada em dez.1949, p. 208-9. Trata-se de um celeiro feito em pedra e shingles, que foi transformado em residência moderna. Outro projeto de Stubbins, n.55, em Concord, Mass., publicado em abr.1949, p. 248-251, com estar, jantar e hall integrados, foi feito
} 


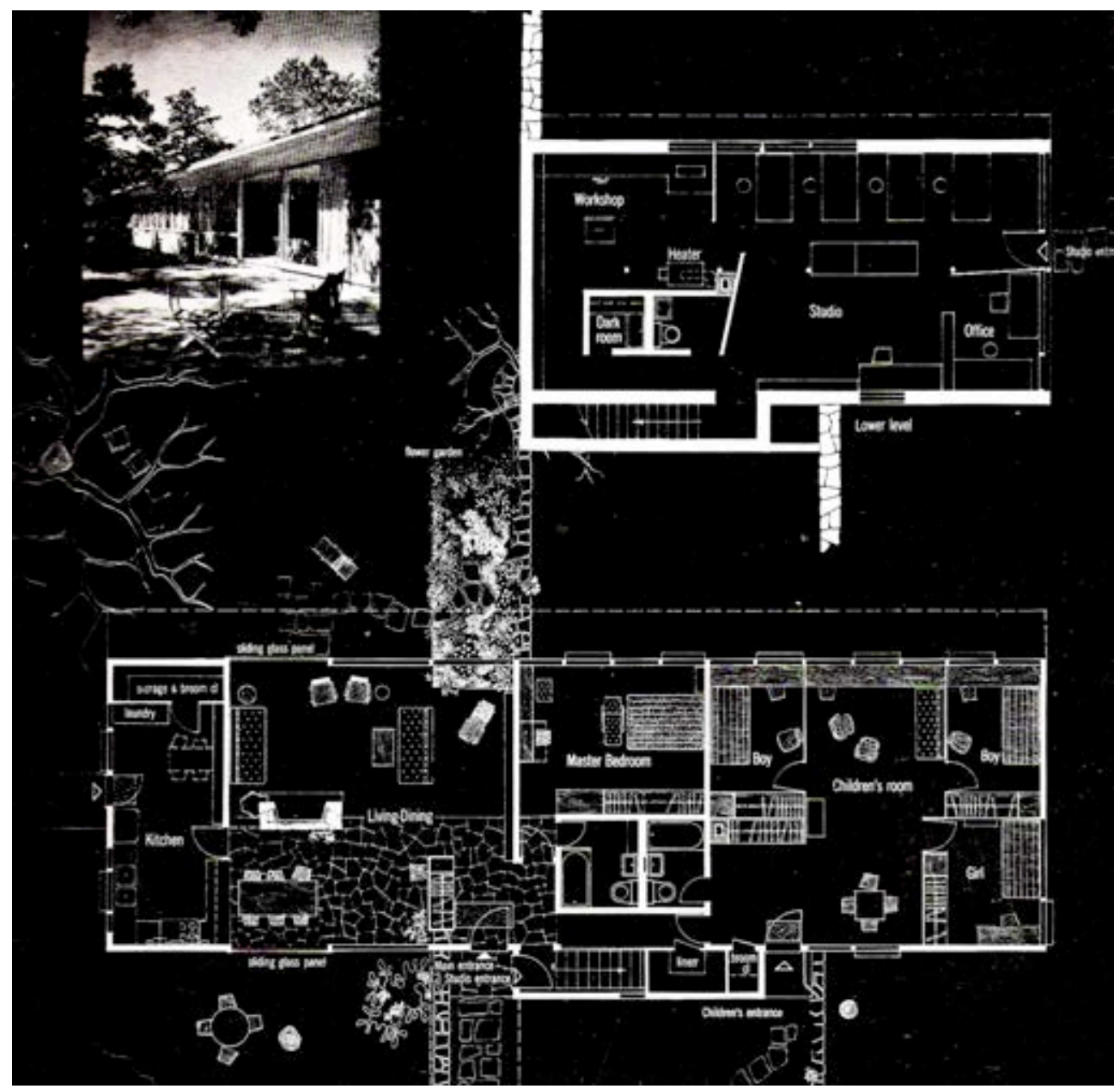

Fig.4.12 - Planta baixa da residência de Stubbins.

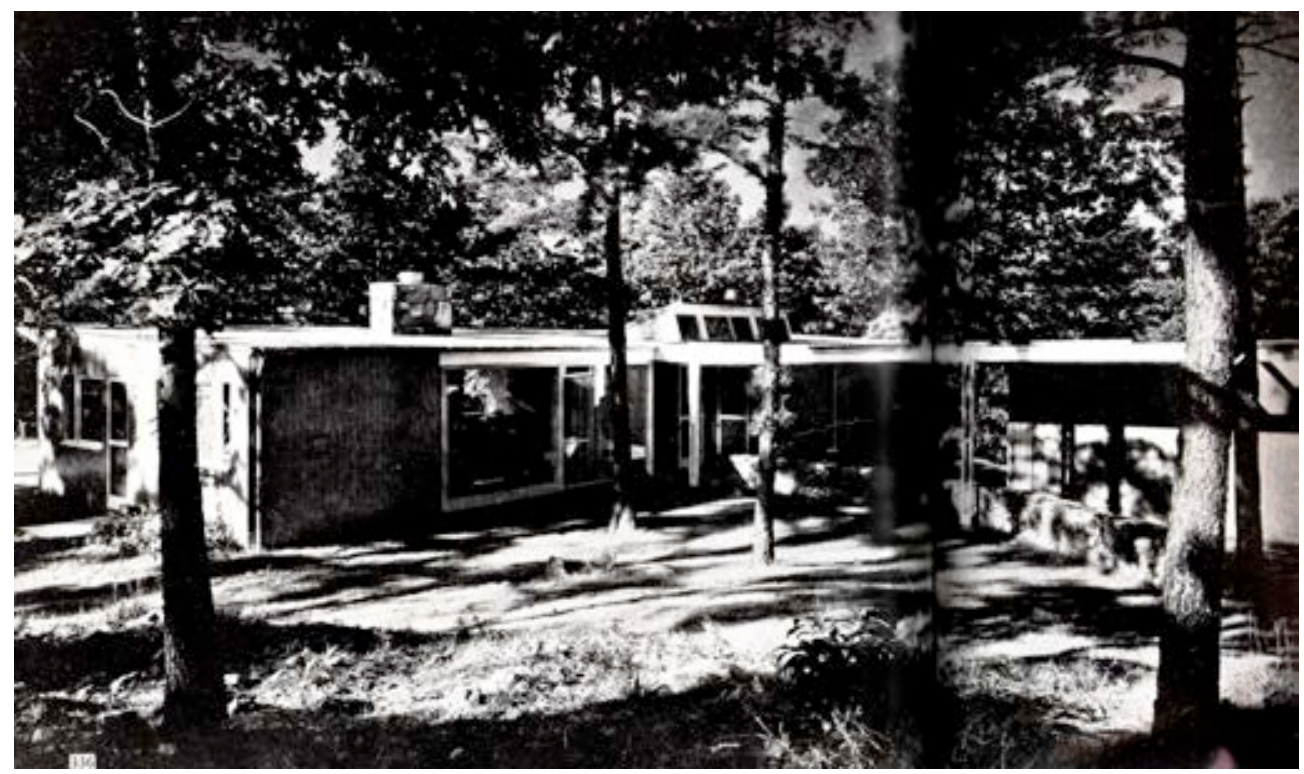

Fig.4.13 - Casa de Stubbins.

para um casal de músicos, com um orçamento restrito. O espaço limitado parece mais amplo através de um pé direito maior e uma fachada envidraçada. 
A atuação profissional de Stubbins o distancia do grande arquiteto, aquele que faz "obras de arte." Mock (1946, p.63) os distingue - o grande e o bom arquiteto: "Quando o arquiteto moderno era uma voz solitária em um amontoado de falsas fachadas coloniais e reproduções Chippendale, ele tendia a ser algo como uma prima-dona. Agora que é reconhecido como um cidadão extremamente útil, seu tom é outro e surge uma nova e bem conveniente humildade."

Quando a arquitetura do Movimento Moderno ainda se restringia às grandes e poucas obras de custo elevado, para uma clientela seleta, os arquitetos que ajudaram a desenvolver essa linguagem tinham grande visibilidade, eram os "grandes mestres."

Apenas arquitetos com as maiores quantidades de capital simbólico ou de reputação, como Wright, Le Corbusier e Mies, no ponto alto de suas carreiras, poderiam ditar seu termos e dizer ao cliente o que é bom para ele, o que define a superioridade simbólica do próprio cliente. (STEVENS, 2003, p.113)

Porém, na adaptação do vocabulário moderno para um público muito mais extenso, ${ }^{40}$ os grandes mestres desempenharam um papel menor. Arquitetos menos conhecidos se incumbiram dessa tarefa.

Mock (1946, p.7) fala sobre o que era necessário nesse novo arquiteto: precisamos "de uma abordagem nova e humana, uma sensibilidade aos materiais e proporções, e a habilidade para conceber um edifício em suas três dimensões e não apenas como algo desenhado no papel. Pois, há outras exigências rigorosas, e elas excluem não apenas os tradicionalistas, mas alguns que se consideram modernos."

Esse bom arquiteto poderia tolerar até mesmo a presença de um decorador de interiores. No entanto, ele deveria ser consultado antecipadamente sobre várias questões: se era desejável que a mobília realçasse o caráter da arquitetura, sem negá-lo ou competir com ele, por exemplo. Pois, a mão do arquiteto poderia ser tão onipresente que seria uma afronta mover uma cadeira ou pendurar um quadro.

E, Mock (1946, p.63) lembra que "a rixa entre arquitetos e decoradores está bem fundamentada, pois a 'decoração' de um interior moderno é frequentemente também sua profanação."

\footnotetext{
${ }^{40}$ Essa clientela, que envolve uma faixa maior da população, apresenta menor poder aquisitivo.
} 
O relacionamento do cliente com esse profissional pragmático seria diferente do que ele teria com um grande mestre: "se seu arquiteto é apenas bom, não grande, então provavelmente existe um limite" (MOCK, 1946, p.63) para o quanto você o quer próximo. Mas, provavelmente, ele não quer mais contato com você do que você com ele.

Nesse sentido, é sintomático que se tenha escolhido Gregory Ain para elaborar a casa nos jardins do MOMA em 1950, um profissional com experiência no mercado imobiliário, que faria uma "boa arquitetura de consumo." (FULLAONDO, 2010, p.183) Todas essas questões refletiam-se na geração mais jovem que, como assinala Gropius (1954b, p.30), perdia a confiança no "caráter tutelar do nosso sentido profissional e seu resultado lógico - o arquiteto prima-dona, autonomeado." A ideologia do século XIX havia eleito esse "gênio individual como a única encarnação da arte legítima". (Ibid., p.30)

Essa geração mais jovem apresenta um número de arquitetos muito maior. $\mathrm{O}$ aumento foi bastante expressivo, ao longo da década de 1950, com problemas para acomodar o afluxo maciço de estudantes. ${ }^{41}$ Ao final da Segunda Guerra Mundial, os Estados Unidos tinham quarenta e nove escolas de arquitetura e o Canadá, três. Por volta de 1950, eram sessenta e seis, nos dois países. No Georgia Institute of Technology, mais de 450 estudantes estavam matriculados na escola de arquitetura, no final dos anos 1940, enquanto eram 22, durante a guerra, e 66 antes dela. (OCKMAN; SACHS, 2012, p.123 e 126) Esses estudantes consideravam a educação extremamente importante, após a experiência da guerra, agora mais maduros, mesmo entre os que haviam começado a estudar antes do conflito.

Esse número crescente de arquitetos trata do espaço e do tempo cotidiano, real, dos pequenos fatos, dos itens necessários ao conforto para a vida diária. Estas questões estão mais presentes no trabalho do profissional do que as formais, abstratas, que, no entanto, não foram abandonadas. Não queremos, com isso, dizer que no início do Movimento Moderno, a vida cotidiana e outros aspectos práticos não fossem partes constituintes no processo de projeto, apenas os "pesos" eram diferentes.

Para Avermaete (2005, p.127), o papel do arquiteto foi redefinido. Mas, na verdade, o profissional "menor," pragmático, já existia, ao menos desde o século XIX. No movimento Arts and Crafts, por exemplo, projetavam pequenos cottages ou grupos

\footnotetext{
${ }^{41}$ Devemos lembrar a importância do GI Bill of Rights, oficialmente Servicemen's Readjustment Act, já mencionado no capítulo 3, a legislação aprovada ainda durante a Guerra que, entre outras medidas, subvencionava veteranos que quisessem estudar antes de voltar ao trabalho.
} 
deles. A diferença é que ele agora se utiliza da linguagem moderna. E, determinado arquiteto pode ser um "grande mestre" em certos momentos e em outros ter uma atuação mais pragmática.

Em determinada época, esses arquitetos eminentes, que possuem maior capital simbólico, procuram uma reputação de alta criatividade, que fica para a posteridade. O sucesso, nesse caso, não é, necessariamente, o econômico, mas sim o intelectual, estético. Em outra fase de suas vidas, tornam-se praticantes cotidianos da atividade e a satisfação também vem na forma do dinheiro e da tarefa bem feita.

A imagem do arquiteto, assim, mudou: da heroica figura pioneira do Movimento Moderno à de um profissional mais pragmático.

(...) começando a trabalhar nos anos 1950, nunca pudemos aceitar as inocentes hipóteses à disposição do Heroico Período da Arquitetura Moderna. Nas revistas americanas das décadas de 1940 e 1950, pudemos antever a sociedade de consumo que modificaria, através dos anúncios, as nossas vidas... A Segunda Guerra Mundial foi o grande divisor entre nós e nossos avós arquitetos, que construíram para uns poucos, carros exagerados, e para os cavalheiros que compravam para repor os poucos objetos substituídos. $^{42}$

Colomina (2007, p.12) mostra essa mudança na imagem pública do arquiteto - da figura heroica, pública, austera e masculina, vestida formalmente - à do sujeito domesticado do pós guerra - relaxado, vestido de forma casual, em casa, simbolizado por Gropius.

Ele, Mies e Breuer, entre outros, adaptam-se à prática profissional e construtiva americana, sem desafiar a redução perpetrada pela exposição do MOMA na constituição do International Sytle. Como seus colegas americanos, alinham "a agenda da arquitetura moderna aos imperativos da sociedade capitalista americana." (OCKMAN, 1997, p.127)

Pois, nesse processo de ambientação, aspira-se menos aos vanguardismos, à discussão de questões sociais e mais à integração no sistema de produção americano. Não se deve esquecer que, principalmente após a Segunda Guerra Mundial, alinhar-se politicamente à esquerda torna-se muito problemático nos Estados Unidos.

\footnotetext{
${ }^{42}$ SMITHSON, Alison "Patio and Pavilion", 1956. Publicado novamente em Places: A Quarterly Journal of Environment Design 7, n.3, p.11, 1991 apud COLOMINA, 2007, p.194.
} 
Alguns arquitetos envolveram-se em problemas, entre eles, Frank Lloyd Wright, que foi objeto de um extenso dossiê, compilado pelo $\mathrm{FBI}$, e escrutinado pelo senador Joseph McCarthy. E, em Los Angeles, Gregory Ain, que alinhava-se politicamente à esquerda, pressionado, viu-se forçado a retirar-se da prática profissional, no inicio dos anos 1950. Permaneceu ensinando na University of Southern Califórnia, onde foi "acolhido," apesar do processo de despolitização da arquitetura moderna, que Philip Johnson e Henry-Russel Hitchcock iniciaram em 1932, haver se institucionalizado nas escolas, que adotaram 0 modernismo em termos especificamente "americanos." (OCKMAN; SACHS, 2012, p.135) Outra questão a ser ressaltada é a ligação entre as universidades e o complexo industrial-militar emergente, visto por muitos de forma cautelosa.

Mesmo a afinidade entre a arquitetura e o pensamento técnico-científico, nessa década, pode ser tributada, ao menos em parte, a essas questões politicas.

\subsection{A nova geração e o trabalho em equipe}

A nova geração de americanos, da qual faziam parte firmas como Skidmore, Owings \& Merril (SOM), nos anos 1950 e início dos 1960's, aperfeiçoou a estética do vidro e do aço, uma linguagem refinada, utilizada nos grandes edifícios comerciais e institucionais. ${ }^{43}$

A estrutura do SOM era bastante organizada, com grande capacidade de produção, utilizando a linguagem moderna de forma sofisticada. $O$ trabalho compreendia desde o planejamento da área até os detalhes construtivos.

O escritório enfatizava a autoria coletiva e o trabalho em equipe. Mas, apesar da omissão da identidade do responsável, alguns talentos individuais sobressaíam, porém, não como o "grande arquiteto."

O trabalho em equipe é uma questão muito importante na prática profissional nos Estados Unidos. O grande escritório já estava presente na arquitetura americana desde o século XIX. Os dois arquitetos mais influentes nos anos 1870 e 1880, nos EUA, Richard Morris Hunt e Henry Hobson Richardson, estavam entre os primeiros americanos a frequentar a École des Beaux-Arts, em Paris. A partir de sua

\footnotetext{
${ }^{43}$ Durante a Segunda Guerra Mundial, o SOM desenhou e supervisionou em segredo habitações para 75.000 pessoas em Oak Ridge, no Tennessee, parte do projeto para o desenvolvimento da bomba atômica. No pós-guerra tinha quatro escritórios regionais e grandes projetos em nível internacional.
} 
experiência francesa, criaram escritórios, que teriam grande impacto sobre o treinamento e a prática arquitetônicas americanas.

Esse tipo de organização do exercício profissional tentava atender às demandas resultantes do aumento do volume de trabalho e de sua complexidade, já no século XX. O Empire State Building e o Rockefeller Center, construídos nos anos 1930, são alguns desses projetos que necessitavam de grande número de profissionais treinados - como arquitetos, engenheiros estruturais e mecânicos -, construtoras, fornecedores de materiais, entre outros.

Para atingir esse objetivo, foi necessária a separação entre a instância da tomada de decisões e o trabalho em si, além da escolha de indivíduos para liderar e coordenar os diversos setores. Essa divisão do trabalho acabou por diminuir a participação do individuo no processo de projeto e construção, mas parecia inevitável. Esse modelo de organização encontrado no grande escritório, por volta de 1950, estava bastante difundido na prática americana, inclusive nas firmas menores. (BOYLE, 1986, p. 317-9)

No caso de Stubbins, através da análise dos desenhos de sua casa, podemos ter uma ideia do porte de seu escritório e de sua organização. Havia espaços separados para o trabalho - o studio -, com quatro pranchetas e outra para o que seria, provavelmente, o coordenador de projetos. Outra sala era um escritório office -, certamente para a administração. Havia, ainda, uma espécie de oficina workshop -, possivelmente para modelos e maquetes, onde ficava uma sala para revelação de fotos - dark room. Assim, ao menos oito pessoas trabalhavam ali.

Estes escritórios acabavam crescendo, como aconteceu com Stubbins que teria, mais tarde, uma grande firma com projetos para escolas, universidades, clubes, bibliotecas, bancos, inclusive no exterior, com destaque para o Citicorp Center em Nova York (1976-8). ${ }^{44}$

Grande parte dos escritórios acabava, também, especializando-se em algum programa específico, como edifícios religiosos, escolares, hospitais, grandes projetos para o governo ou residências unifamiliares.

Gropius, nos EUA, também é parte de uma equipe, no escritório fundado por ele, The Architects Collaborative (TAC), com sete arquitetos mais jovens. ${ }^{45}$ O TAC, já

\footnotetext{
${ }^{44}$ Stubbins não produziu teorias, nem uma arquitetura radical, mas consistente e de qualidade.

${ }^{45}$ Em 1946, em Cambridge, Massachusetts, com Jean e Norman Fletcher, John e Sarah Harkness, Robert McMillan, Luis McMillen e Benjamin Thompson.
} 
mencionado no capítulo 3, foi muito respeitado por seu amplo leque de realizações no pós-guerra, com diversos projetos de sucesso.

A base do escritório era a ideia de colaboração, sem enfatizar a autoria individual. Mas, em cada projeto, havia um sócio responsável pelo relacionamento com o cliente e pela tomada das decisões. Com o crescimento, surgiram outras equipes, mas com a mesma filosofia. A presidência era exercida por cada um dos sócios principais de forma rotativa. ${ }^{46}$

Para Gropius (1954b, p.31), falando no IV Congresso Brasileiro de Arquitetos, ${ }^{47} \mathrm{O}$ trabalho na indústria da construção, da mesma forma, deveria ser feito por um "time," coordenado pelo arquiteto, que desenvolveria os componentes do edifício, depois utilizados no projeto. Assim, o profissional se tornaria, novamente, "efetivo."

No Brasil, houve escritórios de arquitetura com vários sócios, como o de Levi, que valorizava 0 trabalho em equipes interdisciplinares, onde tornava-se o elemento catalisador. ${ }^{48}$ (SANTOS, 1988, p.50)

Aqui ou nos EUA, o trabalho de um time de profissionais possibilitava a troca de conhecimento e de ideias, aperfeiçoando o projeto e o edifício. Apesar do processo criativo se originar no indivíduo, o trabalho em equipe estimularia a crítica, impedindo que o profissional se isolasse em uma torre de marfim.

Gropius também aconselhava que arquitetos recém-formados, mesmo mantendo um emprego para sua sobrevivência, formassem equipes em suas comunidades, conservando seus interesses vivos e tentando encontrar soluções para temas pertinentes àquele grupo. Depois, poderia tornar-se um conselheiro junto às autoridades.

\footnotetext{
${ }^{46}$ Inicialmente, o TAC dedicou-se a projetos residenciais, principalmente unifamiliares. Outra de suas especialidades foram os edifícios para escolas e universidades, como a Harvard University Graduate Center (1949-50) e a Universidade de Bagdá (1960), além da embaixada americana em Atenas (1956). Gropius esteve com o TAC até sua morte em 1969.

${ }^{47}$ Realizado entre 17 e 24 de Janeiro de 1954, em São Paulo, onde o arquiteto fez três conferências.

${ }^{48}$ Nas décadas de 1940 e 1950, Levi associou-se a Roberto Cerqueira César e Luiz Roberto Carvalho Franco, intensificando as pesquisas de materiais e métodos construtivos, na busca do conforto ambiental e da racionalização do projeto e da obra. Após a morte de Levi, em 1965, os sócios continuaram o trabalho do escritório com o nome de Rino Levi Arquitetos Associados e dois outros sócios se juntam à equipe na década de 1970, os arquitetos Paulo Bruna e Antônio Carlos Sant'Anna.
} 


\subsection{A função social do arquiteto}

O trabalho em equipe para servir à comunidade é a discussão possível a respeito da função social do arquiteto em uma sociedade como a americana, particularmente na época do Macarthismo. Reflete o individualismo americano, na ideia de que todos devem desempenhar seu papel na comunidade.

Essas discussões sobre o papel do profissional e também em relação ao ensino da arquitetura estavam presentes, nos anos 1950, no Brasil.

Procurava-se um caminho para a renovação da prática profissional e debatia-se a atuação do arquiteto em relação às questões sociais, econômicas e políticas do país. Estes temas estavam presentes no IV Congresso Nacional de Arquitetos. ${ }^{49}$ Houve grandes polêmicas, refletindo o clima de insatisfação, críticas e discussões. A presença de Walter Gropius provocou ainda mais controvérsias. O ensino da arquitetura também foi debatido. ${ }^{50}$

Afirmava-se a necessidade dos arquitetos assumirem suas responsabilidades, em relação às demandas do país, à racionalização da produção e à articulação com a indústria.

Isso também transparece em vários dos textos de Luiz Saia. ${ }^{51}$ Uma de suas críticas é a de que o arquiteto teria se afastado dessas questões, políticas, econômicas e sociais, ao se colocar a serviço da elite. (SAIA, 1957a, p.51-2 e SAIA, 1957b, INTRODUÇÃO, s.n.p.) Adotando uma posição esteticista, com o predomínio das intenções plásticas, a arquitetura se desvincularia de seu contexto e o arquiteto dos

\footnotetext{
${ }^{49}$ As comissões de estudos eram: Comissão n.1, a de Arquitetura e Tradição; Comissão n.2, a de Arquitetura e Indústria; Comissão n.3, Ensino da Arquitetura; Comissão n.4, A Profissão do Arquiteto Quanto à integração entre arquitetura e indústria, não haviam sido submetidos trabalhos. Houve apenas a conferência de Walter Gropius - "O Arquiteto na Sociedade Industrial" - e os debates posteriores, em que se basearam as resoluções submetidas ao plenário.

${ }^{50}$ Nas seis teses apresentadas à comissão n.3, sobre o ensino, as questões mais importantes foram: a inadequação dos currículos para a formação do profissional; a falta de entrosamento entre as disciplinas; o ensino deficiente sob o ponto de vista prático; a formação falha dos docentes; as relações entre professores e alunos e a direção inadequada das escolas de arquitetura. Pedia-se também maior participação dos alunos nas decisões.

Em 1958, no $1^{\circ}$ Encontro Nacional de Estudantes e Arquitetos, a relação entre o ensino e o exercício da profissão constituiu-se em uma das discussões fundamentais.

${ }^{51}$ Profissional e teórico, em suas reflexões transparecem as questões suscitadas pela arquitetura à época e as críticas feitas ao Movimento Moderno, como dissemos no capítulo 2. E, a ser considerada, a amizade que unia Saia e Vilanova Artigas, militante do Partido Comunista, à época, quando fez pesadas críticas a Le Corbusier.
} 
problemas da coletividade. Por outro lado, também não poderia haver uma preocupação única com as questões técnicas.

Em poucos momentos, esses temas chegam a Casa e Jardim. Dois depoimentos surpreendem, pelas posições mantidas pelos arquitetos, em uma revista dedicada à classe média.

Em um deles, Saia fala da posição do arquiteto diante da coletividade, principalmente em relação à habitação social, que deveria envolver o desenho, a técnica, as ciências sociais e a política.

Questionando, mais uma vez, a atuação profissional apenas para os "grupos dominantes," Saia (1956, p.4) crê que a evolução da sociedade, com o progresso técnico e o aumento populacional, poderia ampliar o campo de atuação do profissional, fazendo "o povo tornar-se o cliente mais importante dos arquitetos." (SAIA, 1956, p.4) Mas, não haveria condições financeiras para atendê-lo individualmente. Além do que, isso "corresponderia a aburguesar o povo" (SAIA, 1956, p.4), mantendo-se o dualismo proletário-burguês.

Se a arquitetura englobasse toda a coletividade, haveria o "arquiteto do povo," superando a posição de "arquiteto de príncipes". (SAIA, 1956, p.5)

Lotufo (1956, p.2,3 e 85) segue na mesma linha, criticando arquitetos de deuses e de reis, a autonomização da arquitetura e o imediatismo do capital. No entanto, o profissional contemporâneo, por convicção e por necessidade, estaria se voltando aos problemas do homem comum, considerado célula viva da sociedade. ${ }^{52}$

Além do aspecto formal, estariam presentes nas transformações da arquitetura, as questões contemporâneas, inspiradas pela psicologia e pela sociologia.

$\mathrm{O}$ arquiteto deveria contribuir para a coletividade "de tal modo, que a função seja mais importante que o seu CARÁTER, embora nunca se possa preterir as razões artísticas aplicadas à Arquitetura." (PEREIRA, 1954, p.203)

\footnotetext{
${ }^{52}$ Lotufo (1956) faz a única menção ao tema do ensino encontrada na revista, associando a visão estreita e individualista da profissão ao ensino sem contato direto com a realidade, baseando-se em casos isolados, dificultando uma nova abordagem. Para Bratke (1988, p.164), não se deveriam formar gênios, que apresentam soluções diferentes, "'de impacto'(...), (mas) profissionais que sejam senhores do métier e resolvam de maneira modesta e com honestidade tudo o que deva constituir o espaço de uma comunidade, elevando seu padrão." Na verdade, um profissional ciente das questões que o cercam.
} 
De forma um tanto confusa, consideram-se a habitação popular e para a classe média: ${ }^{53}$ “(...) a Arquitetura tem que ser estudada de tal forma, a fim de ser eminentemente popular, ao fácil alcance da classe média e principalmente, AUXILIADA, no sentido de se atender às classes menos favorecidas." (PEREIRA, 1954, p.203-4)

Contrapondo-se ao profissional que projeta para as elites, ora se fala em arquiteto para o povo, para as classes menos favorecidas, ora ele trabalha para a classe média.

Mas, na verdade, esse arquiteto "popular" e esse arquiteto "que serve a pequena burguesia" são quase sempre a mesma pessoa. No caso de Saia, apesar de suas reflexões sobre a habitação popular e a necessidade da "arquitetura englobar toda a sociedade," existem projetos seus para a burguesia - residências unifamiliares para a classe média. $^{54}$

\footnotetext{
53 Essa questão já era discutida há certo tempo. No V Congresso Pan-Americano de Arquitetos, realizado entre 4 e 9 de Março de 1940, em Montevidéu, a importância da casa para essa camada social leva-a a ser objeto do tema II, a "Vivenda da Classe Média," onde Eduardo Kneese de Mello e Marcelo Roberto teriam atuado "brilhantemente em torno das interessantes conclusões relativas ao atualista problema da habitação para a classe média." (FIGUEIREDO, 1940, p.91)

${ }^{54}$ Mencionadas no capítulo 2.
} 


\section{Conclusão}

Acreditamos que muitas das questões que nos propusemos foram respondidas ao longo de nossa narrativa. Outras surgiram e foram estudadas. Outras, ainda, aparecem agora, ao final, e necessitam ser também formuladas. Mas, é necessário finalizar e cabem algumas últimas observações, sobre o "bem viver" e o Good-Life Modernism.

Claramente, em nosso "bem viver," está presente a dimensão cotidiana, constituindo um campo mais amplo que a disciplina da arquitetura

A vida diária é componente da casa, com suas experiências, símbolos, objetos. Assim, a "construção" da casa - ou lar - não se esgota com projeto e obra. Vem, depois, "a tarefa silenciosa, a da arquitetura humana (...) mostrando a personalidade dos moradores. (...) (Uma) combinação de vida e matéria, que lutam desde o primeiro dia, durante meses (...)." (M., 1961, p.50)

Era necessário produzir uma espécie de unidade subjetiva, um ambiente criado "sob medida" para o morador. Um "tomar conta da casa" que envolve o morador, e pode ou não vir a constituir um conjunto harmônico. Para se chegar ao ponto desse morador reconhecer-se nesse ambiente e viver uma vida plena ali. Se essa unidade estiver fechada "em si," exclui o morador.

Deve ser estabelecida uma relação "emocional" dos moradores com a casa, ainda como espaço físico, para transformá-la em um lar.

Mas, como se dá a criação desse conjunto, desse ambiente harmônico? Além de ser idealizada pelo arquiteto ou, quando este não está presente, orientada pela revista, ela envolve a compra de uma ampla variedade de produtos.

Pode-se dizer que, nesse estágio inicial, e não apenas nele, a indústria da construção e a da produção de bens de consumo invade o espaço doméstico.

Os meios de comunicação apresentam um papel importante nesse processo, ao mostrar ao morador-consumidor as alternativas possíveis. Casa e Jardim constitui uma das vias, como a televisão, o rádio e os jornais. Estabelecem-se laços, sendo o das revistas, em muitos casos, o mais firme.

Pois, elas, em geral, criam uma relação íntima com seu público, uma identificação 
com o leitor. A partir dela, inventam-se desejos e necessidades e ensina-se como atendê-los. Um vínculo forte, pois ela está sempre presente; é colecionável, pode ser emprestada, relida, consultada. Este é um aspecto que deve ser considerado no apelo que Casa e Jardim consegue ter junto a seu leitor. Lembrando que ela chegou trazendo rosas para as mulheres. ${ }^{1}$

Através desses veículos, entre outros meios, a casa consolida-se como elemento da sociedade de consumo. Ela media o consumo e a utilização dos produtos. ${ }^{2} \mathrm{O}$ habitar cotidiano é cercado por objetos e vivido por meio deles.

Desta forma, estabelece-se uma relação com esse contexto, urbano, moderno, de consolidação da sociedade de consumo. Ressaltamos vários aspectos desses anos 1950, em uma grande metrópole como São Paulo, cujos traços fundamentais são as transformações - inclusive nos costumes e hábitos.

Nela estavam presentes valores modernos, grande parte inspirada pelo modelo americano, que contrastava com um Brasil, que se urbanizava rapidamente, mas ainda com valores e hábitos conservadores.

Podemos refletir sobre as ligações entre a casa do "bem viver" e a cidade. Se, na metrópole, as experiências vividas diminuem, a casa, em contrapartida, afirma-se como o local para a existência. Os vínculos com o mundo exterior, no qual a casa está inserida, se dão, cada vez mais, através dos meios de comunicação de massa.

Essa vida vivida na casa, que em muitos aspectos é uma representação, tem a família como personagem. Personagem também dos artigos e da publicidade, em cenas com forte apelo: "famílias comuns," de classe média, não especialmente elegantes, que poderiam representar qualquer um dos leitores.

A forte identificação criada com a revista torna possíveis as "aulas modernas" e outros conselhos variados a respeito da casa. Apresentam-se ambientes modernos e refinados, que conferem status social. O status de ser "moderno" e cidadão do mundo. Nessa metrópole, mas, talvez, nos confins do Brasil, também, onde Casa e Jardim chegava, permitindo sentir-se parte dessa sociedade moderna. Talvez vivendo em uma casa com as características apontadas para o "bem viver." Ou comprando os produtos que se identificam com ele.

\footnotetext{
${ }^{1}$ Capa do primeiro número.

${ }^{2}$ Existem anúncios por toda a revista, em sua maior parte de mobiliário, equipamentos e materiais de construção modernos, mas também de produtos que não seriam "aprovados" nos artigos e reportagens da própria revista.
} 
O tapete, ou outro produto qualquer, cria uma metáfora para a arquitetura e para a vida. De refinamento, elegância, elitismo, status. Assim, a revista procura estabelecer seu modelo de arquitetura, o "bem viver." Sofisticado, elaborado, requintado, primoroso.

Como é constituído esse modelo? Trata-se de uma espécie de "casa virtual," que existe nas páginas desse periódico, como uma imagem criada, a partir de habitações "reais." Estas são adaptadas para a criação do modelo. Apropriam-se de "fragmentos" do discurso americano do Good-Life Modernism e os "realizam" nas reportagens, através de partes da casa real: uma porta de correr, uma janela panorâmica, um jardim, um ambiente decorado.

Percebem-se reflexos da arquitetura americana, mas não tanto quanto se vê na produção erudita paulistana da época. São mais esparsos. Apenas alguns pontos ressaltados em relação ao Good-Life Modernism, analisados por nós, como amplidão, totalidade, contrastes, outdoor living, são replicados aqui.

Constitui-se, assim, uma espécie de modelo para exemplares populares com traços modernos.

Como uma espécie de "colagem." Mesmo quando a casa é mostrada em sua totalidade,$^{3}$ enfatizam-se certos aspectos dela. E, outros, são desconsiderados.

$\mathrm{Na}$ colagem que se elabora, às referências americanas juntam-se o método orgânico de projeto e outros componentes, estes "brasileiros," como elementos-tipo formalistas: pilotis em V, rampas circulares, amebas e outros.

Esse modelo virtual é acompanhado de um discurso, que constrói fatos, não necessariamente os descreve.

Estas "revistas produzem uma retórica a respeito da vida cotidiana, instalando-se como modelo social." (PEREZ; GODOY, 2009, p.6) (...) Um imaginário com possibilidades variadas, onde existe um lado prático contrapondo-se e completando o dos sonhos veiculados.

Que apresenta certas expectativas que extrapolam a arquitetura da casa e incluem aspectos sociais e culturais. Essa fala é capaz de influenciar as escolhas dos leitores, a partir da identificação e do vínculo que foram construídos.

\footnotetext{
${ }^{3}$ Grande parte das "casas reais" que inspiram os modelos são assinadas pelos "modernos," arquitetos conhecidos ou nem tanto.
} 
Não afirmamos, aqui, que todas os leitores de Casa \& Jardim estavam convencidos ou satisfeitos com essas representações. E foge do âmbito dessa tese esse tipo de estudo. Ou quanto desse modelo efetivamente foi aproveitado em habitações construídas naqueles anos.

Seria, assim, o "bem viver" uma arquitetura "implementada artificialmente," como o Good-Life Modernism? (JARZOMBEK, 1991, p.80) Acreditamos que o modelo e o discurso são implementados artificialmente. Ainda que se perceba, realmente, características do Good-Life Modernism nas casas e que elas verdadeiramente façam sentido no contexto brasileiro, soam sempre um tanto forçadas.

Se atentarmos para as fontes americanas, os projetos apresentam uma coerência com a análise que se faz deles; entre imagens e texto. Eles correspondem às características apontadas. Ou seja, no contexto americano, esta é uma arquitetura constituída artificialmente, com propósitos que extrapolam a construção das habitações necessárias para resolver a grave crise habitacional. E a casa transforma-se em objeto de consumo.

O Good-Life Modernism foi muito bem construído como imagem e como realidade do edifício construído. A racionalidade e o pragmatismo americano tiveram papel importante.

Cria-se, nos EUA, um mercado de habitação organizado, onde articulavam-se incorporadores, construtores, arquitetos, fabricantes de materiais de construção e de objetos de consumo para a casa, fabricantes de eletrodomésticos, bancos, museus, revistas, o governo. Esse mercado ajudou muito na manutenção da atividade produtiva em níveis elevados. Condições inexistentes no Brasil.

Visualmente, as características são mais fáceis de reconhecer do que no Brasil.

Aqui, no entanto, apesar dessa "colagem," acaba existindo um discurso mais sofisticado, que inclui spaciousness, vistas, integração, totalidade, método orgânico de projeto. Mesmo com algumas colocações um tanto forçadas, ele fala ao leitor de forma mais complexa. Tenta-se mudar seu gosto e suas preferências, mas procurase fornecer instrumentos para julgar. São lições de moderno, com aulas de estética.

O conteúdo vai além das referências ao moderno americano, como dissemos. No primeiro editorial de Casa e Jardim, mencionam-se as novas técnicas construtivas, o "equilíbrio dos ambientes e as linhas claras e nítidas." (REICHENBACH, 1953, p.6) Seria uma evolução compartilhada pelos arquitetos, ao ajudar a "moldar o moderno semblante do Brasil (...) fazendo surgir uma arquitetura peculiar brasileira (...)." 
Haveria muito por fazer pois seria muito menor o número de "construções belas, modernas e funcionais (do que de), construções velhas e de má aparência." (Ibid. p.6) E, essas moradias sem qualidade impeliam seus moradores para as ruas.

Modernização técnica, linguagem moderna e arquitetos. Ampliação do público do moderno. O lar como solução para questões sociais. São essas as questões nas quais a revista se propõe intervir.

Esperamos, caro leitor e cara leitora, que CASA E JARDIM se torne útil na construção e no embelezamento se seu lar e que the avive o interesse pelas realizações da moderna arquitetura brasileira (...). (REICHENBACH, 1953, p.7)

Existe todo um trabalho para esclarecer o público da revista, em relação a questões que vão dos condicionantes do projeto - escolha do lote, implantação, orientação solar, ventilação, etc. - à decoração dos ambientes. São apresentados desde detalhes técnicos da construção até plantas baixas ilustradas com desenhos para facilitar sua compreensão.

E surge esse lar moderno, funcional, feito sob medida para uma família de classe média viver com as alegrias e as questões mais prosaicas da vida cotidiana, como as tarefas diárias e o custo de vida.

A casa tem a justa medida, com ambientes multifuncionais, devidamente projetados, e os equipamentos e mobiliário necessários. Sob medida, para que cada membro da família possa levar sua vida autônoma, vivendo suas próprias experiências. Tudo isso faz dessa casa um lar único. Com "alma."

Cria-se um mundo somente nosso, que pode incluir uma natureza particular, no jardim. Ou este "invade" a casa, em jardineiras, vasos, grades, por onde se espalha a vegetação.

É relevante o presente, o individualismo, a subjetividade. A residência torna-se um sistema de vida, planejado para eles, por eles (...)."(VOCÊ...,1959, p.7)

Espaços para o prazer e para o consumo, sendo que a associação entre ambos estabelece-se, de forma definitiva, nessa época. Como algo insaciável, criam-se necessidades a serem satisfeitas. A casa nunca está realmente pronta, há sempre algo a ser comprado.

Assim, o consumo faz parte dessas experiências vividas através da casa. Ainda que o consumo se dê fora da casa, ela está diretamente associada a ele. 
Pois, em contraposição a esse lar onde é possível o cultivo da subjetividade, existe uma metrópole, ou ao menos um grande centro urbano, em meio a grandes transformações.

Nesse prazer do consumo está implícita, também, a eliminação das dificuldades da vida no mundo moderno, afastando os conflitos sociais. Segundo Tota (2000, p.19), esses são aspectos do americanismo, ${ }^{4}$ ao qual estão associadas a ideia de racionalidade, de transformação do mundo natural e de progresso. Que conduz ao desenvolvimento do capitalismo e da modernidade.

Possivelmente, o presidente bossa nova, Juscelino, o JK, represente melhor que tudo essa década de modernização brasileira. Ao menos é a percepção que temos desses anos dourados. Progressista, moderno, inovador, sorridente, otimista. É o construtor de Brasília, o homem do "plano de metas", que foi nome de automóvel e adorava dançar. E que abriu um pouco mais o Brasil a um mundo onde a hegemonia americana crescia.

Essa imagem, que traz o estilo de vida americano, foi cuidadosamente construída e teve forte impacto sobre a sociedade brasileira. Promoveram-se desde métodos e práticas, relativos aos negócios, até a cultura americana. ${ }^{5}$ Mas, segundo Haines (1989, p.6), a imagem dos EUA, que os brasileiros formaram, estava distorcida, era diversa da realidade. Seu padrão de vida material era desejado, pois os americanos eram vistos como ricos e poderosos.

Mas, apesar da imagem estereotipada, essa política americana foi bem sucedida e possibilitou influir nos caminhos que tomavam a modernização brasileira, em benefício dos EUA, e também angariar aliados na luta anticomunista.

A "americanização" é, no entanto, muito complexa. Não pode ser encarada, nem como o grande perigo que poderia destruir nossa cultura, nem como a panaceia que poderia livrar-nos do atraso econômico.

\footnotetext{
${ }^{4}$ Fenômeno político, ideológico e econômico, o americanismo, para Gramsci, é um modo de vida profundamente imbricado na esfera produtiva com o taylorismo e o fordismo - como mecanismo global de acumulação de capital. (BRAGA, p.12-13)

${ }^{5}$ Segundo Haines $(1989$, p.6), imagens preconceituosas, atitudes e estereótipos afetaram profundamente os esforços americanos para conduzir os negócios brasileiros. Americanos tinham a tendência a simplificar as referências e contextos culturais de outros países. A política americana foi formulada e projetada quase inteiramente baseada em imagens e mitos, sem atenção às diferenças de sensibilidade e culturas.
} 
E não se pode dizer que o Brasil simplesmente seguiu a "orientação" americana. Seu processo de desenvolvimento foi único, brasileiro, inclusive a industrialização. A arquitetura do "bem viver" é, também, uma experiência brasileira.

Não houve simplesmente uma recepção passiva, por parte dos brasileiros, mas uma interação entre a cultura americana e a brasileira, sem desintegração da nossa, mas produzindo-se novas formas de expressão. O mesmo acontece com a arquitetura.

Em uma análise superficial, já se percebe que não seria possível "copiar" todo um modo de pensar a arquitetura e a vida, como é o Good-Life Modernism, simplesmente porque não existiam as condições americanas aqui.

São, no entanto, pequenas "partes" dessa arquitetura que encontramos em nosso "bem viver." Tota (2000, p.193) lembra que um povo só incorpora um valor cultural de outro, se faz sentido em sua própria cultura. Não se trata simplesmente de imitação, mas de um processo de recriação. A assimilação cultural nunca ocorre em bloco. Um povo não aceita todos os elementos culturais do outro, mas apenas uma parte e, mesmo assim, atribuindo a ele novos sentidos.

Assim, o que realmente fazia sentido para nossa cultura, clima, contexto, foi apropriado e recriado no "bem viver," com outros elementos brasileiros, resultando em algo que tem referências americanas, mas que pode-se sentir como "brasileiríssimo." Nesta análise, existem alguns componentes que ainda não conseguimos apontar e analisar com profundidade, mas essa percepção nos leva a começar a descrever nosso objeto como "nosso 'bem viver'."

Só a título de reflexão, devemos lembrar que Elizabeth Mock elogia aspectos de nossa arquitetura, que ela conheceu melhor ao participar da elaboração da exposição e de editar o catálogo Brazil Builds, em 1943. Para ela, muitas das características modernas eram uma continuação das arquiteturas colonial e barroca dos séculos XVII e XVIII, inclusive o brise soleil, em suas qualidades estéticas e funcionais: "Por séculos, os brasileiros têm sombreado suas casas com varandas cobertas e grandes beirais, com treliças e venezianas." ${ }^{\prime 6}$ Em 1946, ela escreveu If you want to build a house. Algo se manteve, do que ela pesquisou para a exposição de 1943? Apenas conjecturas, para lembrarmos que referências podem acontecer nos dois sentidos.

Tota (2000) mostra um exemplo interessante, sobre assimilação cultural. Uma canção na voz de Carmem Miranda, mesmo em inglês, mantém sua irreverência, de

\footnotetext{
${ }^{6}$ MOCK, Elizabeth. Travel, p.29, jun.1943 apud QUEZADO DECKKER, 2001, p.149
} 
certa forma resistindo à americanização. Apesar de se comentar justamente o contrário. "Americanizar" era visto com muitas reservas.

Em outras áreas, também percebia-se, na cultura americana, suas limitações:

Esperamos que, aproveitando o que temos de bonito e regional, nos deem futuramente, coisas úteis e agradáveis, sem copiar o exagero dos americanos que são como suas comidas: lindas para os olhos, "miseráveis" para os paladares ... (OBRIGADO!..., 1953, p.2)

E, o que é aparentemente igual, na verdade, guarda muitas diferenças. Podemos olhar para duas casas mostradas, ${ }^{7}$ que apresentam muitas semelhanças à primeira vista, como a cobertura pouco inclinada, em duas águas, o pé direito baixo, a marcada horizontalidade pontuada por elementos verticais. Ambas utilizam, ainda, tijolos aparentes. Foram fotografadas com um automóvel na garagem.

Mas, se começarmos a analisar melhor, vemos mais diferenças do que semelhanças. A casa brasileira foi construída provavelmente pelo proprietário ou comprada diretamente do construtor, mas, em todo caso, é única. Enquanto a americana, faz parte de um conjunto com várias habitações, executadas por um incorporador. As diferenças no arranjo espacial, mais óbvias, são o provável dormitório e banheiro de empregada, no exemplar brasileiro, possivelmente localizados na edícula, acompanhados de um quarto de despejo e um local para o tanque. ${ }^{8} \mathrm{Na}$ casa americana, em contrapartida, a racionalização do espaço é milimétrica e nada é "desperdiçado." Existe apenas uma lavanderia pequena, "taylorizadamente" planejada, para que as tarefas domésticas sejam desempenhadas da melhor forma, com o mínimo esforço.

Podemos cogitar por que os exemplares são iguais. Será que o proprietário da casa brasileira viu e fez igual? O fato de haver sido publicada depois, não quer dizer que a casa brasileira seja mais nova. Era uma tipologia comum? Ou a revista Casa e Jardim procurou um exemplar desse tipo - lembremos que ela se apropriava dessas habitações de "carne e osso," para criar seu modelo e "ensinar." Talvez o editor tenha visto a capa de House \& Home ou a Life. ${ }^{9}$ Achou que era relevante, encontrou a casa do Brooklyn e, eis que surge a "casa do 'morar bem'."

\footnotetext{
${ }^{7}$ Casa da capa da revista House \& Home, de junho de 1954, mostrada na p.261 deste trabalho, e foto que inicia o capítulo 2, a casa do "morar bem," na p.82, publicada em 1958.

${ }^{8}$ Para a lavagem de algumas peças de roupa pois, provavelmente, a maior parte era lavada fora da casa.

${ }^{9}$ Do mesmo grupo, que publicava às vezes as mesmas casas.
} 
Ou a casa teve como modelo um exemplar de um arquiteto moderno brasileiro que "inspirou-se" na arquitetura americana.

Logicamente, não importa para nós elucidarmos esta questão. Essa reflexão serve para pensarmos que referências, "influências," modelos são questões muito mais complexas. E, muito mais prosaicas, como as hipóteses que levantamos.

Uma última consideração é possível. Sobre esse discurso definido, mais "profissional," americano, ligado ao "negócio da construção," incentivado pelo governo, fundamental na economia do pós-guerra.

Mas, negócio da construção de habitações? A casa como bem de consumo, com obsolescência programada. Podemos refletir sobre esse tema à luz, novamente, de algumas ideias desenvolvidas por Heidegger. O filósofo nos convida a refletir sobre nosso habitar no mundo e acreditamos que, muito do que se falou, pode ser analisado sob essa ótica. ${ }^{10}$

Ele nos diz que, ao contrário do que pensamos, o construir já é em si mesmo habitar, pois, o homem é, à medida que habita. Desta forma, habitar é o traço fundamental da existência humana, uma experiência que não mais experimentamos.

A essência do habitar seria permanecer apaziguado, ser e permanecer em paz. Resguardado. Construindo a si mesmo, entregue à sua própria essência.

Mas, o que é estar entregue à sua própria essência?

Significa permanecer sobre esta terra, sob o céu, junto aos homens e perante os deuses. Pois, os quatro, terra e céu, divinos e mortais, formavam uma unidade originária, a que chamamos quadratura.

No verdadeiro habitar, refaz-se a unidade originária, ela é resguardada em seu vigor de essência. Habita-se, por exemplo, à medida que salva-se a terra - no sentido de a deixar livre em seu próprio vigor. Nem assenhorar-se nem submeter-se a ela. Ou quando os mortais cuidam e cultivam o campo vivo e edificam com materiais.

Mas, Heidegger nos diz que habitar é bem mais. É um demorar-se junto às coisas, mas estas não fazem parte da quadratura.

\footnotetext{
${ }^{10}$ HEIDEGGER, Martin. Construir, Habitar, Pensar (Bauen, Wohnen, Denken) (1951) Conferência proferida por ocasião da "Segunda Reunião de Darmastad." A ideia principal da conferência é redefinir a ideia de espaço a partir do homem e fazer desse espaço humano o princípio orientador da arquitetura. Não pretendemos fazer uma análise desse texto, mas apenas nos valermos de suas reflexões para pensarmos essa "ideia" de habitação que se constitui no pós-guerra, a casa pragmática. Assim, apresentaremos apenas algumas de suas colocações. No texto, como são várias referências iguais, colocamos apenas o ano e a página.
} 
Habitar é viver esse núcleo originário, mas aberto às coisas e residindo junto a elas. Esse guardar e proteger é construir. Assim, construindo, já estamos habitando.

A "quadratura se resguarda à medida que leva para as coisas o seu próprio vigor de essência." (1951, p.4) Quando os mortais protegem e cuidam das coisas ou cultivam e edificam, estão construindo.

E o que seria uma coisa construída? Heideggger usa a ponte, como exemplo, que reordena o que existia e permite descobrir as coisas ao seu redor, "criando" a paisagem. A ponte aglutina, "à sua maneira" o núcleo de terra, céu, mortais e imortais, cumprindo uma "reunião integradora" (1951, p.5) junto a si, de um modo particular, mas sempre como coisa, que foi construída pelo homem.

Ao invés da ponte, podemos tentar pensar a habitação, onde o homem permanece abrigado, não apenas nela, mas junto a ela, unindo gerações.

A ponte reúne e integra a quadratura e lhe propicia estância e circunstância. A partir dessa circunstância, determinam-se os lugares. O lugar onde o homem pode demorar-se, integrado na unidade da quadratura. A dimensão temporal está presente também, quando se "cria" a circunstância. ${ }^{11}$

Apenas outra questão que se relaciona especificamente à casa - o espaço. A distância entre os lugares determinados pela ponte pode ser fixada como simples intervalos mensuráveis entre posições - o spatium. A partir dele, extraem-se as relações de largura, altura e profundidade, como na casa, ou dimensionam-se as coisas, segundo intervalos e direções, que podem ser aplicados de modo universal. Mas, "não justifica que os números das medidas e das dimensões constituam $o$ fundamento da essência dos espaços e lugares, dimensionados através do matemático.(...).” (1951, p.7)

"Construir é edificar lugares.(...) Assim é que, por produzir coisas como lugares, o construir está mais próximo da essência dos espaços e da proveniência essencial "do" espaço do que toda geometria e matemática." (1951, p.8)

E, "coisas construídas com autenticidade marcam a essência dando moradia a essa essência."(p.9) O que é construído dessa forma é um deixar-habitar privilegiado.

Heidegger nos faz pensar em uma casa camponesa de duzentos anos atrás, que um habitar camponês ainda sabia construir, na encosta da montanha, ao abrigo dos

\footnotetext{
${ }^{11}$ Estância=espaço; circunstância= tempo.
} 
ventos e do sol forte, próxima à fonte, capaz de suportar chuvas e neve. Sob esse mesmo teto, as várias gerações se abrigam ao longo do tempo. Preparando a vida e depois a morte em um ciclo que se repete.

Heidegger não quer dizer que se deva, ou mesmo que seja possível, construir dessa forma. Ele apenas aponta que "o habitar foi capaz de construir." (1951, p.10) Para ele, já seria muito bom se "habitar e construir tornarem-se dignos de se questionare, assim, permanecerem dignos de se pensar." (1951, p.10)

Termina aqui nossa conclusão, que não conclui. Finalizamos a tese, mas esperamos haver deixado algo para se pensar.

Acreditamos que há muito ainda por ser estudado em relação a nosso objeto, mas cremos que essa é a ideia contida em uma tese: indicar caminhos para o próprio pesquisador e para outros, assim como essa pesquisadora seguiu caminhos para chegar até aqui. 


\section{Referências}

- ÁBALOS, Iñaki. La buena vida: visita guiada a las casas de la modernidad. Barcelona: Editorial Gustavo Gili, c2000.

- $\quad$ ACAYABA, M. M. Branco e preto: uma história do design brasileiro nos anos 50. São Paulo: Instituto Lina Bo e P. M. Bardi, 1994.

- ACAYABA, M. M. Residências em São Paulo: 1947-1975. São Paulo: Romano Guerra Editora, 2011.

- ALOFSIN, Anthony American Modernism's Challenge to the Beaux Arts. 2012. In: OCKMAN, Joan (ed.) Architecture School: Three Centuries of educating Architects in North America. Cambridge, Mass., London: The MIT Press, 2012, p. 90-119.

- $\quad$ ARANTES, Otília Beatriz Fiori Lúcio Costa e a "Boa Causa" da Arquitetura Moderna. In: ARANTES, Otília Beatriz Fiori. Sentido da formação: três estudos sobre Antônio Cândido, Gilda de Mello e Souza e Lúcio Costa. Rio de Janeiro: Paz e Terra, 1997.

- AVERMAETE, Tom Another Modern: the Post-war Architecture and Urbanism of Candilis-Josic-Woods. Rotterdam: NAi Publishers, 2005.

- AYMONINO, Carlo Vivienda racional: ponencias de los congressos ciam 19291930. Barcelona: Gustavo Gili, 1973.

- BEHNE, Adolf 1923: La construcción funcional moderna. Barcelona: Demarcatión de Barcelona del Colegio de Arquitectos de Cataluña e Ediciones del Serbal.1994.

- BEHRENDT, Walter Curt Arquitectura moderna: su naturaleza, sus problemas y formas. Buenos Aires: Infinito, 1959.

- BELLUSCHI, Pietro The Meaning of Regionalism in Architecture. In: CANIZARO, Vincent B. (ed.) Architectural Regionalism: Collected Writings on Place, Identity, Modernity, and Tradition. Nova York: Princeton Architectural Press, 2007, p.321-325. Originalmente publicado em 1955.

- BLAU, Eve The Architecture of Red Vienna, 1919-1934. Cambridge: Mass MIT Press, c1999.

- BLOMFIELD, Reginald Modernismus (1934). In: BENTON, Tim; BENTON, Charlotte ; SHARP, Dennis (ed.). Form and Function: a source book for the History of architecture and design 1890-1939. London: Crosby Lockwood Staples, 1975, p.175178.

- BOYLE, Bernard Michael Architectural Practice in America, 1865-1965 - Ideal and Reality. In: KOSTOF, Spiro (ed.) The Architect: Chapters in the History of the Profession. New York; Oxford: Oxford University Press, 1986. c.1977, p.309-344

- BRAGA, Ruy Introdução. In: GRAMSCI, Antônio. Americanismo e Fordismo. São Paulo: Hedra, 2008. 
- BRASIL, Luciana Tombi David Libeskind: ensaio sobre as residências unifamiliares. São Paulo: Romano Guerra Editora; Edusp, 2007.

- $\quad$ BRUAND, Yves Arquitetura contemporânea no Brasil. São Paulo: Editora Perspectiva, 2005.

- CALABI, Donatella História da arquitetura e história da cidade: um casamento difícil. Entrevista a RETTO JR., Adalberto da Silva; BOIFAVA, Barbara. Disponível no site www.vitruvius.com.br, jul/ago/set 2003, ano 4, vol. 15, p. 018.

- CANIZARO, Vincent B. Introduction. In: CANIZARO, Vincent B. (ed.) Architectural Regionalism: Collected Writings on Place, Identity, Modernity, and Tradition. Nova York: Princeton Architectural Press, 2007, p.16-33.

- CANTERO, Francisco Arte e Técnica da Imprensa no Brasil: Teoria e Prática. São Paulo: Editoria Jornal dos Livros, 1971

- CARVALHO, Vânia Carneiro de Gênero e Artefato: o Sistema Doméstico na Perspectiva da Cultura Material - São Paulo, 1870-1920. São Paulo:

EDUSP/FAPESP, 2008.

- CLARKE, Alison J. Tupperware: Suburbia, sociality and mass consumption. In: SILVERSTONE, Roger Visions of Suburbia. London u.a.: Routledge, 2007, p. 132160.

- COHEN, Jean-Louis Architecture in Uniform: Designing and Building for the Second World War. Montreal e Paris: CCA e Editions Hazan, 2011.

- COHEN, Jean-Louis. The Future of Architecture since 1889. London: Phaidon, 2012.

- COLOMINA, Beatriz Domesticity at war. Cambridge: MIT Press, c2007.

- COLOMINA, Beatriz Privacy and Publicity: Modern Architecture as Mass Media. Cambridge: Mass. MIT Press, 1994.

- COLOMINA, Beatriz. Media as Modern Architecture. In: VIDLER, Anthony (ed.) Architecture between spectacle and use. Williamstown, Mass: Sterling and Francine Clark Art Institute, 2008, p.58-73.

- COLQUHOUN, Alan Critica e autocritica del moderno. In: DE MICHELIS, Marco (org.) Espressionismo e Nuova Oggettività. La nuova architettura europea degli anni Venti. Milano: Electa, 1994.

- COLQUHOUN, Alan Critique of Regionalism. In: CANIZARO, Vincent B. (ed.) Architectural Regionalism: Collected Writings on Place, Identity, Modernity, and Tradition. Nova York: Princeton Architectural Press, 2007a, p.141-145. Originalmente publicado em 1996.

- COLQUHOUN, Alan Essays in architectural criticism: modern architecture and historical change. Cambridge: MIT Press, 1985, c1981.

- COLQUHOUN, Alan Modern Architecture. Oxford: Oxford University Press, 2002

- COLQUHOUN, Alan Modernidade e Tradição Classica: Ensaios sobre Arquitetura, 1980-1987. São Paulo: Cosac \& Naify, 2004. 
- COLQUHOUN, Alan The Concept of Regionalism. In: CANIZARO, Vincent B. (Ed.) Architectural Regionalism: Collected Writings on Place, Identity, Modernity, and Tradition. Nova York: Princeton Architectural Press, 2007b, p.147-155. Originalmente publicado em 1997.

- CRESPO, Raúl Arnaldo Gomez e COVA, Roberto Osvaldo Arquitectura Marplatense: El Pintoresquismo. Resistencia: Editorial del Instituto Argentino de Investigaciones de Historia de la Arquitectura y del Urbanismo, 1982.

- CROMLEY, Elizabeth Domestic Space Transformed, 1850-2000. In: BALLANTYNE, Andrew (Ed.) Architectures: Modernism and After. Malden, MA: Blackwell Pub., 2004, cap. 7, p.163-201.

- CROSS, Gary. The Suburban Weekend: Perspectives on a vanishing twentiethcentury dream. In: SILVERSTONE, Roger Visions of Suburbia. London u.a.: Routledge, 2007, p.108-131.

- CURTIS, William J. R. Modern architecture since 1900. London Phaidon, 1996

- DE CARLO, G. "Memoria sui contenuti dell'architettura moderna." In: DE CARLO, G. Questioni di architettura e urbanística. Santarcangelo di Romagna (RN): Maggioli Editore, 2008. Texto apresentado no último Congresso internacional de Arquitetura Moderna, outubro, 1959.

- DE MICHELIS, Marco (org.) Espressionismo e Nuova Oggettività. La nuova architettura europea degli anni Venti. Milão: Electa, 1994.

- DREXLER, Arthur Engineer's Architecture: Truth and its Consequences. In: Drexler, Arthur (ed.) The Architecture of the École des Beaux-Arts. Londres: Secker \& Warburg, 1977b, p.13-59.

- DREXLER, Arthur Preface and Acknowledgments. In: Drexler, Arthur (ed.) The Architecture of the École des Beaux-Arts. Londres: Secker \& Warburg, 1977a, p.6-10.

- ECO, Umberto Como se faz uma tese. São Paulo: Perspectiva, 2004.

- EGGENER, Keith L. Placing Resistance; A Critique of Critical Regionalism. In: CANIZARO, Vincent B. (ed.) Architectural Regionalism: Collected Writings on Place, Identity, Modernity, and Tradition. Nova York: Princeton Architectural Press, 2007, p. 395-407. Publicado originalmente em 2002.

- $\quad$ FAIRBANKS JÚNIOR, Douglas O papel das Artes na América. Rio de Janeiro: Instituto Brasil-Estados Unidos, s.d.

- FERRAZ, Geraldo Warchavchik e a introdução da nova arquitetura no Brasil: 1925-1940. São Paulo : Museu de Arte, 1965.

- FICHER, Sylvia Os Arquitetos da Poli: Ensino e Profissão em São Paulo. São Paulo: EDUSP, 2005.

- FRAMPTON, Kenneth Ten Points on an Architecture of Regionalism: A Provisional Polemic. In: CANIZARO, Vincent B. (ed.) Architectural Regionalism: Collected Writings on Place, Identity, Modernity, and Tradition. Nova York: Princeton Architectural Press, 2007, p.375-385. Publicado originalmente em 1987.

- FULLAONDO BUIGAS DE DALMAU, María Casas en el jardín del MOMA: La consolidación de un museo. Barcelona: Fundación Caja de Arquitectos, 2010. 
- GARCÍA ROIG, José Manuel Heinrich Tessenow: pensamiento utópico, germanidad, arquitectura. Valladolid: Universidad de Valladolid, Secretariado de Publicaciones e Intercambio Editorial, 2002.

- GIDDENS, Anthony The Consequences of Modernity. Cambridge: Polity Press, 1990.

- GIEDION, Siegfried Mechanization takes command: a contribution to anonymous history. New York: Norton, 1969.

- GIEDION, Sigfried The New Regionalism. In: CANIZARO, Vincent B. (ed.) Architectural Regionalism: Collected Writings on Place, Identity, Modernity, and Tradition. Nova York: Princeton Architectural Press, 2007, p.311-319. Publicado originalmente em 1958.

- GINZBURG, Carlo "Controlando a evidência: o juiz e o historiador". In: NOVAIS, Fernando Antônio e SILVA, Rogério Forastieri (ed.) Nova história em perspectiva. São Paulo: Cosac Naify, 2011, vol.1.

- GOMES, Ângela de Castro "A Política Brasileira em busca da Modernidade: na Fronteira entre o Público e o Privado." In: SCHWARCZ, Lilia Moritz (org.) e NOVAIS, Fernando A. (coord.). História da Vida Privada no Brasil: Contrastes da Intimidade Contemporânea. São Paulo: Companhia das Letras, 2012, p.489-558.

- GROPIUS, Walter "Eight Steps toward a Solid Architecture". (1954a) In: OCKMAN, Joan; EIGEN, Edward Architecture culture, 1943-1968: a documentary anthology. New York: Columbia University Graduate School of Architecture, Planning, and Preservation, Rizzoli,1993, p.177-180 (1954a)

- GROPIUS, Walter Bauhaus: Novarquitetura. São Paulo: Perspectiva, 1988

- HAINES, Gerald K. The Americanization of Brazil: A Study of U.S. Cold War Diplomacy in the Third World, 1945-1954. Wilmington, Del.: SR Books, 1989.

- HINE, Thomas The Search for the Postwar House. In: SMITH, Elizabeth A.T. Blueprints for Modern Living: History and Legacy of the Case Study Houses. Los Angeles: Museum of Contemporary Art, c1989. Cambridge, Mass: MIT Press, p.167182.

- ISENSTADT, Sandy The Modern American House: Spaciousness and MiddleClass Identity. New York: Cambridge University Press, 2006

- JACKSON, NEIL Pierre Koenig: 1925-2004. Living with Steel.Köln, Alemanha: Taschen, 2007.

- KLEIN, Alexander Vivienda Mínima: 1906-1957. Barcelona: Gustavo Gili, 1980.

- KREISMAN, Lawrence e MASON, Glenn The Arts and Crafts Movement in the Pacific Northwest. Portland: Timber Press, 2007

- LANE, Bárbara Miller. Architecture and Politics in Germany, 1918-1945. Cambridge and London: Harvard University Press, 1985 (1968).

- LEVINE, Neil The Romantic Idea of Architectural Legibility: Henri Labrouste and the Neo-Grec. In: Drexler, Arthur (ed.) The Architecture of the École des Beaux-Arts. Londres: Secker \& Warburg, 1977, p.325-416. 
- LEWIS, Mumford Excerpts from The South in Architecture. In: CANIZARO, Vincent B. (ed.) Architectural Regionalism: Collected Writings on Place, Identity, Modernity, and Tradition. Nova York: Princeton Architectural Press, 2007, p.97-101.

- LIRA, José Tavares Correia de História e cultura estudantil: revistas na USP. São Paulo: Edusp; CPC, 2012.

- MARTINS, Carlos A. Ferreira Martins Gregori Warchavchik: combates pelo futuro. Introdução. In: WARCHAVCHIK, Gregori Arquitetura do século XX e outros escritos. São Paulo: Cosac Naify, 2006, p.11-29.

- MCCOY, Esther Case Study Houses, 1945-1962. Los Angeles: Hennessey \& Ingalls, 1977.Segunda edição.

- MELLO, João Manuel Cardoso de; NOVAIS, Fernando A. Capitalismo Tardio e Sociabilidade Moderna." In: SCHWARCZ, Lilia Moritz (org.) e NOVAIS, Fernando A. (coord.). História da Vida Privada no Brasil: Contrastes da Intimidade Contemporânea. São Paulo: Companhia das Letras, 2012, v.4, p.559-658.

- MOCK, Elizabeth B. If you want to build a house. New York: The Museum of Modern Art, 1946.

- MORRISON, Hugh S. After the International Style-What? In: CANIZARO, Vincent B. (ed.) Architectural Regionalism: Collected Writings on Place, Identity, Modernity, and Tradition. Nova York: Princeton Architectural Press, 2007, p.281-287. Publicado originalmente em 1940.

- MOURA, Gerson Tio Sam chega ao Brasil: a penetração cultural Americana. São Paulo: Brasiliense, 1986.

- MUMFORD, Eric. The CIAM Discourse on Urbanism, 1928-1960. Cambridge e Londres: The MIT Press, 2000.

- MUMFORD, Lewis Technics and civilization. New York: Harcourt, Brace and company, c1934

- MUMFORD, Lewis A Backward Glance. In: MUMFORD, Lewis (ed.) Roots of contemporary American architecture: a series of thirty-seven essays dating from the mid-nineteenth century to the present. New York: Reinhold, 1952, p.1-30.

- MUMFORD, Lewis The Sky Line: Status Quo. In: CANIZARO, Vincent B. (ed.) Architectural Regionalism: Collected Writings on Place, Identity, Modernity, and Tradition. Nova York: Princeton Architectural Press, 2007, p.289-291. Originalmente publicado em 1947.

- NESBITT, Kate (Org.) Uma nova agenda para a arquitetura: antologia teórica (1965-1995). São Paulo: Cosac Naify 2008

- O'GORMAN James F. Neff and Neutra: Regionalism versus Internationalism. In: CANIZARO, Vincent B. (ed.) Architectural Regionalism: Collected Writings on Place, Identity, Modernity, and Tradition. Nova York: Princeton Architectural Press, 2007, p.215-221. Originalmente publicado em 1989.

- OCKMAN, Joan Architecture culture, 1943-1968: a documentary anthology. New York: Columbia University Graduate School of Architecture, Planning, and Preservation; Rizzoli, 1993 
- OCKMAN, Joan "Toward a Theory of Normative Architecture". In: HARRIS, Steven; BERKE, Deborah Architecture of the everyday. New York: Princeton Architectural Press, c1997, p.122-152.

- OCKMAN, Joan Mirror Images: Technology, consumption, and the representation of gender in American architecture since World War II. In: EGGENER, Keith L.

American Architectural History: A Contemporary Reader. London e New York: Routledge, 2004, p.342-351.

- OCKMAN, Joan; SACHS Avigail Modernism takes Command. In: OCKMAN, Joan (ed.) Architecture School: Three Centuries of educating Architects in North America. Cambridge, Mass., London: The MIT Press, 2012, p. 120-159.

- OCKMAN, Joan. Foreword. In: AVERMAETE, Tom Another Modern: the Post-war Architecture and Urbanism of Candilis-Josic-Woods. Rotterdam: NAi Publishers, 2005, p.8-9.

- OZKAN, Suha Regionalism with Modernism. In: CANIZARO, Vincent B. (ed.) Architectural Regionalism: Collected Writings on Place, Identity, Modernity, and Tradition. Nova York: Princeton Architectural Press, 2007, p.103-9. Originalmente publicado em 1985.

- PALLASMAA, Juhani 2007 Tradition and Modernity: The Feasibility of Regional Architecture in Post-Modern Society. In: CANIZARO, Vincent B. (ed.) Architectural Regionalism: Collected Writings on Place, Identity, Modernity, and Tradition. Nova York: Princeton Architectural Press, 2007, p.129-139. Publicado originalmente em 1988.

- PIGAFETTA Giorgio; ABBONDANDOLO Ilaria; TRISCIUOGLIO, Marco Architettura Tradizionalista: Architetti, Opere, Teorie. Milão: Jaca Book, 2002.

- POLAN, Dana. Power and Paranoia: History, Narrative and the American Cinema, 1940-1950. New York: Columbia University Press, 1986.

- POMMER, Richard e OTTO, Christian F. Weissenhof 1927 and the Modern Movement in Architecture. Chicago e Londres: The University of Chicago Press, 1991.

- QUEZADO DECKKER, Zilah Brazil built: the architecture of the modern movement in Brazil. London/New York: Spon Press, 2001

- REBECCHINI, M. II metodo del progetto nella tradizione del Movimento Moderno: scritti sull'architettura e la città. Roma: ESA, 1985.

- RENDEL, Jane (Ed.); PENNER, Barbara (Ed.); BORDEN, lain (Ed.) Gender Space Architecture: An Interdisciplinary Introduction. London e New York: Taylor \& Francis e-Library, 2003.

- RICHARDS, J M Introduccion a la arquitectura moderna. Buenos Aires: Infinito, 1959.

- RICE, Charles The Emergence of the Interior. Architecture, Modernity, Domesticity. London e New York: Routledge, 2007.

- RICHARDS, J.M. Towards a rational aesthetic. In: RICHARDS, J.M.; PEVSNER, Nikolaus; SHARP, Dennis (ed.) The anti-rationalists and the rationalists.

Oxford: Architectural, 2000. 
- ROSA, Joseph A Constructed View: The Architectural Photography of Julius Shulman. New York: Rizzoli International Publications, 1994.

- ROWE, Colin Manierismo y arquitectura moderna y otros ensayos

Barcelona: Gustavo Gili 1999. Obs: Os ensaios de Rowe foram escritos entre 1950 e 1956.

- SACHS, Avigail The Pedagogy of Prefabrication: Building Research at MIT in the Postwar. In: DUTTA, Arindam (ed.) A Second Modernism: MIT, Architecture, and the 'Techno-Social' Moment. Cambridge, Mass. e London: The MIT Press, 2013, p.226-251.

- SAIA, L. A fase heroica da arquitetura contemporânea brasileira já foi esgotada há alguns anos. In: XAVIER, A. F. M. Arquitetura Moderna Brasileira: depoimento de uma geração São Paulo: Abea, 1987, p.199-202. Publicado originalmente em 1954.

- SAIA, L. Da Arquitetura. Tese apresentada ao concurso para provimento da cadeira n.14, "Teoria da Arquitetura", da Faculdade de Arquitetura e Urbanismo da Universidade de São Paulo. São Paulo, 1957a.

- SAIA, L. Notas sobre a Evolução da Morada Paulista. Notas relacionadas com a Tectônica Demográfica de São Paulo. São Paulo: Editora Acrópole, 1957b.

- SCULLY JR., Vincent Arquitetura Moderna: a Arquitetura da Democracia. São Paulo: Cosac \& Naify, 2002.

- SCULLY JR., VINCENT J. The Shingle Style and the Stick Style: Architectural Theory and Design from Downing to the Origins of Wright. New Haven e Londres: Yale University Press, 1971 (1955)

- SEGAWA, Hugo; DOURADO, Guilherme Mazza Oswaldo Arthur Bratke. São Paulo: ProEditores 1997.

- SMITH, Elizabeth A.T. Introduction. In: SMITH, Elizabeth A.T. Blueprints for Modern Living: History and Legacy of the Case Study Houses. Los Angeles: Museum of Contemporary Art, c1989. Cambridge, Mass: MIT Press, p.13.

- SODRÉ, Nelson Werneck História da Imprensa no Brasil. Rio de Janeiro: Civilização Brasileira, 1966.

- SOLÀ - MORALES I RUBIÓ, Ignasi de Archeologia del moderno da Durand a Le Corbusier. Nova York: Torino U. Allemandi, 2005.

- SOLÀ-MORALES Rubió, Ignasi Eclecticismo y vanguardia. El caso de la Arquitectura Moderna en Catalunya. Barcelona: Gustavo Gili, 1980.

- SPECK, Lawrence W. Regionalism and Invention. In: CANIZARO, Vincent B. (ed.) Architectural Regionalism: Collected Writings on Place, Identity, Modernity, and Tradition. Nova York: Princeton Architectural Press, 2007, p.71-9. Originalmente publicado em Center: New Regionalism 3. (1987): 8-19.

- SPIGEL, Lynn. From Theatre to Space Ship: Metaphors of suburban domesticity in postwar America. In: SILVERSTONE, Roger Visions of Suburbia. London u.a.: Routledge, 2007, p.217-239.

- STEVENS, Garry $O$ círculo privilegiado: fundamentos sociais da distinção arquitetônica; tradução Lenise Garcia Corrêa Barbosa; revisão técnica Sylvia Ficher. Brasília: UNB, 2003. 
- STIRLING, James Regionalism and Modern Architecture. In: CANIZARO, Vincent B. (ed.) Architectural Regionalism: Collected Writings on Place, Identity, Modernity, and Tradition. Nova York: Princeton Architectural Press, 2007, p.327-330. Publicado originalmente em 1957.

- SUMMERSON, John A linguagem clássica da arquitetura. São Paulo: Martins Fontes, 2006.

- TAFURI, Manfredo e DAL CO, Francesco. Modern Architecture/1, Milão, Faber and Faber, 1979.

- TAFURI, Manfredo Projecto e Utopia: arquitectura e desenvolvimento do capitalismo. Lisboa: Presença, 1985.

- TAUT, Bruno. Costruire. La nuova edilizia abitativa. Bologna: Zanichelli Editore, 1983 (1927).

- TESSENOW, Heinrich La Costruzione della Casa. Milão: Edizioni Unicopli, 1999 (1909).

- THE MUSEUM OF MODERN ART What is Happening to Modern Architecture? In: CANIZARO, Vincent B. (ed.) Architectural Regionalism: Collected Writings on Place, Identity, Modernity, and Tradition. Nova York: Princeton Architectural Press, 2007, p.293-309.

- TOTA, Antônio Pedro O Imperialismo Sedutor: a Americanização do Brasil na época da Segunda Guerra. São Paulo: Companhia das Letras, 2000.

- VAN ZANTEN, David Architectural Composition at the Ecole des Beaux-Arts from Charles Percier to Charles Garnier. In: Drexler, Arthur (ed.) The Architecture of the École des Beaux-Arts. Londres: Secker \& Warburg, 1977, p.111-323.

- VON MOOS, Stanilslau Le Corbusler: Elementos of a Synthesis. Cambridge and London: The MIT Press, 1982

- WAIZBORT, Leopoldo. As Aventuras de Georg Simmel. São Paulo: Editora 34, 2000.

- WOLFF, Sílvia Ferreira Santos. Jardim América: O Primeiro Bairro-jardim de São Paulo e Sua Arquitetura. São Paulo: EDUSP, 2000.

- WRIGHT, Gwendolyn Building the Dream: a Social History of Housing in America. Cambridge, Mass. e London: The Mit Press, 1992.

- WRIGHT, Gwendolyn USA: Modern Architectures in History. London: Reaktion Books, 2008.

\section{Website}

<http://edificiojequitaia.blogspot.com.br/2009/07/antiga-sede-da-petrobras.html>. Acesso em: 18 Dez. 2013.

< http://www.greatbuildings.com/architects/Hugh_Stubbins.html/>. Acesso em: 07 Jan. 2014. 
$<$ http://www.docomomo-us.org/register/fiche/landis_gores_house>. Acesso em: 03 Jun. 2014.

<http://historicsurvey.lexingtonma.gov/lexareas/area_u.htm>. Acesso em: 23 Jun. 2014.

< http://www.fredericklawolmsted.com/ajdowning.htm>. Acesso em: 26 Ago. 2014.

< http://marcosocosta.wordpress.com/2010/12/24/entrevista-com-lygia-fernandes/>. Acesso em: 21 Nov. 2014.

\section{Trabalho de evento em suporte eletrônico}

- HEYNEN, Hilde. Modernity and domesticity. Tensions and contradictions. In: Savoirs de genre: quel genre de savoir?, 1., 2005, Sophia. Anais eletrônicos... Sophia: Réseau belge des etudes de genre, 2005. Disponível em: <http://www.anef.org/wpcontent/uploads/2014/04/Actes-colloque-Sophia-2005.pdf>. Acesso em: 30 Jun. 2014 p.101-113.

\section{Trabalho apresentado em evento}

- CONGRESSO BRASILEIRO DE ARQUITETOS, 4., 1954, São Paulo. Anais... São Paulo: I.A.B., 1954, 289 p.

- GROPIUS, Walter. O Arquiteto na Sociedade Industrial. In: CONGRESSO BRASILEIRO DE ARQUITETOS, 4., 1954, São Paulo. Anais .... São Paulo: I.A.B., 1954b, p. 25-32.

- PEREIRA, Antônio Botelho. A profissão do arquiteto. In: CONGRESSO BRASILEIRO DE ARQUITETOS, 4., 1954, São Paulo. Anais .... São Paulo: I.A.B., 1954, p.202206.

- PINHEIRO, Maria Lúcia Bressan; D'AGOSTINO, Mário Henrique Simão. A noção de pitoresco no debate cultural das primeiras décadas do século XX no Brasil. In: COLÓQUIO DE HISTÓRIA DA ARTE, 23., 2004, Rio de Janeiro. Anais...Rio de Janeiro: CBHA/UERJ/UFRJ, 2004, v.1, p. 339-351.

\section{Teses e dissertações}

- BUZZAR, Miguel Antonio João Batista Vilanova Artigas: elementos para a compreensão de um caminho da arquitetura brasileira, 1938-1967. 1996. Dissertação (Mestrado em Arquitetura e Urbanismo) - Faculdade de Arquitetura e Urbanismo, Universidade de São Paulo, São Paulo, 1996.

- CAMARGO, Mônica Junqueira de Princípios de Arquitetura Moderna na obra de 
Oswaldo Arthur Bratke. 2000. 187 f. Tese (Doutorado em Arquitetura e Urbanismo) - Faculdade de Arquitetura e Urbanismo, Universidade de São Paulo, São Paulo, 2000.

- FERRONI, Eduardo Rocha Aproximações sobre a obra de Salvador Candia. 2010. 308 f. Dissertação (Mestrado em Arquitetura e Urbanismo) - Faculdade de Arquitetura e Urbanismo, Universidade de São Paulo, São Paulo, 2008.

- IRIGOYEN DE TOUCEDA, Adriana Marta Da Califórnia a São Paulo: referências norte americanas na casa moderna paulista 1945-1960. 2005. Tese (Doutorado em Arquitetura e Urbanismo) - Faculdade de Arquitetura e Urbanismo, Universidade de São Paulo, São Paulo, 2005.

- JANJULIO, Maristela da Silva. Arquitetura Residencial Paulistana dos Anos 1920: Ressonâncias do Arts and Crafts? 2009. 394 f. Dissertação (Mestrado em Arquitetura e Urbanismo) - Escola de Engenharia de São Carlos, Universidade de São Paulo, São Carlos, 2009.

- MACHADO, Paula Merlino Casa e Jardim: a revista e a divulgação do ideário moderno na década de 1950. 2007. 202 f. Dissertação (Mestrado em Arquitetura e Urbanismo) - Faculdade de Arquitetura e Urbanismo, Universidade Federal do Rio de Janeiro, Rio de Janeiro, 2007.

- MARTINI, Silvia Rosana Modena O IBOPE, a opinião pública e o senso comum dos anos 1950: hábitos, preferências, comportamentos e valores dos moradores dos grandes centros urbanos brasileiros. (Rio de Janeiro e São Paulo). 2011. 340 f. Tese (Doutorado em Sociologia) - Instituto de Filosofia e Ciências Humanas, Universidade Estadual de Campinas, Campinas, 2011.

- MARTINS, Carlos Alberto F. Arquitetura e Estado no Brasil: elementos para uma investigação sobre a constituição do discurso moderno no Brasil; a obra de Lucio Costa 1924/1952. 1987. Dissertação (Mestrado em História) - Faculdade de Filosofia, Letras e Ciências Humanas, Universidade de São Paulo, São Paulo,1987.

- MEYER, Regina Maria Prosperi Metrópole e Urbanismo: São Paulo anos 50. 1991. Tese (Doutorado em Arquitetura e Urbanismo) - Faculdade de Arquitetura e Urbanismo, Universidade de São Paulo, São Paulo, 1991.

- PINHEIRO, Maria Lúcia Bressan Modernizada ou Moderna? A arquitetura em São Paulo, 1938-45. 1997. Tese (Doutorado em Arquitetura e Urbanismo) - Faculdade de Arquitetura e Urbanismo, Universidade de São Paulo, São Paulo, 1997.

- SILVA, Paula Rafaela da Ladies no Batente: A Representação do Trabalho Feminino na Revista Lady: a Companheira da Mulher (1956-1959). 2010. 157 f. Dissertação (Mestrado em História) - Faculdade de Filosofia e Ciências Humanas, Pontifícia Universidade Católica do Rio Grande do Sul, Porto Alegre, 2010.

\section{Conferências}

FAIRBANKS JR., Douglas. O Papel das Artes na América," fez parte de uma série "Lições da Vida Americana." Conferência proferida no auditório da Associação Brasileira de Imprensa, 2 de maio de 1941, Rio de Janeiro. 
HEIDEGGER, Martin. Construir, Habitar, Pensar (Bauen, Wohnen, Denken) (1951) Conferência proferida por ocasião da "Segunda Reunião de Darmastad", publicada em Vortäge und Aufsätze, G. Neske, Pfullingen, 1954. Disponível em:

<http://www.prourb.fau.ufrj.br/jkos/p2/heidegger_construir,\%20habitar,\%20pensar.pdf>. Acesso em: 25 Jun. 2014. Tradução de Marcia Sá Cavalcante Schuback

WIENER, Paul Lester. Uma nova era cultural para as Américas. Conferência proferida no Instituto Brasil-Estados Unidos, s.d., Rio de Janeiro.

\section{Artigos em Periódicos ${ }^{1}$}

- 82 Distinctive Houses from Architectural Record. New York: F.W. Dodge Corp., c1952.

- ABREU, João Clodomiro. O arquiteto não onera o custo da construção. Casa e Jardim, São Paulo, n.28, p.2-3 e 70, ago.1956. De uma série de entrevistas de Regina Zonta com arquitetos.

- A CAÇULA de nossa recreação caseira: Televisão. Casa e Jardim, São Paulo, n.11, p.22-26, nov./dez.1954.

- A CULTURA de morar. Casa e Jardim, São Paulo, n. 9, p.10-13 e 78, jul./ago.1954.

- A HABITAÇÃO num só piso. Casa e Jardim, São Paulo, n.13, p.20-24 e 67, mar./ abril 1955.

- A HOUSE with "emotional content." 82 Distinctive Houses from Architectural Record, New York, c1952, p.169-174.

- ALEXANDER, Henrique. Vamos alterar o projeto! Casa e Jardim, São Paulo, n.14, p. 5 e 62 , maio/jun. 1955.

- A PAISAGEM também influi no cenário da casa. Casa e Jardim, São Paulo, n. 29, p.26-28 e 30-31, set./out.1956.

- APRESENTAMOS. Casa e Jardim, São Paulo, n.1, p.5, mar./abr.1953.

- AQUI DORME UMA SENHORA. Casa e Jardim, São Paulo, n.50, p.48, mar.1959.

- $\quad$ AQUI DORME UM HOMEM. Casa e Jardim, São Paulo, n.50, p.47, mar.1959.

- AQUI DORMEM CRIANÇAS. Casa e Jardim, São Paulo, n.50, p.49, mar.1959.

- AQUI DORMEM OS PAIS. Casa e Jardim, São Paulo, n.50, p.50-52, mar.1959.

- ARCHITECTS turn merchant builders: produce a model community of well-designed houses. House \& Home, New York, v.6, n. 2, p. 88-93, ago.1952.

\footnotetext{
${ }^{1}$ Sempre que o nome do artigo estiver grafado em letras minúsculas, será assim reproduzido, pois consideramos essa a marca de algo moderno, descontraído, simples, como a revista Casa e Jardim define a linguagem moderna.
} 
- ARQUITETURA Libeskind. Casa e Jardim, São Paulo n.43, p.13-16 e 18-21, jun.1958.

- A SMALL HOUSE of impressive stature. 82 Distinctive Houses from Architectural Record, New York, c1952, p.316-319.

- AS NECESSIDADES reais dos moradores... Casa e Jardim, São Paulo, n.11, p.410, nov./dez.1954.

- A TRAditional House in the Modern Idiom. House \& Home, New York, v.1, n. 1, p.108-114, jan. 1952.

- BECKER, Alfredo Ernesto. Vamos alterar o projeto! Casa e Jardim, São Paulo, n.14, p.5 e 62, maio/jun. 1955.

- BERNARDES FILHO, Jovino. A decoração em Crise. Casa e Jardim, São Paulo n.43, p.2, jun.1958.

- BIANCHI; LANDERSET. Casa para quem? Casa e Jardim, São Paulo, n. 56, p.3-4 e 6 , set.1959

- BILL, Max. O arquiteto, a arquitetura, a sociedade. Habitat, São Paulo, n. 14, p.2728, jan./ fev. 1954.

- BRATKE, Oswaldo. A arte de bem projetar e bem construir: depoimento. (jan. 1988). São Paulo: Projeto, n. 106. Entrevista concedida a Hugo SEGAWA,

- CALLENDER, John Hancock. Six East and West Coast Houses. 82 Distinctive Houses from Architectural Record, New York, c1952, p.116-135.

- CAMPOBELO, Huberto. A Casa do Galo. Casa e Jardim, São Paulo, n. 27, p.12-17, jul.1956.

- CAMPOBELO, Humberto. Modernos Projetos. Casa e Jardim, São Paulo, n.41, p.46-51, mar./abr. 1958a.

- CAMPOBELO, Huberto. Meu apartamento. Casa e Jardim, São Paulo, n.42, p.1821, maio 1958b.

- CARNEIRO, Dulce G. proprietário, arquiteto, decorador, paisagista falam sobre uma casa. Casa e Jardim, São Paulo, n.39, p.22-33, nov./dez.1957.

- CASA com Rampa. Casa e Jardim, São Paulo, n.10, p. 36-37 e 74, set./out.1954.

- COM o mínimo de manutenção - o máximo de prazer. Casa e Jardim, São Paulo, n. 55, p.3, ago.1959.

- COMO DESENVOLVER o senso crítico do estilo. Casa e Jardim, São Paulo, n. 26, p.4-8 e 69. jun. 1956.

- COMO o nosso mundo particular modificou. Casa e Jardim, São Paulo, n. 52, p.8-9, maio 1959.

- COMO CONSTRUIR a nossa casa. Casa e Jardim, São Paulo, n. 4, p.8 e 66, set./ out.1953.

- COMPLETE a casa deixando entrar a natureza. Casa e Jardim, São Paulo, n.50, p.10-11, mar.1959. 
- CONFORTO Doméstico - Aspiração Coletiva de Nossos Dias. Casa e Jardim, São Paulo, n.51, p.88-89, abr. 1959.

- CONSELHOS e sugestões. Casa e Jardim, São Paulo, n.2, p.62-3, maio/jun.1953.

- CORNERSTONE for a New Magazine. House \& Home, New York, v.1, n. 1, p.107, jan.1952. Editorial.

- CRIVELLI, Vilma. Graça na magnitude, encanto no detalhe. Casa e Jardim, São Paulo, n. 14, p.16-18 e 20-22, maio/jun. 1955a.

- CRIVELLI, Vilma. O ambiente que os jovens desejam. Casa e Jardim, São Paulo, n.18, p.22-23 e 71 , out.1955b.

- CRIVELLI, Olga Meraviglia. Dê aos seus Filhos o seu Próprio Mundo." Casa e Jardim, São Paulo n. 52, p.10-12, maio 1959. ${ }^{2}$

- DEAR subscriber. House \& Home, New York, v.1, n. 5, p.101, maio 1952. Editorial.

- DECORAÇÃO a serviço do conforto. Casa e Jardim, São Paulo, n.41. p.10-14, mar./abr.1958.

- DENBY, Elaine. Para principiantes. Casa e Jardim, São Paulo, n. 43, p.8, jun.1958.

- DESCANSO na represa de Santo Amaro. Casa e Jardim, São Paulo, n. 51, p.18-23, abr.1959.

- DO RASCUNHO à planta final. Casa e Jardim, São Paulo, n. 25, p.2-5 e 68, maio 1956.

- DORCA. Passeio na llha Porchat. Casa e Jardim, São Paulo, n 29, p.21-25 e 90, set./out.1956.

- DORCA. Arquitetura Contemporânea. Casa e Jardim, São Paulo, n. 49, p.10-15, fev.1959.

- DUTRA, Neli. Linhas e Horizontes sob o céu da Bahia. Casa e Jardim, São Paulo n.30, p.16-20, nov.1956.

- EGÊ. Mais vale um móvel autêntico do que dez imitações. Casa e Jardim, São Paulo, n.28, p.22-28, ago.1956.

- EM TERRENO mais ou menos quadrangular. Casa e Jardim, São Paulo, n.5, p.1015, nov./dez.1953.

- EVITE estragar a aparência de sua casa. Casa e Jardim, São Paulo, n.1, p.26-27, mar./abr. 1953.

- EVOLUÇÃO. A CASA. Rio de Janeiro, ano XXIV, n. 9-10, set./out. 1945.

- FEIRA NACIONAL de Utilidades Domésticas. Casa e Jardim, São Paulo, n.52, p.8485, maio 1959.

- FEIRA NACIONAL DE Utilidades Domésticas: uma realização a serviço do conforto humano. Casa e Jardim, São Paulo, n.53, p.80-81, jun. 1959.

\footnotetext{
${ }^{2} \mathrm{O}$ nome dessa autora às vezes aparece como Olga Meraviglia Crivelli, outras como Olga Meraviglia.
} 
- FERRAZ, Geraldo. Novos valores na arquitetura moderna brasileira. Habitat, São Paulo, n.45, p.21-36, nov./ dez.1957.

- FIGUEIREDO, Nestor E. O V Congresso Pan-Americano de Arquitetos. Arquitetura e Urbanismo, ano V, n.?, p.91-?, mar./abr. 1940.

- FRAMPTON, Kenneth. Prospects for a Critical Regionalism. Perspecta, New Haven, V. 20,1983 , p. 147-162.

- GALEAZZI, Ítalo. Mies van der Rohe no Brasil. Projeto para o Consulado dos Estados Unidos em São Paulo, 1957-1962. Arquitextos, São Paulo, 05.056, Vitruvius, jan 2005. Disponível em <http://www.vitruvius.com.br/revistas/read/arquitextos/05.056/511>. Acesso em 04 Jun. 2013.

- GYGAS, Théo. Casa e Jardim entra no seu $3^{0}$ ano. Casa e Jardim, São Paulo, n.13, p.2-3, mar./ abr. 1955. Editorial.

- GRABOWSKI, Myeczyslaw. Myeczyslaw Grabowski. Casa e Jardim, São Paulo, n.34, p.28-33, abr.1957.

- HEDVIG, Aurélio. O Lar Funcional. Casa e Jardim, São Paulo, n.5, p.20-24, nov./dez.1953.

- HOME Show House. House \& Home, New York, v.V, n.6, p.146-153, jun.1954.

- HOOKWAY, Ray H. Novas Aventuras em Cores. Casa e Jardim, São Paulo, n.1, p.14-15, mar./abr.1953.

- HOUSE designed for a magazine cliente. 82 Distinctive Houses from Architectural Record, New York, c1952, p.104-109.

- HOUSE IN Andover, Massachusetts. 82 Distinctive Houses from Architectural Record, New York, c1952, p.195-199.

- HUBERTO ${ }^{3}$. a casa do 'morar bem.' Casa e Jardim, São Paulo, n.45, p.52-55, ago. 1958.

- HUBERTO. Na Serra da Cantareira. Casa e Jardim, São Paulo, n.48, p. 18-23, jan.1959a.

- HUBERTO. A Vivenda da Harmonia. Casa e Jardim, São Paulo, n.51, p.36-43, abr.1959b.

- IJJASZ, llona Murcia. El desarrollo del espacio doméstico en Bogotá en el siglo XX: un reflejo de la construcción de la identidad local. dearq 07. ISSN 20113188. Bogotá, p. 18-35. Dez.2010. Disponível em <http://dearq.uniandes.edu.co>

- IV CONGRESSO Pan-Americano de Arquitetos. Architectura e Construcções, São Paulo, v.I, n.12, p. 3-7, jul. 1930.

- JACKSON, Edwina. A casa que surgiu do nada. Casa e Jardim, São Paulo, n.10, p.10-14, set./ out. 1954.

\footnotetext{
${ }^{3}$ Esse autor, algumas vezes, aparece apenas como Huberto, outras como Huberto Campobelo e outras, ainda, como Humberto Campobelo.
} 
- JARDIM de real originalidade. Casa e Jardim, São Paulo, n.14, p.46-49, maio/jun. 1955.

- JAZOMBERG, Mark "Good Life Modernism" and Beyond. The American House in the 1950s and 1960s: A Commentary. The Cornell Journal of Architecture. Ithaca, Nova York: Cornell University, 1991.

- JEAN, Yvonne. O bom gosto não depende do espaço. Casa e Jardim, São Paulo, n.31, p.32-37, dez.1956.

- LEVI, Rino. Vamos alterar o projeto! Casa e Jardim, São Paulo, n.14, p.4, maio/jun.1955.

- LOTUFO, Zenon. Arquiteto dos deuses, arquiteto dos Reis, Arquiteto dos Homens? Casa e Jardim, São Paulo, n.30, p.2-3 e 85, nov.1956. Entrevista à Regina Zonta.

- LOUREIRO, Betina; LOUREIRO, Hélio. Porque souberam persistir eles encontraram o terreno ideal. Casa e Jardim, São Paulo, n. 49, p.4-6, fev. 1959.

- LUCCAS, Luis Henrique Haas. La arquitectura moderna brasileña en los años cincuenta: entre el modelo corbusiano-carioca en declive y las alternativas en ascenso. APUNTES, Bogotá, Colômbia, v. 23, n. 1, p.32-45, jan. / jun. 2010. ISSN 1657-9763.

- LUCKMANN, G. Tem muitas possibilidades o emprego de pedras. Casa e Jardim, São Paulo, n. 38, p.20-26, set./out. 1957.

- LUCKMANN, G. "Home Sweet Home." Casa e Jardim, São Paulo, n. 32, p. 8-9 e 81, jan./fev.1957.

- LUCKMANN, G. Casa Térrea ou Sobrado? Casa e Jardim, São Paulo, n. 42, p.2829, maio 1958.

- LUCKMANN, G. O Sobrado no Terreno de 12 × 30m. Casa e Jardim, São Paulo, n. 49, p.42-44, fev.1959.

- M., F. de. Considerações sobre uma residência. Casa e Jardim, São Paulo, n.77, p.48-52, jun.1961.

- MARCEL Breuer: teacher and architect. House \& Home, New York, v.1, n. 5, p.102115, maio 1952.

- MARGÔ. "O Sr. está satisfeito com sua casa?" Casa e Jardim, São Paulo, n.33, p. 14-16; $18-19$ e 21-23, mar.1957a.

- MARGÔ. "Quando construímos nossa casa..." Casa e Jardim, São Paulo, n.39, p.10-15, nov./dez.1957b.

- MARGÔ. O que faz o Sucesso desta Casa? Casa e Jardim, São Paulo, n. 40, p.1017, jan./fev.1958.

- MASON, Joseph B. Introduction. 82 Distinctive Houses from Architectural Record, New York, c1952, s.n.p.

- MENU em alto mar. Casa e Jardim, São Paulo, n.1, p.56-58, mar./abr.1953.

- MERAVIGLIA, Olga. Cores novas e atrativas. Casa e Jardim, São Paulo, n.13, p.28, 30-33 e 34, mar./abr.1955a. 
- MERAVIGLIA, Olga. O paisagista é importante. Casa e Jardim, São Paulo, n.18, p.48-49 e 78 , out.1955b.

- MERAVIGLIA, Olga. Totalidade como ideia de estética. Casa e Jardim, São Paulo, n.24, p.12-17, abr.1956. Esse artigo sobre o decorador Carlos Martins Spira.

- METZENER, Alda. Janelas que são Molduras. Casa e Jardim, São Paulo, n.13. p.35-37, mar./abr.1955.

- MILA, Ariosto. Vamos alterar o projeto! Casa e Jardim, São Paulo, n.14, p.4 e 62, maio/jun.1955.

- MILA, Ariosto. Presença do Arquiteto. Casa e Jardim, São Paulo, n.31, p.2-3, dez.1956. De uma série de entrevistas de Regina Zonta com arquitetos.

- MORE BEM na casa feita para você. Casa e Jardim, São Paulo, n.32, p.4-6, jan./ fev. 1957

- MYERS, Howard. Modern Houses in America. Architectural Forum, Boston, v. LXX1, n.1, p.1-2, jul. 1939. Editorial.

- REICHENBACH, Carlos. Prezado Leitor. Casa e Jardim, São Paulo, n.1, p.6-7, mar./abr.1953. Editorial.

- NÃO acredite na falta de espaço... Casa e Jardim, São Paulo, n. 5, p.24- 28, nov./ dez.1953.

- NEVES, Christiano Stockler. A Pretensa Arquitetura Moderna. Architectura e Construcções, São Paulo, v. !, n.2, p.11-17, set.1929.

- NO ALTO da serra. Casa e Jardim, São Paulo, n. 18, p.24-29, out.1955.

- OBRIGADO! Casa e Jardim, São Paulo, n.2, p.2, maio/jun.1953.

- O ARQUITETO Rino Levi projetou. Casa e Jardim, São Paulo, n.6, p.10-15, jan.fev.1954.

- O CONFORTO e a intimidade contra o estandardismo. Casa e Jardim, São Paulo, n.55, p.49-53, ago.1959.

- O HOMEM e o móvel. Casa e Jardim, São Paulo, n.48, p.4, jan.1959.

- O JARDIM é a moldura da casa. Casa e Jardim, São Paulo, n.1, p.47-48, mar./abr.1953.

- O LAR de um celibatário. Casa e Jardim, São Paulo, n.1, p.16-20, mar./abr. 1953.

- ONDE se sentam nossos hóspedes. Casa e Jardim, São Paulo, n.50, p.32-34, mar.1959

- ORTENBLAD FILHO, Rodolpho. A arquitetura moderna paulista olhando para Wright e Neutra. São Paulo, Vitruvius, 12.048, out 2011. Entrevista concedida a Sabrina Souza Bom PEREIRA; Abilio GUERRA. Disponível em < http://www.vitruvius.com.br/revistas/read/entrevista/12.048/4083.> Acesso em 04 Jun. 2014

- O SEGREDO de sentir-se beatificado. Casa e Jardim, São Paulo, n.11, p.16-20, nov./dez.1954. 
- PASTILHAS, Pedras e Palmeiras. Casa e Jardim, São Paulo n.29, p.6-8, set./out.1956.

- PEREZ, Francisca; GODOY, Carmen Gloria. Territorios imaginarios de lo domestico. Vida cotidiana en las revistas femeninas 1930-1960: el caso de Margarita. Revista Chilena de Antropología Visual, Santiago, n.13, p. 104/128, jun.2009.

- PINTO JUNIOR, Rafael Alves. Casa, Substantivo Feminino: Representações da Cultura de Morar em Casa e Jardim e Casa Cláudia (1953-1979). Disponível em <http://pos.historia.ufg.br/up/113/o/Rafael_Alves_Pinto_Junior.pdf.>. Acesso em 16 Set. 2014.

- PORQUE GOSTAMOS desta ou daquela casa? Casa e Jardim, São Paulo, n. 9, p.5 e 64-65, jul./ago.1954.

- "PRESENÇA" do jardim. Casa e Jardim, São Paulo, n.2, p.8-13, maio/jun.1953.

- PROBLEMAS da Vida Matrimonial. Casa e Jardim, São Paulo, n.3, p.2 e 70, jul./ ago. 1953.

- PROCHNIK, Rachel E. conforto e simplicidade. Casa e Jardim, São Paulo, n.10, p.7-9, set./out.1954a.

- PROCHNIK, Rachel E. Dois Núcleos em um Bangalô. Casa e Jardim, São Paulo, n. 11, p.12-14 e 94, nov./dez 1954b.

- PROCHNIK, Rachel E. Os jardins de Roberto Burle Marx. Casa e Jardim, São Paulo, n.13, p.44-45 e 74, mar./abril 1955.

- PROCHNIK, Rachel E. Sérgio Bernardes projetou esta casa. Casa e Jardim, São Paulo, n.23, p.16-21 e 75, mar.1956a.

- PROCHNIK, Rachel E. Proteção contra o calor. Casa e Jardim, São Paulo, n. 31, p.11-16, dez.1956b.

- PROCHNIK, Rachel E. Escolhemos morar no alto da serra. Casa e Jardim, São Paulo, n. 31, p.21-26, dez.1956c.

- PROCHNIK, Rachel E. é possível viver numa obra de arte. Casa e Jardim, São Paulo, n.32, p.12-17 e 81, jan./fev.1957a.

- PROCHNIK, Rachel E. Proporção e detalhes definem uma arquitetura. Casa e Jardim, São Paulo, n.39, p.34-36 e 38-41, nov./dez. 1957b.

- PROCHNIK, Rachel E. Moderno é sinônimo de informal? Casa e Jardim, São Paulo, n.45, p.22-24 e 26-28, ago.1958.

- QUANDO uma única sala "Grande" é mais interessante do que duas menores. Casa e Jardim, São Paulo, n.46, p.27, set./out.1958

- QUE DIFERENÇA faz um projeto bem estudado! Casa e Jardim, São Paulo, n.11, p.11 e 96, nov./dez. 1954.

- REICHENBACH, Carlos. Prezado Leitor. Casa e Jardim, São Paulo, n.1, p.6-7, mar./abr.1953.

- REICHENBACH, Carlos. Prezado Leitor. Casa e Jardim, São Paulo, n.50, p.4, mar.1959. 
- REIS, Sílvia. dois pavimentos sobre um grande terreno. Casa e Jardim, São Paulo, n. 33, p.8-13, mar.1957.

- RESIDÉNCIA de Veraneio. Casa e Jardim, São Paulo, n.28, p.16-18 e 20, ago.1956.

- RESIDÊNCIA EM três níveis. Casa e Jardim, São Paulo, n.41, p.18-23 e 25-26, mar./abr.1958.

- RESIDÊNCIA NO ALTO de Pinheiros. Acrópole, São Paulo, ano XIX, n.224, p.280282, 1957.

- RESIDÊNCIA NO MORUMBY. Acrópole, São Paulo, ano XVIII, n.209, p.176-179, 1956.

- SAIA, Luiz. Você é um cliente potencial do arquiteto. Casa e Jardim, São Paulo, n.29, p.4-5, set./out. 1956,. Entrevista a Regina Zonta.

- SANTOS, Cecília Rodrigues. Rino Levi Arquitetos Associados: permanência e continuidade de uma obra. Projeto, São Paulo, n.111, p.48-50, jun.1988.

- SANTOS, Marinês Ribeiro. Domesticidade e identidades de gênero na revista Casa \& Jardim (anos 1950 e 60). cadernos pagu, n.36, p.257-282, jan./jun. 2011.

- SCHULTZ, Harald; SCHULTZ, Vilma. último achado na decoração do lar. folclore. Casa e Jardim, São Paulo, n.30, p.36-39, nov.1956.

- SIMÕES, Roberto. a casa do arquiteto. Casa e Jardim, São Paulo, n.34, p.5, abr.1957.

- SOUZA, Abelardo. Arquitetura sem Preconceitos de Classe. Casa e Jardim, São Paulo, n.27, p.2-3 e 73, jul.1956. Série de depoimentos à Regina Zonta.

- SOUZA, Heitor Ferreira. Equilibrar a vida social e a vida familiar. Casa e Jardim, São Paulo, n.26, p.16-20, jun. 1956.

- SUHR, Eduard. o "BOM" também é "RUIM" quando em excesso. Casa e Jardim, São Paulo, n.12, p.4-5 e 71, jan./fev.1955.

- SYMmETRICAL Cantilevers on Asymmetrical Base. House \& Home, New York, v.1, n.1, p.120-123, jan.1952.

- TOSI, Osmar. Estudo de uma pequena residência que crescerá futuramente. Casa e Jardim, São Paulo, n.7, p.16-17, mar./abr. 1954.

- TEDDY. o quarto próprio. Casa e Jardim. São Paulo, n.10, p.38-39, 70 e 80, set./out.1954.

- THE SPECULATIVE House: Pueblo Gardens: Tucson, Arizona, A. Quincy Jones, Jr.; Paul R. Williams, Associate Architects. Progressive Architecture, p. 73-81, jul. 1950. Disponível em <http://socalarchhistory.blogspot.com.br/2010/12/quincy-jonesand-pueblo-gardens-first_29.html> Acesso em 18 Jun. 2014.

- UMA CASA diferente das outras! Casa e Jardim, São Paulo, n.8, p.16-18 e 20-22, maio/jun. 1954.

- UMA CASA HOJE moderna... amanhã tradicional. Casa e Jardim, São Paulo n. 37, p.38-43, jul./ago. 1957. 
- UMA CASA IDEAL para férias. Casa e Jardim, São Paulo, n. 26, p.30-33, jun. 1956.

- UMA RESIDÊNCIA em Campinas. Casa e Jardim, São Paulo, n.6, p.20-23, jan./fev.1954.

- UM SOLTEIRO construiu a casa que posteriormente poderia servir para uma família de duas ou três pessoas. Casa e Jardim, São Paulo, n.7, p. 11-14 e 96, mar./abr. 1954.

- UNÍSSONO Feliz. Casa e Jardim, São Paulo, n.20, p.11-12 e 16-20, dez.1955

- VAMOS TESTAR seu talento para decoração? Casa e Jardim, São Paulo, n.53, p.55-56, jun. 1959.

- VOCÊ pode possuir a melhor casa possível. Casa e Jardim, São Paulo, n.49, p.7-8, fev.1959.

- VILLELA, Ivy Cox. A Psicologia das Cores. Casa e Jardim, São Paulo, n.53, p.4-5, jun.1959a.

- VILLELA, Ivy Cox. Decoração Moderna. Casa e Jardim, São Paulo, n.54, p.9-11, jul.1959b.

- WHAT DO people want? House \& Home, New York, v.V, n. 5, p.123-167, maio 1954.

- WHERE is Modern Now? Architectural Forum, Boston, v. LXVIII, n.6, p.465-470, jun.1938.

- ZONTA, Regina. na praia de Guarujá. Casa e Jardim, São Paulo, n. 31, p.4-9, dez.1956.

- ZONTA, Regina. ....arquitetura na Bahia. Casa e Jardim, São Paulo n.41, p.29-33, mar./abr. 1958.

\section{Anúncios em periódicos}

- AGORA MAIS desejado do que nunca! - o mais útil dos liquidificadores. Walita. Casa e Jardim, São Paulo, n.7, p.93, mar./abr.1954.

- ATINGINDO Novos Mundos com televisores Super Philips. Casa e Jardim, São Paulo, n.13, p.9, mar./abr.1955.

- DOIS AMORES. Casa e Jardim, São Paulo, n.29, p.87, set./out.1956.

- EM TORNO de cada Refrigerador G-E há uma historia humana... uma historia de família. Casa e Jardim, São Paulo, n.28, p.83, ago.1956; n.29, p.97, set./out.1956; n.31, p.84, dez.1956.

- ...E QUE NESTE Natal mamãe ganhe um Walita. Casa e Jardim, São Paulo, n.11, p.77, nov./dez.1954.

- ESTE NATAL vai ficar na história da família... Casa e Jardim, São Paulo, n.39, verso da contracapa, nov./dez.1957. 
- FRIGIDAIRE. Vale pela economia. Casa e Jardim, São Paulo, n.20, p.38, dez.1955; n.23, s.n.p., mar.1956,

- HÁ UM BRASTEMP para cada conveniência e com o máximo padrão de qualidade! Casa e Jardim, São Paulo, n.26, p.57, jun.1956; n.27, p.65, jul.1956; n.28, p.73, ago.1956; n.32, s.n.p., jan./fev.1957.

- PARA AMBIENTES modernos onde impera o conforto! Casa e Jardim, São Paulo, n.8, p.7, maio/jun.1954.

- PARA ELA... com graça e sutileza. Rosas, Croisé, Marajoara, Barroco Moderno. Casa e Jardim, São Paulo, n.9, p.61, jul./ ago.1954.

- SUBLIME perfeição. Casa e Jardim, São Paulo, n.9, s.n.p., jul,/ago.1954; n.11, s.n.p. nov./dez.1954; n.14, s.n.p. maio/jun.1955; n.18, p.9, out.1955; n.23, p.23, mar.1956; n.36, p.9, jun.1957.

- TRANSFORME seu lar num pedacinho do Céu. Casa e Jardim, São Paulo, n.18, p.10-11, out.1955; n.20, p.6-7, dez.1955.

- UM ACORDE encantado... no reino das melodias - na realização do tapete - uma harmonia feliz para ver e ouvir. Casa e Jardim, São Paulo, n.10, p.15, set. /out.1954; n. 12, p.9, jan./ fev.1955; n.16, p.19, ago.1955; n.24, p.11, abr. 1956; n.24, p.11, abr.1956. 